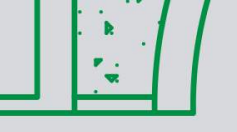





\title{
MODERNIDADE PAULISTANA O PAISAGISMO DE ROBERTO COELHO CARDOZO
}

\author{
Gabriela Tie Nagoya Tamari
}

Dissertação apresentada a Faculdade de Arquitetura e Urbanismo da Universidade de São Paulo para obtenção do título de Mestre em Arquitetura e Urbanismo

Área de Concentração

Paisagem e Ambiente

Orientador

Prof. Dr. Vladimir Bartalini

São Paulo, 2017 
AUTORIZO A REPRODUÇÃO E DIVULGAÇÃO TOTAL OU PARCIAL DESTE TRABALHO, POR QUALQUER MEIO CONVENCIONAL OU ELETRÔNICO, PARA FINS DE ESTUDO E PESQUISA, DESDE QUE CITADA A FONTE.

gabriela.tamari@usp.br

Tamari, Gabriela Tie Nagoya

T153m Modernindade Paulistana: o paisagismo de Roberto Coelho Cardozo / Gabriela Tie Nagoya Tamari ; orientador Vladimir Bartalini. --São Paulo, 2017. 364 p. : il.

Dissertação (Mestrado) - Faculdade de Arquitetura e Urbanismo da Universidade de São Paulo. Área de Concentração: Paisagem e Ambiente

1. Cardozo, Roberto Coelho 2. Arquitetura paisagística 3. São Paulo 4.História da arquitetura 5. Arquitetura Moderna 6. Espaços livres 7. Paisagistas - Brasil. I. Bartalini, Vladimir, orient. II. Título. 


\section{AGRADECIMENTOS}

Agradeço ao meu orientador Vladimir Bartalini, pela confiança depositada e pelo apoio durante o percurso; aos membros da banca de qualificação, Catharina Lima e Givaldo Medeiros, pela leitura cuidadosa e pelos comentários estimulantes para o desenvolvimento final da dissertação.

Ao Benedito Abbud, Gregório Zolko, Luciano Fiaschi, Marcos Acayaba, Miranda Martinelli Magnoli, Peri Jon Osborn Coelho e Tereza Peres pelos depoimentos concedidos e pelas informações sem as quais esta pesquisa estaria incompleta. A Marlene Milan Acayaba, por ter lido meu memorial de qualificação e ter me incentivado em um momento de insegurança.

Às funcionárias da biblioteca da FAUUSP, em especial Gisele, Eliane, Rejane, Satiko e Rita de Cássia, que me socorreram até os últimos momentos da entrega disponibilizando material essencial para a pesquisa. A Luciene, do departamento de Projetos, por também ter apresentado documentos inéditos e essenciais para o trabalho.

Às funcionárias do Environmental Design Archives da UCBerkeley, em especial a Chris Marino, que não poderia ter sido mais atenciosa e solícita.

Às minhas queridas companheiras da Oficinazmais: Carol Leo, pela amizade, pela incrível parceria profissional e pela compreensão durante minha ausência; Ruth e Alessandra pelo entusiasmo e apoio no dia-a-dia.

Às amigas Rê Koga e a Sil Amaro, que generosamente me acolheram em seus lares durante a pesquisa na Califórnia.

Às colegas da pós, Berta, Letícia e Clarissa, pelas trocas e conversas. Aos paisageiros Beto, Jung e Julio, pelas viagens oníricas às paisagens bachelardianas.

Aos queridos amigos que me ajudaram na finalização do trabalho: Luiz Florence, pela revisão de texto; Maíla e Ana Clara pelas revisões do abstract e do resumo; Max, pelos livros emprestados; Aninha e Vito, pelas intervenções gráficas; João Yamamoto, pelo lindo projeto gráfico; e Paula Dedecca, pelo contínuo estímulo desde o projeto de pesquisa, pelas revisões e por ser uma amiga do coração.

À turma da bagunça que contribui simplesmente por existir: Thea, Dalva e Fernando, Paloma e Alemão, Rê e Maik, Clau, Deinha, Leo Nakan, Nina Jacobi, Gau, Rafa Golin, Dri Borghi, Ana Gabriela, Miami, Marina, Pri, Yumi, Carol, Yuri e Pablo, Manu e Marcel, Ana Tomi e Carlos, Iraima e Pu.

À minha família: Cristina, Fátima, Lúcia, Wilson, Mariko, Chinen, Daniel, Denis, Otávio, Vitor, Ana Rosa, Miguel e Bê - pelo carinho e apoio constante.

Agradecimentos especiais à Mari, por ser minha melhor amiga, querida irmã e uma maravilhosa revisora; aos meus pais, por tudo e muito mais; ao Cauê, meu amado parceiro, por toda ajuda e paciência. Dedico a vocês este trabalho. 


\section{ABSTRACT}

TAMARI, Gabriela Tie Nagoya. Modernidade paulistana: o paisagismo de Roberto Coelho Cardozo. 2017. Dissertação (Mestrado) - Faculdade de Arquitetura e Urbanismo, Universidade de São Paulo, São Paulo, 2017.

This research intends to contribute to the studies on the formation of the landscape architecture field in the city of São Paulo from the 1950 s onwards, focusing on the expressions of modern landscaping. Therefore, we trace the trajectory of the American landscape designer Roberto Coelho Cardozo, since his graduation at UCBerkeley where he had his first contact with the landscape architecture renovation movement that permeated the cultural and urban environment of the West Coast of the United States; through his teaching at FAUUSP, introducing the Landscape Architecture discipline; up to his technical production as a landscaper between 1950 and 1970 - from his arrival in São Paulo until his departure to England, period in which he captured and transformed the principles of the Californian modernists, such as Garrett Eckbo and Thomas Church, making his work gain a specific modernity, distinct from other contemporary landscape designers. This analysis brings the work of Roberto Coelho Cardozo into a historical perspective, trying to contribute to the questions concerning the emergence of the Landscape Architecture field in São Paulo.

Keywords: Cardozo, Roberto Coelho; Landscape architecture; São Paulo; History of architecture; Modern architecture; Green spaces; Landscape designers - Brasil. 


\section{RESUMO}

TAMARI, Gabriela Tie Nagoya. Modernidade paulistana: o paisagismo de Roberto Coelho Cardozo. 2017. Dissertação (Mestrado) - Faculdade de Arquitetura e Urbanismo, Universidade de São Paulo, São Paulo, 2017.

A presente pesquisa pretende contribuir para os estudos sobre a formação do campo paisagístico na cidade de São Paulo a partir da década de 1950, com enfoque nas expressões do paisagismo moderno. Para tanto, apresenta a trajetória do paisagista norte-americano Roberto Coelho Cardozo, desde a sua formação na UCBerkeley onde teve contato com o movimento de renovação paisagística que permeava o ambiente cultural e urbano da Costa Oeste dos Estados Unidos, passando pela atuação na docência na FAUUSP - quando inaugura a disciplina de paisagismo no curso de Arquitetura - até a sua produção técnica como paisagista, entre 1950 e 1970. Desde sua chegada a São Paulo até a partida à Inglaterra, na qual apreendeu e transformou os princípios da "corrente californiana", fez com que sua obra ganhasse uma modernidade específica, diferente dos outros paisagistas à época. O trabalho coloca a obra de Roberto Coelho Cardozo em perspectiva histórica esperando contribuir para o entendimento das questões relacionadas ao surgimento do campo profissional da Arquitetura Paisagística em São Paulo.

Palavras-chave: Cardozo, Roberto Coelho; Arquitetura paisagística; São Paulo; História da arquitetura; Arquitetura moderna; Espaços verdes; Paisagistas - Brasil. 



\section{SUMÁRIO}

INTRODUÇÃO

1.1 Do Golden State a São Paulo - a formação de um paisagista.

1.2 As relações nos trópicos: sociabilidade e paisagismo.

2 INFLUXOS, RUPTURA E A NOVA FORMA DO PAISAGISMO PAULISTANO.

2.1 O século XX e o advento do jardim moderno.

Algumas expressões paisagísticas europeias e possíveis caminhos para um novo olhar paisagístico.

Exposition Internationale des Arts Décoratifs et Industriels Modernes.

2.2 Os pioneiros do paisagismo moderno nos Estados Unidos. 71 Thomas D. Church

Havard Rebels

2.3 Ruptura e renovação: a construção de uma modernidade verde no Brasil.

Os primeiros lampejos de modernidade

Expandindo o panorama paisagístico: a atuação de Roberto Coelho Cardozo 

ROBERTO COELHO CARDOZO

3.1 Critérios para análise de projetos $\quad 135$

3.2 Residência Anthony B. Heinsbergen 139

3.3 Residência Ilda e Waldormiro Zarzur 144

3.4 Escola Estadual Perus 152

$\begin{array}{lll}3.5 & \text { Usina hidrelétrica de Xavantes } & 168\end{array}$

$\begin{array}{lll}3.6 & \text { Fichas de projetos } & 186\end{array}$

CONSIDERAÇÕES FINAIS $\quad 327$

BIBLIOGRAFIA 333

$\begin{array}{ll}\text { LISTA DE IMAGENS } & 349\end{array}$

$\begin{array}{ll}\text { ANEXOS } & 355\end{array}$

$\begin{array}{ll}\text { Cronologia dos projetos } & 357\end{array}$ 
INTRODUÇÃO 

"No começo havia dois Robertos". É com essa frase que Rosa Grena Kliass, renomada paisagista brasileira, prenuncia a sua trajetória profissional em seu livro. Quando Kliass cita os "dois Robertos", refere-se a Roberto Burle Marx e Roberto Coelho Cardozo:

"Costumo dizer que o paisagismo moderno brasileiro tem dois pilares, que são dois Robertos: Roberto Burle Marx e Roberto Coelho Cardozo. Cardozo no ensino, Burle Marx na práxis; um trabalhando em São Paulo, outro no Rio de Janeiro, onde o paisagismo foi estimulado por sua presença. Em São Paulo, o paisagismo moderno começa com essa forte ligação com a linha norte-americana, tanto por influência do Roberto Coelho Cardozo como pela presença de Waldemar Cordeiro, artista plástico e um dos líderes do movimento concretista dos anos 1950, que atuava também no campo do paisagismo, integrando, nas suas propostas, sua experiência artística" (KLIASS, 2006).

Sempre colocado em evidência pela inegável qualidade de sua obra, Roberto Burle Marx teve seu trabalho aclamado pela crítica internacional e inseriu o paisagismo brasileiro no circuito mundial. Ao mesmo tempo, a atenção quase exclusiva a seu trabalho limitou o reconhecimento da diversidade histórica que constitui o desenho da paisagem no Brasil. "Em termos historiográficos, o foco em Burle Marx ofuscou a valiosa contribuição de inúmeros outros profissionais para o desenvolvimento de um campo de conhecimento ainda em formação no Brasil" (LIMA, 2015, tradução nossa).

De fato, uma bibliografia específica que abarque a formação do campo disciplinar do paisagismo à época ainda é escassa. Apesar da colaboração desses outros atores na história do paisagismo ser inquestionável, ainda são poucos os estudos dedicados a seus feitos: a produção imprescindível de Waldemar Cordeiro na arquitetura paisagística foi contemplada nos preciosos estudos de Ana Maria Belluzzo e Givaldo Medeiros; Tatiana Perecin nos apresenta a incipiente participação de Mina Klabin Warchavchik na arte dos jardins tropicais, empregando os belos mandacarus na residência Santa Cruz; Cássia Mariano traz à luz a atividade de Otavio Augusto Teixeira Mendes, engenheiro agrônomo desconhecido por muitos e que foi responsável por projetos fundamentais de paisagismo em São Paulo, incluindo o Parque do Ibirapuera; Zeuler Lima ressalta essa lacuna no campo historiográfico em artigo 
que destaca a participação feminina no campo paisagístico, expondo as atuações profissionais de Mina, Lota Macedo Soares, Rosa Kliass e o indispensável aporte na área acadêmica da Profa. Miranda Martinelli Magnoli. Mesmo não sendo numerosas, essas pesquisas monográficas têm contribuído substancialmente para a formação de um panorama mais amplo do paisagismo moderno no Brasil'.

Nesse sentido, este trabalho propõe-se a introduzir mais um agente formador dessa história apresentando a contribuição profissional e acadêmica do paisagista norte-americano Roberto Coelho Cardozo, durante sua atuação no Brasil, no período entre 1950 e 1970. Acreditamos que um estudo mais minucioso de sua produção criará elementos concretos para colocar sua obra em perspectiva histórica, inserindo-a no contexto geral do paisagismo em São Paulo a partir da década de 1950.

Roberto Coelho Cardozo (1923-2013), californiano de ascendência açoriana, nasceu em Watsonville e formou-se paisagista pela University of California Berkeley (UCBerkeley), em 1947. Logo em seguida atuou como arquiteto paisagista no escritório Eckbo, Royston \& Williams, onde teve contato com o movimento de renovação paisagística que permeava o ambiente cultural e urbano da Costa Oeste dos Estados Unidos. Com essa carga cultural e profissional começa sua carreira no Brasil, inicialmente no escritório de Roberto Burle Marx no Rio de Janeiro, e depois em seu próprio escritório na cidade de São Paulo. Em 1952 inicia a carreira acadêmica ao ser contratado como professor da Faculdade de Arquitetura e Urbanismo da Universidade de São Paulo (FAUUSP) onde lecionou a disciplina "Arquitetura Paisagística" na cadeira no. 28. Em 1970 muda-se com a família para a Inglaterra, voltando eventualmente ao Brasil em algumas ocasiões, em meados de 1990.

O interesse pelo tema desta pesquisa se deu pela carga colocada na figura do "outro Roberto", ou do "outro pilar ao lado de Roberto Burle Marx", como se refere Kliass a Cardozo. Afirma-se que Roberto Coelho Cardozo foi responsável por ter introduzido o desenho do jardim modernista norte-americano no Brasil e por ter conseguido transpor as ideias

1. Os trabalhos que nos referimos são: BELLUZZO (1986), MEDEIROS (2004), PERECIN (2003), MARIANO (2005) e LIMA (2015). 
da "corrente californiana" de paisagismo à realidade brasileira, uma vez que teve contato com o trabalho de Garrett Eckbo (CARDOSO, 1992; VACCARINO, 2002). Porém, logo no início da pesquisa, constatamos que não havia um levantamento de sua produção que pudesse abastecer com conteúdos técnicos essas afirmações, e também não havia elementos que demonstrassem como se deu o processo de transposição dos ideais californianos para a realidade brasileira.

Por conta disso, colocou-se um primeiro objetivo da pesquisa: catalogar e organizar a produção do paisagista entre 1950 e 1970, criando uma base documental que possibilitaria dar unidade à sua obra. $\mathrm{O}$ segundo objetivo volta-se a verificar como Roberto Coelho Cardozo apreendeu as orientações dos paisagistas californianos e eventualmente as transformou, adaptando-as às singularidades brasileiras (materiais, vegetação, clima) e quais foram os traços inovadores em seus projetos que fizeram com que sua produção ganhasse uma modernidade específica, diferente dos outros paisagistas atuantes à época.

Um primeiro levantamento foi feito no acervo da biblioteca da FAUUSP, onde foram encontradas cópias dos projetos originais, doados pelo próprio paisagista ${ }^{2}$. Ao lado desses projetos foi feita uma relação de artigos que mencionam o paisagista nas revistas especializadas da época, Acrópole, Casa e Jardim e Habitat, consultando os volumes publicados no período recortado pela pesquisa ${ }^{3}$.

A partir dessa identificação preliminar iniciou-se o processo de catalogação. A grande dificuldade dessa catalogação foi conseguir mais informações sobre cada projeto, uma vez que muitos dados não constavam nas pranchas digitalizadas ou nos artigos referentes aos mesmos. Muitas vezes o carimbo das pranchas informava data e localização, ou-

2. Na seção de projetos da biblioteca da FAUUSP estão arquivados 42 projetos da autoria de Cardozo, com a colaboração de Miranda Magnoli, Rodolpho Fernandes de Almeida, Luciano Fiaschi, Antônio Augusto Antunes Netto, entre outros arquitetos-paisagistas.

3. Foram consultados os volumes 1 a 191 da Casa e Jardim, que teve sua primeira publicação em 1953. Da revista Habitat foram consultados todos os volumes do periódico, de 1 a 84 , já que a revista foi extinta em 1965. Da revista Acrópole, foram consultados os volumes 141 a 380, de janeiro de 1950 a dezembro de 1970. 
tras vezes apresentava somente o nome do cliente (ex: Casa de Cláudia ou Residência de Hans Trostli). Nos artigos das revistas especializadas, os títulos não apresentavam mais referências: "Residência no Pacaembu" ou "Atividades ao ar livre", por exemplo. Porém, foi possível cruzar os dados dessas duas bases e complementar as informações para as fichas catalográficas.

Percebeu-se, ainda, que Roberto Coelho Cardozo mantinha uma relação profissional contínua com muitos profissionais, como era o caso dos arquitetos Henrique Ephim Mindlin, Gregório Zolko e Lucjan Korngold ${ }^{4}$. Nesse sentido, começamos uma busca pelos projetos não identificados em monografias referentes a realização dos arquitetos com os quais Cardozo trabalhou. Mais uma vez, foi possível acrescentar mais dados a essa catalogação. A tese de doutorado de Anat Falbel sobre Lucjan Korngold subsidiou esta pesquisa com mais informações sobre arquitetos colaboradores, nome dos clientes e datas precisas dos projetos. Outras monografias como a de Regina Constantino, sobre a produção de Abelardo de Souza, e a de Célia Yoshida, sobre os trabalhos de Henrique Mindlin, também contribuíram com mais elementos catalográficos ${ }^{5}$.

A segunda fase da catalogação refere-se aos estudos sobre Roberto Coelho Cardozo. São poucos os estudos que abordam o tema: a iniciação científica A obra do paisagista Roberto Coelho Cardoso compreendida entre 1950 e 1970 de Demétrius Borges dos Santos Gomes de Araújo, orientada pelo Prof. Dr. Silvio de Macedo Soares, o artigo Roberto Coelho Cardoso - A vanguarda da arquitetura paisagística moderna paulistana de Omar Cardoso e por fim, o Trabalho de Graduação Interdisciplinar (TGI) intitulado Um procedimento em pesquisa: A obra do arquiteto paisagista Roberto Coelho Cardozo, do arquiteto paisagista Benedito Abbud ${ }^{6}$. Os trabalhos de Araújo e de Cardoso abarcam uma pequena parcela da obra do paisagista e fazem

4. Poderemos identificar essas obras nas fichas catalográficas, que serão anexadas ao fim desse trabalho.

5. FALBEL, 2003; YOSHIDA, 1975; CONSTANTINO, 2004.

6. O TGI do arquiteto Benedito Abbud não está disponível na biblioteca da FAUUSP e foi gentilmente disponibilizado pelo autor em agosto de 2015 . 
descrições resumidas dos projetos, não conferindo muita informação à pesquisa. Já o trabalho de Abbud contribuiu muito para a pesquisa, uma vez que apresentava um curriculum vitae de Roberto Coelho Cardozo listando 166 projetos do paisagista, constando nomes dos clientes, endereços e datas das propostas.

Por fim, foram feitas entrevistas com arquitetos e paisagistas que tiveram contato profissional com Cardozo, fornecendo mais informações para o levantamento ${ }^{8}$. Com o cruzamento desses dados foi possível catalogar 192 projetos, que serão apresentados ao fim do terceiro capítulo.

O fichamento dos projetos do paisagista possibilitou a análise de sua obra como um todo, sendo possível verificar as reverberações dos princípios da "corrente californiana" na concepção dos programas, nas soluções formais e no emprego dos materiais e da vegetação. Para isso, foi feita uma revisão bibliográfica nos livros de Garrett Eckbo e nos estudos e análise feitos pelo estudioso da "corrente californiana", Marc Treib".

Notamos que a proposta dos paisagistas norte-americanos era a de integrar as ideias arquitetônicas do modernismo no desenho da paisagem, tendo como principal preocupação as condições sociais e tecnológicas da vida contemporânea à época. "A planta livre e os espaços

7. Posteriormente constatamos que esse currículo também se encontra anexado ao Processo de contratação do docente pela FAUUSP (Processo 52.1.14106.1.2)

8. Entrevistamos Benedito Abbud, Gregório Zolko, Luciano Fiaschi, Marcos Acayaba e Miranda Magnoli para obter mais informações sobre os projetos do paisagista. Também entrevistamos Peri Jon Osborn Coelho, filho de Roberto Coelho Cardozo, que nos forneceu dados específicos sobre datas de chegada e partida da família no Brasil.

9. Marc Treib é professor emérito do Departamento de Arquitetura da University of Berkeley, California, e atualmente atua nas áreas de pesquisa de Arquitetura e Jardins escandinavos e japoneses, desenho de cemitérios e história do paisagismo. É responsável pela importante bibliografia referente à história do paisagismo moderno norte-americano: Modern landscape architecture: a critical review (1993), Garret Eckbo: Modern Landscapes for Living (1997), The Architecture of Landscape: 1940-1960 (2002), Thomas Church Landscape Architecture: Designing a modern California Landscape (2003), Settings and stray paths writings on landscapes and gardens (2005), Dan Kiley: Landscapes - the Poetry of Space (2009) e Meaning in landscape architecture and gardens (2011). 
interpenetrados da arquitetura moderna forneciam um modelo valioso para repensar a arquitetura paisagística nos Estados Unidos" (TREIB, 1993, tradução nossa). Assim, os paisagistas da "corrente californiana" adotaram alguns princípios comuns para o desenvolvimento de projeto: ter como ponto de partida das propostas as particularidades do lugar; a ordenação e a regularidade do desenho, através dos elementos construtivos e das massas de vegetação; a integração do interno (edifício) com o externo, a utilização de novos materiais e o controle sobre o detalhamento do projeto, entre outros ${ }^{10}$.

Segundo Franco Panzini (2013), "a arquitetura da paisagem nos Estados Unidos deve seu caráter distintivo ao se vincular à arte moderna abstrata, expresso por meio do uso de formas livres e irregulares, criadas por canteiros ou pelos diversos tratamentos das superfícies". De fato, percebe-se o uso de formas coloridas bem marcadas, desenhadas por linhas sinuosas e quebradas, criando uma composição livre pondo em desuso o antigo paradigma dos eixos e simetrias que marcaram o paisagismo dos séculos XVIII e XIX.

Roberto Coelho Cardozo incorpora essas orientações da "corrente californiana" e seus esquemas são facilmente identificados, uma vez que suas plantas são fortemente marcadas pelas formas geométricas, formando espaços dinâmicos, onde os elementos estruturais se sobrepõem, muretas circulares delimitam espaços e são arrematadas por patamares angulados, piscinas com formatos peculiares sobrepõem-se a áreas gramadas delimitadas por degraus semicirculares. A modificação para materiais locais e a vegetação adaptada a nosso clima caracteriza a transposição às singularidades brasileiras. Os aspectos de sua produção serão desenvolvidos no decorrer desta dissertação, estruturada em três capítulos.

O primeiro capítulo, "A trajetória de um paisagista moderno", introduz Roberto Coelho Cardozo, apresentando seu percurso profissional desde sua formação na UCBerkeley até deixar o Brasil, mudando-se para a Inglaterra em 1970. Desvendando um pouco de sua trajetória foi

10. No livro Landscape for Living, Garrett Eckbo detalha mais alguns desses axiomas para a construção de uma nova visão da arquitetura paisagística. 
possível compreender como se constituíram as relações com parceiros profissionais, clientes, estagiários e arquitetos com quem manteve contato durante sua estadia neste país. Esses fatos também contribuíram para um entendimento maior sobre as relações que se estabeleceram entre o campo do paisagismo e da arquitetura na cidade.

O segundo capítulo, "Influxos, ruptura e a nova forma do paisagismo paulistano", trata de contextualizar algumas expressões paisagísticas - dos fins do século XIX e início do século XX - que se destacaram por apresentar formulações teórico-plásticas de caráter inovador, apontando para a construção de uma nova visão de paisagismo. Destacamos as expressões europeias que desviaram o olhar da tradição em busca de novos conceitos paisagísticos e que, invariavelmente, repercutiram nas discussões desenvolvidas a partir da década de 1930 nos Estados Unidos. Daí nos deslocamos à elaboração, escrita e prática, dos protagonistas da "corrente californiana" e à produção introdutória dos jardins modernos no Brasil. Esse panorama nos permite inserir a obra de Roberto Coelho Cardozo em perspectiva histórica, criando a ambiência necessária para apresentar e entender a relação entre sua prática profissional e docente.

No último capítulo, "Plasticidade e organicidade na obra de Roberto Coelho Cardozo", fizemos um recorte em sua produção, discorrendo sobre quatro projetos: a residência Anthony Heinsbergen (1947), a residência Ilda e Waldomiro Zarzur (1963), a Escola Estadual de Perus (1968) e a Usina Xavantes (1968). O argumento deste capítulo tentou esclarecer questões relativas ao modo de projetar de Cardozo e como o paisagista adequou as orientações da "corrente norte-americana" em seus projetos, tornando-os singulares e específicos, inovadores e modernos, criando uma linguagem própria e diferenciada dos outros paisagistas que atuaram à época.

Espera-se que o material levantado e as informações apresentadas por esta pesquisa permitam novos questionamentos e abertura para futuros desdobramentos em relação ao desenvolvimento do paisagismo moderno no Brasil. 

A TRAJETÓRIA DE UM

PAISAGISTA MODERNO 



\subsection{DO GOLDEN STATE A SÃO PAULO: A FORMAÇÃO DE UM PAISAGISTA.}

Robert Francis Coelho nasceu em 10 de agosto de 1923 na cidade de Watsonville, no estado da Califórnia, nos Estados Unidos da América. O pai, José Coelho, nativo da Região Autônoma dos Açores, era horticultor, e a mãe, Celestina Cordoza, nascida na Califórnia, mas também filha de imigrantes açorianos, cuidava do lar e dos dois filhos. A família, bastante humilde, vivia na simplicidade dentro da comunidade rural portuguesa que se estabelecera na Califórnia a partir de 1880 (SANTOS, 1983). As economias da família foram direcionadas para a educação superior dos filhos, que seriam a primeira geração da família a ingressar na faculdade (COELHO, 2015).

Em janeiro de 1947, Robert se formou no curso de Paisagismo e Floricultura ${ }^{1}$ (Landscape Design and Floriculture) da Escola de Agricultura da Universidade de Berkeley, onde teve uma formação ampla, embasada principalmente no projeto de plantação e na prática da horticultura - com aprendizagem sobre cultura e propagação de plantas e identificação botânica - e na qual reverberavam diversas mudanças substanciais adotadas pouco antes nas diretrizes pedagógicas do curso.

Além das disciplinas de botânica com o Professor Harry Shepherd², renomado pelo seu vasto conhecimento sobre plantas exóticas e nativas

1. O primeiro curso de Paisagismo da University of California, Berkeley UCBerkeley, foi fundado em 1913 e chamava-se Plantio e Floricultura (Landscape Gardening and Floriculture). Em 1925 o curso foi renomeado para Paisagismo e Floricultura (Landscape Design and Floriculture) e ainda fazia parte da School of Agriculture, que hoje recebe o nome de College of Natural Resources (CNR). Foi somente em 1959 que o curso de Arquitetura Paisagística (Landscape Architecture) passou a ser ministrado junto ao curso de Arquitetura no College of Environmental Design (CED).

2. Harry Whitcomb Shepherd (1890-1965) formou-se no curso de Engenharia Paisagística e Planejamento da UCBerkeley em 1914. Lecionou na UCDavis entre 1922 e 1925 e na UCBerkley de 1926-1955. Além da carreira acadêmica, Sheperd praticou a atividade profissional através de seu escritório de projetos. Era membro da American Society of Landscape Architecture (ASLA), onde foi presidente entre 1941-1942. 
[1.1]

Capa da revista Axis de novembro de 1930.

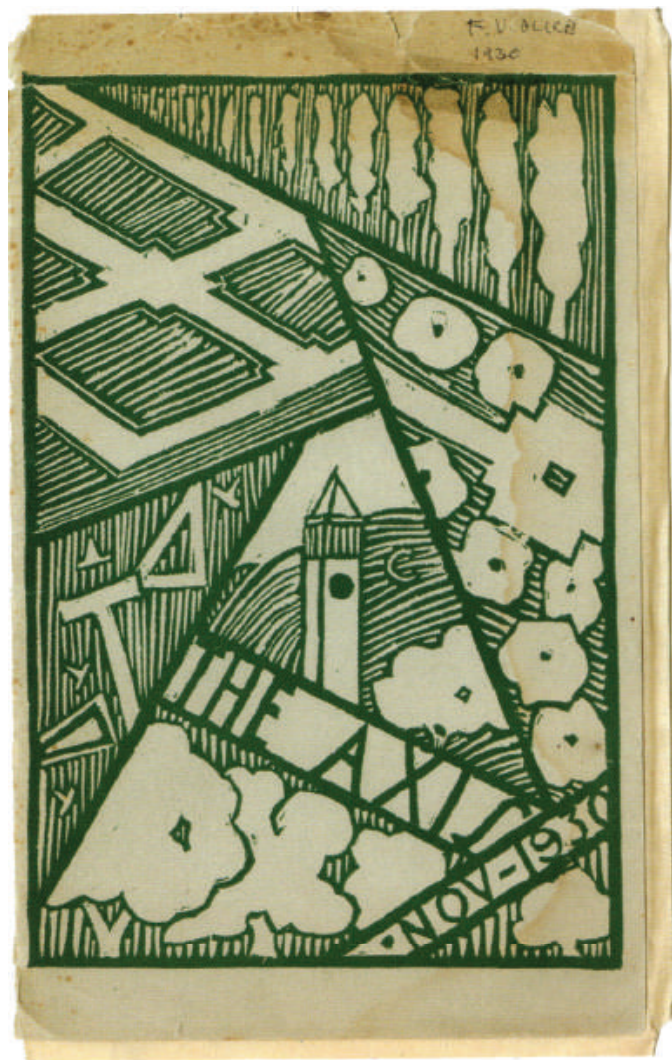

[1.2]

Entrada da exposição

"A space for Living", realizada no SFMOMA em 1940.

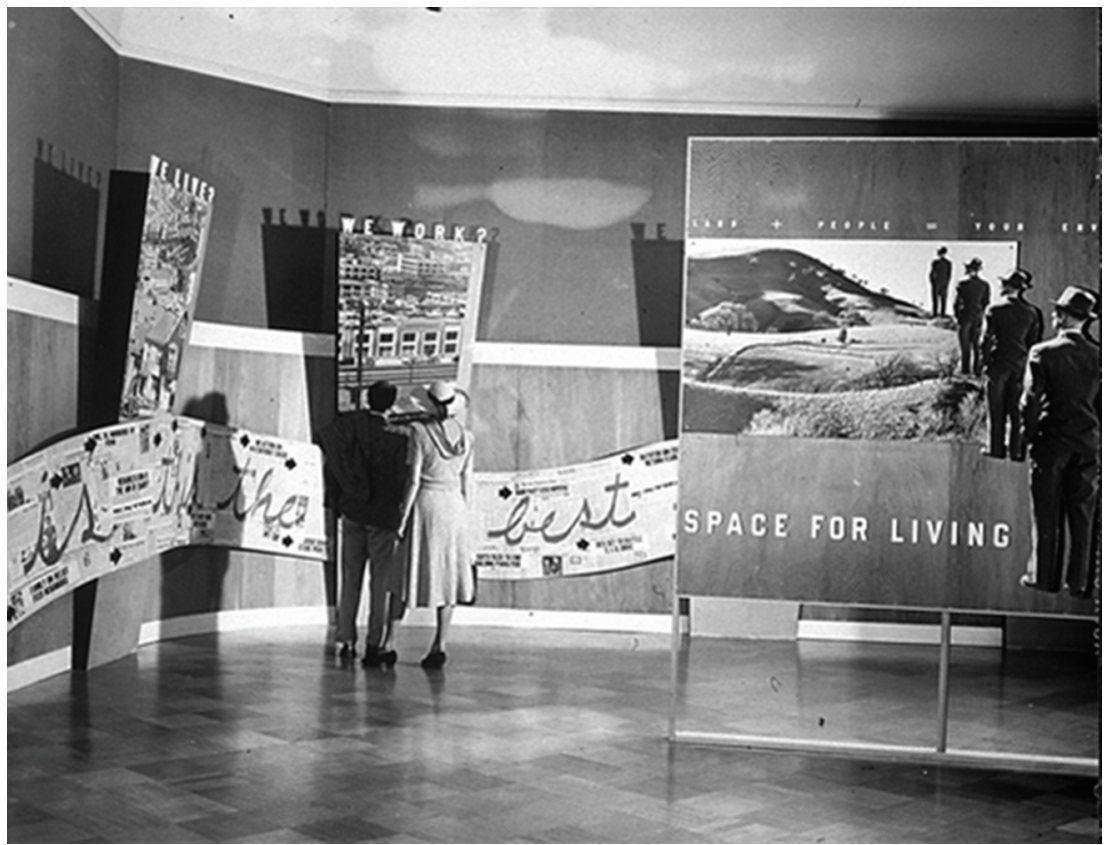


e por suas lições ao ar livre com aulas práticas no Blake Garden³, o curso também abordava questões sobre as variações e as influências climáticas na Paisagem. Em 1930, o professor Leland "Punk" Vaughan ${ }^{4}$ foi contratado como diretor da Escola de Agricultura e trouxe consigo "uma sensibilidade moderna ao programa de paisagismo" (BYRNE; McDADE; LOWELL, 2013). Nesse mesmo período foram acrescentados ao curso de Paisagismo e Floricultura algumas disciplinas relacionadas ao projeto, provenientes da Faculdade de Arquitetura, como desenho em perspectiva, geometria descritiva e sombras e sombreamento, e também disciplinas relacionadas à Faculdade de Artes, como pintura, escultura e teoria da arte contemporânea. Em paralelo ao cotidiano do curso, a faculdade organizava viagens de campo para Los Angeles e para a Serra Nevada, o que proporcionava aos alunos o contato direto com a insólita paisagem da Califórnia. Entusiasmados com a nova formatação do programa, os alunos se envolviam em assuntos acadêmicos e publicaram, entre 1930 e 1947, a revista Axis, divulgando os trabalhos projetuais dos estudantes do curso (SULLIVAN, 2013).

A efervescência no campo do paisagismo na Costa Oeste dos Estados Unidos não se limitava aos meios acadêmicos: os projetos sociais do New Deal, fomentados entre 1933 e 1937 pela política do presidente Franklin Roosevelt, empregavam os recém-formados paisagistas nos grandes projetos públicos da Califórnia, como a construção das áreas da Golden Gate Brigde, da Oakland Brigde e da barragem de Hetchy Hetchy, próxima ao Parque Yosemite.

A grande repercussão da exposição "Contemporary Landscape Architecture and its sources", realizada em 1937, aponta para a importância desta nova e variada produção, extrapolando os limites do paisagismo e reverberando no meio arquitetônico norte-americano. Promovida pelo San

3. Anita e Anson Blake doaram sua residência à UC Berkeley em 1957. O jardim, projetado por Anson Blake e Mabel Symmes, foi doado para o Departamento de Arquitetura Paisagística para servir de laboratório aberto nas experiências botânicas e estudo nas relações espaciais de jardins.

4. Hollyngsworth Leland Vaughan (1905-1974) formou-se arquiteto paisagista pela Ohio State University em 1929. Mudou-se para a Califórnia, onde iniciou a prática profissional ao lado da esposa, Adele Vaughan. Foi professor na UCBerkeley entre 1930 e 1969. 
Francisco Museum of Art (atual SFMOMA), teve sua introdução escrita por Henry-Russell Hitchcock, responsável também por outras exposições relevantes para a história da arquitetura nestas décadas, como a International Style exibida pelo MoMA em 1932 (BYRNE; McDADE; LOWELL, 2013).

Dois anos depois, em 1939, o recém-formado coletivo Telesis, formado por arquitetos, urbanistas e paisagistas, buscava discutir questões para uma nova agenda modernista voltada para as cidades da região da Baía de São Francisco. O grupo, que contava com personalidades notórias como William e Catherine Wurst, Vernon DeMars, Thomas Church, Grace McCann Morley, Joseph Allen Stein, Jack Hillmer, Corwin Mocine, Geraldine Knight Scott, Francis e Clementine Violich, Garrett Eckbo e Jack Kent, organizou a também significativa exposição "A Space for Living" no mesmo museu para difundir seus ideais sobre um urbanismo centralizado e planejado e divulgar a importância do papel dos profissionais da área (IMBERT; TREIB, 1997. ALLEN, 2009).

Tais movimentações - acadêmicas, profissionais e culturais - indicam a formação gradual do que se pode chamar de pensamento do Landscape americano, que aos poucos se consolidava como proposta de paisagismo moderno e ganhava espaço no meio intra e extra disciplinar. É nesse contexto rico e efervescente que Coelho se diploma na UCBerkeley.

Além da formação acadêmica, Robert também contava com a experiência prática que adquirira acompanhando o trabalho de horticultura de seu pai, José Coelho. O pai possuía um viveiro de plantas e, nesses trabalhos, o paisagista cativou o gosto e o prazer pelo manuseio da terra, compreendendo suas especificidades e características, e ganhou expertise na arte do manejo e poda da vegetação. Miranda Magnoli relata sobre essa aptidão de Robert:

Isso é uma coisa que eu me lembro, que me impressionava quando eu ia na obra com ele, ele botava a mão naquela terra e sentia a terra granulando. Isto vinha do pai, com quem ele trabalhava, e eles faziam os vasos, as plantas, as coisas. É uma experiência que é inerente à criação. A gente não tem essa coisa. Eu tenho aquela coisa de estudar, o Primavesi ${ }^{5}$, o Manual Ecológico do Solo e tal. É diferente de você sentir isso (MAGNOLI, 2015).

5. Aqui, Miranda refere-se ao precursor livro Manejo ecológico do solo: a agricultura em regiões tropicais de Ana Maria Primavesi. 


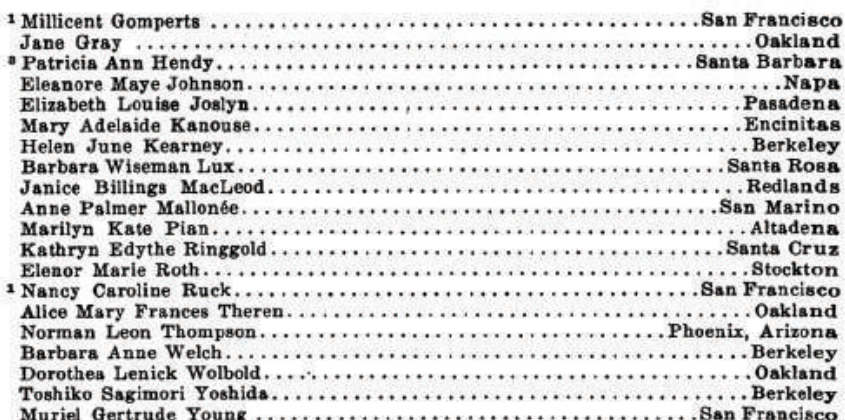

\section{[1.3]}

Registros no livros de formados da UCBerkeley: Robert Francis Coelho consta na lista da Escola de Agricultura de janeiro de 1947

\section{COLLEGE OF AGRICULTURE}

\section{The Degree of Bacbelor of Science upon}

Calven Samuel Aerick.

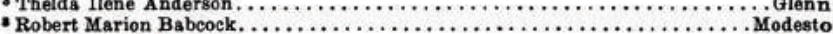
Richard Louis Baldwin . . . . . . . . . . . . . . . . . . . . . . . . . . . .

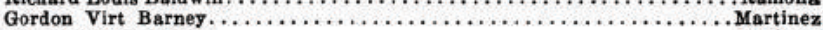
sonald Wilber Barton $\ldots \ldots \ldots \ldots \ldots \ldots \ldots \ldots \ldots \ldots \ldots \ldots \ldots \ldots \ldots \ldots \ldots \ldots$ Modesto Marian Holmes Batchelor. . . . . Santa Cruz

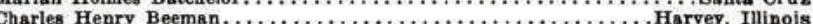

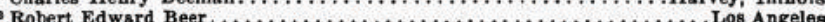

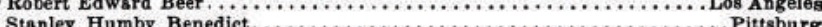

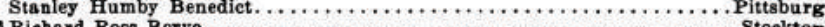

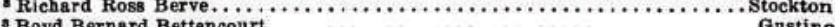

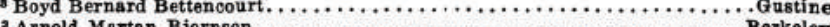

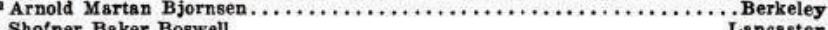

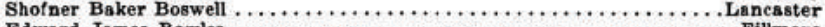

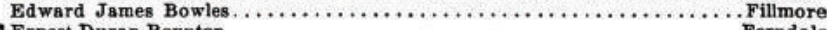

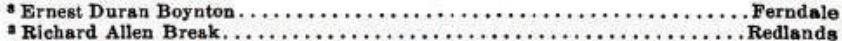

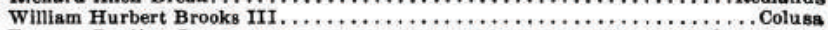

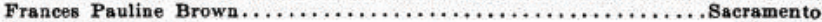
Robin Lurene Burr $, \ldots \ldots \ldots, \ldots, \ldots, \ldots \ldots \ldots \ldots \ldots \ldots \ldots \ldots$ Hantord

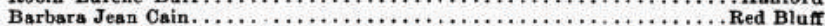

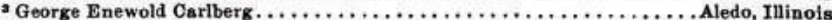
3ames Luther Carneal.

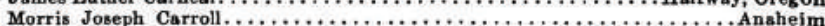
(1) Daniel waters Cessard II. . . . . . . Thomes Elers Ceard

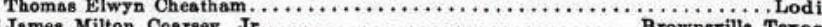
Jatsonville Morris Cohen $\ldots \ldots \ldots \ldots \ldots \ldots \ldots \ldots \ldots \ldots \ldots \ldots \ldots \ldots \ldots \ldots \ldots \ldots \ldots \ldots$ Los Angeles

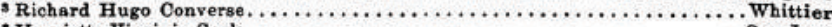

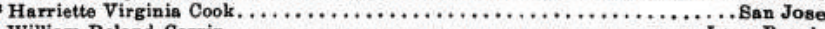

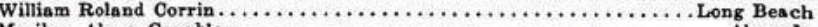

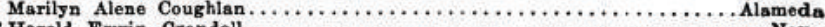

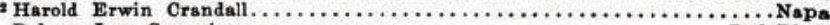

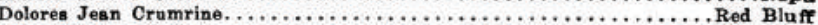
s Robert Hawley Culbertson $\ldots \ldots \ldots \ldots \ldots \ldots \ldots \ldots \ldots \ldots \ldots \ldots \ldots \ldots$. Hayward 
[1.4]

Planta da Residência Anthony Heinsbergen,

1947.

Ekcbo, Royston

\& Williams com

colaboração de

R. Coelho-Cordoza.

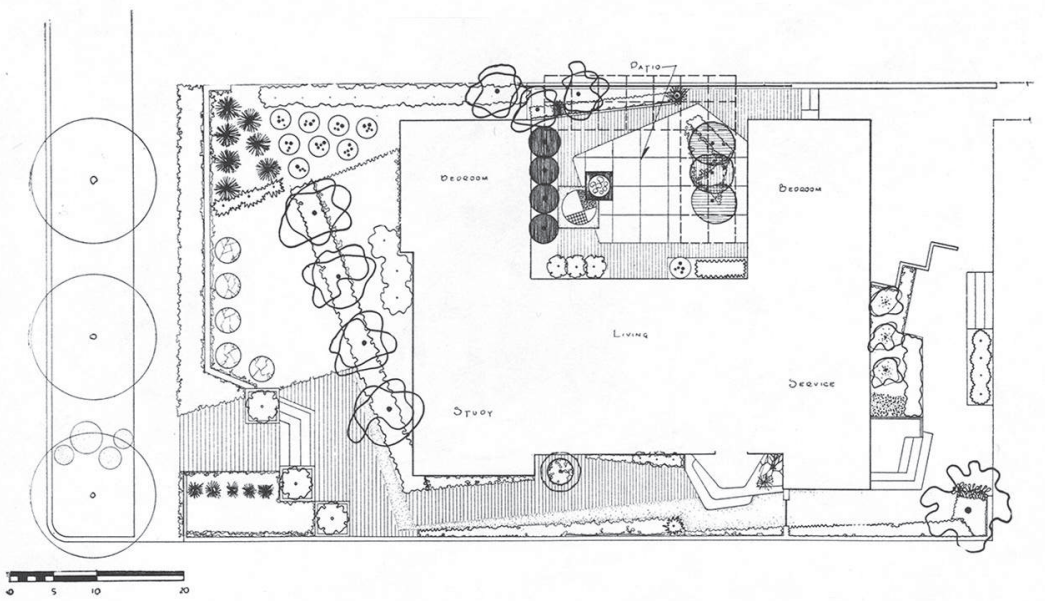

[1.5]

Jardim lateral da Anthony Heinsbergen, 1947.

Fotografia de Maynard

Parker para a revista House Beautiful

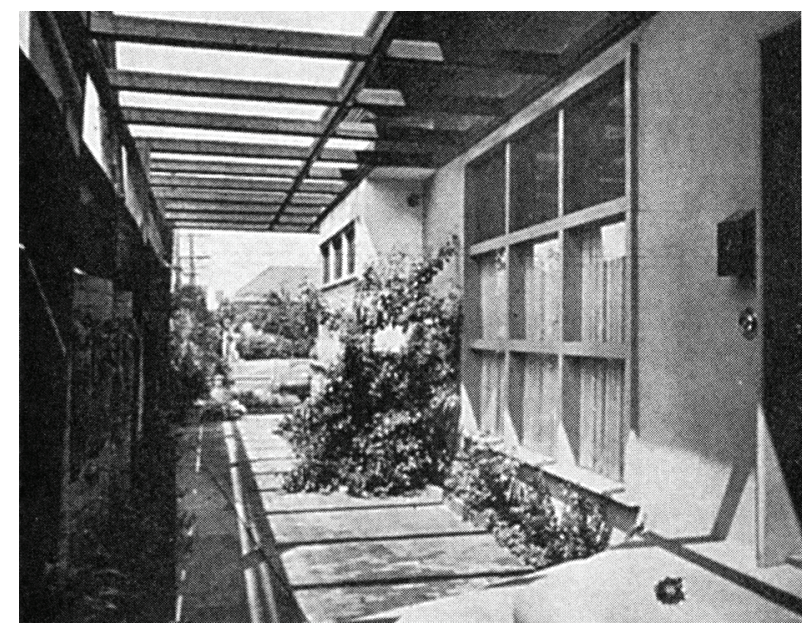

[1.6]

Entrada principal da Residência Anthony Heinsbergen, 1947.

Fotografia de Maynard Parker para a revista House Beautiful

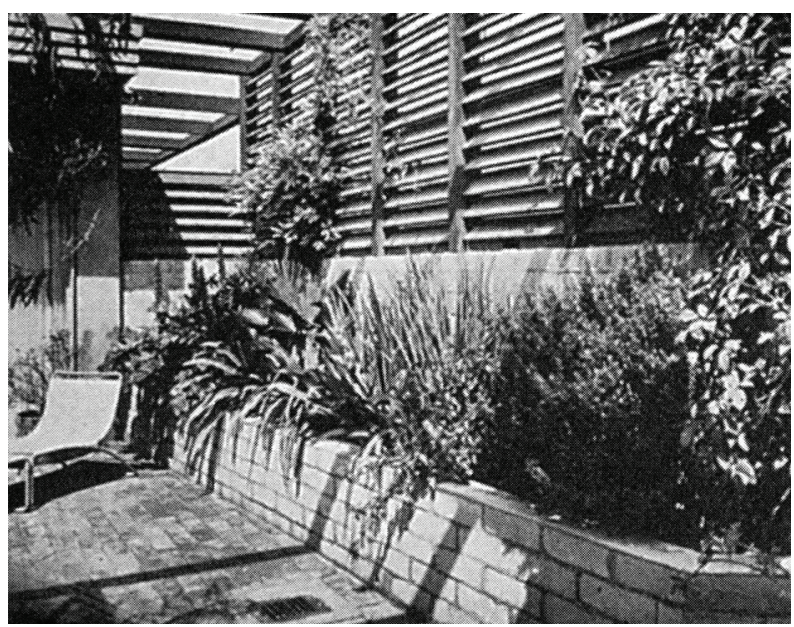


Ao se formar, Robert é contratado pelo escritório Eckbo, Royston \& Williams, onde trabalhou entre 1947 e 1949. Fundado por Garrett Eckbo, Robert Royston (que trabalhava com o já renomado paisagista Thomas Church) e Edward Williams (irmão de Airline Willams, esposa de Eckbo), o escritório foi estabelecido em 1945 e, nos cinco anos seguintes a sua abertura, foi considerado a principal firma de paisagismo no país. Com a Segunda Guerra Mundial, o estado da Califórnia teve um substancial crescimento populacional ao receber uma leva de trabalhadores que lá permaneceu no momento de volta à normalidade. Com isso, o subúrbio aumentava e o crescimento súbito das construções residenciais no sul do estado - tanto na região da Baía de São Francisco quanto em Los Angeles, áreas de atuação do escritório - propiciou ao escritório oportunidades amplas de experimentação projetual, possibilitando o desenvolvimento de novas ideias de planejamento, vocabulário moderno e inovador, e alta qualidade de execução (IMBERT; TREIB, 1997). Apesar de ter permanecido pouco tempo no escritório, Robert Francis teve contato intenso com essa produção, o que o possibilitou incorporar a linguagem empregada pelo escritório Eckbo, Royston \& Williams em seus projetos.

No livro Landscape for Living, de Garrett Eckbo, encontramos dois projetos que fazem referência à colaboração de Robert Coelho no escritório. O primeiro, a residência de Anthony Heinsbergen, ou "Garden in Los Angeles, California, 1947" como o próprio Eckbo descreve, é um jardim pequeno, em terreno plano e que apresenta "texturas na pavimentação, cobertura vegetal, suculentas, arbustos e árvores" (ECKBO, 1950b, tradução nossa). Podemos observar na implantação do projeto que alguns elementos são bastante característicos do desenho do escritório californiano: os degraus bem marcados e com forte geometrização; o uso de árvores em linha, nesse caso em diagonal, marcando a fachada da residência; e o emprego do pergolado, compondo texturas com luzes e sombras, incrementado por uma piscina ornamental e escultórica construída com material moderno, o acrílico. O projeto foi inicialmente publicado na revista House Beautiful e fotografado por Maynard Parker 6 .

6. Maynard L. Parker (1900-1976) foi pioneiro na documentação dos espaços 


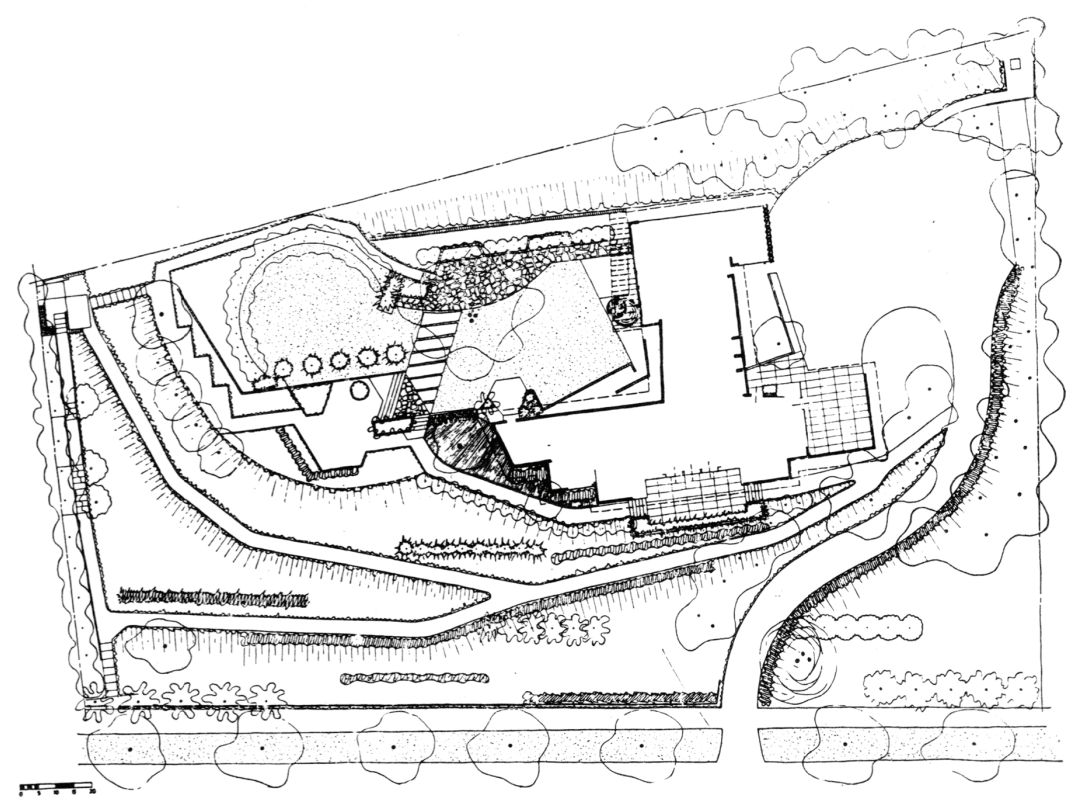

O segundo projeto, a residência I. H. Prinzmetal ou "Garden in Holmby Hills, Los Angeles, California, 1947”, é a remodelação de um grande jardim de residência moderna no luxuoso bairro de Holmby Hills, no distrito de Westwood, também em Los Angeles. Como proposta, os projetistas se apropriam de materiais modernos e de diferentes texturas para compor a nova área do terraço: o terrazzo (conhecido como granilite), muito empregado nas regiões mais quentes como Califórnia e Flórida, reveste o piso; as lascas de mármore (marble chip pattern, conhecido como fulget) recobrem a área da piscina, que também é ornamentada por uma escultura de concreto armado; e as toras de sequóias (redwood) incrustradas no piso formam um novo percurso, que direciona a uma área reservada na encosta do jardim, revestida de pedra natural (flagstone). A topografia do terreno é preservada, sendo transposta a partir de escadas e rampas que acompanham o desenho de taludes.

residenciais e das paisagens no pós-guerra americano, se destacando por promover o "american lifestyle" que se difundia a partir das revistas House Beautiful e Sunset. 

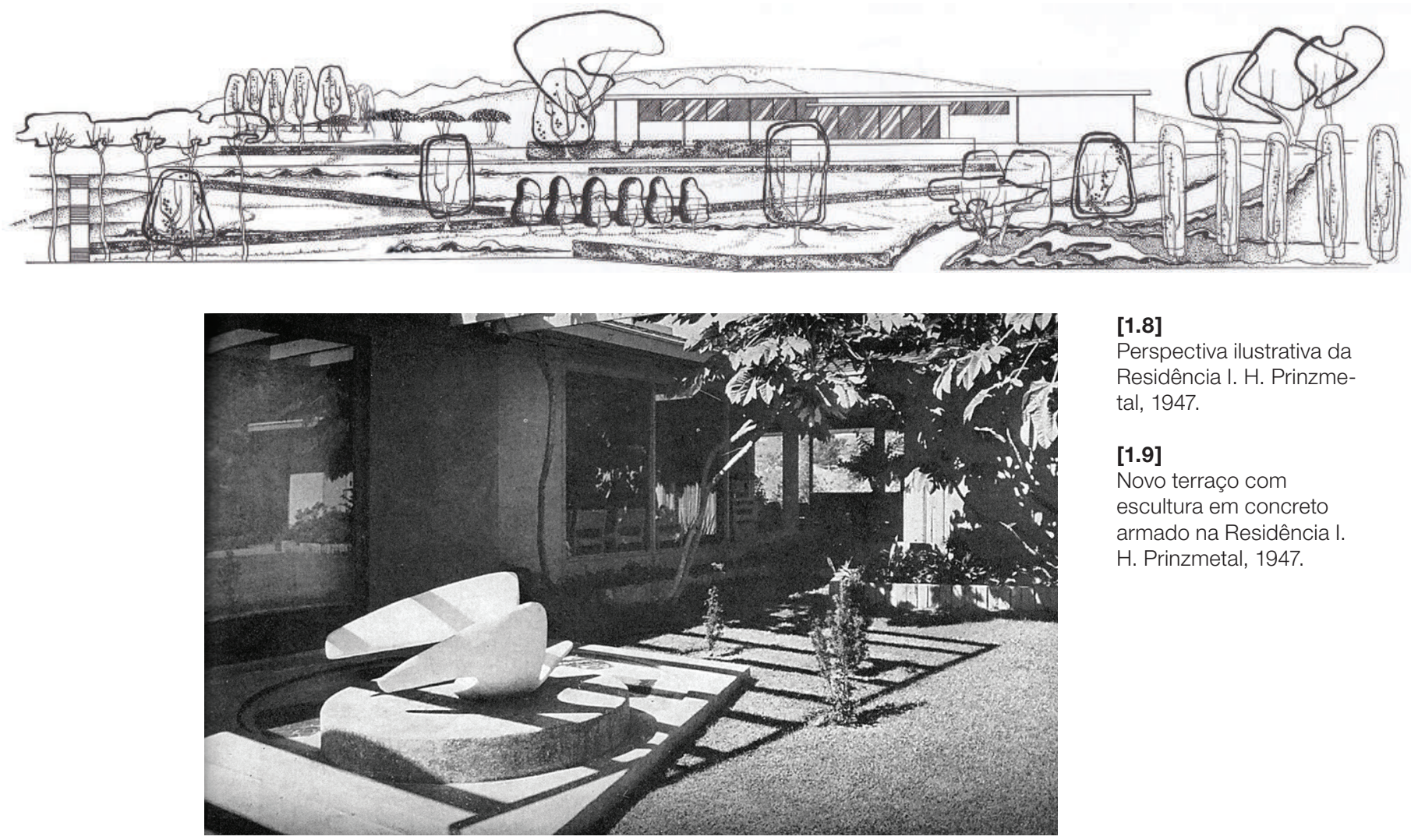

\section{[1.8]}

Perspectiva ilustrativa da Residência I. H. Prinzmetal, 1947.

\section{[1.9]}

Novo terraço com escultura em concreto armado na Residência I. H. Prinzmetal, 1947.

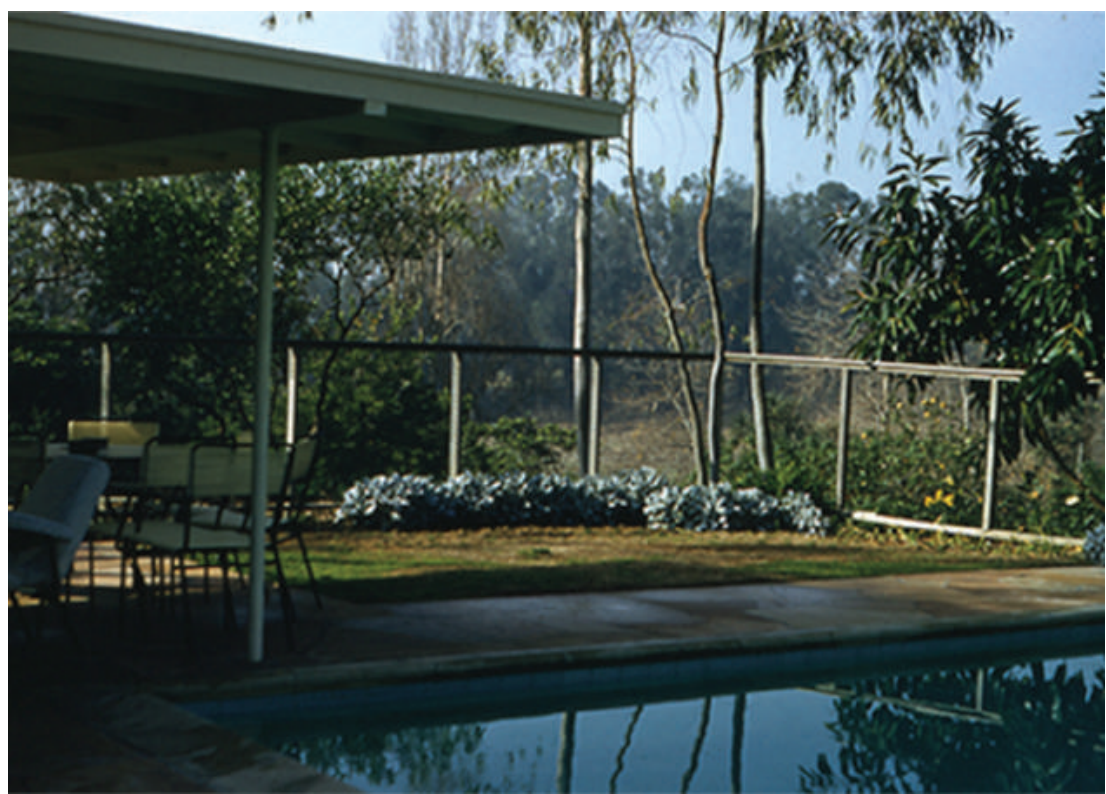

\section{[1.10]}

Vista da piscina e área de churrasco na Residência I. H. Prinzmetal, 1947. 
É interessante notar que nessa época, Robert Francis Coelho assinava como R. Coelho-Cordoza. Verificamos o nome tanto no livro de Eckbo quanto no desenho da churrasqueira para Stan Hawk, projetada em 1947, e que nesse caso, está assinada de próprio punho pelo paisagista.

Nesse projeto, Robert desenha uma churrasqueira portátil de ferro fundido com formato redondo e um rebuscado desenho de grelhas. De desenho arrojado, a peça foi exposta em 2012 no LACMA (Los Angeles County Museum of Art), na exposição "California Design, 1930- 1965: 'Living in a Modern Way"', ao lado de peças de Charles e Ray Eames, Richard Neutra, entre outros.

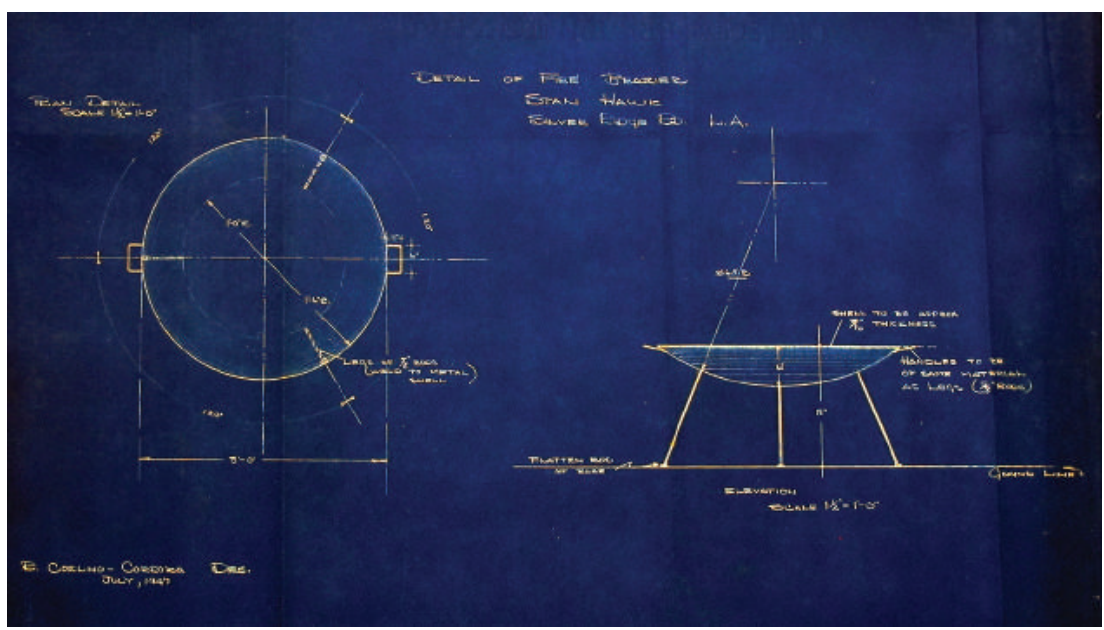

[1.12]

R. Coelho-Cordoza (n.d.) Hawk House (Los Angeles, n.d.) Barbecue-brazier, c.

1948

Cast iron 
No início de 1950, Robert Francis Coelho foi contratado pela Comissão de Planejamento de Los Alamos, no estado do Novo México, para trabalhar nas instalações da reserva federal militar da Atomic Energy Comission, que à época da Segunda Guerra Mundial sediava o Projeto Manhattan, designado para criar bombas nucleares. Esse trabalho é descrito, em artigo que apresenta o paisagista na revista Habitat, da seguinte maneira:

(...) Roberto após sua primeira experiência prática, teve a oportunidade de aplicar suas capacidades em trabalhos mais complexos e de maior alcance, como foi o projeto de Los Alamos, a cidade - oficina da bomba atômica, surgida no meio do deserto da Nova México em condições de tudo especiais. O estudo desta cidade, pensada para 12.000 habitantes, compreendia, além de residências particulares e apartamentos, escolas, hospitais, conjuntos de lojas, jardins e mesmo projetos para dar um aspecto panorâmico agradável e familiar a êsse recanto isolado das demais cidades americanas (CARDOZO, R. C.; COELHO, S.O., 1952).

Apesar da descrição do trabalho em Los Alamos parecer bastante atraente, o trabalho na reserva militar durou pouco tempo. A partir de relatos de amigos e familiares, Robert teria sofrido preconceito racial, por ser filho de imigrantes açorianos. A exclusão se dava tanto no âmbito socioeconômico, pela condição de imigração e também pela simplicidade da família, quanto pelas singularidades físicas, já que Coelho tinha traços fortes, cabelo bem escuro e a pele parda. Talvez por tal motivo, relatos indicam que Robert nunca havia se sentido parte da nação estadunidense e chegou ao limite de sua tolerância quando sofreu maus tratos na reserva militar de Los Alamos (ACAYABA, 2015; COELHO, 2015). 


\subsection{AS RELAÇÕES NOS TRÓPICOS: SOCIABILIDADE E PAISAGISMO.}

Durante seus anos de formação acadêmica, Robert conhece Mary Susan Osborn, nascida em 24 de janeiro de 1927 na cidade de Los Angeles, e que posteriormente se tornaria sua esposa. Mary Susan também estudou na Escola de Agricultura da UCBerkeley e era considerada uma aluna brilhante, tendo se formado dois anos mais tarde, em janeiro de 1949, em primeiro lugar de sua turma (ZOLKO, 2015).

Uma vez que Portugal não era uma opção para o movimento migratório, dada a situação de destruição e penúria do pós-guerra na Europa, o casal decidiu mudar-se para o Brasil. Ainda em 1950, deram entrada com o pedido de visto de permanência no Consulado do Brasil em Los Angeles. Chegando ao Brasil, com o intuito de integrar-se completamente à cultura do país, o paisagista adota o sobrenome Cardozo, uma possível variação "abrasileirada" do sobrenome de solteira de sua mãe $e^{7}$ Cordoza, e passa a apresentar-se como Roberto Coelho Cardozo. Sua esposa, seguindo seus passos, também passa a ser conhecida como Susana Osborn Coelho.

É importante ressaltar que antes de deixar o escritório Eckbo, Royston \& Williams, Robert Francis Coelho pediu uma carta de recomendação de trabalho para Garrett Eckbo, que o apresenta como "muito competente e imaginativo em seu trabalho profissional, uma pessoa cuja a integridade e a honestidade não podem ser questionadas" (ECKBO, 1950a, tradução nossa). Foi a partir dessa carta de apresentação que o paisagista conseguiu seu primeiro emprego no país, no escritório de Roberto Burle Marx, iniciando sua trajetória no Brasil (KLIASS, 2009).

7. Essa foi uma questão discutida com a família do paisagista. A princípio, nem os próprios filhos sabiam do sobrenome da avó Celestina. Acreditavam que o sobrenome era Cardozo, dada a familiaridade com que absorveram esse sobrenome. Porém, com a busca de registros da família, foi possível descobrir que o sobrenome da mãe de Roberto era, de fato, Cordoza. E a suposição do "abrasileiramento" do sobrenome realmente surgiu com a questão de aceitação do estrangeiro no Brasil. 
Sua estadia no escritório durou menos de um ano. Roberto Coelho Cardozo era conhecido por seu grande magnetismo, irreverência e intuição e, ao mesmo tempo, por seu caráter intempestivo e muitas vezes vaidoso. Os amigos próximos afirmam que os dois paisagistas não conseguiram conciliar suas personalidades fortes e em curto espaço de tempo tiveram um desentendimento. Mas, mesmo nesse diminuto período, Roberto Coelho Cardozo foi enviado, pelo escritório carioca, a uma expedição na Amazônia. Não existe registro acerca da data dessa viagem, mas foi nela que Roberto teve o primeiro contato com a exuberância da vegetação nativa brasileira.
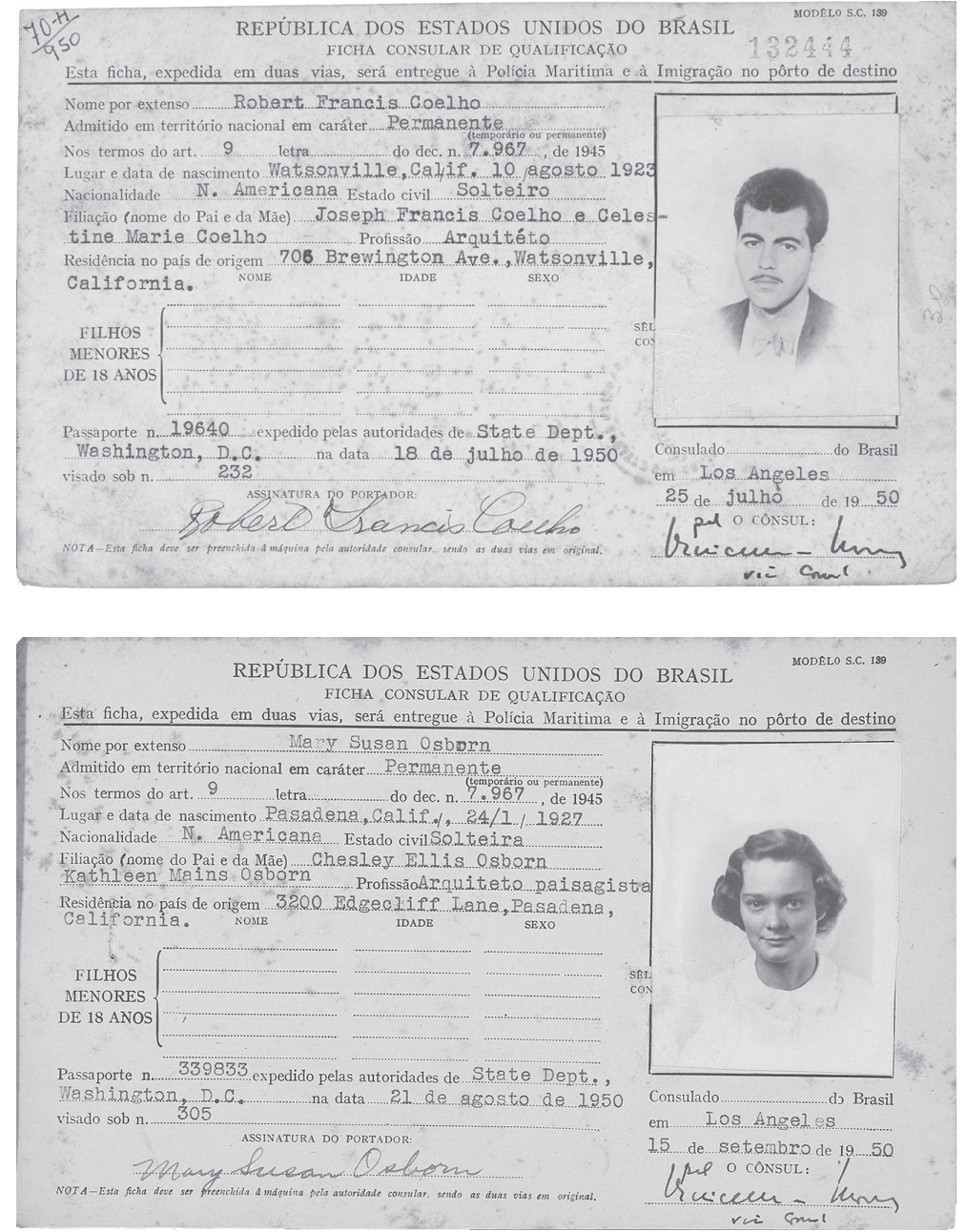

[1.13]

Permissão de imigração ao Brasil de Robert Francis Coelho.

[1.14]

Permissão de imigração ao Brasil de Mary Susan Osborn. 
[1.15]

Carta de apresentação escrito por Garrett Eckbo para Robert Francis Coelho (1950).

\section{[1.16]}

Roberto Coelho Cardozo (dir.) e Roberto Burle Marx (esq.) em 1951.
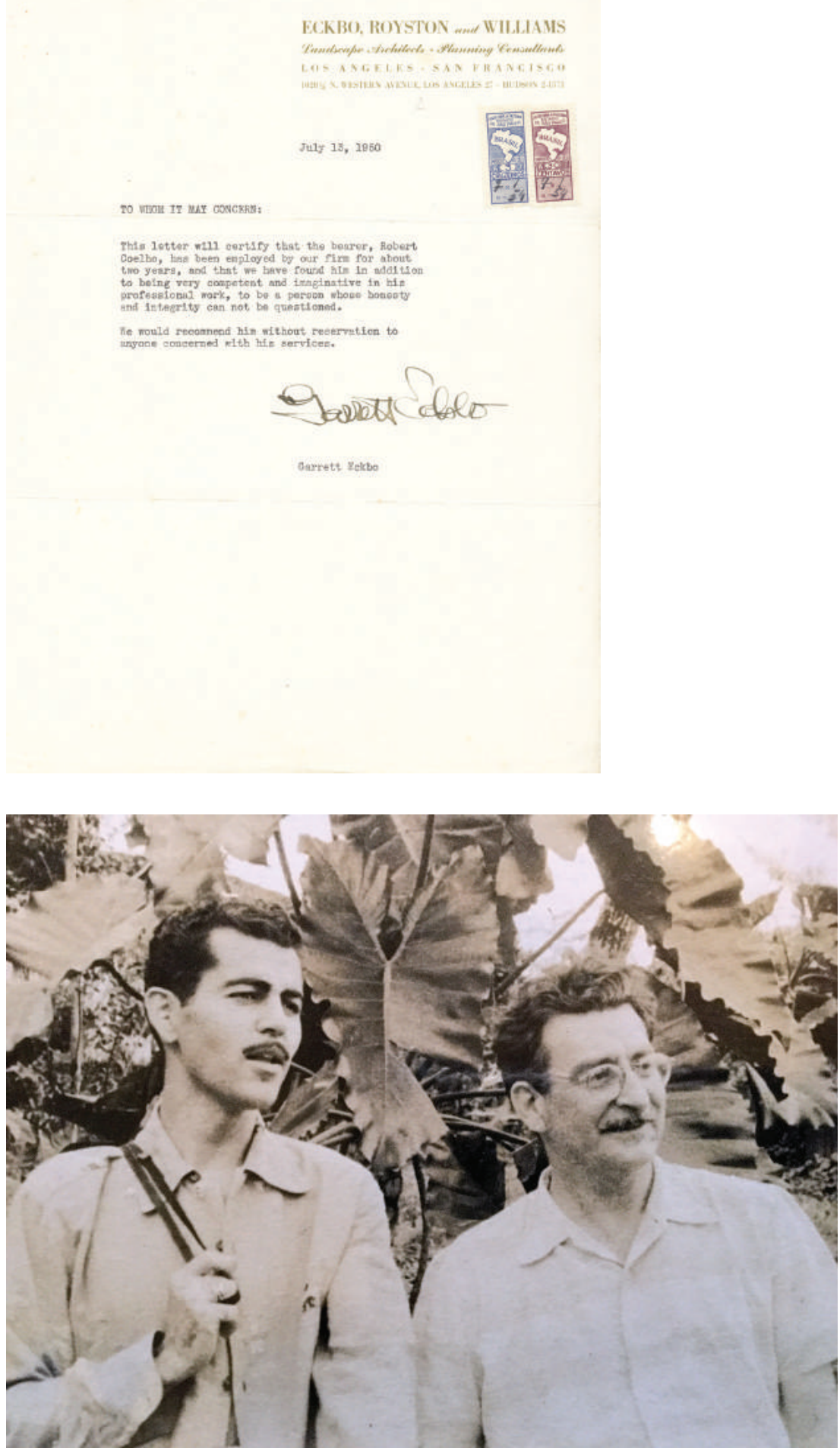
Após esse período no Rio de Janeiro e na Amazônia, Cardozo decide se mudar para São Paulo, que neste momento não contava com um campo profissional de paisagismo muito desenvolvido. O recém-constituído curso de Arquitetura e Urbanismo da Universidade de São Paulo, em 1948, ainda não abarcava a disciplina de paisagismo e não existia na cidade qualquer outro curso na área, mesmo que profissionalizante. A atuação na "arte de jardins" era preenchida por técnicos de todos os tipos: botânicos, agrônomos, produtores de mudas e jardineiros. Esses técnicos tinham grande expertise na área técnica, como era o caso de fornecedores de mudas como a Casa Flora, de Germano Zimber, e a Dierberger \& Cia., de Reynaldo Dierberger, que foram os responsáveis pela reprodução e posterior distribuição das mudas autóctones que eram produzidas na cidade (PERECIN, 2003). Ao mesmo tempo, os projetos desses técnicos não apresentavam sinais da inovação almejada pelos clientes e pelas instituições públicas, mais próximos do ideário e da linguagem moderna. É justamente esta demanda que abre espaços para profissionais como Roberto Coelho Cardozo e o artista plástico Waldemar Cordeiro ${ }^{8}$ no mercado paulistano de paisagismo.

Em artigo publicado pela Folha da Manhã em 10 de junho de

8. Waldemar Cordeiro (1925-1973) nasceu em Roma, Itália, e frequentou o Liceo Tasso e a Accademia di Belle Arti. Filho de uma italiana e um brasileiro, veio ao Brasil em 1946 pela primeira vez para conhecer seu pai e trabalhou como jornalista e crítico na Folha da Manhã. Voltou à Itália e iniciou suas primeiras produções artísticas abstratas. Em 1949 voltou ao Brasil, onde fixou residência até o período de sua morte. Cordeiro foi mais conhecido pela sua obra artística como líder do Grupo Ruptura, movimento concretista de São Paulo, mas também trabalhou paralelamente como paisagista. Inicialmente, Cordeiro optou pelo paisagismo como meio de subsistência, porém, após estudar dois anos de Botânica, o artista plástico começa a explorar em seus estudos artísticos as estruturas que observa na Natureza. Segundo o artista: "A natureza é ainda, ao lado do conhecimento livresco, um manancial inesgotável de conteúdos. A flora ornamental é uma lição de arte para quem observe a riqueza morfológica, a economia dos acabamentos, a riqueza cromática e principalmente para quem queira refletir um instante sobre a linguagem substancialmente idêntica dos produtos da natureza e daqueles da cultura". Em 1954, abre o escritório Jardins de Vanguarda Ltda., onde trabalhou em parceria com Luiz Sacilotto. Waldemar Cordeiro projetou mais de duzentos jardins de residências, edifícios residências e obras públicas entre 1953 e 1973. 
1956, Yvonne Jean apresenta o casal Roberto e Susana como Landscape architects e segundo ela:

emprego a palavra estrangeira porque, por estranho que possa parecer, ainda não temos no Brasil, "arquitetos-paisagista" oficialmente reconhecidos, apesar da importância sempre maior dada aos jardins que completam a casa. A Faculdade de Arquitetura e Urbanismo só forma arquitetos. Não cogitou, ainda, de estabelecer a complexa e importante profissão de arquiteto de jardins. Quem quiser se especializar neste ramo terá que fazê-lo de modo autodidático, a não ser que estude em outro país. O casal Coelho estudou em Harvard e entende profundamente de uma profissão árdua, pois não se trata, como tantos imaginam, de encher alguns espaços com plantas, ao acaso da vontade, mas de um planejamento em três dimensões: de um planejamento em que o jardim, ou melhor, a paisagem ambiente e a arquitetura das casas se integrem; de um planejamento que prevê o crescimento das árvores e plantas e seu aspecto futuro; de um planejamento que dê a todos os materiais empregados a mesma importância (...) (JEAN, 1956).

Dessa maneira, Roberto e Susana, que inicialmente trabalhavam em conjunto e assinavam os projetos como Osborn Coelho Cardozo, logo começaram a ser requisitados para diversos trabalhos na cidade de São Paulo. O primeiro deles foi a residência de Alfredo Rosenthal, localizada no bairro do Pacaembu e projetada por João Batista Vilanova Artigas em 1951. Com um lote estreito, o jardim foi restrito às laterais da casa e à fachada principal. Mesmo com esse espaço reduzido, o casal conseguiu criar componentes que dialogassem com a arquitetura de Artigas, como é o exemplo do caminho formado por lajotas redondas de cimento que perpassam a área de garagem, coberta por uma estrutura de concreto em arco. A massa vegetal das fachadas frontal e lateral servem de anteparo, fornecendo mais privacidade aos moradores através de uma textura pulverizada nas visuais das janelas.

Porém, o mais marcante desse projeto é o conjunto dos desenhos técnicos, intimamente relacionado ao modo de representação dos paisagistas norte-americanos. Percebe-se que desde o primeiro projeto em São Paulo, o casal já adotava um padrão bastante criterioso, com desenhos de planta bem resolvidos, indicação de vegetação adequada a cada espaço e cuidado no detalhamento do projeto, que eram bastante elaborados para a época. Essa sistematização do projeto de paisagismo ainda estava em desenvolvimento no Brasil e nesse sentido, 
esses desenhos que exploram as relações de proporção e densidade do conjunto vegetal e da edificação podem facilmente ser reconhecidos como herança de uma sistematização adquirida tanto na UCBerkeley quanto no escritório Eckbo, Royston \& Williams.

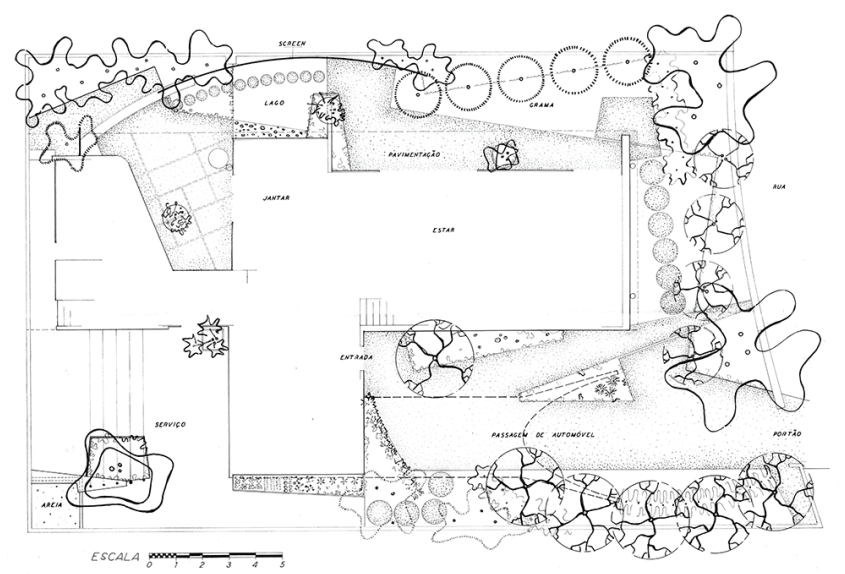

ROBERTO COELHO. CARDOZO
SUSAN OSBORN COELHO

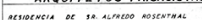

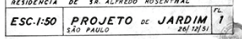

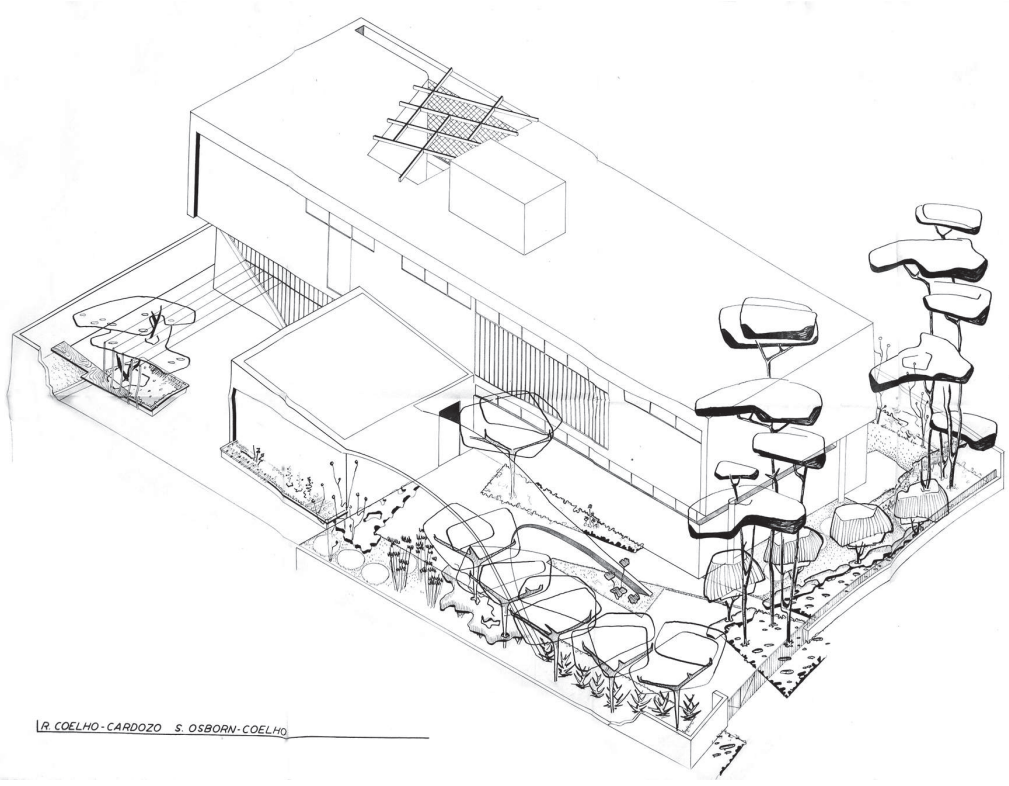

[1.17]

Projeto de Jardim para a residência Elphy e Alfredo Rosenthal. Data do desenho: 26/12/1951

\section{[1.18]}

Perspectiva ilustrativa para a residência Elphy e Alfredo Rosenthal. 
Recorte sobre a participação de Susan Osborn Coelho e mais 13 participantes na VIII Bienal de Arte de São Paulo, na seção de Jóias.

\section{ARTES PLASTICAS}

\section{Bienal de Jóias: 14 artistas aceitos}

Ivo ZANINI

Com um total de 217 peças, 14 artistas inscritos à Bienal de Jóias foram aceitos para figurar no certame internacional, a inaugurar-se no inicio de setembro no Ibirapuera. Houve a eliminaçấo de 5 concorrentes.

Os aceitos são: Burle Marx, Pedro Correia de Araujo, Calabrone, Susan Osborn Coelho, Geraldo Mayer Jurgense, Ulla Johnson, Marcel Kung, Livio Levi, Edith Low-beer, Valter Gomes Marques, Marcio Mattar, Caio Mourão, Renée Sasson e Luigi Zanotto.

Integraram o juri os mesmos elementos do setor de Artes Plasticas, exceção do sx. Mario Pedrosa que não compareceu, ou seja, os srs. José Geraldo Vieira, Fernando Lemos, Geraldo Ferraz e Mario Schemberg.

Pouco a pouco, o casal norte-americano foi ganhando mais espaço no meio arquitetônico e formando parcerias com diversos escritórios, como foi o caso de uma série de projetos feitos para o Escritório Técnico Lucjan Korngold Engenharia e Construções, onde trabalharam com o próprio Korngold e também com a arquiteta Marjan Ryszard Glogowski.

Entretanto, apesar do importante papel de Susana, mais um desentendimento rompe com as relações profissionais estabelecidas por Cardozo. Segundo o relato de Gregório Zolko e do filho Peri Jon, havia uma rivalidade profissional entre o casal, principalmente por conta da atitude ciumenta de Roberto em relação ao seu trabalho (ZOLKO, 2015; COELHO, 2015). Sendo assim, a parceria profissional se desfez e Susana iniciou uma prática de joalheria, tornando-se designer de joias. Expôs seu trabalho na $8^{\text {a }}$ Bienal de Artes de São Paulo ${ }^{9}$, ao lado de 14 outros artistas, incluindo Roberto Burle Marx. Em paralelo, executava individualmente e de maneira esporádica trabalhos de paisagismo. Roberto seguiu com seus projetos, eventualmente contratando estagiários e arquitetos para assessorá-lo.

É interessante notar que a notícia da chegada de um paisagista norte-americano chamava a atenção dos arquitetos de São Paulo. Um 
exemplo é o encontro de Cardozo e Gregori Warchavchik, conforme relata Gregório Zolko, arquiteto formado pela University of Illinois, grande amigo do paisagista e que trabalhou como estagiário de Warchavchik em 1955:

O Warchavchik, nessa época, ficou sabendo do Roberto. Como o Roberto tinha dificuldade em se expressar, ele falava meio em inglês e meio em português, e o Warchavchik falava com aquele sotaque russo, fui chamado para ser intérprete (ZOLKO, 2015).

Zolko intermediou uma conversa e a negociação para contratação do projeto de paisagismo do Clube Paulistano. Apesar de um início de diálogo conturbado, no qual Warchavchik e Cardozo pouco se entendiam em meio a discussões acaloradas, logo o arquiteto russo passa a contratá-lo para alguns projetos, como o Paulistano ou o Clube Monte Líbano.

Essa era uma característica muito forte em Roberto, sua habilidade em demonstrar a importância do paisagismo através de "boas ideias". A primeira abordagem nem sempre era bem-sucedida, com momentos de antipatia entre cliente e paisagista, mas depois de algumas conversas, o paisagismo era contratado como parte indispensável do projeto (ZOLKO, 2015).

Foi possível contabilizar 192 projetos de paisagismo em áreas residenciais, institucionais e públicas, realizados ao longo desses vinte anos em que Roberto Coelho Cardozo esteve no Brasil, de 1950 a 1970.

A partir desta listagem, podemos perceber que durante esse período Cardozo estabeleceu um grande contato com a elite política e econômica paulistana. Por um lado, foi contratado para consultorias em paisagismo nos programas públicos implantados durante a gestão do governador Roberto Costa de Abreu Sodré ${ }^{10}$ - como o Fundo Estadual de Construção de Escolas (FECE) e as unidades da Repartição de Esgotos e Águas (REA) - e durante a gestão de Laudo Natel ${ }^{11}-$

10. Roberto Costa de Abreu Sodré (1917-1999) era advogado e foi governador do Estado de São Paulo entre 1967 e 1971. Durante sua gestão criou a Fundação Padre Anchieta, o Fundo Estadual de Construções Escolares (FECE) e iniciou as obras do Metrô de São Paulo.

11. Laudo Natel (nasceu em 1920) é empresário e foi governador do Estado 


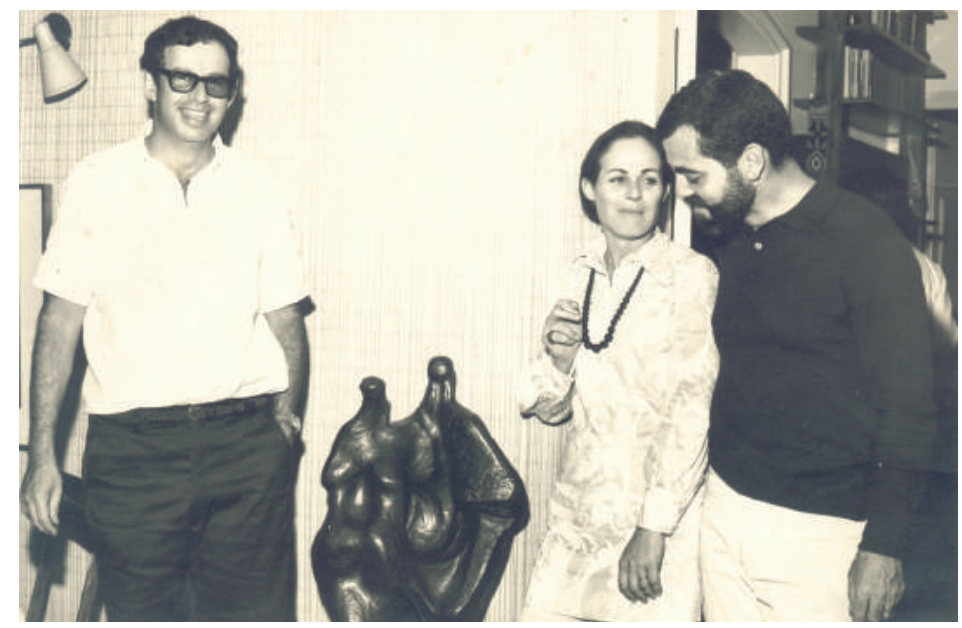

como as usinas das Centrais Elétricas de São Paulo (CESP). Por outro, circulou entre as comunidades judaica e sírio-libanesa de São Paulo, tendo contato com famílias que se relacionavam estreitamente com o mercado imobiliário ${ }^{12}$, como os Kasinski, Landau, Neuding, Rothstein, Zulberman, Cury, Mattar, Maluf, entre outras.

Por fim, construiu uma forte ligação com alguns núcleos da sociedade burguesa tradicional da cidade, como era o caso das famílias Klabin, Matarazzo, Scarpa, Penteado e Villares. Cardozo, não só projetava seus jardins, como muitas vezes fazia o plantio nas obras e acompanhava os clientes nas compras de vegetação e acessórios. Tal atitude permitiu um estreitamento das relações entre o paisagista e seus clientes, estabelecendo muitas vezes laços de amizade. O filho do paisagista, Peri Jon Osborn Coelho, conta que a família era convidada frequentemente para jantares e festas na casa desses clientes, ou para passar fins de semana em suas casas de campo (COELHO, 2015).

de São Paulo em duas ocasiões: entre 1966 e 1967, quando substituiu o governador cassado Adhemar de Barros, e entre 1971 e 1976. Durante sua primeira gestão, unificou as onze usinas hidrelátricas de São Paulo, criando a empresa Centrais Elétricas de São Paulo (CESP), que posteriormente seria renomeada de Companhia Energética de São Paulo (CESP).

12. SILVA (2010) desenvolve as relações entre essas famílias que empreendiam no mercado imobiliário e os arquitetos estrangeiros, Jacques Pilon, Lucjan Korngold e Victor Reif. LIRA (2011) também desenvolve esse assunto ao abordar a clientela de Gregori Warchavchik. 
Tais laços contribuíram de maneira importante para a divulgação do trabalho do paisagista. Mas, para além dessas relações profissionais e pessoais, a divulgação do trabalho de Cardozo também se deu de maneira enfática através das revistas especializadas, principalmente a partir da revista Casa e Jardim, onde muitos de seus trabalhos foram publicados.

Criada em 1953, a publicação mantém até hoje suas atividades, ainda que com um enfoque diferente, mais voltado à arquitetura. No entanto, na década de 1950, buscava aproximar-se dos interesses femininos, com colunas específicas de culinária e costura, dedicando sua atenção principal ao paisagismo. Em suas páginas, foram publicados projetos sobretudo de São Paulo e Rio de Janeiro, com ênfase nas obras de Roberto Burle Marx, Waldemar Cordeiro e Roberto Coelho Cardozo, mas também havia espaço para empresas especializadas, como era o caso da Diergerber Agro Comercial Ltda., da Hortulania Paulista, da Casa Flora e dos Jardins Tropicais Ltda. Também veiculava dicas de plantio e de escolha de plantas, como era o caso das colunas "Ó jardineira" e "Plantando brincando no ano inteiro". Certamente foi um dos meios mais importantes de divulgação dos trabalhos de paisagismo à época, sempre enfatizando a importância da contratação dos serviços especializados (MACHADO, 2007).

Na matéria "O paisagista é importante", Olga Meraviglia descreve de maneira simples e clara a necessidade do paisagista para um bom desenvolvimento do jardim:

Ao construir a sua casa, a maioria das pessoas se preocupa tão-só com a construção em si e a decoração interior, achando desnecessário consultar um especialista para a parte exterior - o jardim.

Julgam que o arquiteto e o decorador de interiores são o suficiente para lhes garantir o paraíso, que reúna beleza e o conforto de há muito sonhados. Parece-lhes coisa simples arranjar depois o jardim, porquanto, uma porção de lojas e floriculturas existem por aí, a oferecer toda espécie de sementes, plantas e árvores. Uma informação tirada de revista, outra de livro e eis o bastante para a pessoa considerar-se perita no assunto. Certamente, algumas chegam a ser bem-sucedidas, porém, são muitas as que ficam perplexas e confusas, sem saber o que fazer, ao terminar a época de chuvas ou quando as plantas sem uma razão aparente começam a fenecer. 
Um arquiteto-paisagista não é somente o homem capaz de projetar um jardim, transformando-o em verdadeiro complemento de salubridade e beleza de nossa casa recém-construída; é aquele que seleciona as flores, plantas e árvores apropriadas, colocando-as cada qual em seu lugar mais conveniente, tendo em vista seus reconhecimentos técnicos no que se refere à vegetação e estrutura. Ele sabe com exatidão escolher o melhor cantinho para uma planta delicada e aproveitar uma determinada parede da casa para protege-la contra o vento ou sol demasiado fortes para ela. Antes de executar, estuda a melhor locação para o próprio jardim, a linha de água, as combinações de cores e pensa não só em sua aparência momentânea como no efeito futuro e nas despesas. Enfim, aplicando esteticamente o bom, ele consegue atingir o belo.

Somando aos projetos publicados, Roberto também escreveu uma série de artigos para o público geral, utilizando linguagem acessível e conteúdo simples, sobre pisos e revestimentos, sobre acessórios para o jardim, sobre plantas e sobre importância do paisagismo em geral. Talvez a nós também, depois de algum tempo, estas coisas se tornarão familiares; contudo, quanto dinheiro não gastaremos em experiências até chegarmos a tal resultado? O paisagista, além de ser uma pessoa formada em assunto de jardinagem, já possui muita prática em trabalhos sob certas condições dos elementos naturais, como clima, água, etc. (MERAVIGLIA, 1955).

Apesar de não haver uma profunda discussão sobre projeto de paisagismo nessas reportagens, a divulgação através dessas revistas ampliou o incipiente mercado para este tipo de profissional em São Paulo. Roberto Coelho Cardozo publicou alguns artigos em que expunha suas ideias sobre a importância dos jardins e seus componentes, como pisos, revestimentos e vegetação. Em textos como "Biombos como barreiras" (CARDOZO, 1955C) ou "Pisos em jardins modernos" (CARDOSO; COELHO, 1958), conseguimos identificar algumas referências da corrente californiana de paisagismo, e uma visão mais ampliada sobre arquitetura paisagística. 

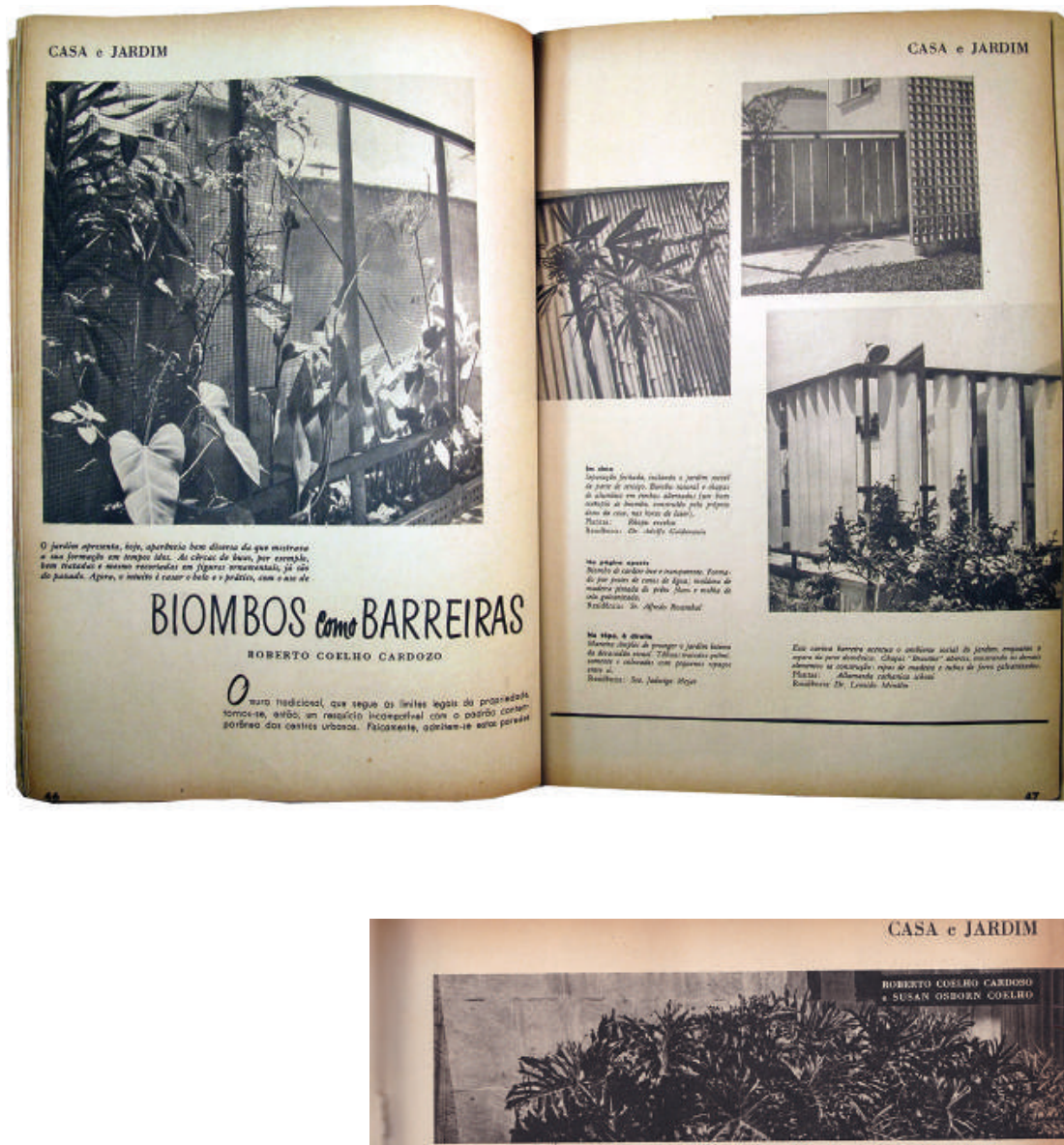

\section{PISOS em jardins modernos}

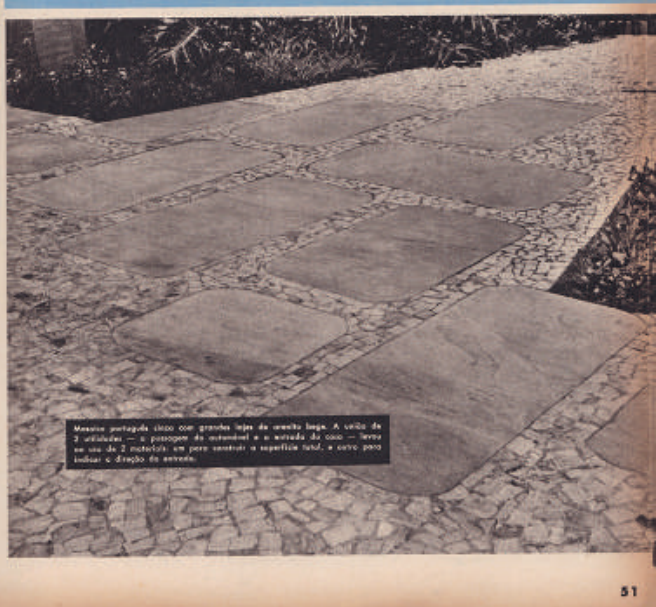

[1.21]

Artigo "Biombos como barreiras" escrito por Roberto Coelho Cardozo e publicado na revista Casa e Jardim, 1955.

\section{[1.22]}

Artigo "Pisos em jardins modernos" escrito por Roberto Coelho Cardozo e Susan Osborn Coelho, publicado na revista Casa e Jardim, 1955. 
Dessa maneira, ao estabelecer laços com grupos sociais variados e se inserir na mídia impressa, a reputação de Roberto Coelho Cardozo foi se ampliando e permitindo a formação de uma rede de contatos e de parceiros no meio arquitetônico bastante ampla, tendo trabalhado com: Abelardo Reidy de Souza, Abrahão Velvu Sanovicz, Adilson C. Macedo, Alfredo J. Duntunch, Ariaki Kato, Arnaldo Furquim Paoliello, Benno Perelmutter, Botti Rubin Arquitetos, Carlos Alberto Cerqueira Lemos, Construtora Waldomiro Zarzur, Danilo Bassani, Dário Imparato, Ernst Robert Carvalho Mange, Escritório Técnico J. C. Figueiredo Ferraz Engenharia Civil, F. Henri Cahen \& Cia Ltda, Flavio Pastore, Luigi Villacecchia e Paulo Ballartio Arquitetos, Francisco Beck, Franz Heep (Construtora Heep), Gilberto M. Tinoco, Gregori Warchavchik, Gregório Zolko, Hélio Correa, Hélio de Queiroz Duarte, Henrique Alexander, Henrique Ephim Mindlin, Ibsen Pivatelli, Ícaro de Castro Mello, Imobiliária Vaz Guimarães Ltda., Israel Sancovski, Jeronimo Bonilhas Esteves, João Bapstista Vilanova Artigas, Joaquim Guedes, Joaquim Procópio de Araújo, Jorge Caron, Jorge Nasser, Jorge Wilheim, José L. Fleury de Oliveira, José Maria de Mello, Julio D’Este Penrose, Julio Roberto Katinsky, Kaiser Engenharia e Construções Ltda., Leonidas Soares Botelho, Lúcio Grinover, Lucjan Korngold, Marjan Ryszard Glogowski, Mieczyslaw Grabowski, Miguel Badra Jr., Renato Teixeira (Eng.), Nelson Daruj, Pedro Antonio G. Cury, Ricardo Sievers, Rino Levi, Roberto Cerqueira Cesar, Roberto José Goulart Tibau, Rubens Carneiro Vianna, Rubens de Camargo Monteiro, Silvano Wendel Filho, Vaidergon \& Verona Arquitetura e Construções e Victor Reif. 


\subsection{A ATUAÇÃO DOCENTE NA FAUUSP.}

Paralelamente ao trabalho profissional, Roberto Coelho Cardozo desenvolveu a atividade docente. Cardozo foi o primeiro professor de paisagismo da graduação da Faculdade de Arquitetura e Urbanismo da Universidade de São Paulo (FAUUSP) sendo oficialmente contratado em setembro de 1952 para ministrar a "Disciplina no. 20 - Arquitetura Paisagística".

O diretor da recém-inaugurada faculdade, Luiz Ignácio de Anhaia $\mathrm{Mello}^{13}$, procurava alguém para preencher o posto de professor da disciplina, uma vez que o Engenheiro Arquiteto Francisco Prestes Maia, indicado para exercer tal função, havia declinado ao seu convite. Tendo notícia do paisagista recém-chegado a São Paulo, logo articulou a contratação de Cardozo para preencher a vaga. José Maria da Silva Neves, professor da disciplina "Composição Decorativa" e Joaquim Bezerra da Silva, professor da disciplina "Arquitetura Analítica", escrevem sobre Cardozo em carta para os Membros da Comissão de Ensino e Regimentos do Conselho Universitário:

se trata de pessoa de preparo profissional especializado, artista de delicado sentimento e fértil imaginação, hábil projetista, homem prático na escolha e distribuição das espécies vegetais, aproveitando espaços entre as construções com admirável senso de forma e equilíbrio das massas a par de uma perfeita harmonia entre a arquitetura e a vegetaçãa ${ }^{14}$.

Essa era a justificativa para Cardozo se tornar professor catedrático na nova faculdade, ministrando sua disciplina no $5^{\circ}$ ano da graduação. Em 1956, a disciplina foi renomeada para "Cadeira no. 28 - Arquitetura Paisagística” e se manteve assim até 1962, quando ocorreu a Reforma Curricular de Ensino da FAUUSP e a disciplina

13. Luiz Ignácio de Anhaia Mello (1891-1974) era engenheiro-arquiteto, formado pela Escola Politécnica em 1913. Nessa mesma instituição foi catedrático da cadeira "Estética, composição geral e urbanismo I e II". Também se engendrou na política, sendo eleito vereador e prefeito de São Paulo pelo Partido Democrático (PD). Na FAUUSP foi diretor em duas ocasiões: entre 1948 e 1951 e entre 1959 e 1961.

14. Processo no.52.1.14106.1.2 - Contratação de docente, Roberto Coelho Cardozo - folhas 5 e 6. Data: 01/09/1952. 
passou a ser ministrada no Departamento de Projetos, dentro do grupo de disciplinas de Planejamento Urbano. Nesse momento, Roberto Coelho Cardozo passou a lecionar a "Cátedra no. 28 - Planejamento I".

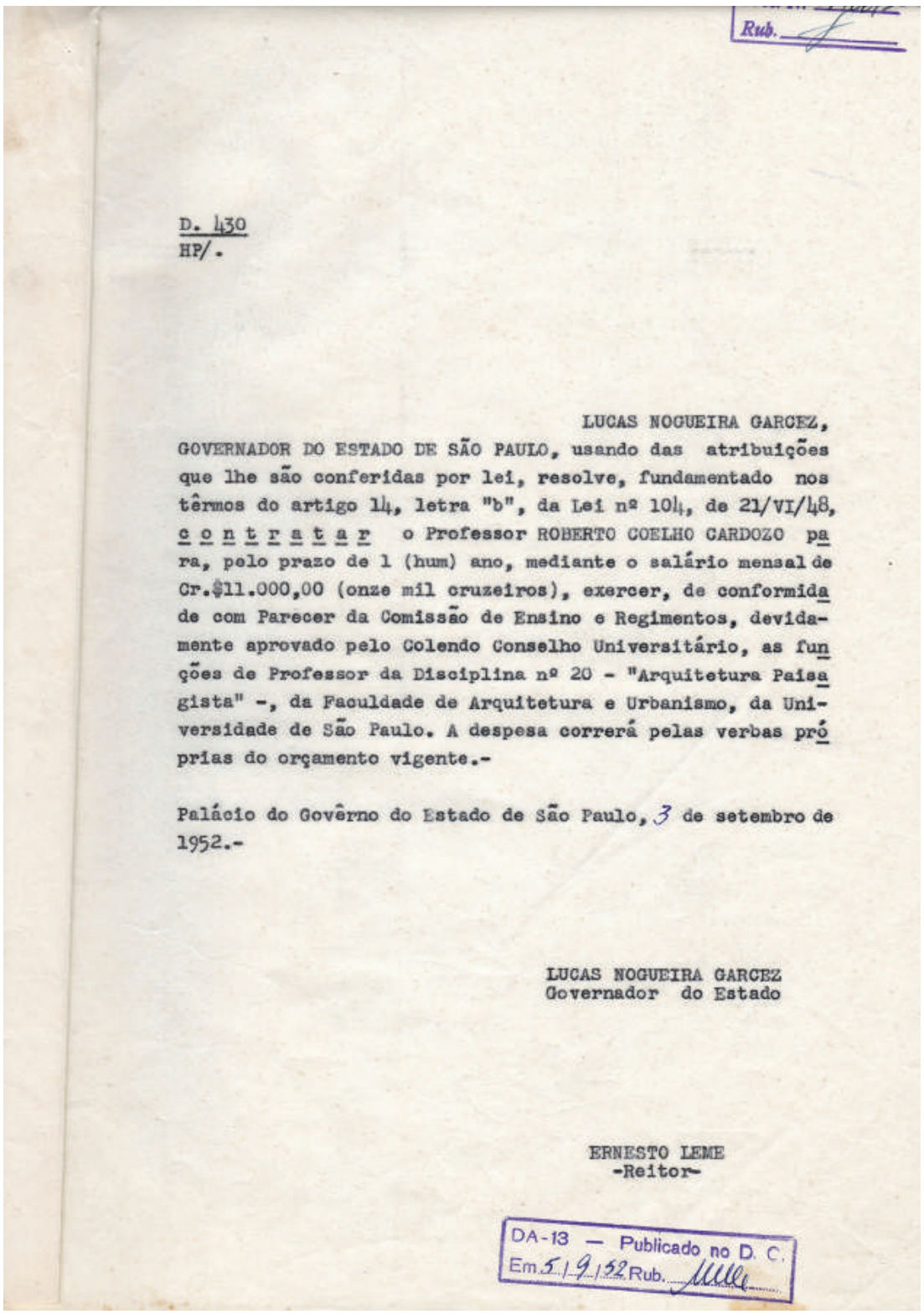


Em 1953, logo de seu ingresso, Roberto acompanhou os alunos em uma viagem organizada pelo grêmio da Faculdade para as cidades históricas de Minas Gerais (SODRÉ, 2010). Sobre isso Miranda Magnoli conta:

Os alunos faziam viagens nas férias. Daquela vez, foi para as cidades de Minas. Em outra ocasião, fomos a Recife. Para Recife foi o Fracarolli ${ }^{15}$ (acompanhando os alunos). Sempre tinha um professor acompanhando porque teoricamente era uma viagem com os alunos da faculdade. E, no do $3^{\circ}$ ano da faculdade, fomos, em julho, para as cidades mineiras. E o professor que nos foi acompanhando foi o Roberto Coelho Cardozo. Ele estava curiosíssimo por conhecer as cidades mineiras, conhecer os alunos, estar com os alunos. E foi tão marcante para mim. Não me lembro em que trecho, nós estávamos de trem. Nós estávamos indo, já não me lembro de que pedaço a que pedaço. Não sei se era de Belo Horizonte a Ouro Preto.

Mas lembro ainda que ele estava em uma janela de trem, e eu também. Parece tão distante e olha que tenho péssima memória. Mas lembro dele vendo a paisagem. Aquela montanha, aquela pedra. A paisagem mineira é muito típica, é muito própria. E ele seguia colocando perguntas para mim, perguntas como quem está fazendo você refletir: por que isso é assim? Não que se você tivesse lido algum livro você saberia a resposta, mas ele perguntava: "por que é assim, o você acha que aconteceu para formar isso?". Eu pensava: "Onde esse cara foi inventar essas coisas?"; "Como que passa pela cabeça dele esse tipo de questão? ”. Eu ouvi com ele, pela primeira vez naquela época, questões que hoje estão falando sobre proteção do meio ambiente. Evidentemente eu não entendia na época. Achava aquilo tudo muito estranho! Estranho!!! Estranho!!! Muito esquisito, mas muito interessante (risos) (SILVA, 2006).

Por esse depoimento de Magnoli percebe-se que a figura do professor era intrigante. Muitos gostavam de suas aulas, mas, ao mesmo tempo, havia uma dificuldade de compreensão por parte dos alunos, seja pela comunicação por conta do idioma (a mistura de inglês e português), seja pela complexidade dos assuntos abordados em aula. Cardozo muitas vezes colocava questões em sala de aula voltadas à paisagem e à natureza, questões que não eram abordadas até então. A disciplina englobava aulas teóricas, que discutiam sobre o desenvolvimento de

15. Refere-se ao professor Caetano Fracarolli. 
"uma sensibilidade madura para a paisagem, a vida e os elementos nela integrados" (CARDOZO, 1956) e exercícios práticos, que trabalhavam questões de topografia e implantação, da relação da rua e do lote e dos sistemas viários da cidade (SILVA, 2006).

Nesse sentido, Roberto teve grande importância no ambiente acadêmico da FAUUSP. Apresentava novas indagações que eram abordadas nas disciplinas de Paisagismo e de Planejamento e envolveu, nesses anos, muitas pessoas ao redor de seu trabalho. Além das aulas, Cardozo também empregava alunos e recém-formados em seu escritório. Trabalharam com ele Ayako Nishikawa, Miranda Magnoli, Luciano Fiaschi, Antônio Augusto Antunes Neto e Marcos de Souza Dias, sendo que os dois últimos também lecionaram na FAUUSP. Teve como professores assistentes a paisagista Daisy Ruth Igel Hoffenberg e o arquiteto Rodolpho Almeida Fernandes.

[1.24]

Viagem para Congonhas do Campo (MG), julho de 1953. Da esquerda para direita: Rosa Grena Alembick, Wlademir Kliass, Miranda Martinelli e Edoardo Rosso (sentados). Osmar Tosi, Prof. Roberto Coelho Cardozo, Jorge Salomão e Yoshimara Kimachi (em pé).

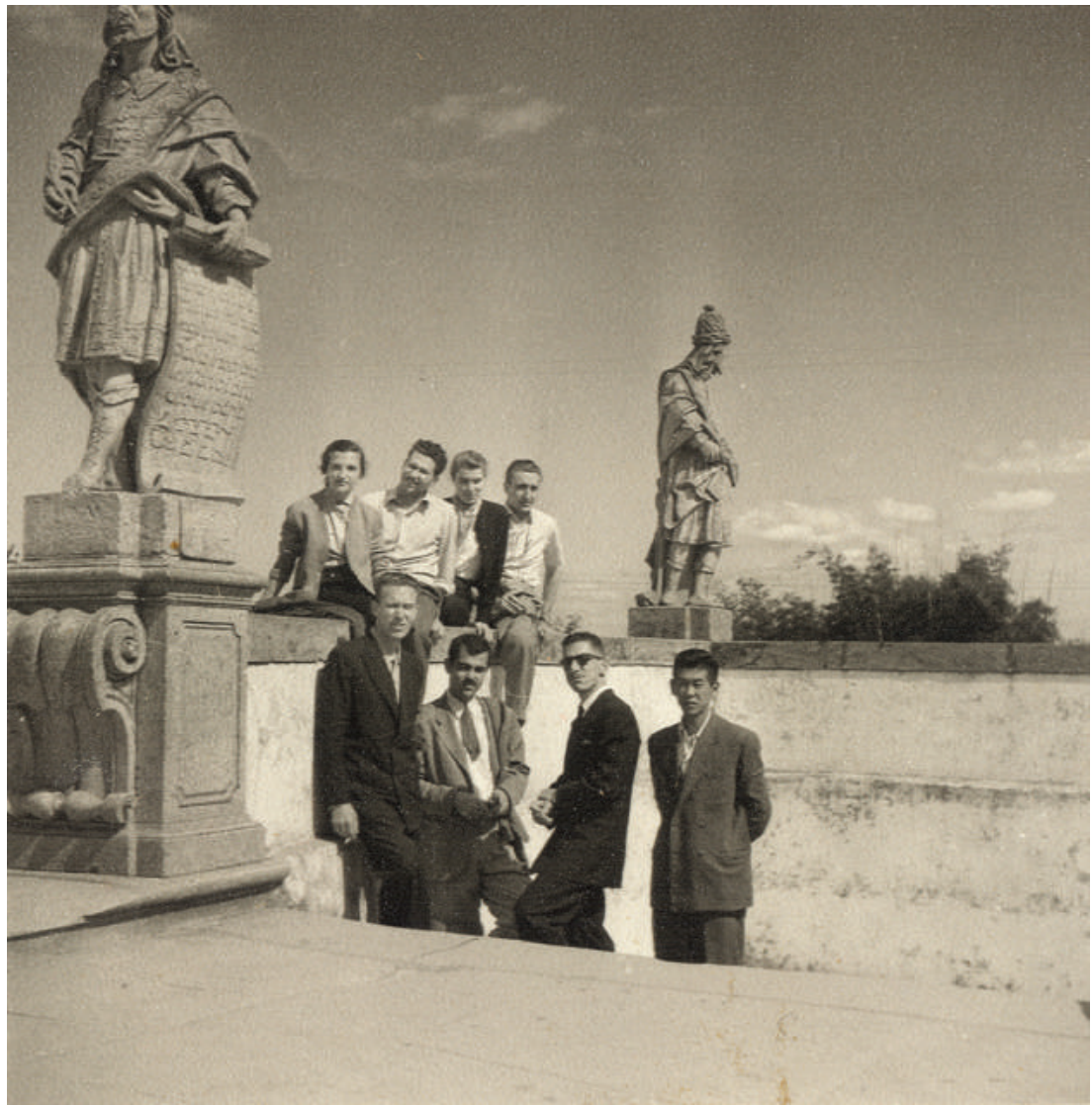


O meio acadêmico foi mais um local no qual Cardozo ampliou seus contatos profissionais. Muitos professores do departamento de projetos da FAUUSP o contratavam para projetar os jardins das novas construções que realizavam, como era o caso de Abelardo Reidy de Souza, Abrahão Velvu Sanovicz, Carlos Alberto Cerqueira Lemos, Ernst Robert Carvalho Mange, Hélio de Queiroz Duarte, Ícaro de Castro Mello, João Bapstista Vilanova Artigas, Lúcio Grinover, Marcos de Souza Dias, Miranda Maria M. Magnoli, Rino Levi, Roberto Cerqueira Cesar e Roberto José Goulart Tibau.

A grande crítica a Cardozo, em relação a sua atuação na FAUUSP, foi não ter formado um quadro de professores para atuar e preencher as vagas disponíveis para a disciplina de Paisagismo. Todos os arquitetos citados anteriormente não se mantiveram na escola como professores. Muitos preferiram o trabalho profissional "de prancheta" e outros não podiam se manter no cargo de professor sem antes entregar os trabalhos de pós-graduação, que passaram a ser exigidos a partir de meados dos anos de 1960. Dessa maneira, a "Cadeira no. 28" de Paisagismo ficou abandonada, com aulas esporádicas de Antunes e Coelho. Finalmente, em 1972, houve uma nova reestruturação curricular na grade de ensino da FAUUSP e foi criado um grupo específico de disciplinas de Paisagismo (GDPA), conduzido pela Profa. Dra. Miranda Martinelli Magnoli. Cardozo, que vinha pedindo algumas licenças-prêmio para afastamento, pede sua exoneração do cargo em dezembro deste mesmo ano ${ }^{16}$.

Não se sabe ao certo porque Roberto decidiu mudar-se do Brasil. Talvez, pelo período político onde o regime militar estava instaurado e muitos colegas da FAUUSP foram perseguidos. Talvez, pelo preconceito que sofreu por ser norte-americano, visto os relatos que contam que havia uma certa hostilidade por sua origem, principalmente por parte de alguns colegas afiliados ao Partido Comunista Brasileiro. Ou ainda, pelo insucesso do projeto da Praça Roosevelt, que foi duramente criticado e que trouxe uma repercussão negativa para o paisagista.

16. Processo no.52.1.14106.1.2 - Contratação de docente, Roberto Coelho Cardozo - folhas 87. Data: 13/12/1972. 
Tentando cercear o assunto, só pudemos chegar a algumas suposições, sem saber ao certo porque o casal se mudou para a Inglaterra com os filhos, no ano de 1970. O casal divorciou-se na década de 1980 e Susana continuou trabalhando no ramo de joalheria, até que se formou em Gemologia e se tornou examinadora do Sistema Britânico de Classificação de Gemas. Roberto lecionou por algum tempo no Gloucestershire College of Arts and Technology, mas sempre voltava ao Brasil em algumas temporadas, e fez mais algumas dezenas de projetos nesse período. Passou parte da velhice nos Estados Unidos, cuidando do rancho de um cunhado e faleceu na Inglaterra, em 02 de abril de 2013. Susan Osborn Coelho faleceu em 28 de agosto de 2011. Os filhos Peri e Lorenzo ainda moram em Londres, na Inglaterra. 
2 INFLUXOS, RUPTURA E A NOVA FORMA DO PAISAGISMO PAULISTANO 



\subsection{O SÉCULO XX E O ADVENTO DO JARDIM MODERNO.}

Por mais de cinco séculos, desde o início do século XV até meados do século XIX, a cultura do paisagismo ocidental foi marcada pela dicotomia entre jardins formais e informais, racionais e sensoriais, regulièr e paysager. O Quattrocento e o Cinquecento foram marcados pelos jardins renascentistas italianos, inspirados na Antiguidade Clássica e que buscavam respeitar suas ordens e princípios. O século XVII foi definido pelos grandiosos jardins em estilo francês, que não só eram formados pelos belos parterres floridos e pelos eixos simétricos e monumentais, mas também modificavam a paisagem existente, a partir de grandes movimentações de terra e ajustes nos cursos d'água. Já no século XVIII viu-se a rejeição pelos estilos geométricos adotados até então, para dar espaço ao jardim pastoril e romântico, com a retomada do campo e a volta à natureza a partir do jardim em estilo inglês (PANZINI, 2013). Essa alternância entre estilos é subvertida no fim dos anos de $1800 \mathrm{e}$ principalmente no início de 1900.

Segundo Dourado, isso se deu porque:

Às vésperas do final do século XIX, os horizontes do paisagismo no Velho Mundo não eram nada promissores. Os conteúdos expressivos da disciplina cada vez mais se esvaziavam pelo alto grau de artificialismo, derivado em boa medida da prática de misturar indiscriminadamente cores e matizes, viabilizada pela permanente substituição e replantio de espécies de pequeno porte para manter o jardim constantemente em flor (DOURADO, 2013).

Assim como a arquitetura, a música e a literatura, a arte dos jardins se constituiu como campo de experimentação tendo em vista a busca por uma identidade estética equivalente aos processos artísticos que se concretizavam nas primeiras décadas do século XX. Invariavelmente inserida no fenômeno da reformulação das artes, a Arquitetura Paisagística tenta se adequar a partir de um novo pensamento de vida e de cidade, transformando os espaços urbanos e regionais.

Neste capítulo vamos contextualizar as expressões paisagísticas que se destacaram por apresentar formulações teórico-plásticas de caráter inovador, apontando para a construção de uma nova visão do paisagismo. Separaremos o capítulo em duas partes: a primeira 
apresenta o contexto do Paisagismo na Europa e nos Estados Unidos e a segunda parte, o contexto no Brasil.

Começaremos pelo contexto europeu, indicando algumas expressões isoladas que, de alguma maneira, desviaram o olhar da tradição em busca de novos conceitos paisagísticos. Na sequência apresentaremos os projetos relevantes da Exposition Internationale des Arts Décoratifs et Industriels Modernes, realizada em Paris, em 1925, e que teve grande repercussão para a formulação teórica no paisagismo moderno, principalmente na Inglaterra e nos Estados Unidos. Dos exemplos da Feira Mundial de 1925 nos deslocaremos para as práticas paisagísticas no Novo Continente, mais precisamente para formação e atuação da chamada "corrente californiana" ${ }^{1}$. A importância da atuação dos norte-americanos no paisagismo está diretamente relacionada à formação do campo disciplinar do paisagismo no Brasil.

Seguindo esta linha, finalizaremos este capítulo com a contextualização de personagens e obras relevantes ao campo disciplinar no Brasil a partir da década de 1930: sinalizaremos os primeiros lampejos de modernidade no paisagismo brasileiro para então desvelar a atuação profissional e docente de Roberto Coelho Cardozo na cidade de São Paulo.

1. Alguns autores (MEDEIROS, 2004; ARAÚJO, 2004 e 2006; FIASCHI, 2015; ABBUD, 2015) referem-se a Garrett Eckbo, Dan Kiley, James Rose e Thomas Church como protagonistas da "corrente californiana" de paisagismo. Gostaríamos apenas de esclarecer que esses paisagistas atuaram em diferentes regiões dos Estados Unidos da América. Garrett Eckbo (1910-200o) nasceu em Nova York, mas sempre atuou na Califórnia. Já Daniel Urban Kiley (1912-2004) e James C. Rose (1913-1991) implantaram seus projetos principalmente na Costa Leste do país. Kiley nasceu em Boston, Massachusetts, e inicialmente trabalhava em New Hampshire e Vermont. Após ter vencido o concurso para o Jefferson National Expansion Memorial (1947), ao lado do arquiteto Louis Kahn, Kiley ganhou notoriedade e desenvolveu projetos por todo o país. Rose nasceu na área rural do estado da Pennsylvania e concentrou seus trabalhos nos arredores de Nova Jersey e Nova York. Os mais atuantes na Costa Oeste foram Eckbo e Thomas Church. Usando a conceituação mais recorrente, também adotaremos o termo "corrente californiana" quando nos referimos aos trabalhos desses paisagistas. 


\section{ALGUMAS EXPRESSÕES PAISAGÍSTICAS EUROPEIASE POSSÍVEIS CAMINHOS PARA UM NOVO OLHAR PAISAGÍSTICO.}

Apesar de inúmeras expressões paisagísticas poderem ser citadas no contexto europeu, nos ateremos a algumas experiências que tiveram maior relevância dentro da linha de estudo que pretendemos delinear neste capítulo. A escolha dessas referências se deu por indicarem, de maneira sutil, mudanças nos paradigmas do paisagismo vigente, como o emprego diferenciado da vegetação ou na relação entre arquitetura e paisagem.

A primeira delas é a obra de Gertrude Jekyll (1843-1932), artista plástica formada na South Kensington School of Art e que iniciou sua carreira paisagística apenas aos 33 anos. Jekyll preconizava a relação entre a arquitetura e os jardins, sempre ressaltando que esta relação deveria se dar por uma fusão dos espaços, onde não se diferencia o trabalho do arquiteto e do paisagista, já que esse trabalho deve estar em função da paisagem circundante. Seu trabalho se sobressai principalmente pela importância dada ao estudo e composição das cores da vegetação nos jardins e ao emprego consciente, quase ecológico, das espécies autóctones.

Contrariamente à tendência dos jardins ingleses inspirados nas pinturas paisagísticas de Claude Lorrain, onde sobressaem os contrastes entre maciços arbóreos, gramados disciplinados e lagos artificiais, Jekyll projeta seus jardins misturando cores e texturas de espécies floridas, criando contornos suaves, que muitas vezes se dissipam em gradações de verdes e amarelos, rosas e brancos. Para ela, a arte paisagística é como "pintar um quadro, mas com plantas vivas" (JEKYLL, 1901), ou seja, tendo o referencial artístico como base, explora as qualidades vegetais a partir de um conhecimento detalhado da planta como um todo, valendo-se de seus matizes e de suas essências.

Com um caráter verdadeiramente naturalista, Gertrude Jekyll tem uma atitude moderna em relação ao mundo natural ${ }^{2}$, compreendendo

2. PANOFSKY (1963) discute o caráter moderno do pitoresco no artigo The Ideological Antecedents of the Rolls-Royce Radiator, estendendo a questão para além de Jekyll. HUNT (1994) vai além e discorre sobre o caráter proléptico do jardim pitoresco e de que esses jardins se tornaram expressões eloquentes de ideias culturais complexas. 
[2.1]

Munstead Wood

(1892-1893), projeto de

Gertrude Jekyll e Edward

Lutyens. Jekyll cria ca-

minhos com sequências

cromáticas e explorando

a vibratilidade e contraste

dos matizes da vegeta-

ção, divergindo do estilo

vitoriano.

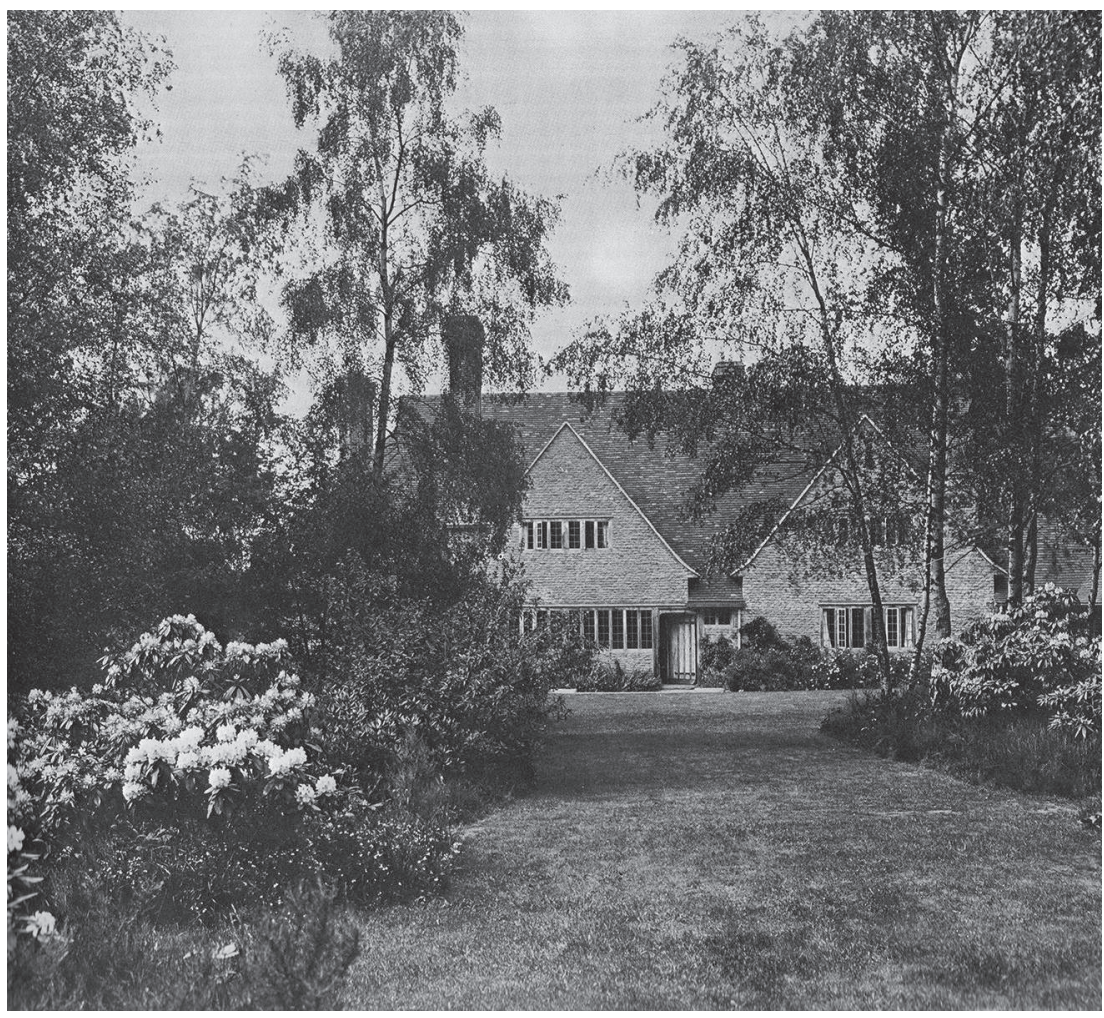

[2.2]

Projeto de plantio para o

Blue Garden, onde Jekyll

explora a cor azul das

flores das campânulas

e lupinos, ao mesmo

tempo que mistura com

a folhagem verde azulada

das arrudas e yucas,

1892-1893.

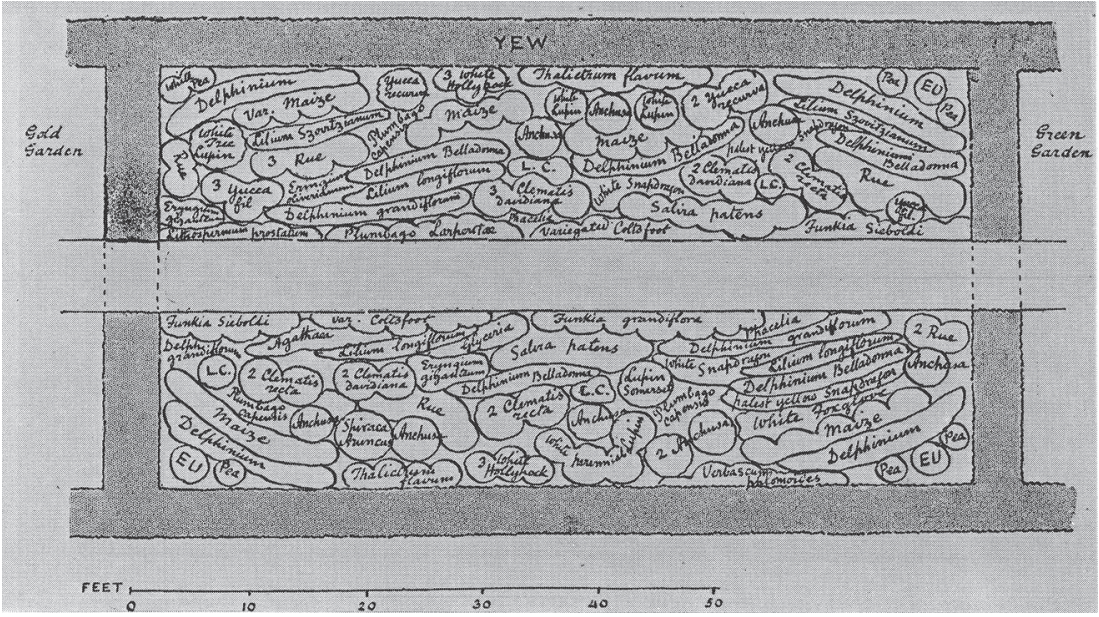


o espírito da paisagem inglesa e trabalhando com a natureza como ela é, sem as artificialidades que até então eram perpetuadas nos jardins ingleses (SHEPEARD, 1982).

Outra experiência que se destaca no início do século XX é o projeto de Antoní Gaudí (1852-1926) para o Park Güell, construído entre 1900 e 1914. Pensado inicialmente como a área de convivência de um loteamento residencial inspirado nos moldes das cidades-jardim, o complexo não foi construído em seu todo, e a área de convivência foi transformada em um parque em 1926.

A entrada ao complexo se dá por uma grande escadaria que leva a uma área coberta, chamada de Sala Hipóstila, com colunas que claramente remetem à tradição clássica - o espaço foi primeiramente pensado como área para abrigar um mercado. A tradição clássica também é retomada no projeto do terraço que, formando um semicírculo, evoca os anfiteatros gregos. Ao mesmo tempo, há elementos rústicos, como as duas torres ao lado da escada de entrada e o viaduto que leva à estrada principal, que associam-se à natureza rochosa e mística do Montserrat. A vegetação do parque também relaciona-se com o regional mediterrâneo: palmeiras, alfarrobeiras e coníferas formam as massas arbóreas enquanto os oleandros e outros arbustos de área desértica compõem o extrato de vegetação de médio porte.

A inspiração de Gaudí para o Parque Güell "foi tirada de imagens catalãs estereotipadas, do passado medieval, do imaginário mediterrâneo, das tradições artesanais e das virtudes da sociedade pré-industrial. Subjacente a esta interpretação do passado tradicional da Catalunha ressoa um novo regionalismo" (MORALES, 1991, tradução nossa). A mistura do imaginário e da tradição são marcantes no trabalho do arquiteto catalão, que consegue enveredar por formas orgânicas, aplicando a racionalidade da matemática e da física, tendo como resultado uma estrutura de perfeito repouso e equilíbrio. 
[2.3]

Vista aérea do Parque Güell, projeto por Antoní

Gaudi e construído entre 1900-1914.

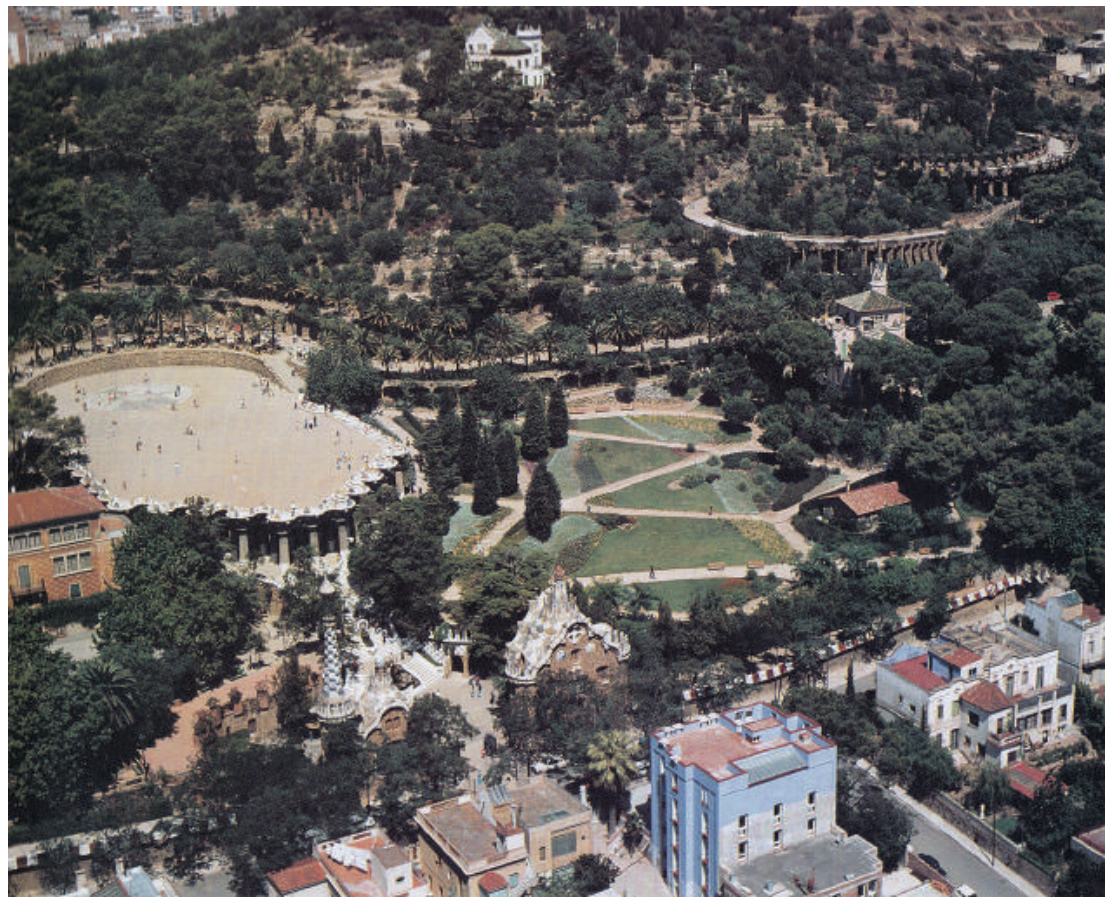

[2.4]

Colunatas do viaduto que dá acesso ao Parque

Güell. Projeto de Antoní

Gaudí, 1900-1914.

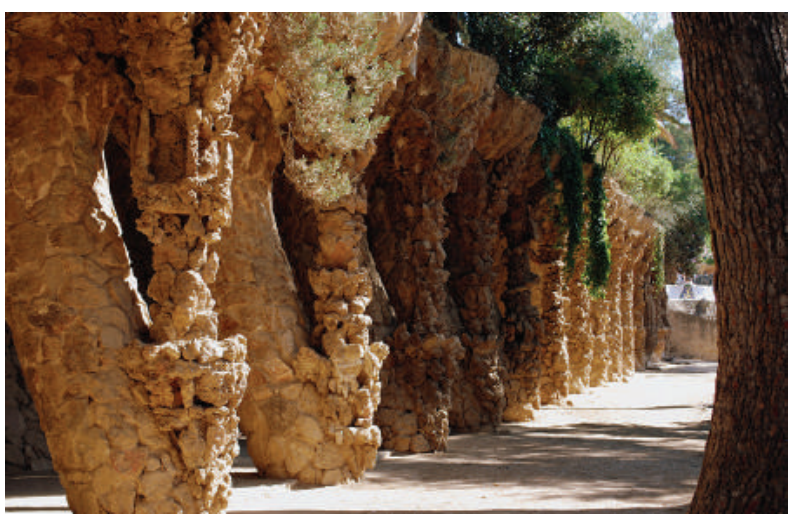

[2.5]

Imagem do Monserrat, na Catalunha, Espanha.

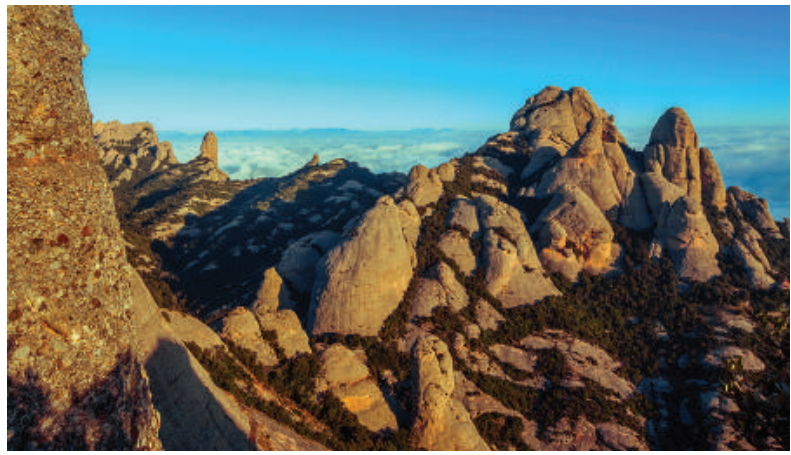


Apesar de algumas experiências paisagísticas apontarem para a conflagração dos jardins moderno, vemos surgir na Europa e mais especificamente na França, uma tendência oposta com a retomada dos jardins históricos e aristocráticos. Refletindo o sentimento entre as guerras Franco-Prussiana e a Primeira Guerra Mundial, voltava-se ao enaltecimento do Nacionalismo e à busca da "essência e qualidade do Espírito Francês” (COPERCHOT, 1912. Apud: MOSSER, 1991). Esse revival na retomada da tradição dos jardins formais se dá a partir da herança paisagística de André Le Notrê, que representava o triunfo da aristocracia em sua estrutura majestosa, solidamente construída, onde tudo rende homenagem às leis sólidas da lógica, da estabilidade e da razão (MOSSER, 1991).

Os dois maiores expoentes dessa corrente foram Henri Duchêne (1841-1907) e seu filho Achille Duchêne (1866-1947). Seus trabalhos são reconhecidos pela adaptação dos princípios clássicos preconizados por Le Notrê e que, tensionados ao ponto do exagero, transformam-se em um trabalho de pura imaginação. Os parterres de broderie ganham um tratamento diagramático, que vistos do alto se relacionam às geometrias do latente Modernismo que se desenvolvia nas artes plásticas. A tendência historicista amplificada pela atuação dos Duchêne se difunde para além do Velho Continente, sendo aplicada também em jardins americanos e marroquinos.

Outra figura importante desse movimento foi Jean Claude-Nicolas Forestier (1861-1930), paisagista que ganhou reconhecimento por seu trabalho de restauração no jardim setecentista de Bagatelle, em Paris, no ano de 1905. Sempre considerando as características específicas de cada lugar, Forestier desenvolveu projetos sensíveis, que amalgamavam as regras da tradição clássica e a cultura local. Em 1911, Forestier foi contratado pelo comitê da Exposição Ibero-Americana de Sevilha para transformar os jardins ${ }^{3}$ do Palácio San Telmo em um grande parque público, o Parque María Luisa. Adotando uma linguagem formal mesclada com a linguagem da cultura árabe-andaluza, Forestier

3. O projeto original dos jardins do Palácio San Telmo, de 1850, foi pensado pelo francês André Lecolant. 
cria uma trama retangular e a preenche com elementos variados, seja da cultura hispano-mulçumana, como fontes de água revestidas com mosaicos de pastilha e canteiros com herbáceas comestíveis e flores rústicas, remetendo aos pátios das residências mouras, seja criando uma sequência de pequenos jardins separados por trilhas de ciprestes em topiária, aludindo aos jardins franceses.

Uma reinterpretação moderna da arte árabe dos jardins e do seu vocabulário básico, o Parque de María Luisa, concluído em 1914, teve um enorme sucesso e deu origem a um movimento estético vital que influenciou os desenhos de muitos parques públicos e jardins privados na Espanha e na França. Pela primeira vez no século XX, o jardim mediterrânico surgiu como uma alternativa ao modelo pitoresco predominante (LEJEUNE; BEUSTERIEN; MENOCAL, 1996, tradução nossa).

A postura de Forestier em conciliar os estilos históricos à cultura local e às modalidades plásticas que se expandiam nas duas primeiras décadas do século XX, lhe rendeu a posição de coordenador da área de Paisagismo na Exposition Internationale des Arts Décoratifs et Industriels Modernes, que ocorreu em Paris, em 1925, e que teve papel fundamental no desenvolvimento do paisagismo moderno, desde a Europa até as Américas e a Ásia.

[2.6]

Plaza de España, dentro do Parque María Luisa. Projeto de J.C.N. Forestier, 1911.

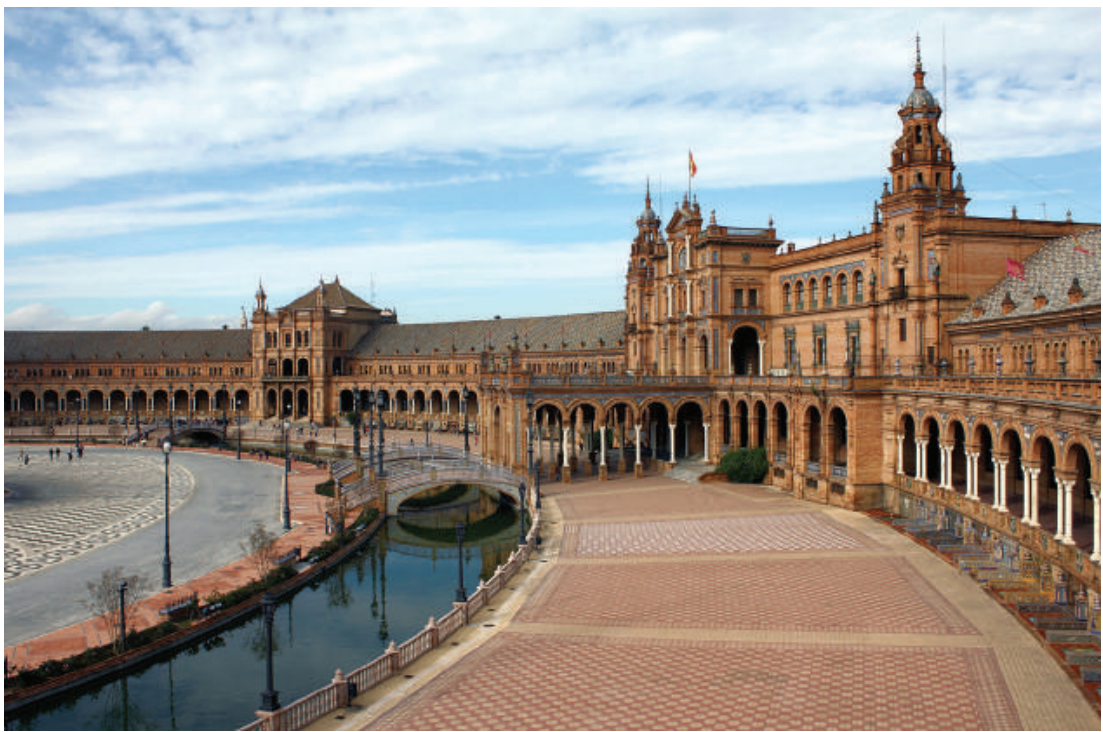




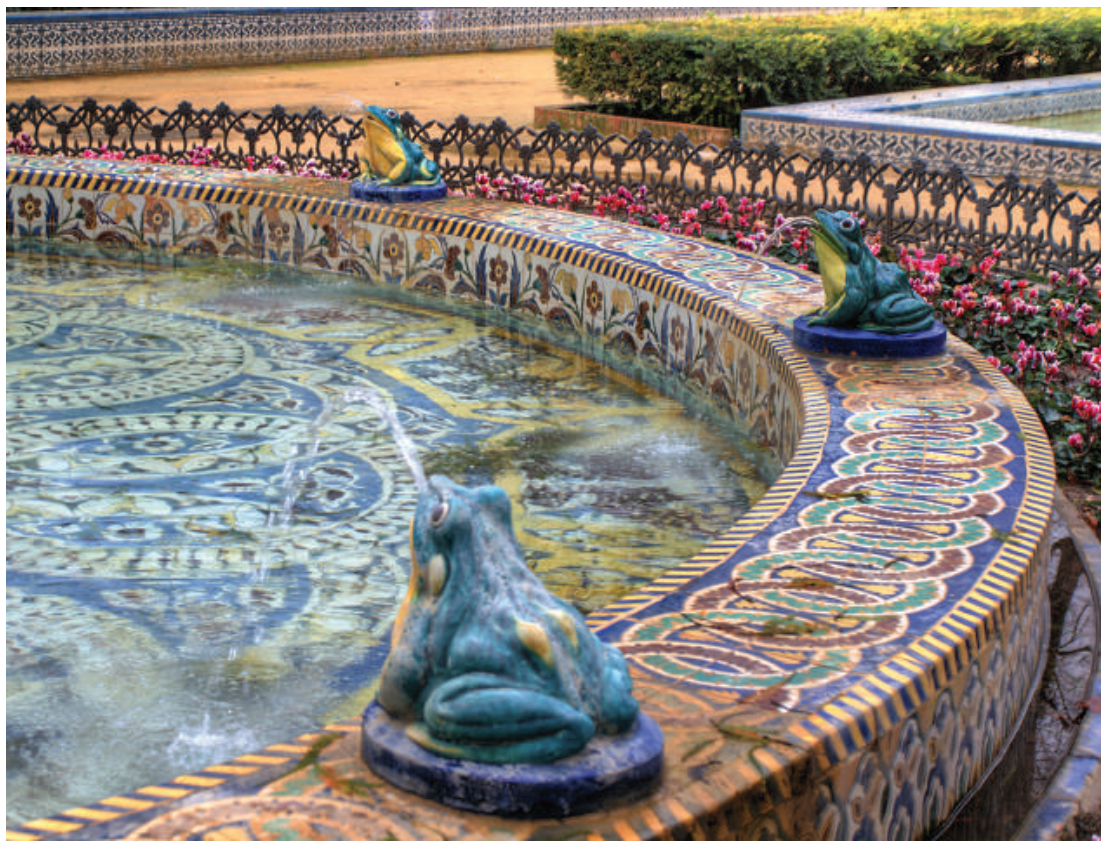

[2.7]

Fuente de las ranas

dentro do Parque María Luisa. Projeto de J.C.N. Forestier, 1911.

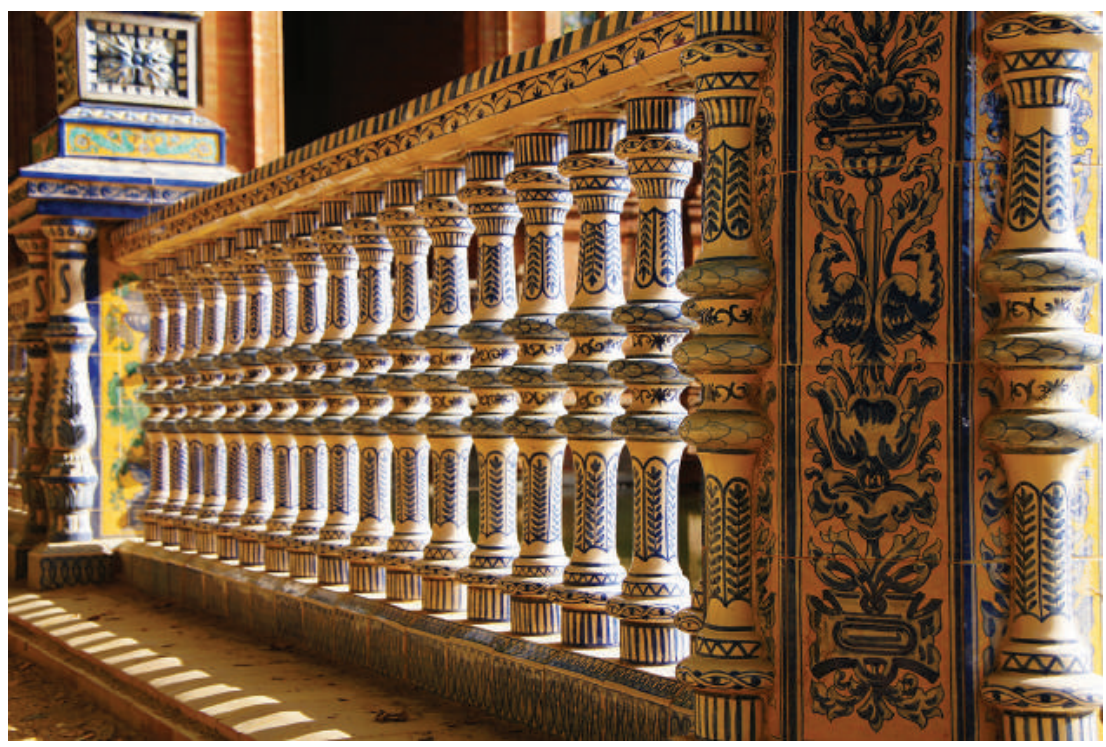

\section{[2.8]}

Detalhe de balaustrada na Plaza de Espana no Parque María Luisa.

Projeto de J.C.N.

Forestier, 1911. 


\section{EXPOSITION INTERNATIONALE DES ARTS DÉCORATIFS ET INDUSTRIELS MODERNES.}

Após a Primeira Guerra Mundial, a França buscou reestabelecer a preeminência do gosto francês nas Artes e no consumo de bens de luxo. Desde 1900 a França não promovia uma Feira Mundial e o governo francês decidiu então financiar a exposição, que foi organizada pela Societé des Artistes Décourateurs e teve como foco as experimentações de inspiração moderna.

Realizada ao longo do Rio Sena, entre o Grand Palais e a Esplanade des Invalides, os organizadores decidiram "alocar a exposição no coração da cidade, quando Paris era o coração do mundo". A exposição durou sete meses, de abril a outubro de 1925, e contou com mostras da Grã-Bretanha, dos países da Europa Continental e da Escandinávia, da Turquia, do Japão, e especialmente do país anfitrião, a França, que dominou grande parte dos pavilhões. Apesar de o regulamento da exposição insistir no caráter moderno das mostras, nem todos os projetos seguiram essa diretriz. Apesar disso, a Exposição conseguiu consagrar esse novo movimento, já que sua visibilidade, com mais de 16 milhões de visitantes, teve impacto imediato e mundial. O Art Deco se consagrava e se difundiu pelo mundo, remodelando-se nas mais diversas facetas artísticas (SCARLETT; TOWNLEY, 1975).

$\mathrm{Na}$ área da Arquitetura Paisagística, essa renovação formal foi desenvolvida pelos jardins que intercalavam as áreas livres entre os pavilhões. Jean Claude-Nicolas Forestier, como coordenador para áreas verdes da Exposição, incitou os arquitetos e paisagistas a elaborarem os espaços verdes como expressões artísticas, a partir da experimentação de formas abstratas, usando os novos materiais disponíveis e trabalhando as cores provenientes da vegetação.

Dentre os jardins projetados, destacaram-se a estufa do pavilhão austríaco, pensada por Peter Behrens (1868-1940), os jardins do Pavilhão de Turismo, projetado por Robert Mallet-Stevens (1886-1945) e o Jardim de Água e Luz do arquiteto armênio Gabriel Guévrékian (1892-1970). 


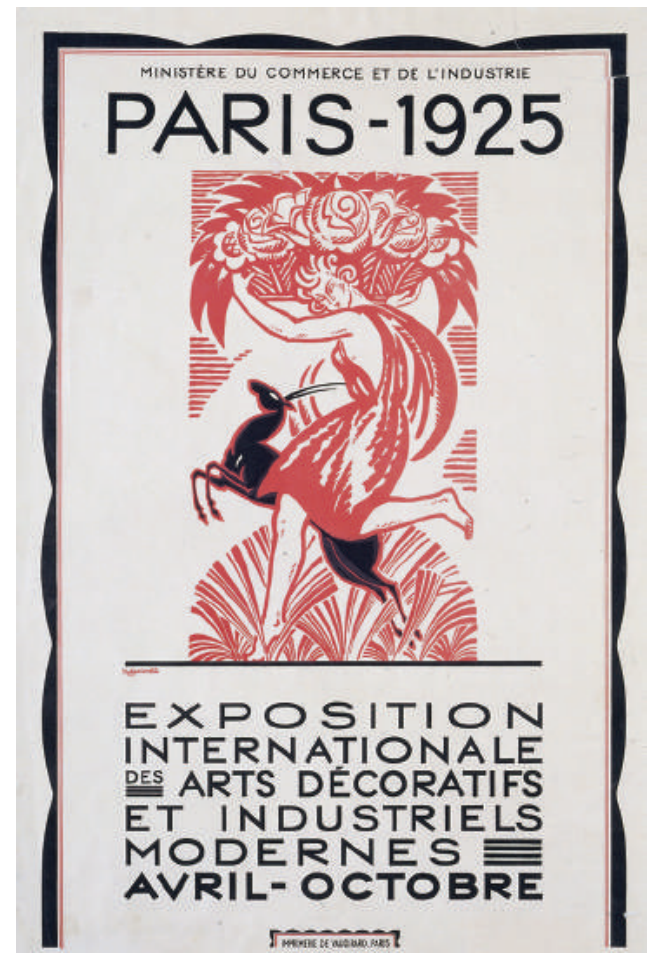

[2.9]

Cartaz de Robert Bonfils para a Exposition Internationale des Arts Décoratifs et Industriels Modernes, 1925.

Peter Behrens projetou para a área externa ao pavilhão austríaco, um volume transparente de vidro, fixado por uma sofisticada estrutura metálica, com desenho geométrico bastante trabalhado ${ }^{4}$. Entre as folhas exuberantes e um grande lustre pendurado ao teto encontravam-se mesas de um café.

O jardim de Robert Mallet-Stevens é formado por dois grandes canteiros retangulares elevados do chão e marcados por vegetação em topiária que contrastam brutalmente com árvores em concreto armado, executadas pelos irmãos Jean e Jöel Martel. As árvores em concreto, de inspiração claramente cubista, dão indícios do interesse dos arquitetos modernos pelos jardins e também pela relação que começa a surgir entre arquitetura, paisagismo, escultura e arte.

4. Nesse período, Peter Behrens já tinha contato com os expoentes da Deutscher Werkbund. Nesse sentido, a estufa projetada por ele se caracteriza mais como uma expressão dos expressionistas alemães do que com o caráter da Art Deco desenvolvido na Feira Mundial de Pris. Porém, estende-se aqui como exemplo do caráter vanguardista do evento. 
[2.10]

Estufa projetada por Peter Behrens para o

Pavilhão Austríaco na

Exposition Internationale des Arts Décoratifs et Industriels Modernes,

1925.

[2.11]

Café dentro da estufa de Peter Behrens na

Exposition Internationale des Arts Décoratifs et Industriels Modernes,

1925.

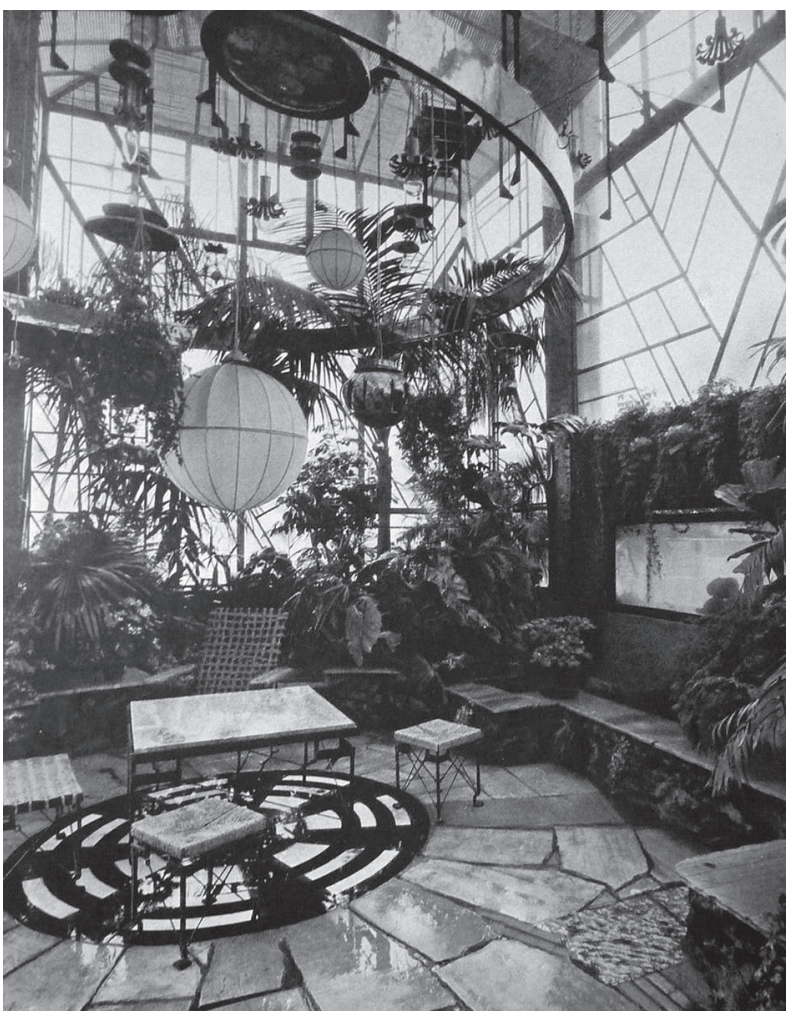




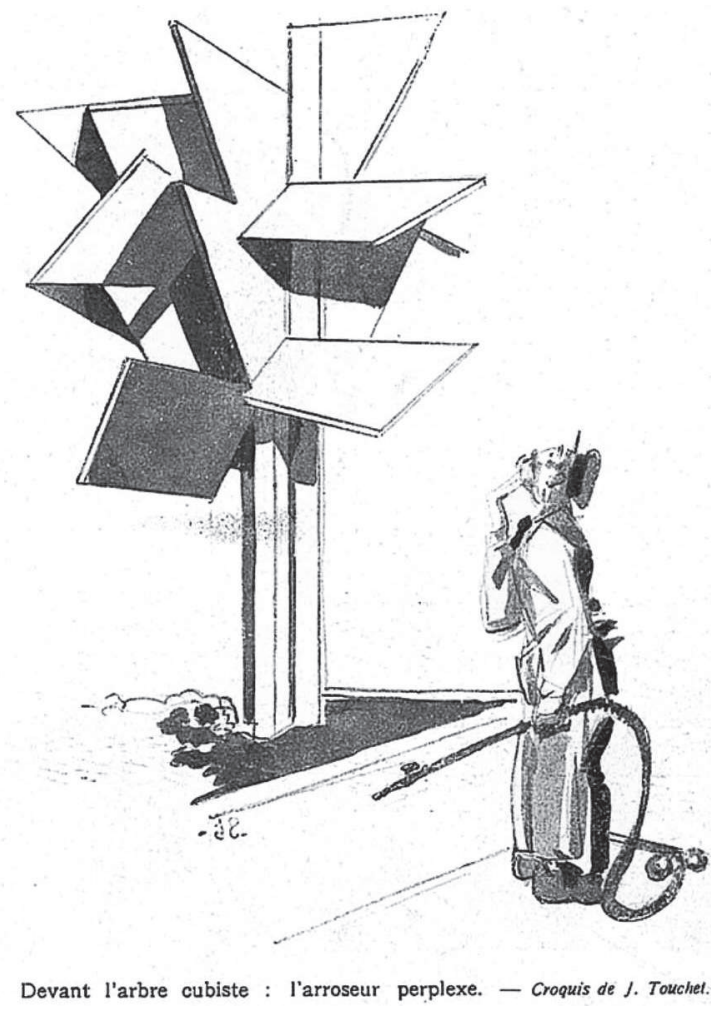

Devant l'arbre cubiste : l'arroseur perplexe. - Croquis de J. Touchet.

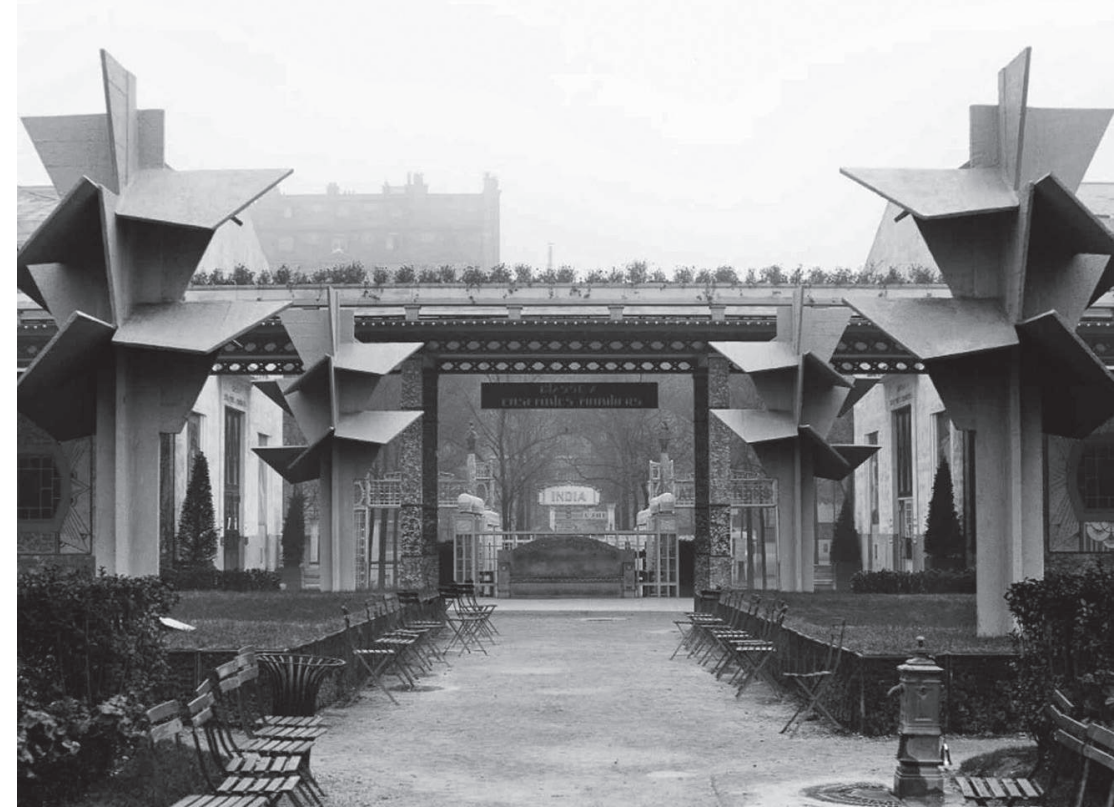

[2.12]

llustração de Jacques Touchet sobre as árvores de concreto dos irmãos Martel: "Devant l'arbre cubiste: l'arrouser perplexe", 1925.

\section{[2.13]}

O jardim com árvores cubistas projetado por Robert Mallet-Stevens para a Exposition Internationale des Arts Décoratifs et Industrie/s Modernes, 1925. 
Talvez o projeto mais emblemático da Exposição seja o Jardim de Água e Luz, do arquiteto armênio Gabriel Guévrékian. Nesse projeto, Guévrékian mantém o eixo simétrico mas explora, por meio do uso de triângulos nos canteiros e nos muros que cerceiam o jardim, a tridimensionalidade do espaço. Ele reforça o caráter abstrato da composição quando destaca as vistas multifacetadas da vegetação colorida que são refletidas na escultura esférica espelhada - projetada pelo pintor cubista Robert Delaunay - situada no centro do jardim, dentro do espelho d'água (PANZINI, 2013).

Distanciando-se dos jardins tradicionais, torna-se um jardim abstrato no momento em que constrói canteiros puramente decorativos, baseando-se na teoria de contraste de cores de Chevreul's, criando uma ilusão de ótica que demonstra a aplicação dos princípios da pintura moderna na tridimensionalidade do jardim (ROYER, 1991).

Para além da Feira Mundial de 1925, outros arquitetos também ousaram ao modificar a composição clássica dos jardins, trabalhando com assimetrias, opondo espaços cheios e vazios e contrastando cores a partir da vegetação. Exemplo disso é o jardim para a Place des ÉtatsUnis, em Paris, projetado pelos irmãos André e Paul Vera em 1926. Nesse projeto, os artistas criam um jardim com caráter pictórico para ser visto do alto da residência e exploram, assim como Guévrékian, o forte colorido, as formas triangulares e a multiplicidade de vistas formada pelo reflexo dos espelhos embutidos nos muros, que diluem as barreiras do jardim tornando as dimensões do espaço visualmente indefinidas (STEELE, 1930).

5. Segundo a Lei dos Contrastes Simultâneos das Cores de Michel Eugéne Chevreul (1786-1889), os efeitos corretos das cores se relacionam a partir de questões da óptica. Em termos práticos, a aparência das cores pode sofrer alteração visual quando justaposta a outras cores (cores são percebidas de maneira diferente quando em fundo claro ou escuro, por exemplo). Chevreul cria um círculo com cores primárias e secundárias, no qual é possível observar como funciona essa transformação óptica quando essas cores se combinam. 
Essas expressões no campo do paisagismo, apesar de ainda estarem ligadas aos princípios clássicos e muitas vezes se reduzirem a experimentações compositivas de planos e cores, indicam a busca de um novo paradigma na arte de jardins. Uma nova forma de pensar a Arquitetura Paisagística se projetava, tendo o referencial da Arte Moderna como um de seus alicerces principais.

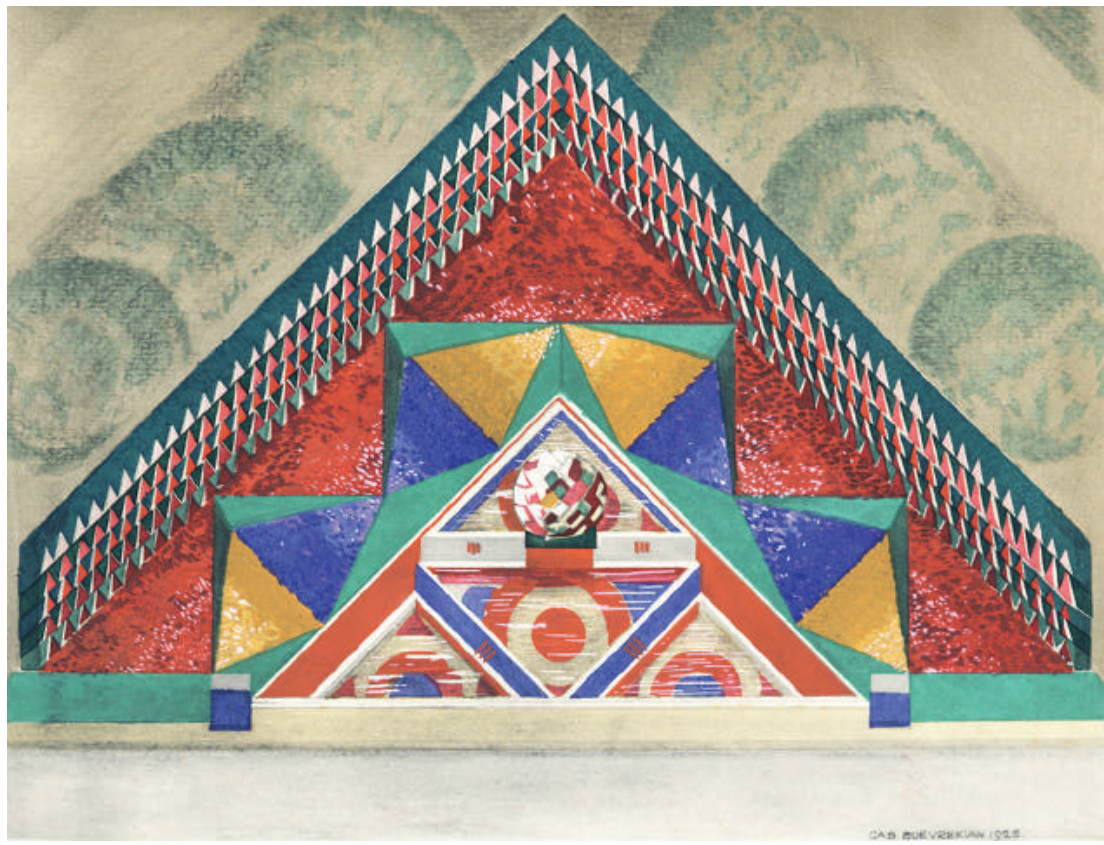

[2.14]

Aquarela colorida do Jardim de Água e Luz, do arquitetos Gabriel Guévrékian para a Exposition Internationale des Arts Décoratifs et Industriels Modernes, 1925. No esquema, pode-se ver a aplicação da Lei dos Contrates de Cores de Michel Chevreul.

\section{[2.15]}

Vista geral do Jardim de água e luz.

\section{[2.16]}

Escultura esférica de caráter abstrato de Robert Delaunay no Jardim de Água e Luz.
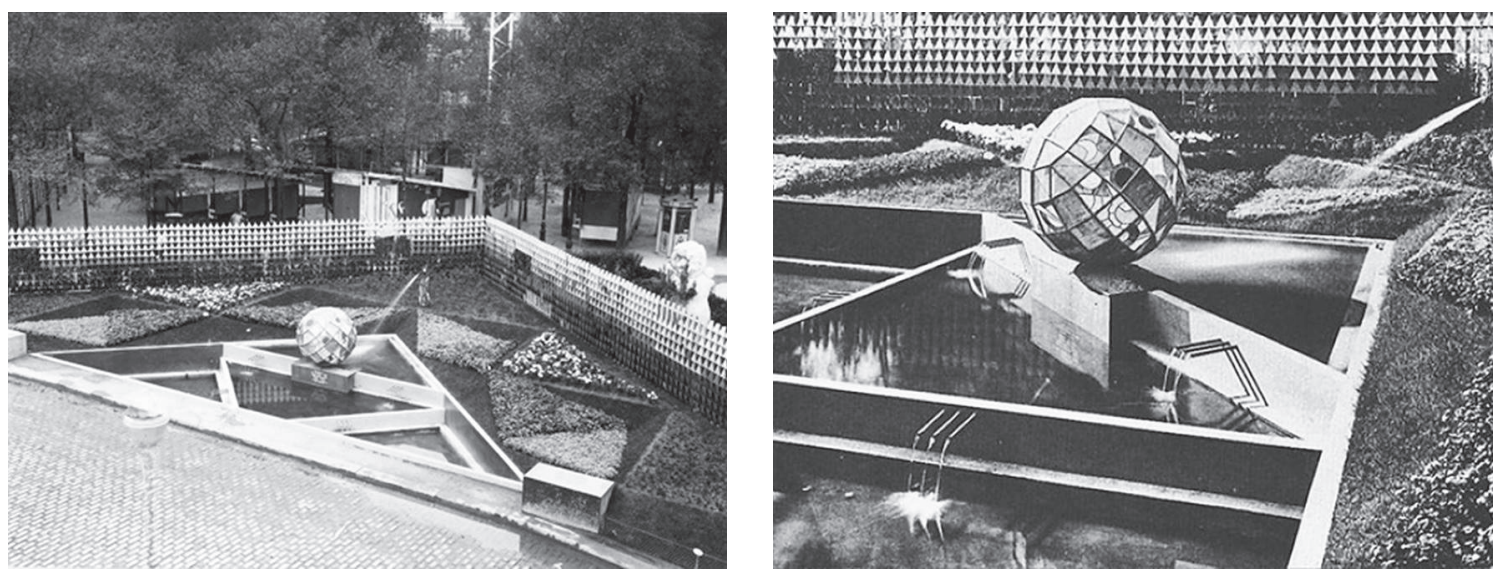


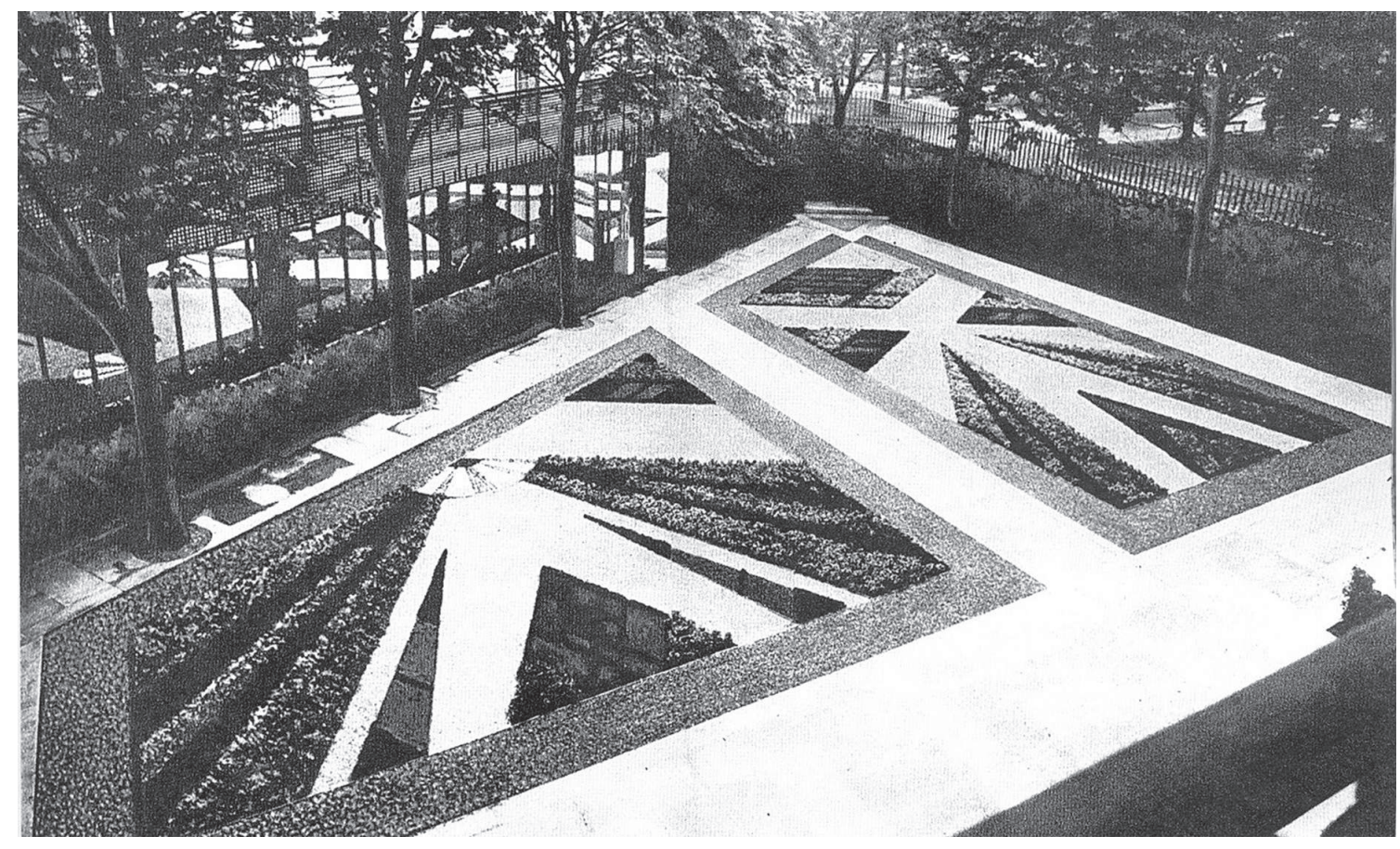

[2.17]

Jardim feito por Paul e André Vera no Hotel de Noailles, na Place des États-Unis, em Paris, 1926.

[2.18] Aquarela do projeto na Place des États-Unis, Paris, 1926.

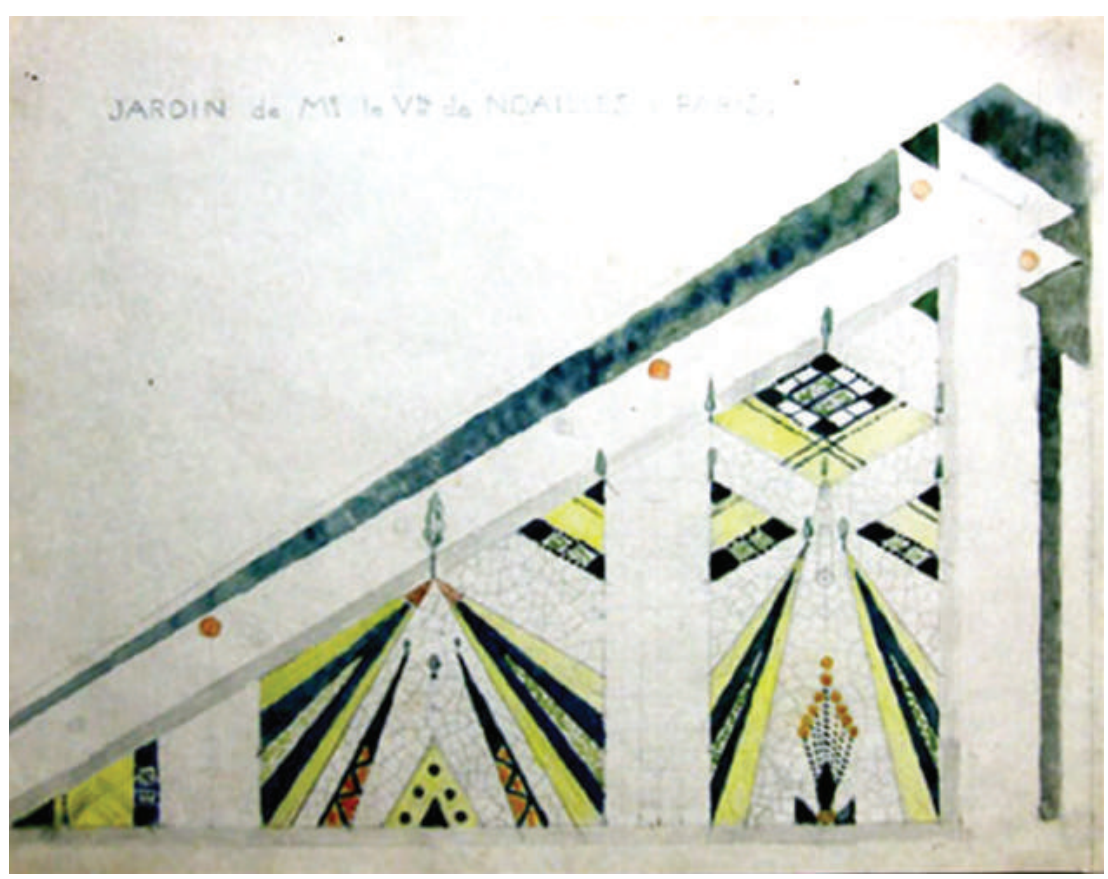




\subsection{OS PIONEIROS DO PAISAGISMO MODERNO NOS ESTADOS UNIDOS.}

A tendência historicista revivida na Europa, citada anteriormente a partir dos exemplos dos Duchêne e de Nicolas Forestier, também pôde ser vista nos Estados Unidos da América, a partir de exemplos literários e experiências concretas de jardins.

Em 1984, Charles Adams Platt (1861-1933) publicou o livro Italian Gardens ${ }^{6}$ onde descreve jardins das villas italianas, como a Villa Medici e Villa Borghese, e também jardins de maior porte, como os Jardins de Boboli. O livro de Platt foi a primeira obra ilustrada da época moderna que publicou e descreveu os jardins tradicionais italianos. Edith Wharton (1862-1937), novelista e vencedora do Prêmio Pulitzer, também escreveu sobre os jardins italianos, a partir de uma cronologia e evolução das vilas ajardinadas. Seu livro Italian Villas and Their Gardens ${ }^{7}$ foi publicado em 1904. Esses estudos teóricos eram reproduzidos nos meios acadêmicos das universidades americanas e a aplicação dos princípios clássicos se perpetuou em muitos jardins por todo país (PANZINI, 2013).

Contudo, em contraponto aos adeptos dos jardins formais e a partir da Exposition Internationale des Arts Décoratifs et Industriels Moderne surge uma nova linha de pensamento paisagístico nos Estados Unidos, embasada nos preceitos da arte e na arquitetura moderna, conhecida como "corrente californiana". Os protagonistas da "corrente californiana" foram Thomas Church e Garrett Eckbo, que atuaram profissionalmente no mercado paisagístico californiano no pós-Guerra e tendo estabelecido uma nova linha de pensamento e padrão de projetos paisagísticos. A atuação crítica de Garrett Eckbo remonta à sua formação na Harvard University, ao lado de James Rose e Dan Kiley, que juntos formavam os Harvard Rebels (TREIB, 1993). Descreveremos mais detalhadamente a atuação de Church e dos Harvard Rebels e como

6. PLATT, C. Italian gardens. New York, Harper \& Brothers, 1894. 154p.

7. WHARTON, E. Italian Villas and Their Gardens. New York, The Century CO., 1904. 27op. 
a atuação dos norte-americanos no campo paisagístico influenciou de forma direta o campo disciplinar do paisagismo no Brasil. Waldemar Cordeiro e Roberto Coelho Cardozo tiveram como base teórica os escritos dos Harvard Rebels ${ }^{8}$ e, mais especificamente, Cardozo trabalhou no escritório Eckbo, Royston \& Williams ${ }^{9}$ e sua formação profissional está diretamente relacionada ao contato com os californianos. Essas relações serão explicitadas mais adiante e assim será possível ampliar o entendimento da formação do campo paisagístico na cidade de São Paulo a partir da década de 1950.

\section{THOMAS CHURCH}

Thomas Dolliver Church (1902-1978) nasceu em Boston, Massachusetts, mas cresceu na cidade de Oakland, na Califórnia. Graduou-se paisagista em 1923 na UCBerkeley e posteriormente, em 1926, formou-se na pós-graduação em Planejamento Urbano na Escola de Paisagismo da Harvard University. Formado com louvor em Harvard, Church recebeu uma bolsa de estudos de um ano, a Sheldon Travelling Fellowship, que tinha como intuito o recolhimento de material iconográfico e bibliográfico referente aos jardins e parques desenvolvidos na França, na Espanha, na Itália e na Inglaterra à época. Segundo Imbert (2003), "Church estudou a herança paisagística mediterrânea como uma corrente transnacional. Tinha uma visão semelhante à de Jean-Claude Nicolas Forrestier sobre o 'clima amigável à flor de laranjeira ${ }^{10^{\prime \prime \prime}}$. Sendo assim, Thomas Church passou a buscar

8. Givaldo Medeiros descreve o "amplo desdobramento" que as questões colocadas por Garrett Eckbo, com Landscape for Living (1950), e Peter Shepeard, com Modern Gardens (1953), tiveram na obra de Waldemar Cordeiro. Cardozo teve contato com os princípios da "corrente californiana" desde a sua formação na UCBerkeley e ao final deste capítulo, explorando o conteúdo da disciplina "Arquitetura Paisagística" será feito um paralelo entre sua atuação docente e as formulações dos norte-americanos.

9. Como exposto no Capítulo 1, Cardozo trabalhou no escritório Eckbo, Royston \& Williams entre 1947 e 1950.

10. Forestier desenvolve o conceito do "jardim de laranjeiras" no livro Jardins: carnet de plans et de dessins (FORESTIER, 1920). 
na tradição mediterrânea um modelo a ser desenvolvido nos projetos paisagísticos da Califórnia. Seja na inspiração dos pátios das casas espanholas e dos jardins das villas italianas, seja no uso inteligente da água em fontes - e no caso dos Estados Unidos, em piscinas - a busca de referências para o projeto da "vida ao ar livre" se desenvolvia. Sem rejeitar os estilos precedentes, o paisagista transformou alguns princípios tradicionais, adaptando-os às novas condições e necessidades da vida moderna californiana (SIMO; WALKER, 1994).

Thomas Church começou sua carreira durante os anos da Grande Depressão, entre 1929 e o começo dos anos de 1930, e sempre manteve um fluxo contínuo de trabalho, provenientes das indicações dos parceiros arquitetos, principalmente de William Wurster ${ }^{11}$, com quem manteve uma relação sólida e duradoura de trabalho desde 1929. Seus trabalhos muitas vezes eram resumidos a pequenos jardins ou áreas externas de convivência com orçamento reduzido. Entre a Grande Depressão e a Segunda Guerra Mundial, Church ganha grande visibilidade e sua clientela passa a ser a abastada classe alta da Região da Baía de São Francisco. Os projetos para esses clientes apresentam uma mistura entre os princípios da tradição formal dos jardins e as tendências formalistas dos jardins abstratos do início do século XX: os eixos bem marcados por alamedas de árvores, entradas monumentais e fontes se misturavam com canteiros geometricamente desenhados e topiarias em ziguezague, seguindo o exemplo dos jardins de André e Paul Vera (IMBERT, 2003).

11. William Wilson Wurster obteve seu diploma em Arquitetura na UCBerkeley, em 1919. Associou-se a Theodore Bernarde e Donn Emmons criando a firma Wurster, Bernardi \& Emmons (WBE) - premiado pelo American Institute of Architects (AIA) como empresa do ano em 1965. Tornou-se diretor da Faculdade de Arquitetura da UCBerkeley. Foi responsável pela fusão dos cursos de Arquitetura, Paisagismo e Planejamento Urbano, criando, em 1959, o College of Environmental Design (CED/UCBerkeley). 
[2.19]

Griffin Garden em São Francisco. Projeto de Thomas Church, 1936.
[2.20]

Jacques Rouché Garden em Paris de André e Paul Vera, 1930. Nota-se que os irmãos Vera foram referências para Church desde as viagens feitas pela Sheldon Travelling Scholarship.

[2.21]

Rheem Garden em Orinda. Projeto de

Thomas Church, 1936. Church adota os princípios clássicos no início de sua carreira profissional.
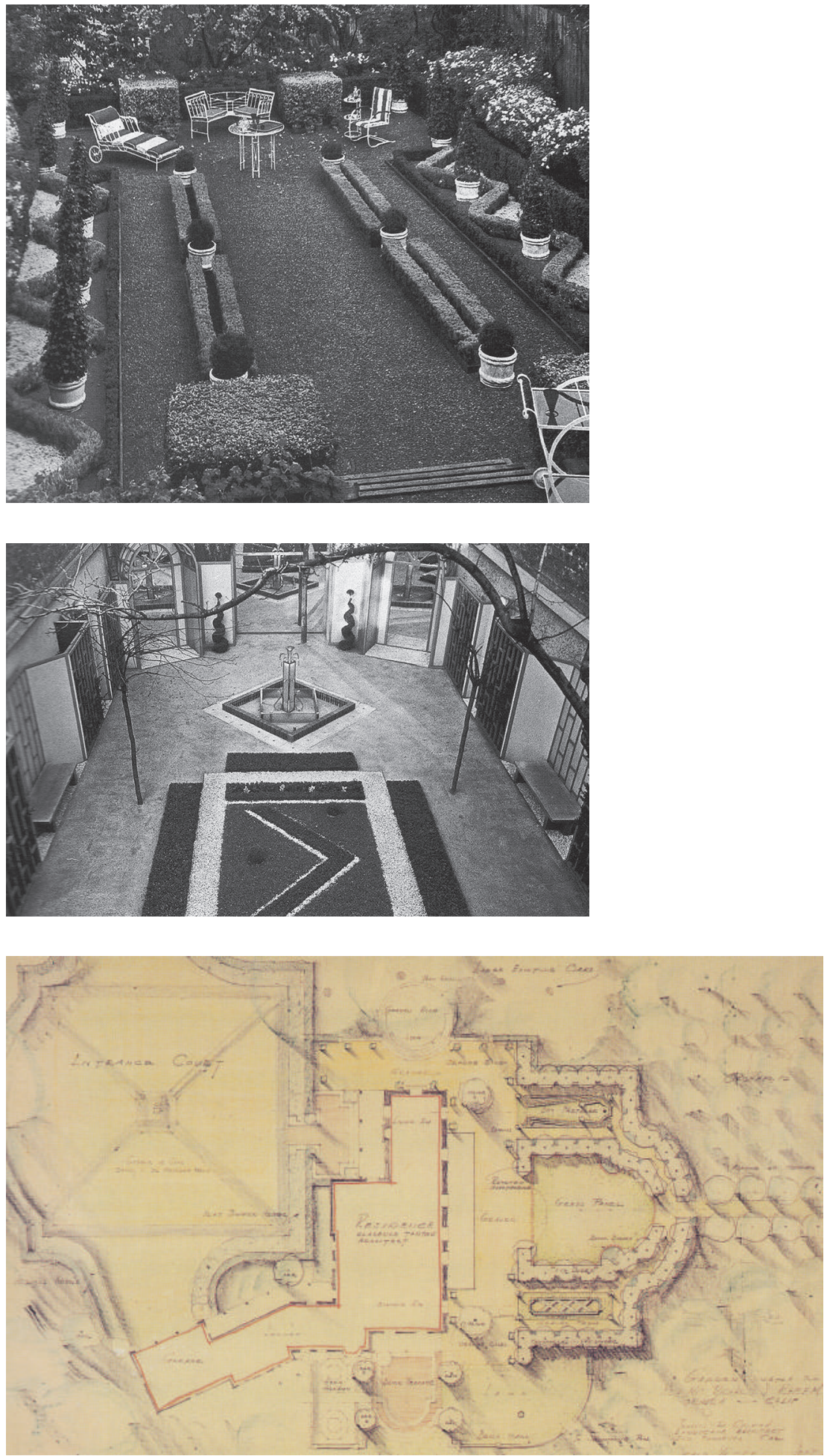
Foi a partir desse amálgama de experimentações que Church desenvolveu a linguagem formal que caracterizou sua obra a partir da década de 1940. A integração das áreas internas e externas, proporcionavam espaços de lazer abrangendo piscinas em formato biomórficos, pérgolas cobertas com trepadeiras e áreas sombreadas para reuniões de amigos. O clima ameno da Califórnia proporcionava o uso dessas áreas durante o ano inteiro, sem preocupações com invernos rigorosos ou verões extremos. A vegetação autóctone era empregada em composições naturalmente esparsas em áreas descampadas ou demarcando alguns recintos mais específicos dos jardins, sempre de forma bastante espontânea, sem massas de topiarias ou de folhas exuberantes que não condiziam com o clima semidesértico. Observa-se o respeito à escala $\mathrm{e}$ à função dos jardins e a simplicidade de soluções, que estabeleciam conexão precisa entre arquitetura e paisagem. Para Church, "a verdadeira beleza não está nem no jardim nem na paisagem, mas na relação de ambos com o indivíduo...buscando não só um cenário para a piscina, a fonte e o parterre, mas um ambiente para a vida" (CHURCH, 1955).

A rede de clientes crescia não só por seu carisma e sua personalidade afável, mas também por sua visibilidade crescente no mercado de paisagismo, proporcionada principalmente pelas inúmeras publicações nas revistas especializadas, primeiramente na revista Sunset e, a partir de $1941^{12}$, na revista House Beautiful. Através dessas publicações Thomas Church não só divulgou seu próprio trabalho, mas também se tornou o porta-voz dos profissionais da arquitetura paisagística no pós-guerra nos Estados Unidos. Em seus artigos, pregava aos americanos a importância de contratarem um profissional especializado para fazer um melhor planejamento de suas áreas livres. Segundo Diane Harris:

12. De 1939 a 1964 a editora da revista House Beautiful foi Elizabeth Gordon, amiga próxima de Thomas Church. Apoiadora da nova arquitetura e também de uma nova forma de se fazer paisagismo, Gordon publicou a maioria dos projetos de Thomas Church enquanto a revista estava sob sua direção. Outra personalidade muito próxima a Elizabeth Gordon e que teve diversos de seus projetos publicados foi Frank Lloyd Wright. 
"Ele convidou seus leitores a buscarem melhores composições de jardins que inspirassem seu uso, estimulando-os a cultivar um estilo de vida que incluísse muita limonada e martinis tomados em redes e espreguiçadeiras, em terraços construídos com boa iluminação e pavimentação e em jardins que requeressem pouca manutenção, oferecendo privacidade em abundância. Mas foi sua capacidade única de articular conceitos de design em termos diretos, combinada com sua aptidão fotográfica e profundo senso de publicidade como uma ferramenta do Modernismo que o colocaram como a figura central da arquitetura da paisagem nos meados do século XX nos Estados Unidos" (tradução nossa, HARRIS, 2003, p.194).

Esse esforço de Church em divulgar a arte de jardins se efetivou de maneira tão enfática que o projeto do Donnell Garden (1948) em Sonoma City, foi o projeto mais fotografado em toda a história do paisagismo nos Estados Unidos (TREIB, 2003). A piscina em formato de ameba, lembrando uma pintura de Jean Arp e ornamentada pela bela escultura de Adaline Kent, representava todos os princípios que Thomas Church preconizou e se tornaram símbolo dessa nova linha de paisagismo americano.

Além das publicações em revistas, Thomas Church publicou, em 1955, no auge de sua carreira, o icônico livro Gardens are for People. Aclamado pela crítica e publicado em inúmeras línguas, o livro apresenta diversos trabalhos de Church e de mais alguns paisagistas e, mais uma vez, estimula o americano comum a cultivar esse novo estilo de

[2.22]

Capa da revista Sunset de fevereiro de 1937 com imagem do Griffin Garden, projeto de Thomas Church.

[2.23]

Capa da revista House Beautiful de abril de 1950 com imagem do Donnell Garden, projeto de Thomas Church.
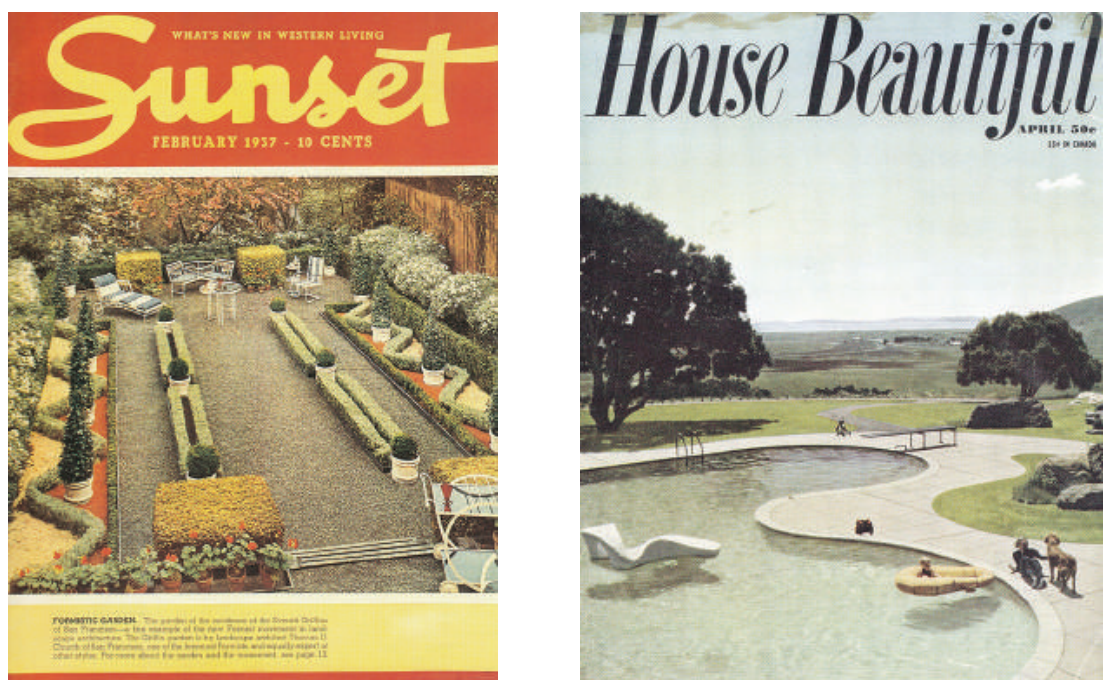
vida do pós-guerra, o American Dream, seja através de um jardim diferenciado, seja através de uma área para recepção dos vizinhos do subúrbio (JANJULIO, 2014).

Em termos profissionais, Thomas Church contribuiu de tal maneira para a exaltação da profissão do paisagista que sua atitude abriu caminho para todos os outros profissionais que o sucederam. Em termos artísticos, Church contribuiu para a modificação dos parâmetros de projeto de paisagismo. Conseguiu promover de modo simples e convincente a nova linguagem que vinha se desenvolvendo nas correntes artísticas europeias, sem causar grandes rupturas nas ideias vigentes à época e que foi aceita de maneira bastante natural. Dessa maneira, Church consagrou-se como um dos paisagistas mais influentes e importantes dos Estados Unidos da América.
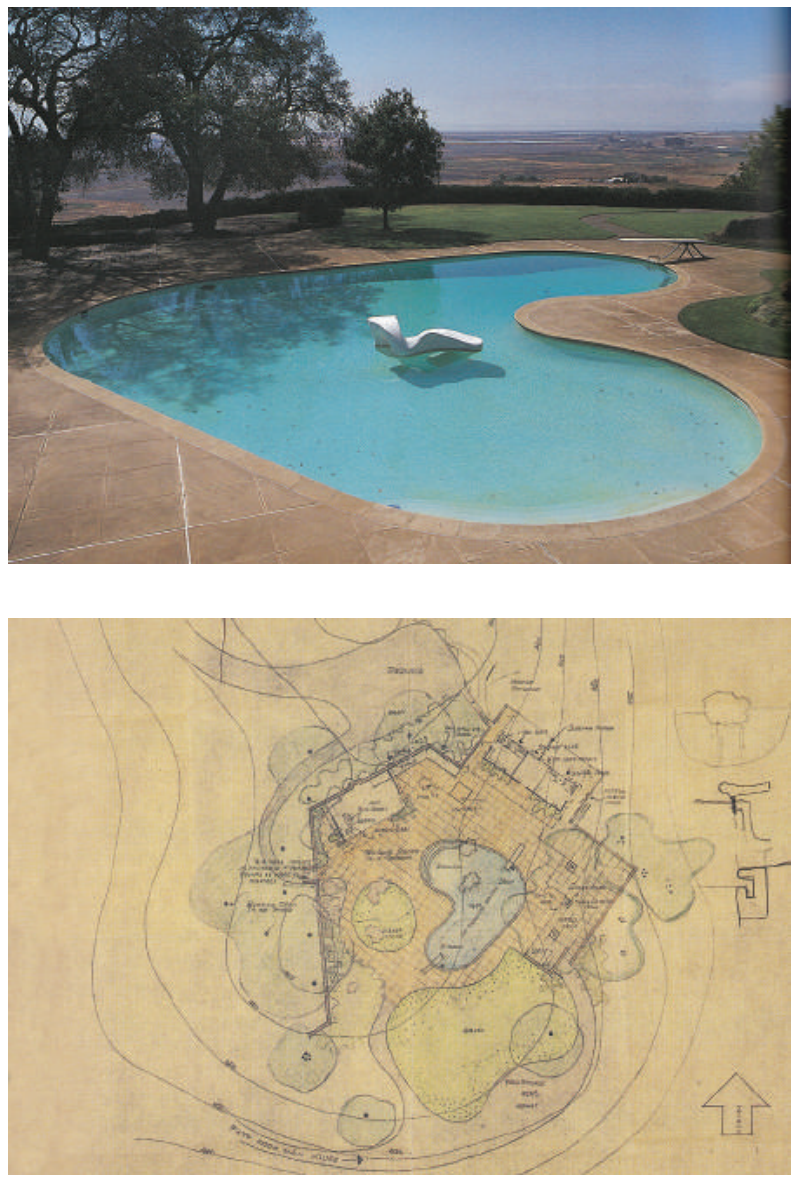

[2.24]

A emblemática piscina do Donnell Garden.

Projeto de Thomas Church, 1948.

[2.25]

Implantação da área de lazer no Donnell Garden. Projeto de Thomas Church, 1948. 


\section{HAVARD REBELS}

Garret Eckbo, Daniel U. Kiley e James C. Rose foram arquitetos paisagistas que ganharam notoriedade por suas produções acadêmicas e projetuais no final da década de 1930, sendo reconhecidos como protagonistas da "escola norte-americana de paisagismo moderno". Eles se conheceram na Harvard University em 1936, quando ingressaram na Graduate School of Design. O curso de arquitetura paisagística da pós-graduação da Harvard University seguia o método voltado às tradições das Beaux Arts e assim as questões relativas aos jardins se resolviam na dicotomia do jardim formal, com os rígidos eixos simétricos, ou informal, com o desenho naturalista herdado dos projetos de Frederick Law Olmsted (IMBERT; TREIB, 1997). Sobre isso, Garrett Eckbo escreveu:

Quando cheguei em Harvard, em 1936, me deparei com uma faculdade de paisagismo que acreditava que uma vez que as árvores não eram feitas em fábricas, não era necessário (para a profissão) se preocupar com as novas ideias que se propagavam na Arquitetura ou nas Artes. O comprovado sistema formal/informal funcionava desde o século XVIII e ainda continuava sendo confortável e confiável (ECKBO, 1983 apud FRAMPTON, 1991).

Simultaneamente a isso, ainda no mesmo prédio, mas no andar acima, os conceitos modernistas propagavam-se rapidamente na Faculdade de Arquitetura, já que o novo reitor da unidade, Joseph Hudnut, decidiu renovar o currículo da escola em $1935^{13}$. Para isso, convidou o ex-diretor da Bauhaus, Walter Gropius, e o arquiteto Marcel Breuer, para juntos completarem o corpo docente da faculdade e injetarem, no terreno norte americano, os novos ideais sobre o papel social da arquitetura que se desenvolviam na Europa. A efervescência da faculdade de arquitetura fascinou tanto os três estudantes do curso de paisagismo que, distanciando-se dos ensinamentos tradicionais, começaram a buscar novas referências na arte moderna e iniciaram novas

13. Thomas Church não chegou a experimentar a efervescência da Harvard University nessa época, já que cursou a pós-graduação nessa instituição até 1926. Sua formação foi tradicional e teve pouco contato com os ideais modernistas preconizados por Walter Gropius. 
formulações sobre a relação entre a sociedade e o desenho da paisagem. Seguindo esse caminho, os Harvard Rebels, como foram apelidados Eckbo, Kiley e Rose, adotaram a planta livre e a interpenetração dos espaços propostos pela Arquitetura Moderna para repensar os modelos de projeto em Paisagismo. Para Imbert (2003), foram os Harvard Rebels que elevaram o Paisagismo a um status moderno, por meio de uma teoria que se baseava em precedentes arquitetônicos e artísticos.

Além das referências provindas da arquitetura, os jovens estudantes também embasaram suas novas concepções nos artigos publicados pelos paisagistas ingleses Fletcher Steele e Christopher Tunnard em revistas especializadas de arquitetura ${ }^{14}$. Posteriormente, Tunnard compilou seus artigos no livro Gardens in the Modern Landscape (TUNNARD, 1950) onde contextualiza histórica e criticamente a arquitetura paisagística praticada no início do século XX e indica alguns caminhos potenciais para serem seguidos no paisagismo contemporâneo.

De maneira geral, Tunnard e Fletcher criticam a postura adotada pelos paisagistas em se aterem aos preceitos estilísticos dos jardins formais e informais. Os ingleses buscam novos pontos de vista para olhar a arte e a paisagem, expandindo o senso das dimensões e do espaço, em um novo entendimento sobre a forma e a cor e na mudança de atitude em relação à natureza, através da apreciação poética das plantas em detrimento do olhar historicista que recaía sobre seu uso. Acreditam que o projeto moderno possibilita a criação de espaços fluidos e sem barreiras, que possam fundir áreas internas e externas. Mas, segundo Tunnard, "O estilo certo para o século XX é não ter qualquer estilo, mas sim, uma nova concepção de planejamento do meio ambiente humano" (TUNNARD, 1942, tradução nossa), ou seja, o cerne da questão para esses novos preceitos é projetar o paisagismo para a realidade existente, com ênfase na integração do homem à natureza.

14. Fletcher Steele e Christopher Tunnard publicaram nas revistas Landscape Architecture. Os artigos foram reproduzidos no livro Modern landscape architecture: a critical review organizado por Marc Treib (TREIB, 1993). 
Para além das considerações teóricas, a grande importância dos artigos escritos por Flecther e Tunnard se deu pela disseminação de exemplares de projetos paisagísticos pioneiros que buscaram explorar, ainda que de maneira primária, essa nova visão da paisagem a partir da tendência formalista que se inspirava na arte moderna abstrata, como os jardins de Gabriel Guévrékian e de André e Paul Vera.

Já no caso de Eckbo, Kiley e Rose, foi a partir dos artigos nas revistas Pencil Points e Architectural Records, que o trio difundiu seus ideais em relação a uma nova visão da arquitetura paisagística. Assim como Tunnard e Fletcher, criticavam os projetos de paisagismo que repetiam as mesmas fórmulas adotadas pelo formalismo tradicional das Beaux Arts. Propunham, então, a criação de vistas multifacetadas a partir de canteiros irregulares e formas livres, onde o olhar, sem as rígidas perspectivas proporcionadas pelos eixos simétricos, sempre encontra uma vista privilegiada do espaço. Tendo o lugar como ponto de partida, o paisagista poderia projetar não só a partir de proposições estéticas e formais, mas também explorando a "honestidade dos materiais", sejam estes minerais ou vegetais, revelando suas qualidades intrínsecas e suas potencialidades.

A ideia defendida pelos professores mais tradicionais da Academia, que o paisagismo não precisaria se modernizar já que os materiais utilizados se mantêm os mesmos, são rebatidas no artigo Freedom in the Garden, de James Rose. Ele defende que, apesar de não haver mudança nos materiais básicos empregados no paisagismo, é necessário propor uma nova concepção de jardim que explore a verdade dos materiais e expresse a mentalidade contemporânea, tendo como inspiração a arte construtivista. Isto porque, para ele, é a arte que mais oferece ao paisagismo noções de espaço e volume através do senso de transparência da quebra da visibilidade por sucessão de planos (ROSE, 1938a).

Na série de três artigos denominados Landscape in the urban environment, Landscape in the rural environment, Landscape in the primeval environment, os três paisagistas conceituam as diferenças entre os ambientes urbanos, rurais e primevos ${ }^{15}$, e apontam de forma 
simples e assertiva as proposições pertinentes a cada um deles. Em relação ao ambiente urbano, reiteram a necessidade de áreas livres para lazer e recreação, já que o homem moderno passa grande parte do seu dia no trabalho e precisa, para ter uma vida saudável, de espaço de qualidade para se exercitar ou simplesmente descansar. Ressaltam a importância de prover essas áreas de recreação com espaços flexíveis e de usos múltiplos (para diversos públicos, por exemplo), expandindo o lazer para fora dos jardins privativos e propiciando a convivência social, sempre pensando a recreação urbana como uma demanda a ser atendida. No tocante aos elementos que compõem o jardim, fica expressa a preferência por materiais e equipamentos modernos, além da vegetação que se integra organicamente ao espaço, criando massas que conformem circulação, topografia e estares (ECKBO; KILEY; ROSE, 1939b).

Por outro lado, o ambiente rural é quase o reverso do ambiente urbano: se de um lado a cidade precisa de mais espaço livre para lazer, ao contrário, o campo não precisa de tanto espaço para recreação, mas esse espaço precisa ter um uso mais intenso, que permita a integração social de uma população territorialmente esparsa. As aspirações do homem urbano e do homem do campo são bem similares, mas as características de trabalho, o ritmo de vida e as potencialidades dos ambientes são bem diferentes e devem ser pensadas de modos diversos. É necessário olhar o campo de modo a desenvolvê-lo para a população rural: mais do que o retorno à natureza tão almejado pela população urbana, o homem do campo não quer um retiro natural, mas sim áreas que lhe sejam úteis para sua vida cotidiana. Por conta disso, os paisagistas propõem que as atividades de lazer sejam desligadas do trabalho físico na lavoura e sejam relacionados à prática das artes, como artesanato, pintura, dança e teatro, e de esportes "indoors", em quadras esportivas ou piscinas cobertas. Os espaços também devem ter usos múltiplos, para abrigar atividades para as diversas idades, principalmente com a dificuldade de mobilidade na área rural, que propicia um fluxo conjunto da família

à primeval, palavra adotada pelos autores para descrever o ambiente não habitado pelo homem. 
Revista Pencil Points, onde foram publicados artigos de autoria de James Rose e Garret Eckbo. para as áreas de lazer, normalmente localizadas nos pequenos centros comerciais. Ademais, a zona rural precisa de incrementos estruturais, com a melhoria das rodovias e estradas vicinais e com a estruturação de pequenos centros comerciais e institucionais, com escolas, igrejas e ginásios esportivos, que possibilitem o encontro social e interação física desses habitantes (ECKBO; KILEY; ROSE, 1939a).

Para o ambiente primevo, os paisagistas indicam a proteção territorial, principalmente com proteção e controle da fauna e da flora, com o mínimo de intervenção humana, já que são ambientes de contemplação, observação e estudo científico (ECKBO; KILEY; ROSE, 1940).

Pode-se afirmar, a partir da análise dos artigos escritos por esses paisagistas, que estes normalmente se conformam como manuais de paisagismo, divididos em itens para serem seguidos, explicitando de uma maneira sucinta como proceder em relação às novas ideias da arquitetura paisagística. James Rose se destacou pelos artigos nas revistas especializadas ${ }^{16} \mathrm{e}$ Garrett Eckbo se sobressaiu com a publicação de diversos livros, sendo Landscape for Living, de 1950, o mais notório deles.

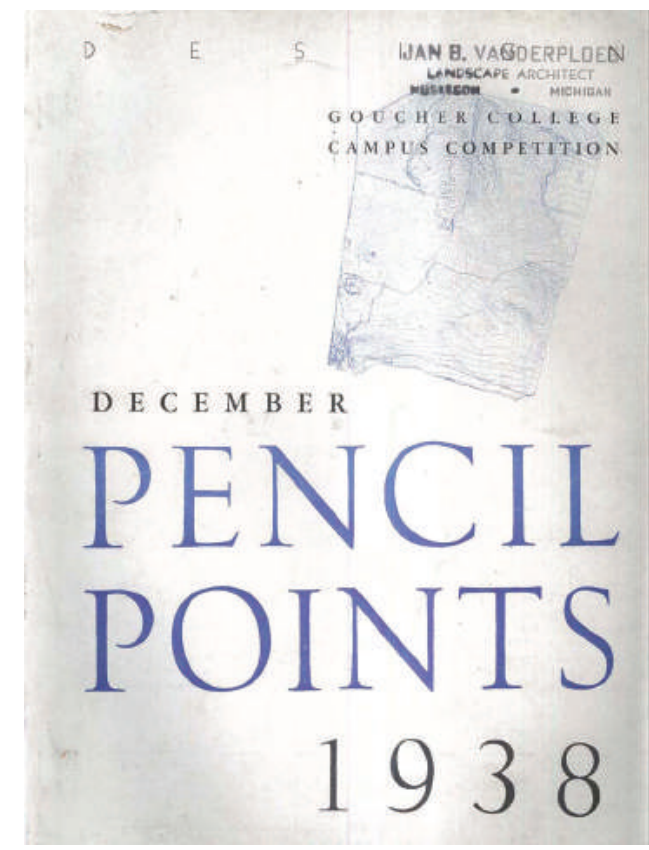

16. James Rose publicou artigos nas revistas American Home, California Arts \& Architecture, Pencils Points e Progressive Architecture. 


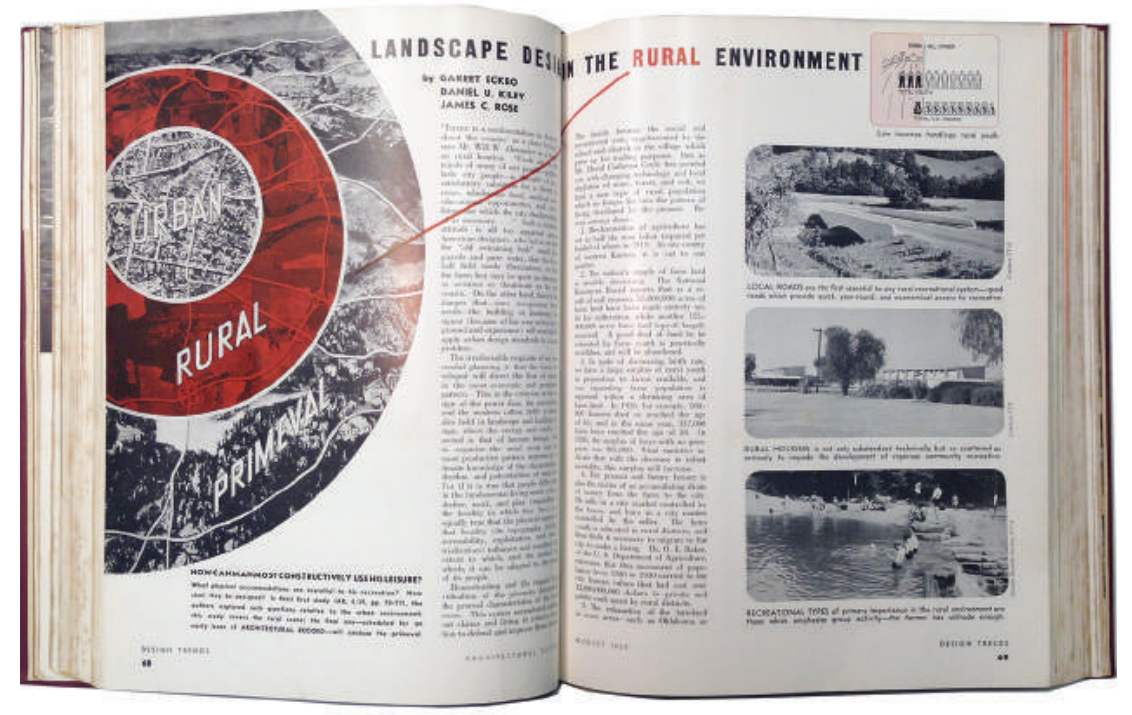

[2.27]

Artigo Landscape in the rural environment publicado na revista Architectural Review, em agosto de 1939.

\section{[2.28]}

Artigo Landscape in the urban environment, publicado na revista Architectural Review, em maio de 1939. 
Em termos gerais, os três paisagistas procuraram explicitar a necessidade de encarar a relação entre arquitetura e paisagem com um novo olhar. A ideia principal girava em torno do mote "Landscapes are for people" - 'os jardins/paisagens são para as pessoas' - que buscava a aproximação do paisagismo à sociedade industrial, ou seja, o programa seguia as condições sociais e tecnológicas da vida contemporânea e, ao mesmo tempo, respeitava as especificidades do local através de uma atitude mais sensível em relação à paisagem e às construções do ambiente externo. Nesse sentido, Garrett Eckbo (1942, tradução nossa) afirmava que "a escala do projeto não é um problema; cada projeto, seja grande ou pequeno, requer um planejamento coerente, referente à organização do ambiente para as pessoas".

Em consequência dessa nova demanda, outras questões se desenvolveram, como a negação dos estilos históricos, que, para eles, não se traduziam em espaços livres e agradáveis e não propiciavam projetos feitos para a escala do indivíduo. Com a proposta da quebra dos eixos simétricos e da perspectiva linear foi possível criar novas formas que se traduzissem em espaços com mais ritmo e movimento; com mais vida, ação e felicidade ${ }^{17}$, potencializando a tridimensionalidade e a volumetria dos estares a partir de elementos geométricos bem marcados. O uso dos novos materiais, como blocos de concreto, telas metálicas e elementos plásticos, e o emprego da vegetação solta, como entidades botânicas e escultóricas, representavam uma postura moderna oposta à tradição que até então se impunha nos projetos.

Além dos trabalhos escritos, o que proporcionou notoriedade aos paisagistas norte-americanos foi a possibilidade de experimentar, a partir dos projetos, a conceituação teórica que formularam nos anos seguintes à graduação na Harvard University. Os três paisagistas tentaram transpor a conceituação teórica na prática projetual e os resultados são bastante diferentes. Mesmo assim, seus projetos são, muitas vezes, considerados puramente formalistas, já que as "formas

17. Eckbo escreveu "Que haja ritmo, que haja movimento; que haja vida, ação e felicidade. Que nada seja estático, balanceado e cuidadosamente definido" (ECKBO, 1937, tradução nossa). 
livres" e os canteiros altos não constituem, necessariamente, espaços fluidos e integrados. Sobre a obra de Eckbo, Medeiros (2004) escreve:

(São) formas nitidamente dissonantes em relação à arquitetura ou ao entorno, que decorrem de um exercício experimental puramente abstrato, autocentrado, cuja fonte ética era a profunda insatisfação com os padrões acadêmicos superados, mas que sempre se conceberam como inquietação e problematização e não como estilo a ser indiferenciadamente reproduzido.

De fato, alguns projetos não conseguem transpor a conceituação teórica para a prática, como o próprio Eckbo escreve em Landscape for Living: "Pode-se notar que a prática ilustrada não é inteiramente consistente com a teoria descrita neste livro, ou não está inteiramente à sua altura (...) Se nossa prática fosse tão boa quanto a nossa teoria, algo estaria muito errado nessa teoria" (ECKBO, 1950b, tradução nossa).

Isso ocorre devido ao campo de atuação existente nos Estados Unidos à época ser fortemente dominado pelo mercado imobiliário, destinado à construção de residências e loteamentos privados, o que diminuía muito as possibilidades de expandir a prática projetual do lote para a cidade. O panorama profissional sofreu uma mudança a partir da década de 1960, quando o paisagismo se distancia do desenho do jardim e vai ao encontro à preservação do ambiente urbano através da Ecologia e dos métodos analíticos desenvolvidos por Ian MacHarg ${ }^{18}$.

Apesar disso, os projetos de Eckbo, Kiley e Rose representaram uma grande mudança do olhar em relação à paisagem e à natureza. Eles disseminaram a necessidade de um novo desenho paisagístico correspondente às novas necessidades do homem, ressaltando a importância das áreas de recreação coletivas e dos espaços livres que refletissem o

18. Ian McHarg (1920-2001), nasceu na Escócia mas viveu boa parte de sua vida no Estados Unidos da América. Estudou paisagismo e urbanismo na Harvard University, entre 1946-1949, e foi professor da University of Pennsylvania a partir de 1954, no recém-inagurado Department of Land and City Planning e em 1956 passou a lecionar no Departament of Landscape Architecture. Dentre seus colegas da Penn University estavam os notáveis: Lewis Mumford, J. B. Jackson, William Wheaton, David Crane, Louis Kahn, Holmes Perkins, Gordon Cullen, Aldo Van Eyck e Denise ScottBrown. Seu livro Design with Nature, propiciou mudanças fundamentais no ensino e na prática da arquitetura paisagística (SPIRN, 2000). 
crescimento e desenvolvimento da sociedade contemporânea. Pregavam a apropriação das dimensões do jardim seguindo suas diversas funções, e a conformação de ambientes flexíveis e orgânicos a partir de desenhos livres. E, o mais relevante, destacavam a importância da natureza na vida do homem: o respeito às condições naturais do sítio; o emprego de materiais locais; a adequação do projeto à paisagem existente; e a importância do uso escultórico da vegetação.

Nesses jardins, entretanto, a despeito das fotografias em preto e branco, sabe-se (...) que inauguram uma nova forma de ver a natureza, seja por aspectos já mencionados, ligados à morfologia vegetal, à unidade do plantio, ao plantio estruturador do espaço, à preocupação em modular o espaço vertical e horizontalmente com a vegetação; seja pela escolha de uma paleta rebaixada, que raramente usa flores como componente principal, atentando para os valores tonais, cromáticos e de texturas das folhagens, para a valorização não-dogmática da flora nativa (MEDEIROS, 2004).

Entretanto, é certo que a repercussão dos artigos publicados por eles e a agitação social gerada pelo trio de paisagistas contribuiu para acentuar um movimento transcontinental no desenho da paisagem (FRAMPTON, 1991). 


\subsection{RUPTURA E RENOVAÇÃO: A CONSTRUÇÃO DE UMA MODERNIDADE VERDE NO BRASIL.}

Os anos de 1930 foram marcados, no Brasil, por uma grande mudança no campo das artes, da literatura e da arquitetura. O país sofria grandes mudanças devido à acelerada industrialização e a migração da população rural para a área urbana impactava o crescimento das cidades, principalmente dos dois grandes centros urbanos do país, São Paulo e Rio de Janeiro. Os projetos de reestruturação urbanas eram iminentes e alguns segmentos da sociedade, principalmente a elite intelectual, queriam construir uma nova imagem de uma nação modernizada e, ao mesmo tempo, enraizada na cultura brasileira. Foi a partir dessas premissas que o Movimento Moderno Brasileiro ganhou espaço e se relacionou com a representação dos ideais de nação moderna. Os princípios do pensamento moderno nortearam não só as artes plásticas e a arquitetura, mas também o paisagismo, antes referenciado nas tradições europeias de jardins.

Até então, víamos projetos paisagísticos em estilo francês e inglês, divididos na dicotomia dos jardins formais e informais, que empregavam principalmente vegetação exótica importada da Europa e da Ásia. Os projetos de jardins tradicionais eram reproduzidos indiscriminadamente nas grandes cidades como modelos de projeto paisagísticos e urbanísticos.

Nesse sentido, essa nova busca pelo paisagismo moderno tentou caminhar ao lado das grandes mudanças estruturais que aconteciam nas cidades, seja na forma dos novos planos urbanísticos, como o Plano de Avenidas de Prestes Maia ou o Plano da Light ${ }^{19}$, seja na mudança da configuração das residências, que passavam a contar com áreas verdes integradas aos espaços internos das edificações.

19. Someck e Malta descrevem detalhadamente esses planos urbanísticos em A Cidade não pode parar: planos urbanísticos de São Paulo no século XX. 
Com a intenção de preencher algumas lacunas existentes em relação à atuação profissional e docente de Roberto Coelho Cardozo e compreender, consequentemente, a ampliação do campo profissional do paisagismo na cidade de São Paulo, introduziremos a seguir algumas experiências que precederam sua atuação profissional na cidade de São Paulo.

\section{OS PRIMEIROS LAMPEJOS DE MODERNIDADE}

Um primeiro lampejo de modernidade nos jardins brasileiros surge com o projeto de Mina Klabin Warchavchik (1896-1969) para os jardins da Casa Santa Cruz, projetada e construída por seu marido, Gregori Warchavchik, em 1927. Inserido no meio artístico efervescente que sucedeu a Semana de Arte Moderna de 1922, o casal convivia dentre os artistas modernistas, como Tarsila do Amaral, Oswald de Andrade, Mário de Andrade e Anita Malfatti. Invariavelmente, o pensamento desses artistas embebeu o trabalho de Mina, que, seguindo os passos de Tarsila, adotou a vegetação nativa, principalmente o cacto e o mandacaru, como imagem síntese de brasilidade ${ }^{20}$. Ao adotar cactos e palmas em contraponto aos buxos e pinheiros, vegetação frequentemente empregada nos jardins do início do século XX, Mina consegue contrastar a sobriedade das linhas retas e da cor branca da casa modernista de Warchavchik com a rara e peculiar vegetação. É a primeira vez, no paisagismo brasileiro, que se usa o elemento vegetal como índice de localidade, como expressão do espírito do lugar: Mina enobrece a vegetação autóctone, tornando-a símbolo da nacionalidade e tirando-a da condição de "mato" (PERECIN, 2003).

20. Aracy Amaral desenvolve a questão do cacto como símbolo de brasilidade na obra de Tarsila Amaral em Tarsila: sua obra e seu tempo (AMARAL, 1975) e em Blaise Cendrars no Brasil e os modernistas (AMARAL, 1997). Guilherme Mazza Dourado também discorre sobre a presença de Tarsila na obra de Mina Klabin Warchavchik no primeiro capítulo do livro Modernidade Verde - jardins de Burle Marx (DOURADO, 2009). 


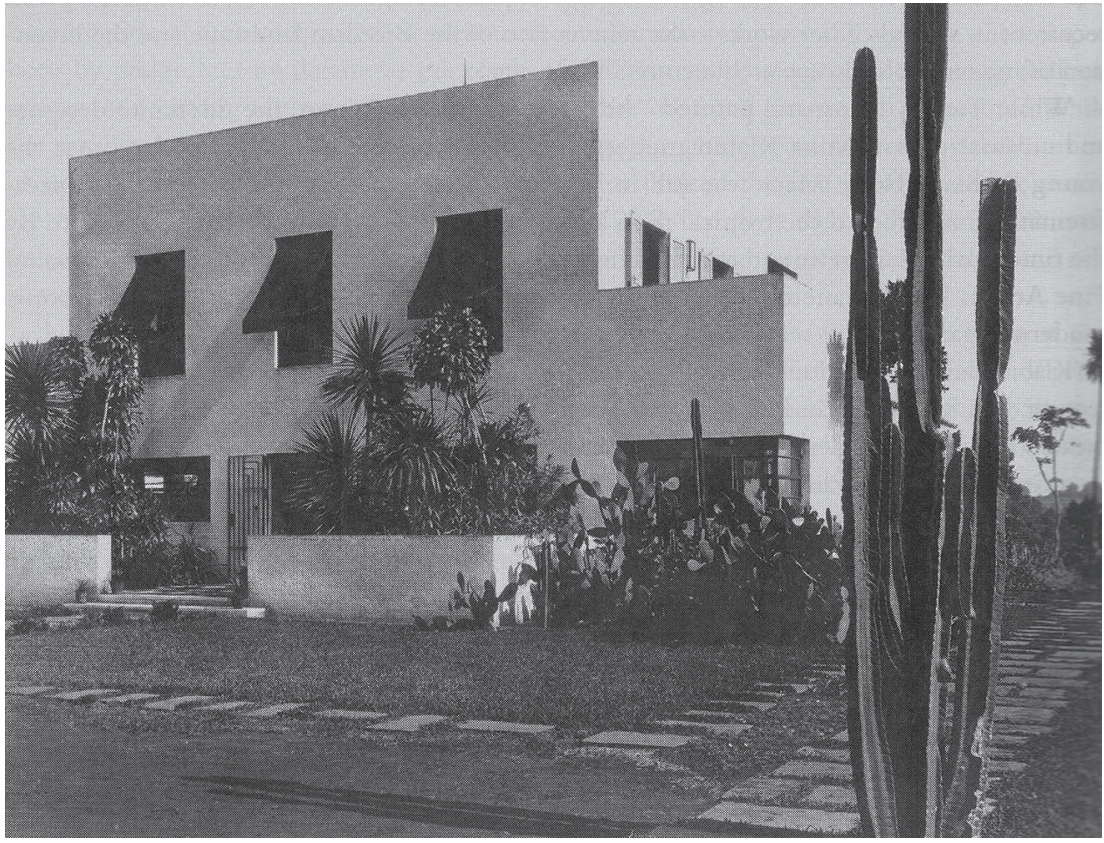

Sendo assim, na Casa à Rua Santa Cruz, Mina esculpe a fachada frontal da casa com dracenas, agaves ${ }^{21}$ e palmas e a entrada do caminho lateral, formado por pedras irregulares, é introduzido com a presença de um grande mandacaru. Os jardins dos fundos são trabalhados com massas de mandacarus e outros cactos. Mina trabalhou nesse jardim por vinte anos, uma vez que o terreno foi ampliado e o jardim ganhou a dimensão de um parque de vizinhan

Mina ainda projetou os jardins das casas à Rua Itápolis e à Rua Bahia (Residência Luiz da Silva Prado), este último merecendo destaque por sua composição em patamares. A fachada da casa, formada por grandes cubos brancos, ganha um novo desenho com a presença das dracenas, dos cactos e de um grande guapuruvu (Schizolobium parahyba) plantado na calçada em frente à rua. $\mathrm{O}$ jardim posterior é formado por patamares compostos por pequenas árvores, como a copaíba (Copaifera langsdorfi), e por caminhos desenhados com pe-

\section{[2.29]}

Vista do jardim frontal da Residência à Rua Santa Cruz. Projeto de Mina

Warchavchik, 1929.

21. Agaves e dracenas não são espécies nativas, mas se aproximam da linguagem das cactáceas e das plantas do sertão brasileiro. Nesse sentido, Mina trabalhava mais com a estrutura formal das plantas do que com sua origem. 
dras rústicas. O segundo patamar se destaca pelo desenho que evoca diretamente o jardim de Charles Noailles de Gabriel Guevrékian. Mina repete o tabuleiro xadrez em alto relevo, intercalando pisos e canteiros de flores. Certamente Mina, sempre conectada às vanguardas artísticas europeias, já conhecia o trabalho do arquiteto armênio (LIRA, 2011).

Também vemos ressoar no trabalho paisagístico de Mina Klabin, o regionalismo citado anteriormente, no Parque Güell de Gaudí - ambos se alimentam das referências vernaculares, dos elementos naturais e dos símbolos nacionais, no caso de Gaudí com o Montserrat e no caso de Mina com o mandacaru, tomando a dianteira na guinada para os caminhos da modernidade nos jardins.

[2.30]

Vista superior do jardim dos fundos da Residência Luiz da Silva

Prado. Projeto de Mina Warchavchik, 1930.

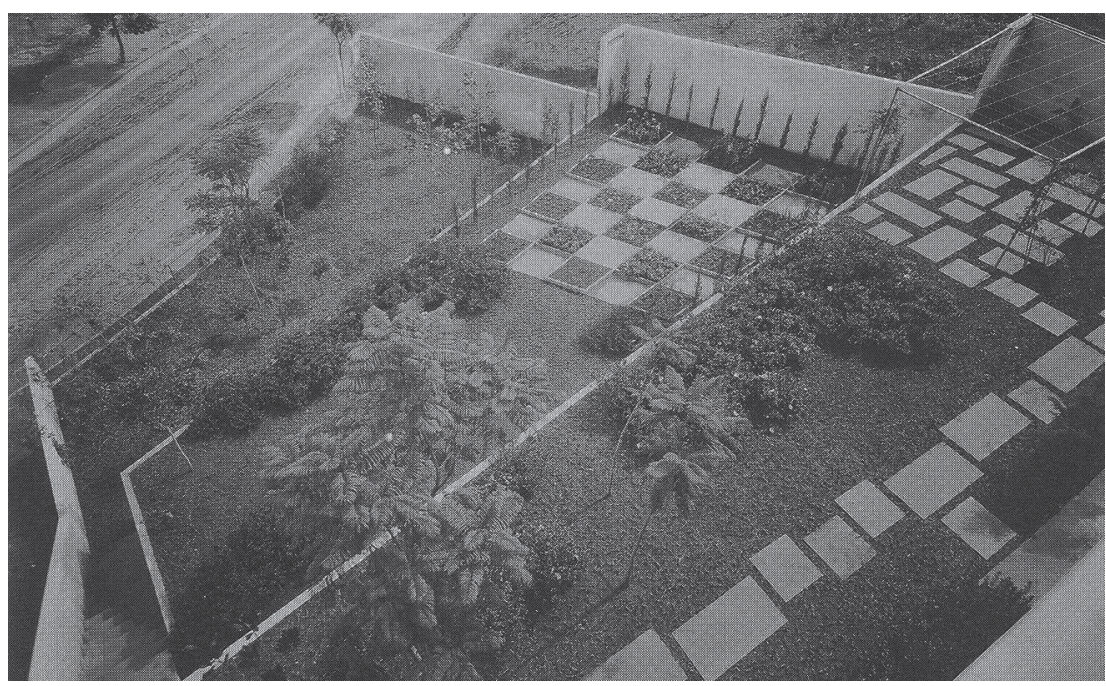

[2.31]

Vista do jardim dos fundos da Residência Luiz da Silva Prado a partir da

Rua Itápolis. Projeto de Mina Warchavchik, 1930.

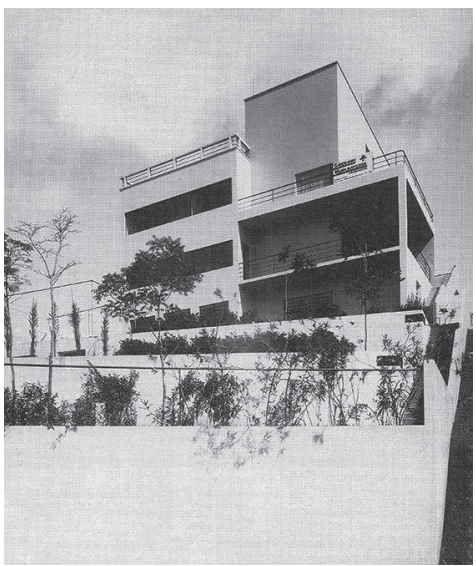


Outro personagem que também se aventura no campo do paisagismo, exaltando a vegetação exuberante como símbolo de brasilidade é o arquiteto Flávio de Carvalho (DOURADO, 2009).

O projeto da sede da Fazenda Capuava, de 1929, é pensado desde sua concepção como uma intervenção na paisagem. Em entrevista à revista Casa e Jardim, Flávio argumenta:

Na escolha do local fugi à prática comum de colocar a casa nos vales. Preferi os morros, com a paisagem que os circunda. Os ventos são controlados artificialmente pela disposição adequada da alvenaria e pelo plantio de árvores. Até o clima em cima do morro, no local onde foi construída a casa, foi alterado pela vegetação em torno (CARNEIRO, 1958).

A sede, projetada como um volume trapezoidal bastante incomum, que "não tem lados", é assentado no terreno a partir de varandas horizontais que acompanham os desenhos dos morros e também da piscina, que tem seu azul turquesa contrastado com o verde do gramado. Quebrando a linearidade do edifício estão cactos, palmas e agaves que competem com as vivas cores da cortina colorida, que se encontra esvoaçante entre interior e exterior do salão central. Trabalhando ainda a questão das cores entre espaços internos e externos, Flávio projeta uma luminária feita em alumínio pendurada ao teto da sala principal, que não só proporciona luz indireta em todo ambiente, mas que também traz a cor do gramado e da cortina, refletidas no interior do ambiente. Nesse sentido, Flávio de Carvalho explora a questão formal e plástica da arquitetura, integrando o edifício à paisagem de maneira singular, tencionando as várias possibilidades estéticas de uma nova forma de paisagismo. 
[2.32]

A sede da Fazenda

Capuava, projetada por

Flávio de Carvalho publi-

cada na revista Casa e

Jardim em 1954.

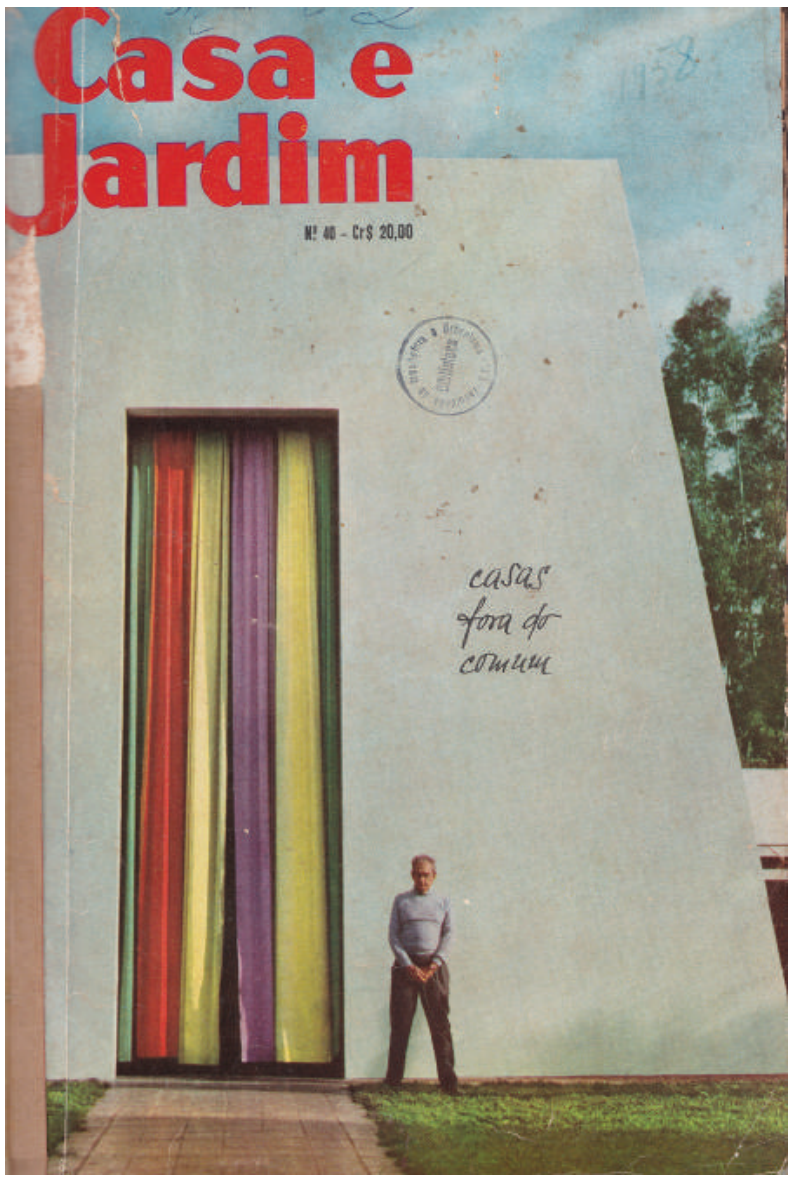

[2.33]

Jardins da sede da

Fazenda Capuava após passar por reformas em

1958.

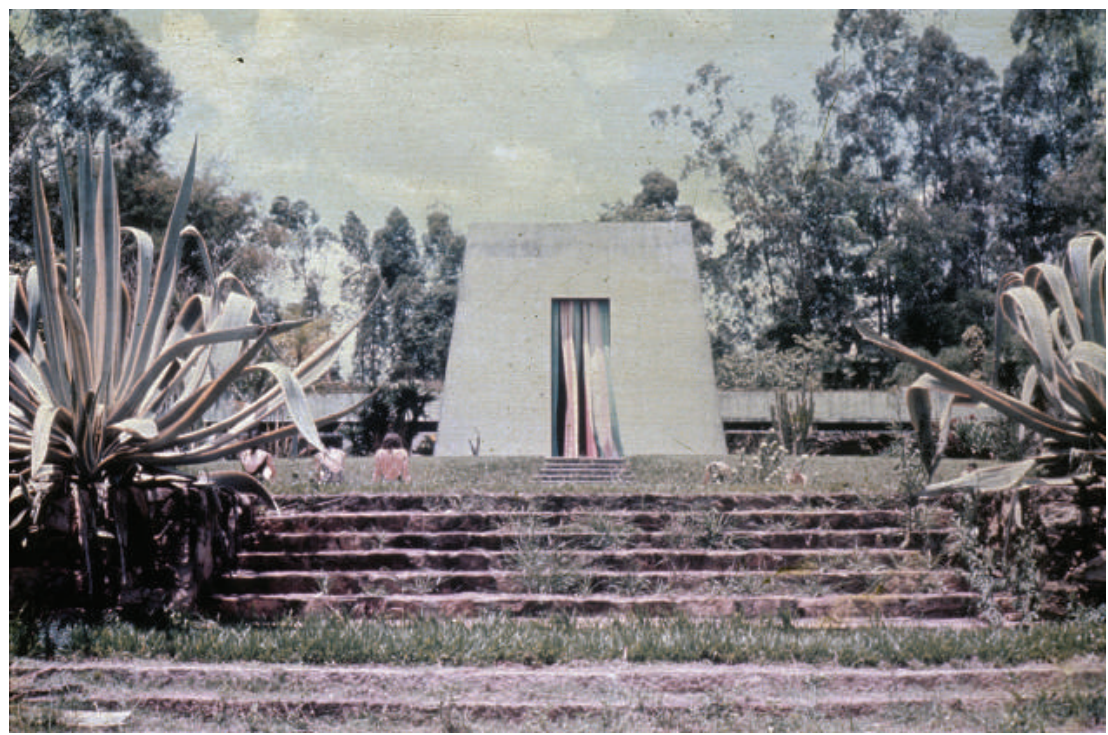


Próximo a Mina e a Flávio de Carvalho surge o expoente mais importante do paisagismo brasileiro: Roberto Burle Marx. A partir da obra de Burle Marx o desenho da paisagem ganhou espaço nos debates do meio arquitetônico nacional e internacional. O paisagismo passava a conciliar-se com movimentos de renovação arquitetônica que então se processavam e que levaram Michel Racine a denominar o Movimento Moderno Brasileiro como "Um movimento-modernista-com-jardim" (LEENHARDT, 1994, p.114). Entendendo o jardim como uma intervenção humana com a natureza, Burle Marx assume desde cedo uma postura de ruptura com o paisagismo vigente à época. Tal conduta foi fundamental como contribuição para uma nova condição na disciplina paisagística.

Para Flávio Motta, os projetos de Burle Marx são "projetos de um homem atualizado pelas atenções do viver urbano" (MOTTA, 1986, p.1). Sua obra buscava o rigor artístico e científico e ao mesmo tempo a valorização da paisagem. Buscava também a renovação mediante a investigação de valores plásticos, próprios à Arte Moderna. Para Motta, Burle Marx realiza a paisagem com uma consciência histórica, impregnando-a de sentido didático e cultural.

Sua ligação com os arquitetos modernos lhe garantiu uma autonomia de projeto singular no meio profissional contemporâneo. Seu envolvimento com tais movimentos arquitetônicos e o contato direto com diversos de seus expoentes, lhe abre a possibilidade de elaboração de projetos nas mais diversas escalas, desde as grandes reestruturações urbanas no Rio de Janeiro, como o Aterro do Flamengo, até experimentações artísticas em murais, como no Instituto Oswaldo Cruz ou na Residência Jean Marie Diestl (DOURADO, 2009).

Mesmo com a relevância incontestável de Roberto Burle Marx no campo paisagístico e artístico, sua atuação prática não foi significativa em São Paulo entre as décadas de 1950 e 1970 e seus trabalhos eram divulgados pelas publicações em revistas especializadas e na exposição realizada no Museu de Arte Moderna de São Paulo (MASP) em 1952. Essa "ausência" de Burle Marx no mercado paisagístico em São Paulo proporcionou a oportunidade para a atuação de Waldemar Cordeiro e Roberto Coelho Cardozo na capital paulista. 


\section{EXPANDINDO O PANORAMA PAISAGÍSTICO PAULISTANO: A ATUAÇÃO DE ROBERTO COELHO CARDOZO}

A cidade de São Paulo, no início da década de 1950, tinha um crescimento desenfreado e já apresentava mais de dois milhões de habitantes na área metropolitana. Com a liberalização dos controles do crescimento vertical, surgiam edifícios comerciais e quitinetes em toda a região central. As construções industriais eram impelidas para as áreas de várzea dos Rios Tietê, Pinheiro e Tamanduateí enquanto as áreas nobres eram reservadas para construção de grandes residências da alta burguesia, através dos loteamentos da Companhia City. Investir no mercado imobiliário era uma das atividades mais lucrativas da cidade e os setores da classe dominante aplicavam seus excedentes em construções projetadas pelos arquitetos modernos (Mello, 2010). Essas novas edificações construídas nos terrenos dos bairros recém-estruturados, contavam com lotes maiores e mais áreas verdes. Dado esse contexto, com essa nova necessidade em se projetar as áreas verdes, inicia-se a atuação dois expoentes do Paisagismo na cidade: Roberto Coelho Cardozo e Waldemar Cordeiro, artista plástico que tinha o paisagismo como meio de subsistência ${ }^{22}$. Segundo Ana Belluzzo (1986), "em São Paulo só por volta de 1950 alarga-se o espaço antes preenchido pelo arquiteto e pelo jardineiro, dando lugar à figura do profissional paisagista. Contavam-se nos dedos: eram Roberto Coelho Cardozo e Cordeiro".

Curiosamente, o percurso profissional dos dois paisagistas apresenta muitas convergências, que se iniciam com o período em que trabalharam: Cardozo inicia sua carreira quando chega em São Paulo em 1951 e deixa a cidade, mudando-se para a Inglaterra em 1970; Cordeiro projeta seus primeiros jardins entre 1953 e $1954^{23}$ e a

22. "Pensado no início como meio de subsistência, o paisagismo logo passaria a demandar maior atenção, constituindo-se num campo paralelo de reflexão artística" (MEDEIROS, 2004). A tese de Givaldo Medeiros explora toda a complexidade envolvida na obra paisagística de Waldemar Cordeiro. Estamos aqui apenas ressaltando alguns aspectos de sua trajetória que coincidem com o percurso profissional de Roberto Coelho Cardozo.

23. "Algumas notícias dão conta da sua atuação como paisagista já em 1953" (MEDEIROS, 2004). 
atividade como paisagista perdura até seu falecimento precoce, em 1973. Ambos iniciaram suas carreiras com o estímulo do arquiteto João Batista Vilanova Artigas, que os convida para projetar os jardins de seus projetos, Cardozo projetando o jardim da residência Alfredo Rosenthal (1951) e Cordeiro da residência David Rosenberg (1954).

Grande parte de seus trabalhos iniciais consistiu em projetos de jardins e áreas internas para as residências modernas unifamiliares que ganhavam espaço na área urbana. De fato, considerando que o mercado de trabalho dos paisagistas se restringia aos trabalhos de menor escala, "o campo de atuação existente pouco ultrapassava os espaços mínimos e recuos das habitações dentro dos lotes" (MAGNOLI, 2003). A alta sociedade paulistana, que formava a clientela abastada tanto dos arquitetos modernos quanto dos dois paisagistas começa a se distribuir para além do Pacaembu e Jardim América, ocupando também o Jardim Paulista e Jardim Europa e os recém-inaugurados bairros do Brooklin, Jardim Guedala (subdistrito do Butantã) e Morumbi.

Aos poucos, o escopo de seus projetos vai se ampliando, uma vez que passam a projetar jardins para construções de maior escala, como edifícios residenciais e comerciais, chácaras, fazendas e espaços públicos. Isso se deve a três fatores: ao contato mais próximo com os arquitetos que atuavam na cidade (sendo que o contato de Waldemar Cordeiro com arquitetos se deu pela sua inserção no meio artístico e também pela convivência com arquitetos no "Clubinho" ${ }^{24}$ e no IAB, e Cardozo ampliou sua rede de contatos através da sua atividade docente na FAUUSP); à conquista da fidelidade dos clientes, que inicialmente contratavam seus serviços para projetarem os jardins de suas casas na cidade e posteriormente requeriam projetos para chácaras, fazendas e empreendimentos imobiliários; e por fim, com à divulgação de seus projetos nas revistas especializadas de Arquitetura e Paisagismo.

Os dois paisagistas tiveram muitos de seus projetos divulga-

24. O "Clubinho" ou Clube dos Artistas e Amigos da Arte de São Paulo (CAAA) foi fundado no início dos anos de 1930 e era sediado no subsolo do edifício do Instituto dos Arquitetos do Brasil (IAB) em São Paulo. Ganhou notoriedade por ser um ponto de encontro de intelectuais e artistas paulistanos (pintores, escultores, jornalistas, músicos e arquitetos). 
dos nas revistas Acrópole, Habitat e principalmente na revista Casa e Jardim. Assim como ocorreu nos Estados Unidos, com a divulgação dos projetos de Thomas Church nas revistas Sunset e House Beautiful e com a divulgação dos estudos teóricos dos Harvard Rebels nas revistas Pencil Points e Architecture Review ${ }^{25}$, o papel dessas revistas brasileiras foi fundamental para estabelecer a presença desses paisagistas no mercado paulistano. No artigo "Reflexões sobre um jardim" (REFLEXÕES, 1956), o autor desconhecido ressalta a importância dada ao papel do paisagista: "Casa e Jardim ao publicar esta reportagem, deseja mais uma vez realçar o papel preponderante dos jardins em nossas vidas cotidianas. (...) Jardins que, como verdadeiras obras de arte, resultam de trabalhos bem pensados, estudados e primorosamente executados".

Por fim, os dois paisagistas têm como base conceitual e prática o conjunto de questões que vinham sendo discutidas e destacadas pelos paisagistas ingleses e os norte-americanos em seus livros e artigos. Para Cordeiro, destacam-se os preceitos levantados pelo americano Garrett Eckbo em Landscape for Living e pelo inglês Christopher Tunnard em Modern Gardens: masterworks of international garden architecture (MEDEIROS, 2004). Já Cardozo, por ter tido contato direto com Garrett Eckbo a partir do trabalho no escritório Eckbo, Royston \& Williams, se inspira em seus conceitos e muitas vezes reproduz a linguagem formal da "corrente californiana" em seus projetos. Cardozo é considerado o principal responsável pela incorporação dos ideais californianos no projeto paisagístico praticado em São Paulo e pela perpetuação desses preceitos no modo de projetar por várias gerações de paisagistas que o sucederam ${ }^{26}$.

25. Beatriz Colomina aborda a questão sobre do desenvolvimento da publicidade da Arquitetura Moderna a partir das revistas especializadas (e meios de comunicação em massa) no livro Privacy and publicity: Modern Architecture as Mass Media. Sobre a publicitação no meio paisagístico norte-americano, também temos como referência os artigos de Diane Harris e Daniel Gregory e a tese de Maristela Janjulio. No âmbito da Arquitetura Moderna Brasileira, incluindo o Paisagismo, temos a referência da dissertação de Paula Dedecca, sobre as revistas Acrópole, Projeto e Habitat e a dissertação de Paula Machado sobre a revista Casa e Jardim (COLOMINA, 1994; HARRIS, 2003; GREGORY, 2003; JANJULIO, 2014; DEDECCA, 2012; MACHADO, 2007). 


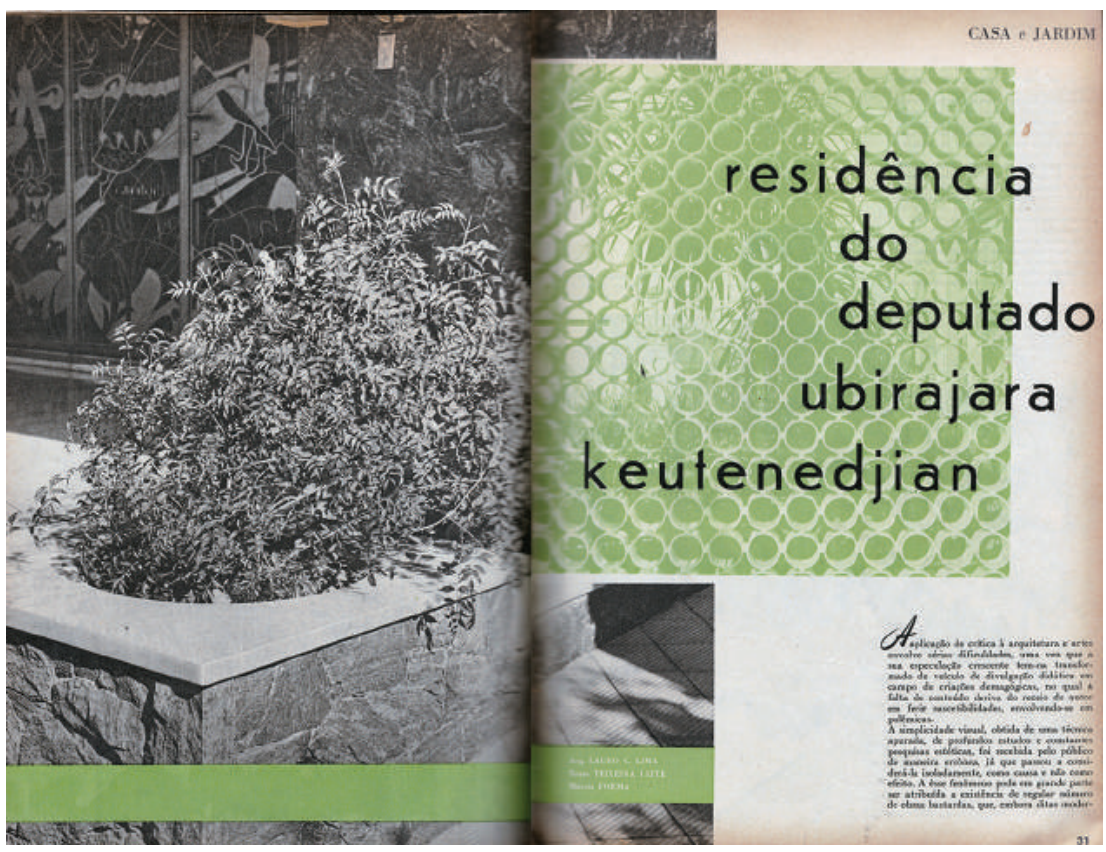

[2.34]

A residência

Keutenedjian, projetada por Lauro Costa Lima, com paisagismo de Waldemar Cordeiro. Publicada em 1958 na revista Casa e Jardim.

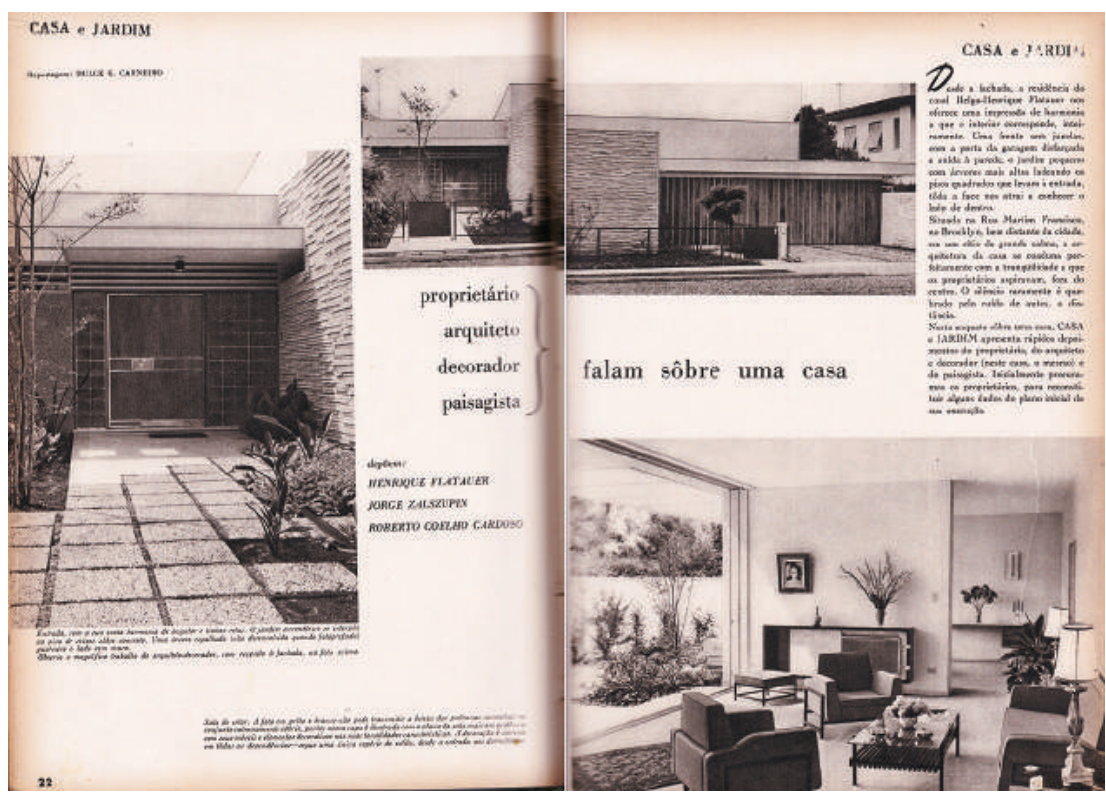

[2.35]

A residência Henrique Flatauer, projetada pelo mesmo, decorada por Jorge Zalszupin e com paisagismo de Roberto Coelho Cardozo. Publicada em 1958 na revista Casa e Jardim. 
Afora essas convergências, as obras de Cordeiro e Cardozo são bastante distintas. Waldemar Cordeiro, assim como Roberto Burle Marx, tem o referencial artístico como base de sua obra paisagística. Na tentativa de desdobrar o "estado da arte" no paisagismo, Cordeiro transpõe sua arte (bi e tridimensional) para os jardins, seja através da forte marcação de pisos e da disposição da vegetação, onde algumas espécies são matematicamente distribuídas, como componentes marcantes que criam ritmo no jardim, através de elementos esculturais, nos quais desenvolve jogos de luz, de cores e de texturas, ressaltando os aspectos lúdicos dos percursos e de seus usos. Além disso, Cordeiro desenvolve uma reflexão teórica sobre o paisagismo, através de pinturas e textos que se inter-relacionam, desde pequenos esboços sobre a estrutura das plantas, até textos sobre as relações da arte-paisagem ${ }^{27}$.

[2.36]

Hedera helix/

Estrutura celular aerênquima (s.d.). Desenhos

de autoria de Waldemar Cordeiro.

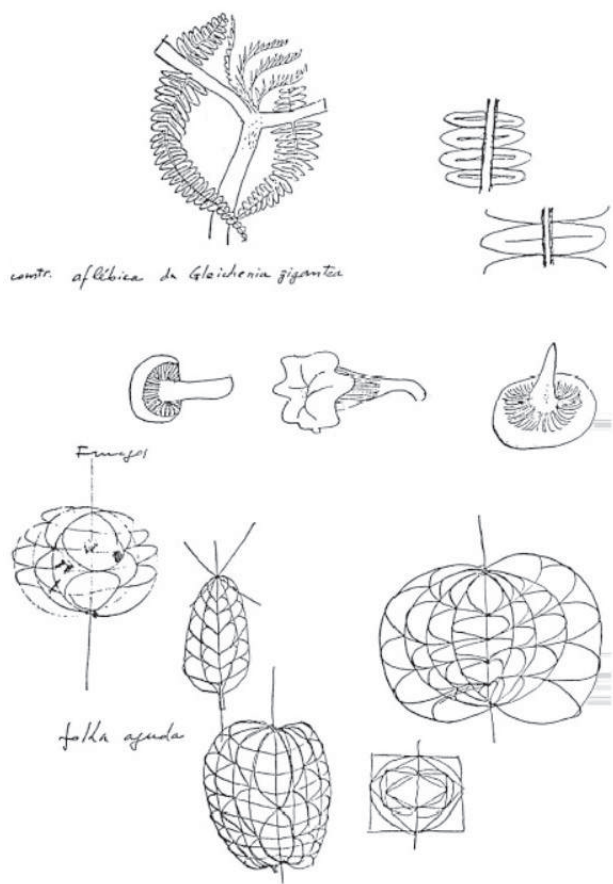

em São Paulo e difusor dos conceitos californianos, como MEDEIROS (2004), FARAH (2010), ZEIN (2006), (CARDOSO, 1992) e ARAÚJO (2006).

27. Hedera helix/Estrutura celular aerênquima (s.d.) e Glechenia gigantea (s.d.) ilustram esses desenhos referenciados na vegetação, assim como o texto Para uma justa proporção entre volumes edificados e espaços livres. Apud MEDEIROS, 2004. 

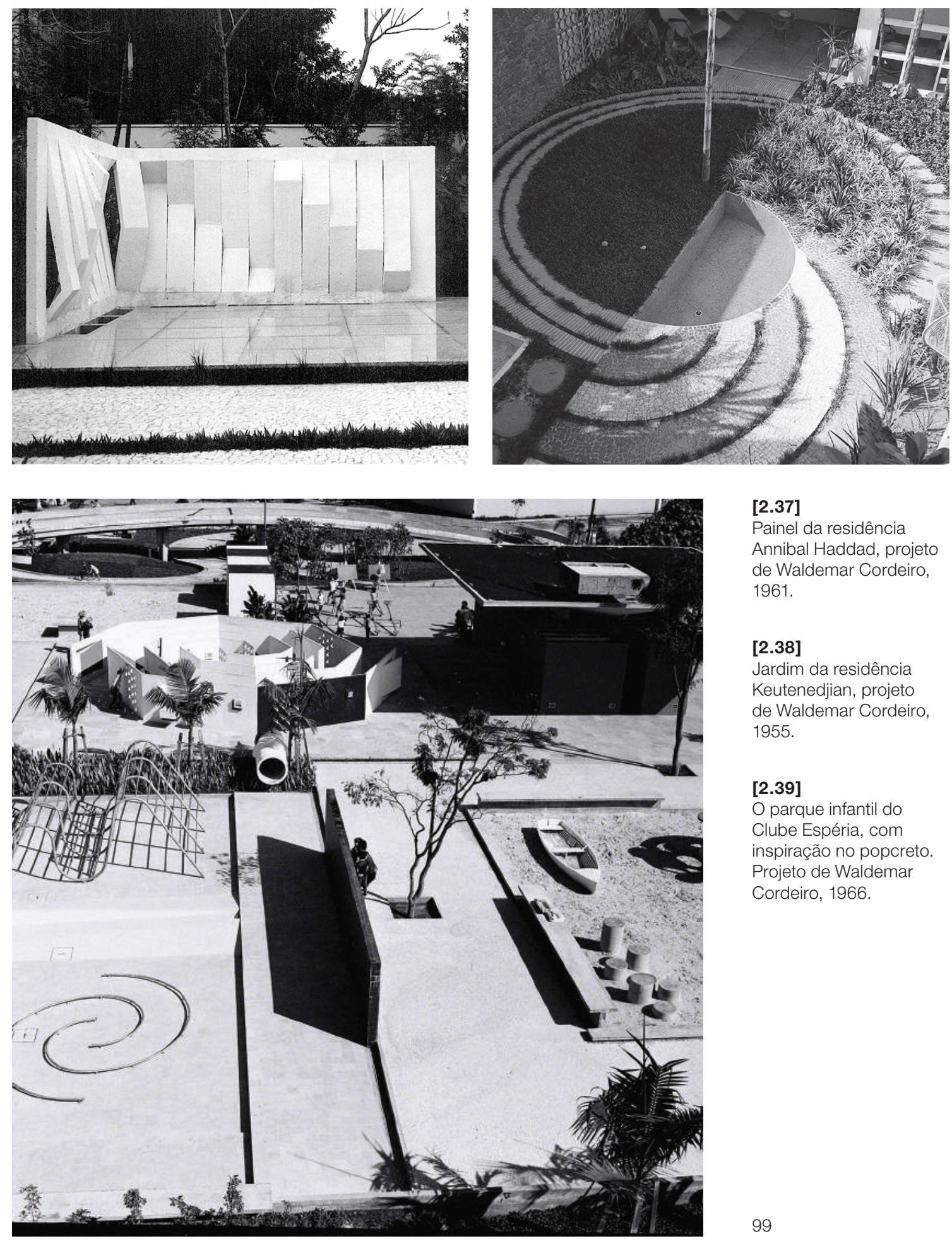

[2.37]

Painel da residência Annibal Haddad, projeto de Waldemar Cordeiro, 1961.

\section{[2.38]}

Jardim da residência Keutenedjian, projeto de Waldemar Cordeiro, 1955.

\section{[2.39]}

O parque infantil do Clube Espéria, com inspiração no popcreto. Projeto de Waldemar Cordeiro, 1966. 
Em contraposição, Roberto Coelho Cardozo tinha uma aproximação mais analítica do paisagismo, quase pragmática, orientada pelas condições urbanas e pela reflexão sobre a cidade (LIMA; SANDERVILLE, 1997). Analisando sua obra e seus escritos ${ }^{28}$, observa-se através de seus comentários que seus projetos têm como premissa a adequação às especificidades do local. Pelo influxo de seu trabalho com Garrett Eckbo, o local é o ponto de partida para o desenho e fornece ao paisagista a possibilidade do enriquecimento da experiência espacial, trabalhando com a tridimensionalidade e o desenvolvimento de vistas multifacetadas e dinâmicas, criando planos volumétricos fluidos e mesclando geometria ao organicismo vegetal (TREIB, 2003). O jardim é pensado como uma experiência sensorial, de contemplação e apreciação do espaço e de seus elementos, sejam vegetais ou minerais. Nas palavras de Cardozo:

O paisagista procura compreender as finalidades que envolvem o círculo de valores culturais que influenciam o projeto local (...) os princípios de paisagismo não são fixos; devem ser encontrados em uma envolvente dos princípios gerais do projeto e devem ser aplicados, adaptados a cada caso particular (CARDOZO, 1955a).

Nesse mesmo artigo, Cardozo define como o projeto de paisagismo abrange três fases: a primeira, um esquema de organização dos espaços que permita a continuidade espacial entre ambientes internos e externos; a segunda, a planta de níveis, mesclando os elementos da topografia com elementos estruturais e de piso; e, por fim, o projeto de plantação, descriminando as massas vegetais e os revestimentos naturais (CARDOZO, 1955a).

Uma vez que Cardozo transpôs os conceitos da "corrente californiana" para os jardins que projetou no Brasil e que seguia as orientações gerais dos livros de Garret Eckbo ${ }^{29}$ em seus projetos paisagísticos,

28. Roberto Coelho Cardozo não se dedicou às reflexões teóricas escreveu poucos textos, publicados em forma de artigos, para a revista Acrópole e Casa e Jardim. Tentaremos, quando possível, mencionar esses pequenos textos, já que são as únicas fontes escritas que traduzem seu trabalho conceitual.

29. Garrett Eckbo escreveu quatro livros que são formatados como manuais de paisagismo. Além de escrever sobre a paisagem e a natureza, Eckbo 
podemos levar em consideração as instruções de Eckbo para áreas verdes. Segundo ele:

(...) desenhar a paisagem consiste em abranger todas as decisões sobre materiais, elementos e arranjos em uma determinada área, estabelecer conexões e relações entre as construções, o sitio e a paisagem ao redor. A discussão filosófica das relações entre homem e natureza, no desenho da paisagem, consiste na exploração de relações entre o viver nos ambientes internos e externos, em todos os climas e escalas, desde uma simples casa até os prédios de apartamentos (ECKBO, 1964, tradução nossa).

Nesse sentido, Eckbo fazia estudos das condições naturais do local considerando o clima, levando em conta as variações de temperaturas, os níveis de precipitação e a umidade; a topografia do terreno e como tirar partido desta através de desenhos "ousados e dramáticos" (ECKBO, 1956); a disponibilidade de vegetação, pesquisando quais espécies nativas e exóticas são cultivadas no mercado; e por fim, o solo, analisando sua composição e seus nutrientes.

Além dessas condições naturais, Eckbo também previa a análise de problemas estruturais do sítio, entendendo como se configuravam os bairros, quem eram as pessoas que viviam no local e em suas redondezas, quais as facilidades disponíveis nas proximidades da área do projeto, como eram os formatos dos lotes e como as construções se configuravam nesses espaços, dentre outras considerações (ECKBO, 1956).

Vemos que essas orientações são adotadas por Cardozo, uma vez que percebemos, nos projetos do paisagista, espaços externos bem definidos e interligados entre si, construindo espaços fluídos e que se integram às áreas internas através de áreas avarandadas e pisos contínuos de acesso. Em seus desenhos, muretas e bancos em curva separam os ambientes, mas sem criar barreiras visuais. Num primeiro momento,

descreve diretrizes claras de como se fazer um projeto bem-sucedido de paisagismo. Em alguns casos, Eckbo organiza as orientações em tópicos, como é o caso do livro The art of home landscaping (1956), no qual o autor ensina aos "leigos" como melhorar o "planejamento residencial". Outros livros são: Landscape for living (1950), Urban landscape design (1964), The landscape we see (1969). Nesses livros, além de falar sobre a paisagem e a natureza, Eckbo descreve diretrizes claras de como se fazer um projeto bem-sucedido de paisagismo. 
analisando as plantas de seus projetos, temos a impressão de que os espaços criados são rígidos e vigorosamente marcados. Porém, quando consideramos todos os elementos que compõem o jardim percebemos que o paisagista consegue suavizar essa forte geometrização com os mais diversos materiais e formas, provenientes tanto do tratamento escultórico da vegetação, quanto das texturas mistas de pisos, criando espaços externos ricos e fluidos.

[2.40]

Lar Golda Meir, projeto de Roberto Coelho Cardozo, 1955. Forte geometrização da planta,

mas com espaços conectados e sem barreiras visuais. As massas de vegetação suavizam a

rigidez das muretas e o uso de diversos materiais

cria uma textura mais orgânica.

[2.41]

Planta de paisagismo do Lar Golda Meir, projeto de Roberto Coelho Cardozo, 1955.
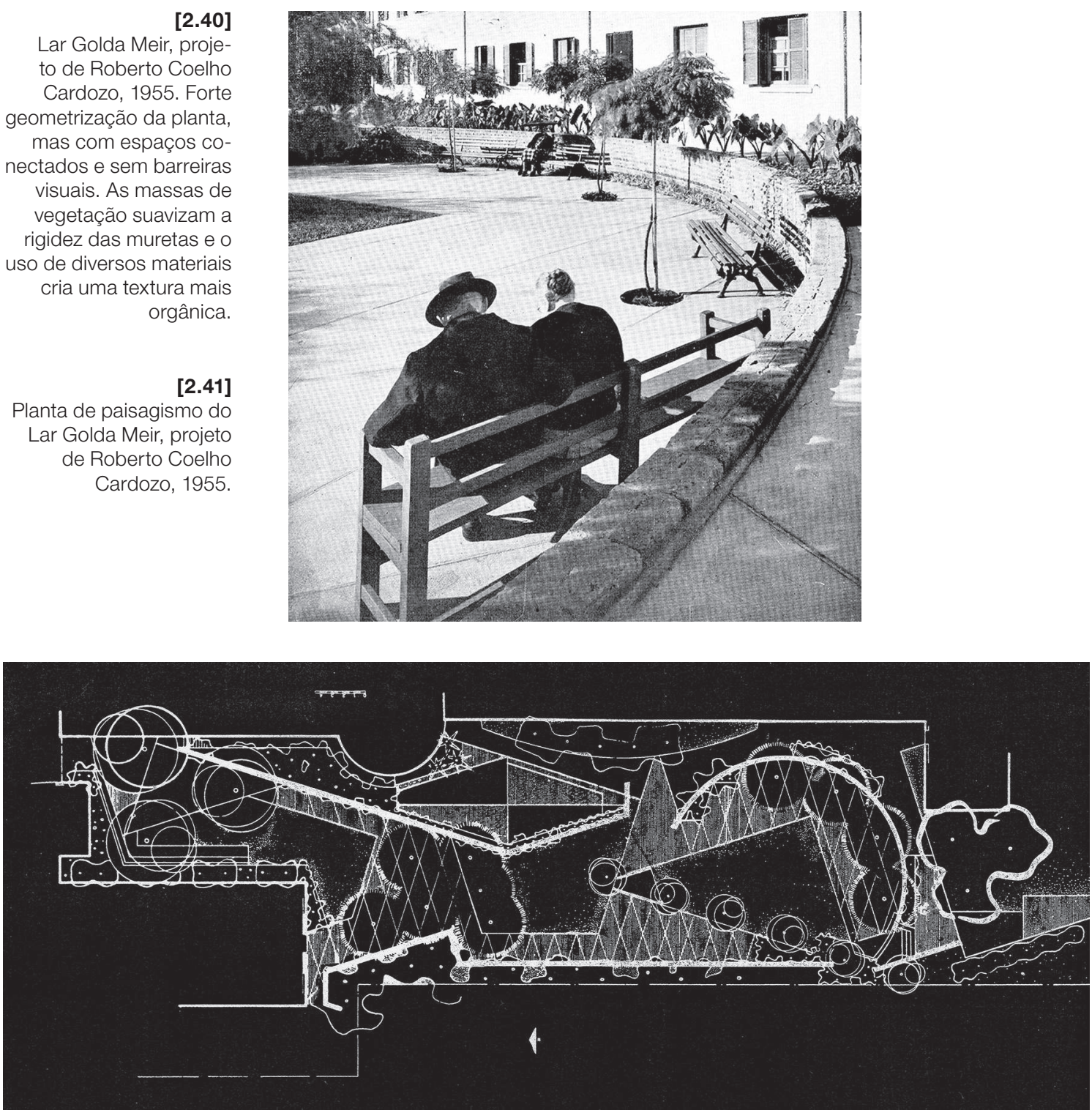

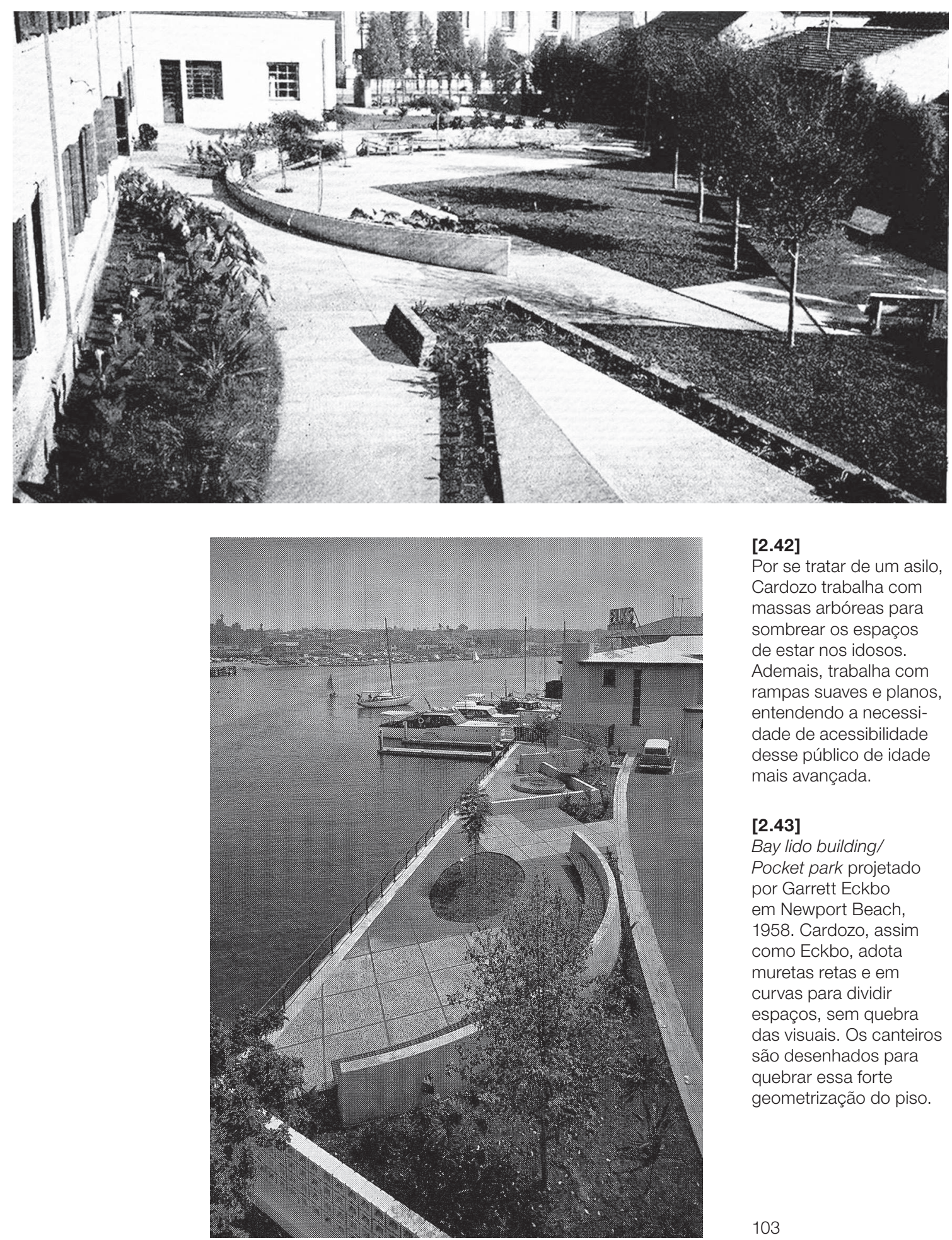

\section{[2.42]}

Por se tratar de um asilo, Cardozo trabalha com massas arbóreas para sombrear os espaços de estar nos idosos. Ademais, trabalha com rampas suaves e planos, entendendo a necessidade de acessibilidade desse público de idade mais avançada.

\section{[2.43]}

Bay lido building/ Pocket park projetado por Garrett Eckbo em Newport Beach, 1958. Cardozo, assim como Eckbo, adota muretas retas e em curvas para dividir espaços, sem quebra das visuais. Os canteiros são desenhados para quebrar essa forte geometrização do piso. 
Mesmo inserido em uma outra realidade espacial urbana, diferente do desenho das cidades da Califórnia, Cardozo é atento às especificidades dos bairros nos quais estão localizadas as residências que projeta em São Paulo. No artigo "Áreas de entrada" (CARDOZO, 1954B) e "Acesso à residência" (CARDOZO, 1954B), o paisagista discorre sobre o projeto das áreas de acesso às residências, nomeadas "áreas semi públicas" e como representam "a exposição honesta da maneira de viver" de seus proprietários, ou seja, representam uma maneira moderna. Defende então a importância de um projeto bem estruturado dessas áreas, demonstrando respeitar as "unidades de vizinhança" (lote) e, consequentemente a interligação entre elas, constituindo uma unidade coletiva. Em um sentido mais amplo, Cardozo reflete sobre como esses bairros podem se tornar áreas mais agradáveis para seus moradores, a partir do programa de necessidades das unidades individuais e expandindo esse programa para o ambiente público.

[2.44]

Entrada da residência Herbert Shier: tratamento das áreas semi-públicas com portões baixos, que possibilitam a conexão visual entre o lote a rua.

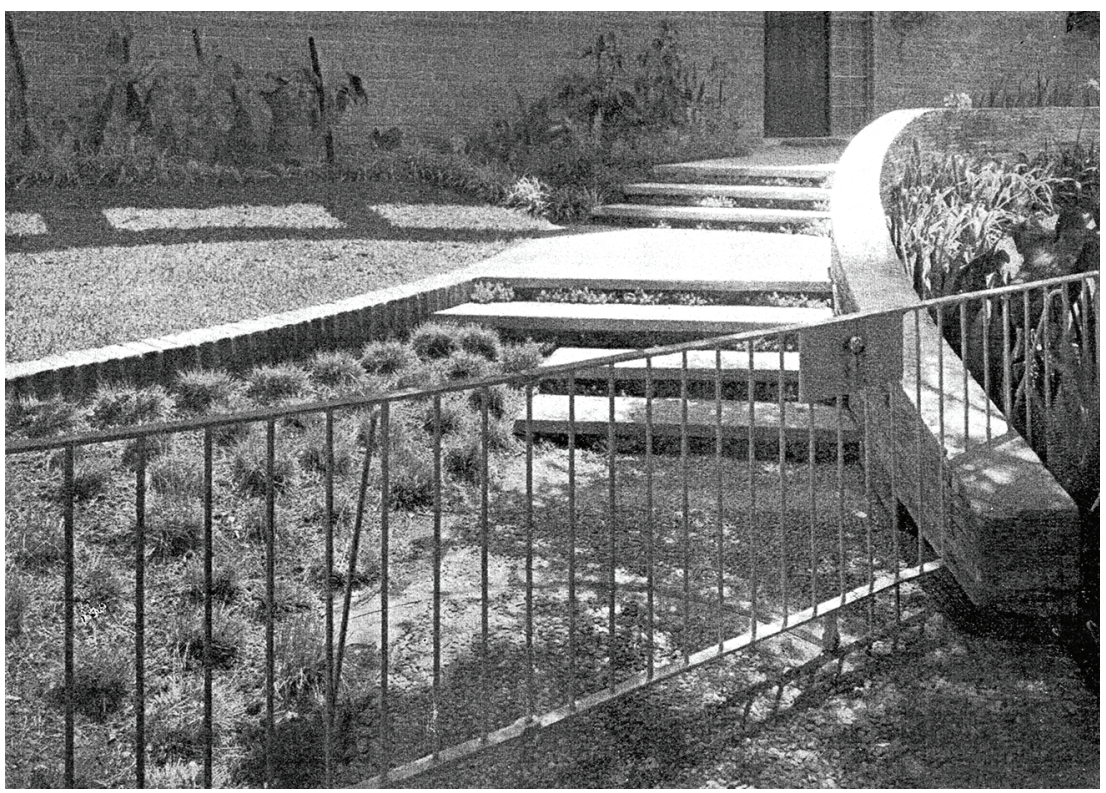




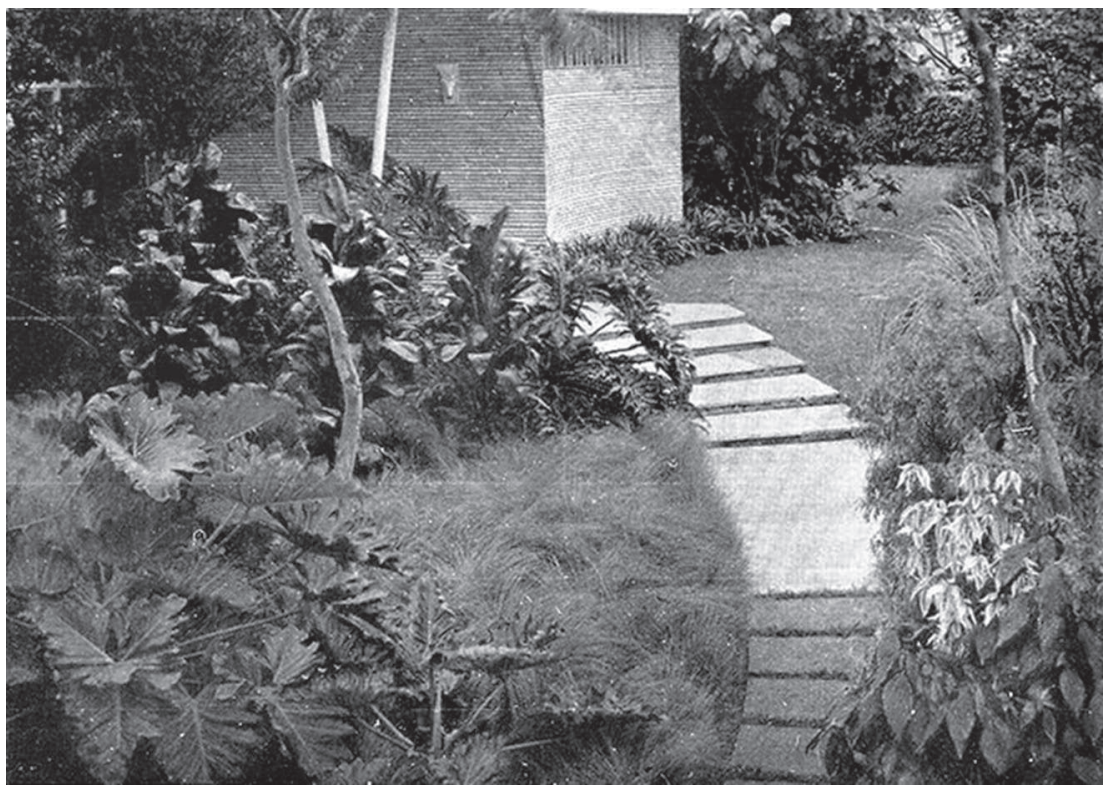

O paisagista assume a postura de adotar os materiais e a vegetação disponíveis no mercado. Apesar do emprego de plantas autóctones no paisagismo ter ganhado muita importância com a defesa constante de seu uso por Roberto Burle Marx, os produtores de vegetação ainda dispunham de muitas plantas exóticas que foram utilizadas durante todo século XIX e boa parte do século XX. Assim, Cardozo emprega tanto plantas nativas quanto exóticas em seus projetos. Usa clerodendros, fórmios, agapantos misturados a costelas de adão, filodendros e marantas. Emprega tanto o resedá gigante (exótica) como o ipê amarelo (nativa). A escolha da vegetação é baseada principalmente no efeito que se pode extrair de cada espécime, nas sombras densas ou mais pulverizadas, no ritmo que a aglomeração de caules possibilita ou na massa que se forma com folhagens exuberantes. Dado seu conhecimento profundo sobre vegetação, adquirido tanto pela sua formação na Faculdade de Agricultura da UCBerkley como pela convivência com o pai (horticultor), Cardozo explorava as características formais das plantas, através do controle sobre seu crescimento e do conhecimento de seu comportamento em determinadas condições climáticas, conseguindo assim atingir intenções compositivas únicas. Ao exemplo disso, escreve sobre as palmeiras: "quando a palmeira alcança uma certa altura, a copa
[2.45]

Área de entrada da Residência Stefan Neuding: área de entrada ornamentada com vegetação exuberante, permitindo privacidade e ao mesmo tempo convidando para a passagem. 
não entra mais na consideração visual imediata da planta, tendo então o tronco exclusivamente a função de coluna, as faixas na superfície provêm do crescimento e das marcas das folhas" (CARDOZO, 1952).

Apesar de nem sempre ser fácil entender os escritos de Cardozo, pela sua dificuldade com a língua portuguesa, acreditamos que neste pequeno trecho ele expõem o modo como trabalha os diversos aspectos que podem ser extraídos da composição vegetal. Nesse caso, explica como as estirpes das palmeiras crescidas servirão como elementos arquitetônicos complementares à construção e que suas copas, que não mais se encontra na altura dos olhos do observador, terão um efeito mais sutil através de sua sombra, que recai sobre o piso criando uma nova textura. Nesse sentido, Cardozo segue as palavras de James Rose que acredita que "para usar plantas inteligentemente deve-se conhecer, para cada planta, sua forma, altura na maturidade, taxa de crescimento, rusticidade, exigências de solo, deciduidade, cor, textura e época de floração" (ROSE, 1941, tradução nossa).

Ademais, percebemos que Cardozo utiliza-se da vegetação para determinar "subespaços" dentro de um mesmo ambiente, ou seja, com o plantio cria diferentes ambiências dentro de um mesmo estar. Usa bambus para criar barreiras visuais, guaimbês e inhames para assinalar diferentes espaços, e palmeiras e árvores de copa alta para criar pontos de referência. Sempre muito atento às características naturais da vegetação, o plantio era feito de maneira a respeitar o crescimento e a manutenção necessária de cada espécie.

Em relação aos pisos, geralmente cria planos geométricos, a partir de formas retangulares ou hexagonais, que são dispostos em diferentes níveis, dissociando áreas sem quebrar a fluidez do espaço. Cardozo cria movimento no ambiente a partir do uso de texturas diversas combinadas à paginação irregular do piso: arranjos de mosaico português de cores diversas e pedras irregulares intercaladas com massa de granito criam espaços dinâmicos e arrojados. Adota tanto os materiais tradicionais - arenitos e granitos - quanto os materiais modernos ou pouco explorados, por exemplo, elementos pré-moldados de concreto ou ardósia. 


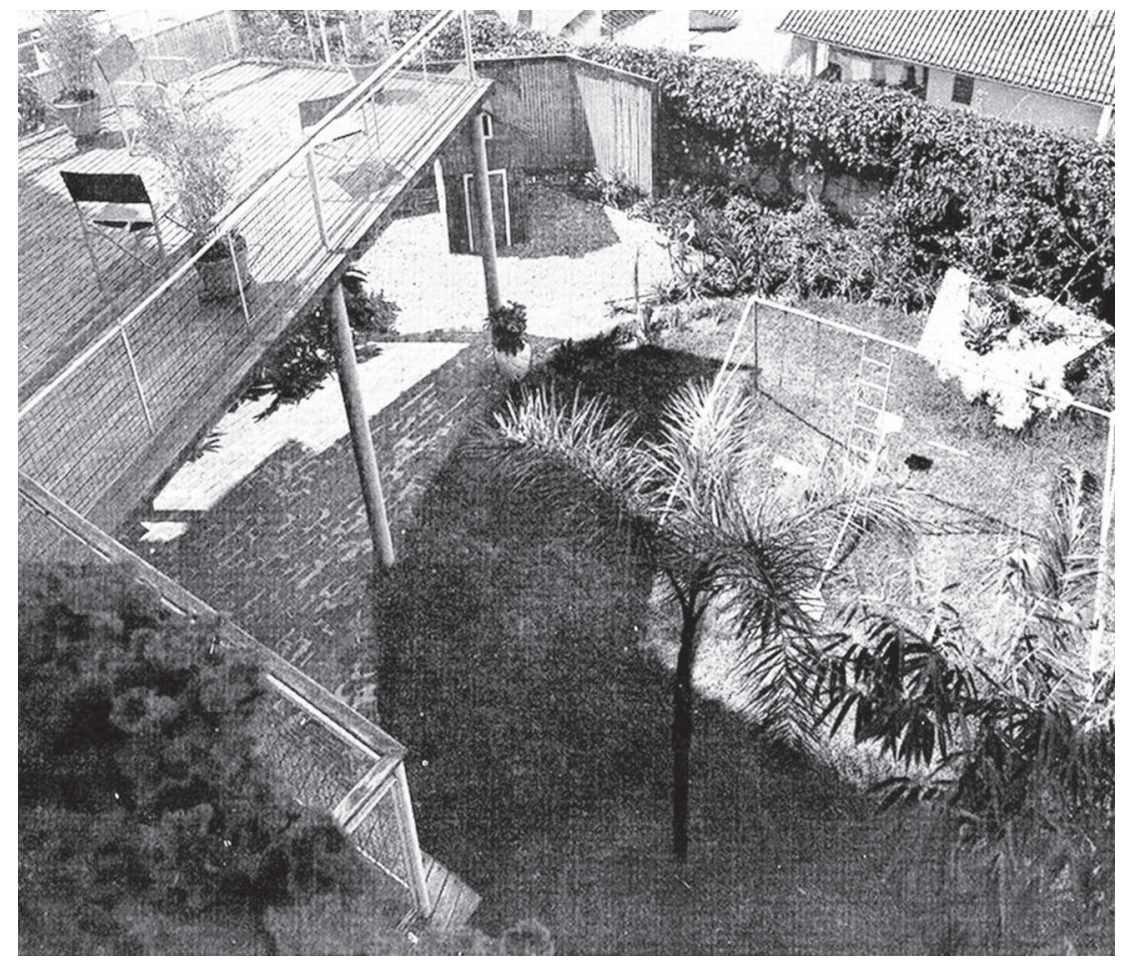

[2.46]

Residência Dischlia

Steivartz e Adolpho

Bume Goldenstein:

espaços separados para diferentes atividades - 0 playground gramado é observado pela varanda elevada.

\section{[2.47]}

Residência Michel

Mattar: demarcação dos espaços com vegetação, onde a entrada para o jardim lateral e os arbustos altos reservam a área da piscina.

\section{[2.48]}

Residência Michel Mattar Mattar: Uso de palmeiras como colunas, com copas altas que passam a altura do telhado.

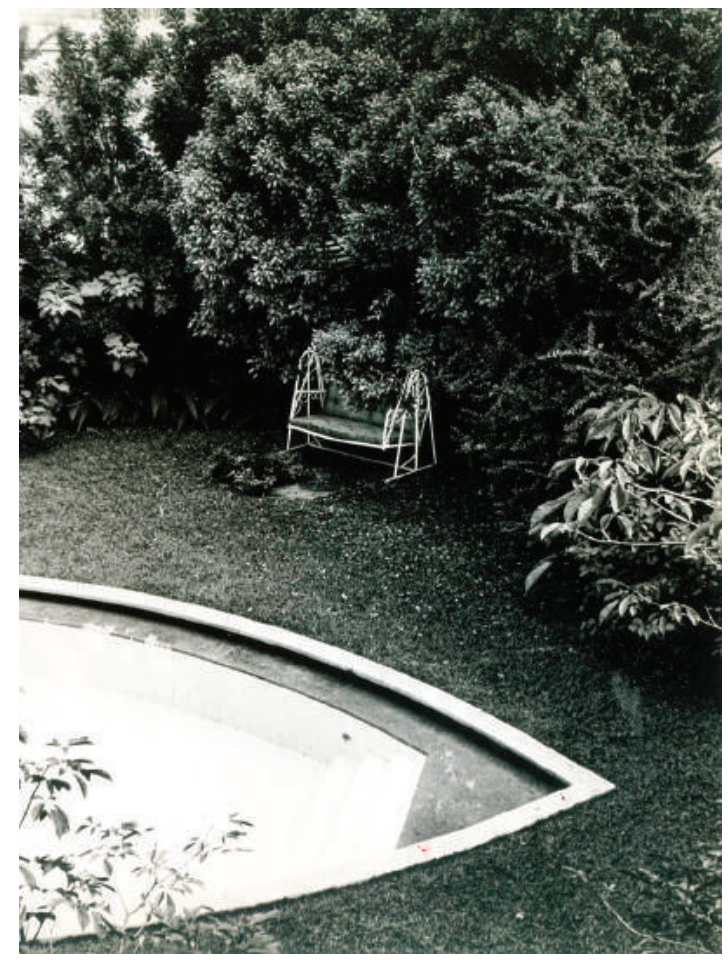

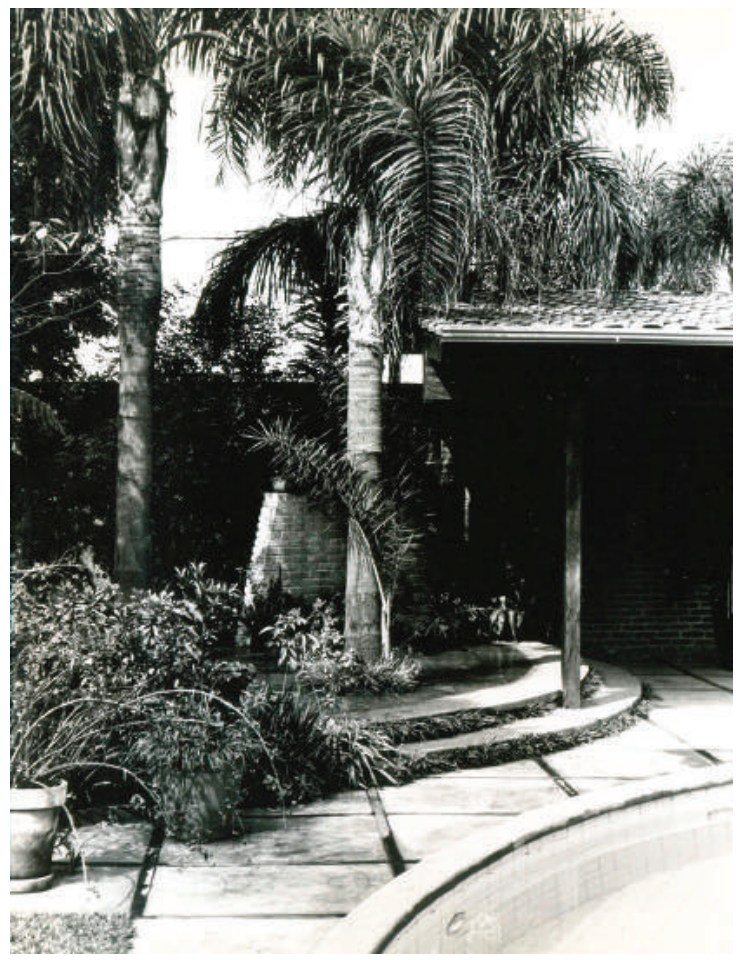


[2.49]

Residência Riwczes: fotografia do piso implantado. A borda dos pisos é suavizada com

plantio de vegetação, como inhames e outros arbustos.

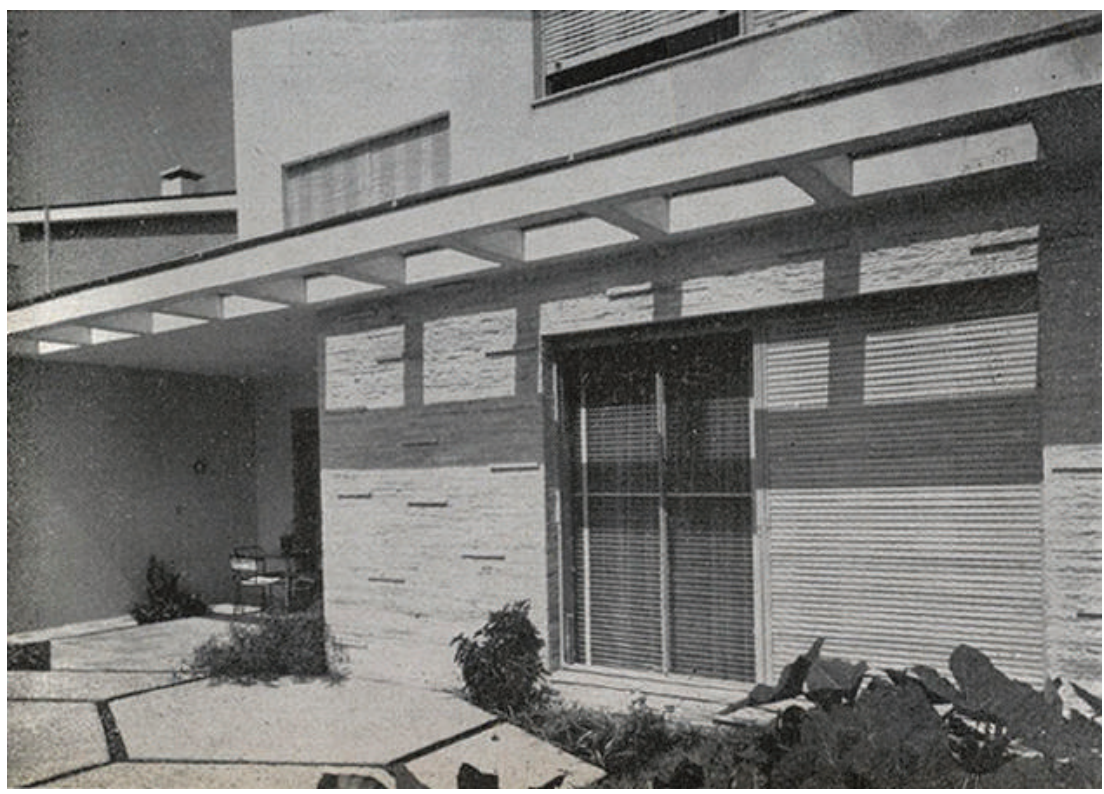

[2.50]

Residência Riwczes:

desenho técnico de

degraus e pisos em formato hexagonal, com

junta preenchida com grama preta.

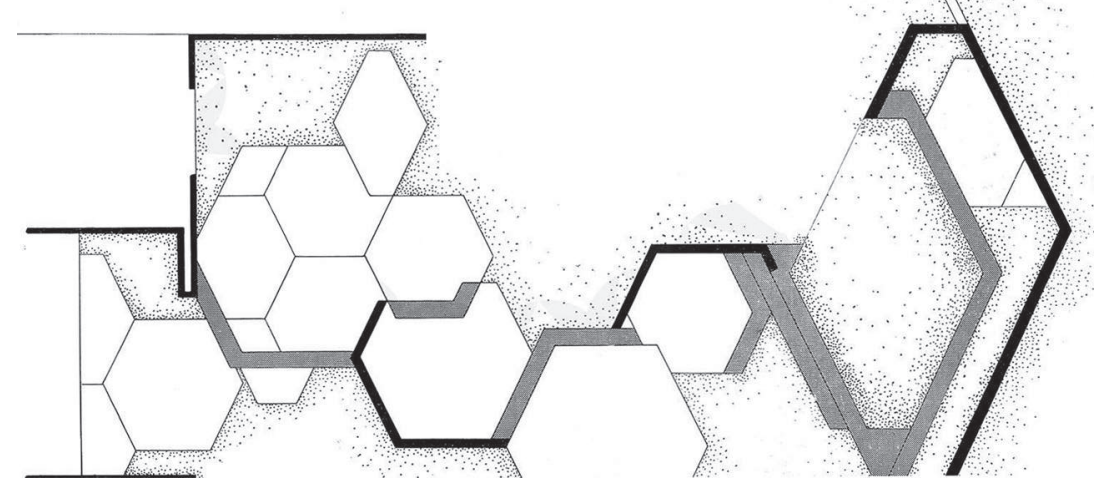

[2.51]

Residência Riwczes: detalhe do piso hexagonal em fulget e a mureta com acabamento de em filetes de arenito (mais conhecido como canjiquinha).

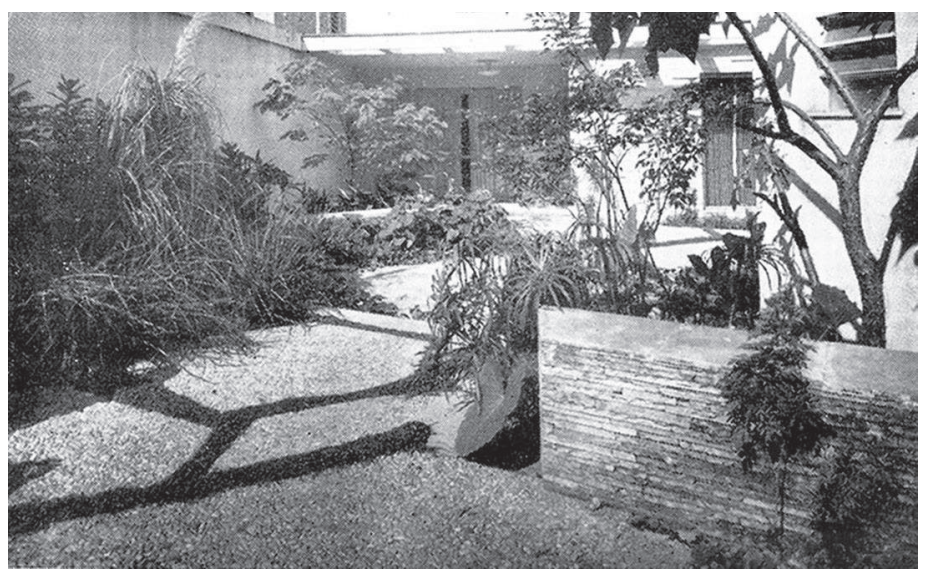




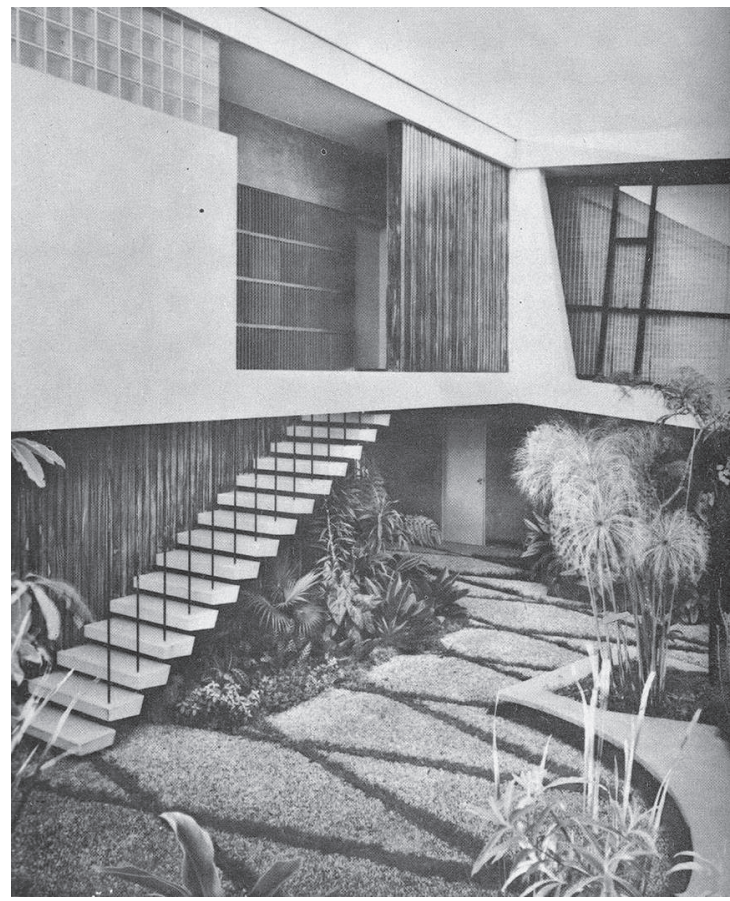

A princípio, Cardozo tentava propiciar ao usuário de seus jardins uma experiência sensorial: através da construção de trajetos inusitados conseguia explorar a singularidade do local e ainda sensibilizava o usuário com o emprego das mais diversas texturas de materiais vivos, como a vegetação exuberante, ou inorgânicos, como as pedras, tijolos e a água.

A obra de Roberto Coelho Cardozo mostra-se moderna não só pelo emprego da linguagem modernista no uso de materiais e elementos construtivos e na composição vegetal, mas também no modo de pensar o projeto que, baseado no trabalho intelectual, era desenvolvido e detalhado, para então ser encaminhado à obra para execução. Seus projetos formam panoramas modernos quando contextualizados na produção paisagística do século XX. A importância da atividade de Cardozo transcende ao seu trabalho profissional, estendendo-se à Academia, já que foi o primeiro professor da área de paisagismo na FAUUSP, tendo lecionado e contribuído para a formação de um grupo de paisagistas que preencheram os quadros profissionais na área e que são atuantes até hoje na transformação da paisagem da cidade de São Paulo.
[2.52]

Residência Alberto Cintra Filho: Uso de papiros e capins para compor jardim, em meio a piso com juntas preenchidas com grama. 


\title{
A DISCIPLINA "ARQUITETURA PAISAGÍSTICA"
}

\begin{abstract}
O percurso do ensino de Paisagismo na FAUUSP se confunde com a evolução da profissão de paisagista no Brasil. Grande parte dos profissionais que atuam na área de Paisagismo tiveram sua formação estruturada a partir dos conceitos e métodos de projetos emanados das disciplinas ministradas na FAUUSP em cursos de graduação, de aperfeiçoamento, de especialização ou de pós-graduação (LIMA; et al; 1998).
\end{abstract}

Como já exposto no Capítulo 1, Roberto Coelho Cardozo foi o primeiro professor de paisagismo da graduação da FAUUSP, contratado em 1952 para lecionar a "Disciplina no. 20 - Arquitetura Paisagística” (de 1952 a 1956) e posteriormente na "Cadeira no. 28 - Arquitetura Paisagística” (de 1956 a 1962). Em 1962, com a Reforma Curricular de Ensino da FAUUSP, as cadeiras foram agrupadas em três departamentos, História, Projeto e Tecnologia, e a disciplina de Cardozo, "Cátedra no. 28 - Planejamento I", foi inserida no grupo de disciplinas de Planejamento Urbano do Departamento de Projeto. Em 01/10/1969, o professor é dispensado dos encargos de sua aula por conta de uma licença-prêmio que dura até $30 / 06 / 1970^{30}$, ano em que se muda para a Inglaterra. Sua exoneração é efetivada em $1972^{31}$, mesmo ano em que é criado o grupo específico de disciplinas de paisagismo (GDPA), coordenado pela Profa. Dra. Miranda Esmeralda Martinelli Magnoli.

O interesse pelo conteúdo das aulas de Roberto Coelho Cardozo surgiu a partir da busca de imagens de projetos do paisagista nos slides da Seção de Projetos da Biblioteca da FAUUSP para essa pesquisa. Foram encontradas poucas imagens de projetos de Cardozo, mas, para nossa surpresa, foram encontrados alguns lotes de imagens doados pelo paisagista. São imagens de paisagens inóspitas como desertos, de espaços públicos como pequenas praças, de espécies de vegetação, de áreas naturais com pequenas intervenções humanas, etc. Descobriu-se que essas imagens eram utilizadas durante suas aulas e estão divididas

30. Processo no.52.1.14106.1.2 - Contratação de docente, Roberto Coelho Cardozo - folhas 62 e 63. Data: 22/03/1969.

31. Processo no.52.1.14106.1.2 - Contratação de docente, Roberto Coelho Cardozo - folhas 87. Data: 13/12/1972. 
nas seguintes seções: espécies vegetais, paisagem natural, paisagem cultural, materiais processados e não processados pelo homem, luz e sombra, circulação mecânica de pedestres, feiras livres e exposições, climas e manutenção, soluções geográficas na arquitetura brasileira, praças e jardins, orientação visual e equilíbrio.
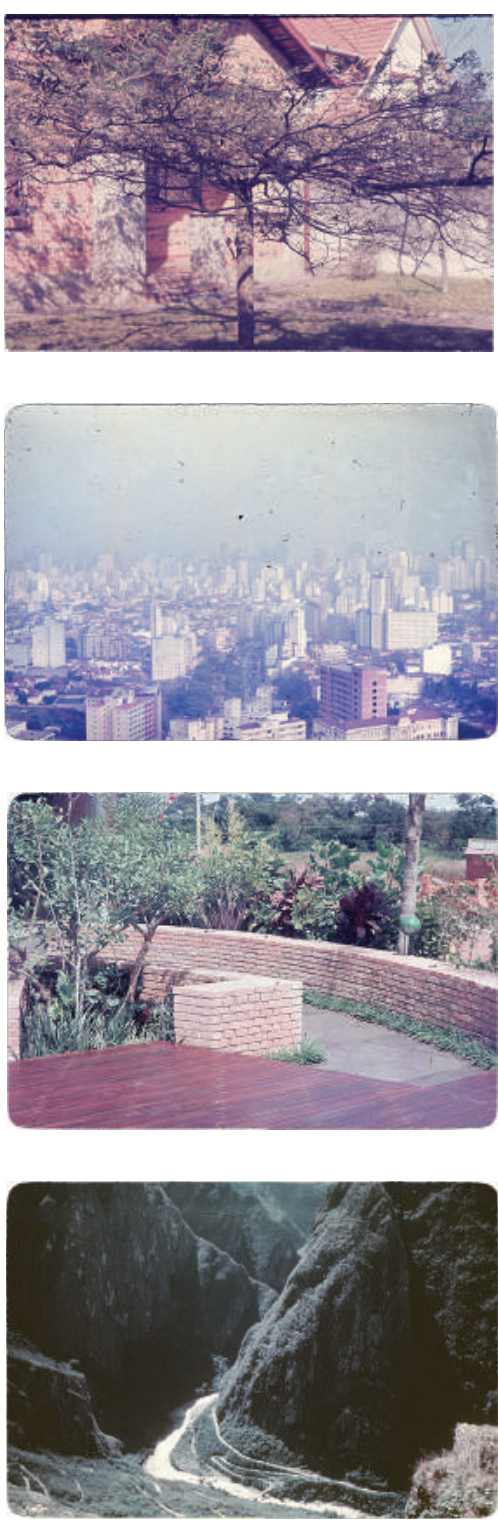
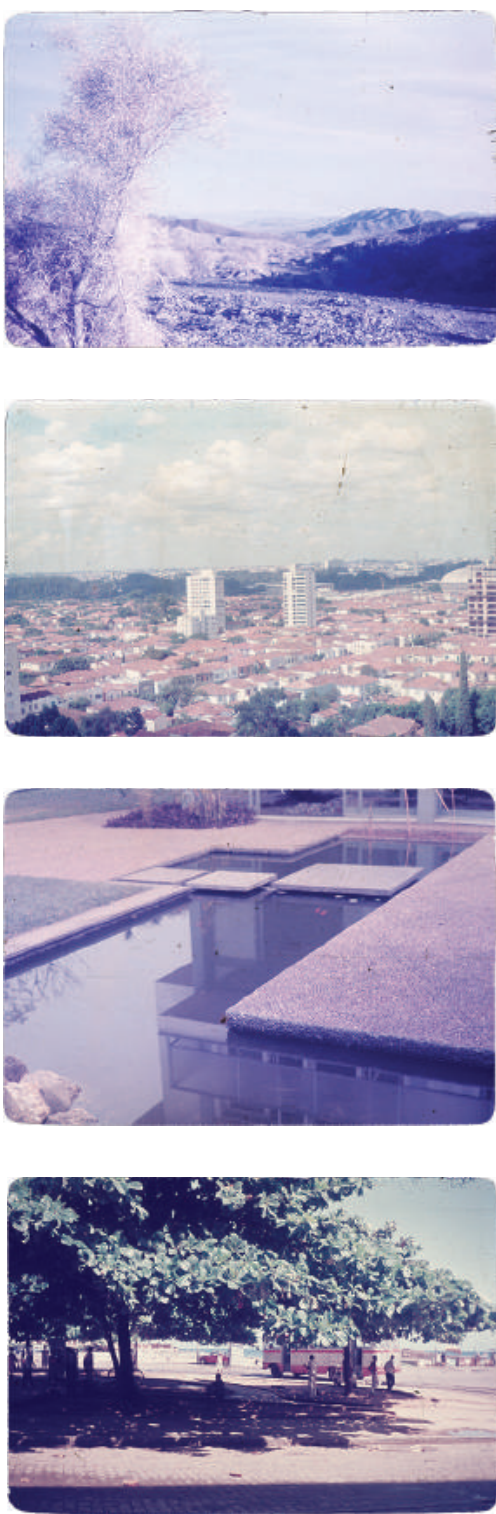

[2.53]

Espécies vegetais. [2.54]

Paisagem Natural. Paisagem árida.

\section{[2.55]}

Paisagem Cultural. Avenida Paulista.

\section{[2.56]}

Paisagem Cultural. Vista do Ibirapuera.

\section{[2.57]}

Materiais processados. Residência Jorge Arruda. [2.58]

Materiais processados. Residência Tufy Mattar.

\section{[2.59]}

Materiais não processados.

Rio em Machu Picchu. [2.60]

Luz e sombra. Rio Vermelho. 
[2.61]

Circulação mecânica de

pedestres

Convento do Carmo

[2.62]

Feiras e exposições Feira de Santana

[2.63]

Feiras e exposições.

[2.64]

Climas e manutenção.

Luminosidade da atmosfera.

[2.65]

Soluções geográficas da arquitetura brasileira.

Solar do Unhão.

[2.66]

Soluções geográficas da arquitetura brasileira. Clube Santa Monica.

[2.67]

Praças e jardins.

Praça Cachoeira do

Campo.

[2.68]

Praças e jardins.

Túnel Avenida 9 de Julho.
Feira de palha (BA)
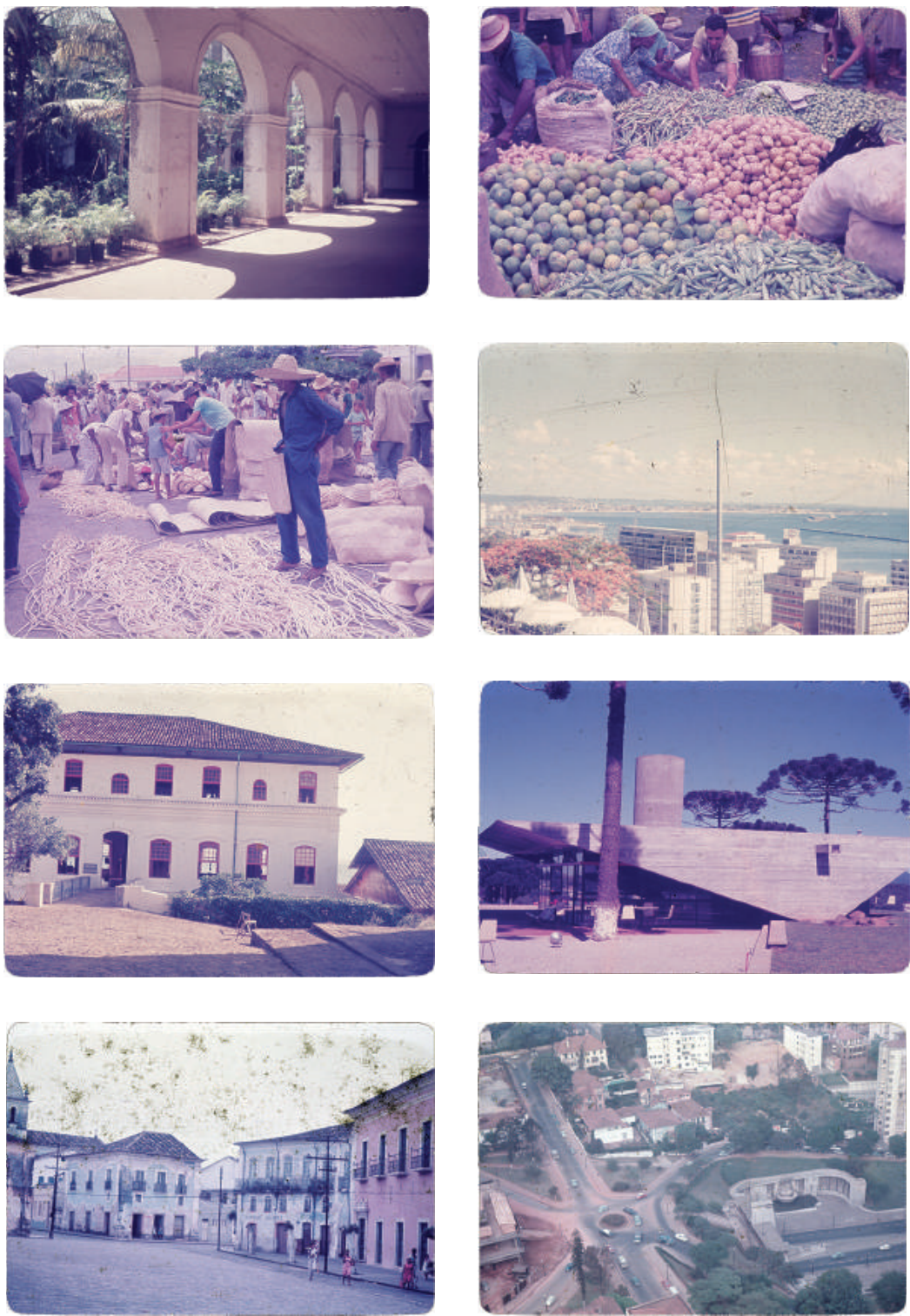

[2.69]

Orientação visual. Piazza del Quirinal .

[2.70]

Equilíbrio.

Desembarque da Feira de São Joaquim.
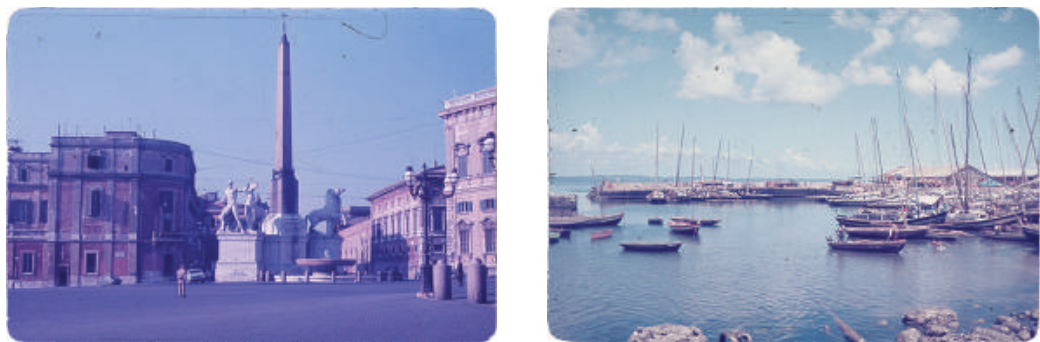
A partir desse material iconográfico, decidimos buscar os programas das disciplinas ministradas por Cardozo para entender em qual contexto essas imagens eram expostas aos alunos. Foram encontrados os programas das disciplinas "Cadeira no. 28 - Arquitetura Paisagística" e "Cátedra no. 28 - Planejamento I", arquivados na Seção de Alunos da FAUUSP'32. Tendo essas fontes primárias como dados, foi possível confrontar os objetivos, definições e práticas dessas disciplinas, descritos nos programas, com os slides que eram expostos em sala de aula. Além desse material, o estudo também foi complementado por artigos publicados à época em revistas especializadas e pelo processo de contratação do Professor Roberto Coelho Cardozo, arquivado no Departamento de Projetos da FAUUSP.

Partindo do programa da disciplina "Cadeira no. 28 - Arquitetura Paisagística”, consideraremos o que Cardozo estabelece como objetivos e definições da aula:

- Desenvolver uma sensibilidade madura para a paisagem, a vida e os elementos nela integrados;

- Aumentar seus conhecimentos e entendimentos da influência do ambiente físico-humano;

- Desenvolver um entendimento do papel do arquiteto, do urbanista, do engenheiro e do paisagista no estudo e utilização da área;

- Desenvolver métodos ordenados e eficientes para resolver os problemas do "design";

- Desenvolver as maneiras próprias para o "design" profissional;

- Adquirir informações básicas sobre plantas e outros materiais processados e não processados empregados na organização paisagística;

- Despertar uma atenção específica para desenvolver um conceito, capacidade para através do "design", localizar cada esquema no local apropriado no espaço.

32. Foi feito um levantamento dos programas arquivados na Seção de Alunos da FAUUSP e foram encontrados os programas de 1956, 1958, 1960, 1961, referentes à Cadeira no. 28 - "Arquitetura Paisagística" e os programas de 1963, 1965, 1966, 1967, 1971 e 1972, referentes à Cátedra no. 18 - "Planejamento I". 
[2.71]

Programa de 1958 da cadeira n.28 "Arquitetura Paisagística". Folha 01.

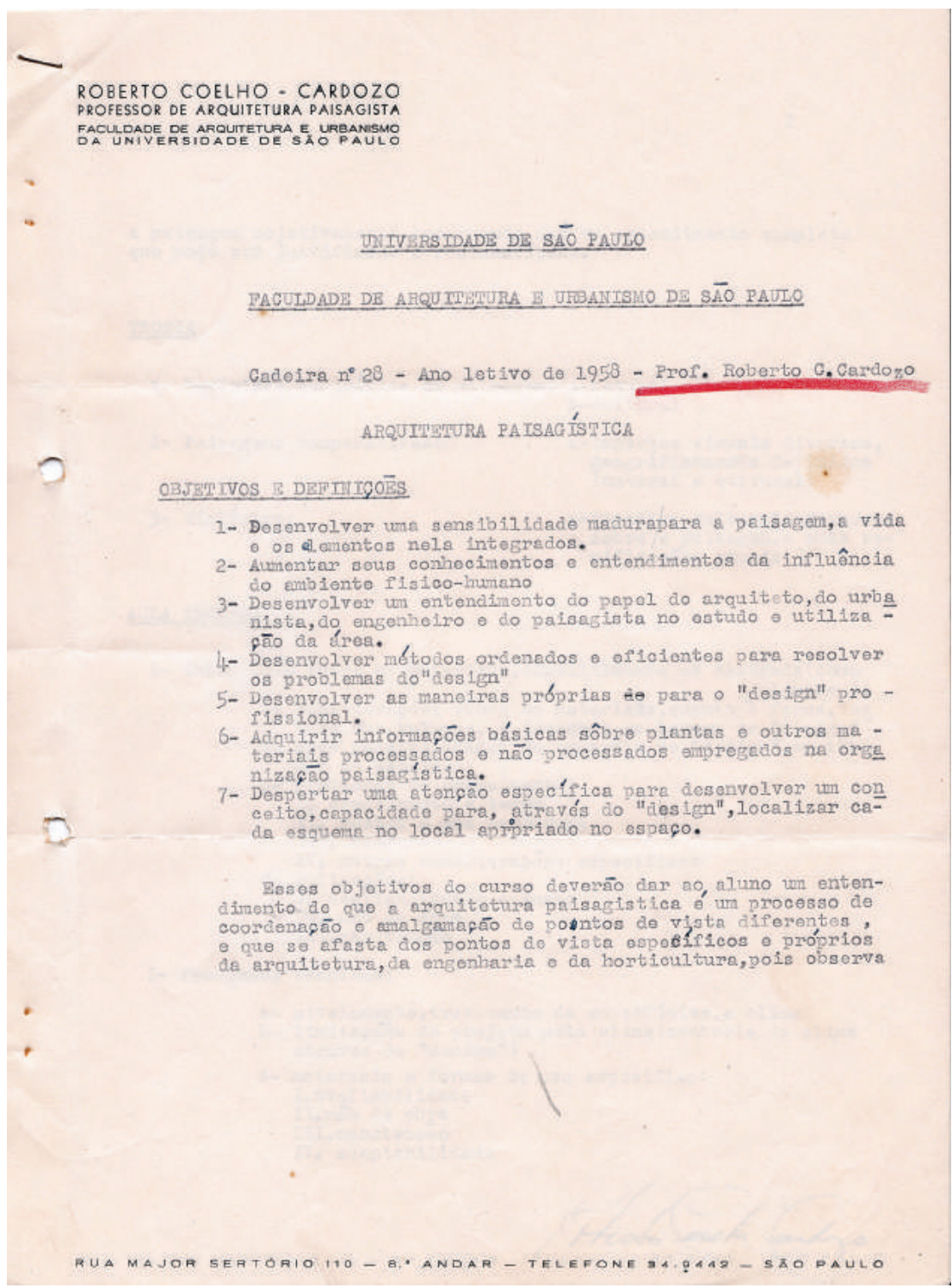




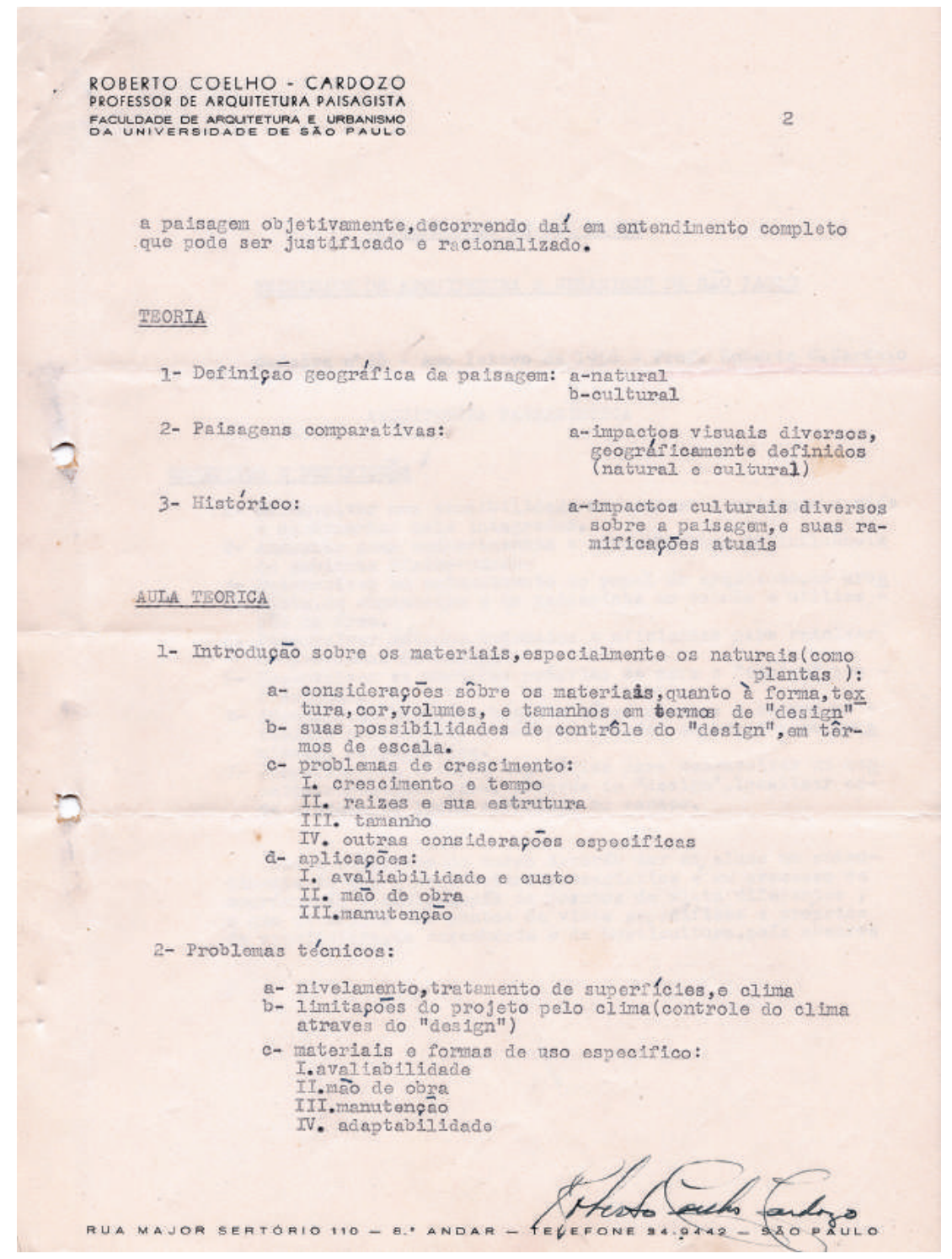

[2.72]

Programa de 1958 da cadeira n.28 "Arquitetura Paisagística". Folha 02. 
Segundo Cardozo, esses objetivos do curso dariam ao aluno um entendimento de que:

A arquitetura paisagística é um processo de coordenação e amalgamação de pontos de vista diferentes, e que se afasta do ponto de vista específicos e próprios da arquitetura, da engenharia e da horticultura, pois observa a paisagem objetivamente, decorrendo daí entendimento completo que pode ser justificado e racionalizado.

Mais uma vez nos deparamos com a linguagem empregada por Cardozo. Talvez por ser norte-americano, filho de açorianos, o professor adotava a língua portuguesa de uma forma peculiar, uma mistura da língua inglesa e do pouco domínio da língua portuguesa com um sotaque incomum ${ }^{33}$. Porém, já podemos notar, em uma primeira leitura, alguns conceitos difundidos por Garrett Eckbo.

A sensibilidade madura em relação à paisagem, à vida e aos elementos nela integrados e o aumento dos conhecimentos e entendimentos da influência físico-humano citados por Cardozo encaixam-se na colocação de Garrett Eckbo sobre a função social do paisagista, que é a "habilidade de juntar os elementos complexos e desconexos do desenvolvimento externo e convertê-los em unidades de paisagem úteis e agradáveis" (ECKBO, 1956, tradução nossa). Ainda segundo Eckbo:

"Os paisagistas devem projetar para o mundo em que vivem e expressar o mundo que os alimenta, os abriga e os agasalha. Essa é verdade em sua interpretação máxima. Não há outra fonte de inspiração; aqueles que expressam apenas seus desejos têm pouco a dizer. Quais são então, especificamente, nossas principais fontes de inspiração? Primeiro, os elementos gerais descritos acima: Pessoas (todas as pessoas, sem exceção de quaisquer estratos sociais); Espaço (análise da experiência em todos os espaços parcial ou totalmente fechados); e Materiais (toda a enorme paleta de elementos estruturais à prova de intempéries, a terra, as rochas, a água, as plantas). Em segundo lugar, a história do paisagismo considerando tudo o que foi feito até hoje. Em terceiro lugar, o patrimônio cultural da humanidade. Há outras fontes de inspiração que não podem ser ignoradas: toda a maravilha

33. O sotaque do paisagista, que tornava algumas de suas falas quase ininteligíveis, sempre foi motivo de comentários entre os alunos, como pode-se concluir através de entrevistas feitas pela autora com Miranda Martinelli Magnoli, Marcos Acayaba, Marlene Milan Acayaba e Luciano Fiaschi. O casal de amigos Gregório e Monika Zolko e a cliente Tereza Peres Soares também comentam sobre o sotaque de Cardozo. 
e beleza da natureza selvagem; toda a rica e variada produção da pintura, escultura e arquitetura modernas; todos os complexos padrões das civilização industriais que ainda não foram violados por meios comerciais - barragens, pontes, refinarias de petróleo, estações de transmissão elétrica, máquinas de terraplanagem - bem como elementos diversos - o Jazz de Nova Orleans, o canto folclórico (a música folk), que são expressões claras de diferentes seções da estrutura social" (ECKBO, 1950b, p.131).

Nesse sentido, Eckbo e Cardozo defendem o reconhecimento do objeto de intervenção, o respeito às especificidades locais, a adequação das escolhas de materiais e da vegetação ao clima, isto é, o entendimento do objeto de estudo em sua complexidade, sempre considerando suas particularidades e a interação desse espaço com o modo de viver contemporâneo.

Quando Cardozo fala sobre "design", entendemos que, assim como os californianos, se refere ao projeto de paisagismo. Propõe desenvolver métodos organizados e eficientes para resolver os problemas e desenvolver "maneiras próprias" para o projeto profissional, que, nesse caso, acreditamos estar se referindo à prática profissional baseada na padronização das etapas.

Por ter trabalhado por três anos no escritório Eckbo, Royston e Williams, Cardozo traz em sua bagagem a sistematização do projeto de paisagismo, onde as etapas de trabalho são bem divididas: o processo intelectual e o projeto conceitual seguidos pela organização de desenhos para detalhamento na execução. Assim, o professor é pioneiro ao introduzir na Academia uma prática de sistematização em projeto que vinha sendo desenvolvida na área profissional.

Continuando no programa da disciplina "Arquitetura Paisagística", Cardozo descreve a teoria das aulas em três itens:

- Definição geográfica da paisagem: natural e cultural.

- Paisagens comparativas: impactos visuais diversos geograficamente definidos (natural e cultural).

- Históricos: impactos culturais diversos sobre a paisagem e suas ramificações atuais.

E na sequência cita os itens das aulas teóricas:

Introdução sobre os materiais, especialmente os naturais (como plantas):

- Considerações sobre os materiais, quanto à forma, textura, cor, volumes, 
e tamanhos e termos de "design";

- Suas possibilidades de controle do "design", em termos de escala.

Problemas de crescimento:

- Crescimento e tempo;

- Raízes e estrutura;

- Outras considerações específicas.

Aplicações:

- Avaliabilidade (sic) e custo;

- Mão de obra;

- Manutenção.

Problemas técnicos:

- Nivelamento, tratamento de superfícies, e clima;

- Limitações do projeto pelo clima (controle do clima através do “design”).

Materiais e formas de uso específicos:

- Avaliabilidade (sic);

- Mão de obra;

- Manutenção.

Podemos perceber que a organização do programa é bastante confusa, onde ele separa os tópicos "teoria" e "aulas teóricas" e que supostamente deveriam ser correspondentes. Isso dificulta a compreensão de alguns dos conteúdos. Mesmo assim, considerando os itens descritos no programa, pudemos nos aprofundar um pouco mais sobre as temáticas das aulas a partir de definições encontradas em artigos escritos pelo paisagista e analisando os slides usados em aula.

Se Cardozo não desenvolve o tema da paisagem natural e cultural em seus escritos, demonstra, através de exemplos ilustrados pelos slides, a sua visão da paisagem. Confronta as paisagens naturais, inóspitas e inabitadas, como o Grand Canyon e do Death Valley, com paisagens culturais, urbanas, cheias de vida e movimento como a imagem da Galeria Nova Barão. Mas também nomeia de paisagem cultural a horta urbana, onde a intervenção do homem é mais sútil e menos agressiva. Sua visão pode ser traduzida a partir do depoimento de Marcos Acayaba: 


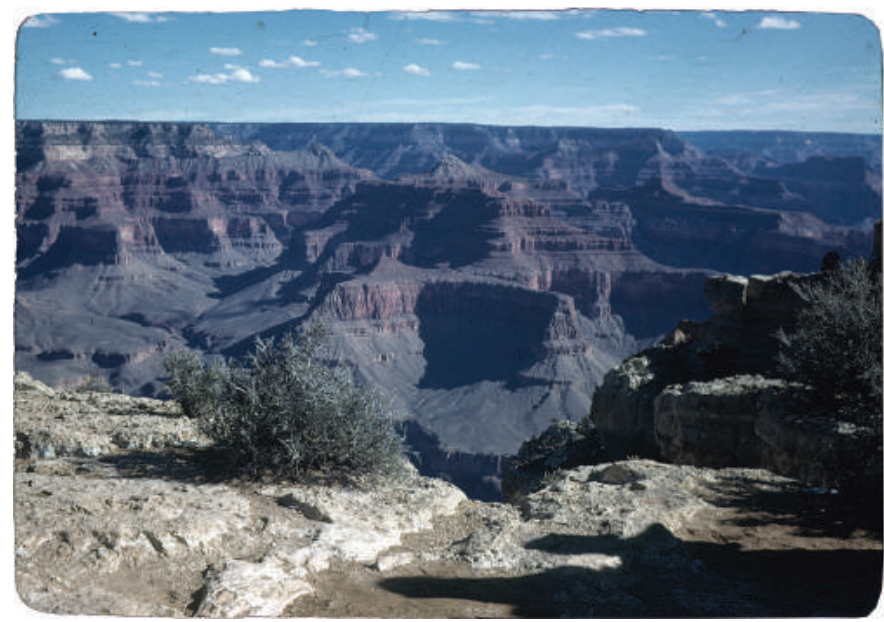

[2.73]

Exemplo de Paisagem natural usado por Cardozo em suas aula: a paisagem inóspita do Grand Canyon, em Nevada e Arizona (EUA).

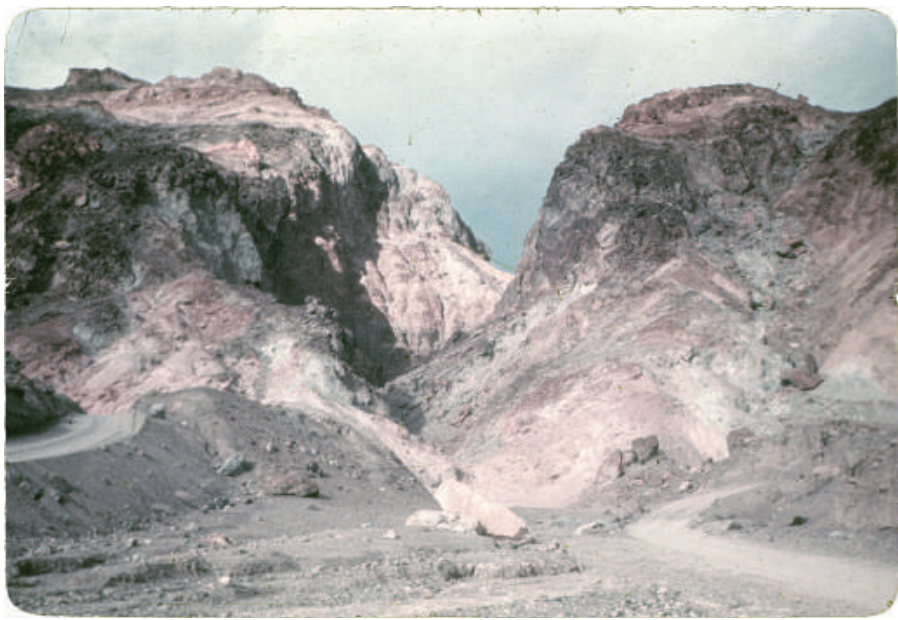

[2.74]

Exemplo de Paisagem natural a paisagem desértica do Death Valley, na Califórnia (EUA).

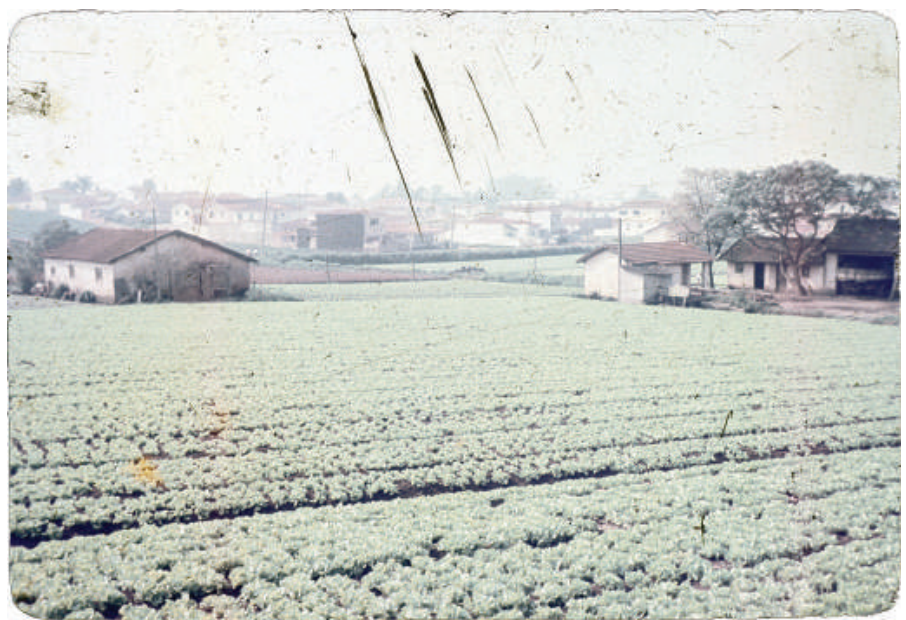

\section{[2.75]}

Exemplo de Paisagem cultural: uma horta urbana na periferia de São Paulo. 
[2.76]

Exemplo de paisagem cultural: Galeria Nova Barão, no centro da cidade de São Paulo.

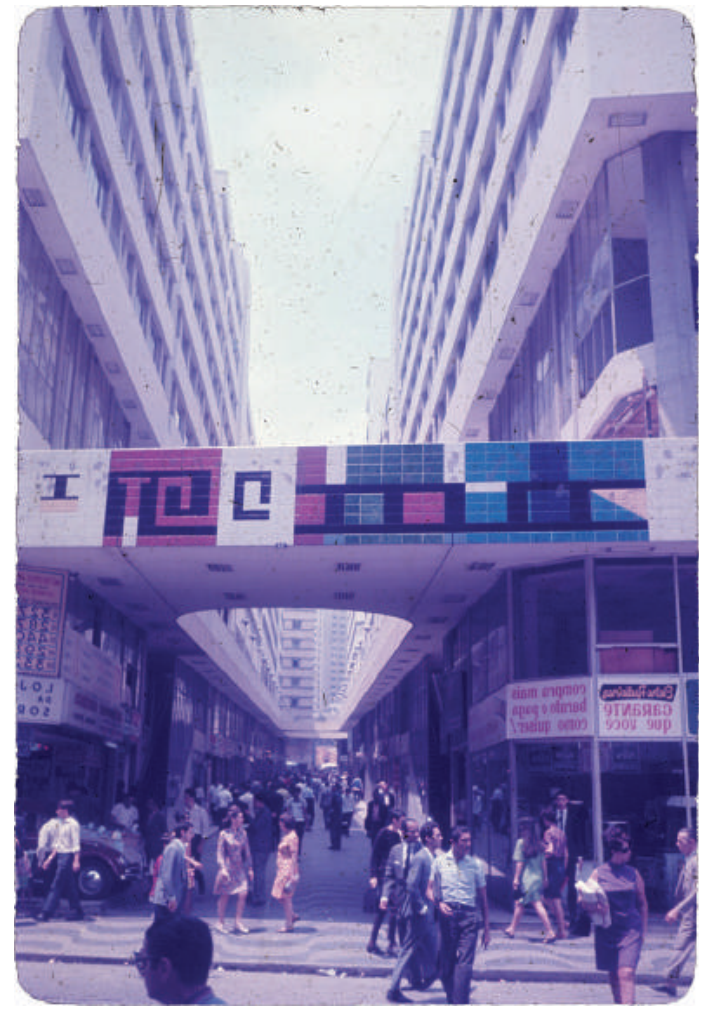

Tinha umas aulas introdutórias marcantes e inesquecíveis. Eu me lembro de slide projetado na parede e o Cardozo falando: "Este é paisagem natural" e mostrava uma paisagem em que você não via nada humano visível, mas era uma paisagem inglesa. Ele falava: "Este é paisagem cultural. Vocês acreditam?". Ele era provocador. "Tudo foi o homem que fez. Não tem nada da natureza aqui, espontâneo", e mostrava. "Isto é plantado, plantado em tal época, existe desde tanto tempo...". Dava uma leitura da paisagem na foto que estava projetada, para você entender: "olha, você constrói isso aí, você projeta, você planta, depois de um tempo isso vai ficar assim. Não parece, mas é paisagem cultural, porque foi uma certa cultura que fez isso, não é a natureza que fez isso". É interessante, porque esse tipo de visão, para um menino do terceiro ano.

Me lembro de uma imagem muito bonita: uma vista em Salvador, aquele convento que tem umas arcadas assim... Um pátio assim, umas arcadas e a baía atrás. Os arcos, essa paisagem atrás dos arcos e esse pátio. Você conhece. Essa é uma imagem que ficou marcada, do Cardozo mostrando e falando: "Olha só o que acontece com esse espaço relacionado com aquele outro espaço, com essas molduras aqui, esses arcos, isso é paisagem cultural". Foi na mesma aula. Com esses arcos do Bom Jesus da Lapa. Lá na ponta (ACAYABA, 2015). 
Apesar de não discorrer sobre os assuntos da mesma maneira que estão descritos nos programas da disciplina, Roberto Coelho Cardozo trata constantemente de materiais orgânicos e inorgânicos em seus artigos. No ano de 1955, a revista Casa e Jardim publicou uma série de artigos "informativos e ilustrados" ${ }^{34}$ de autoria do paisagista sobre a melhor forma de resolver problemas de pavimentação ao ar livre. Nesses artigos, ele discorre sobre as condicionantes para escolha de determinados materiais em projetos de paisagismo. No artigo "Pisos no jardim - terraços, passeio, áreas privadas", levanta as considerações indispensáveis para a melhor escolha dos pisos externos:

A pavimentação para esses pisos inclui um vasto número de estimativas, as quais podem ser satisfeitas por muitos meios e formas, desde a areia usada nos notáveis jardins do Japão, os espessos tapetes de folha seca sob árvores - excelentes para piqueniques - os gramados e água dos famosos jardins de Versailles e, finalmente, aos simples passeios de terra nua, cada qual com as suas cambiantes. Uma vez, porém, que nos dias atuais, distante do Interior, vivendo em grandes centros urbanos, somos forçados a trabalhar e viver em áreas cada vez mais limitadas e intensas, necessitamos aplicar materiais mais refinados, com desenhos de texturas interessantes, outras vezes simples, em nossos pátios, jardins e parques (CARDOZO, 1955c).

Continua o artigo enumerando as considerações indispensáveis para a escolha correta para a pavimentação ao ar livre. Em primeiro lugar, defende que "(...)o revestimento de pisos deve ser de acordo com a atividade que irá desenvolver e que espécie de atividade seja”. Em segundo lugar, questiona a quais condições climáticas estará sujeito o piso e como isso influi na escolha certa dos materiais. O terceiro ponto que deve ser levado em conta nessa escolha é o problema de limpeza e conservação do material. Em quarto lugar, deve-se levar em conta as condições financeiras para a escolha do material. Por fim, escreve sobre o mais importante, a "Concordância":

34. O editor da Revista Casa e Jardim introduz os artigos de Cardozo: "Com a intenção de auxiliar nossos leitores na escolha do material para pavimentação de áreas ao ar livre, iniciamos hoje a publicação de uma série de artigos informativos e ilustrados, do paisagista Sr. Roberto Coelho Cardozo, que elucidam como e qual a melhor forma de resolver esse problema" (CARDOZO, 1955c). 
Finalmente, é ainda necessário pensar na boa coordenação do desenho, que está em íntima correlação com o revestimento do piso, bem como os outros materiais usados e aplicados dentro ou fora da área em questão. A coordenação dos desejos deve partir de: o tamanho da área, se o revestimento é em pedra ou laje; escala; grau das texturas superficiais; direção da colocação; luz e sombra requeridas e assim, tudo o mais em relação ao seu interesse, a sua atividade e ao seu meio de vida (CARDOZO, 1955c).

A importância que Cardozo dá aos materiais pode ser percebida nas imagens de seus projetos, que ele também usava como exemplos em aulas. Nas imagens da residência Tufy Mattar, vemos Cardozo explorar diferentes texturas, misturando lascas de ardósias a panos de mosaico português amarrados a degraus em pedra bege (talvez pedra mineira). Esses degraus são acabados com juntas de dilatação preenchidas com grama preta. Ainda, o paisagista joga com formas circulares e retangulares, criando contrastes formais que, quando vistos no todo, criam um conjunto coeso e de desenho peculiar.

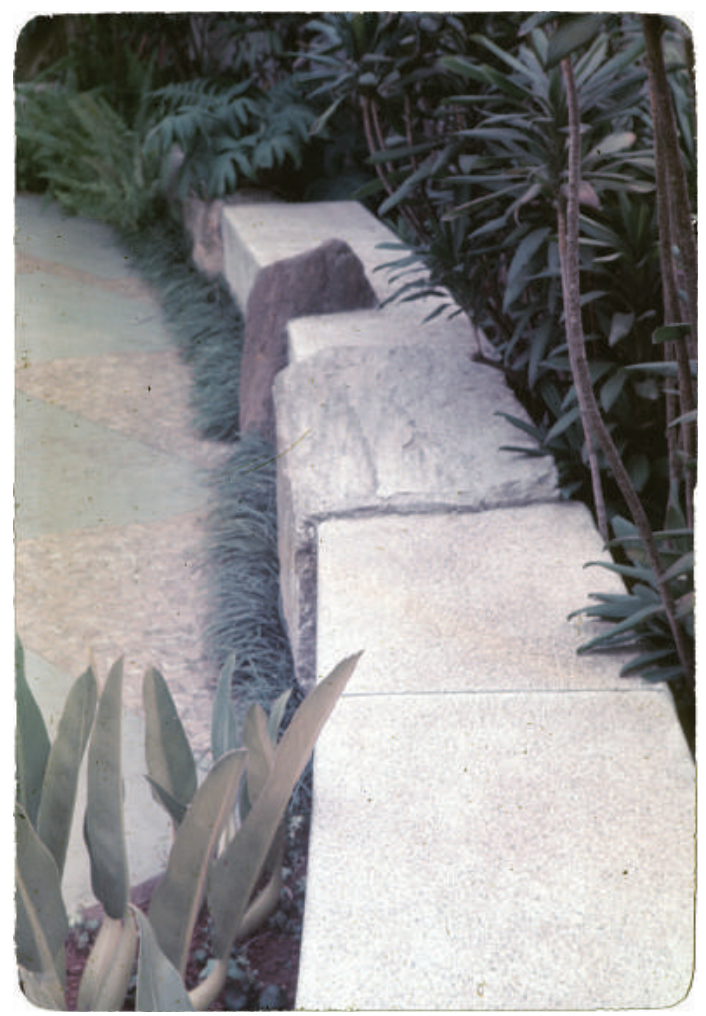



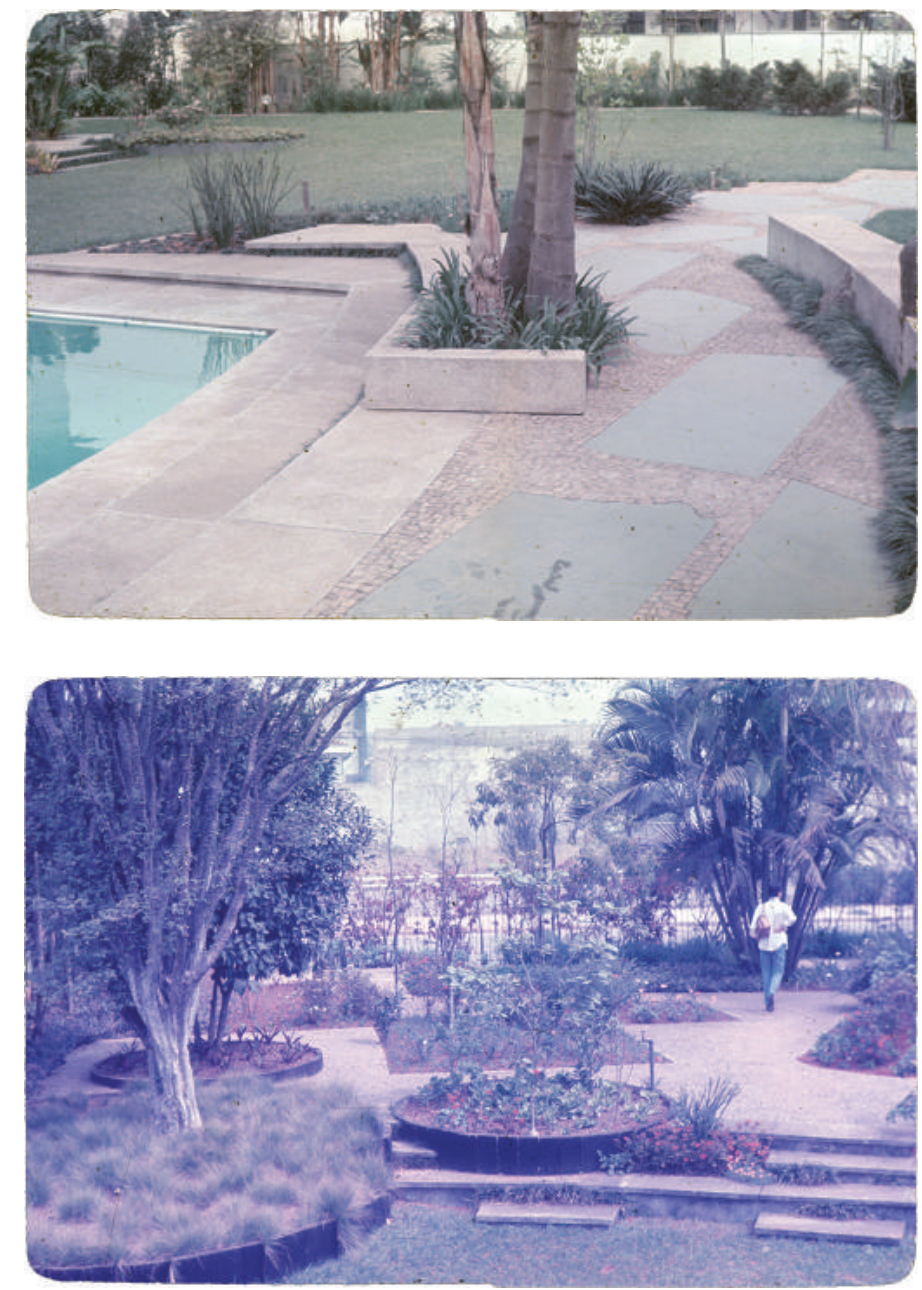

Ao mesmo tempo, explora aspectos sutis e imateriais do projeto de paisagismo, como podemos notar a partir da legenda de uma imagem que ilustra um de seus artigos ${ }^{35}$, onde ele descreve como a pedra "ganha expressão" a partir da sombra que as plantas fazem no piso. Cardozo usa os jogos de sombra para incluir texturas nos mais diversos elementos do projeto, seja a sombra de um pergolado no desenho de piso, reforçando a regularidade do piso, seja o sombreamento de palmeira em uma praça, aliviando a claridade do mosaico português branco.

35. Cardozo escreveu três artigos que abordam a questão dos pisos em jardins: Pisos em jardins modernos, Pisos: suas preferências e necessidades e Pisos no jardim.

\section{[2.78]}

Variação de texturas no piso, com uso intercalado entre mosaico português e lajotas de ardósia. Os degraus e muretas são revestidos em arenito bege. Residência Tufy Mattar.

\section{[2.79]}

Canteiros redondos com borda de ardósia são inseridos em plano de mosaico português, em meio a outros canteiros retangulares ao nível do chão. 
[2.80]

Descrição de Cardozo para a imagem: "Cacos de cerâmica com cimento cinza; material simples e de fácil obtenção,

tomando expressão com novas formas; bom exemplo de material

enriquecido simplesmente com sombras das plantas".

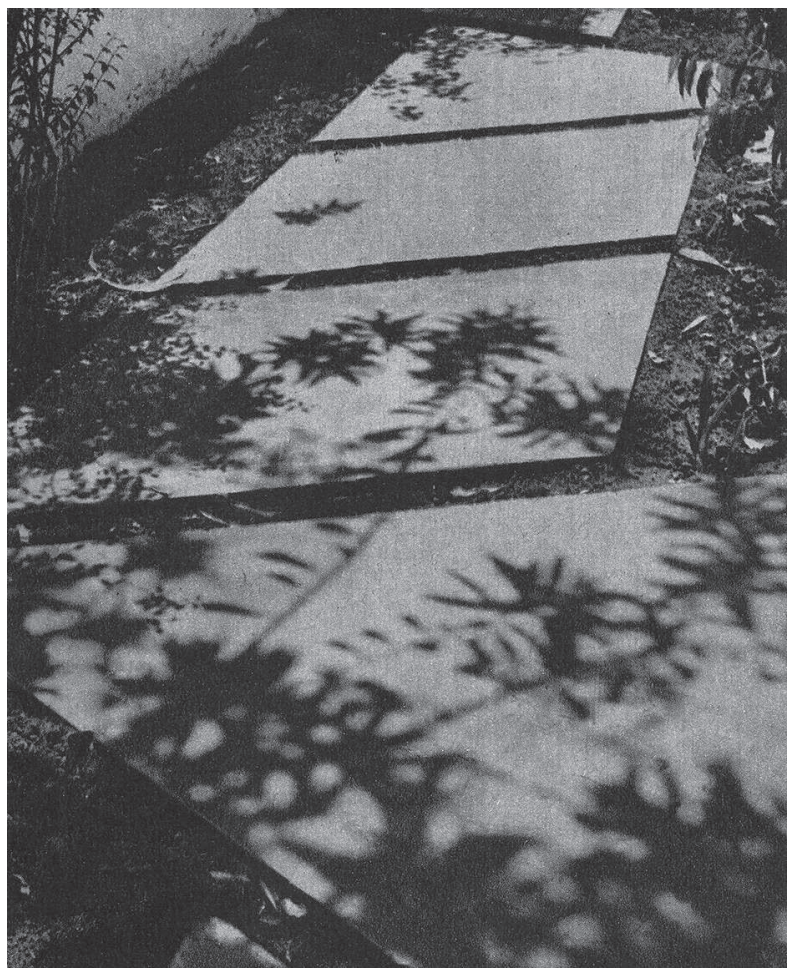

[2.81]

Descrição de Cardozo para a imagem: "Cepas

de dormentes de estrada de ferro cortados transversalmente; eirado de cerâmica vermelha; executado em um jardim de inverno, constituindo mais uma superfície para se pisar do que propriamente um tipo de piso. Material de capacidade de absorção de som, escuro e com forma estudada em relação à direção da sombra da pérgula".

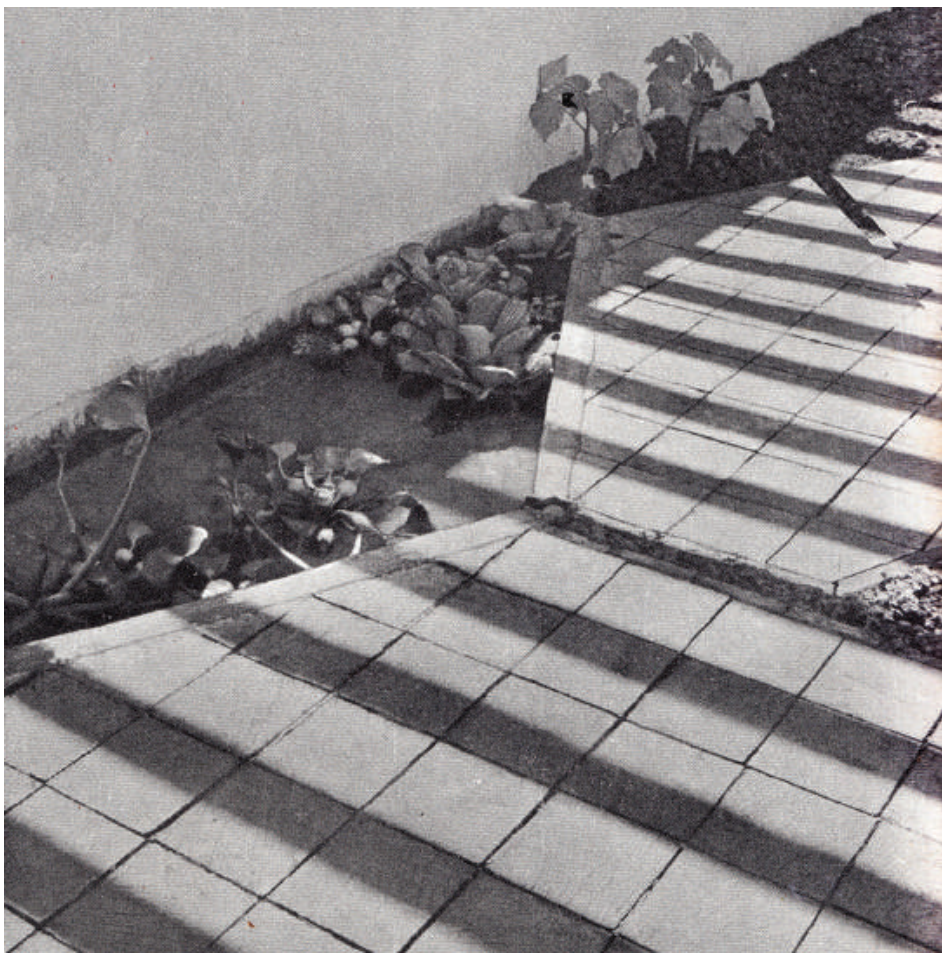




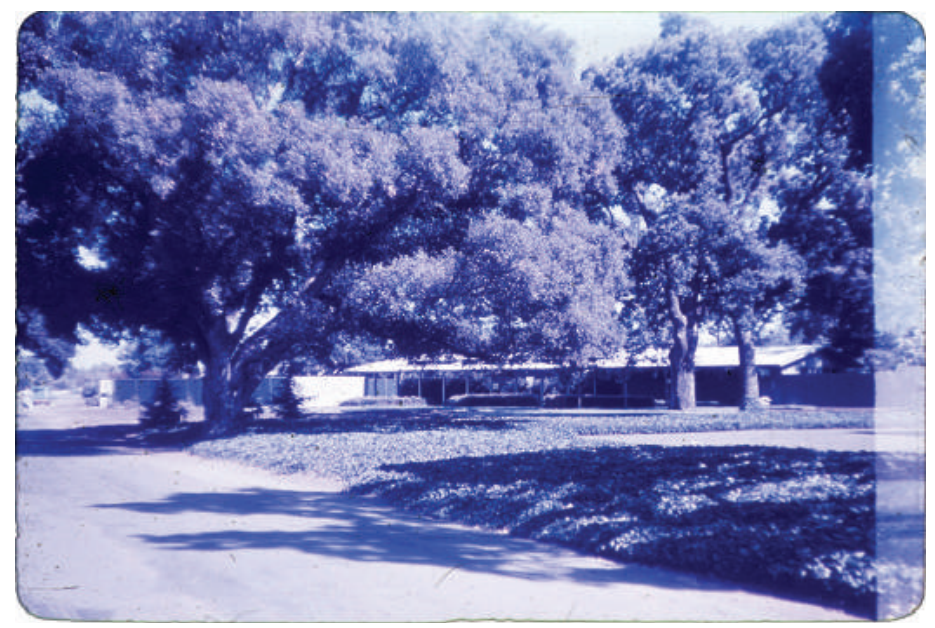

\section{[2.82]}

Exemplo de Luz e sombra: árvores sombreando canteiros em condomínio habitacional nos EUA.

\section{[2.83]}

Exemplo de Luz e sombra: sombra das palmeiras marcando o piso do Largo da Matriz em São Sebastião".

\section{[2.84]}

Equilíbrio: ação dos ventos sobre as árvores à beira-mar. 
Em outro artigo, Cardozo discorre sobre as árvores e sua função na cidade. Inicia o artigo afirmando que "A presença do elemento verde em nossos centros urbanos faz parte da expressão de equilíbrio entre o homem com suas atividades e o espaço com os materiais que o organizam". Escreve como as árvores podem dar escala e criar volumes e formas na massa urbana. E como, a partir da vegetação, é possível controlar alguns problemas climáticos, como diminuição das velocidades de ventos, as variações bruscas de temperaturas e climatizar ambientes tornando-os mais frios e úmidos. Encaminhando-se para o lado botânico, o paisagista descreve as três zonas de uma árvore (zona de raízes, plano da superfície ou colo da árvore e zona superior ou tronco e copa) e como cada uma dessas zonas deve ser analisada criteriosamente para uma escolha certeira na arborização urbana e ornamental.

Para além das definições e escolhas de vegetação, Cardozo também mantinha um vasto arquivo de imagens de espécies vegetais. Separadas entre espécies exóticas e nativas, as imagens eram nomeadas pelos nomes científicos e populares. O conteúdo do arquivo era raro e único já que, diferente dos diversos manuais de vegetação que existem na atualidade, à época não havia qualquer material de divulgação sistematizado com esse tipo de informação. Foi somente no ano de 1965 que o botânico Harry Blossfeld publicou o livro Jardinagem, livro pioneiro em compilar informações precisas sobre espécies vegetais e o desenvolvimento da evolução da jardinagem pública em São Paulo.

Espécies vegetais: Piteira-do-caribe (Agave angustifolia), espécie exótica proveniente da América Central.

[2.86]

Espécies vegetais: Palmeira rabo-de-peixe (Caryota Mitis), espécie exótica proveniente da
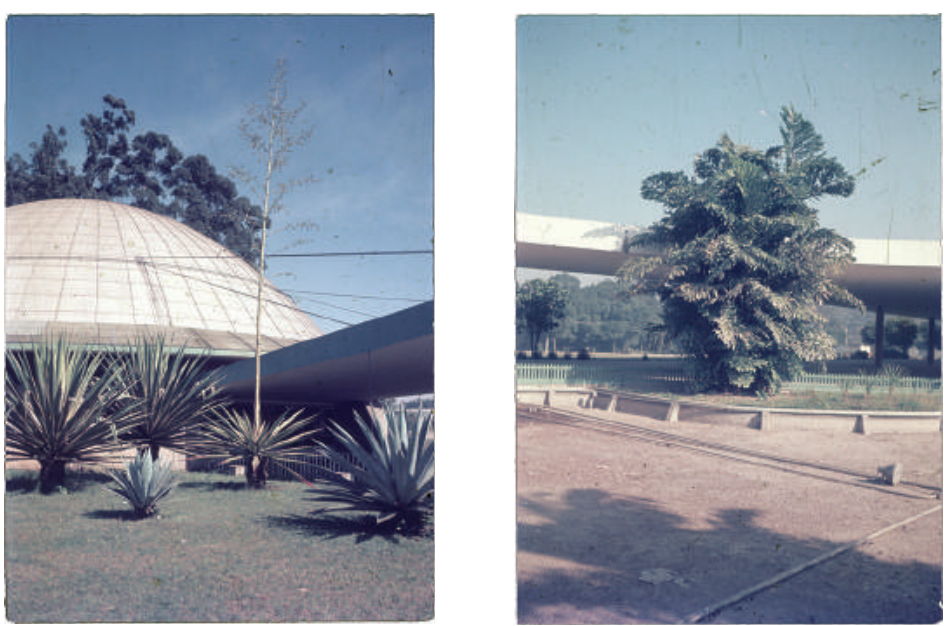
As considerações sobre a vegetação se expandem para a paisagem no momento em que Cardozo inclui nos temas de suas aulas as "limitações do design pelo clima". Mais do que uma limitação, seriam as necessidades de cada espaço segundo o clima de cada região. Cardozo insiste numa escolha adequada de materiais para cada clima. Confronta, a partir de alguns slides, como a madeira se deteriora em climas úmidos e em climas com a presença de maresia ou como em determinadas regiões mais secas a madeira pode ser uma escolha acertada.
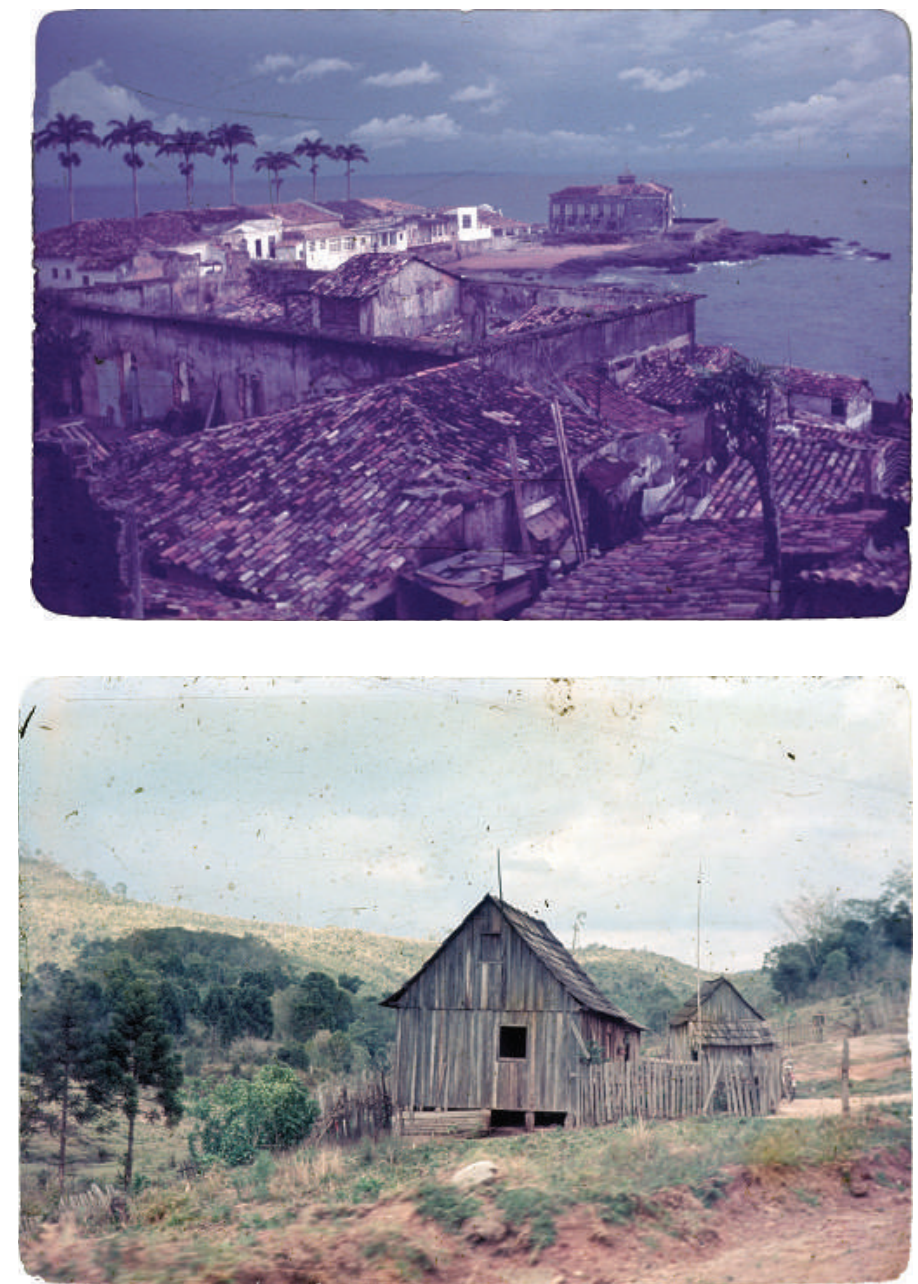

\section{[2.87]}

Climas e manutenção: telhados danificados pela maresia em Monte Serrat, Santos.

\section{[2.88]}

Clima e manutenção: "telhados de tábua" em regiões de clima seco. 
Esses são apenas alguns exemplos de como Cardozo se colocava perante a escolha dos materiais, da vegetação e de outros elementos em projetos de Paisagismo. O paisagista sempre se mostrou muito preocupado com a forma e o volume que esses materiais podem propiciar, no modo como as texturas se mesclam no espaço ou em como a cor e o brilho de cada material pode influenciar na luminosidade das áreas externas. Outros fatores que levava em consideração nas escolhas dos materiais são a disponibilidade (ou "avaliabilidade" ${ }^{36}$, como escreve nos programas) desses materiais no mercado, sua correta instalação com mão de obra especializada e seu custo. Resume que:

O planejamento de um jardim contemporâneo requer que o projetista tenha liberdade plena, no uso e seleção do material e sua combinação, a fim de que a solução do projeto de uma área sirva verdadeiramente à finalidade a que se destina.

Essencialmente, é isso que acontece em nossos pequenos jardins de cidade, onde é necessária uma infinita variedade de funções e se exige estrita colaboração entre as atividades de áreas internas e externas. Essa estreita colaboração entre as duas áreas clama por uma nova arquitetura de jardim, que apresente unidade na diversidade de materiais, como se verifica nas residências de hoje, com o vidro, aço, madeira, água e plantas, entrelaçadas e combinados em um só todo (CARDOSO; COELHO, 1958).

Notamos que muitas das colocações de Roberto Coelho Cardozo, tanto do programa da disciplina como nos artigos que escreve, podem ser identificadas nas questões levantadas pelos californianos. Segundo o pensamento dos californianos, o mote "Gardens are for people" se traduz a partir de uma visão de jardim que tem como premissa estimular, divertir deleitar e relaxar o usuário. Muito mais que uma "sala ao ar livre", deve proporcionar o contato revitalizante com o crescimento das plantas, com a fecundidade da terra, que proporcionam ao homem força e inspiração. Toda a visita a um jardim deve ser uma aventura e uma experiência de prazer e felicidade. Ao mesmo tempo, os califor-

36. Cardozo empregava a palavra "avaliabilidade" com frequência. Mais uma vez vemos a dificuldade do paisagista com a língua portuguesa, uma vez que seria um "abrasileiramento" da palavra inglesa availability, que significa disponibilidade. 
nianos ressaltam que cada local é diferente e as especificidades de cada região (topografia, clima, plantas, estruturas e tipos de uso) devem ser tratadas e resolvidas de forma singular, sempre valorizando a cultura regional com sensibilidade e clareza (ECKBO, 1950b).

Não só os conteúdos das aulas de Cardozo são inspirados nos ideais da "corrente californiana", mas também o modo de exposição das questões se dá de maneira similar, a partir da linguagem de manuais de paisagismo, com enumerações de modos de se fazer um bom paisagismo, como se pode observar nos livros Art of Home Landscaping e Urban Landscape Design, de Garrett Eckbo.

Além do interessante conteúdo dos programas de "Arquitetura Paisagística", acompanhado dos slides que eram expostos em sala de aula, ainda podemos relacionar os relatos dos alunos que cursaram a disciplina para entender a complexidade da disciplina. Os depoimentos são bastante divergentes.

Segundo a Profa. Dra. Miranda Martinelli Magnoli, que foi aluna e estagiária do paisagista, os exercícios propostos na disciplina:

Não era propriamente nem praça, nem jardim. Eles (Roberto e Daisy ${ }^{37}$ ) escolhiam algumas situações que pudessem discutir. Eram exercícios bastante selecionados, nem eram tirados da realidade, eram montados mesmo, irreais. Por meio deles se podia discutir um pouco a implantação, a relação entre lote, rua e sistema. Lembro-me de um trabalho que fizemos sobre lote, rua e sistema de tráfego (MAGNOLI, 2006).

Em outra ocasião, Magnoli ainda acrescenta:

Ele se aproximava com uma conversa diferente. E isso me encantou, ele punha perguntas que nunca haviam passado por nossas cabeças. Era, no fundo, o 'Landscape americano' que estava se projetando no fundo da cabeça de um arquiteto (MAGNOLI, 2015).

Luciano Fiaschi, outro aluno e estagiário e que veio a se tornar sócio de Cardozo escreve:

37. Refere-se a Daisy Igel, que foi a primeira assistente de Roberto Coelho Cardozo. 
(...) gostava bastante dos exercícios práticos dele, mas talvez não entendesse muito bem o que ele queria transmitir com aqueles exercícios, com as aulas e as palestras que fazia (...) e só comecei a entender as aulas do Cardozo e a ver como elas eram boas depois que comecei minha própria prática profissional. Demorou bastante para 'cair a ficha'. E isso não só na área de arquitetura paisagística, mas em todas as áreas (FIASCHI, 2004).

Por fim, o arquiteto Marcos Acayaba, também depõe sobre o curso de paisagismo:

A figura do Roberto era instigante, não conseguíamos entender o que ele dizia e, ao mesmo tempo, os exercícios eram interessantes. Nesse ano as disciplinas de Projeto e Planejamento decidiram fazer uma temática comum: era o projeto de uma cidade, a construção de uma usina hidrelétrica.Então, tinha as arquiteturas, o desenho urbano, as implantações, onde entrava Planejamento. Então, teve uns exercícios de Planejamento iniciais que era uma coisa... (Eu até vi a não muito tempo atrás um exercício muito parecido proposto pelo Silvio Macedo, de implantação de bloquinhos, casinhas repetidas. Fazer a implantação e criar o tratamento das áreas externas).

Tinha esse tipo de exercício. Independentemente da cidade para a hidrelétrica, cujo projeto urbano foi só começar a tomar corpo mais adiante. Imagina, a gente no terceiro ano não tinha condição de começar fazendo um desenho urbano. Então, teve uma proposta de projetos e imagina assim: um terreno que tem uma encosta, um plano inclinado uniforme, suave, porque vai chagar na represa; e sobre esse plano inclinado vamos imaginar as casas operárias. Primeiro, individualmente as casas operárias, casas individuais, isoladamente, o projeto de uma casa para ser repetido. Independente do desenho urbano. Depois faz o desenho urbano e refaz a casa, eventualmente. Mas o primeiro exercício foi isso aí: fazer projeto de casa.

Em paralelo, em Planejamento, com o Cardozo e com o Antunes, era essa coisa de fazer esses arranjos de volumes construídos, repetidos, áreas externas e de repente você começa a tentar organizar as circulações. Era um exercício bem elaborado, mas acho que a maioria dos estudantes não entendia bem o que estava acontecendo (ACAYABA, 2015).

Pelo depoimento dos alunos é bastante difícil qualificar as aulas de Cardozo. Nos parece que o professor propunha alguns exercícios que não se faziam compreender à época, mas que passaram a fazer mais sentido para os alunos com o passar dos anos. Ademais, percebe-se, por esse e outros depoimentos, que Cardozo sempre indagava os alunos 
sobre as "visuais" (panoramas), os "contornos" (morros e morrotes, como Cardozo os chamava) e a proteção do meio ambiente. Nesse sentido, com essa "conversa diferente", como escreveu a Profa. Miranda Magnoli, Cardozo margeava algumas questões mais amplas sobre a paisagem e também trazia alguns conceitos do Landscape americano em sua didática, buscando apurar a percepção dos jovens arquitetos em relação à paisagem e ao ambiente habitado pelo homem.

Uma outra forma de contribuição de ensino praticado por Roberto Coelho Cardozo se deu através do estágio em seu escritório. Prática bastante comum à época, os professores de projeto da Faculdade convidavam alguns alunos para estagiarem em seus escritórios para ganharem experiência na área, trabalhando em desenhos técnicos, levantamentos e acompanhamento de obras. Através da análise de seus projetos, percebemos que Cardozo adotava um padrão bastante criterioso, com desenhos de planta bem resolvidos, indicação de vegetação adequada a cada espaço e cuidado no detalhamento do projeto, que eram bastante elaborados para a época. Essa sistematização do projeto de paisagismo ainda estava em desenvolvimento no Brasil e, nesse sentido, a presença de Cardozo auxiliou na criação e sistematização de padrões de projetos de paisagismo e nos modos de projetar, que podemos ver presentes nos desenhos de seus discípulos, como os paisagistas Luciano Fiaschi e Miranda Magnoli.

Como dito anteriormente ${ }^{38}$, o grande problema de Roberto Coelho Cardozo na área acadêmica foi não ter formado outros professores e assistentes na área da arquitetura paisagística. Em alguns períodos a disciplina ficou sem professor titular, pois Cardozo estava de licença e não havia quem o substituísse. Além disso, nos fins da década de 1960, a Faculdade começou a exigir que os professores tivessem a titulação na pós-graduação. Tanto Cardozo quanto Antônio Augusto Antunes Neto, que também passou a lecionar na disciplina, se negaram a fazer a titulação (MAGNOLI, 2015). Foi apenas em 1972 que, finalmente, a Profa. Dra. Miranda Martinelli Magnoli tornou-se a titular da disciplina, criando também o Grupo de Disciplinas de Paisagismo.

38. Citamos esse fato em "A atuação docente na FAUUSP" no Capítulo 1. 
Apesar desse contexto conturbado na Academia, a presença de Cardozo contribuiu na formação de alunos das primeiras turmas da FAUUSP, e esse legado é percebido nos paisagistas contemporâneos atuantes até hoje. Além disso, as imagens e programas da disciplina pesquisados contribuíram para a compreensão histórica da disciplina, ampliando sua importância, para além de uma visão simplificadora de que "era, em geral, reconhecida apenas como uma disciplina de caráter complementar, 'disciplina de jardinagem', de ensino do plantio e do estudo de espécies vegetais" (LIMA, C; et al, 1998). 
PLASTICIDADE E ORGANICIDADE NA OBRA DE ROBERTO COELHO CARDOZO 



\subsection{CRITÉRIOS PARA A ANÁLISE DE PROJETO}

Desde o início da pesquisa, um dos objetivos deste trabalho era fazer uma análise de um grupo de projetos paisagísticos de Roberto Coelho Cardozo, subsidiando-se do levantamento e do inventário da obra do paisagista. Mais especificamente, tínhamos dois objetivos especiais, que eram:

- Verificar eventuais alterações das orientações dos paisagistas californianos a partir das singularidades brasileiras (materiais, vegetação) na obra de Roberto Coelho Cardozo.

- Verificar quais foram os traços inovadores nos projetos de Roberto Coelho Cardozo que fizeram com que sua obra ganhasse uma modernidade específica, diferente dos outros paisagistas atuantes à época.

Mais além, propusemo-nos a analisar os projetos a partir de elementos técnicos, ou seja, com base no material iconográfico e projetual disponível, visto que uma pesquisa in loco seria comprometida, já que muitos dos projetos não existem mais - como residências que foram demolidas ou como a Praça Franklin Roosevelt, que foi inteiramente reestruturada - ou não têm suas características originais preservadas.

Devido a isso, começamos a pontuar quais seriam esses parâmetros que indicariam alterações das orientações dos paisagistas californianos. Levamos em consideração os preceitos contidos nos livros de paisagismo de Garrett Eckbo e também usamos como base os estudos e a análise de projetos já feitos pelo estudioso da corrente californiana Marc Treib ${ }^{1}$, que examina os projetos de Garrett Eckbo, Dan Kiley e

1. Marc Treib é professor emérito do Departamento de Arquitetura da University of Berkeley, Califórnia, e atualmente atua nas áreas de pesquisa de Arquitetura e Jardins escandinavos e japoneses, desenho de cemitérios e história do paisagismo. É responsável pela importante bibliografia referente à história do paisagismo moderno norte-americano: Modern landscape architecture: a critical review (1993), Garret Eckbo: Modern Landscapes for Living (1997), The Architecture of Landscape: 1940-1960 (2002), Thomas Church Landscape Architecture: Designing a modern California Landscape (2003), Settings and stray paths writings on 
James C. Rose. Fixamos, então, os seguintes parâmetros:

- o exercício plástico abstrato, embebido pela arte moderna abstrata de Arp, Miró e Kandinsky - trazido ao jardim por meio da forte geometrização de seus elementos estruturadores;

- a quebra dos eixos simétricos e da suntuosa estrutura perspectivada inspirada nos exemplos dos jardins franceses, tentando assim criar espaços mais fluídos, volumétricos e dinâmicos, com vistas multifacetadas;

- a concepção do jardim de forma a explorar a verdade dos materiais, expressando assim a mentalidade contemporânea - nesse caso, a mentalidade que se formava a partir da consolidação da Arte e da Arquitetura Moderna; a necessidade de área livre para lazer e recreação nas áreas urbanas;

- a busca da conciliação entre a arquitetura e a natureza - o projeto da arquitetura associado ao projeto de paisagismo, criando soluções que interliguem os espaços internos e externos dos edifícios e englobem a paisagem do entorno; - o uso de vegetação autóctone ou adaptada ao clima regional;

- o desenho dos espaços para as pessoas, uma vez que são os principais protagonistas nos projetos de jardins.

Feita uma análise inicial, percebemos que não só Roberto Coelho Cardozo projeta seus jardins a partir desses parâmetros, mas que seus contemporâneos, Roberto Burle Marx e Waldemar Cordeiro, também estruturaram seus trabalhos seguindo essas orientações. Isso não quer dizer que todos tinham como motivação os escritos da "corrente californiana”, mesmo porque os norte-americanos não foram os únicos a tentar desenvolver uma nova conceituação para pensar o paisagismo, como já foi mostrado no Capítulo 2. O que nos parece é que esses preceitos serviram como uma base comum para um pensamento moderno no paisagismo. Assim como na Arquitetura Moderna, alguns preceitos foram difundidos e tomaram as mais variadas formas conforme os diferentes contextos em que se inseriram, e vemos na obra desses paisagistas que cada qual concebeu os jardins de maneira peculiar, seja nas mudanças de referencial artístico - Burle Marx com sua pintura 
policromática e abstrata, e Cordeiro com a arte concreta -, seja em uma forma mais pragmática de desenhar os ambientes externos, como fez Cardozo. Trouxeram, em seus traçados geometrizados, com emprego de vegetação adaptada à região, explorando os materiais locais de maneira natural e tentando conciliar os espaços externos com a arquitetura, diferentes modos de pensar essa nova forma do paisagismo, e cada um deles apresenta traços de uma modernidade específica em seus projetos.

No caso de Roberto Coelho Cardozo, o influxo direto da obra dos californianos, especialmente da atuação do escritório Eckbo, Royston \& Williams, é inegável, dada sua formação acadêmica e profissional. Para mais, quando catalogamos seus projetos, duas características nos chamaram a atenção. A primeira é o aspecto formal de seus projetos, que são facilmente identificados pelo emprego dos círculos para estabelecer estares, desenho geometrizado de pisos, sejam pisos hexagonais com juntas preenchidas com gramas, sejam faixas de granito que percorrem os gramados, e o emprego de escadas e patamares para vencerem desníveis do terreno. Essa parece uma descrição comum de muitos projetos, mas, como veremos mais adiante com alguns exemplos, a confluência desses elementos faz com que o desenho de Cardozo seja realmente único. A segunda característica que se ressalta é a massa vegetal que circunda as edificações: isso foi percebido com o mapeamento das obras do paisagista por meio de fotos aéreas. Dessa forma, constatamos que ele extrapola o espaço comum que poderia ser destinado à vegetação de grande porte e faz o plantio de árvores e palmeiras com espaçamento mínimo, explorando ao máximo as possibilidades de adaptação dessa vegetação a pequenos espaços, modificando até mesmo o modo como se desenvolvem. Sabemos que Coelho Cardozo tinha grande domínio das plantas ${ }^{2}$ por ter formação em horticultura e que, nos acompanhamentos da implantação de seus projetos, ele fazia manejos de vegetação e modificações de galhadas para conseguir os efeitos de volumetria necessários. Mais além, verificamos que

2. Luciano Fiaschi descreve como Roberto Coelho Cardozo trabalhava a vegetação em entrevista concedida a Silvio Macedo e Fany Galender. Paisagem e Ambiente, n.19, p. 7-30. 
Cardozo trabalhava com a manipulação das espécies vegetais, criando bonsais e plantando espécies de grande porte em vasos de concreto para delimitar seu crescimento e, mesmo assim, beneficiar-se de sua capacidade ornamental.

Assim, seguiremos essa linha para discorrer sobre os projetos de Cardozo. Tendo em mente os parâmetros do paisagismo moderno, vamos nos ater mais às características específicas de sua obra: forma e vegetação, plasticidade e organicidade, ou como conseguia valorizar seus jardins explorando a morfologia e a volumetria dos espécimes vegetais e de que maneira integrava essa vegetação aos outros materiais, que, trabalhados nas mais diversas formas, criavam espacialidades integrando os ambientes externos aos internos, arquitetura e paisagem, tornando sua obra peculiar.

Os seguintes projetos foram selecionados por apresentar a planta de vegetação bem detalhada, com especificação de espécies, e a planta de pisos, com discriminação dos materiais empregados e das medidas adotadas, para podermos analisar tais elementos e compará-los. Tentamos, também, analisar projetos com programas diversos, sendo o jardim de duas residências - uma em Los Angeles e a outra em São Paulo -, o planejamento para a implantação de uma escola e o desenho urbano de uma usina hidrelétrica.

Ao final do capítulo, apresentaremos as fichas catalográficas dos 192 projetos de Roberto Coelho Cardozo levantados durante a pesquisa. Esse levantamento foi feito no acervo de projetos da biblioteca da FAUUSP e nas revistas especializadas ${ }^{3}$ da época. Essa análise projetual só se concretizou devido à organização desse material, que por isso se faz tão importante dentro desta seção da pesquisa.

3. Foram consultados os volumes de 1 a 191 da revista Casa e Jardim, que teve sua primeira publicação em 1953. Da revista Habitat, foram consultados todos os volumes do periódico, de 1 a 84, já que a publicação foi extinta em 1965. Da revista Acrópole, foram consultados os volumes de 141 a 380, de janeiro de 1950 a dezembro de 1970. 


\subsection{RESIDÊNCIA ANTHONY B. HEINSBERGEN}

O primeiro projeto a ser analisado é o da Residência Anthony B. Heinsbergen, realizado em 1947 no escritório Eckbo, Royston \& Williams com a colaboração de Roberto Coelho Cardozo. Esse projeto foi bastante emblemático para a pesquisa, uma vez que confirma o trabalho de Cardozo no escritório de Eckbo e também verifica o codinome que o paisagista usava à época, R. F. Coelho-Cordoza, relacionando-o a outros projetos cuja autoria ainda não havia sido confirmada.

A residência, localizada em área urbana da cidade de Los Angeles, na Califórnia, apresenta um terreno razoavelmente plano que tem os desníveis de entrada resolvidos a partir de pequenos patamares e uma escada. Com medidas aproximadas de 15 metros de largura e 27 metros de comprimento, é um lote considerado pequeno para os modelos de residências de alto padrão de Los Angeles. Os elementos estruturais de piso são um grande patamar que liga a rua até a entrada principal da casa, com formato irregular e bem geometrizado, e um pátio interno formado pelo espaço entre os quartos e a sala de estar.

O patamar de entrada é revestido em tijolos com uma faixa de cimento, que corta transversalmente o piso no encontro com a casa e depois acompanha longitudinalmente o eixo que leva até a entrada principal. O pátio interno também é revestido por tijolos e por placas cimentícias, placas estas que formam um pentágono irregular, abrigando em um dos lados um pequeno canteiro e, no lado oposto, uma fonte de acrílico (lucite pool) de formato peculiar - quadrada em seu exterior e redonda no reservatório de água. Além disso, uma pérgula em formato de "L" foi disposta na área oposta à sala de jantar.

Analisando a planting plan, ou planta de plantio, percebemos que já em seus primeiros trabalhos, desde os Estados Unidos, Cardozo adota o método de alto preenchimento vegetal em seus projetos. Ainda fora do lote, uma linha de Lophostemon confertus ${ }^{4}$, mirtácea endêmica da Austrália que alcança até 15 metros de altura, preenche o canteiro da calçada. Ao adentrar o lote, vemos alguns conglomerados de árvores,

4. Na planta consta a sinonímia Tristania conferta. 
que pontuam os espaços livres do jardim. A escada de entrada é marcada por caixotes altos - elemento muito empregado tanto pelos californianos quanto por Cardozo em seus projetos posteriores -, nos quais as Sophora tetraptera, fabáceas de médio porte nativas da Nova Zelândia, acolhem os moradores com seus belos cachos de flores amarelas. Acrescentando ainda mais tons de amarelo ao lote, as Parkinsonia aculeata, pequenas fabáceas mexicanas de folhagem fina e difusa, formam fileira em diagonal protegendo a fachada principal, dando mais privacidade ao dormitório e ao escritório, sem barrar completamente a insolação nas janelas.

Outro maciço arbóreo importante dentro da composição geral de vegetação da residência é o maciço plantado no pátio interno. Em um espaço relativamente pequeno, de $7 \mathrm{~m} \mathrm{x} \mathrm{7,5} \mathrm{m,} \mathrm{Cardozo} \mathrm{distribuiu}$ duas fileiras de árvores de médio porte: uma fileira de Acer palmatum, o famoso Momiji japonês, próxima às janelas do dormitório da frente, e uma fileira de Pittosporum phillyraeoides, ou chorão australiano, no pequeno canteiro sobre a pérgula, defronte ao dormitório posterior. As duas espécies apresentam folhagem leve, difusa, e permitem a entrada de luz nos dormitórios, ao mesmo tempo que fazem uma leve barreira visual. A folhagem ornamental do Momiji se transforma ao longo do ano, passando do vermelho ao verde e do verde ao amarelo, caindo nos meses do outono.

Além desses maciços arbóreos, outras massas de vegetação mais baixa são plantadas em toda a residência: arbustos ornamentais desenham uma diagonal em um canto noroeste do terreno, e forrações floridas são plantadas aos pés da vegetação mais alta. Apesar de empregar predominantemente espécies exóticas, percebemos que a grande maioria é proveniente da África do Sul, da Austrália e da Nova Zelândia, países com condições climáticas bem similares às da Califórnia. Nesse sentido, percebemos uma preocupação em empregar espécies ornamentais e que, ao mesmo tempo, se adaptem bem às condições locais. Também constatamos que a vegetação, mesmo sendo disposta geometricamente em linhas ou canteiros regulares, consegue deixar os espaços mais fluidos e orgânicos.

Apesar de ser um exemplo de pequenas dimensões e espaços restritos de jardim, já vemos alguns elementos e soluções que serão replicados em muitos dos jardins feitos na cidade de São Paulo. 


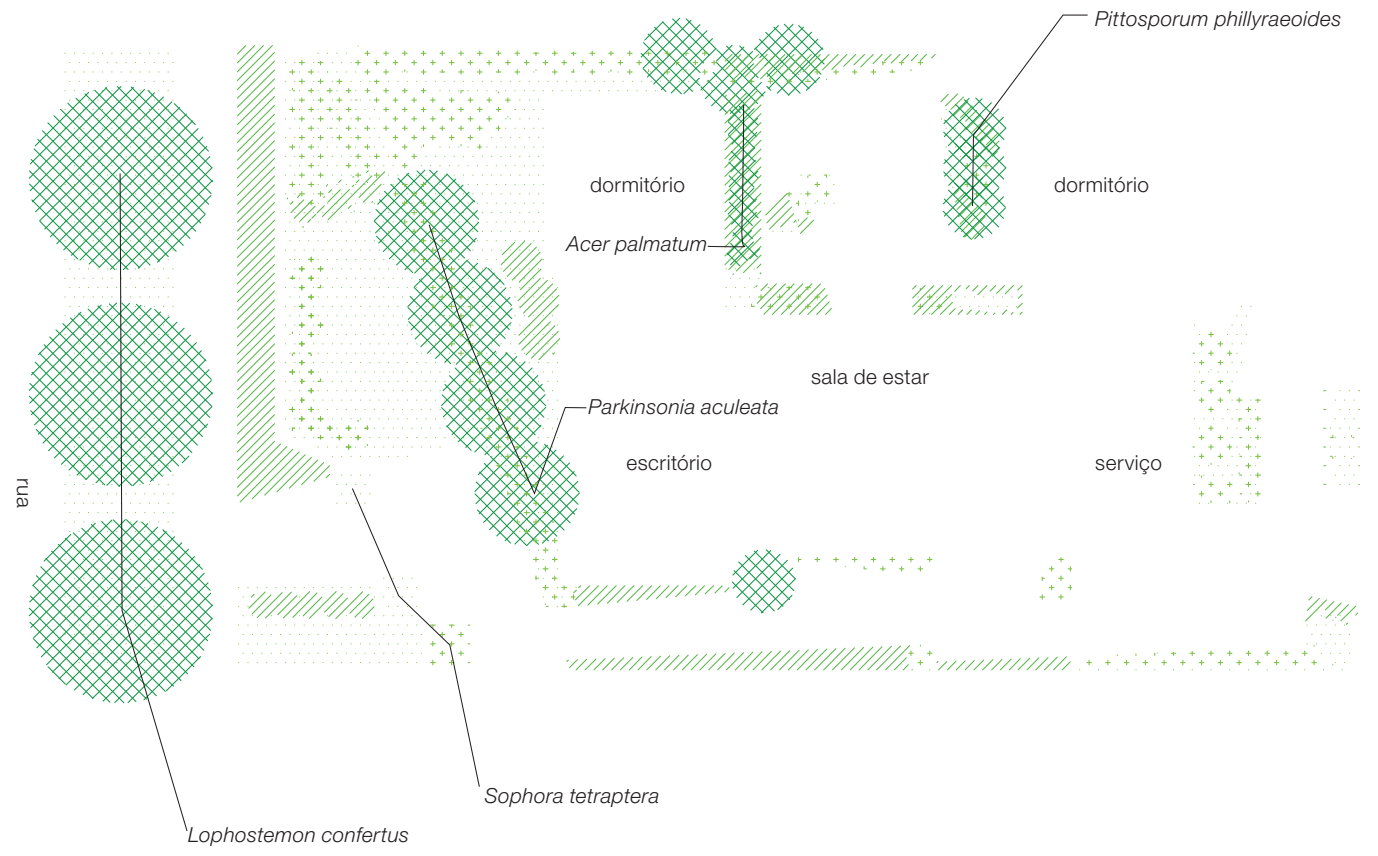





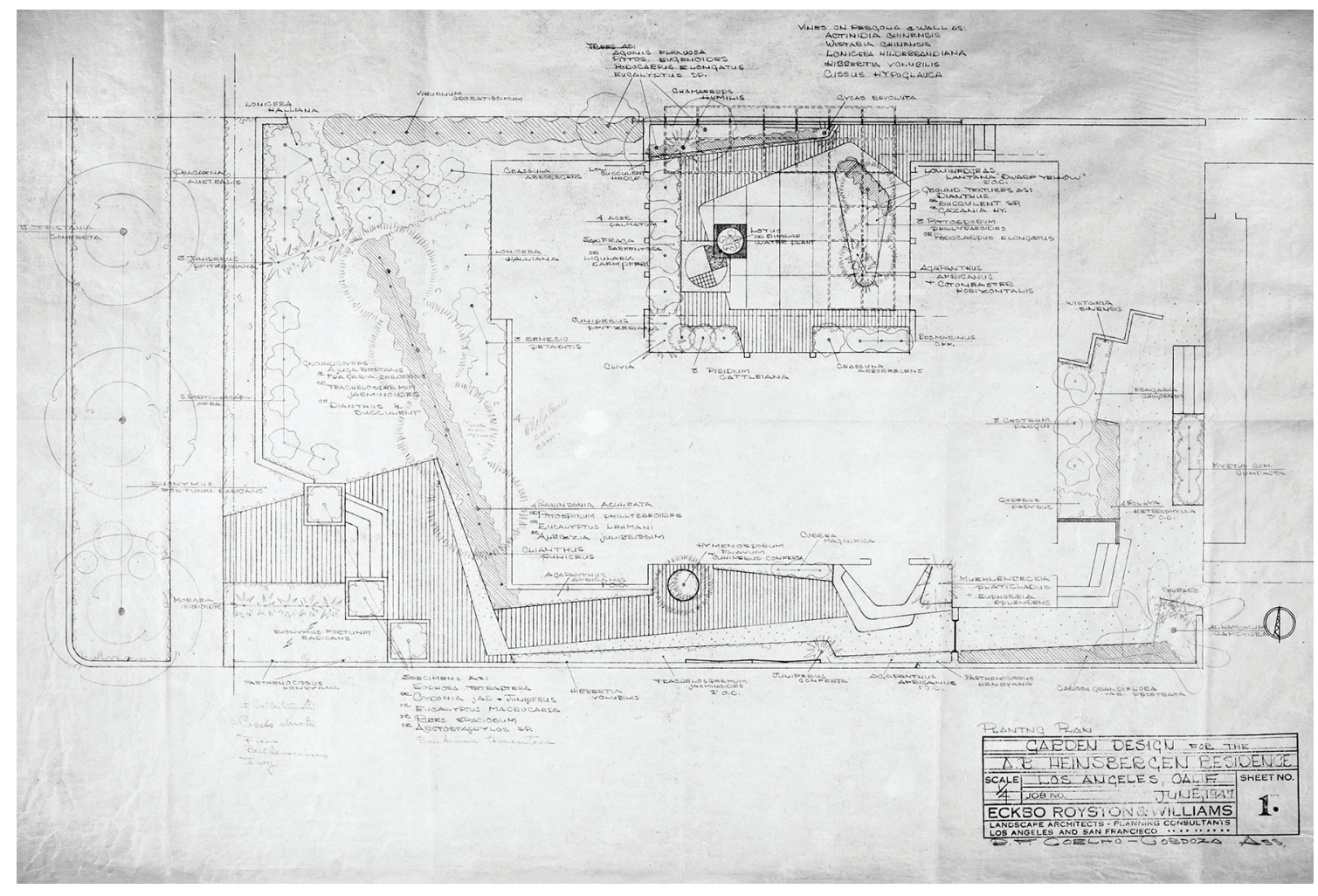

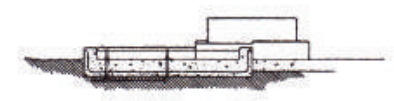

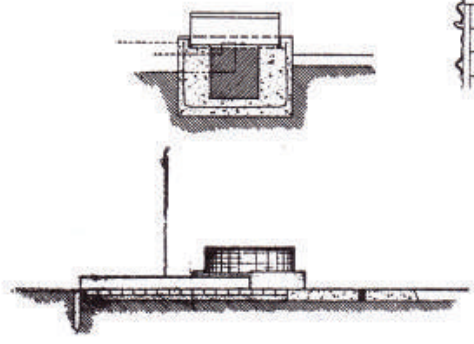

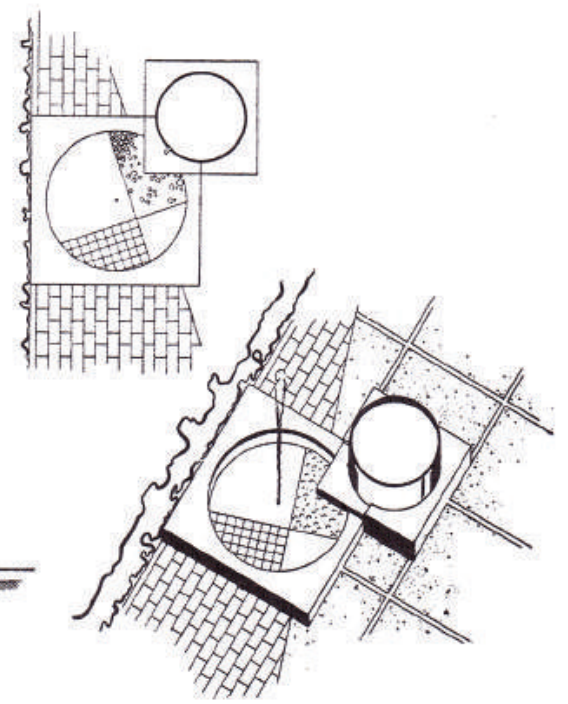

[3.1]

Projeto de paisagismo, Residência Anthony B. Heinsbergen, 1947.

[3.2]

Detalhe da "lucite pool" da Residência Anthony B. Heinsbergen, 1947. 


\subsection{RESIDÊNCIA ILDA E WALDOMIRO ZARZUR (1963)}

A residência de Ilda e Waldomiro Zarzur foi projetada em 1962 por Rubens Carneiro Vianna e Ricardo Sievers 5 e foi construída pela empresa do cliente, a Waldomiro Zarzur Engenharia e Construções ${ }^{6}$. O lote localizado no bairro dos Jardins, em São Paulo, entre as ruas Guaiaquil, Argentina e San Salvador, conta com uma área de aproximadamente $1.935 \mathrm{~m}^{2}$. Uma pequena praça de acesso - ou, como Cardozo denominava, "área semipública" - conecta a residência, implantada bem ao centro do lote, com a Rua Guaiaquil. Ainda hoje, essa área de acesso permanece aberta, sem gradis ou portões, mantendo a continuidade entre a rua e a casa. A praça é sombreada por três grandes sibipirunas (Caesalpinia pluviosa), já existentes à época da construção da casa, e o piso, formando um grande arco, demarca tanto a entrada e saída de veículos, como também a passagem de pedestres na residência. Um canteiro redondo arrematado por um muro é preenchido por dracenas-vermelhas (Cordyline terminalis) e por costelas-de-adão (Monstera deliciosa), marcando a lateral esquerda da entrada principal, e outro canteiro semicircular com murtas-de-cheiro (Murraya paniculata) marca o limite com o lote.

$O$ desenho de piso nas áreas dos fundos e das laterais da residência é bem definido, com forte geometrização, com traçado característico de Cardozo. O piso é estruturado a partir de semicírculos: degraus semicirculares em granito separam a borda da piscina, em pedra mineira, do gramado; tangenciando esses degraus, surge outro semicírculo que

5. Rubens Gouvêa Carneiro Vianna (1914-1987) era engenheiro-arquiteto e formou-se pela Escola Politécnica da Universidade de São Paulo em 1938. Rubens Morton Sievers formou-se arquiteto em Buenos Aires, na Argentina, em 1947, e associou-se à Vianna em 1954. No período do projeto, os dois arquitetos eram sócios na Projetos de Arquitetura e Decorações Avaré, que contava ainda com a participação de José Expedito Povoa (FICHER, 2005).

6. De 1947 a 1960, Waldomiro Zarzur era sócio de Aron Kogan na Construtora Zarzur \& Kogan. Com o falecimento do sócio, Waldomiro Zarzur abriu uma nova empresa chamada Waldomiro Zarzur Engenharia e Construções. Tornou-se um aglomerado empresarial e, atualmente, chama-se Grupo WZarzur. 
faz a borda de um pequeno espelho d'água; na lateral paralela à Rua Argentina, o piso que compõe a varada em frente à sala de estar tem bordas circulares e é composto por mosaico português branco e lajotas retangulares de ardósia; por fim, a área de jogos é determinada por um semicírculo gramado, separando a área de entrada dos fundos da residência. Essa forte geometrização é quebrada com o delineamento irregular dos caminhos, feito em tiras de arenito.
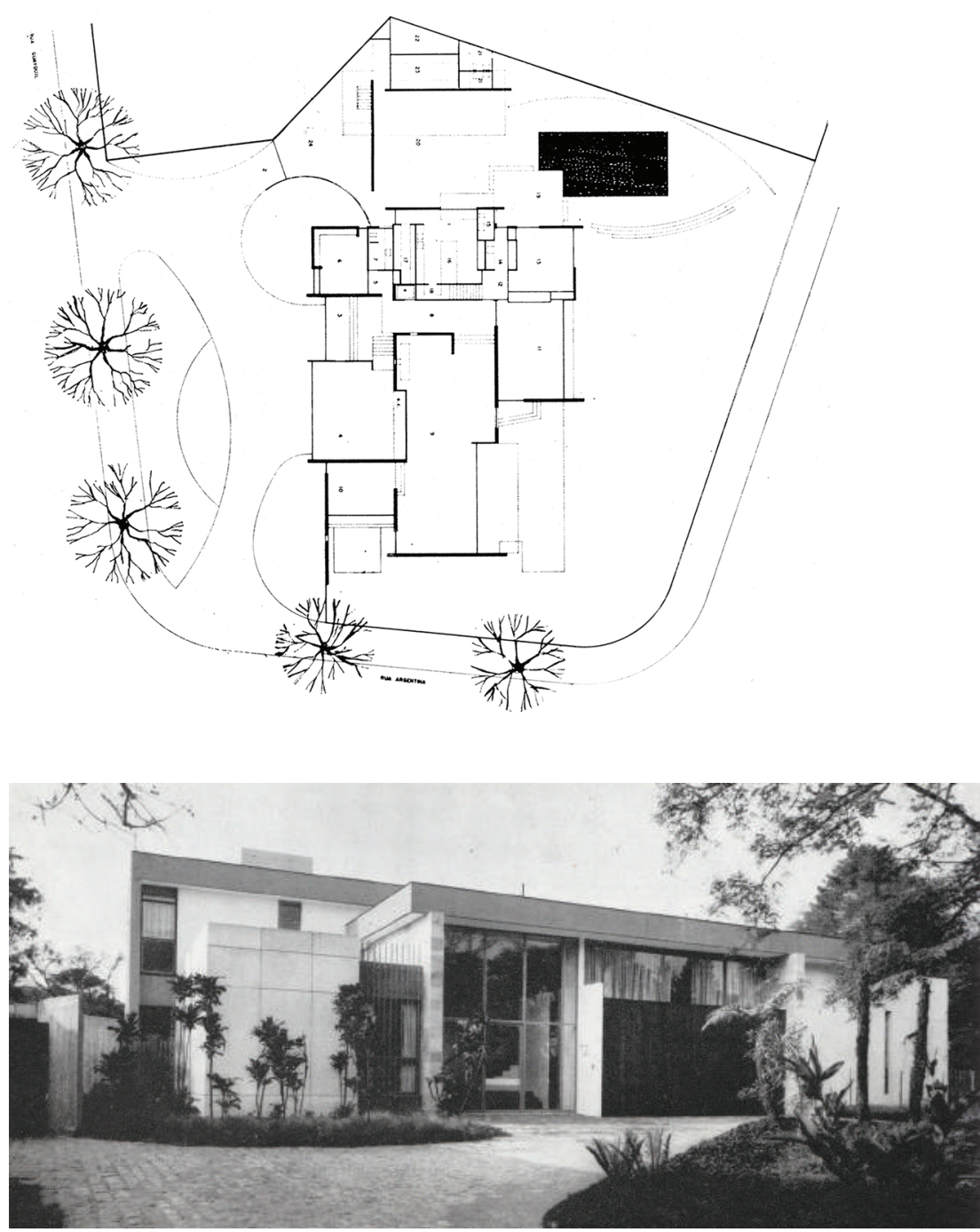

[3.3]

Planta de arquitetura, com algumas incorporações do paisagismo. Residência Ilda e Waldomiro Zarzur, 1963.

[3.4]

Entrada principal da casa, Residência Ilda e Waldomiro Zarzur, 1963. 


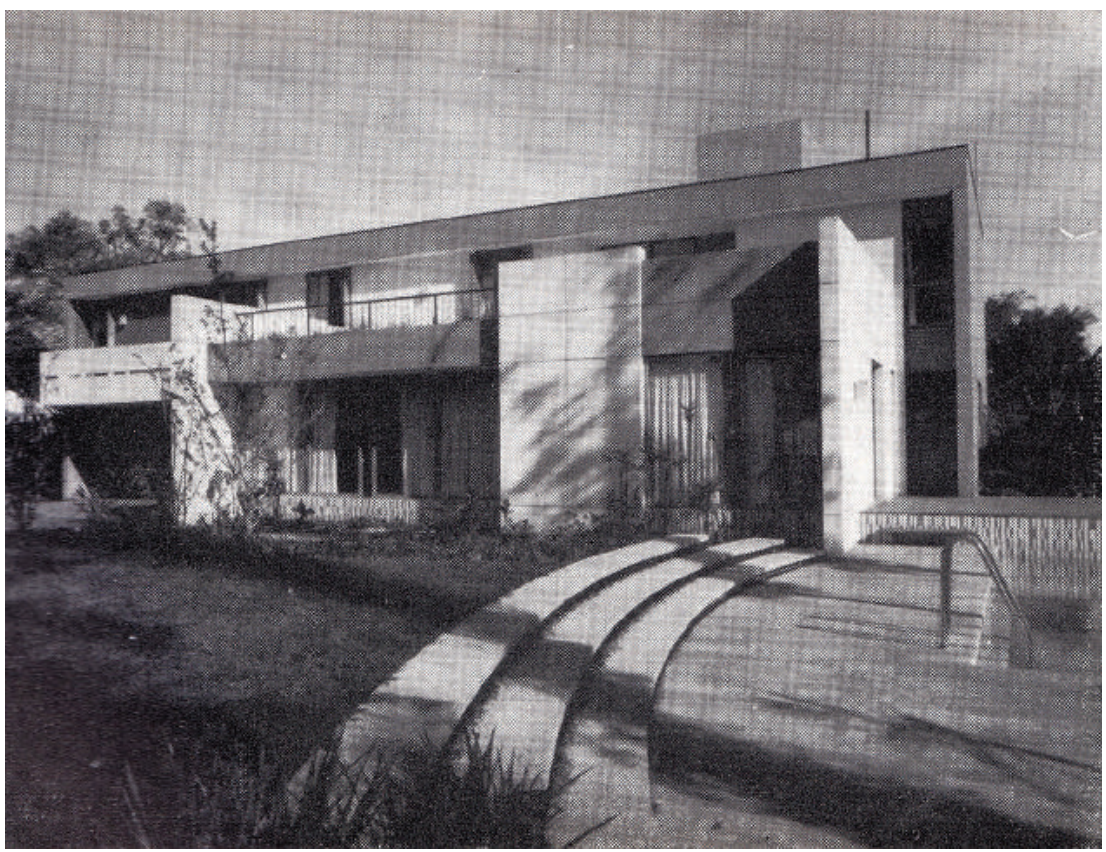

Além disso, a organicidade da vegetação suaviza essa forte geometrização dos pisos. Ao redor de toda a "unidade de vizinhança", são plantadas árvores de médio e grande portes e arbustos fartos que configuram os limites lote. Assim, a massa de sibipirunas da praça de entrada é adensada com um conjunto de 16 ipês amarelos (Handroanthus serratifolius), formando uma grande cobertura verde que dá as boas-vindas aos pedestres e aos veículos que adentram o terreno. É bastante incomum ousar com um plantio tão denso como esse, em que ipês são plantados a cada $1,5 \mathrm{~m}$ a $2 \mathrm{~m}$ de distância, já que estiola o tronco das plantas, fazendo um efeito visual completamente diferenciado de um espécime isolado.

Ao lado dos ipês, uma parede verde se forma com as exuberantes estrelítzias-brancas (Strelitzia augusta) e com um grupo de vistosas azaleias (Rhododendron indicum). Na lateral do lote à Rua San Salvador, temos massas de chefleras (Schefflera actinophylla), de magnólias-anãs (Magnolia figo) e de dracenas (Dracaena fragrans), que ressaltam o limite entre o terreno e a rua?. 


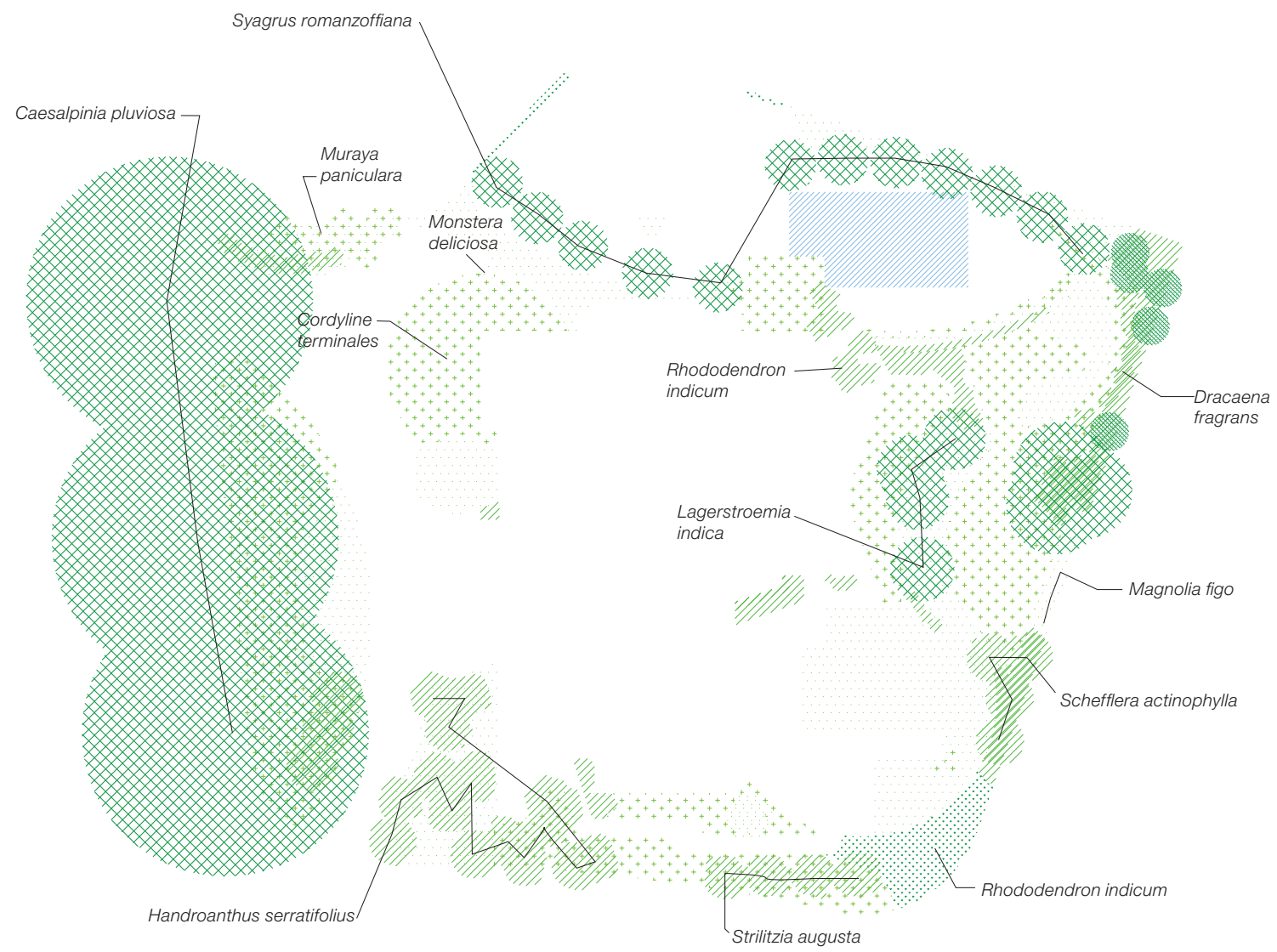





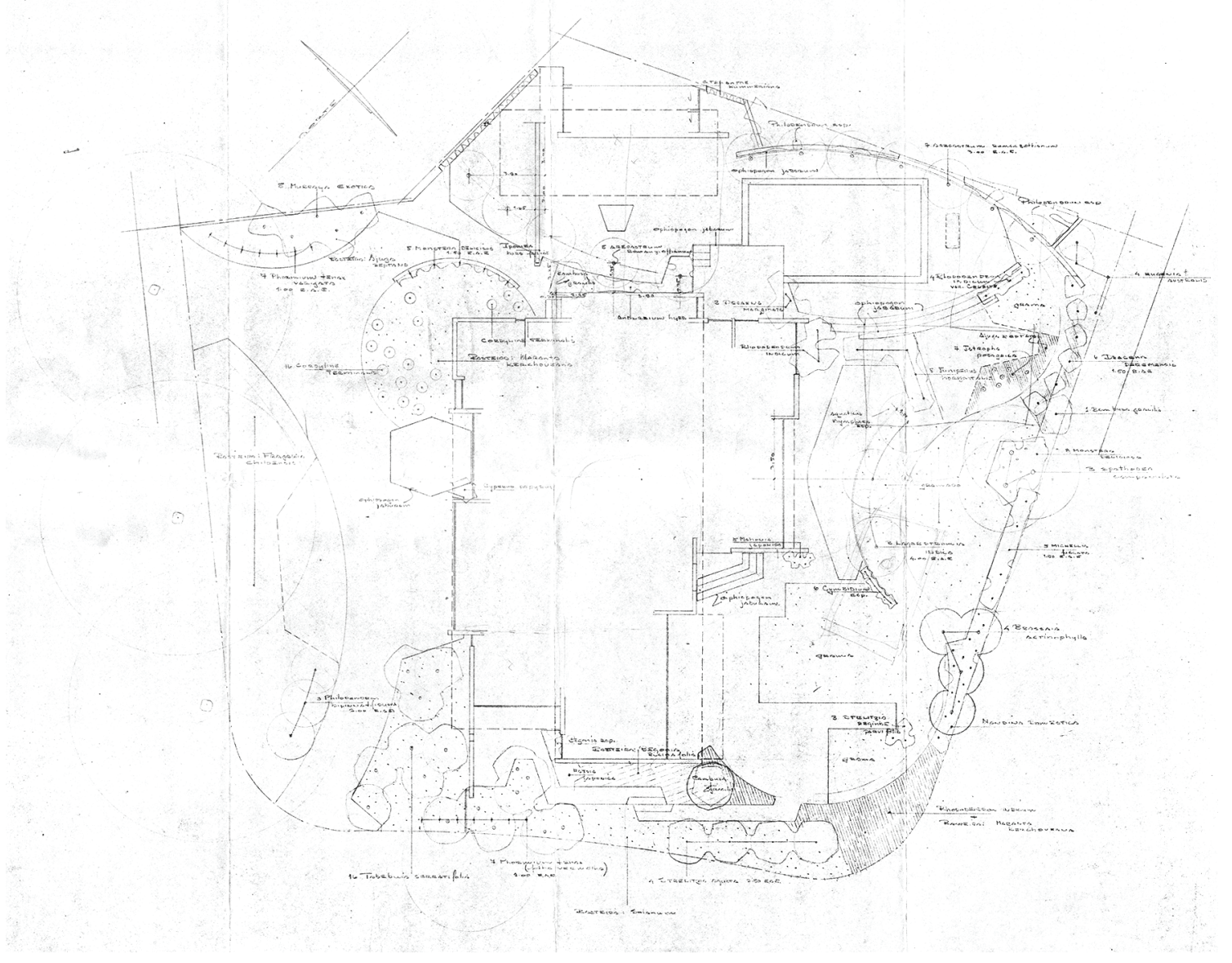

[3.6]

Planta de paisagismo da Residência llda e Waldomiro Zarzur, 1963. 
[3.7]

Espelho d'água com bordas em tiras de arenito.

Residência Ilda e Waldomiro Zarzur, 1963.

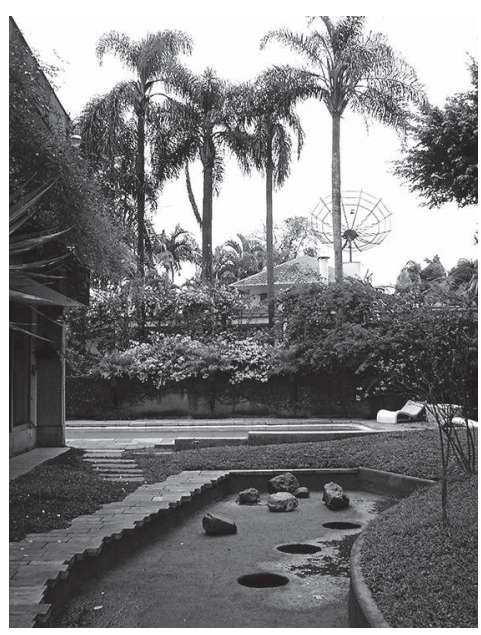

[3.8]

Vista do gramado a partir da piscina. Residência Ilda e Waldomiro Zarzur,

1963.

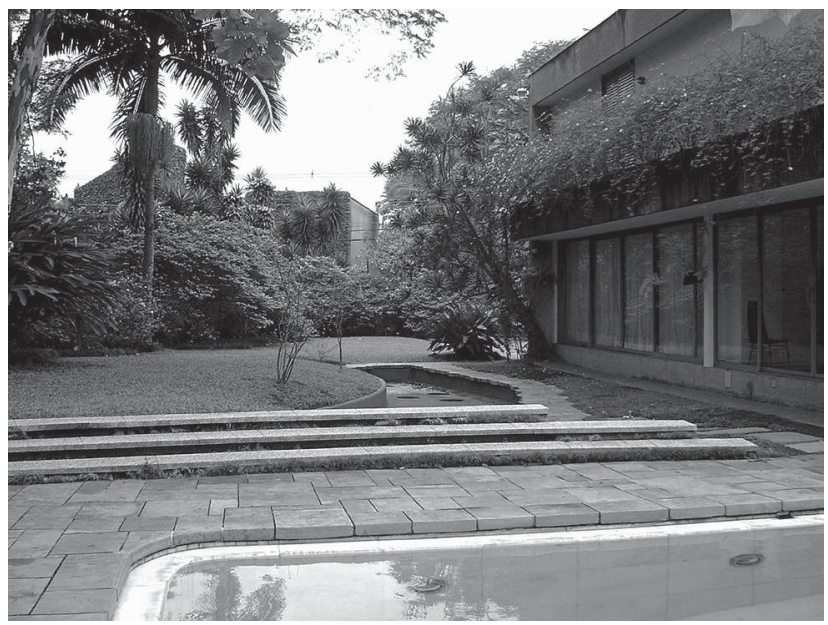

[3.9]

Vista dos degraus de granito com massa vegetal ao fundo do lote. Residência llda e Waldomiro Zarzur, 1963.

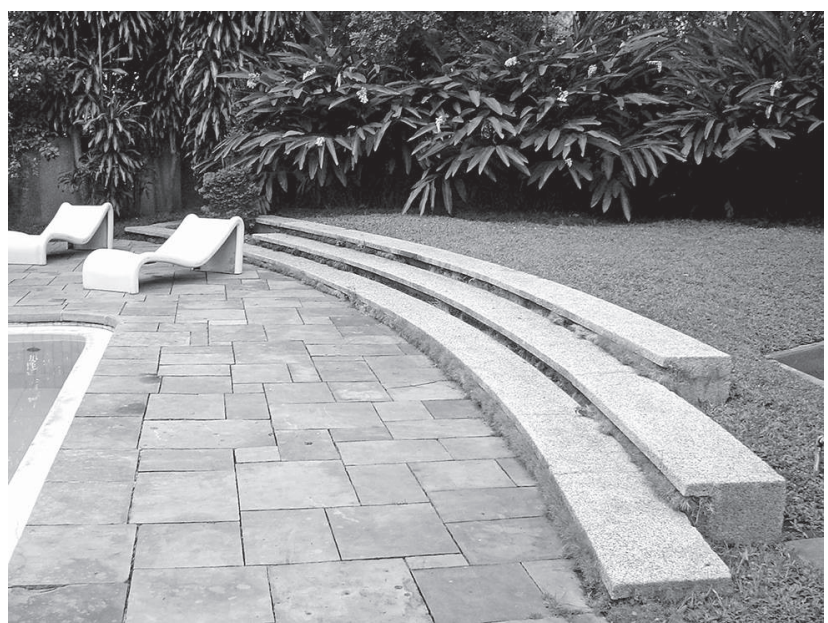


A partir desses maciços arbóreos, uma massa de vegetação arbustiva se expande para dentro do lote da casa. Os resedás (Lagerstroemia indica) fazem a bordadura do gramado, que também é ocupado por azaleias e fórmios variegados e roxos (Phormium tenax). A cerejeira arbustiva (Syzygium australe) também se espalha para dentro do terreno, alcançando a área da piscina. Ainda, esta área é pontuada por uma linha de jerivás ${ }^{8}$ (Syagrus romanzoffiana), que, locados na face norte do terreno, criam uma textura a partir da sombra de suas folhas, que se movimenta ao longo do dia. Essa sobreposição das sombras da vegetação ou de elementos horizontais elevados quando recaem sobre o piso pode intensificar ou suavizar a textura geométrica de pisos e canteiros. Esse efeito, atingido a partir de elementos mais sutis, é muito comum nos projetos de Roberto Coelho Cardozo e uma de suas características mais específicas.

Comparando a vegetação empregada por Cardozo nesse projeto e na residência de Los Angeles, podemos ver como a escolha das espécies se adaptou a partir das condições climáticas brasileiras. Na residência de Ilda Zarzur, vemos os canteiros serem forrados pelas marantas e pelos filodendros, plantas endêmicas da Mata Atlântica, e também por espécies exóticas já adaptadas ao nosso clima, como as costelas-de-adão e as estrilítzias.

droanthus serratifolius - sin. Tabebuia serratifolia; Schefflera actinophylla sin. Brassaia actinophylla; Magnolia figo - sin. Michelia fuscata; Dracaena fragrans - sin. Dracaena deremensis.

8. No projeto original, temos a sinonímia para a seguinte espécie: Syagrus romanzoffiana - sin. Arecastrum romanzoffianum. 


\subsection{ESCOLA ESTADUAL PERUS (1968)}

A Escola Estadual Perus foi construída no âmbito de produção arquitetônica do Fundo Estadual de Construções Escolares ${ }^{9}$ (FECE), primeiro órgão público do Governo do Estado de São Paulo a ter como única atribuição planejar, projetar, construir, ampliar e manter a rede pública estadual de ensino (MELLO, 2012). Hoje, renomeada como Escola Estadual Brigadeiro Gavião Peixoto, é considerada a maior escola da rede estadual paulista, abrigando cerca de 3.400 alunos, que se espalham nos amplos $14.000 \mathrm{~m}^{2}$ de área escolar. A escola oferece os ensinos fundamental, médio e supletivo.

Projetada pelos arquitetos Danilo Bassani e Adilson Costa Macedo, seguiu as especificações de projeto indicadas pelo FECE. A partir do levantamento feito por Mello (2012), e confrontando com o projeto de arquitetura, constatamos que ele tem as seguintes características:

- estrutura de concreto aparente;

- fechamentos com alvenaria convencional;

- lajes de concreto;

- coberturas em telhas de cimento-amianto;

- recreios cobertos com vãos maiores cobertos com telha-vã;

- caixilhos basculantes usados tanto para as salas de aula, como também para as ventilações cruzadas e para os demais ambientes, e escadas com espelhos inclinados;

- pisos de salas de aula em tábua corrida de assoalho de madeira ou taco;

- áreas molhadas em cerâmica vermelha;

- recreios cobertos e circulações com piso cimentado com óxido de ferro;

- paredes internas revestidas com massa fina e pintura látex, e áreas molhadas com paredes revestidas de azulejos brancos;

- caixilhos com pintura anticorrosiva zarcão e tinta a óleo;

- fechamentos dos lotes com muros;

- portões em tela de malha metálica ou tela "Pagé".

9. Segundo Mello (2012), o FECE construiu cerca de 900 escolas e contratou aproximadamente 230 arquitetos durante os dez anos de atividade da instituiçãoo (1966-1976). 

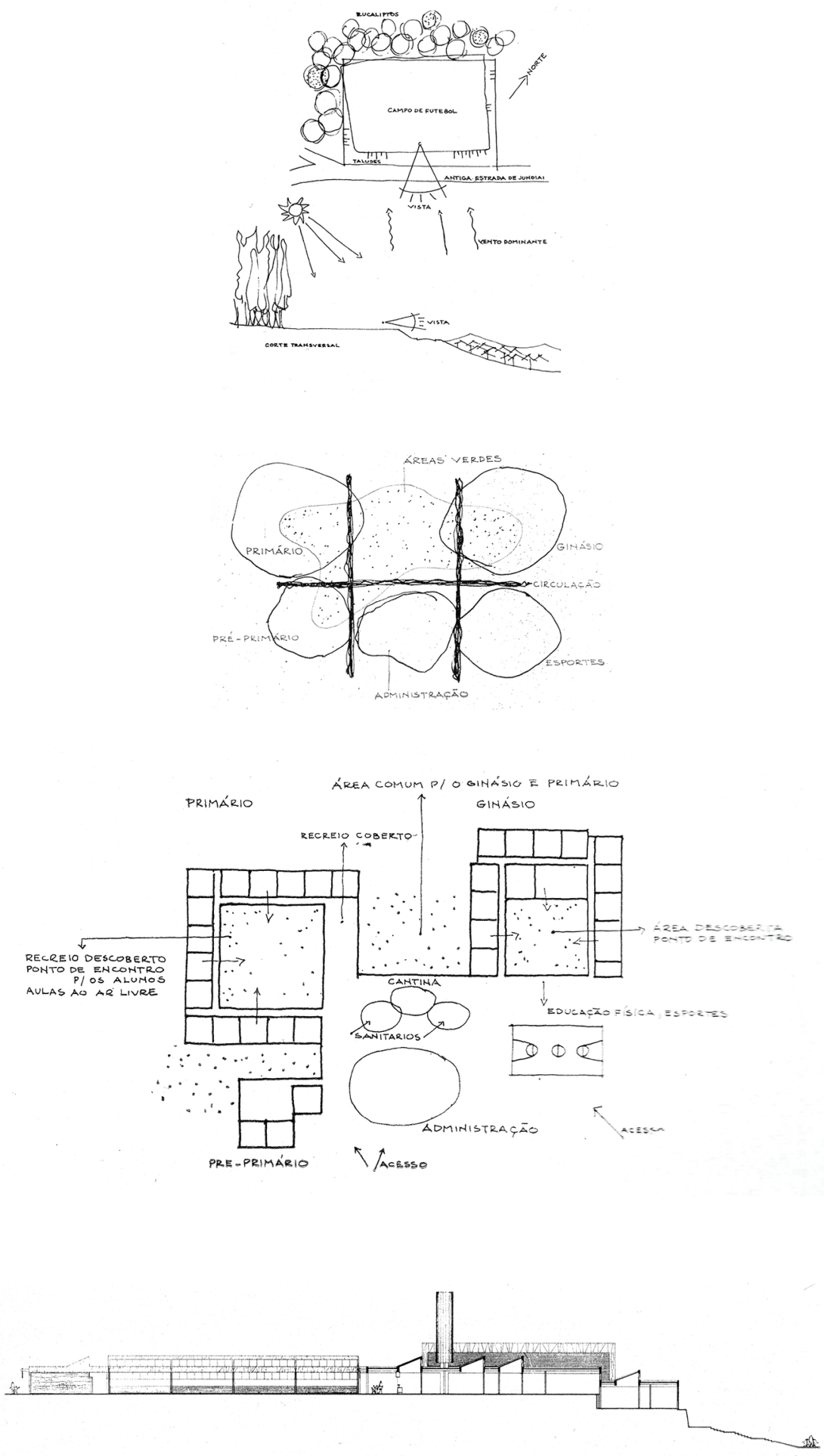

[3.10]

O terreno para o projeto da Escola Estadual

Perus, 1968.

\section{[3.11]}

Estudo de zoneamento dos conjuntos para o projeto da Escola Estadual Perus, 1968.

\section{[3.12]}

Estudo para salas de aula e áreas verdes para o projeto da Escola Estadual Perus, 1968.

\section{[3.13]}

Corte transversal do projeto para a Escola Estadual Perus, 1968. 
Essas indicações de materiais eram seguidas, mas não havia um catálogo de componentes construtivos a ser utilizado. As experimentações do FECE serviram de base para a estruturação desses padrões nas instituições que a substituíram, primeiramente a Construções Escolares do Estado de São Paulo (CONESP) e, depois, a Fundação de Desenvolvimento de Escolas (FDE).

Pensando no programa estabelecido, para abrigar os ensinos pré-primário, primário e ginasial (primeiro ciclo), e trabalhando com os padrões do FECE, os arquitetos conseguiram dar uma forma diferenciada ao espaço, estruturando as áreas de ensino em três edifícios de pré-primário, primário e ginásio (primeiro ciclo), e as áreas administrativas e de lazer em construções distintas, mas sem romper a integração do conjunto geral. Usando um terreno que inicialmente abrigava um campo de futebol, os arquitetos aproveitaram o platô desse campo e trabalharam com os taludes formados ao redor. Nesse sentido, eles projetaram a escola em três diferentes níveis: a cota da rua, que varia entre +94.00 e +96.00; a cota da administração, do pré-primário e das áreas de serviços (casa do caseiro), locada em +98.10; e, por fim, a cota do platô, que abriga o primário, o ginásio, os sanitários, a cantina e a quadra esportiva, locados em +100.15 .

Uma característica bem marcante no projeto são os pátios reservados que se formam com a construção em " $U$ " das áreas do primário e do ginásio. Mais além, eles também reservam algumas áreas livres entre os edifícios do pré-primário/primário e do ginásio/primário.

Desse modo, Cardozo pensa o paisagismo a partir do projeto de arquitetura dado: projeto em três níveis, edifícios com pátios reservados para idades diferentes e integração do conjunto geral. Parece-nos que seu projeto consegue integrar melhor a área do conjunto, uma vez que cria novas conexões entre os espaços e, mesmo com desenhos bem geometrizados, quebra a dura regularidade do desenho arquitetônico, suavizando a rígida simetria existente no projeto de edificação. Os caminhos retos se diluem no espaço, os pátios quadrados se transformam a partir de novas formas e a entrada ganha outra configuração com um desenho mais integrado. 

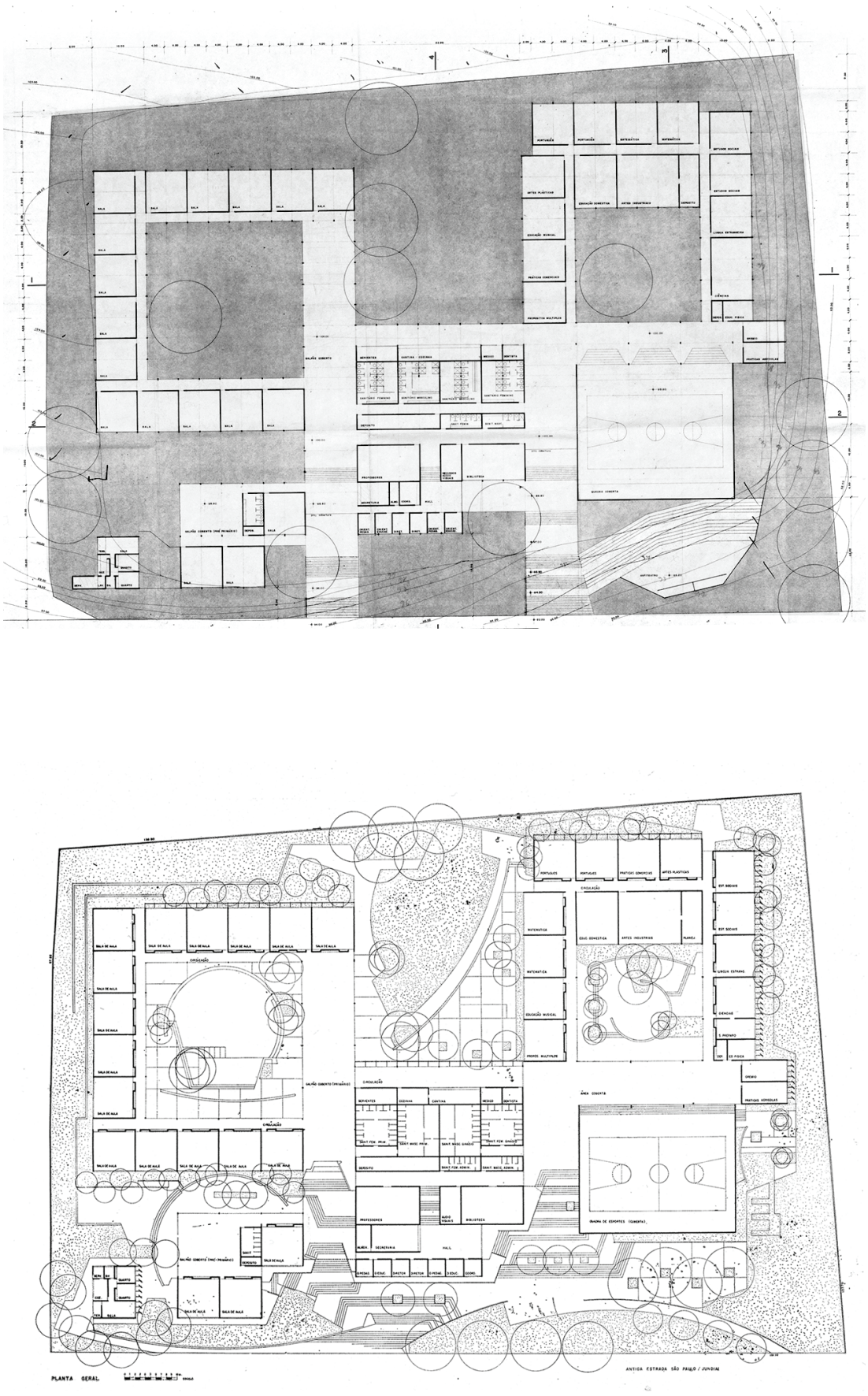

[3.14]

Planta de arquitetura.

Projeto de Danilo Bassani e Adilson C. Macedo para a Escola Estadual Perus, 1968.

\section{[3.15]}

Planta de paisagismo, projeto de Roberto Coelho Cardozo para a Escola Estadual Perus, 1968. 
Começamos a análise pelas escadas de acesso, que antes eram simétricas e se encaixavam entre os blocos do pré-primário/administração e da administração/quadra esportiva. Cardozo quebra essa simetria ao criar um piso único de acesso, estruturado por muros de arrimo curvos, que se espalha pelo terreno por meio de degraus e patamares bem angulados, inserindo pequenas jardineiras entre os desníveis, vegetando a composição de concreto. Ele trabalha com diversas texturas de materiais, sendo que as escadas são revestidas em mosaico português de arenito São Carlos (bege), os muros de arrimos são feitos em concreto aparente e algumas muretas são assentadas em tijolos à vista.

O canteiro da fachada, formado pelos muros de arrimo curvos, é preenchido por palmeiras e árvores de grande porte, como os jerivás (Syagrus romanzoffiana), que marcam a entrada da escola com suas estirpes retificadas, plantados ainda na calçada, e os ipês-amarelos, os eucaliptos, os manacás-da-serra e as quaresmeiras (Handroanthus serratifolius, Tibouchina mutabilis, Corymbia citriodora e Tibouchina granulosa), plantados no talude que sobe até a cota +98.10 . Ao pé dessas árvores, o paisagista especifica espécies mais baixas e rústicas, de baixa manutenção, como os capins (Cortaderia selloana e Eragrostis curvula) e as azaleias (Rhododendron indicum) ${ }^{10}$.

Para ampliar a área para as crianças menores, é criada uma extensão que circunscreve todo o pátio coberto do pré-primário, agora locado um degrau acima na cota +98.30 , a partir de um banco em semicírculo sombreado por dois pés de caqui-japonês (Diospyros kaki) árvore muito ornamental que, em certa época do ano, apresenta folhas de cor alaranjada e que, por ter uma galhada baixa, possibilita às crianças subirem em seus troncos para colher os saborosos frutos -, que ampliam as experiências sensoriais e lúdicas do espaço. Este se conecta a um nível mais alto, um pequeno tanque gramado ${ }^{11}$ na cota +98.66 , protegido por muretas e pelos ornamentais ipês e quaresmeiras. As áreas de serviços

10. No projeto original, temos as sinonímias para as espécies: Handroanthus serratifolius - sin. Tabebuia serratifolia; Corymbia citriodora - sin. Eucalyptus citriodora; Syagrus romanzoffiana - sin. Arecastrum romanzoffianum. 


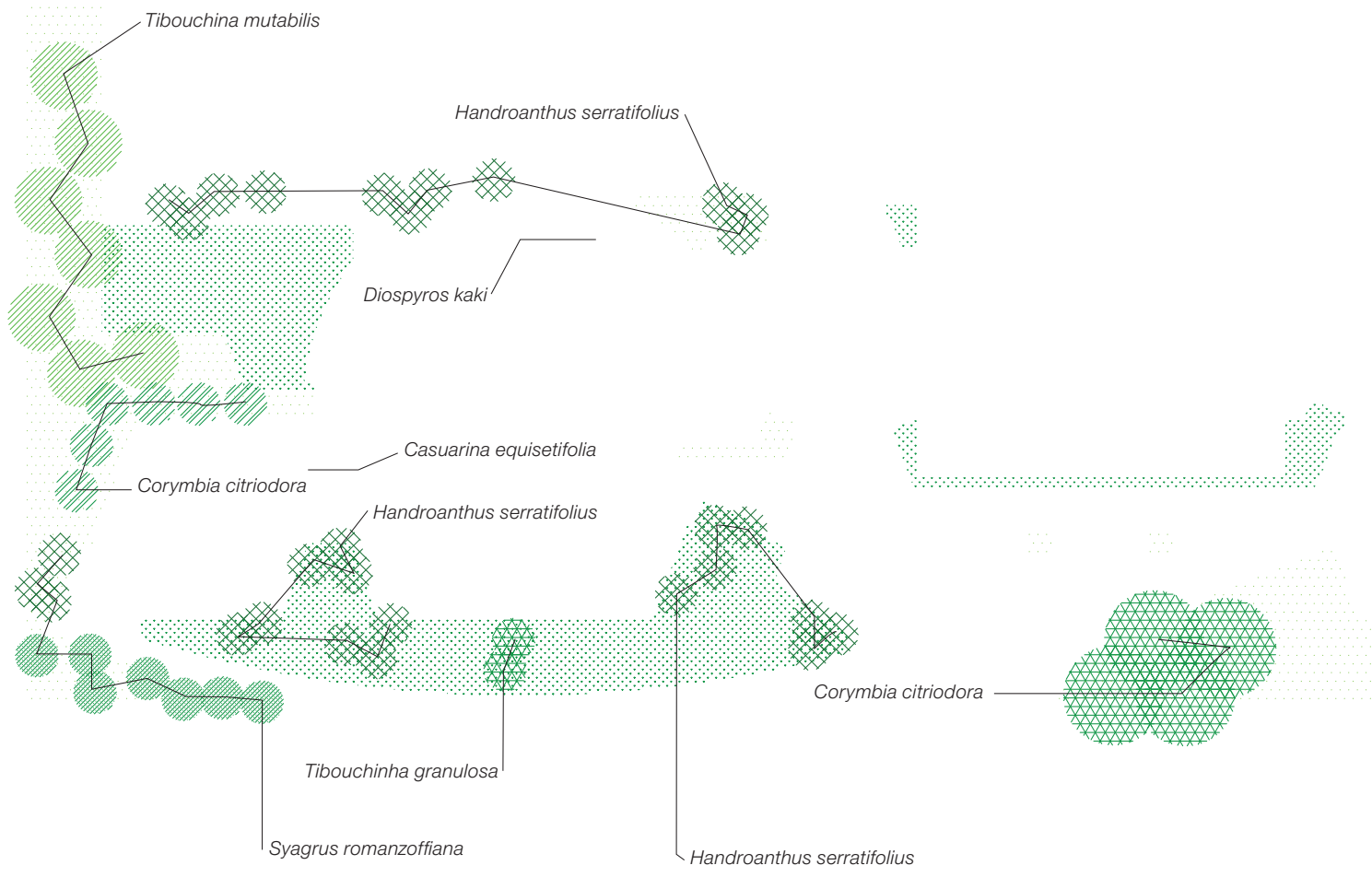



e zeladoria são separadas da região pré-primária por eucaliptos-prateados (Eucalyptus cinerea) e duas grandes casuarinas (Casuarina equisetifolia), criando assim uma barreia visual para dar mais privacidade aos funcionários. Esse patamar do pré-primário se conecta ao nível mais alto, +100.15 , por degraus angulados e patamares angulados que seguem a mesma linha do desenho da escada de entrada. Em geral, os degraus e os patamares das escadas são revestidos em mosaico português bege, e os pisos planos, das áreas cobertas, são revestidos por lajotas cerâmicas.

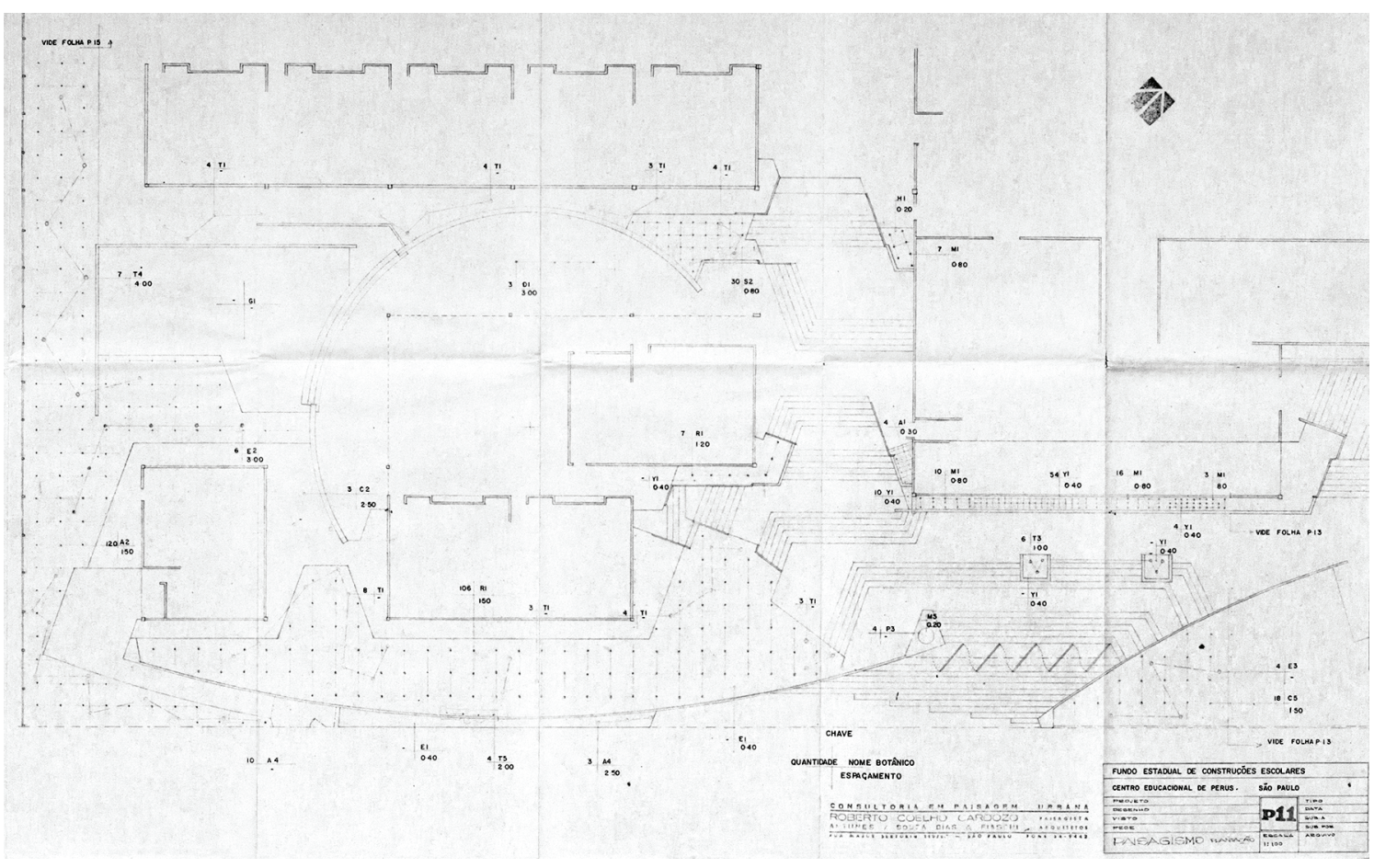

[3.16]

Projeto de paisagismo da zeladoria e do edifício do pré-primário. Escola Estadual Perus, 1968. 
Chegando ao edifício do ensino primário, também na cota +100.15 , vemos um pátio aberto se configurar com muretas em círculos que delineiam um estar rebaixado à cota +99.88 . Dessa maneira, a área de "brincadeiras" fica abaixo da vista das salas de aula, a fim de não desconcentrar aqueles que estão nos ambientes internos. O pátio é sombreado em todo o seu perímetro por grandes árvores de copas generosas: as copas difusas dos paus-ferro (Caesalpinia ferrea) e dos resedás (Lagerstroemia indica) se misturam às sombras largas das espatódeas (Spathodea campanulata), formando uma grande cobertura verde que abriga os estudantes do sol. Um canteiro redondo com banco circular arremata o piso rebaixado, sendo forrado por curcúligos (Curculigo latifolia) e coberto pelas embaúbas (Cecropia palmata).

Outra solução interessante são as mesas de concreto, que, incrustadas na mureta curva que separa os níveis +100.15 e +99.88 , servem de apoio para jogos e trabalhos das crianças. Como não possuem bancos em seus entornos, as mesas baixas, de $55 \mathrm{~cm}$ de altura, possibilitam a livre circulação à sua volta.

O desenho de piso desse espaço aberto é bem variado: degraus em mosaico português bege se misturam com pequenas intervenções em paralelepípedo. A parte rebaixada é revestida com lajota cerâmica, e, aos pés do canteiro redondo, revezam-se planos de mosaicos portugueses bege e branco. A área das mesinhas é revestida em mosaico português bege.

O pátio do primário se conecta diretamente à área comum existente entre os dois prédios em formato de "U". Parece que a intenção de Cardozo era dividir esse descampado separando-o em duas áreas: uma pracinha defronte à cantina e um estar rebaixado, separados por uma mureta curva. A pracinha serve para usufruto dos alunos em seus intervalos de aula, mas também cria, com o plantio de árvores, uma barreira visual para as salas de aula do prédio ginasial, que fica mais protegido do barulho proveniente dessa área de circulação e de serviços (cantina, cozinha, salas de médico e dentista). Para delinear a área da praça, o paisagista explora a textura dos materiais por meio do detalhamento do piso: faixas de mosaico português bege são mis- 


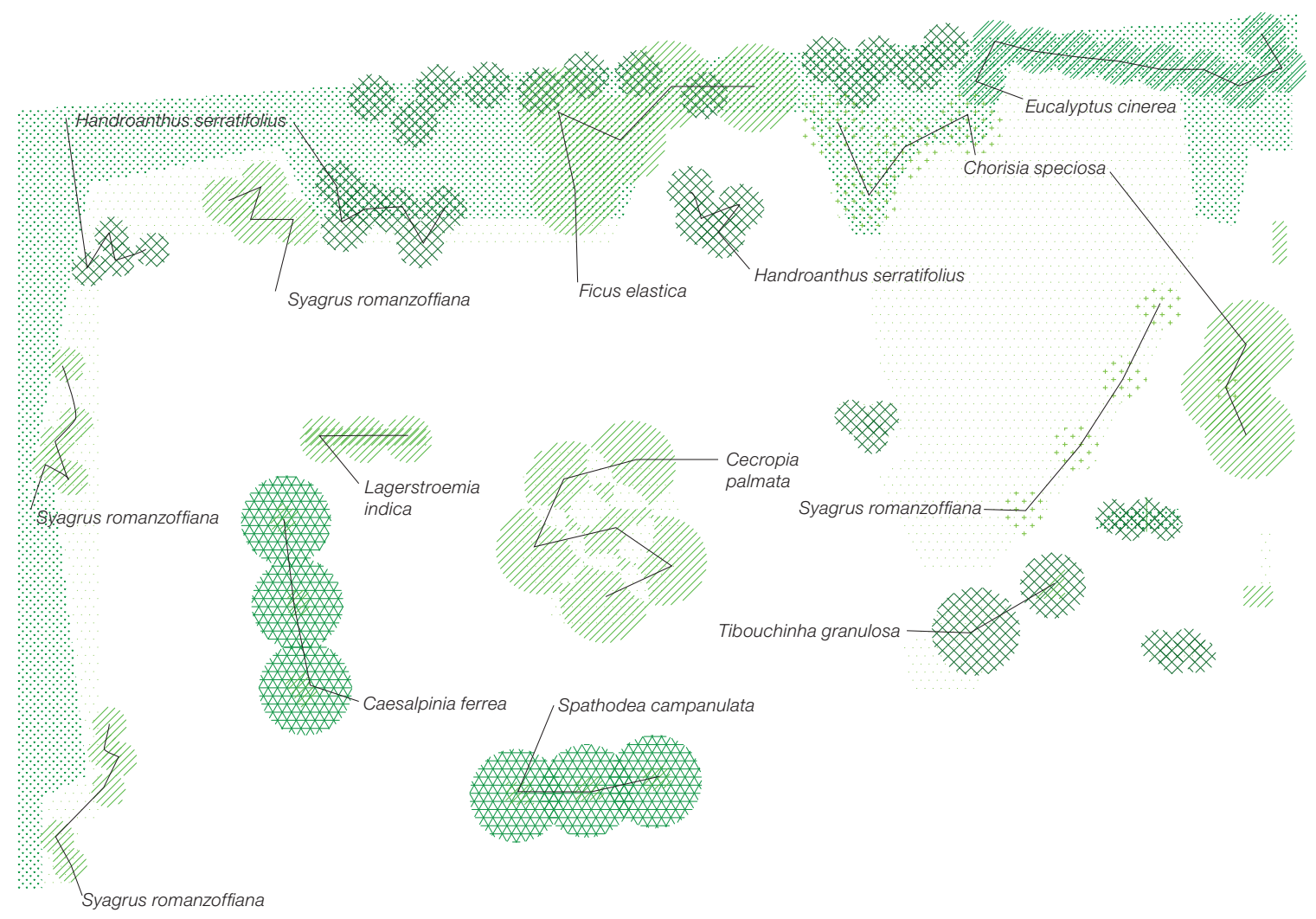



turadas a placas cimentícias e a paralelepípedos, fazendo um desenho retangular que se mistura aos canteiros quadrados das árvores - esse piso se diferencia das lajotas cerâmicas da circulação.

O estar rebaixado tem a mesma solução do pátio do primário, onde a cota +100.15 é rebaixada para +99.80 . Porém, é pensado como uma área verde livre, gramada e arborizada com espécimes de grande porte, formando um bosque.

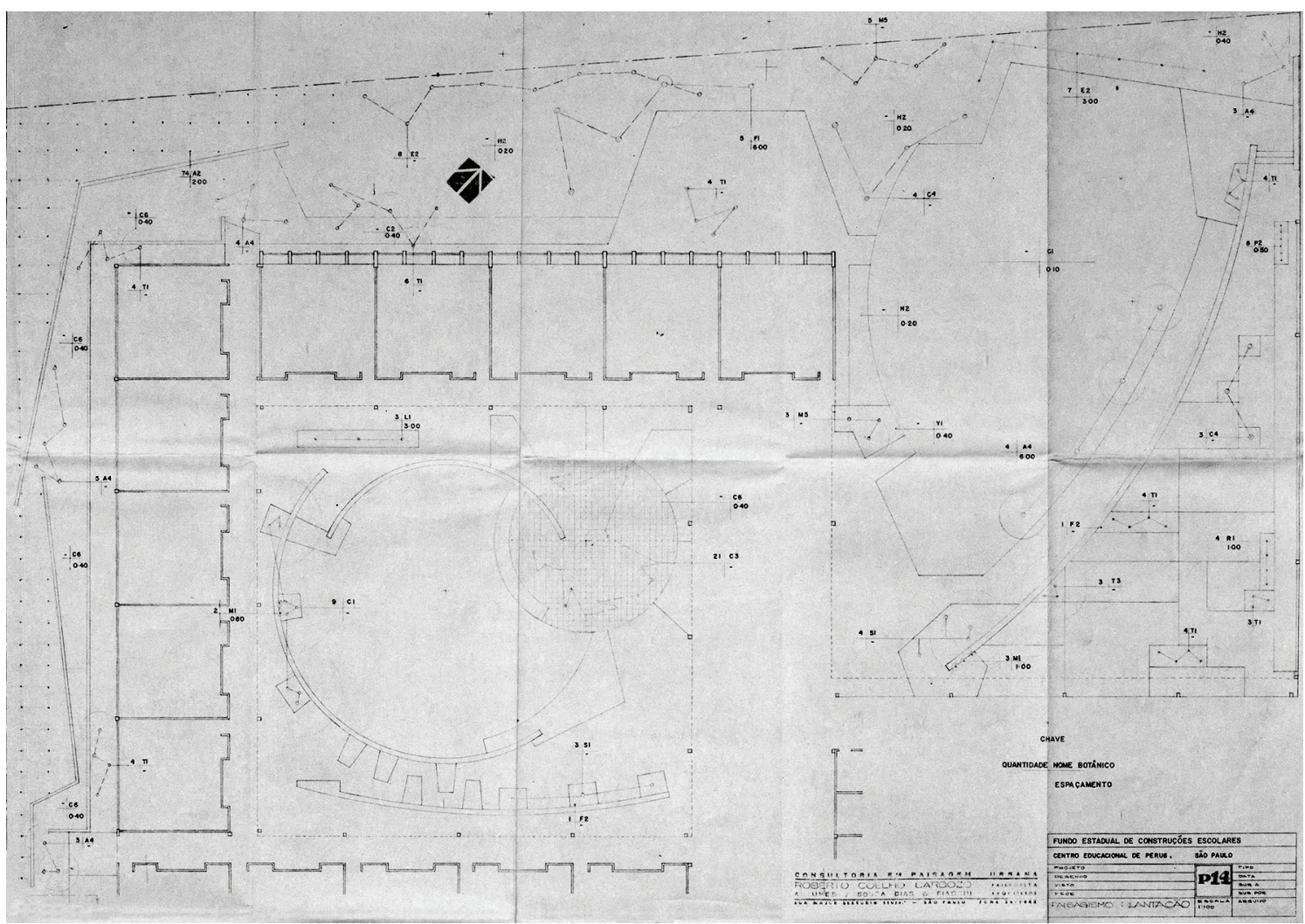

[3.17]

Projeto de paisagismo do edifício do primário e da área comum entre primário e ginásio. Escola Estadual Perus, 1968. 
No pátio do edifício do ginásio, a área de intervenção é um pouco mais delimitada, já que, além das salas de aula convencionais, o espaço é ocupado por um bloco de salas maiores destinadas a educação doméstica, artes industriais e sala de planejamento. $O$ fundo dessas salas é voltado para o pátio, formando uma linha de caixilhos que é protegida por um canteiro de planta-do-papel-arroz (Tetrapanax papyrifera), uma planta exuberante, de folhas palmatilobadas. Assim como nos outros pátios, é empregada a solução de rebaixamento do piso para a cota +99.90. O estar é envolto por uma mureta curva, e canteiros são espalhados nesse espaço redondo, com árvores de médio porte, quaresmeiras e manacás-da-serra. Diferentemente dos outros espaços, que são desenhados como áreas abertas para brincar, esse estar é mais introspectivo, com um grande banco em "L". O piso é intercalado entre lajotas cerâmicas e mosaicos portugueses branco e bege.

À frente do pátio do ginásio, temos a quadra esportiva coberta, que manteve a implantação sugerida pela arquitetura, porém se encontra no mesmo nível do piso de circulação (+100.15). Por fim, ao lado da quadra esportiva, temos um canteiro experimental usado para o plantio de espécies aromáticas e medicinais. Não foram encontrados registros de uso desses canteiros nas aulas ministradas na escola.

Esse projeto é bastante complexo, com um programa amplo, e percebemos que Roberto Coelho Cardozo tentou estabelecer as ligações fluidas e contínuas nos pisos de circulação ao mesmo tempo em que restringiu o livre acesso em áreas específicas, como nos pátios abertos, já que são espaços direcionados para determinado público. Além do desenho, que remete claramente à obra de Cardozo pelos arcos e pisos angulados, vemos que sua preocupação em relação à escolha da vegetação persiste, tendo estudado com cuidado quais espécies empregar nesse projeto. Visto que a escolha dos espécimes depende muito do uso dos espaços, Cardozo selecionou aqueles bem comuns, fáceis de serem encontrados no mercado e de baixíssima manutenção, já que os espaços públicos normalmente têm orçamento restrito destinado ao cuidado da vegetação. 

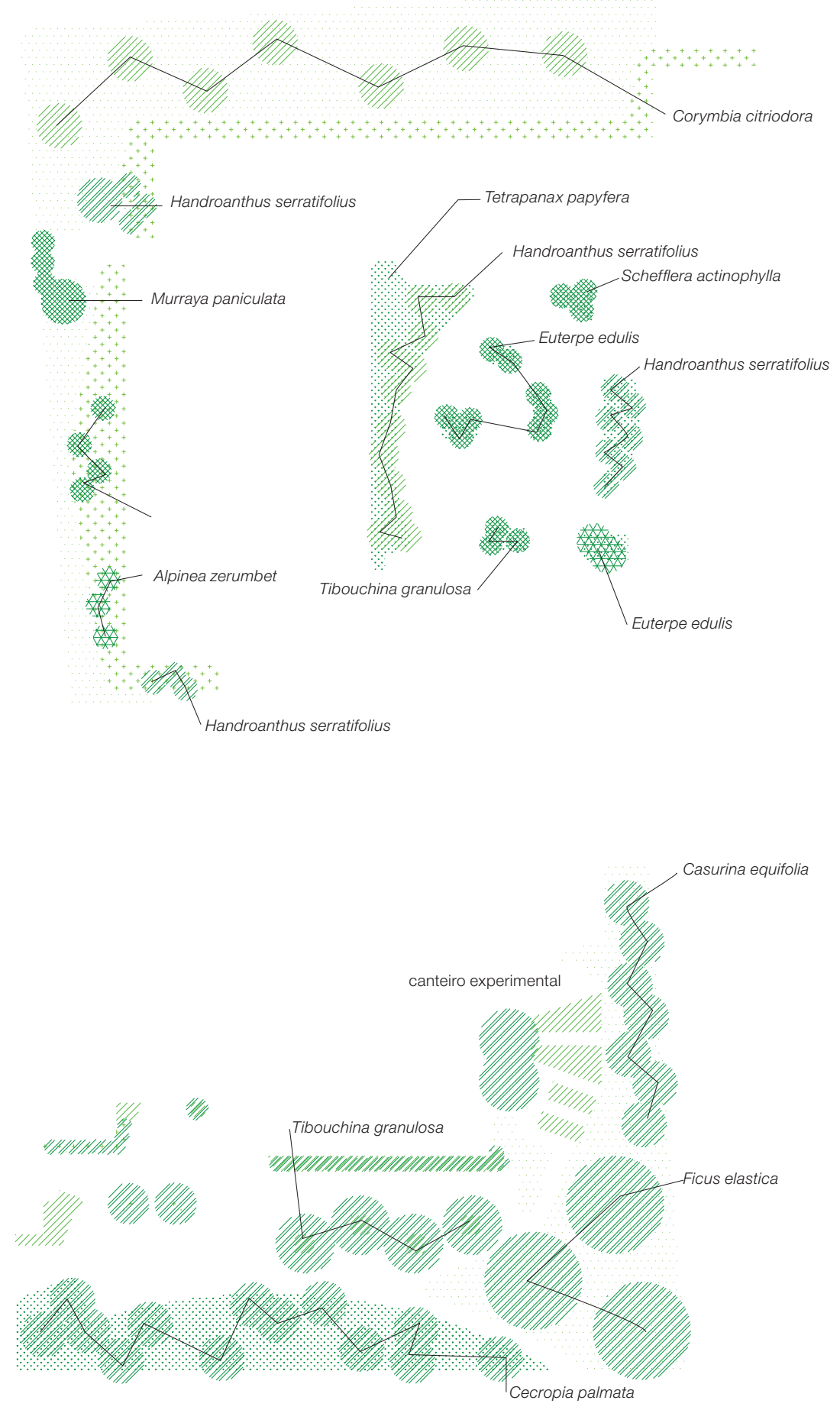


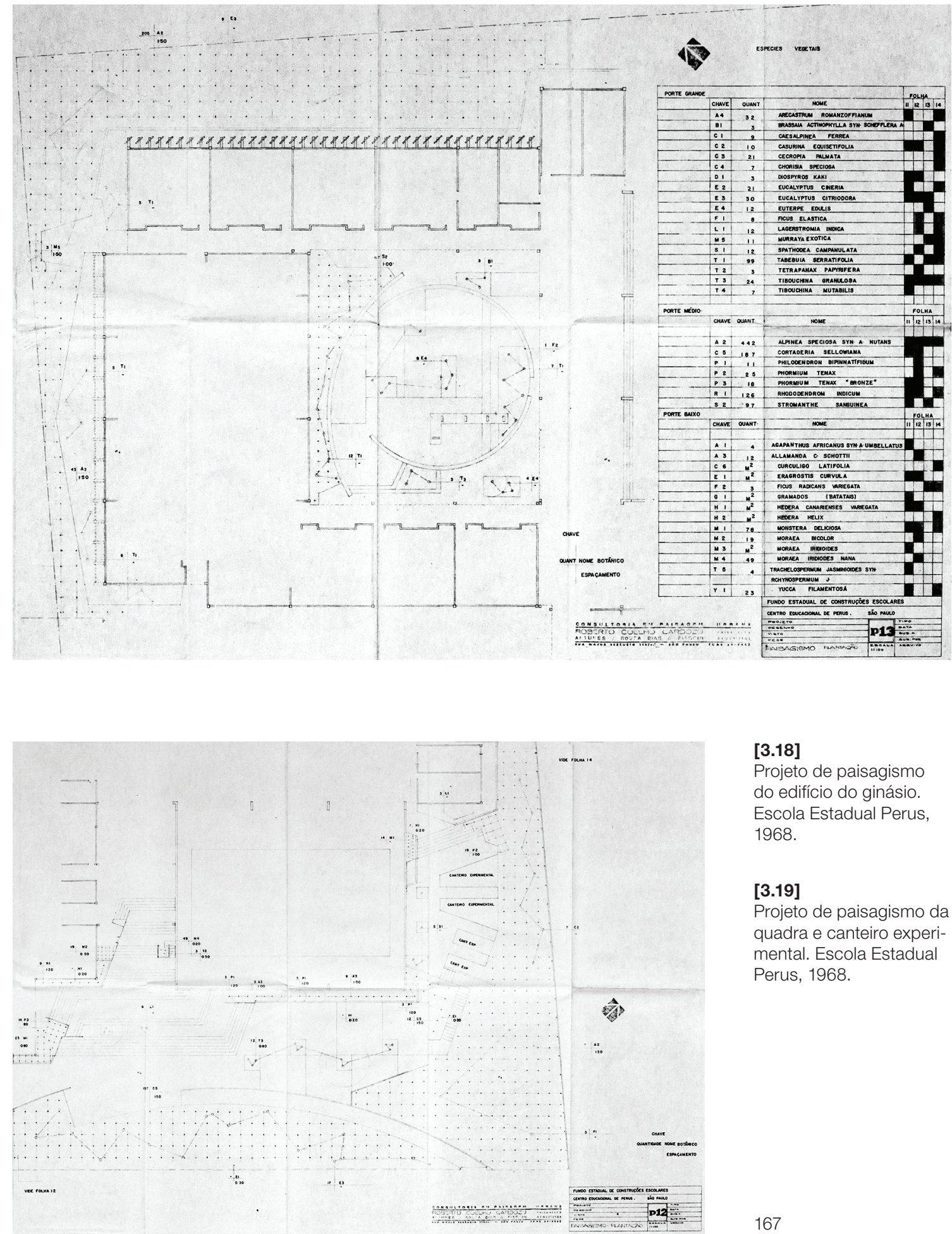

[3.18]

Projeto de paisagismo do edifício do ginásio. Escola Estadual Perus, 1968.

\section{[3.19]}

Projeto de paisagismo da quadra e canteiro experimental. Escola Estadual Perus, 1968. 


\subsection{USINA HIDRELÉTRICA DE XAVANTES (1968)}

A usina hidrelétrica de Chavantes ${ }^{12}$ foi inaugurada em 1971, e o projeto de edificações foi feito três anos antes, em 1968, pelo arquiteto Julio Roberto Katinsky. O programa de arquitetura era amplo e contemplava a construção de uma escola e uma cooperativa, um clube, uma pousada, residências permanentes, residências temporárias (vila de operários) e a casa de comando da usina. Para fazer o projeto urbano, a Centrais Elétricas de São Paulo S.A.13 (CESP) contratou Roberto Coelho Cardozo, que projetou não só a área externa do projeto da Usina de Chavantes, mas também as áreas externas das usinas de Jurumirim e Salto Grande, e da Subestação de Botucatu, todas do complexo hidrelétrico de Paranapanema. Hoje, a Usina de Chavantes pertence à Duke Energy International Geração Paranapanema.

O projeto paisagístico para a área da Usina de Chavantes tem uma escala bem mais ampla do que a dos projetos comentados anteriormente. Neste, Cardozo trabalha na remodelação urbanística da área da usina, projetando o arruamento, implantando os edifícios de residências, pousada, clube e casa de comando, e, consequentemente, desenhando o espaço livre entre esses edifícios e seus respectivos jardins. Ainda propõe intervenções de caráter ecológico, como a recuperação das áreas de talude e a recomposição vegetal da beira-rio.

12. No título, mantivemos a nomenclatura usada no projeto de paisagismo e no artigo da revista Módulo. Porém, confirmamos que a grafia "Xavantes" foi alterada para Chavantes a partir da Lei $\mathrm{n}^{\circ}$ 3.223, de 30/12/1981.

13. A empresa Centrais Elétricas de São Paulo S.A. (CESP) foi constituída em 5 de dezembro de 1966 a partir da fusão de cinco conglomerados de empresas energéticas do Estado de São Paulo: Usinas Elétricas do Paranapanema (USELPA); Companhia Hidroelétrica do Rio Pardo (CHERP), Centrais Elétricas de Urubupungá (CELUSA), Bandeirante de Eletricidade (BELSA) e Companhia Melhoramentos de Paraibuna (COMEPA). Em 27 de outubro de 1977, sua razão social foi modificada para Companhia Energética de São Paulo. 


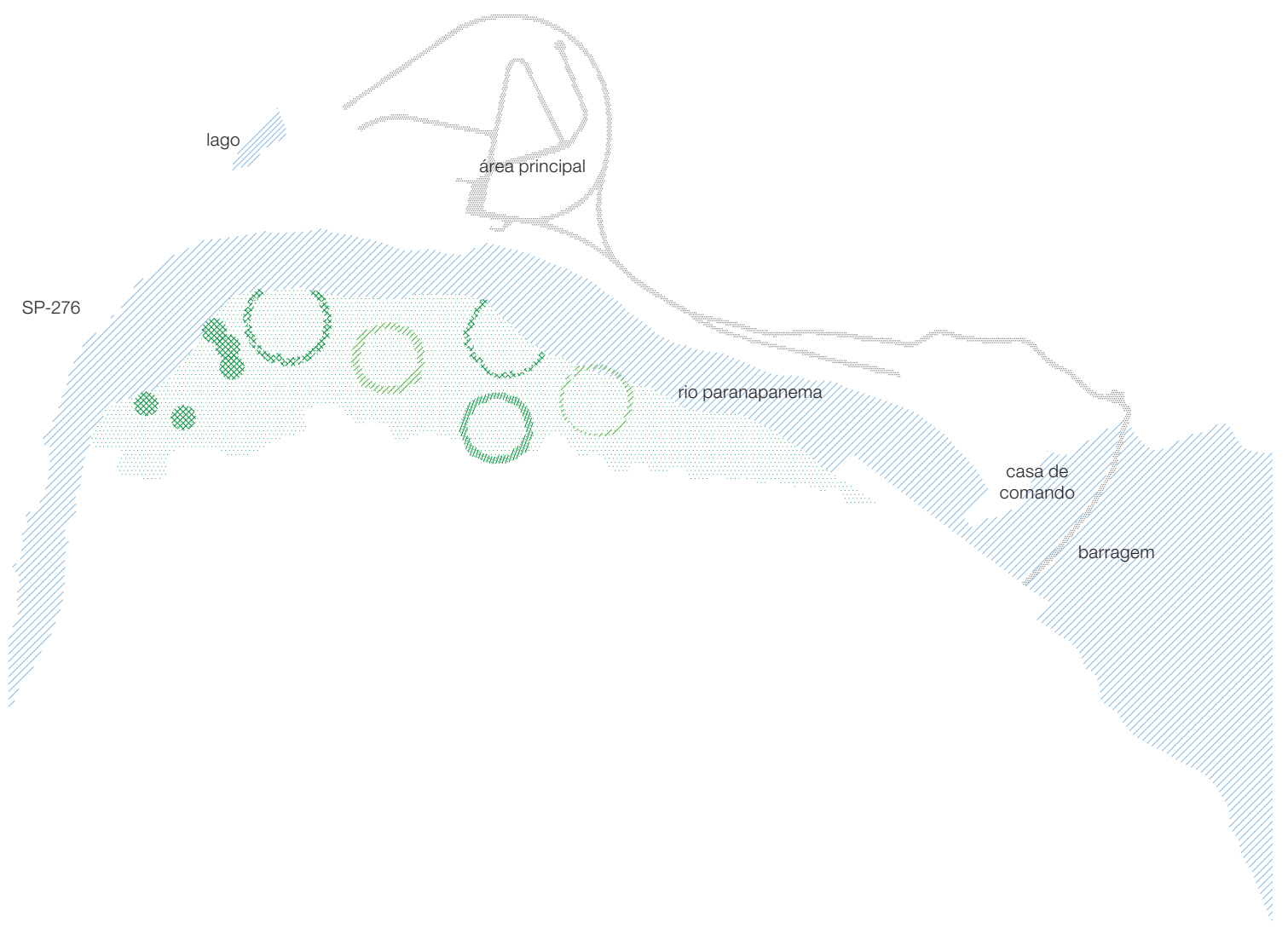



O projeto se configura em duas áreas: a principal, das residências, do clube e da pousada; e a da barragem e da casa de comando. O complexo da usina se desenvolve a partir de uma rua principal, braço da Rodovia Rodrigo Fauzi Mansur (SP-276), que, em formato de espiral, envolve a área principal e, a partir de um entroncamento, leva à região da barragem, que dista $2 \mathrm{~km}$ da área principal.

[3.20]

Projeto de paisagismo, planta geral e plantio na beira do rio. Usina Hidrelétrica de Chavantes, 1968.

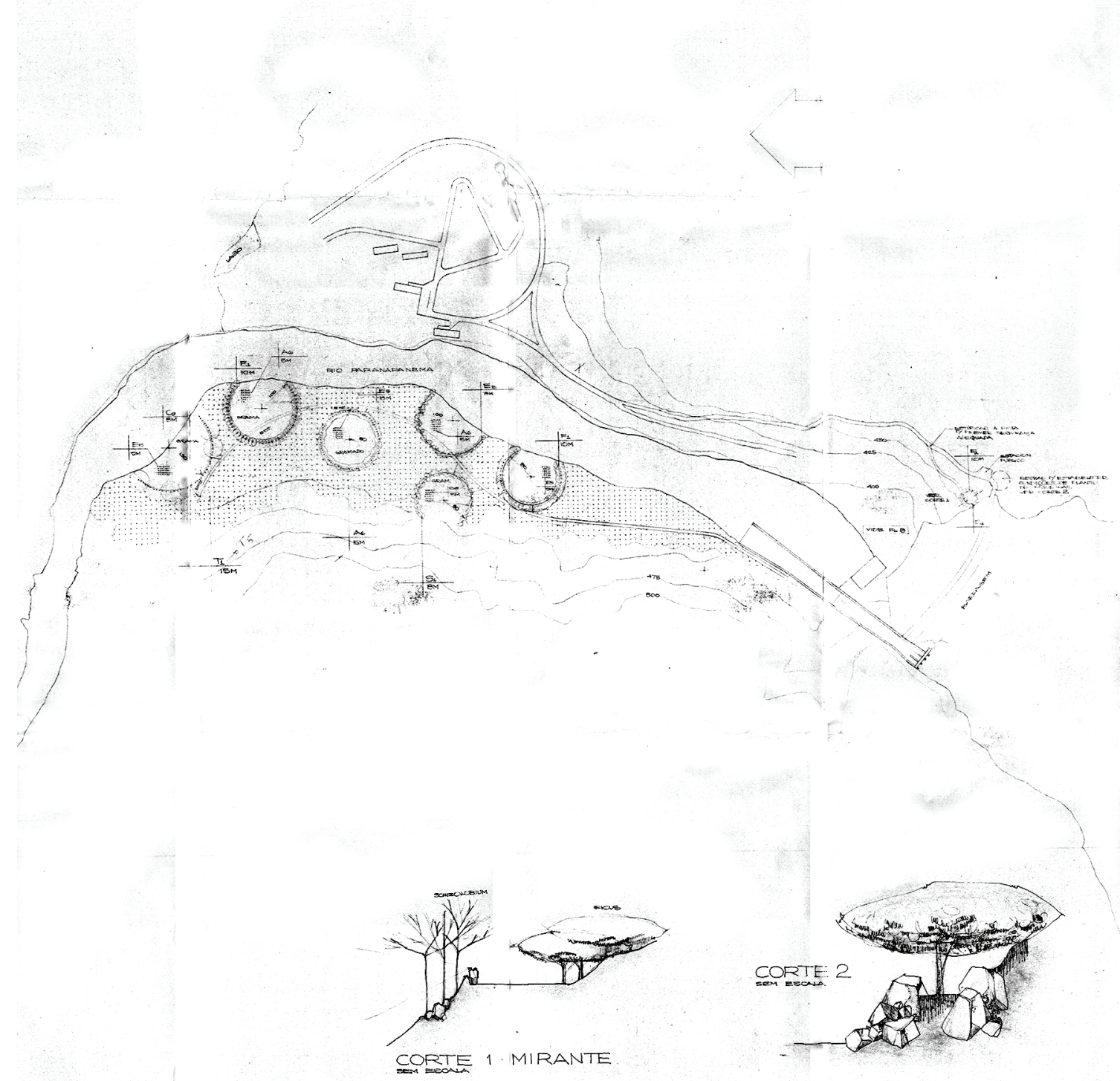


[3.21]

Casa de comando da

Usina de Chavantes.

Projeto de Julio Katinsky.

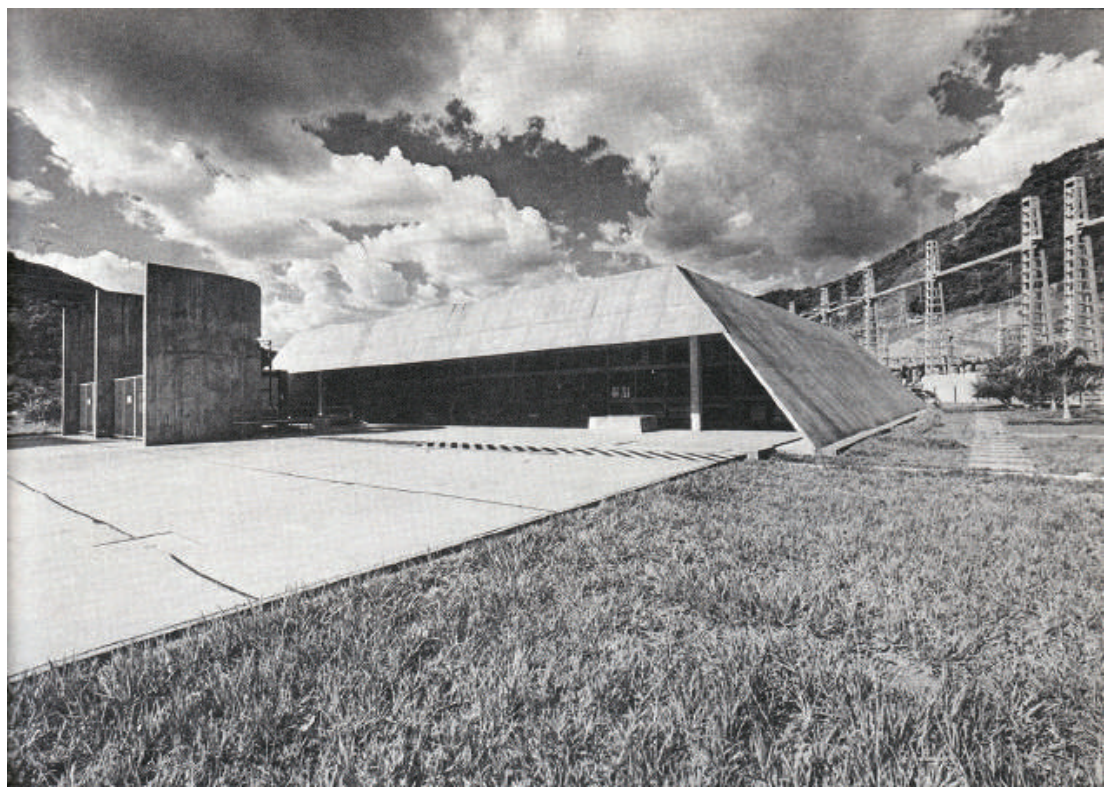

[3.22]

Vista aérea da barreira e da Casa de Comando.

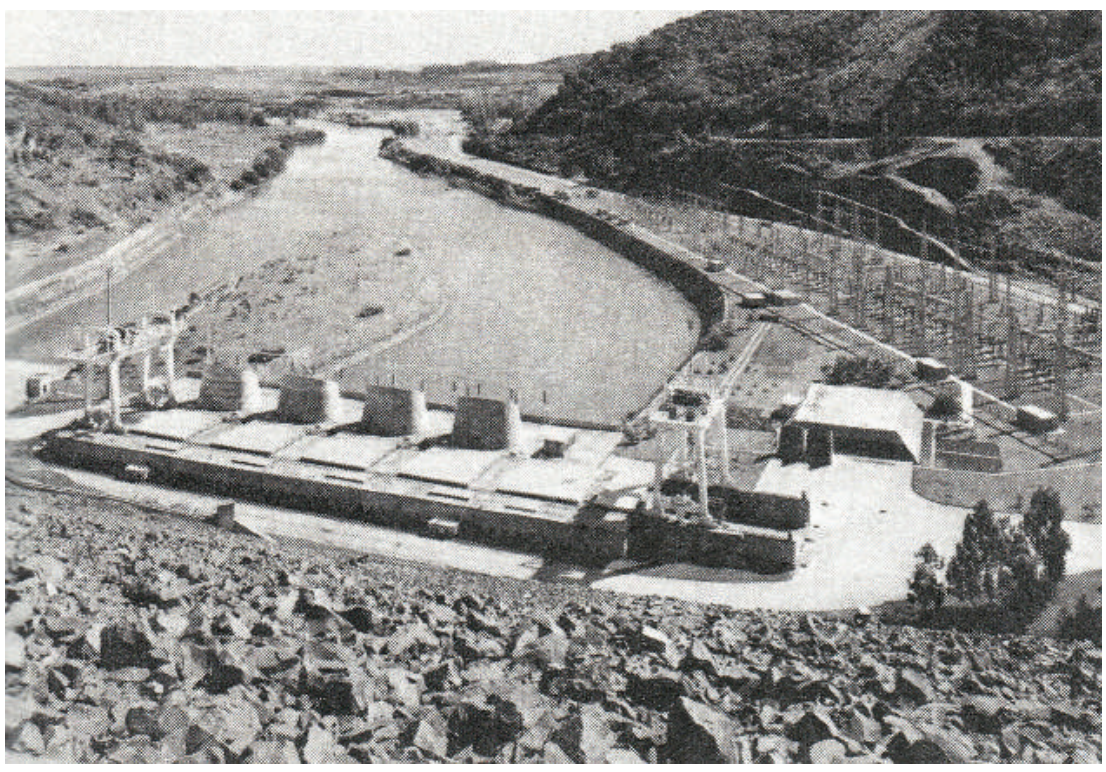






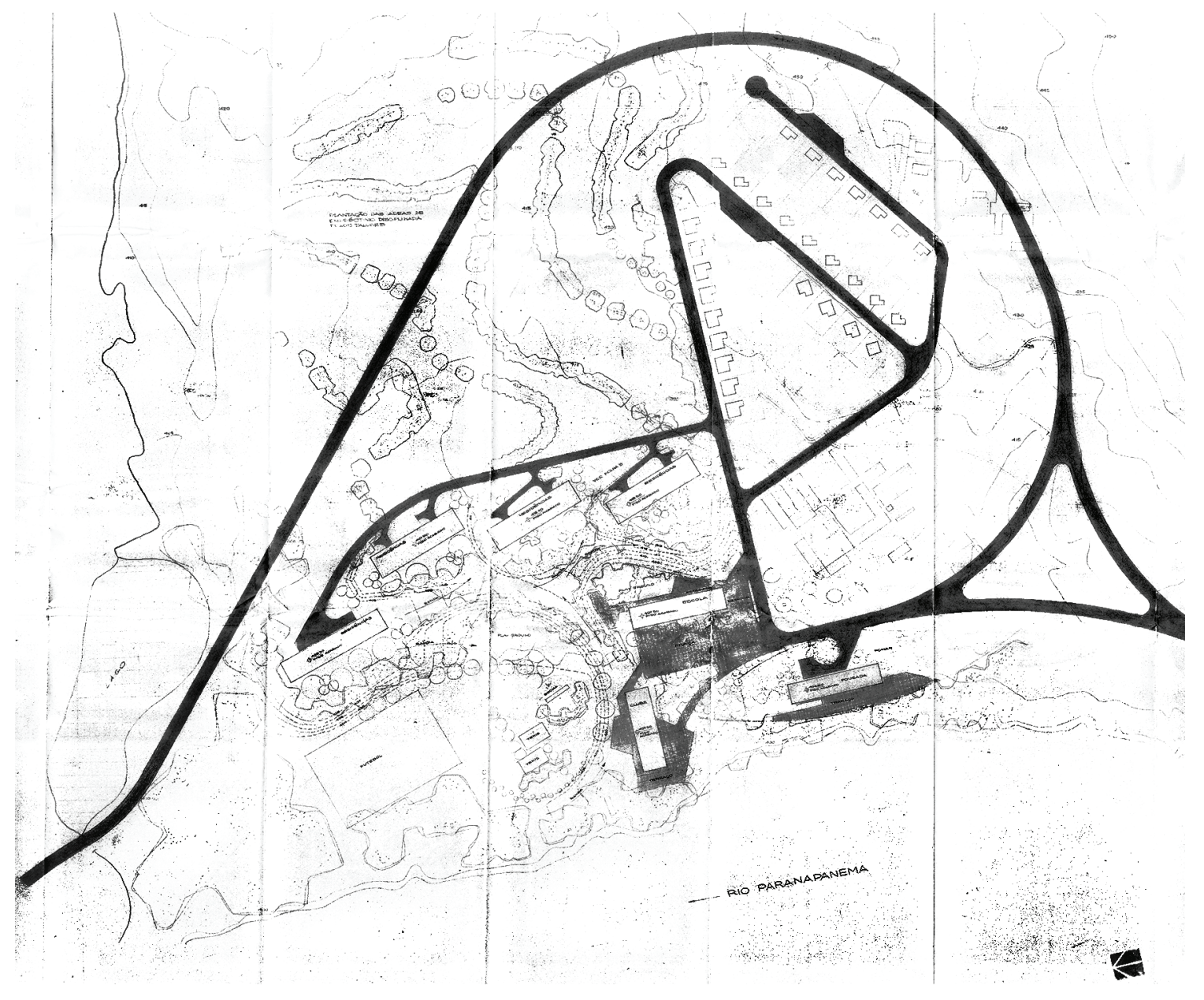

[3.23]

Projeto de paisagismo, planta da área principal geral. Usina Hidrelétrica de Chavantes, 1968. 
Logo após o entroncamento que leva à barragem, temos a pousada, implantada à beira do rio. Cem metros acima, temos a cooperativa e a escola, que se alojam no mesmo prédio, e, ao norte da pousada, temos a sede do clube, que também é implantada na beira do rio. Os três edifícios se conectam por uma praça bem arborizada por guapuruvus (Schizolobium parahyba), paineiras (Ceiba speciosa) e flamboyants (Delonix regia). A área do clube se expande para o norte da sede, onde, por entre bosques formados por plantios em áreas circulares, encontramos quadras de tênis, cancha de bocha, playground e campo de futebol.

Em frente à escola, é instalado um playground com tanques de areia e canteiros circulares, que têm suas bordas transformadas em bancos contínuos de concreto. Árvores floridas, quaresmeiras (Tibouchina granulosa) e cássias-rosas (Cassia grandis), e jabuticabeiras (Myrciaria cauliflora) sombreiam o espaço. O piso tem textura variada, entre trechos de paralelepípedos e de lajotas cimentícias quadradas, que se revezam. A cooperativa, parte integrante do edifício da escola, tem um estacionamento logo à sua frente, para facilitar a carga e a descarga de materiais, e uma linha de figueiras-liras (Ficus lyrata), que protege a fachada do sol da manhã. Aqui, os arbustos ornamentais são utilizados para forrar e florir canteiros e subdividir alguns espaços - para isso, são usados agapantos (Agapanthus africanus), capins (Eragrostis curvula e Cortaderia selloana) e massas de azaleias (Rhododendron indicum). 

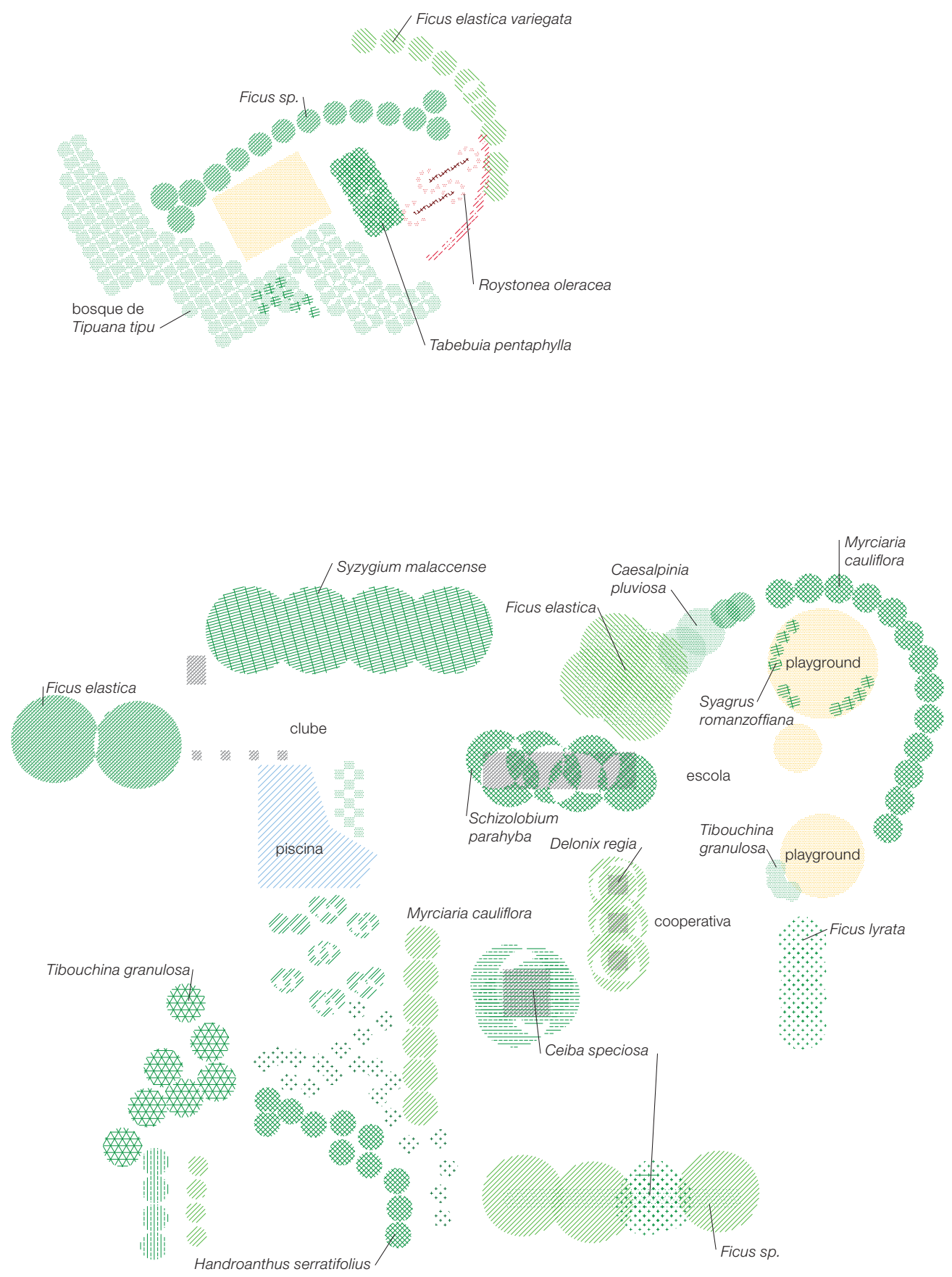



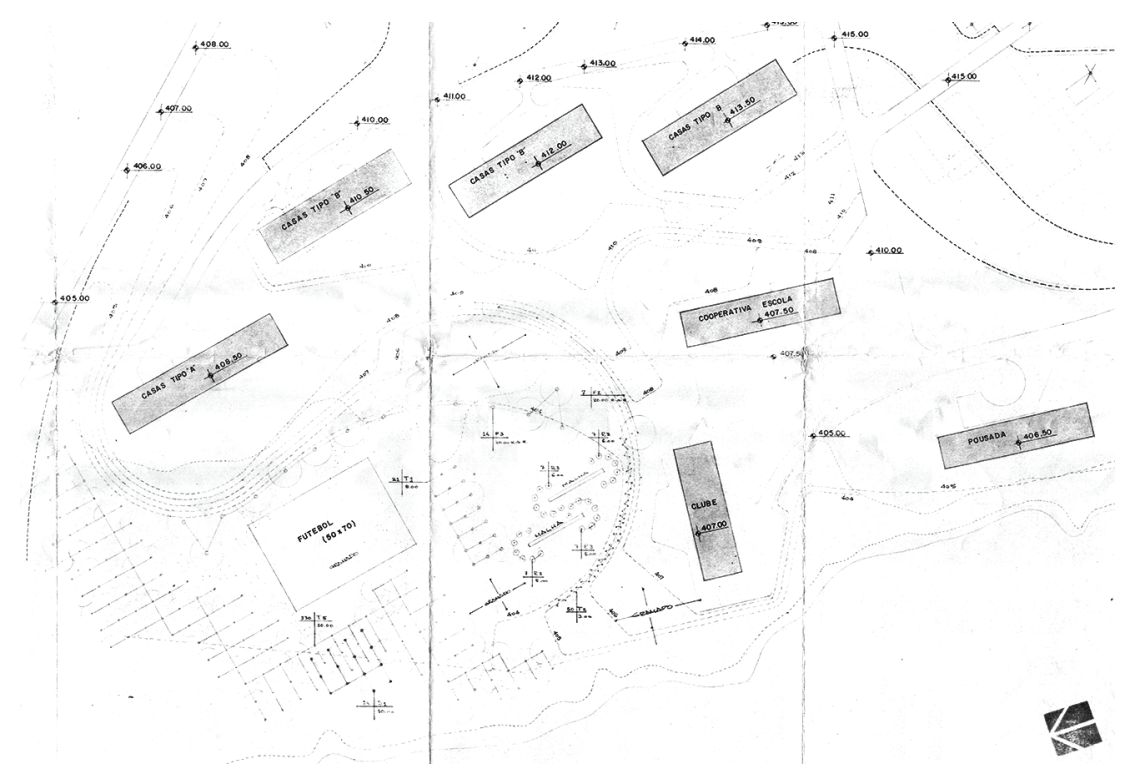

[3.24]

Projeto da área externa ao clube. Usina Hidrelétrica de Chavantes, 1968.

[3.25]

Projeto de paisagismo da praça de convivência - escola, cooperativa e clube. Usina Hidrelétrica de Chavantes, 1968.

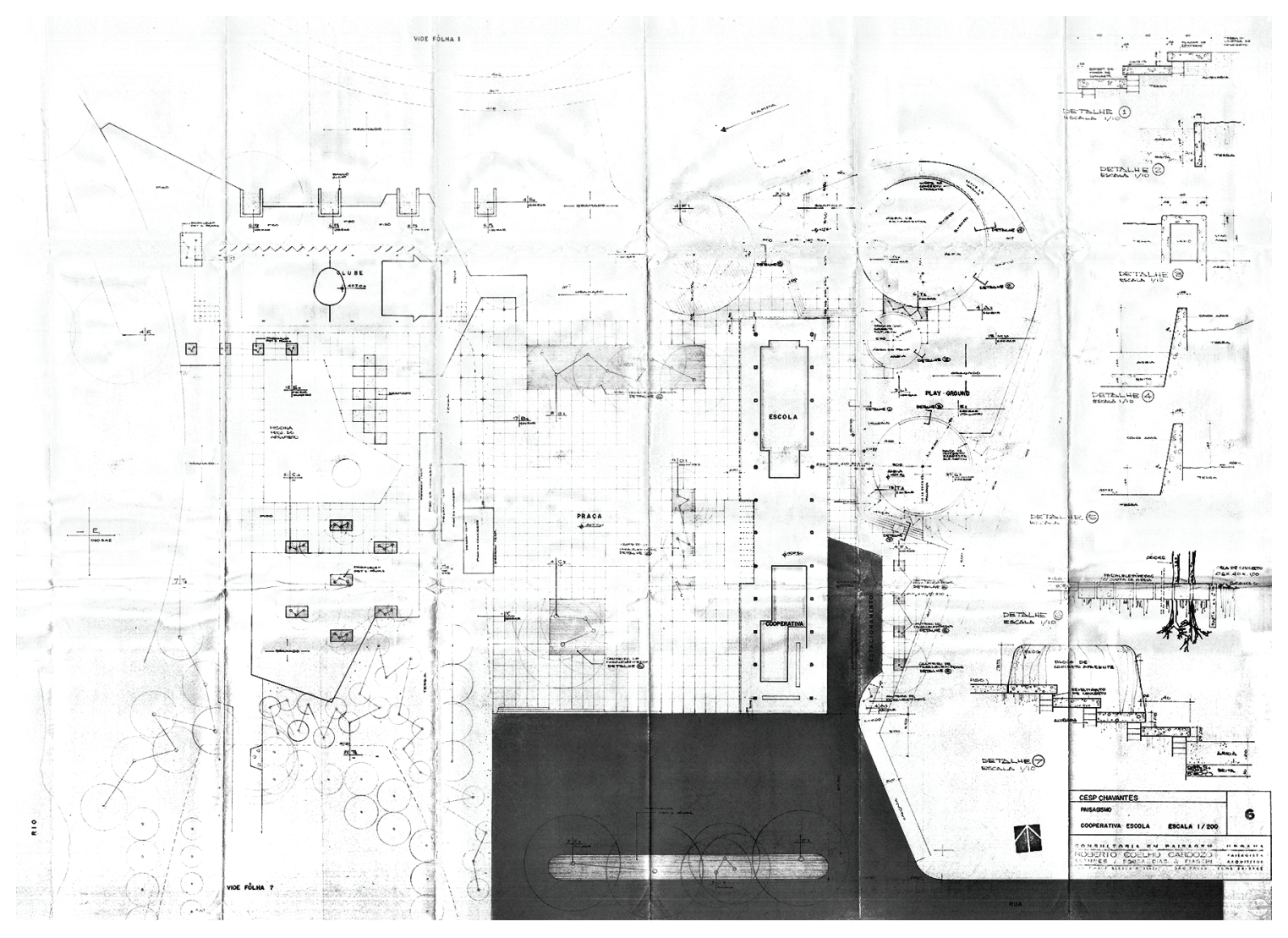


A leste do clube e da escola, uma ruela escapa ao formato de caracol da rua principal e abriga quatro blocos, cada um com duas residências de estrutura em concreto aparente. A ruela recebe um tratamento sombreado com sibipirunas (Caesalpinia pluviosa var. peltophoroides), cássias-javanesas (Cassia javanica), uva-do-japão (Hovenia dulcis) e quaresmeiras (Tibouchina granulosa) em toda a sua extensão.

$\mathrm{Na}$ fachada principal, voltada a leste, já vemos o desenho característico de Roberto Coelho Cardozo marcar a entrada das casas: são canteiros arredondados e semicirculares adensados com grandes árvores - pares de ipês-amarelos e paus-ferro (Handroanthus serratifolius e Caesalpinia ferrea) ao lado de pares de ipês-rosas e eucaliptos-prateados (Tabebuia pentaphylla e Eucalyptus cinerea) -, que tangenciam o traçado das ruas, ressaltando ainda mais a geometria desses canteiros. $\mathrm{Na}$ fachada posterior, direcionada a oeste, o desenho novamente se repete: pisos angulados avançam da varanda para a área ajardinada, unindo redondéis gramados e vegetados com arbustos rústicos e flores baixas. Essa geometrização ainda é ressaltada com um grande arco formado por um renque de primaveras (Bougainvillea spectabilis), que protege a área privada das casas da vista do clube.

Continuando na rua principal, seguindo para a cota mais alta, uma fileira de casas operárias em madeira pode ser vista acompanhando a subida do morro. Outras duas fileiras de casas operárias são projetadas para garantir o número mínimo de moradia para abrigar os operários que construirão a usina. O espaço livre dessa vila também recebe tratamento paisagístico, seguindo o padrão das residências da ruela de baixo: jardins privados, formados por gramados circulares e separados por arbustos altos e conjuntos de árvores.

$\mathrm{Na}$ figura [3.27], podemos ver o esquema que o paisagista sugere para a recuperação vegetal da área envoltória à barragem. Na realidade, o paisagista descreve o espaço como uma área de empréstimo, ou seja, um local de onde foi extraído material mineral (terra, saibro, argila etc.) para o uso na obra civil da barragem ou de vias de transporte. Esse tipo de intervenção remove a camada superficial do solo, a mais rica em matéria orgânica, e suprime a vegetação existente. Sem um bom plano de recuperação das áreas de empréstimo, um processo de 

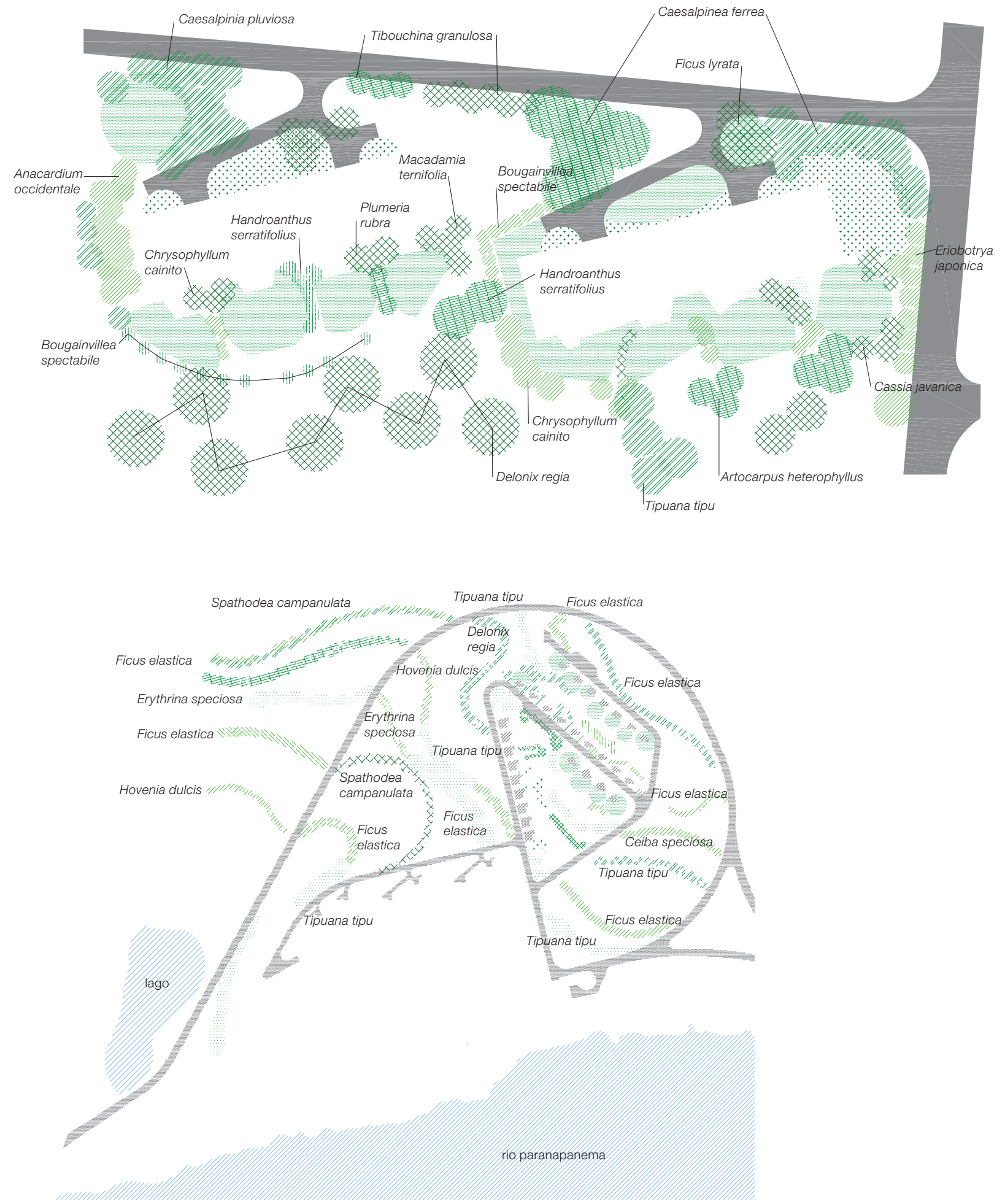



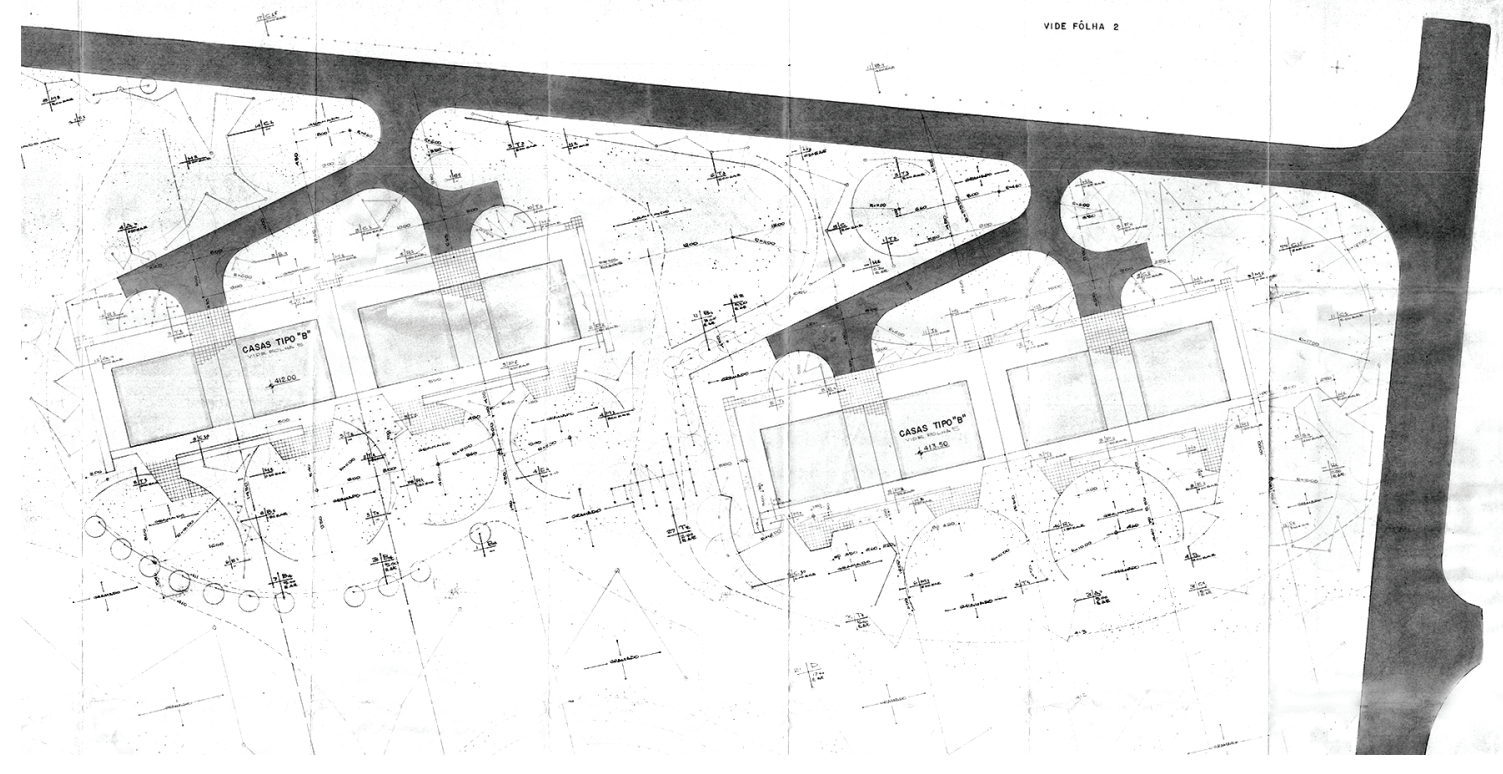

[3.26]

Projeto de paisagismo das novas residências em concreto aparente.

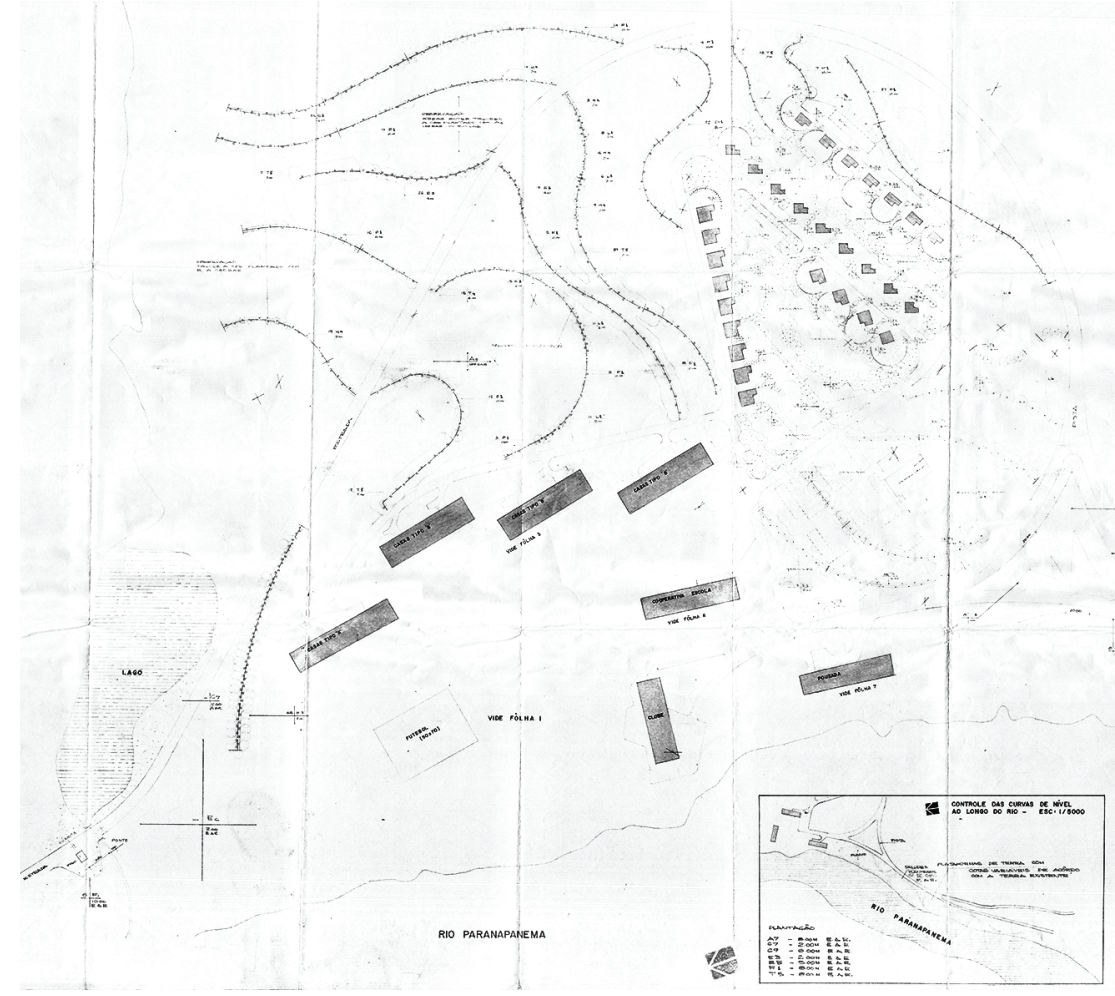
Usina Hidrelétrica de Chavantes, 1968.

[3.27]

Projeto de paisagismo da vila operária e contenção de taludes. Usina Hidrelétrica de Chavantes, 1968. 
erosão do solo pode ser desencadeado, levando à desestabilização das encostas e dos morros. Devido a isso, Cardozo propõe a estabilização geotécnica do solo a partir de plantio específico seguindo as curvas de nível do terreno.

É interessante notar que esse plantio para a estabilização do talude não foi feito exclusivamente com espécies endêmicas, como requer a legislação atual. Talvez por não haver uma lei específica designando o caráter nativo das espécies para a recomposição vegetal, talvez por uma escolha pessoal do paisagista, o plantio foi realizado com árvores de raízes bem agressivas, como as figueiras (Ficus elastica e Ficus guapoi), as tipuanas (Tipuana tipu), os flamboyants (Delonix regia) e as espatódeas (Spathodea campanulata), estas últimas especialmente indicadas para plantio em áreas erodidas. Além da arborização, Cardozo também selecionou forrações agressivas e de rápida propagação, como amendoim ornamental (Arachis repens) e capim-chorão (Eragrostis curvula), para a estabilização do talude em seu estrato mais baixo. A uva-do-japão (Hovenia dulcis) não apresenta raiz agressiva, mas pode ter sido escolhida pela sua frutificação abundante, que atrai aves e mamíferos, possibilitando a restauração da fauna local. Duas espécies nativas (Tibouchina mutabilis e Erythrina speciosa) foram selecionadas provavelmente por serem muito ornamentais e provenientes da Mata Atlântica.

Por meio desse projeto, podemos ver a capacidade projetual de Cardozo nas mais diversas escalas de trabalho: desde o detalhamento de pisos das varandas das residências, até a restauração vegetal, bastante complexa, de áreas de empréstimos. 


\subsection{CONSIDERAÇÕES GERAIS SOBRE A ANÁLISE DOS PROJETOS}

A partir da análise de alguns projetos, tentamos enumerar algumas especificidades em sua obra e o desdobramento de sua formação acadêmica e profissional nos Estados Unidos. Percebemos que a obra de Roberto Coelho Cardozo tem uma coesão e uma unidade, principalmente quando unimos, em uma observação cuidadosa, os aspectos formais e a importância dada à vegetação. Poderíamos considerar cada elemento separadamente, mas não teríamos a mesma visão de seus projetos - essas duas unidades são indissociáveis.

Tivemos certa dificuldade em analisar os projetos de Cardozo não por uma condição inerente à obra do paisagista, mas por uma complexidade dos projetos de paisagismo em geral. O projeto de paisagismo nem sempre corresponde ao que foi implantado. Por se tratar de um projeto que lida com seres vivos, nem sempre é possível seguir exatamente o que está "no papel".

São muitas as variantes que acarretam mudanças durante o processo de implantação do projeto: disponibilidade de vegetação, que depende muito da estação do ano em que ele é executado; adaptação da vegetação ao local do plantio, que muitas vezes não acontece, por mais minuciosa que tenha sido sua escolha para as condições locais; e, por fim, a disponibilidade no mercado.

Dessa maneira, a análise de projeto feita aqui corresponde à análise de sua idealização, por se tratar de uma leitura distanciada do que realmente foi executado. Consequentemente, a realidade existente hoje nesses jardins certamente não corresponde à da época em que o projeto foi executado, mas a beleza do paisagismo está justamente nessa capacidade de transformação e mutabilidade da ideia. Como disse Burle Marx: "O jardim é sempre uma questão de tempo. O tempo completa a ideia."14

14. Declaração de Roberto Burle Marx em entrevista concedida a Rossan Vaccarino em Correspondências de tempo e instabilidade: dois jardins (CAVALCANTI, L.; EL-DAHDAH, F.; 2009). 


\subsection{FICHAS DE PROJETOS}

A catalogação da obra de Roberto Coelho Cardozo gerou 192 fichas de projeto, abrangendo o período recortado pela pesquisa, entre $1950 \mathrm{e}$ 1970, período em que o paisagista esteve no Brasil. Organizadas por ordem alfabética, apresentam: cliente, data de projeto, data de publicação, projeto (de arquitetura), projetos complementares, construção, paisagismo, tipologia, endereço e material bibliográfico.

Uma última ficha de projeto foi acrescentada, com o projeto das residências em Monte Verde, feito pelo arquiteto Marcos Acayaba, por se tratar do único projeto que conseguimos material no período em que Cardozo esporadicamente retornou ao Brasil nas décadas de 1990 e 2000.

Além das fichas catalográficas, foi feito um mapa em plataforma digital, usando o Mymaps da Google, aberto para futuras pesquisas no tema. Nesse mapa é possível consultar a localização de cada obra, além das informações contidas nas fichas catalográficas. Disponibilizado em: <https://drive.google.com/open?id=1cPy>lZStMWnATyMV6HbFkN $2 i w 5 w>$. Para apresentá-lo neste trabalho impresso, geradas imagens das regiões centrais e periféricas da cidade de São Paulo (mapa 1 e 2) e da região externa à região metropolitana (mapa 3).

Observando a localização das obras, podemos ver que a maioria de seus projetos se concentraram nas áreas residenciais nobres da cidade, como Brooklin, Morumbi e Jardins. Muitos projetos que se localizam fora da cidade são projetos institucionais, como os feitos pela CESP, ou projetos privados de fábricas e fazendas.

Esperamos que esse mapa e essas fichas catalográficas ampliem as informações referentes à obra do paisagista. 


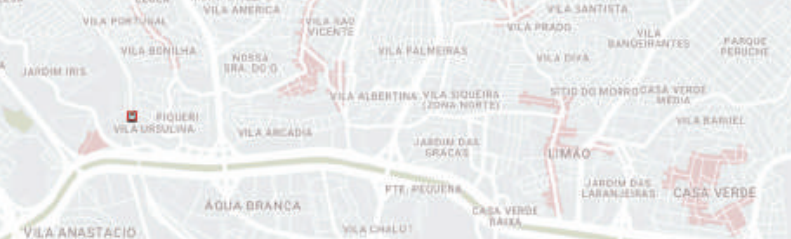

[mapa 1]

Projetos de Roberto

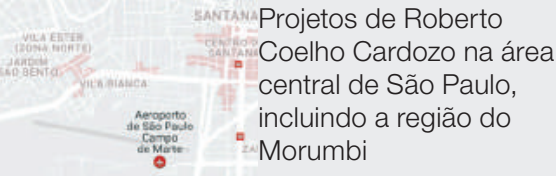

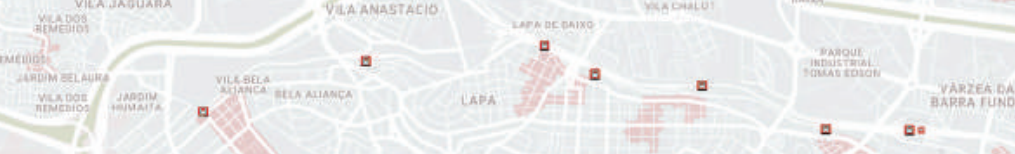

$\bullet$
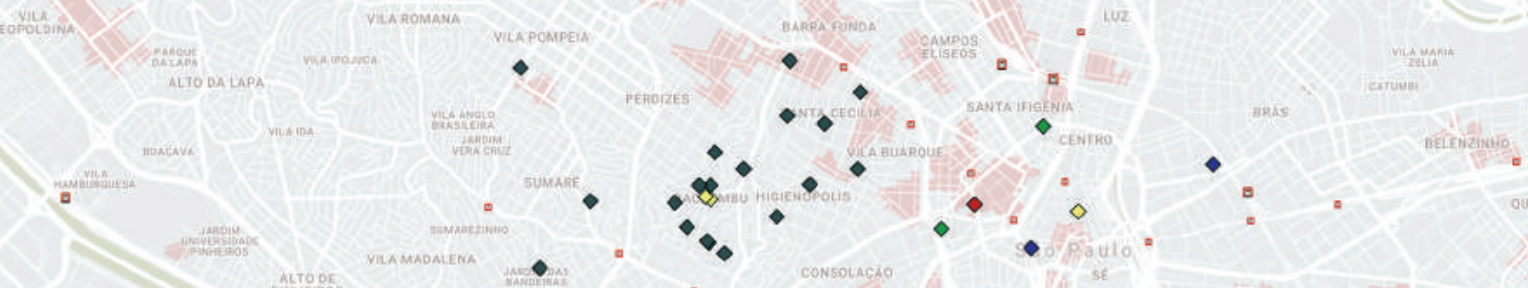

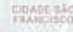

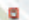
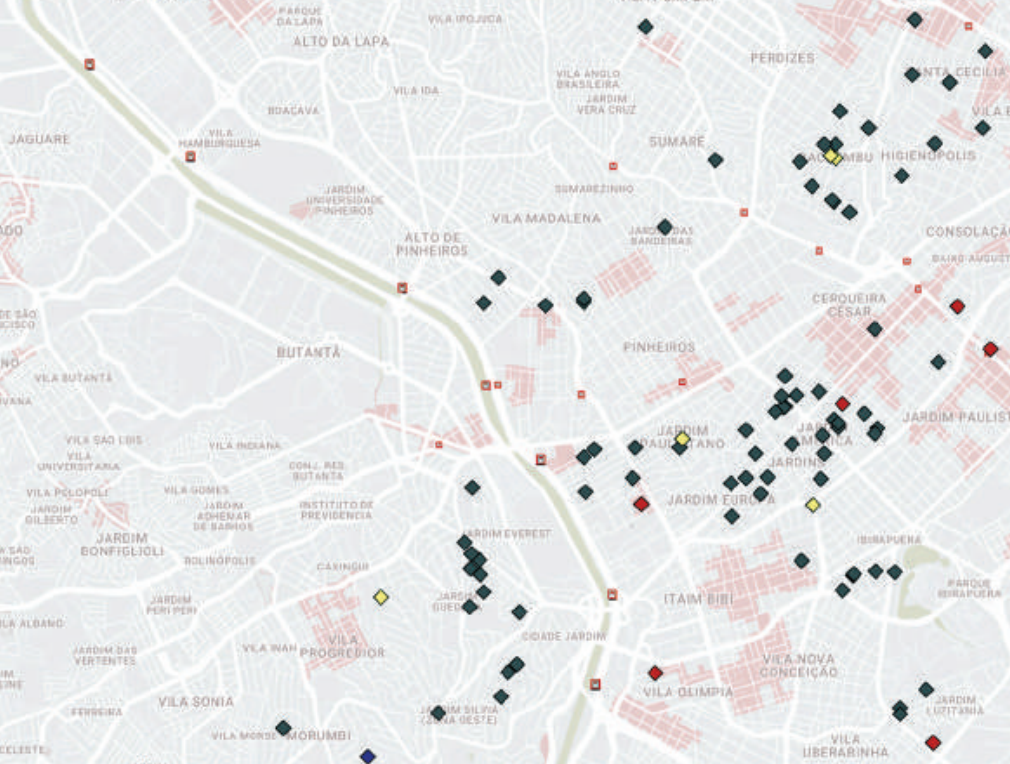

ountorid

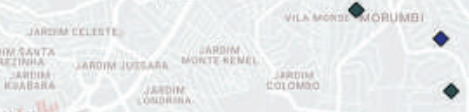

metent pis

$=$

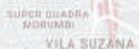

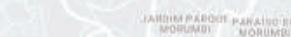
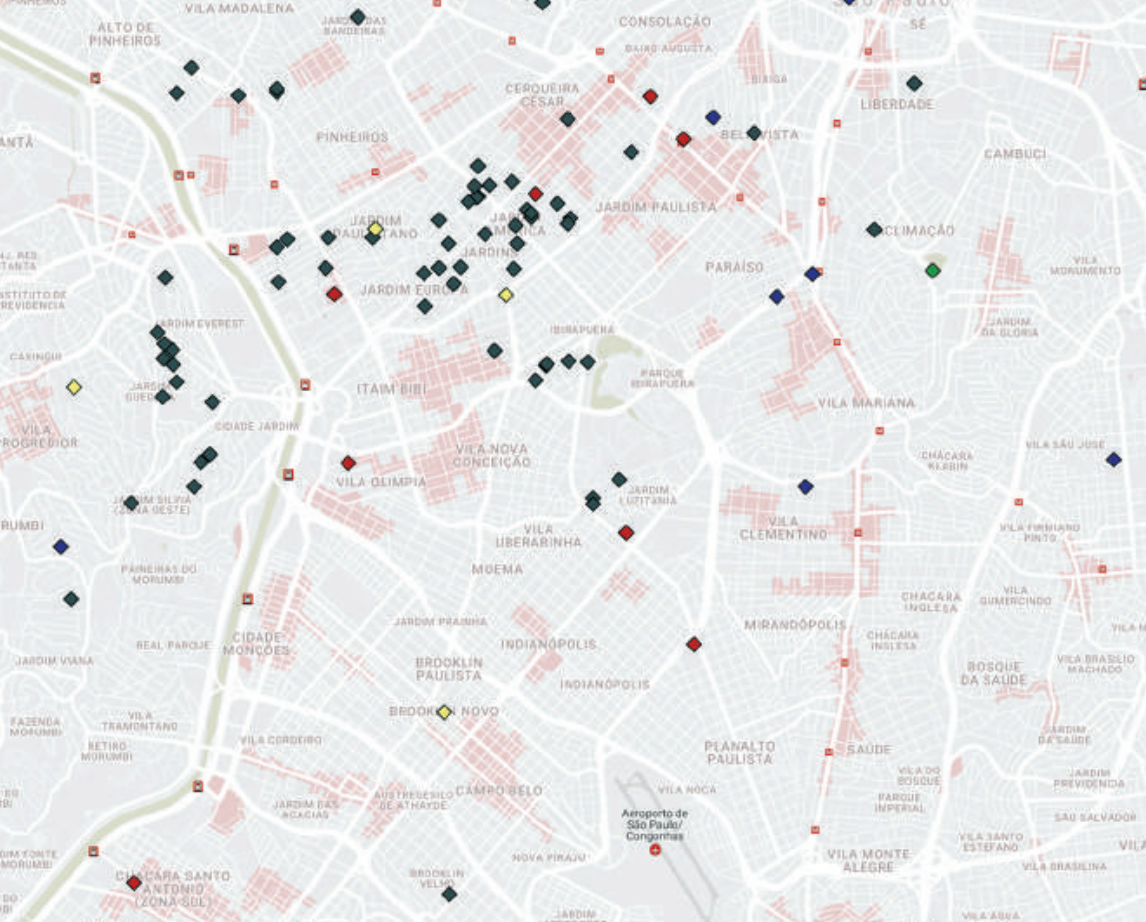

$\square$
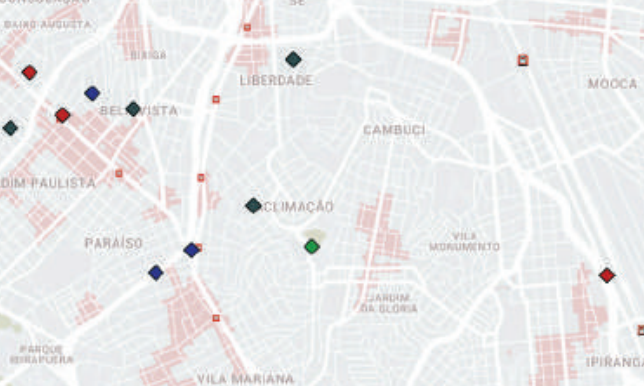

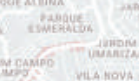
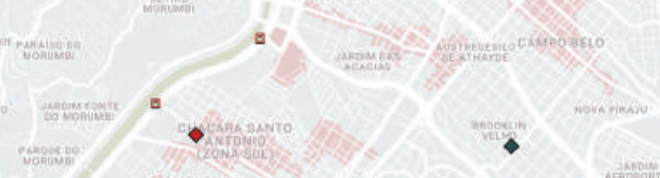

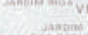
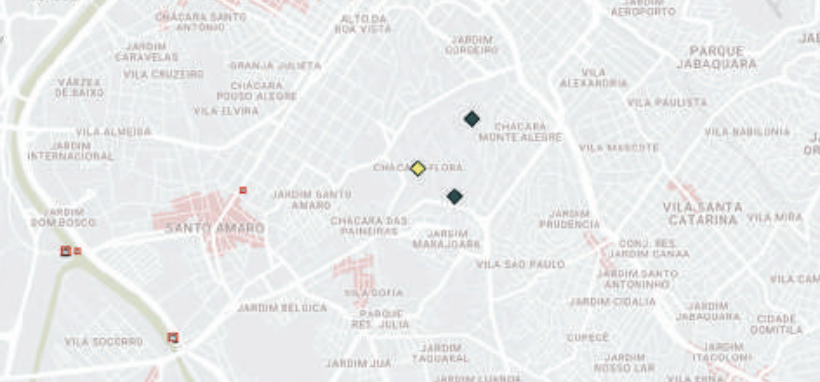

$=-1=$
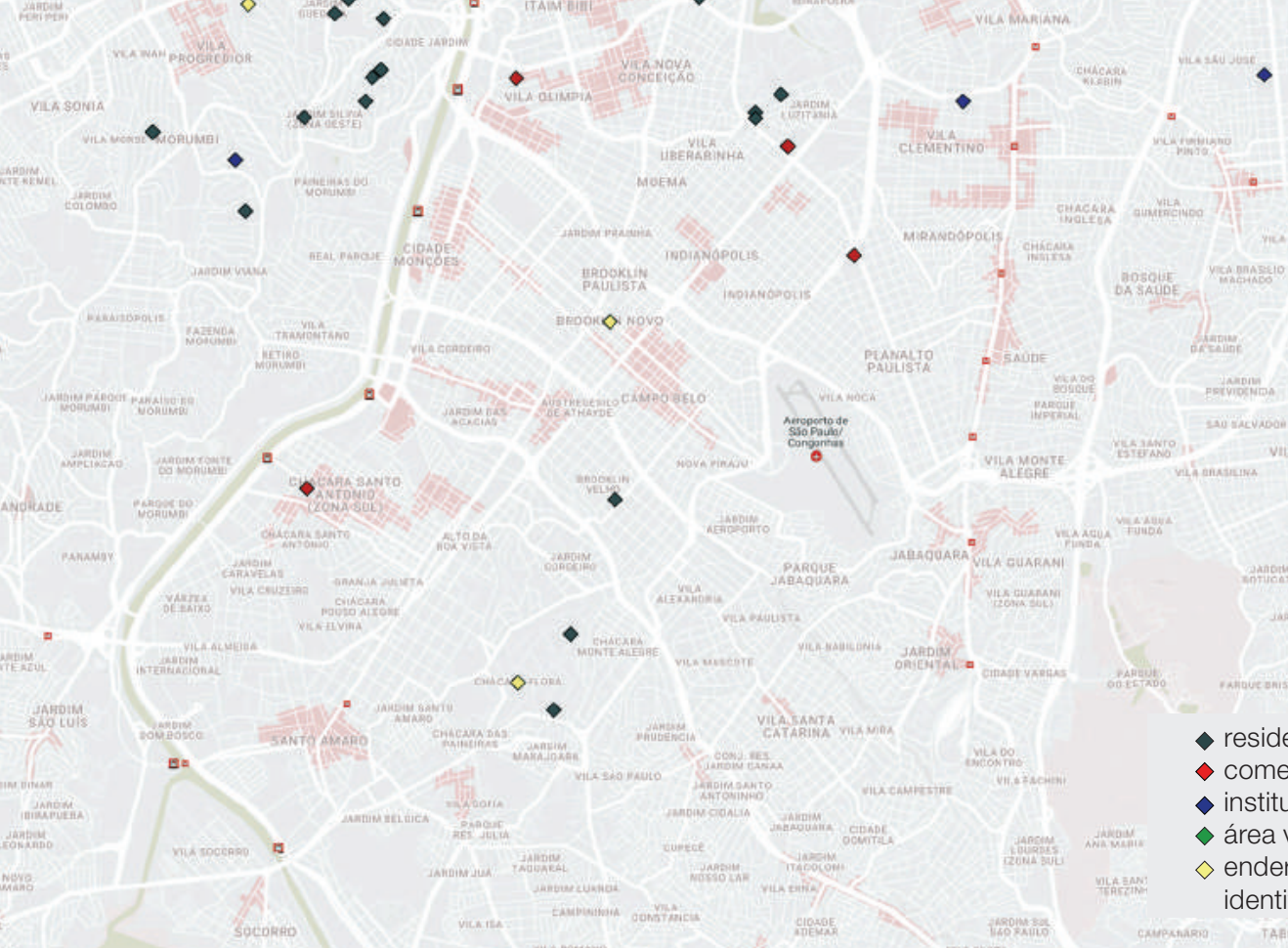

residencial

$\diamond$ comercial

$\diamond$ institucional

área verde

$\diamond$ endereço não

identificado 




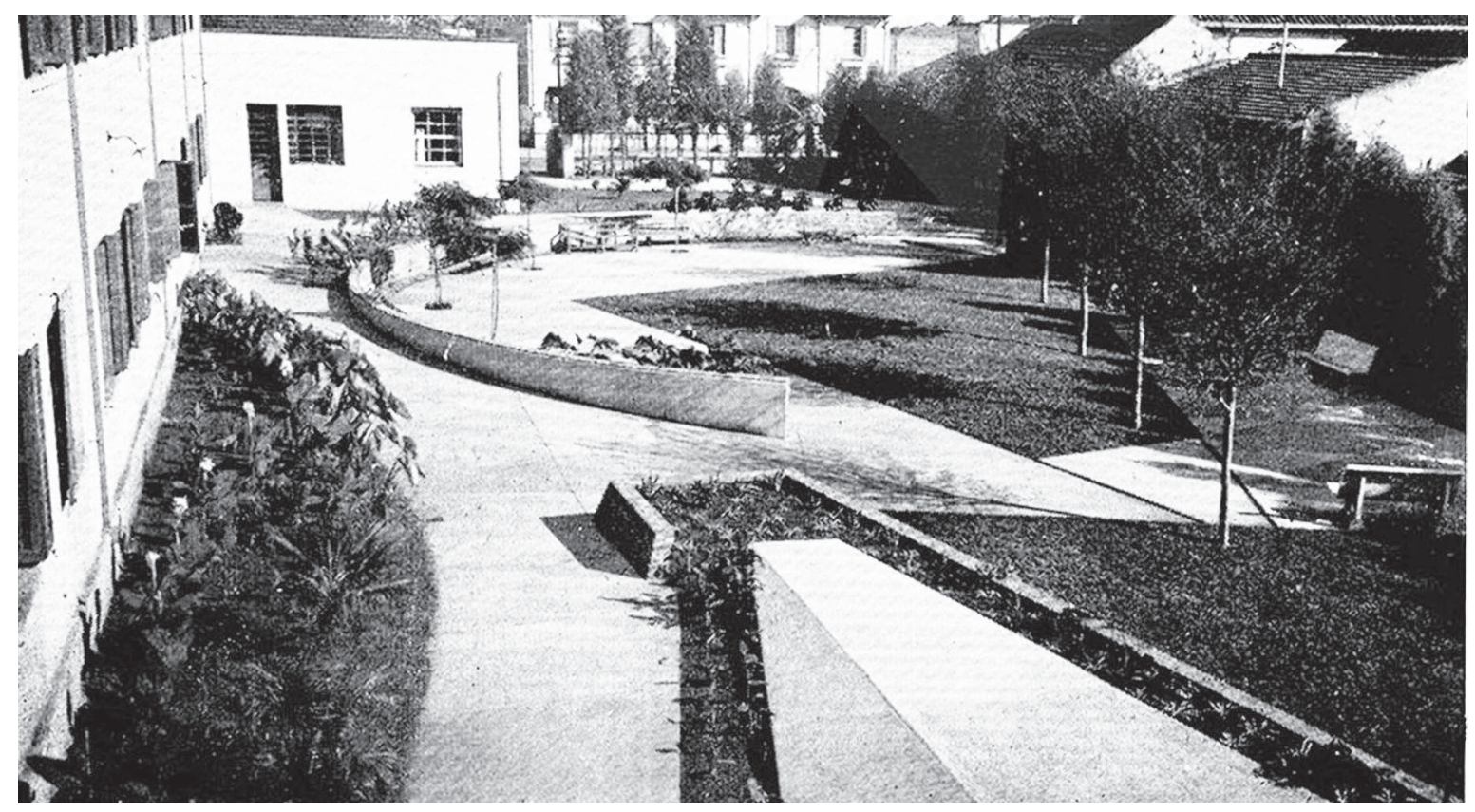

\section{ASILO DOS VELHOS - LAR GOLDA MEIR}

Cliente: Sociedade Religiosa Israelita

Data de projeto: não consta

Data da publicação: 1959

Projeto: Henrique Ephim Mindlin

Projetos complementares: não consta

Construção: não consta

Paisagismo: Osborn Coelho Cardozo

Tipologia: institucional

Endereço: Rua Coronel Lisboa, 139 - Vila Mariana - São Paulo/SP

Material:

UM jardim para velhos. Acrópole, São Paulo, 204, p. 537-9, out. 1955.

\section{ASSOCIAÇÃO CULTURAL RELIGIOSA BRASILEIRA ISRAELITA}

Cliente: não consta

Data de projeto: 1955

Data da publicação: não consta

Projeto: não consta

Projetos complementares: não consta

Construção: não consta

Paisagismo: Roberto Coelho Cardozo

Tipologia: institucional

Endereço: Rua Estado de Israel, 200 - Vila Mariana - São Paulo/SP

Material:

CARDOZO, R. C. Curriculum vitae. In: UNIVERSIDADE DE SÃO PAULO. Processo

52.1.14106.1.2: contrato docente. São Paulo: Departamento de projetos da Faculdade de

Arquitetura e Urbanismo. 15/12/1987. 87p. 


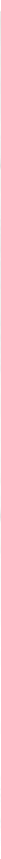

\section{PAISAGISMO AVENIDA 23 DE MAIO}

Cliente: Prefeitura Municipal de São Paulo

Data de projeto: 1968

Data da publicação: não consta

Projeto: Miguel Badra Jr. Arquitetura Ltda.

Projetos complementares: não consta

Construção: executado por Engenharia Brada Ltda.

Paisagismo: Roberto Coelho Cardozo, Antonio A. Antunes Netto, Marcos de Souza Dias

e Miranda Martinelli

Tipologia: institucional

Endereço: Avenida 23 de Maio - São Paulo/SP

Material:

Acervo da biblioteca da FAUUSP (Cód. PE C179/712.6 V): levantamento plani-altimétrico; plantação; planta de pisos e elementos arquitetônicos; folha geral; detalhes; anteprojeto; mureta de arrimo (detalhe); corte arrimo (detalhe); orla de concreto para separação de canteiro (detalhe); muro de arrimo.

CARDOZO, R. C. Curriculum vitae. In: UNIVERSIDADE DE SÃO PAULO. Processo 52.1.14106.1.2: contrato docente. São Paulo: Departamento de projetos da Faculdade de Arquitetura e Urbanismo. 15/12/1987. 87p. 


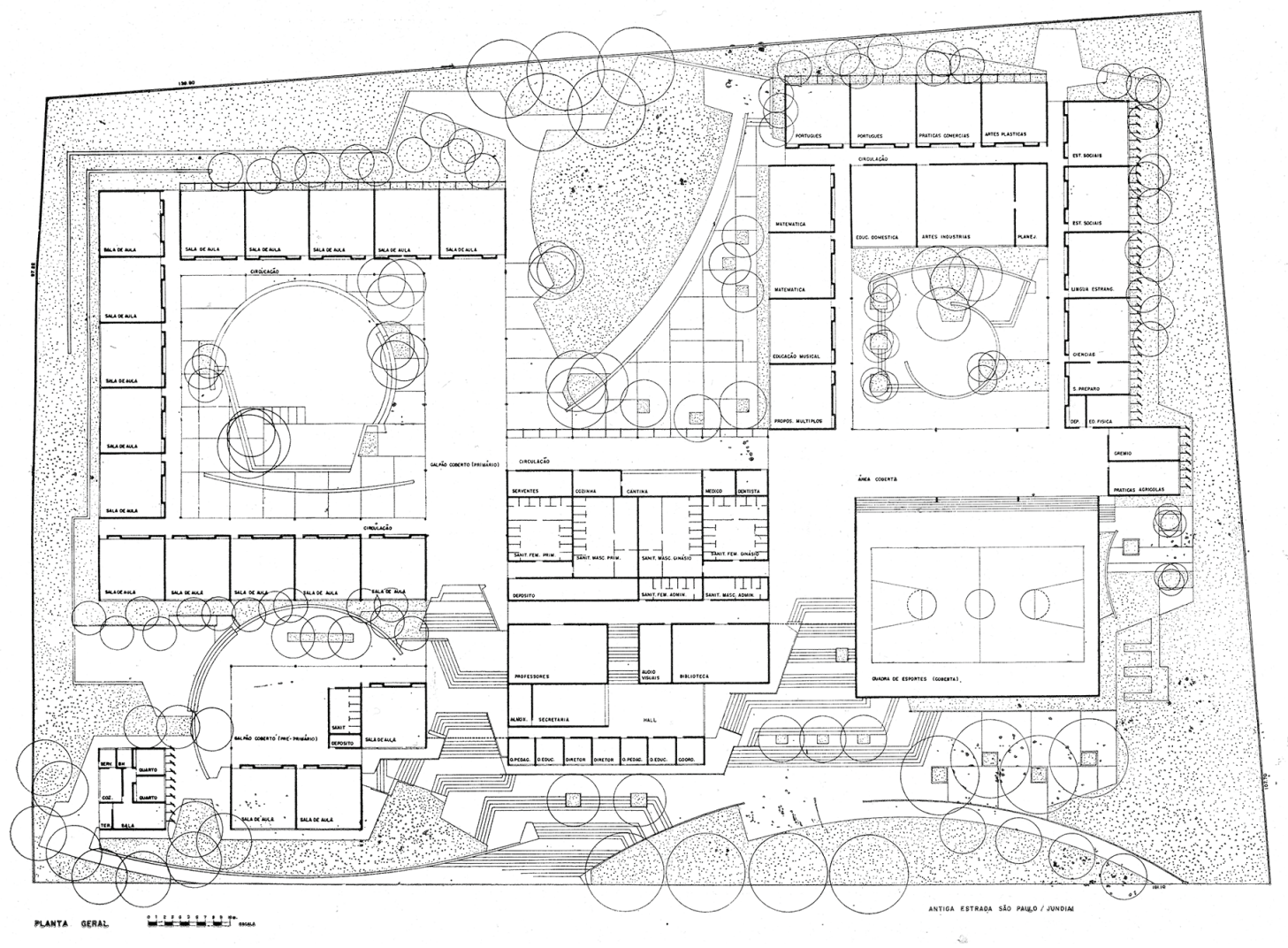

CENTRO EDUCACIONAL DE PERUS - FECE PERUS

Cliente: Fundo Estadual de Construções Escolares (FECE)

Data de projeto: 1968

Data da publicação: 1969

Projeto: Danilo Bassani (CREA 18999/0) e Adilson C. Macedo. Desenhos de Jenner

Negrão, Tharcizio, Newton Coutinho

Projetos complementares: Johhan Schindler (topografia)

Construção: não consta

Paisagismo: Roberto Coelho Cardozo e Antunes / Souza Dias \& Fiaschi

Tipologia: residencial

Endereço: Rua Mogeiro, 710 - Vila Perus - São Paulo/SP

Material:

Acervo da biblioteca da FAUUSP (Cód. PE C179/727 C): Pranchas de arquitetura: planta plani-altimétrica; elevações; anteprojeto; planta de locação; planta de cobertura; planta de setor 1; cortes e detalhes; planta setor 3; cortes AA, BB, CC e DD; planta setor 2; elevação e detalhes fl07. Pranchas de paisagismo: planta locação; plantação 1, 2 e 3; anteprojeto; detalhes de paisagismo; elevações e detalhes; elevações indicadas; planta de acesso trecho 1 e 2.

CARDOZO, R. C. Curriculum vitae. In: UNIVERSIDADE DE SÃO PAULO. Processo

52.1.14106.1.2: contrato docente. São Paulo: Departamento de projetos da Faculdade de Arquitetura e Urbanismo. 15/12/1987. 87p.

CENTRO Educacional. Acrópole, São Paulo, 368, p. 30-2, dez. 1969.

MELLO, M. G. Arquitetura escolar pública paulista: Fundo Estadual de Construções Escolares - FECE (1966-1976). Dissertação (Mestrado em Arquitetura e Urbanismo). FAUUSP, São Paulo, 2012. 419p. 


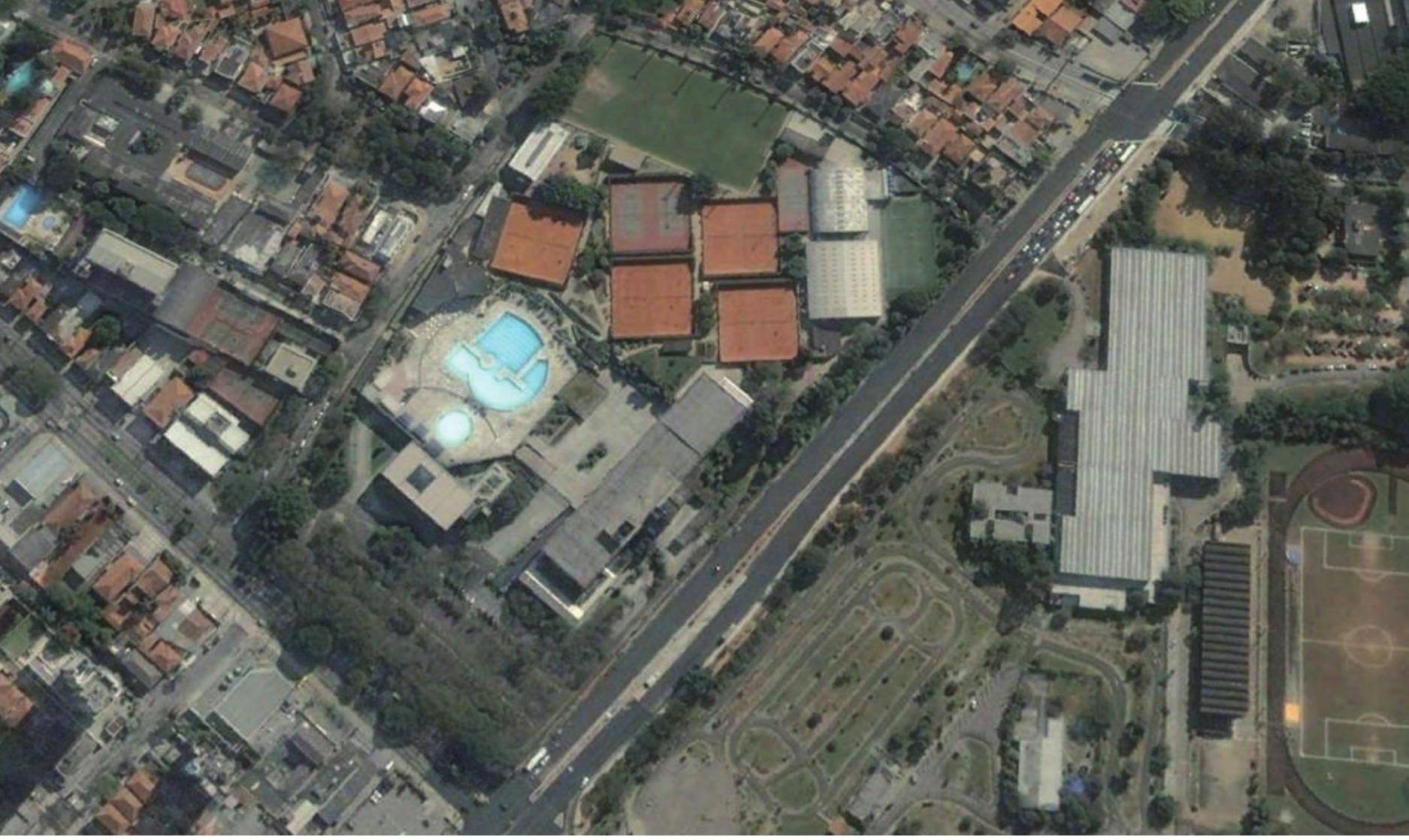

\section{CLUBE ATLÉTICO MONTE LÍBANO}

Cliente: Família Jafet

Data de projeto: 1969

Data da publicação: não consta

Projeto: Gregori Warchavchik (projeto de arquitetura de 1950)

Projetos complementares: não consta

Construção: foi construído, não consta data

Paisagismo: Roerto Coelho Cardozo

Tipologia: comercial

Endereço: Avenida República do Líbano, 2267 - Moema - São Paulo/SP

Material:

CARDOZO, R. C. Curriculum vitae. In: UNIVERSIDADE DE SÃO PAULO. Processo

52.1.14106.1.2: contrato docente. São Paulo: Departamento de projetos da Faculdade de Arquitetura e Urbanismo. 15/12/1987. 87p. 


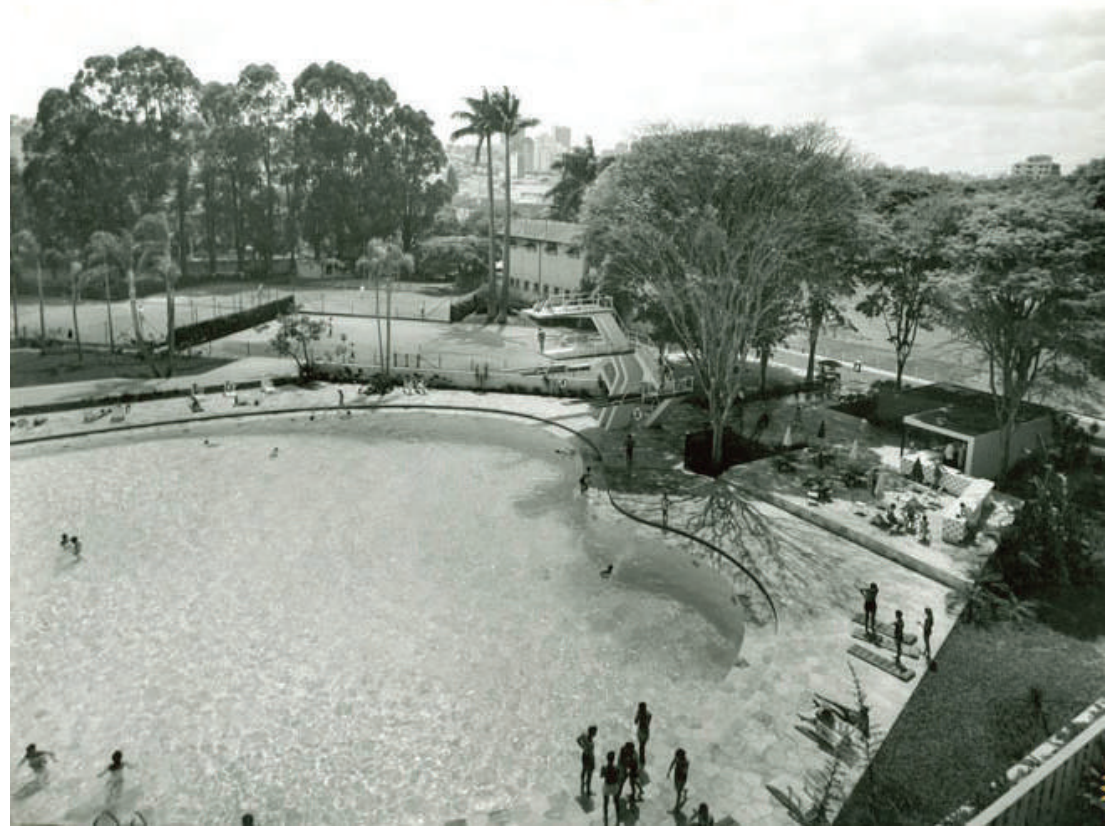

\section{CLUBE ATLÉTICO PAULISTANO}

Cliente: Antônio Prado Júnior

Data de projeto: 1960

Data da publicação: paisagismo não foi publicado

Projeto: Gregori Warchavchik, com colaboração de Telesforo Cristóphani, Zenon Lotufo,

Hélio Duarte e Abelardo de Souza (projeto de arquitetura de 1948)

Projetos complementares: não consta

Construção: Sociedade Comercial e Construtor, construído em 1948

Paisagismo: Roberto Coelho Cardozo

Tipologia: comercial

Endereço: Rua Honduras, 1400 - Jardim Paulistano - São Paulo/SP

Material:

CARDOZO, R. C. Curriculum vitae. In: UNIVERSIDADE DE SÃO PAULO. Processo

52.1.14106.1.2: contrato docente. São Paulo: Departamento de projetos da Faculdade de Arquitetura e Urbanismo. 15/12/1987. 87p.

CLUBE Atlético Paulistano - Nova sede social. Acrópole, São Paulo, 130, p. 299-302, fev. 1949. (Arquitetura)

Observações: A sede do Clube Paulistano foi projetada em 1948 e construída no mesmo ano. Por algumas fotos, parece já existir algum desenho de paisagismo, mas segundo o depoimento de Gregório Zolko, Gregori Warchavichik fez uma reunião com Roberto Coelho Cardozo em 1955, para fazer o paisagismo do Clube Paulistano. Pelo currículo do paisagista, o projeto de paisagismo data 1960. 


\section{APM}

CLUBE DE CAMPO

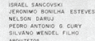

PLanta or sirvaçáo

i

\section{CLUBE DE CAMPO E SEDE DE CONGRESSOS PARA A APM}

Cliente: Associação Paulista de Medicina

Data de projeto: 1965

Data da publicação: não foi publicado

Projeto: Israel Sancovski, Jeronimo Bonilha Esteves, Nelson Daruj, Pedro Antonio G.

Cury, Silvano Wendel Filho

Projetos complementares: Dimensional - Engenharia de dimensões Ltda (Eng.

Agrimensor José Maria de Mello)

Construção: não consta

Paisagismo: Roberto Coelho Cardozo, Antonio A. Antunes Netto, Rodolpho Almeida

Fernandes

Tipologia: institucional

Endereço: Estrada de Santa Inês, km 10 - Parque das Esmeraldas - Caieiras/SP

Material:

Acervo da biblioteca da FAUUSP (Cód. PE C179/728.55 C): implantação de quadras;

topografia; projeto de entradas, acessos e terraplanagem; planta das espécies vegetais I e II; planta de situação (equipe de arquitetura).

CARDOZO, R. C. Curriculum vitae. In: UNIVERSIDADE DE SÃO PAULO. Processo 52.1.14106.1.2: contrato docente. São Paulo: Departamento de projetos da Faculdade de Arquitetura e Urbanismo. 15/12/1987. 87p. 


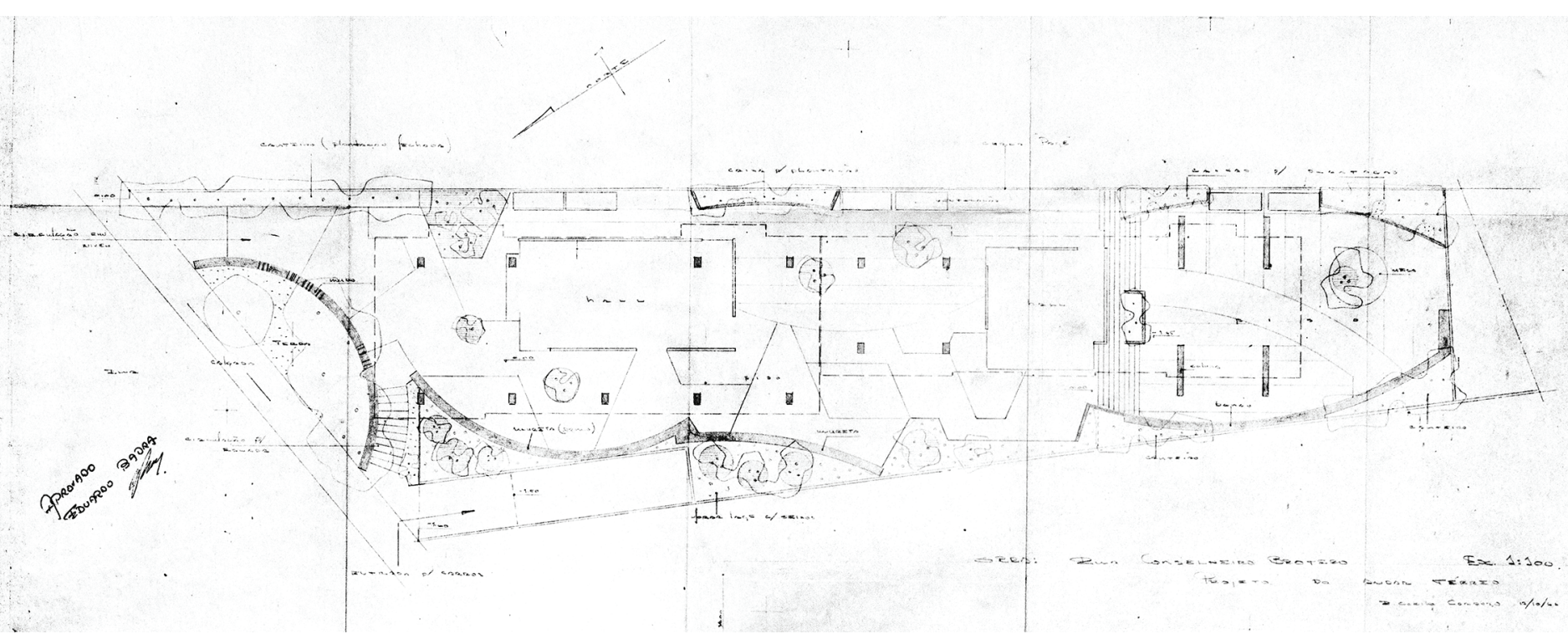

\section{CONDOMÍNIO EDIFÍCIO SÃO MIGUEL}

Cliente: não consta

Data de projeto: 1966

Data da publicação: não foi publicado

Projeto: não consta

Projetos complementares: não consta

Construção: não consta data, mas foi construído

Paisagismo: Roberto Coelho Cardozo

Tipologia: residencial

Endereço: Rua Conselheiro Brotero, 1378 - Santa Cecília - São Paulo/SP

Material:

Acervo da biblioteca da FAUUSP (Cód PE C179/712.6 CB): implantação de paisagismo.

Imagens do Arquiteto Filipe Dória.

Observações: Na planta há uma assinatura de Eduardo Badra. 


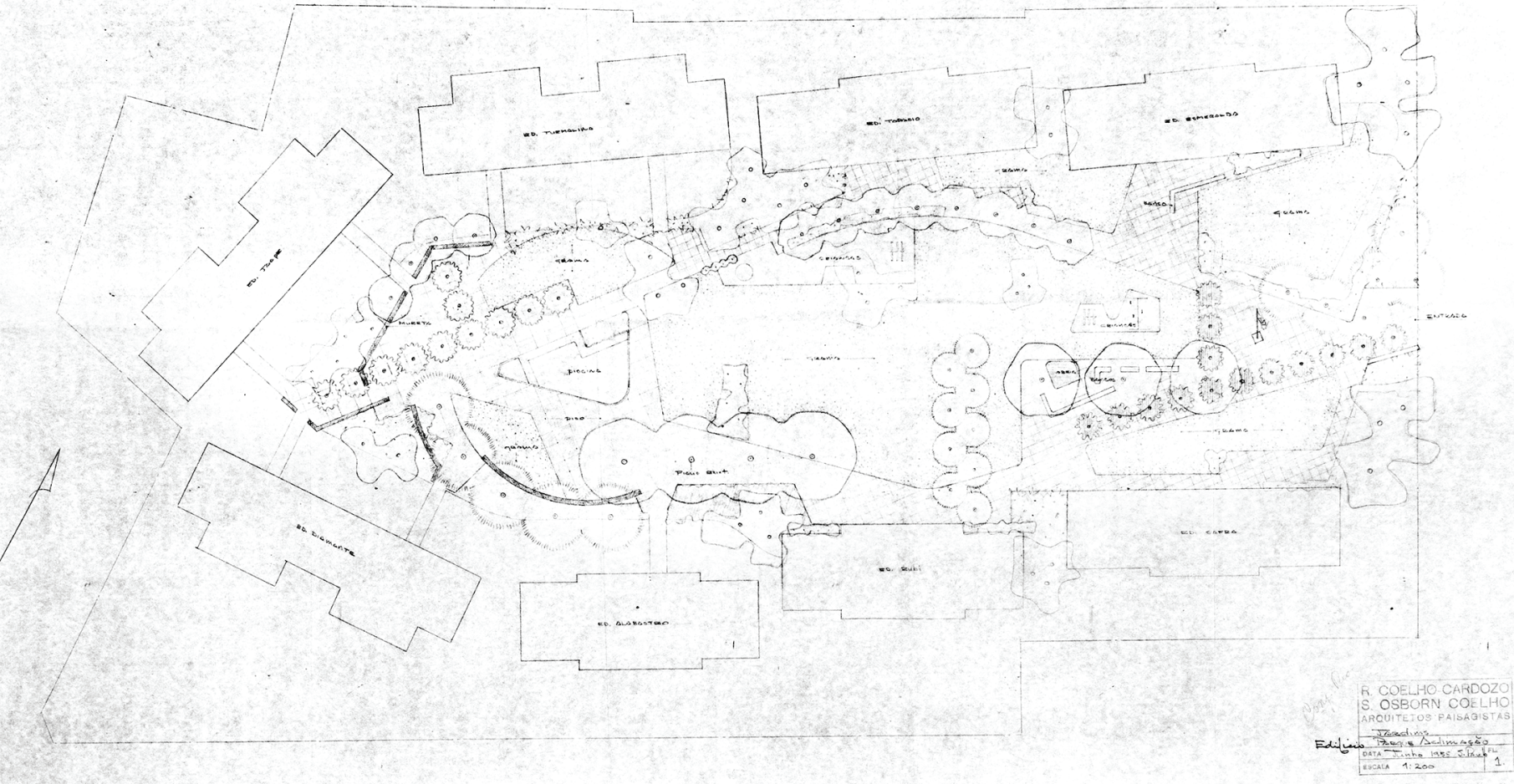

\section{CONDOMÍNIO PARQUE ACLIMAÇÃO}

Cliente: Alexander Marcondes e Imobiliária Vaz Guimarães Ltda.

Data de projeto: 1955

Data da publicação: 1958

Projeto: Imobiliária Vaz Guimarães Ltda.

Projetos complementares: não consta

Construção: construído por Imobiliária Vaz Guimarães Ltda.

Paisagismo: Roberto Coelho Cardozo e Susan Osborn Cardozo

Tipologia: residencial

Endereço: Rua Cândido Nascimento - Itaim Bibi - São Paulo/SP

Material:

Acervo da biblioteca da FAUUSP (Cód. PE C179/712.6 AM): implantação, 4 pranchas de detalhe de escadas, 1 corte e 1 detalhe de tanque de água.

ARAÚJO, D. B. S. G. Roberto Coelho Cardozo: vida, obra, perpetuação e resquícios de uma produção paisagística. Paisagem e Ambiente, São Paulo, n. 22 (especial ENEPEA), p. 94-109. 2006.

CARDOZO, R. C. Curriculum vitae. In: UNIVERSIDADE DE SÃO PAULO. Processo 52.1.14106.1.2: contrato docente. São Paulo: Departamento de projetos da Faculdade de Arquitetura e Urbanismo. 15/12/1987. 87p.

CONJUNTO Residencial. Acrópole, São Paulo, 237, p. 441-3, jul. 1958. 


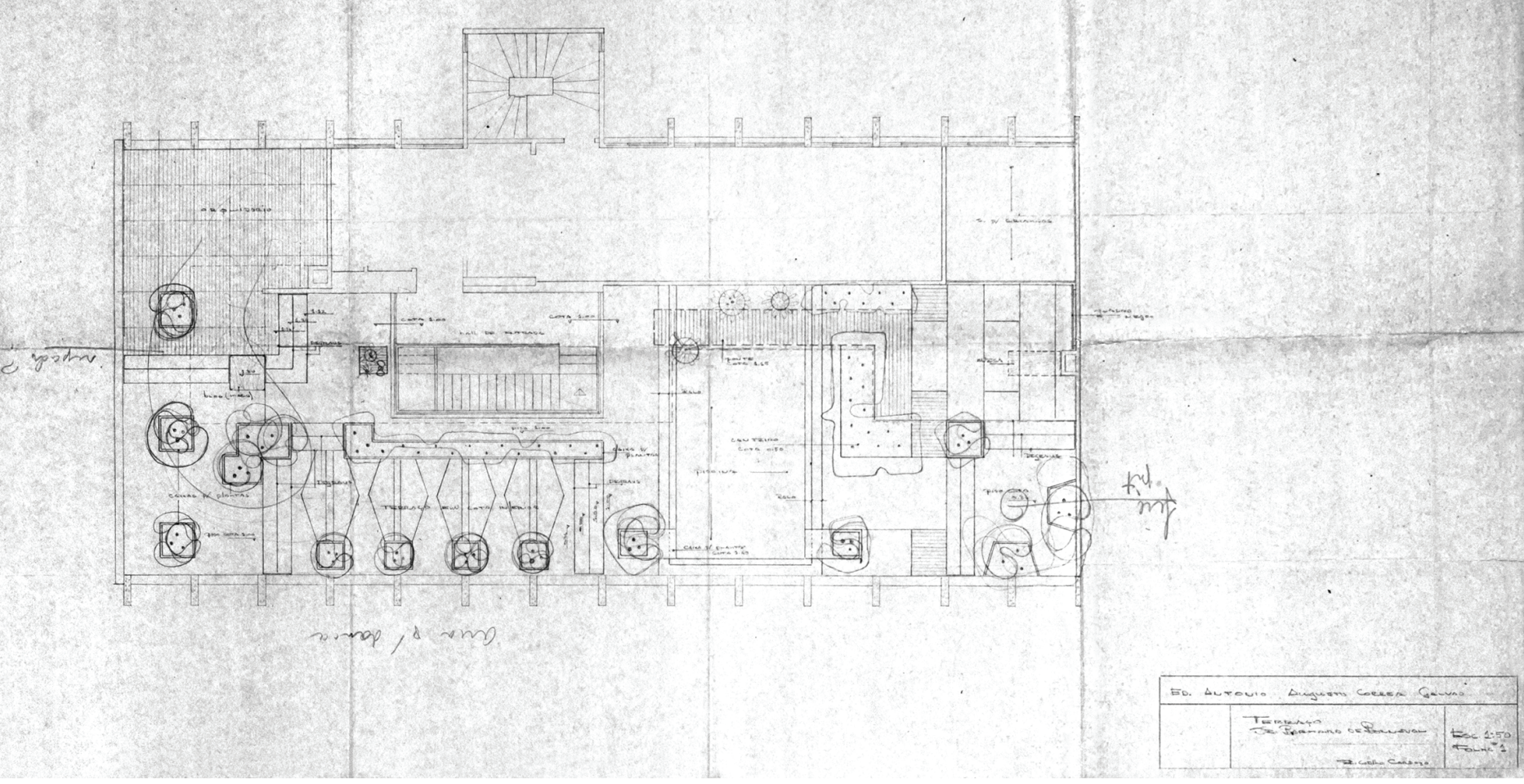

\section{EDIFÍCIO ANTÔNIO AUGUSTO CORRÊA GALVÃO}

Cliente: Conde Barnard de Bonneval

Data de projeto: 1964

Data da publicação: 1969

Projeto: Botti Rubin Arquitetos

Projetos complementares: não consta

Construção: Alberto R. Botti e Marc Rubin Arquitetura e Construtora Ltda.

Paisagismo: Roberto Coelho Cardozo

Tipologia: residencial

Endereço: Alameda Ministro Rocha Azevedo, 45 - Consolação - São Paulo/SP

Material:

Acervo da biblioteca da FAUUSP (Cód. PE C179/712.6 BB): implantação de paisagismo.

OTMER, R. [org.]. Botti Rubin Arquitetos: selected and current works. Mulgrave: Images

Pub. Group, 2002, 355p.

ELEMENTOS de fechamento em edifícios. Acrópole, São Paulo, 367, p. 17-25, nov. 1969. 


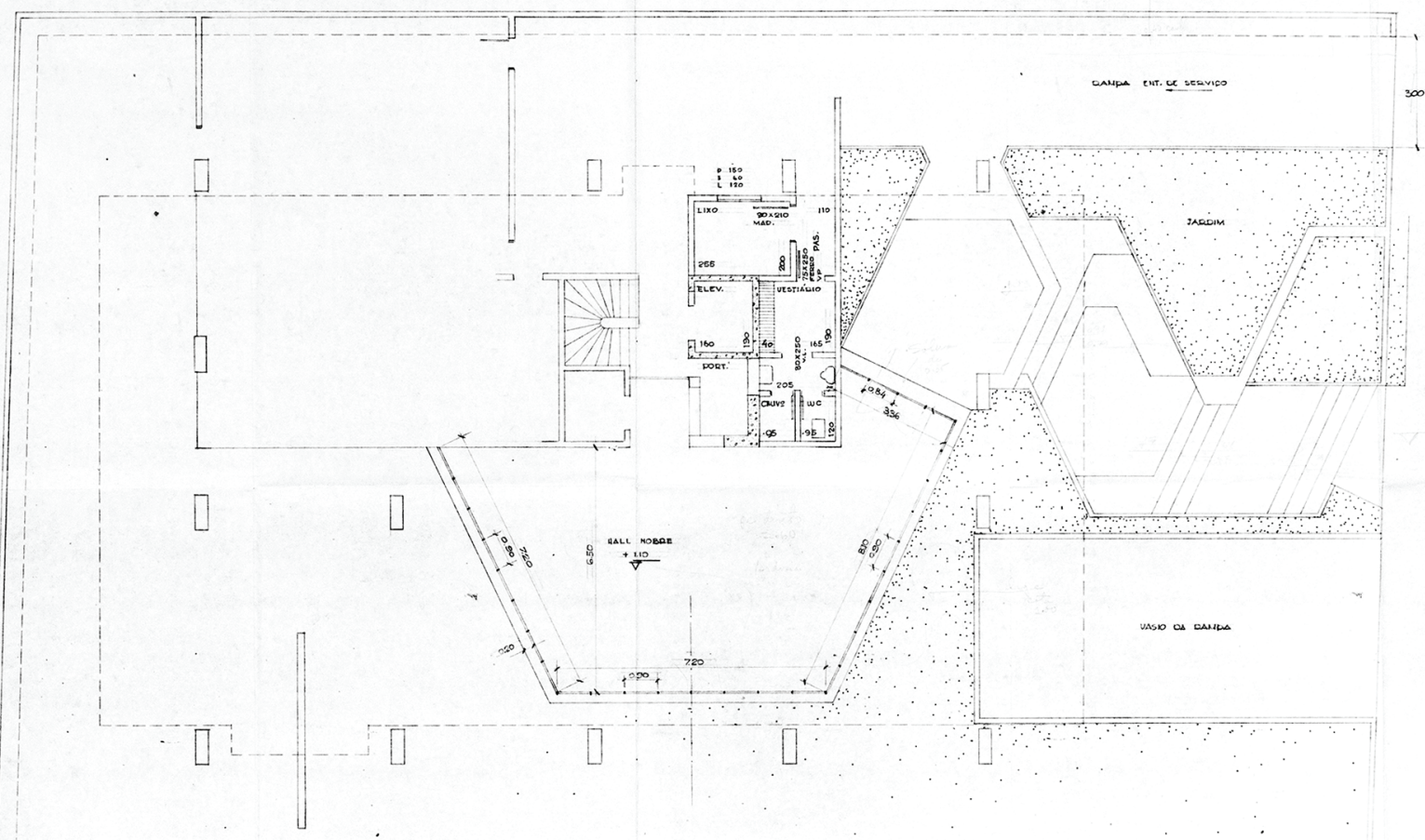

\section{EDIFÍCIO DÓRIO PAMPHILLI}

Cliente: não consta

Data de projeto: não consta

Data da publicação: não foi publicado

Projeto: Flavio Pastore, Luigi Villacecchia e Paulo Ballario Arquitetos

Projetos complementares: não consta

Construção: construído por Comércio e Engenharia L.A.P. Ltda.

Paisagismo: Roberto Coelho Cardozo - Antunes / Souza Dias \& Fiaschi

Tipologia: não consta

Endereço: não consta

Material:

Acervo da biblioteca da FAUUSP (Cód PE C179es/728.1 D): planta do térreo; plantação; planta de pisos. 

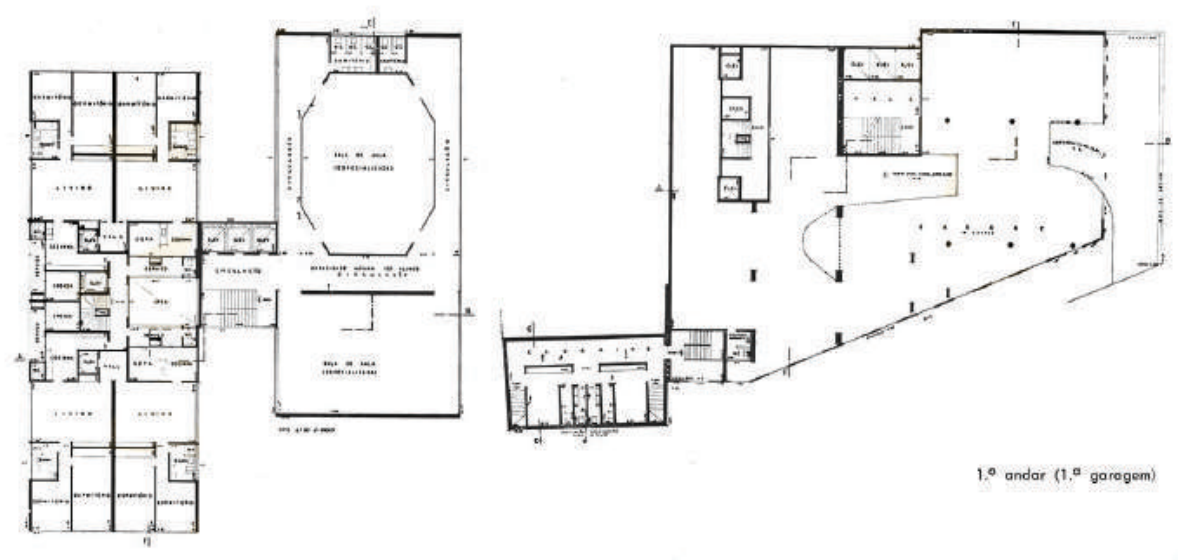

1.0 andar $(1,0$ garogem)
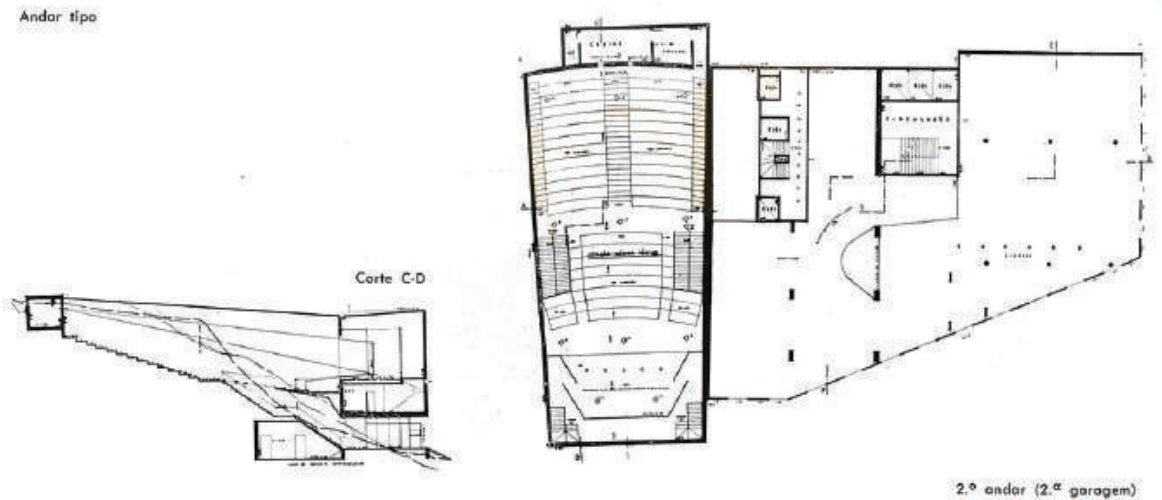

\section{EDIFÍCIO DA FUNDAÇÃO GETÚLIO VARGAS}

Cliente: Fundação Getúlio Vargas

Data de projeto: 1967

Data da publicação: 1961

Projeto: Miguel Brada Jr.

Projetos complementares: não consta

Construção: Better Engenharia

Paisagismo: Roberto Coelho Cardozo

Tipologia: institucional

Endereço: Avenida 9 de Julho - São Paulo/SP

Material:

CARDOZO, R. C. Curriculum vitae. In: UNIVERSIDADE DE SÃO PAULO. Processo

52.1.14106.1.2: contrato docente. São Paulo: Departamento de projetos da Faculdade de Arquitetura e Urbanismo. 15/12/1987. 87p.

EDIFÍCIO para Escola de Administração. Acrópole, n. 275, p. 287-9, out. 1961. 


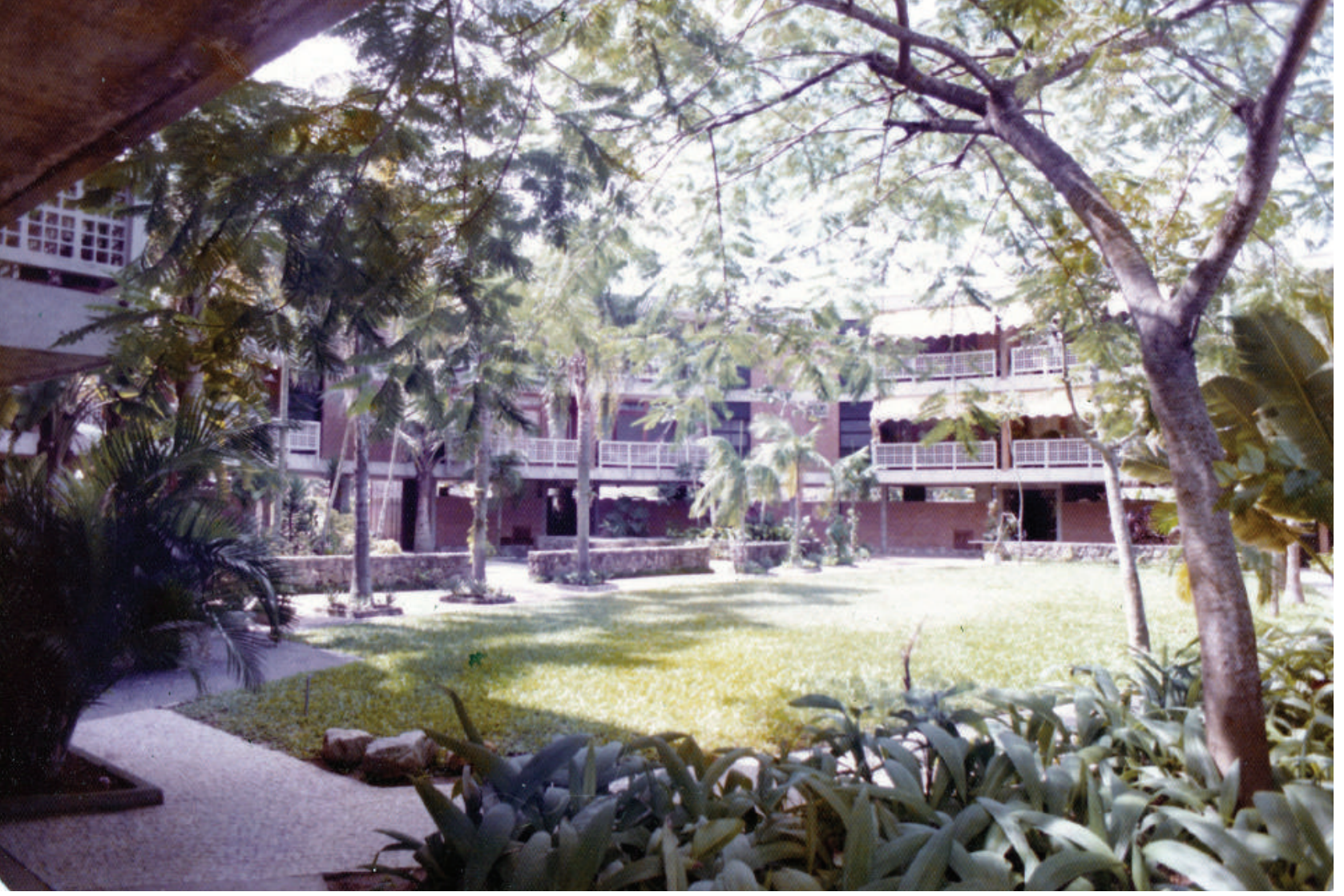

\section{EDIFÍCIO PÁTIO TROPICAL}

Cliente: Zolko Hamburger Ltda.

Data de projeto: 1966

Data da publicação: 1970

Projeto: Gregório Zolko

Projetos complementares: não consta

Construção: Zolko Hamburger Ltda. (finalizado em 1968)

Paisagismo: Roberto Coelho Cardozo

Tipologia: residencial

Endereço: Rua Marivaldo Fernandes, 370 - Praia da Enseada - Guarujá/SP

Material:

Acervo da biblioteca da FAUUSP (Cód PE C179/712.5 T).

Imagens do acervo de Gregório Zolko.

EDIFÍCIO de apartamentos. Acrópole, São Paulo, 371, p. 34-5, mar. 1970.

Observações: Projeto de arquitetura foi escolhido para a X Bienal de Arte de São Paulo. 

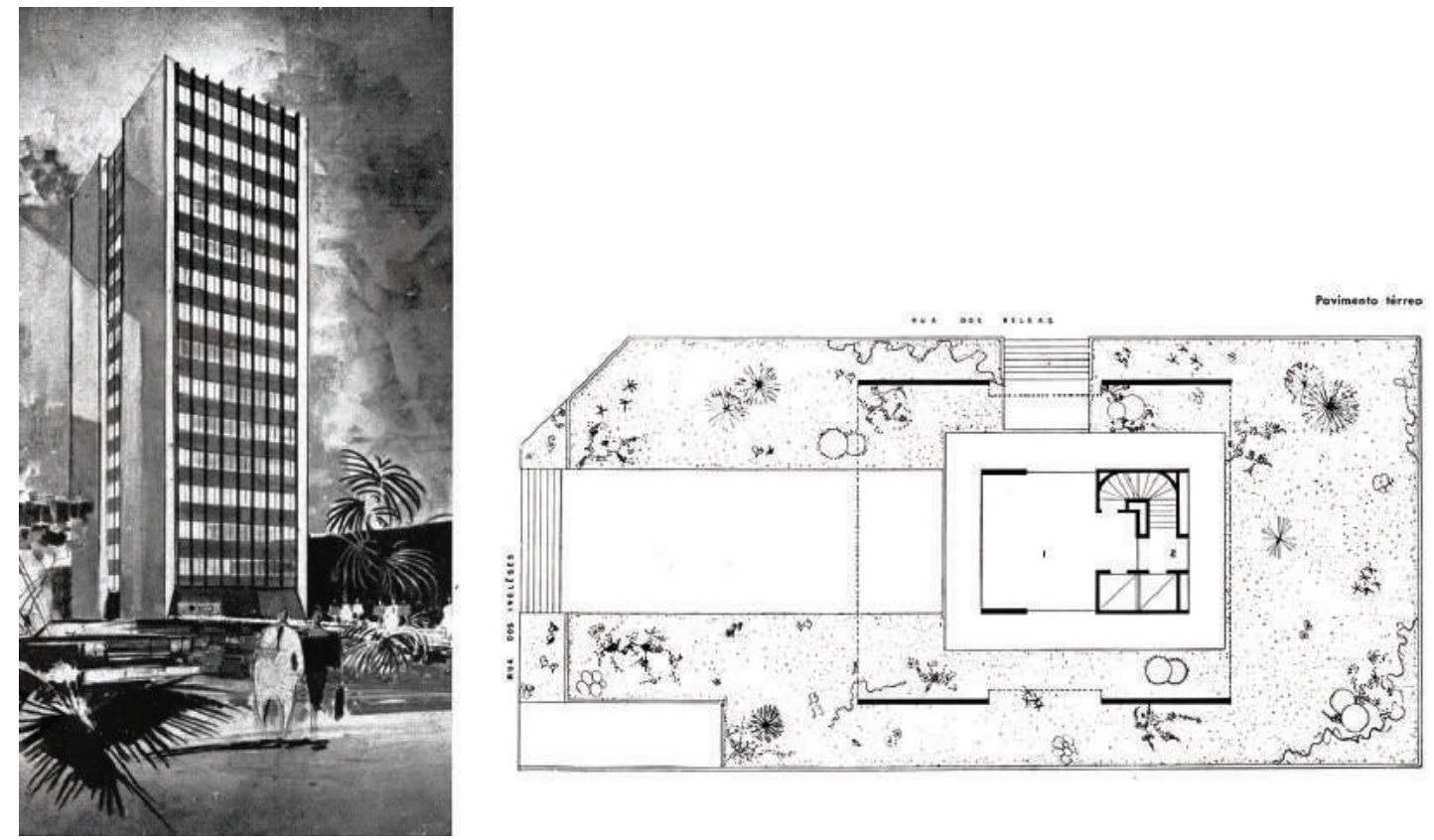

\section{EDIFÍCIO RUA DOS INGLESES}

Cliente: não consta

Data de projeto: não consta

Data da publicação: 1963

Projeto: Botti Rubin Arquitetos

Projetos complementares:

Construção: Construtora Yasbeck Ltda.

Paisagismo: Roberto Coelho Cardozo

Tipologia: residencial

Endereço: Rua dos Ingleses, 524 - Bela Vista - São Paulo/SP

Material:

CARDOZO, R. C. Curriculum vitae. In: UNIVERSIDADE DE SÃO PAULO. Processo

52.1.14106.1.2: contrato docente. São Paulo: Departamento de projetos da Faculdade de Arquitetura e Urbanismo. 15/12/1987. 87p.

EDIFÍCIO de apartamentos. Acrópole, n. 292, p. 119, mar. 1963. 


\section{EMBAIXADA DA LÍBIA}

Cliente: não consta

Data de projeto: 1954

Data da publicação: não consta

Projeto: não consta

Projetos complementares: não consta

Construção: não consta

Paisagismo: Roberto Coelho Cardozo

Tipologia: institucional

Endereço: SHIS QI 15, Chácara 26 - Lago Sul - Brasília/DF

Material:

CARDOZO, R. C. Curriculum vitae. In: UNIVERSIDADE DE SÃO PAULO. Processo

52.1.14106.1.2: contrato docente. São Paulo: Departamento de projetos da Faculdade de Arquitetura e Urbanismo. 15/12/1987. 87p.

\section{ESCOLA PRIMÁRIA RURAL E PLANTAÇÃO MORRO VERMELHO}

Cliente: não consta

Data de projeto: não consta

Data da publicação: não consta

Projeto: não consta

Projetos complementares: não consta

Construção: não consta

Paisagismo: Roberto Coelho Cardozo

Tipologia: institucional

Endereço: Mogi Mirim/SP

Material:

CARDOZO, R. C. Curriculum vitae. In: UNIVERSIDADE DE SÃO PAULO. Processo

52.1.14106.1.2: contrato docente. São Paulo: Departamento de projetos da Faculdade de Arquitetura e Urbanismo. 15/12/1987. 87p. 


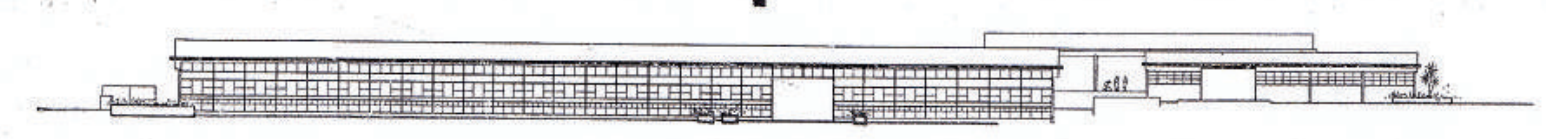

ELEvazo nOATE
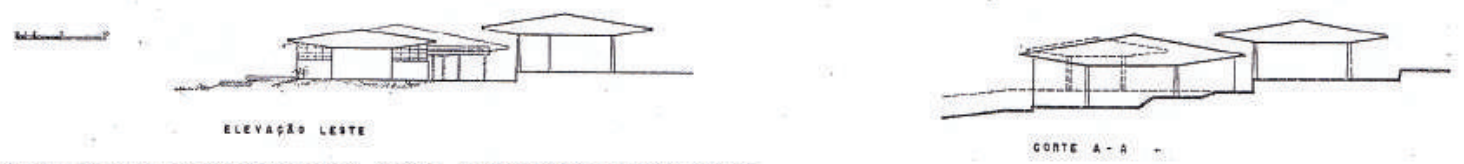

Salas de aula em desnivel de 1 metro. Composição de três cober-

turas, aproveitando os desniveis do terreno. Três funçōes separadas:

oficinas-salas de aula, pavilhão social e administração.

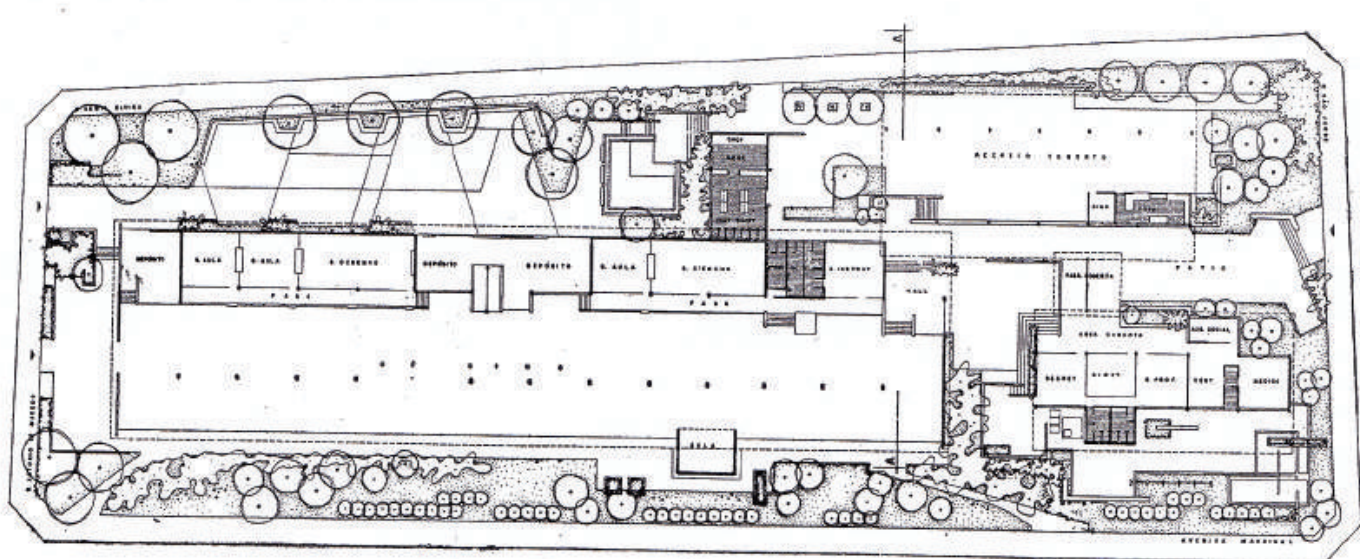

\section{ESCOLA SENAI DE CONSTRUÇÃO CIVIL “FREDERICO JACOB”}

Cliente: Serviço Nacional de Aprendizagem Industrial (SENAI)

Data de projeto: não consta

Data da publicação: 1962

Projeto: Lúcio Grinover

Projetos complementares: não consta

Construção: não consta

Paisagismo: Roberto Coelho Cardozo

Tipologia: institucional

Endereço: Rua São Jorge, 634 - Tatuapé - São Paulo/SP

Material:

Acervo da biblioteca da FAUUSP: diapositivos da coleção Lucio Grinover.

CARDOZO, R. C. Curriculum vitae. In: UNIVERSIDADE DE SÃO PAULO. Processo

52.1.14106.1.2: contrato docente. São Paulo: Departamento de projetos da Faculdade de

Arquitetura e Urbanismo. 15/12/1987. 87p.

ESCOLA Senai de construção civil. Acrópole, São Paulo, 279, p. 78-81, fev. 1962.

ESCOLA de construção civil. Bem Estar, São Paulo, 5/6, p. 15, jun. 1960. 


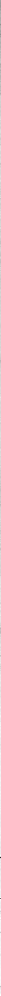

\section{ESCOLA SENAI DE OSASCO "NADIR DIAS DE FIGUEIREDO"}

Cliente: Serviço Nacional de Aprendizagem Industrial (SENAI)

Data de projeto: 1968

Data da publicação: não foi publicado

Projeto: não consta

Projetos complementares: não consta

Construção: não consta

Paisagismo: Roberto Coelho Cardozo, Antônio A. Antunes Netto e Marcos de Souza Dias Tipologia: institucional

Endereço: Rua Ari Barroso, 305 - Presidente Altino - Osasco/SP

Material:

Acervo da biblioteca da FAUUSP (Cód. PE C179/727 so): plantação (3 folhas).

CARDOZO, R. C. Curriculum vitae. In: UNIVERSIDADE DE SÃO PAULO. Processo

52.1.14106.1.2: contrato docente. São Paulo: Departamento de projetos da Faculdade de Arquitetura e Urbanismo. 15/12/1987. 87p. 

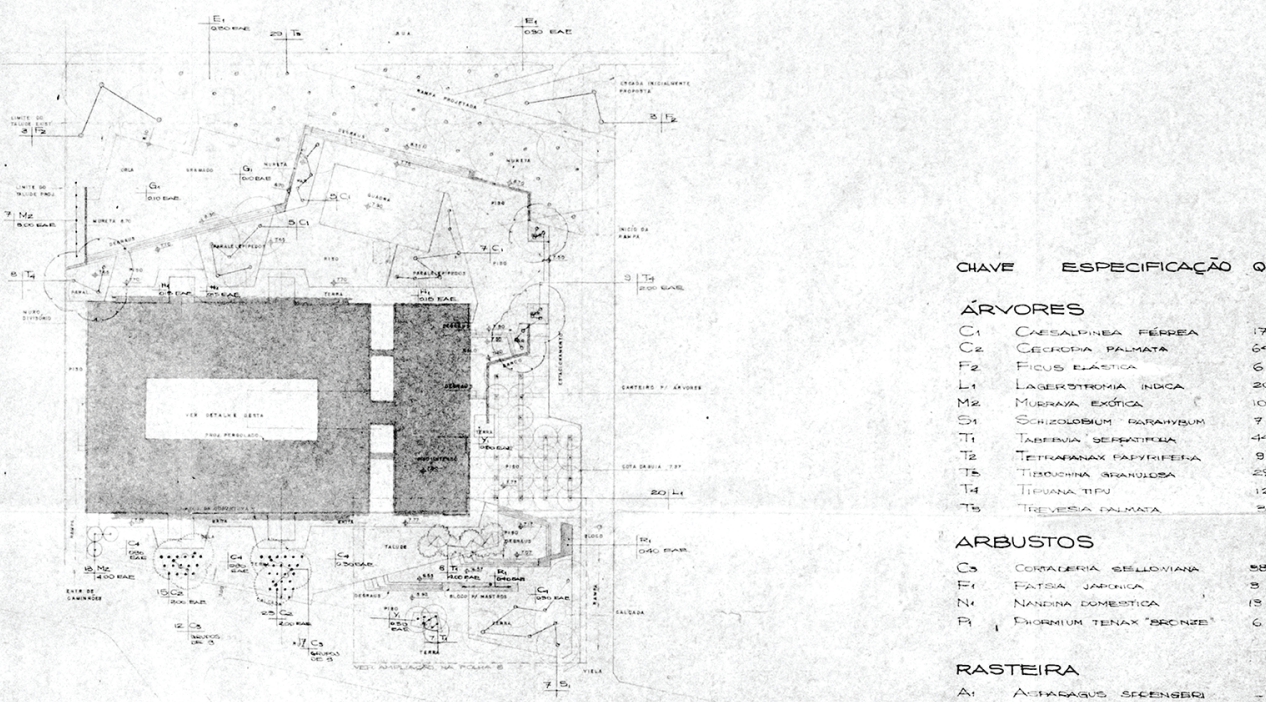

QUANT/

ARBUSTOS

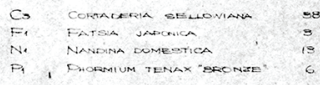

7

44

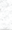

RASTEIRA

A. Ammomavs sefengest

A. Antramaus sefengases

Cueviod mamsoun

Enacaperis curav

GHANAL ONTATA

HiL STMRA HELX

MONSTERA DELCIOSA

MU

tom $m$ vioh

ruda filamentosá

\section{ESCOLA SENAI SÃO CAETANO}

Cliente: Serviço Nacional de Aprendizagem Industrial (SENAI)

Data de projeto: 1969

Data da publicação: não foi publicado

Projeto: Hélio Q. Duarte e Roberto J. G. Tibau (projeto de arquitetura de 1957)

Projetos complementares: não consta

Construção: não consta

Paisagismo: Roberto Coelho Cardozo, Antonio A. Antunes Netto e Marcos de Souza Dias Tipologia: institucional Endereço: não consta

Material:

Acervo da biblioteca da FAUUSP (Cód PE C179es/727 SC): paisagismo; plantação 1 e 2; planta; detalhes 14-25; detalhe de escada; detalhes de 1-13; paisagismo (locação); implantação; planta (edifício).

Observações: Existe um artigo sobre o SENAI São Caetano, mas não corresponde a este projeto. 
Planta do parimente terren com indicacion e de recreasion. 1-Entrada para autos; 2- entrada principal; : e $4-$ mesas; 5 - es ceadaria; 6 - quedra de cin Ch tima; $8-7$ bancos: - Tesraco: 10 - pal
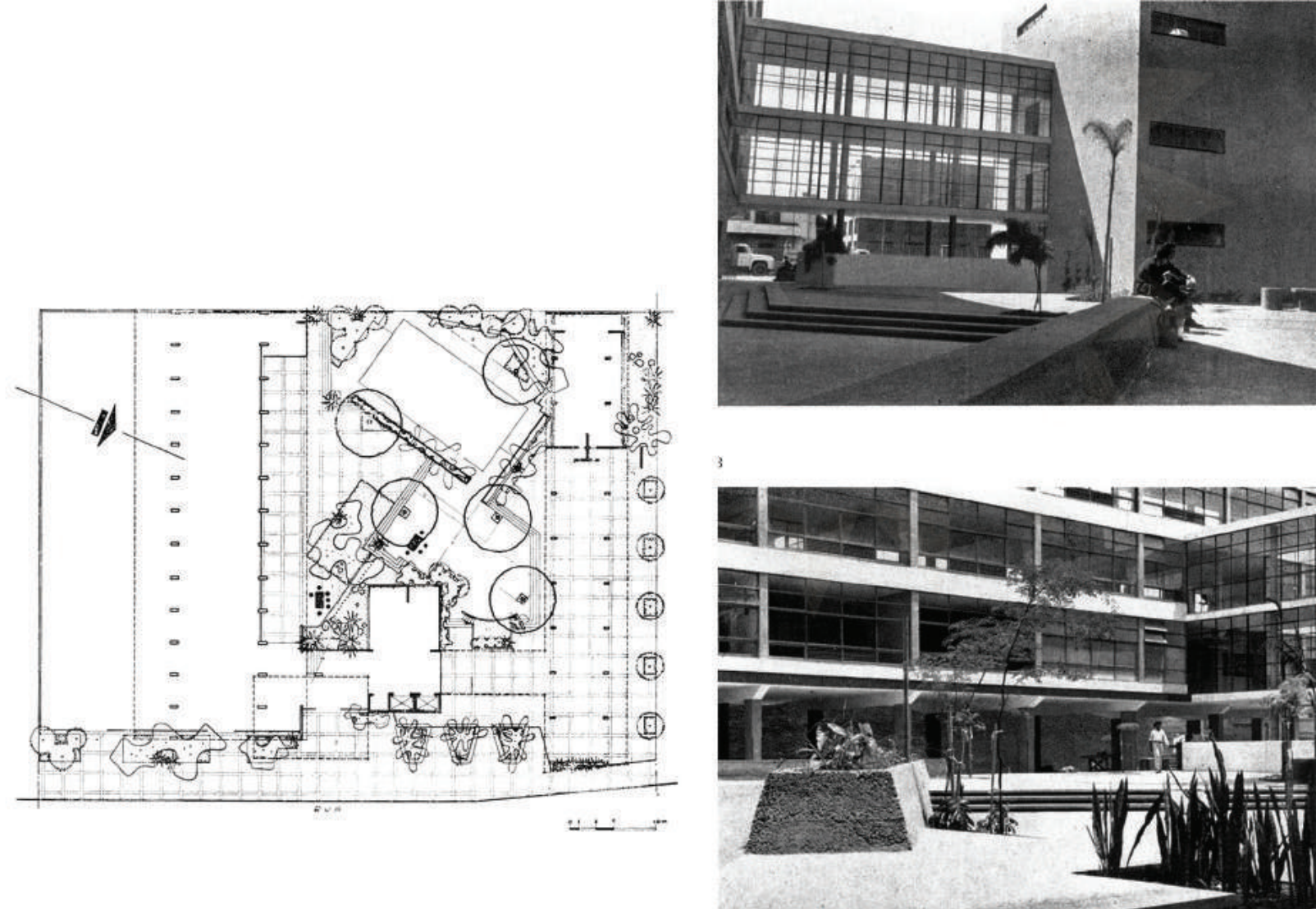

\section{ESCOLA TÊXTIL CENTRAL SENAI "FRANCISCO MATARAZZO”}

Cliente: Serviço Nacional de Aprendizagem Industrial (SENAI)

Data de projeto: não consta

Data da publicação: 1953

Projeto: Hélio Duarte e Ernest Robert Carvalho Mange

Projetos complementares: Eng. J. U. Burke Júnior (cálculo de concreto)

Construção: Eng. L. A. Falcão Bauer (Serviço de Obra do Senai - Departamento Regional de São Paulo).

Paisagismo: Roberto Coelho Cardozo

Tipologia: institucional

Endereço: Rua Correia de Andrade, 232 - Brás - São Paulo/SP

Material:

BAUER. L. A. F. Três escolas do Senai. Habitat, São Paulo, 12, p.16-19, set.1953.

CARDOZO, R. C. Curriculum vitae. In: UNIVERSIDADE DE SÃO PAULO. Processo

52.1.14106.1.2: contrato docente. São Paulo: Departamento de projetos da Faculdade de Arquitetura e Urbanismo. 15/12/1987. 87p.

ESCOLA Técnica Têxtil Francisco Matarazzo. Bem Estar, São Paulo, 5/6, p. 12, jun. 1960.

ESCOLA Têxtil “SENAl” em São Paulo. Acrópole, São Paulo, 241, p. 10-3, nov. 1958.

SENAI - Escola Têxtil Central (Brás - São Paulo). Acrópole, n. 197, p. 217-218, 1955. 


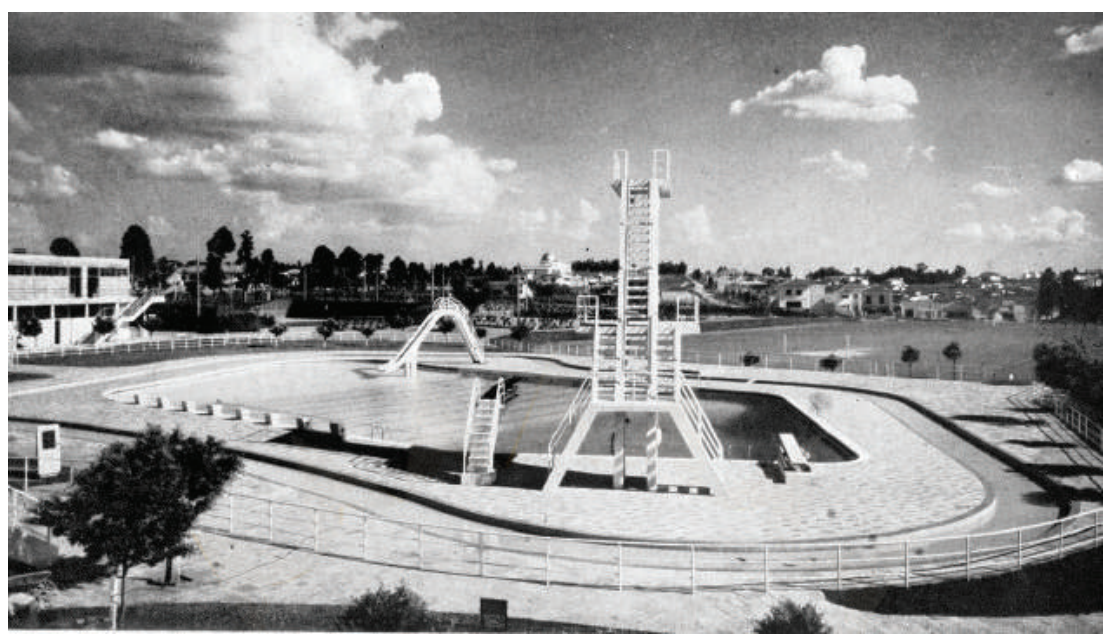

\section{ESPORTE CLUBE SÍRIO}

Cliente: não consta

Data de projeto: não consta

Data da publicação: 1957

Projeto: Ícaro de Castro Mello

Projetos complementares: não consta

Construção: Eduardo Salem

Paisagismo: Roberto Coelho Cardozo

Tipologia: comercial

Endereço: Avenida Indianópolis, 1192 - São Paulo/SP

Material:

CARDOZO, R. C. Curriculum vitae. In: UNIVERSIDADE DE SÃO PAULO. Processo

52.1.14106.1.2: contrato docente. São Paulo: Departamento de projetos da Faculdade de Arquitetura e Urbanismo. 15/12/1987. 87p.

PISCINA do Esporte Clube Sírio. Acrópole, n. 220, p. 124-5, fev. 1957. 


\section{FÁBRICA ARMAÇÕES DE AÇO PROBEL S.A.}

Cliente: Alberto Portella \& Cia Ltda.

Data de projeto: 1958

Data da publicação: não consta

Projeto: não consta

Projetos complementares: Escritório Lina Bo Bardi (arquitetura de interiores)

Construção: não consta

Paisagismo: Roberto Coelho Cardozo

Tipologia: comercial

Endereço: Rua Vilela, 307 - Tatuapé - São Paulo/SP

Material:

CARDOZO, R. C. Curriculum vitae. In: UNIVERSIDADE DE SÃO PAULO. Processo

52.1.14106.1.2: contrato docente. São Paulo: Departamento de projetos da Faculdade de Arquitetura e Urbanismo. 15/12/1987. 87p.

Acervo online do Instituto Lina Bo Bardi (http://www.institutobardi.com.br/documentos_ simples.asp?Obra_Codigo=512)

\section{FÁBRICA CATERPILLAR DO BRASIL S.A.}

Cliente: Caterpillar do Brasil S.A.

Data de projeto: 1969

Data da publicação: não consta

Projeto: não consta

Projetos complementares: não consta

Construção: construída entre 1955 e 1960

Paisagismo: Roberto Coelho Cardozo

Tipologia: comercial

Endereço: Avenida Alexandre Dumas, 1711 - Santo Amaro - São Paulo/SP

Material:

CARDOZO, R. C. Curriculum vitae. In: UNIVERSIDADE DE SÃO PAULO. Processo

52.1.14106.1.2: contrato docente. São Paulo: Departamento de projetos da Faculdade de Arquitetura e Urbanismo. 15/12/1987. 87p.

\section{FÁBRICA COFAP MAUÁ}

Cliente: Abraham Kasinski

Data de projeto: 1965

Data da publicação: não consta

Projeto: não consta

Projetos complementares: não consta

Construção: não consta

Paisagismo: Roberto Coelho Cardozo

Tipologia: comercial

Endereço: Avenida Manoel da Nóbrega, 350 - Capuava - Mauá/SP

Material:

CARDOZO, R. C. Curriculum vitae. In: UNIVERSIDADE DE SÃO PAULO. Processo

52.1.14106.1.2: contrato docente. São Paulo: Departamento de projetos da Faculdade de Arquitetura e Urbanismo. 15/12/1987. 87p. 


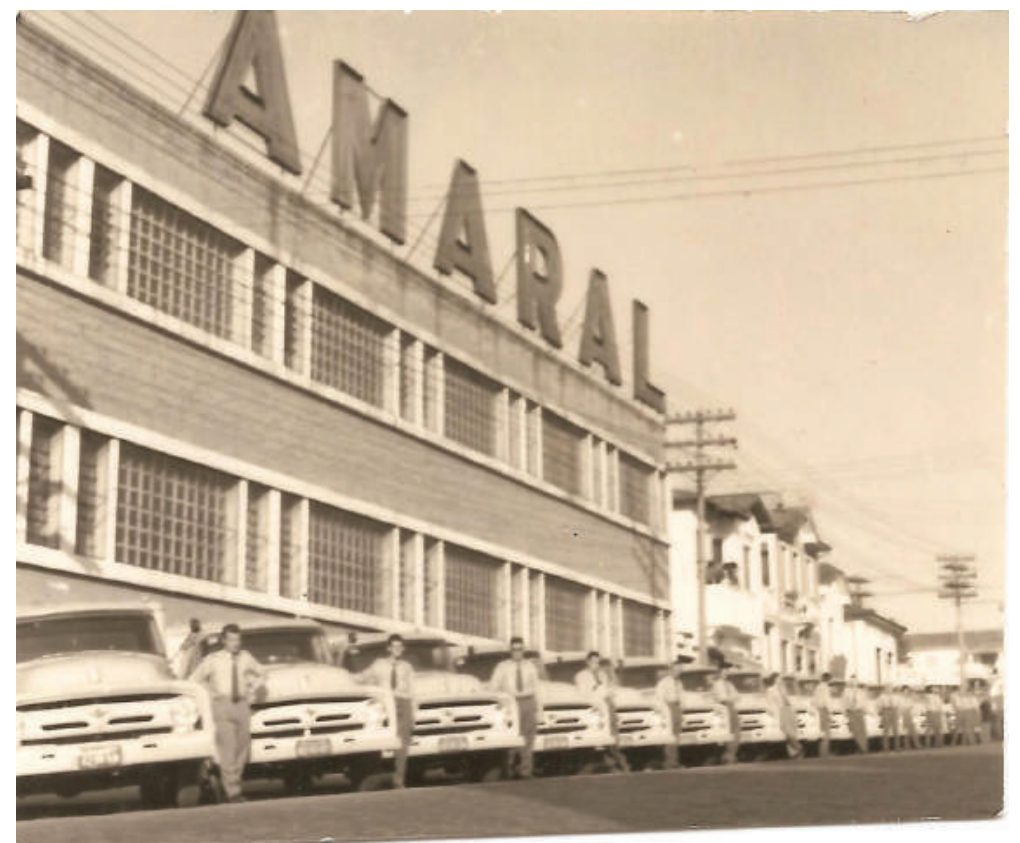

\section{FÁBRICA CESTAS DE NATAL AMARAL S.A.}

Cliente: Cestas de Natal Amaral S.A.

Data de projeto: 1960

Data da publicação: não consta

Projeto: não consta

Projetos complementares: não consta

Construção: não consta

Paisagismo: Roberto Coelho Cardozo

Tipologia: comercial

Endereço: Avenida Presidente Wilson, 2767/2789

Material:

CARDOZO, R. C. Curriculum vitae. In: UNIVERSIDADE DE SÃO PAULO. Processo

52.1.14106.1.2: contrato docente. São Paulo: Departamento de projetos da Faculdade de Arquitetura e Urbanismo. 15/12/1987. 87p. 

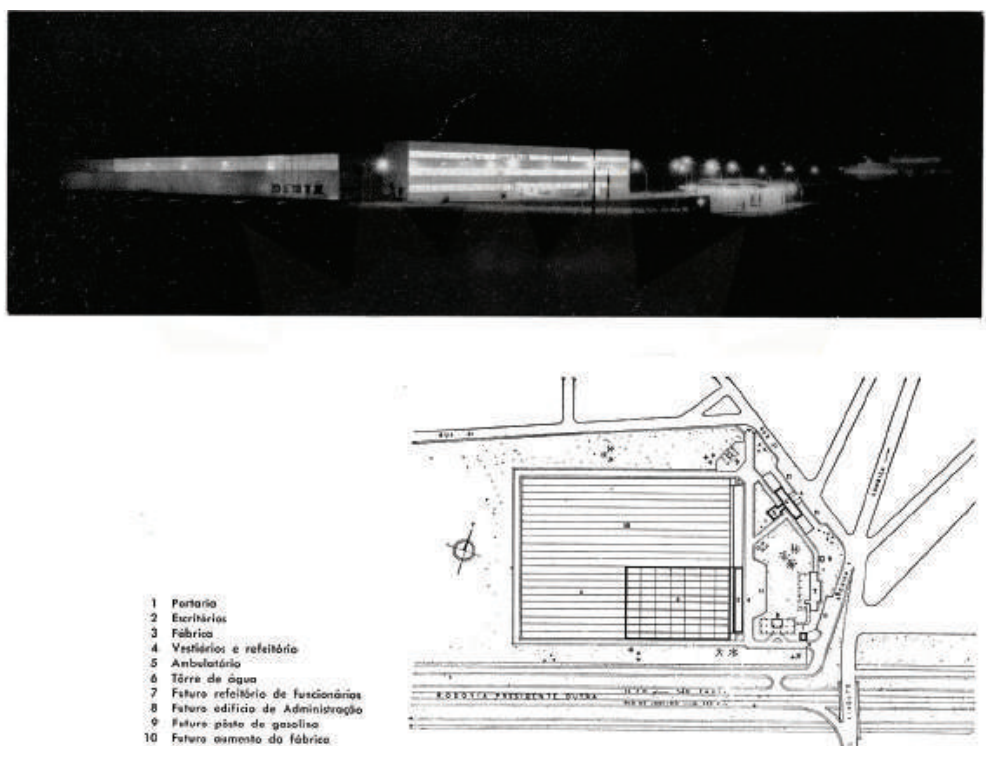

\section{FÁBRICA MOTORES OTTO DEUTZ}

Cliente: Otto Deutz S.A.

Data de projeto: 1965

Data da publicação: não consta

Projeto: Alfredo J. Duntuch

Projetos complementares: não consta

Construção: Arquitetura e Construções "Luz-Ar" S.A.

Paisagismo: Roberto Coelho Cardozo

Tipologia: comercial

Endereço: Rua Jati, 310 - Cumbica - Guarulhos/SP

Material:

CARDOZO, R. C. Curriculum vitae. In: UNIVERSIDADE DE SÃO PAULO. Processo

52.1.14106.1.2: contrato docente. São Paulo: Departamento de projetos da Faculdade de Arquitetura e Urbanismo. 15/12/1987. 87p.

FÁBRICA de motores. Acrópole, 290, p. 56-7, jan. 1963. 


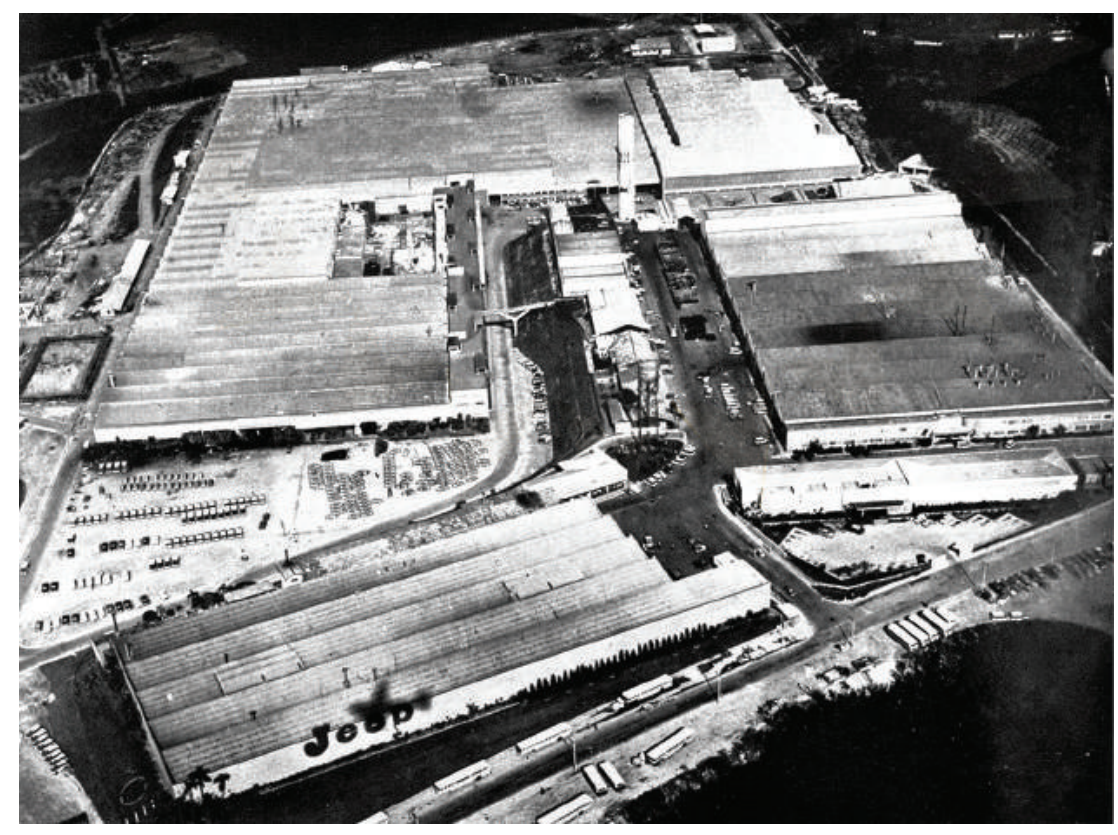

\section{FÁBRICA WILLYS OVERLAND DO BRASIL S.A.}

Cliente: Willys Overland do Brasil S.A.

Data de projeto: 1960

Data da publicação: 1960

Projeto: Kaiser - Engenharia e Construções Ltda.

Projetos complementares:

Construção: Kaiser - Engenharia e Construções Ltda. (subcontratadas: Louzada

Cavalcanti \& Cia. Ltda., Hedeager Bosworth do Brasil S/A, Construtora e de Imóveis S.

Paulo S/A)

Paisagismo: Roberto Coelho Cardozo

Tipologia: comercial

Endereço: Avenida do Taboão, 899 - Taboão - São Bernardo do Campo

Material:

CARDOZO, R. C. Curriculum vitae. In: UNIVERSIDADE DE SÃO PAULO. Processo

52.1.14106.1.2: contrato docente. São Paulo: Departamento de projetos da Faculdade de Arquitetura e Urbanismo. 15/12/1987. 87p.

CONJUNTO Industrial da Willys Overland. Acrópole, n.265, p. 24-27, nov. 1960. 


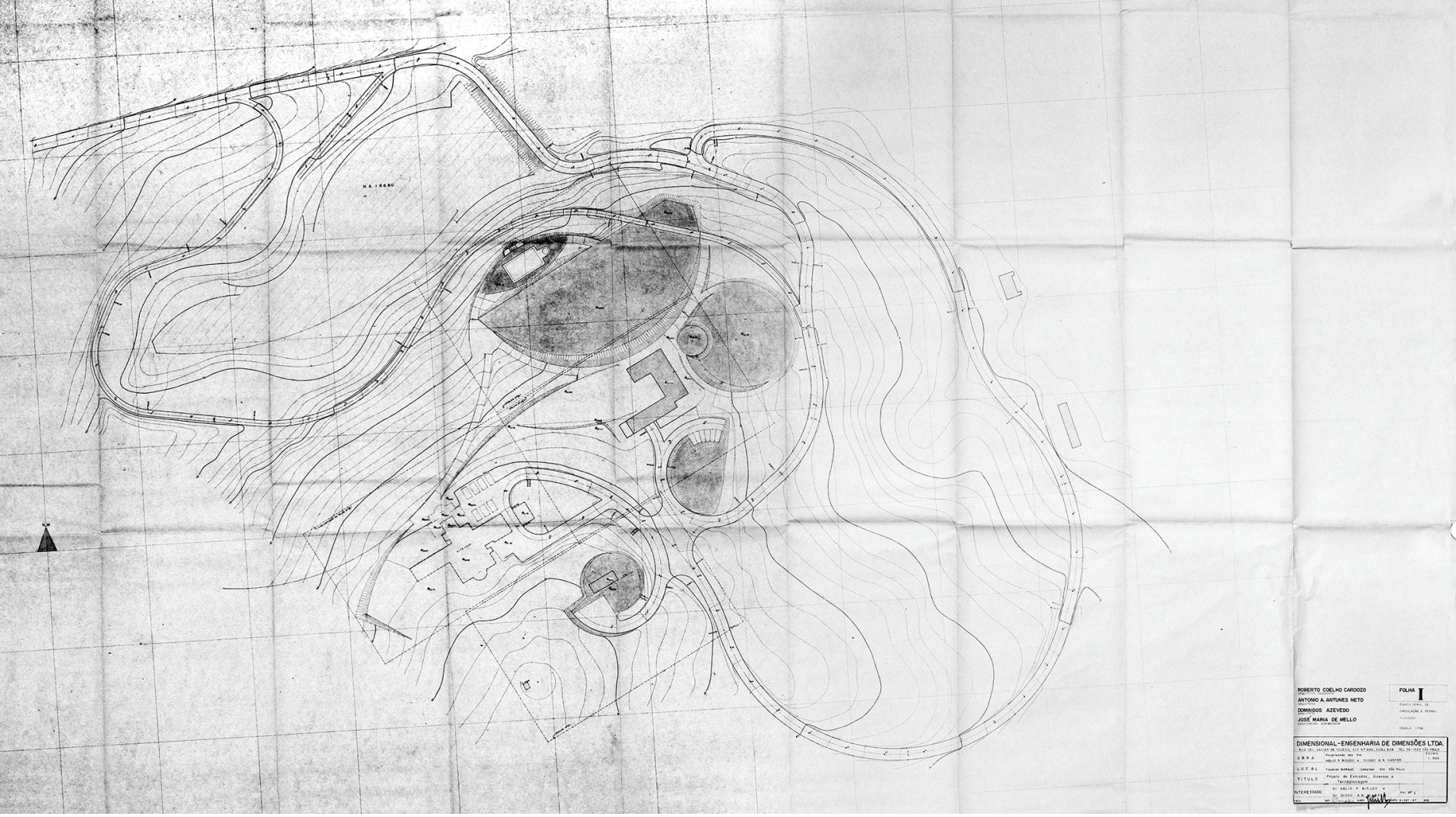

\section{FAZENDA MARAJÓ}

Cliente: Hélio P. Bicudo e Diogo A. N. Gaspar

Data de projeto: 1967

Data da publicação: não foi publicado

Projeto: Roberto Coelho Cardozo, Antonio A. Antunes Neto, Marcos de Souza Dias,

Domingos Azevedo, José Maria de Mello (Eng. Agromensor)

Projetos complementares: Dimensional - Engenharia de Dimensões Ltda.

Construção: não consta

Paisagismo: Roberto Coelho Cardozo, Antonio A. Antunes Neto, Marcos de Souza Dias,

Domingos Azevedo, José Maria de Mello (Eng. Agromensor)

Tipologia: residencial

Endereço: Fazenda Marajó - Campinas/SP

Material:

Acervo da biblioteca da FAUUSP (Cód. PE C179/728.67 H): detalhes da residência de Dr. Diogo Gaspar; residência Dr. Diogo Gaspar; projeto de estradas, acessos e terraplanagem; planta de iluminação e localização de quadras; áreas a serem tratadas com irrigação; projeto geral de plantação; pavilhão para os hóspedes; detalhe do pavilhão para os hóspedes; residência Dr. Hélio Bicudo; detalhes da residência do Dr. Hélio Bicudo.; pavilhão e piscina.

CARDOZO, R. C. Curriculum vitae. In: UNIVERSIDADE DE SÃO PAULO. Processo 52.1.14106.1.2: contrato docente. São Paulo: Departamento de projetos da Faculdade de Arquitetura e Urbanismo. 15/12/1987. 87p. 


\section{FAZENDA MORRO VELHO}

Cliente: Sebastião Camargo

Data de projeto: 1960

Data da publicação: não consta

Projeto: não consta

Projetos complementares: não consta

Construção: não consta

Paisagismo: Roberto Coelho Cardozo

Tipologia: comercial

Endereço: Rodovia Saulo Waldemar Fornazin - Fazenda Morro Velho (Estrada do

Sapezeiro) - Santa Bárbara D’Oeste/SP

Material:

CARDOZO, R. C. Curriculum vitae. In: UNIVERSIDADE DE SÃO PAULO. Processo

52.1.14106.1.2: contrato docente. São Paulo: Departamento de projetos da Faculdade de Arquitetura e Urbanismo. 15/12/1987. 87p.

\section{FAZENDA SÃO CALIXTO}

Cliente: Gastão Vidigal

Data de projeto: 1960

Data da publicação: não consta

Projeto: não consta

Projetos complementares: não consta

Construção: não consta

Paisagismo: Roberto Coelho Cardozo

Tipologia: comercial

Endereço: Rua Augusto Cavedini - Monte Serrat - Itupeva/SP

Material:

CARDOZO, R. C. Curriculum vitae. In: UNIVERSIDADE DE SÃO PAULO. Processo

52.1.14106.1.2: contrato docente. São Paulo: Departamento de projetos da Faculdade de Arquitetura e Urbanismo. 15/12/1987. 87p.

\section{HOSPITAL ISRAELITA ALBERT EINSTEIN}

Cliente: não consta

Data de projeto: 1964

Data da publicação: 1958

Projeto: Rino Levi, Roberto Cerqueira Cesar e Luiz R. Carvalho Franco (projeto de arquitetura de 1958)

Projetos complementares: não consta

Construção: Construtora Waldomiro Zarzur

Paisagismo: Roberto Coelho Cardozo

Tipologia: institucional

Endereço: Avenida Albert Einsten, 627/701 - Morumbi - São Paulo/SP

Material:

Acervo biblioteca FAUUSP (cód. PE L578/725.5 HAV1-3).

Acervo biblioteca FAUUSP: diapositivos da coleção Rino Levi.

ANTE-PROJETO para o Hospital Albert Einstein. Acrópole, São Paulo, 239, p. 510-515, set. 1958

CARDOZO, R. C. Curriculum vitae. In: UNIVERSIDADE DE SÃO PAULO. Processo 52.1.14106.1.2: contrato docente. São Paulo: Departamento de projetos da Faculdade de Arquitetura e Urbanismo. 15/12/1987. 87p. 


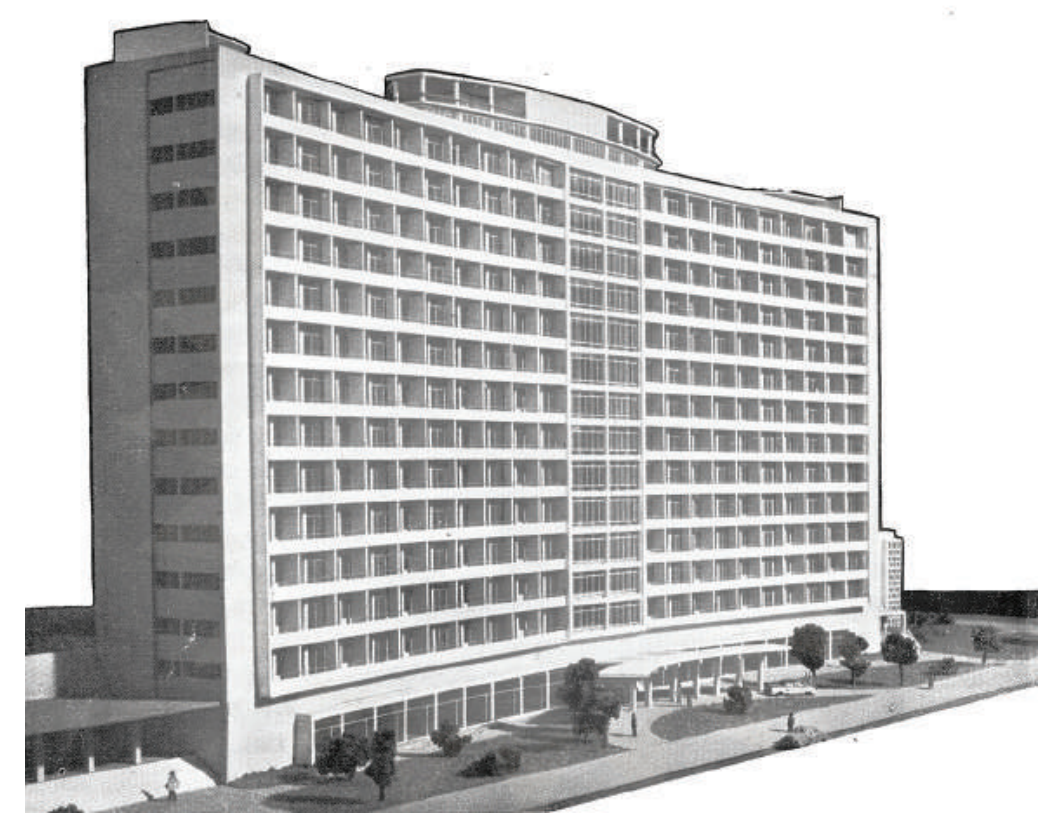

\section{HOTEL INTERLAGOS}

Cliente: não consta

Data de projeto: 1955

Data da publicação: 1953

Projeto: Escritório Técnico de Engenharia

Projetos complementares:

Construção: Mieczyslaw Grabowski Ltda.

Paisagismo: Roberto Coelho Cardozo

Tipologia: comercial

Endereço: Avenida Atlântica, 2113 - Interlagos - São Paulo/SP

Material:

CARDOZO, R. C. Curriculum vitae. In: UNIVERSIDADE DE SÃO PAULO. Processo

52.1.14106.1.2: contrato docente. São Paulo: Departamento de projetos da Faculdade de Arquitetura e Urbanismo. 15/12/1987. 87p.

GRANDE Hotel Interlagos. Acrópole, n. 179, p. 401-2, mar. 1953.

MARTINS, V. Interlagos: Desafios de um Projeto de 'Cidade-Jardim'. Dissertação (Mestrado em Arquitetura e Urbanismo). USJT, São Paulo, 2012. 138p. 


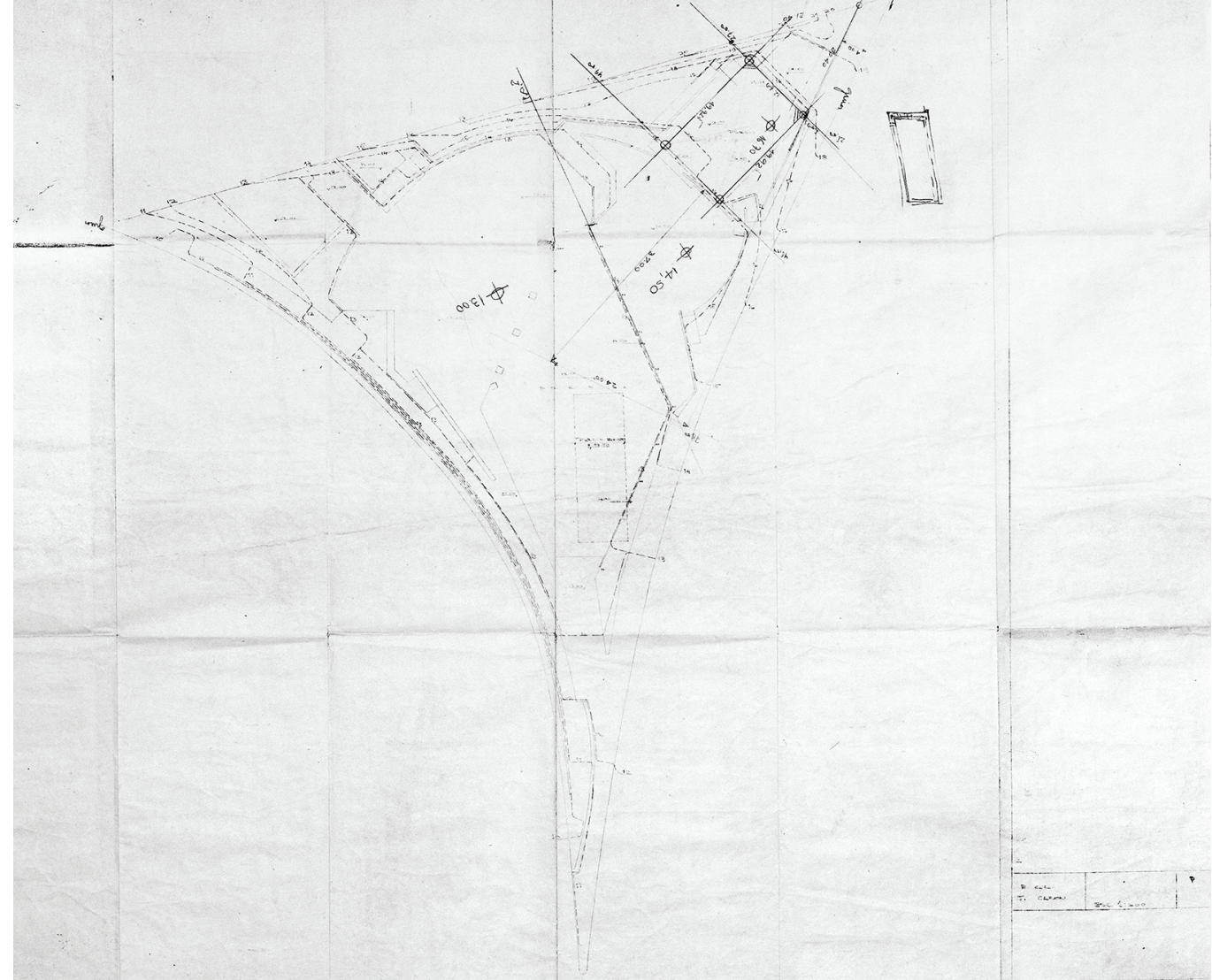

IGREJA DE ZINCO - PARÓQUIA SANTOS APÓSTOLOS

Cliente: Padre Patricio Hughes

Data de projeto: 1969

Data da publicação: não foi publicado

Projeto: Jorge Caron

Projetos complementares: não consta

Construção: não consta

Paisagismo: Roberto Coelho Cardozo, Antunes / Souza \& Fiaschi

Tipologia: institucional

Endereço: Avenida Itaberaba, 3907 - Jardim Maracanã - São Paulo/SP

Material:

Acervo da biblioteca da FAUUSP (Cód. PE C179es/726.5 I): planta do batistério; planta de locação; implantação; execução.

CARDOZO, R. C. Curriculum vitae. In: UNIVERSIDADE DE SÃO PAULO. Processo

52.1.14106.1.2: contrato docente. São Paulo: Departamento de projetos da Faculdade de Arquitetura e Urbanismo. 15/12/1987. 87p.

Observação: No currículo de Roberto Coelho Cardozo ele data o projeto da igreja em 1965. 


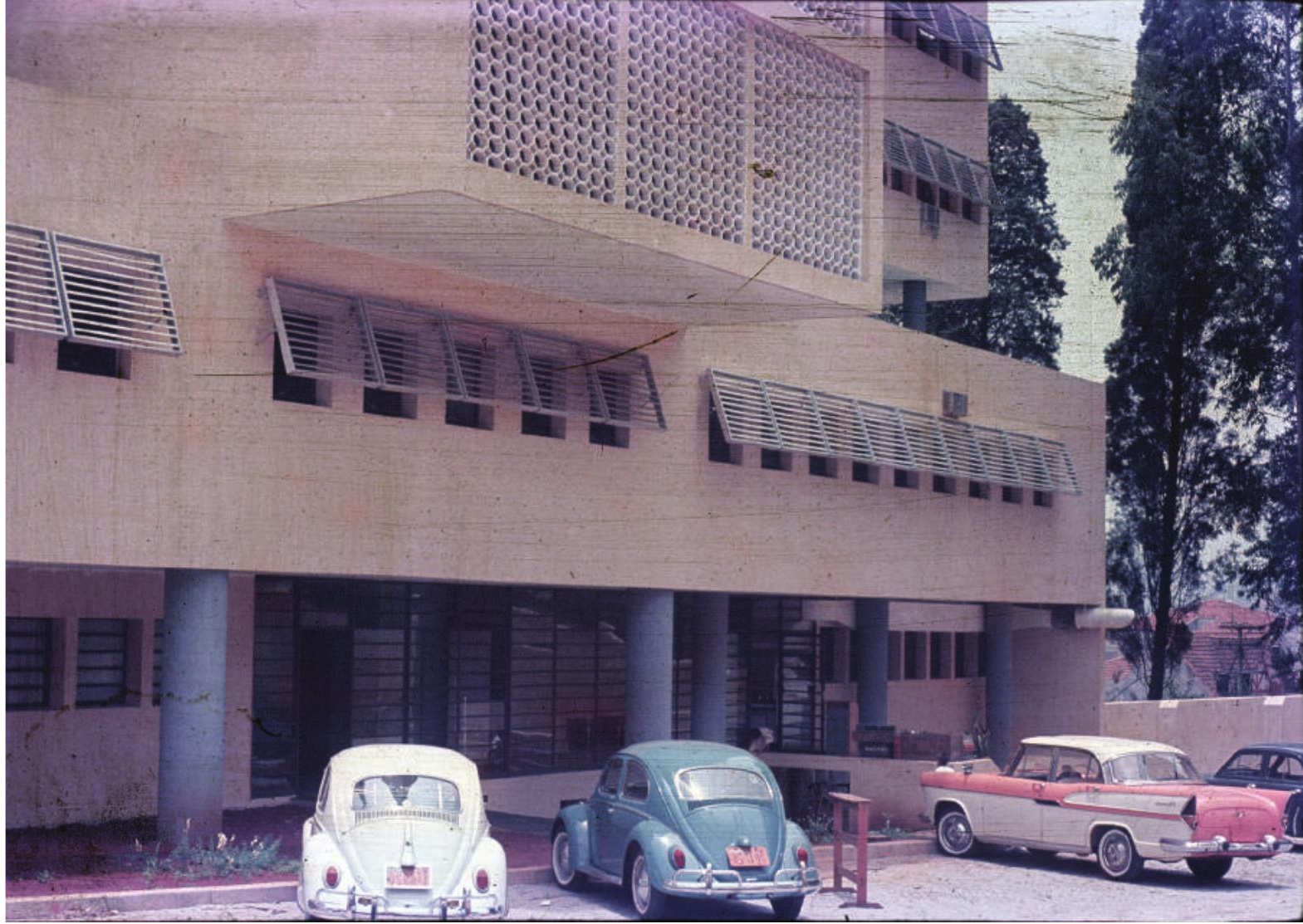

\section{INSTITUTO DE GASTROENTEREOLOGIA DE SÃO PAULO}

Cliente: não consta

Data de projeto: 1964

Data da publicação: não consta

Projeto: Rino Levi (projeto de arquitetura de 1959)

Projetos complementares: não consta

Construção: 1959

Paisagismo: Roberto Coelho Cardozo

Tipologia: institucional

Endereço: Rua Silvia, 276 - Bela Vista - São Paulo/SP

Material:

CARDOZO, R. C. Curriculum vitae. In: UNIVERSIDADE DE SÃO PAULO. Processo

52.1.14106.1.2: contrato docente. São Paulo: Departamento de projetos da Faculdade de

Arquitetura e Urbanismo. 15/12/1987. 87p. 


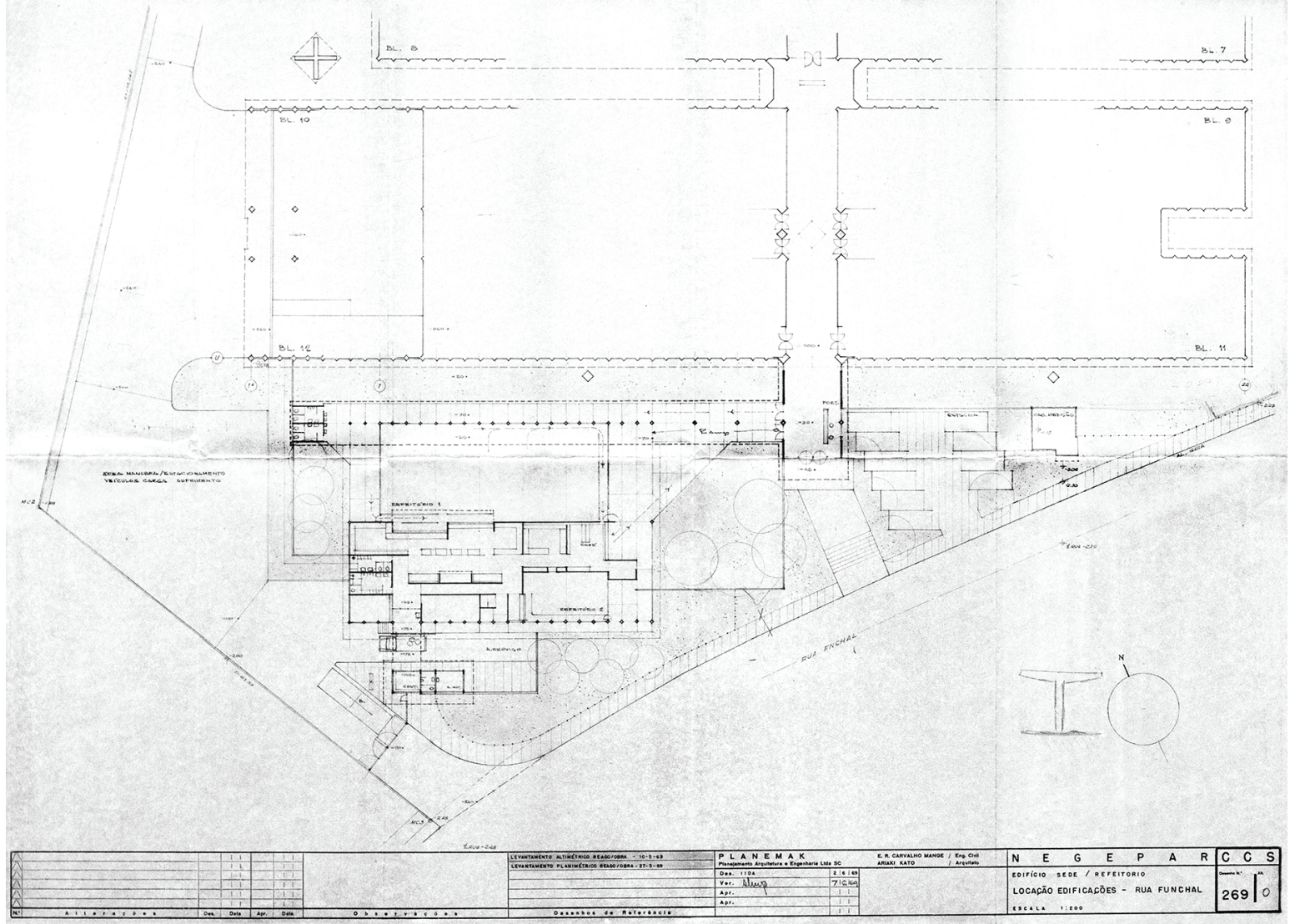

NEGEPAR S.A. PARTICIPAÇÕES E GERÊNCIA DE NEGÓCIOS

Cliente: NEGEPAR S.A. - Participações e gerências de negócios

Data de projeto: 1967 a 1969

Data da publicação: não foi publicado

Projeto: Planemak - Planejamento Arquitetura e Engranheira Ltda. S/C (Arq. Ariaki Kato e

Eng. Ernest R. Carvalho Mange)

Projetos complementares: não consta

Construção: construído por Construções e Comércio Camargo Corrêa S/A

Paisagismo: Consultoria em Paisagem Urbana - Roberto Coelho Cardozo e Antunes/

Souza Dias \& Fiaschi

Tipologia: comercial

Endereço: Rua Funchal, 160 - Itaim Bibi - São Paulo/SP

Material:

Acervo da biblioteca da FAUUSP (Cód PE C179es/725.9 N): Pranchas de arquitetura: locação de edificações 1, 2, 3, 4 e 5; cortes 1 e 2; planta térreo 1 e 2; estudo de acesso bloso 6,8,10 e 12; elevações; plantas, cortes e elevações; proposta de arejamento do subsolo; térreo e subsolo; elevações dos blocos 10 e 12; instalações hidráulicas; locação do trevo; locação escritório e refeitório; locação do edifício sede. Prachas de paisagismo: projeto de áreas não edificadas 1, 2, 3, 4, 5 e 6; área de entrada; projeto de áreas plantadas; projeto de plantação 1 e 2; situação.

ABBUD, B. Um procedimento em pesquisa: A obra do arquiteto paisagista Roberto Coelho Cardozo. Trabalho de Graduação Interdisciplinar (Graduação em Arquitetura e Urbanismo). FAUUSP, São Paulo, 1974. 100p.

CARDOZO, R. C. Curriculum vitae. In: UNIVERSIDADE DE SÃO PAULO. Processo 52.1.14106.1.2: contrato docente. São Paulo: Departamento de projetos da Faculdade de Arquitetura e Urbanismo. 15/12/1987. 87p. 


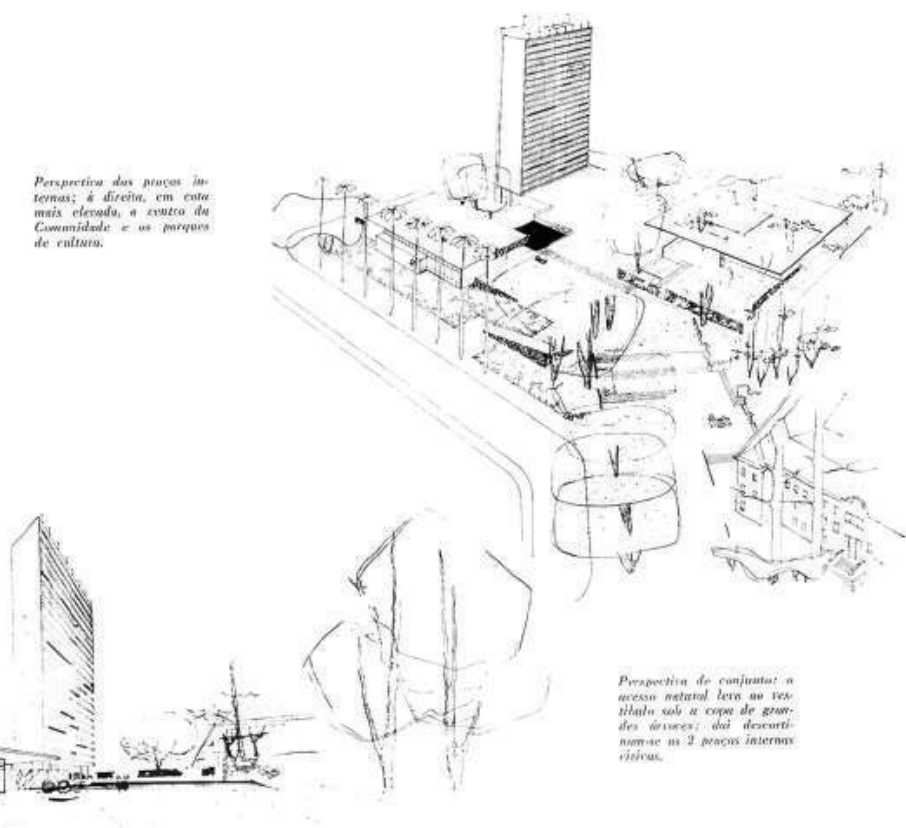

\section{PAÇO MUNICIPAL DE CAMPINAS | CONCURSO}

Cliente: Prefeitura de Campinas

Data de projeto: 1957

Data de publicação: 1957

Projeto: Jorge Wilheim, Jorge Zalszupin, Roberto Coelho Cardozo, Rosa Grena Kliass, Wlademir Kliass, Abrãao Sanovicz

Projetos complementares: A. Carlos Vasconcelos (consultor em projeto estrutural)

Construção: não construído

Paisagismo: equipe de projetos

Tipologia: institucional

Endereço: Avenida Anchieta, 200 - Centro - Campinas/SP

Material:

CAMPINAS, Paço Municipal e Parque. Acrópole, São Paulo, 230, p. 46-9, dez. 1957.

CONCURSO do Paço Municipal de Campinas. Habitat. São Paulo, 45, p.85, nov/dez. 1957.

NOVO edifício do Paço Municipal e Parque Público Central em Campinas. Habitat. São Paulo, 43, p.40, ago. 1957.

Observações: O concurso foi organizado pelo IAB-SP e o projeto construído foi o de Rubens Carneiro Vianna e Ricardo Sievers, ganhadores do $1^{\circ}$ lugar no Concurso. 


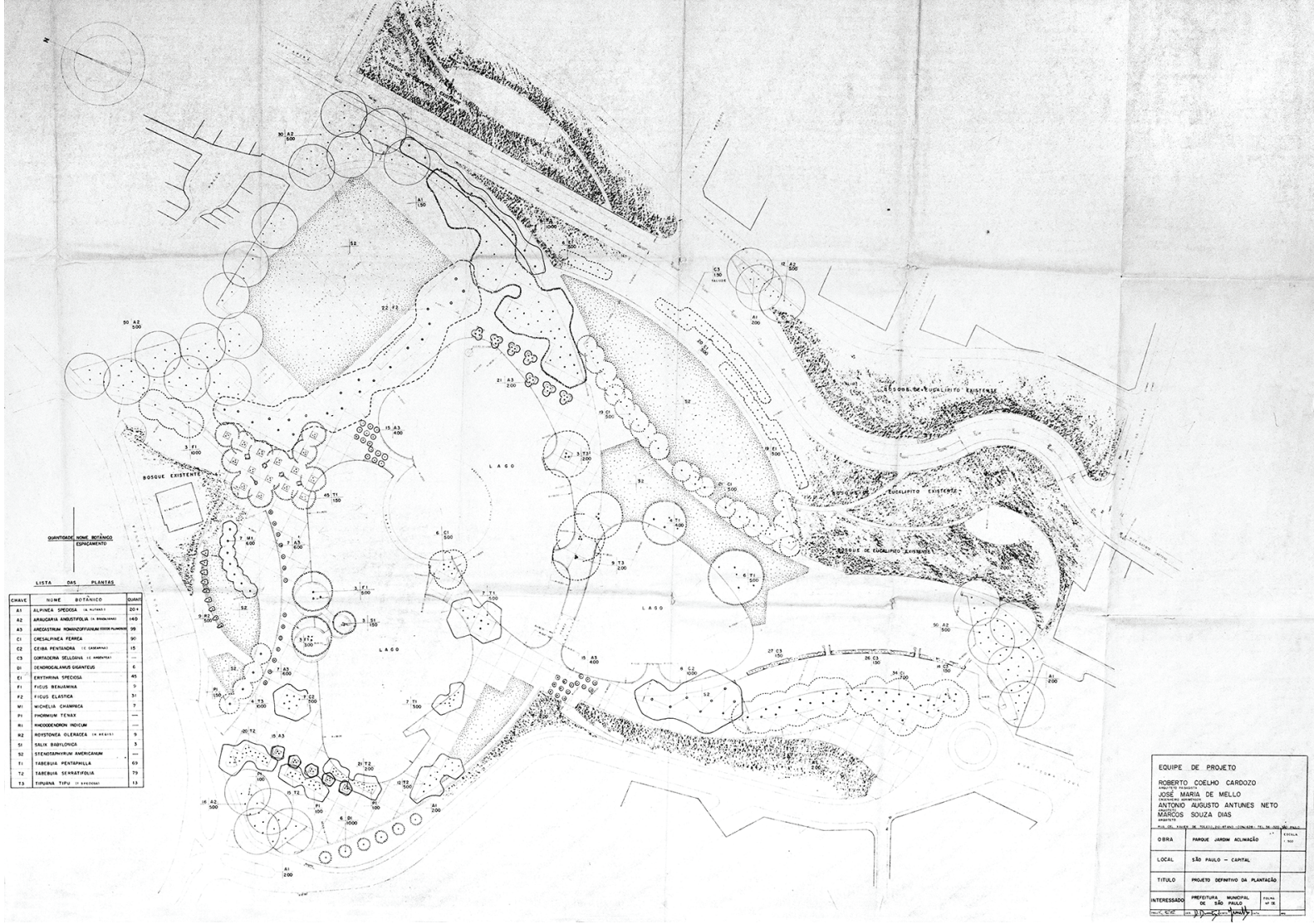

\section{PARQUE JARDIM ACLIMAÇÃO}

Cliente: Prefeitura Municipal de São Paulo

Data de projeto: 1967

Data de publicação: não consta

Projeto: Consultoria em Paisagem Urbana - Roberto Coelho Cardozo, Antonio A. Antunes

Netto e Marcos de Souza Dias

Projetos complementares: José Maria de Mello (Eng. Agromensor)

Construção: não construído

Paisagismo: Consultoria em Paisagem Urbana - Roberto Coelho Cardozo, Antonio A.

Antunes Netto e Marcos de Souza Dias

Tipologia: institucional

Endereço: Rua Muniz de Souza, 1.119 - Aclimação - São Paulo/SP

Material:

Acervo biblioteca FAUUSP (cód. PE C179/712.5 PA e.1/2): Pranchas do DEPAVE: detalhes de construção 1, 2 e 3; projeto de sanitários públicos; levantamento planialtimétrico; estudo inicial de convervação; execução; plantação. Pranchas paisagismo: projeto definitivo sobre relevo do terreno atual; projeto definitivo com relevo do solo futuro; projeto definitivo da plantação.

CARDOZO, R. C. Curriculum vitae. In: UNIVERSIDADE DE SÃO PAULO. Processo 52.1.14106.1.2: contrato docente. São Paulo: Departamento de projetos da Faculdade de Arquitetura e Urbanismo. 15/12/1987. 87p. 


\section{PARQUE MUNICIPAL DA PRAIA DE PERNAMBUCO}

Cliente: Jorge da Silva Prado

Data de projeto: 1959

Data da publicação: não consta

Projeto: Henrique Ephim Mindlin (projeto de arquitetura de 1954)

Projetos complementares: não consta

Construção: não consta

Paisagismo: Roberto Coelho Cardozo

Tipologia: institucional

Endereço: Praia de Pernambuco - Guarujá/SP

Material:

CARDOZO, R. C. Curriculum vitae. In: UNIVERSIDADE DE SÃO PAULO. Processo

52.1.14106.1.2: contrato docente. São Paulo: Departamento de projetos da Faculdade de Arquitetura e Urbanismo. 15/12/1987. 87p.

MINDLIN, H. E. Arquitetura Moderna no Brasil. Rio de Janeiro: Aeroplano Editora/IPHAN, 2000, 286p.

YOSHIDA, C.B. Henrique Ephim Mindlin: o homem arquiteto. São Paulo: Instituto Roberto Simonsen, 1975. 225p.

\section{PARQUE MUNICIPAL EM LENÇOIS PAULISTA}

Cliente: não consta

Data de projeto: 1969

Data da publicação: não consta

Projeto: não consta

Projetos complementares: não consta

Construção: não consta

Paisagismo: Roberto Coelho Cardozo

Tipologia: institucional

Endereço: Lençóis Paulista/SP

Material: ABBUD, B. Um procedimento em pesquisa: A obra do arquiteto paisagista

Roberto Coelho Cardozo. Trabalho de Graduação Interdisciplinar (Graduação em

Arquitetura e Urbanismo) - FAUUSP, São Paulo, 1974. 100p.

CARDOZO, R. C. Curriculum vitae. In: UNIVERSIDADE DE SÃO PAULO. Processo

52.1.14106.1.2: contrato docente. São Paulo: Departamento de projetos da Faculdade de Arquitetura e Urbanismo. 15/12/1987. 87p. 


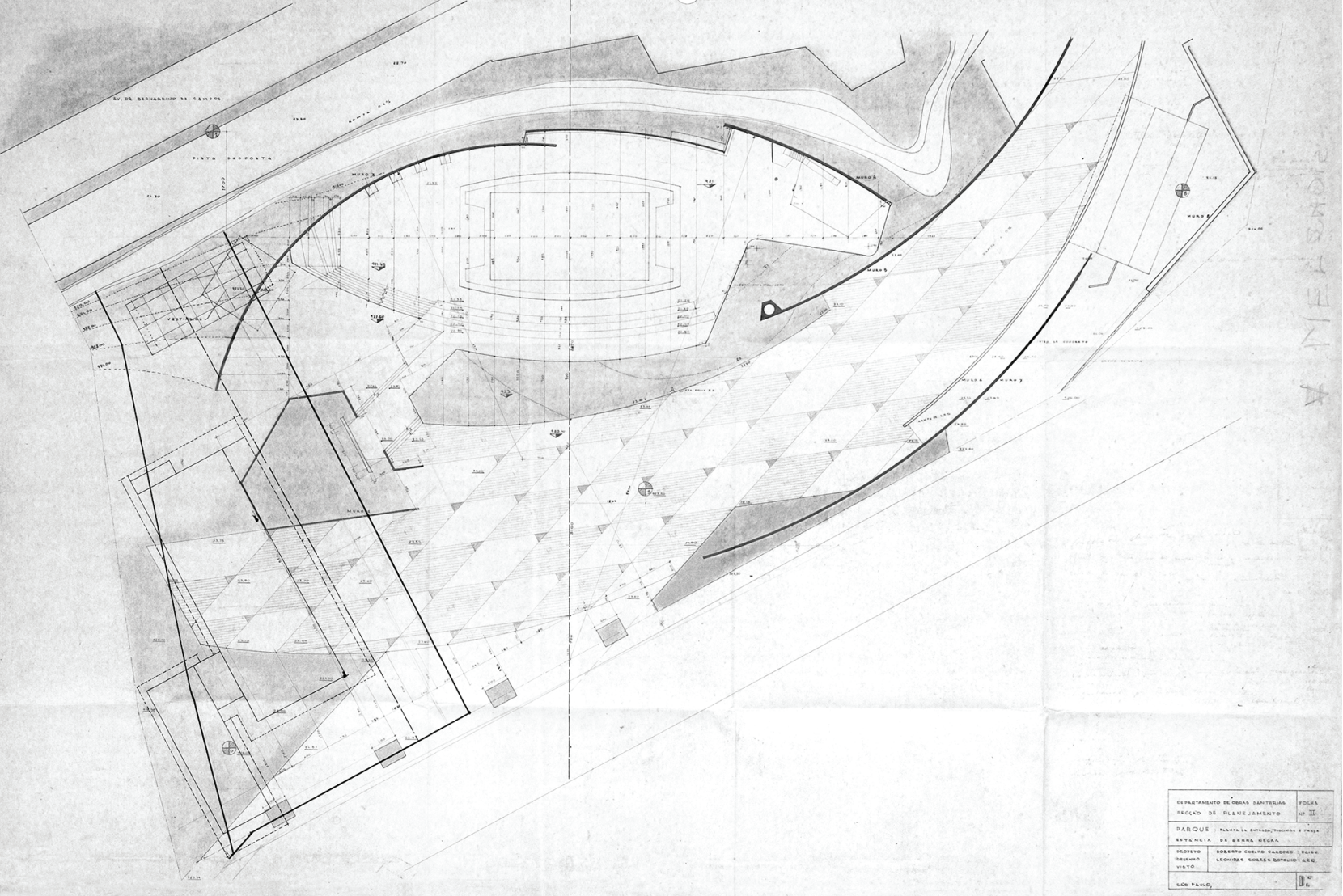

\section{PARQUE RECREATIVO DA ESTÂNCIA DA SERRA NEGRA}

Cliente: Departamento de Obras Sanitárias - Seção de planejamento

Data de projeto: 1962

Data da publicação: não consta

Projeto: Leonidas Soares Botelho

Projetos complementares: não consta

Construção: construído por Tedeschi \& Ogata - Engenharia e Construção Ltda.

Paisagismo: Roberto Coelho Cardozo

Tipologia: institucional

Endereço: Praça João Pessoa e Rua Bernardino de Campos - Serra Negra/SP

Material:

Acervo da biblioteca da FAUUSP (Cód PE C179/725.85 SN): Pranchas de arquitetura:

formas, contenções e armação da piscina infantil; armação da piscina; fachadas e cortes;

planta do pavimento térreo, plantas do $1^{\circ}$ e $2^{\circ}$ pavimento. Pranchas de paisagismo:

planta de entrada, piscina e praça; contenções; cortes; elevação, plantas e cortes. 


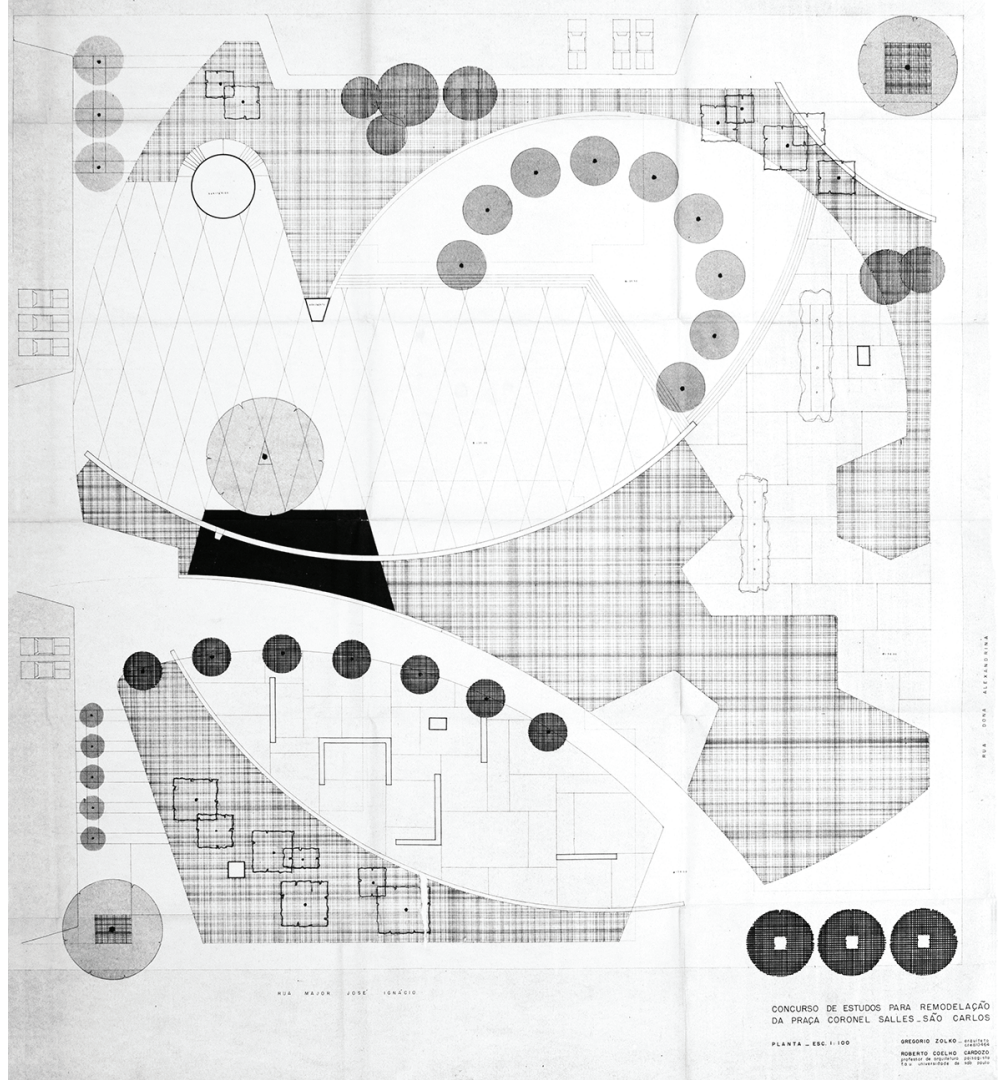

\section{PRAÇA CORONEL SALLES | CONCURSO}

Cliente: Prefeitura de São Carlos

Data de projeto: 1967

Data da publicação: 1967

Projeto: Gregório Zolko. Colaboração de M. Tsobuchi e W. Mumford, S. Loew, S. Nagano

Projetos complementares: não consta

Construção: construída em 1968

Paisagismo: Roberto Coelho Cardozo

Tipologia: institucional

Endereço: Avenida São Carlos x Rua 7 de Setembro - Centro - São Carlos/SP

Material:

Acervo da biblioteca da FAUUSP (Cód. PE C179/711.59 C): perspectiva e implantação de paisagismo.

CARDOZO, R. C. Curriculum vitae. In: UNIVERSIDADE DE SÃO PAULO. Processo

52.1.14106.1.2: contrato docente. São Paulo: Departamento de projetos da Faculdade de Arquitetura e Urbanismo. 15/12/1987. 87p.

PRAÇA Pública em São Carlos, SP. Acrópole, São Paulo, 345, p. 32-3, nov. 1967.

Observações: Classificado em $1^{\circ}$ lugar, Gregório Zolko disse que o projeto foi construído. Porém, a praça foi totalmente remodelada em 2008, com projeto feito pelo arquiteto Marcelo Suzuki. 


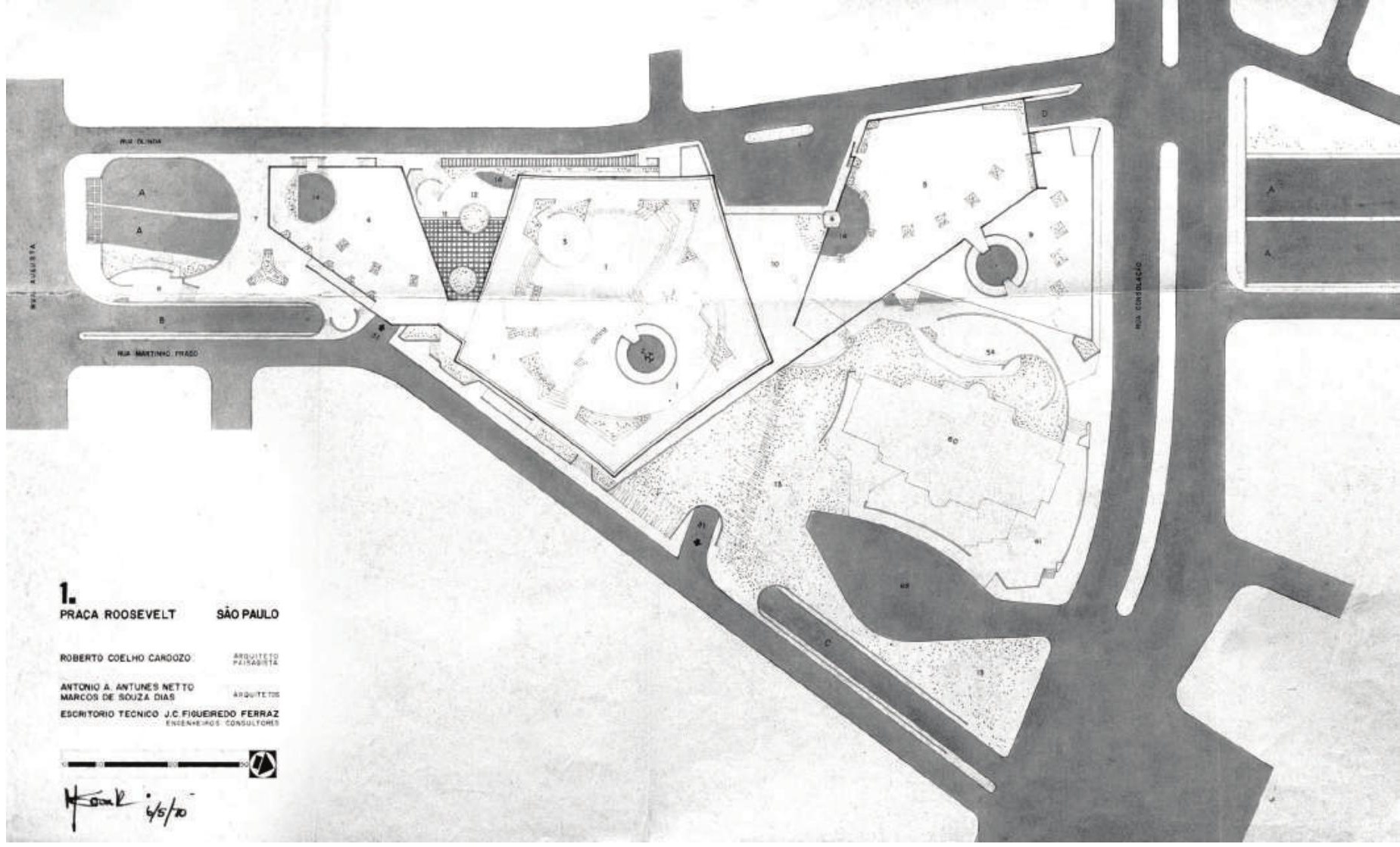

\section{PRAÇA FRANKLIN ROOSEVELT}

Cliente: Prefeitura Municipal de São Paulo

Data de projeto: 1969

Data da publicação: 1970

Projeto: Roberto Coelho Cardozo, Antonio A. Antunes Netto, Marcos de Souza Dias e Luciano Fiaschi

Projetos complementares: não consta

Construção: Escritório Técnico J. C. de Figueiredo Ferraz Engenheiros Consultores

Paisagismo: Roberto Coelho Cardozo, Antonio A. Antunes Netto, Marcos de Souza Dias e Luciano Fiaschi

Tipologia: residencial

Endereço: Praça Franklin Roosevelt - República - São Paulo/SP

Material:

Acervo da biblioteca da FAUUSP (Cód. PE C179/712.524 p): legenda de desenhos; corte; perspectiva; praça roosevelt 1, 2, 3, 4, 5 e 6.

CARDOZO, R. C. Curriculum vitae. In: UNIVERSIDADE DE SÃO PAULO. Processo 52.1.14106.1.2: contrato docente. São Paulo: Departamento de projetos da Faculdade de Arquitetura e Urbanismo. 15/12/1987. 87p.

PRAÇA Roosevelt. Acrópole, São Paulo, 380, p. 11-21, dez.1970.

PRAÇA Roosevelt, São Paulo; histórico e memorial. Engenharia Municipal, São Paulo, 43. 


\section{PRAÇA IGREJA MATRIZ DE COTIA - PARÓQUIA NOSSA SENHORA MONTE SERRATE}

Cliente: não consta

Data de projeto: não consta

Data da publicação: 1964

Projeto: Roberto Coelho Cardozo (projeto da Praça da Matriz)

Projetos complementares: não consta

Construção: não consta

Paisagismo: Roberto Coelho Cardozo

Tipologia: institucional

Endereço: Rua Senador Feijó, 12 - Centro - Cotia/SP

Material:

CARDOZO, R. C. Curriculum vitae. In: UNIVERSIDADE DE SÃO PAULO. Processo

52.1.14106.1.2: contrato docente. São Paulo: Departamento de projetos da Faculdade de Arquitetura e Urbanismo. 15/12/1987. 87p.

\section{PRAÇA ROCHA POMBO - ANTIGA RODOVIÁRIA DE LONDRINA}

Cliente: não identificado

Data de projeto: 1957

Data da publicação: paisagismo não foi publicado

Projeto: João Baptista Vilanova Artigas e Carlos Cascaldi (projeto de Arquitetura de 1948)

Projetos complementares: não consta

Construção: não consta

Paisagismo: Roberto Coelho Cardozo

Tipologia: institucional

Endereço: Rua Sergipe, 640 - Centro - Londrina/PR

Material:

CARDOZO, R. C. Curriculum vitae. In: UNIVERSIDADE DE SÃO PAULO. Processo

52.1.14106.1.2: contrato docente. São Paulo: Departamento de projetos da Faculdade de Arquitetura e Urbanismo. 15/12/1987. 87p.

Observação: Pelo que pesquisamos, na verdade não é o projeto para a Antiga Rodoviária, projeto de Vilanova Artigas, e sim o projeto para a Praça Rocha Pombo, localizada em frente ao edifício.

\section{REPARTIÇÃO DE ÁGUAS E ESGOTOS (REA)}

Cliente: Repartição de Águas e Esgotos (REA)

Data de projeto: 1963

Data da publicação: não consta

Projeto: não consta

Projetos complementares: não consta

Paisagismo: Roberto Coelho Cardozo

Tipologia: institucional

Endereço: não consta

Material:

CARDOZO, R. C. Curriculum vitae. In: UNIVERSIDADE DE SÃO PAULO. Processo

52.1.14106.1.2: contrato docente. São Paulo: Departamento de projetos da Faculdade de Arquitetura e Urbanismo. 15/12/1987. 87p. 


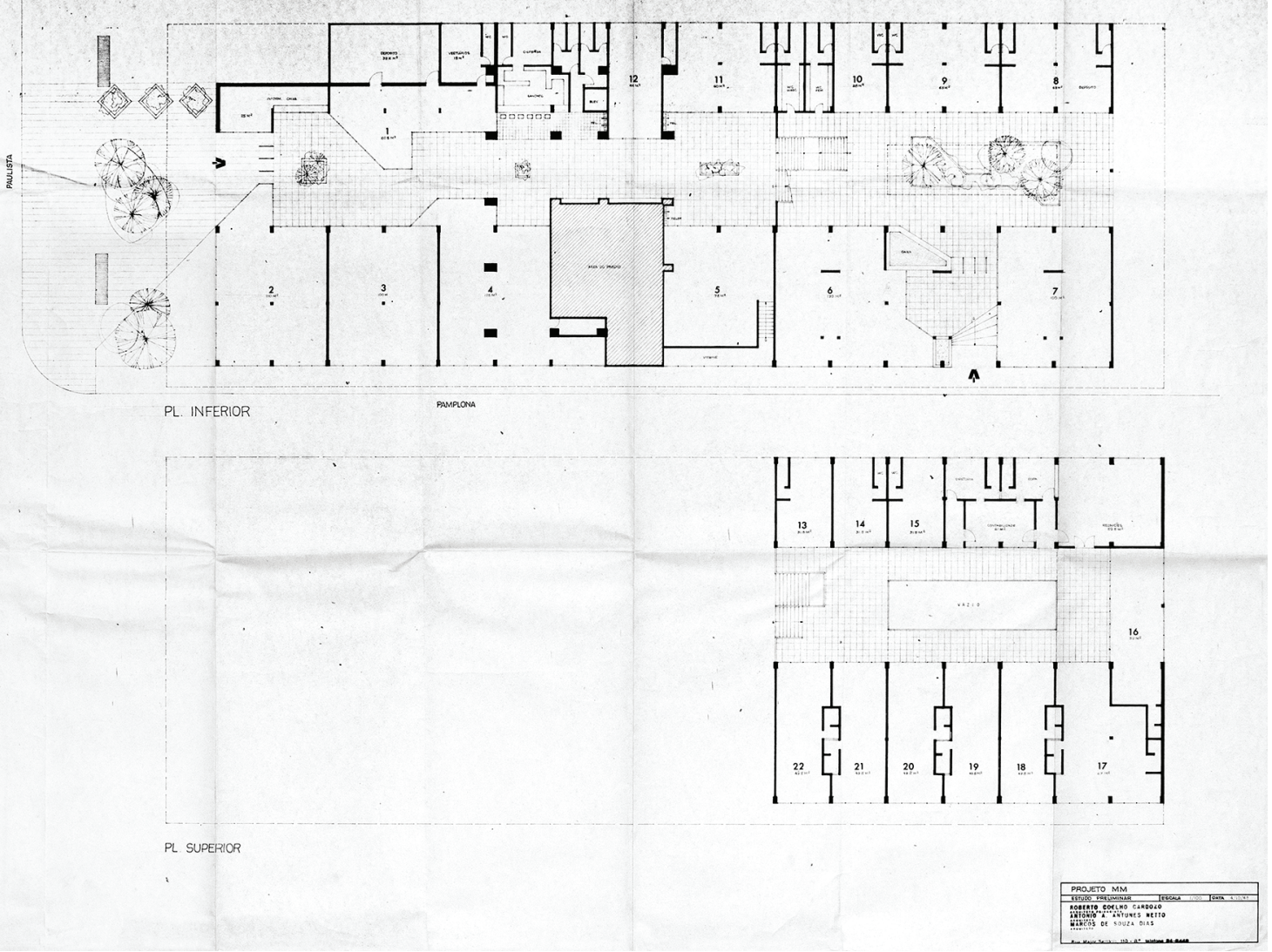

\section{PROJETO MM}

Cliente: não consta

Data de projeto: 1968

Data da publicação: não foi publicado

Projeto: não consta

Projetos complementares: não consta

Construção: não consta

Paisagismo: Roberto Coelho Cardozo, Antonio A. Antunes Netto e Marcos de Souza Dias

Tipologia: comercial

Endereço: Avenida Paulista x Rua Pamplona - Jardins - São Paulo/SP

Material:

Acervo da biblioteca da FAUUSP (Cód PE C179/725.2 M): uma prancha de estudo preliminar. 


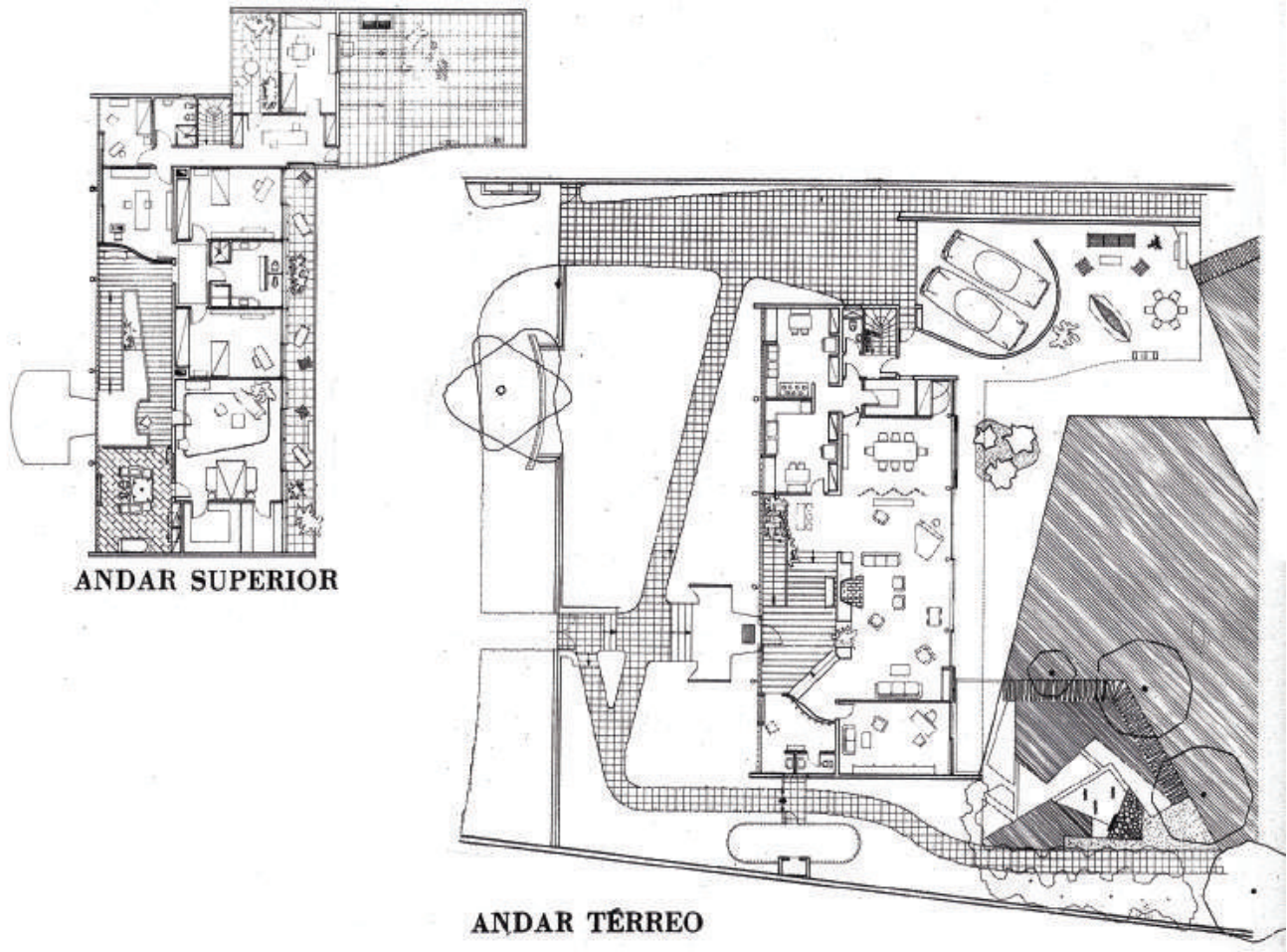

Das peças térreas alcança-se pelo corredor o terraço coberto cujo fundo é formado pela parede arredondada da garagem. Uma das caracteristicas dessa casa são suas dimensóes e amplos espaços.

\section{RESIDÊNCIA ABRAHAM KASINSKI}

Cliente: Abraham Kasinski / Abraão Kasinski

Data de projeto: não consta

Data da publicação: 1955

Projeto: Construtora Heep

Projetos complementares: não consta

Construção: construído por Construtora 3 Leões

Paisagismo: Osborn Coelho Cardozo

Tipologia: residencial

Endereço: Rua Polônia, 200 - Jardim América - São Paulo/SP

Material:

BARBOSA, M.C. A obra de Adolf Franz Heep no Brasil. Dissertação (Mestrado em Arquitetura e Urbanismo). FAUUSP, São Paulo, 2002. 190p.

CAMPOBELO, H. A residência jardim. Casa e Jardim, São Paulo, 40, p. 23-30, jan. 1958.

CARDOZO, R. C. Curriculum vitae. In: UNIVERSIDADE DE SÃO PAULO. Processo

52.1.14106.1.2: contrato docente. São Paulo: Departamento de projetos da Faculdade de Arquitetura e Urbanismo. 15/12/1987. 87p.

CARDOZO, R. C. Pisos no jardim: terraços, passeios ou áreas privadas. Casa e Jardim, São Paulo, 15, p. 51-53, jul. 1955.

MERAVIGLIA, O. O paisagista é importante. Casa e Jardim, São Paulo, 18, p. 48-49 e 70, out. 1955.

RESIDÊNCIA no Jardim América. Acrópole, São Paulo, 213, p. 339-43, jul. 1956. 


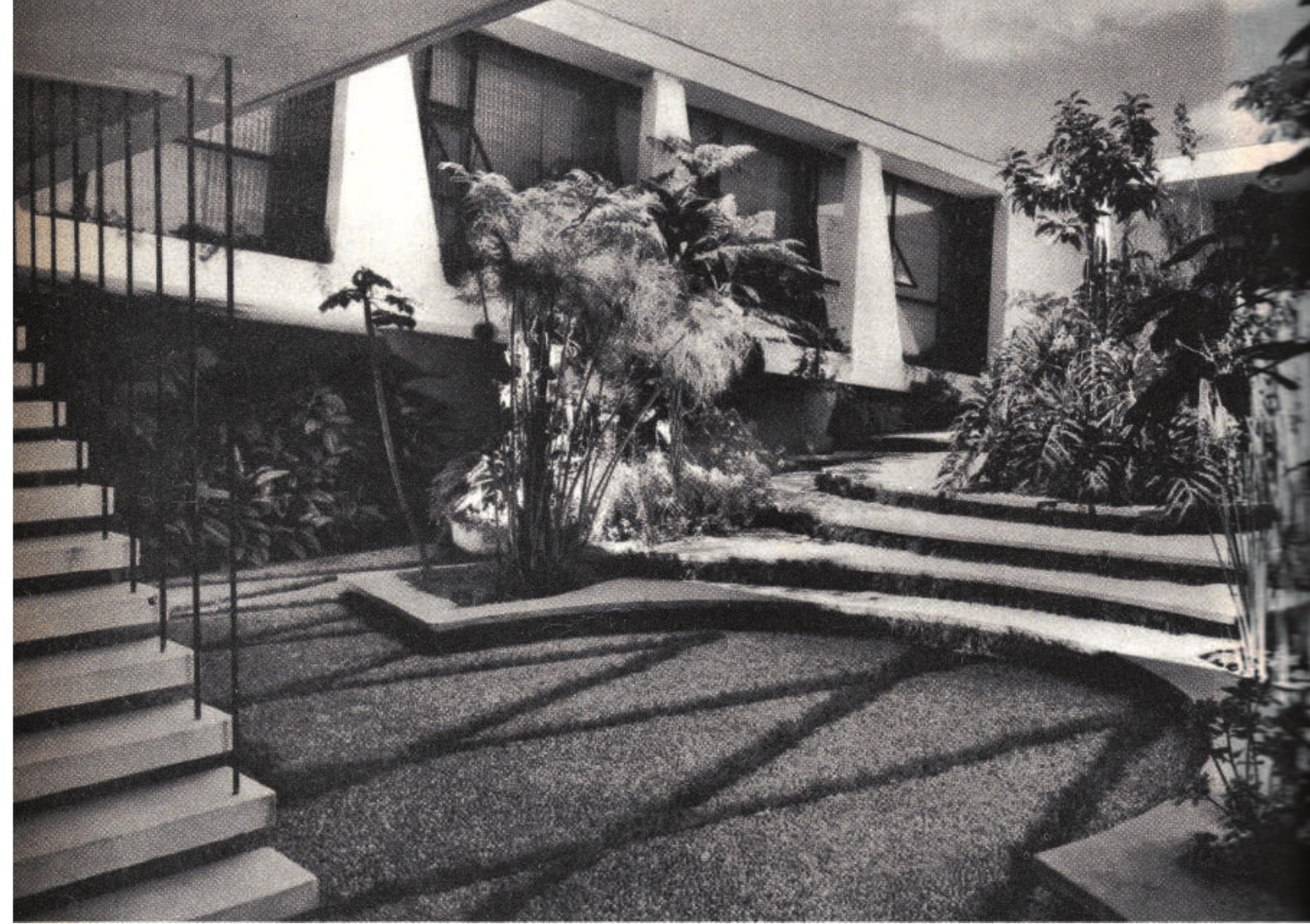

\section{RESIDÊNCIA ALBERTO CINTRA FILHO}

Cliente: Alberto Cintra Filho

Data de projeto: não consta

Data da publicação: 1961

Projeto: Jorge Zalszupin

Projetos complementares: não consta

Construção: não consta

Paisagismo: Roberto Coelho Cardozo

Tipologia: residencial

Endereço: Avenida Rebouças, 3641 - São Paulo/SP

Material:

CARDOZO, R. C. Curriculum vitae. In: UNIVERSIDADE DE SÃO PAULO. Processo

52.1.14106.1.2: contrato docente. São Paulo: Departamento de projetos da Faculdade de Arquitetura e Urbanismo. 15/12/1987. 87p.

CINTRA, L. Um novo jardim de Roberto Coelho Cardoso. Casa e Jardim, São Paulo, 78, p. 71-76, jul. 1961.

UNIÃO ideal entre arquitetura e jardim. Casa e Jardim, São Paulo, 77, p. 16-22, jun. 1961. 


\section{RESIDÊNCIA ALEXANDRE CHAFIC MALUF}

Cliente: Alexandre Chafic Maluf

Data de projeto: não consta

Data da publicação: não consta

Projeto: não consta

Projetos complementares: não consta

Construção: não consta

Paisagismo: Roberto Coelho Cardozo

Tipologia: residencial

Endereço: Rua Bélgica, 92 - São Paulo/SP

Material:

CARDOZO, R. C. Curriculum vitae. In: UNIVERSIDADE DE SÃO PAULO. Processo

52.1.14106.1.2: contrato docente. São Paulo: Departamento de projetos da Faculdade de Arquitetura e Urbanismo. 15/12/1987. 87p.

\section{RESIDÊNCIA ALEXANDRE MARCONDES NETO}

Cliente: não consta

Data de projeto: não consta

Data da publicação: não consta

Projeto: não consta

Projetos complementares: não consta

Construção: não consta

Paisagismo: Roberto Coelho Cardozo

Tipologia: residencial

Endereço: Rua Teodoro Ramos, 261 - Pacaembu - São Paulo/SP

Material:

CARDOZO, R. C. Curriculum vitae. In: UNIVERSIDADE DE SÃO PAULO. Processo

52.1.14106.1.2: contrato docente. São Paulo: Departamento de projetos da Faculdade de Arquitetura e Urbanismo. 15/12/1987. 87p.

\section{RESIDÊNCIA ALFREDO FUCHS}

Cliente: não consta

Data de projeto: não consta

Data da publicação: não consta

Projeto: não consta

Projetos complementares: não consta

Construção: não consta

Paisagismo: Roberto Coelho Cardozo

Tipologia: residencial

Endereço: Rua Corumbá, 109 - São Paulo/SP

Material:

CARDOZO, R. C. Curriculum vitae. In: UNIVERSIDADE DE SÃO PAULO. Processo 52.1.14106.1.2: contrato docente. São Paulo: Departamento de projetos da Faculdade de Arquitetura e Urbanismo. 15/12/1987. 87p. 


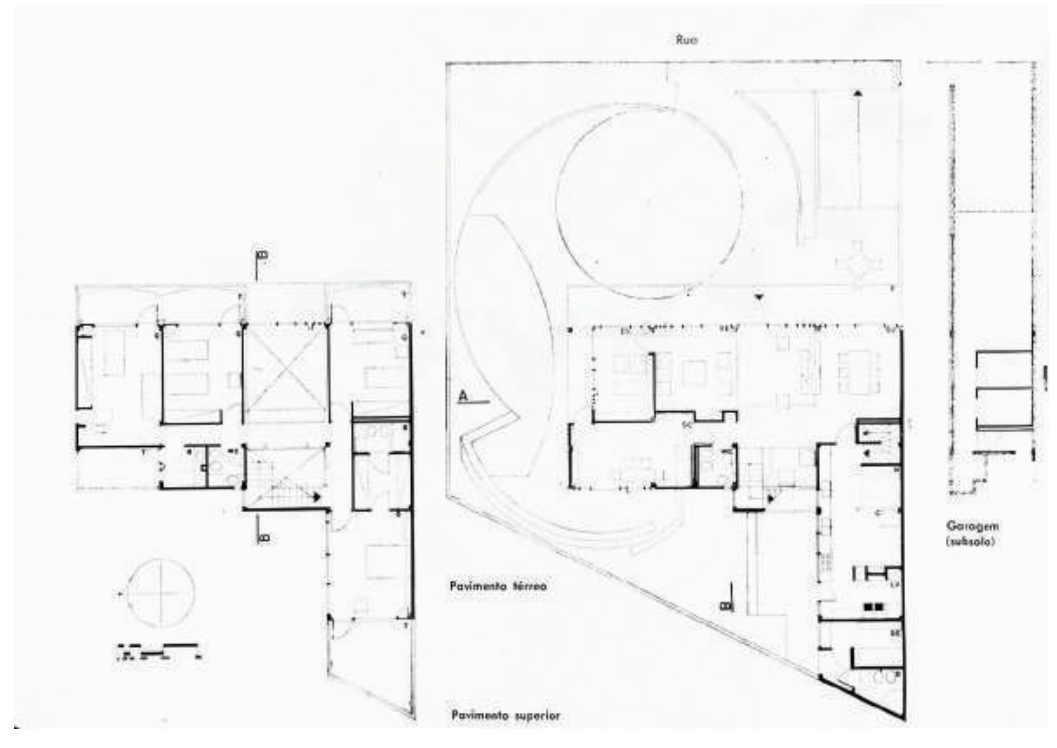

\section{RESIDÊNCIA ANTÔNIO COSTA NETO}

Cliente: Antônio Costa Neto

Data de projeto: não consta

Data da publicação: 1968

Projeto: Joaquim Guedes

Projetos complementares: não consta

Construção: não consta

Paisagismo: Roberto Coelho Cardozo

Tipologia: residencial

Endereço: Rua Deputado Fábio Aranha, 87 (antiga Rua Itapanhau) - Pacaembu - São

Paulo/SP

Material:

CARDOZO, R. C. Curriculum vitae. In: UNIVERSIDADE DE SÃO PAULO. Processo

52.1.14106.1.2: contrato docente. São Paulo: Departamento de projetos da Faculdade de Arquitetura e Urbanismo. 15/12/1987. 87p.

CARDOSO, O. A. Roberto Coelho Cardoso - A vanguarda da arquitetura paisagística moderna paulistana. Paisagem Ambiente. São Paulo, Ensaios IV, p. 171-186. 1992.

RESIDÊNCIA 4. Acrópole, São Paulo, 347, p. 30-33, fev. 1968. 


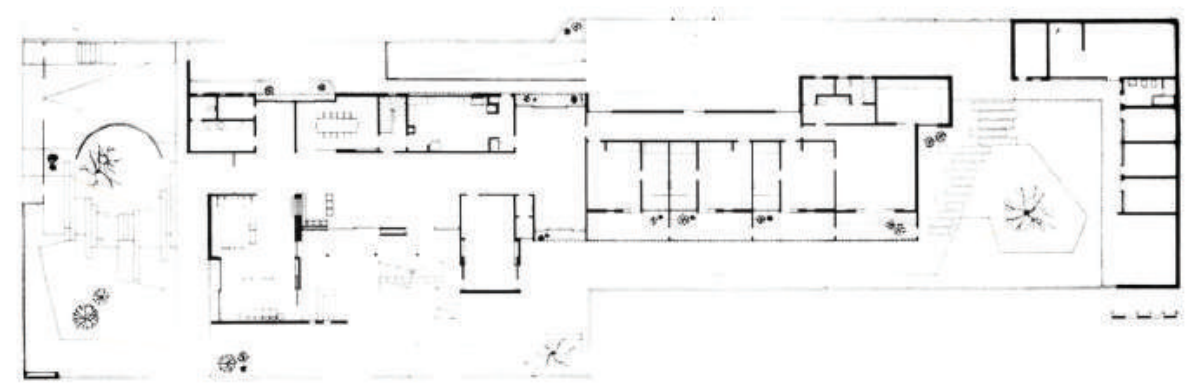

Vista do jordim de entrada, junto a rompo do goragem

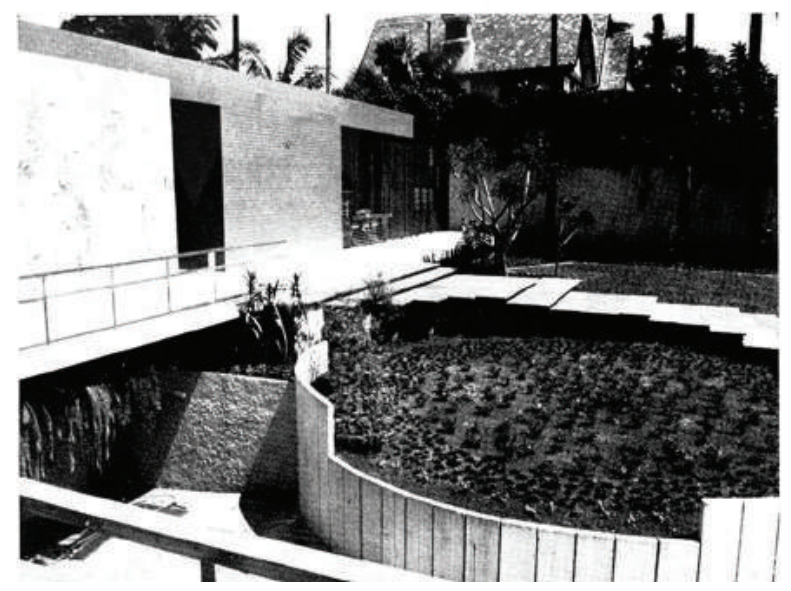

\section{RESIDÊNCIA ANTÔNIO DE ANDRADE COSTA}

Cliente: Antônio de Andrade Costa

Data de projeto: não consta

Data da publicação: 1970

Projeto: Victor Reif (projeto de arquitetura de 1969)

Projetos complementares: não consta

Construção: não consta

Paisagismo: Roberto Coelho Cardozo

Tipologia: residencial

Endereço: Avenida Brasil, 1823 - Jardim América - São Paulo/SP

Material:

REBOUÇAS, Ivy Smits. A trajetória profissional de Victor Reif: de 1909 a 1998.

Dissertação (Mestrado em Arquitetura e Urbanismo). Universidade Presbiteriana

Mackenzie, São Paulo, 2004. 163p.

RESIDÊNCIA no Jardim América. Acrópole, 380, p. 22-24, dez. 1970. 


\section{RESIDÊNCIA ANTÔNIO ERMÍRIO DE MORAES}

Cliente: Antônio Ermírio de Moraes

Data de projeto: não consta

Data da publicação: não consta

Projeto: não consta

Projetos complementares: não consta

Construção: não consta

Paisagismo: Roberto Coelho Cardozo

Tipologia: residencial

Endereço: Rua Gália, 415 - Jardim Everest - São Paulo/SP

Material:

CARDOZO, R. C. Curriculum vitae. In: UNIVERSIDADE DE SÃO PAULO. Processo

52.1.14106.1.2: contrato docente. São Paulo: Departamento de projetos da Faculdade de Arquitetura e Urbanismo. 15/12/1987. 87p.

\section{RESIDÊNCIA AUGUSTO PIRANI}

Cliente: Augusto Pirani

Data de projeto: não consta

Data da publicação: não consta

Projeto: não consta

Projetos complementares: não consta

Construção: não consta

Paisagismo: Roberto Coelho Cardozo

Tipologia: residencial

Endereço: Rua México, 474 - Jardim Paulista - São Paulo/SP

Material:

CARDOZO, R. C. Curriculum vitae. In: UNIVERSIDADE DE SÃO PAULO. Processo

52.1.14106.1.2: contrato docente. São Paulo: Departamento de projetos da Faculdade de Arquitetura e Urbanismo. 15/12/1987. 87p.

\section{RESIDÊNCIA AZIZ MATTAR}

Cliente: Aziz Mattar

Data de projeto: não consta

Data da publicação: não consta

Projeto: não consta

Projetos complementares: não consta

Construção: não consta

Paisagismo: Roberto Coelho Cardozo

Tipologia: residencial

Endereço: Rua dos Nenúfares, 90 - Cidade Jardim - São Paulo/SP

Material:

CARDOZO, R. C. Curriculum vitae. In: UNIVERSIDADE DE SÃO PAULO. Processo

52.1.14106.1.2: contrato docente. São Paulo: Departamento de projetos da Faculdade de Arquitetura e Urbanismo. 15/12/1987. 87p. 


\section{RESIDÊNCIA BERNARDO PASCOWITCH}

Cliente: Bernardo Pascowitch

Data de projeto: não consta

Data da publicação: não consta

Projeto: não consta

Projetos complementares: não consta

Construção: não consta

Paisagismo: Roberto Coelho Cardozo

Tipologia: residencial

Endereço: Avenida Rebouças, 3525 - Pinheiros - São Paulo/SP

Material:

CARDOZO, R. C. Curriculum vitae. In: UNIVERSIDADE DE SÃO PAULO. Processo

52.1.14106.1.2: contrato docente. São Paulo: Departamento de projetos da Faculdade de Arquitetura e Urbanismo. 15/12/1987. 87p.

\section{RESIDÊNCIA BIRO ERNESTO ZEITEL}

Cliente: Biro Ernesto Zeitel

Data de projeto: não consta

Data da publicação: não consta

Projeto: não consta

Projetos complementares: não consta

Construção: não consta

Paisagismo: Roberto Coelho Cardozo

Tipologia: residencial

Endereço: Rua Tabapuã, 161 - Itaim Bibi - São Paulo/SP

Material:

CARDOZO, R. C. Curriculum vitae. In: UNIVERSIDADE DE SÃO PAULO. Processo

52.1.14106.1.2: contrato docente. São Paulo: Departamento de projetos da Faculdade de Arquitetura e Urbanismo. 15/12/1987. 87p.

\section{RESIDÊNCIA CARLOS PASQUALLE}

Cliente: Carlos Paqualle

Data de projeto: não consta

Data da publicação: não consta

Projeto: não consta

Projetos complementares: não consta

Construção: não consta

Paisagismo: Roberto Coelho Cardozo

Tipologia: residencial

Endereço: Rua Estados Unidos, 1151 - Jardim América - São Paulo/SP

Material:

CARDOZO, R. C. Curriculum vitae. In: UNIVERSIDADE DE SÃO PAULO. Processo

52.1.14106.1.2: contrato docente. São Paulo: Departamento de projetos da Faculdade de Arquitetura e Urbanismo. 15/12/1987. 87p. 


\section{RESIDÊNCIA CASSIO MONTEIRO}

Cliente: Cassio Monteiro

Data de projeto: não consta

Data da publicação: não consta

Projeto: não consta

Projetos complementares: não consta

Construção: não consta

Paisagismo: Roberto Coelho Cardozo

Tipologia: residencial

Endereço: Rua Coronel Alfredo Cabral, 262 - Jardim Paulistano - São Paulo/SP

Material:

CARDOZO, R. C. Curriculum vitae. In: UNIVERSIDADE DE SÃO PAULO. Processo

52.1.14106.1.2: contrato docente. São Paulo: Departamento de projetos da Faculdade de Arquitetura e Urbanismo. 15/12/1987. 87p.

\section{RESIDÊNCIA CLAIRE AZADIAN}

Cliente: Claire Azadian

Data de projeto: não consta

Data da publicação: não consta

Projeto: não consta

Projetos complementares: não consta

Construção: não consta

Paisagismo: Roberto Coelho Cardozo

Tipologia: residencial

Endereço: Alameda Itu, 541 - Jardins - São Paulo/SP

Material:

CARDOZO, R. C. Curriculum vitae. In: UNIVERSIDADE DE SÃO PAULO. Processo

52.1.14106.1.2: contrato docente. São Paulo: Departamento de projetos da Faculdade de Arquitetura e Urbanismo. 15/12/1987. 87p. 


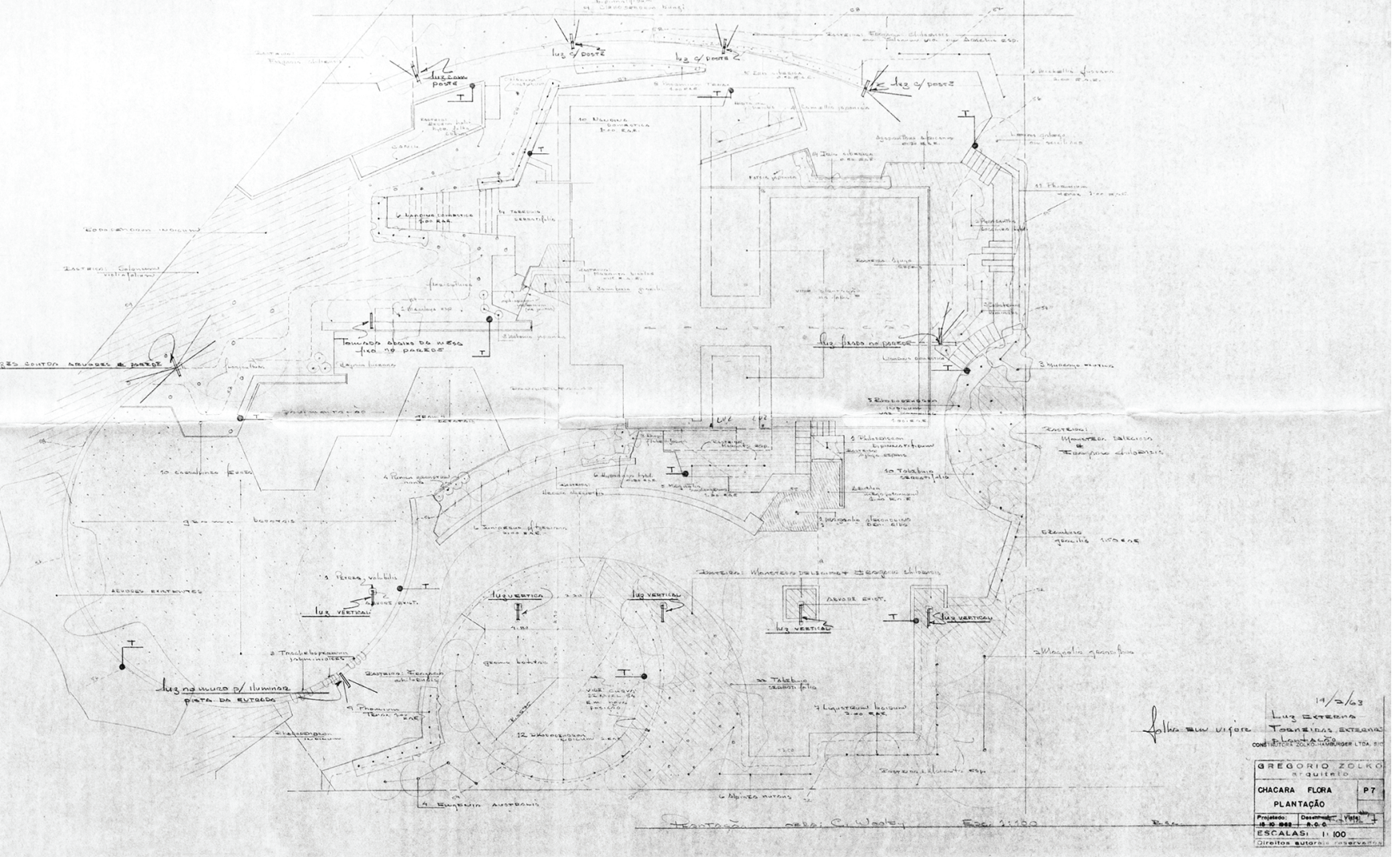

\section{RESIDÊNCIA CHRISTOPHER ANDREW WOOLLEY}

Cliente: Christopher Andrew Woolley

Data de projeto: 1962

Data da publicação: não consta

Projeto: Gregório Zolko

Projetos complementares: não consta

Construção: construído por Construtora Zolko Hambuger Ltda.

Paisagismo: Roberto Coelho Cardozo

Tipologia: residencial

Endereço: Rua Professora Lucinda Alves de Carvalho, 520 - Chácara Flora - São Paulo/

SP

Material:

Acervo da biblioteca da FAUUSP (Cód. PE C179/712.6 C): Planta de locação, pátios centrais, degraus, cotas em vigor, detalhes, plantação, modificação estacionamento. CARDOZO, R. C. Curriculum vitae. In: UNIVERSIDADE DE SÃO PAULO. Processo 52.1.14106.1.2: contrato docente. São Paulo: Departamento de projetos da Faculdade de Arquitetura e Urbanismo. 15/12/1987. 87p. 


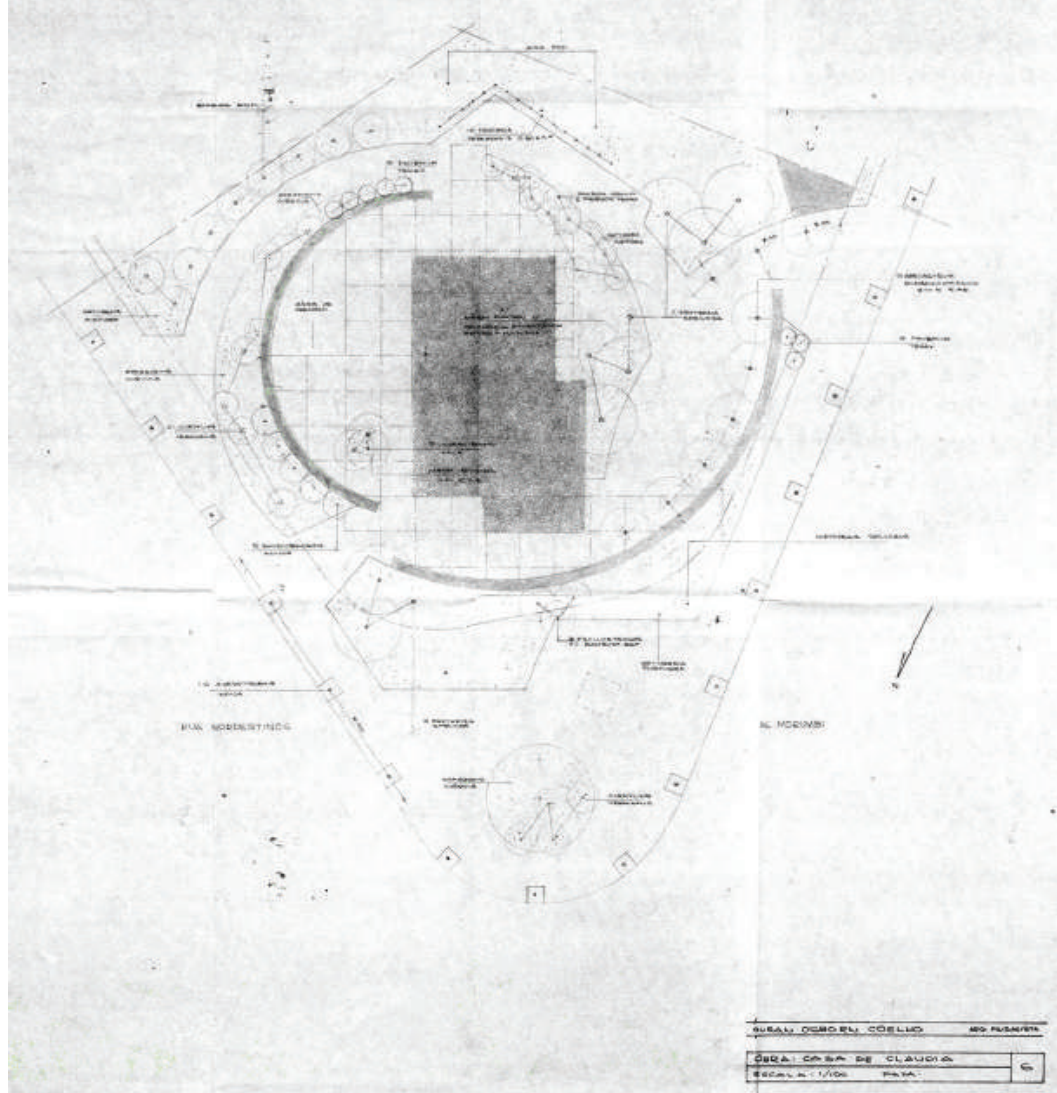

\section{RESIDÊNCIA CLÁUDIA}

Cliente: Cláudia (não identificamos o sobrenome)

Data de projeto: 1969

Data da publicação: não consta

Projeto: não consta

Projetos complementares: não consta

Construção: não consta

Paisagismo: Roberto Coelho Cardozo - Susan Osborn Coelho / Antonio A. Antunes Netto / Marcos de Souza Dias

Tipologia: residencial

Endereço: Avenida Morumbi, 635 - Morumbi -São Paulo/SP

Material:

Acervo da biblioteca da FAUUSP (Cód PE C179es/728.3 C): planta; planta térreo;

quiosque; implantação; planta de pisos; planta de pisos 2; elevação da mureta e detalhe do degrau; terreno 1 e 2 ; terreno proposto.

Observações: Hoje o terreno abriga o Consulado da República Tcheca em São Paulo. 


\section{RESIDÊNCIA CONSTANZA PASCOLATO E ROBERTO HEFLEY BLOCKER}

Cliente: Constanza Pascolato e Roberto Hefley Blocker

Data de projeto: não consta

Data da publicação: não consta

Projeto: Gregório Zolko

Projetos complementares: não consta

Construção: não consta

Paisagismo: Roberto Coelho Cardozo

Tipologia: residencial

Endereço: São Paulo/SP

Material:

Acervo de Gregório Zolko.

\section{RESIDÊNCIA DAVID FEDER}

Cliente: David Feder

Data de projeto: não consta

Data da publicação: não consta

Projeto: não consta

Projetos complementares: não consta

Construção: não consta

Paisagismo: Roberto Coelho Cardozo

Tipologia: residencial

Endereço: Rua Avaré, 428 - Consolação - São Paulo/SP

Material:

CARDOZO, R. C. Curriculum vitae. In: UNIVERSIDADE DE SÃO PAULO. Processo

52.1.14106.1.2: contrato docente. São Paulo: Departamento de projetos da Faculdade de Arquitetura e Urbanismo. 15/12/1987. 87p.

\section{RESIDÊNCIA DÉCIO DE MORAES}

Cliente: Décio de Moraes

Data de projeto: não consta

Data da publicação: não consta

Projeto: não consta

Projetos complementares: não consta

Construção: não consta

Paisagismo: Roberto Coelho Cardozo

Tipologia: residencial

Endereço: Rua Lopes de Azevedo, 995 - Jardim Guedala - São Paulo/SP

Material:

CARDOZO, R. C. Curriculum vitae. In: UNIVERSIDADE DE SÃO PAULO. Processo

52.1.14106.1.2: contrato docente. São Paulo: Departamento de projetos da Faculdade de Arquitetura e Urbanismo. 15/12/1987. 87p. 


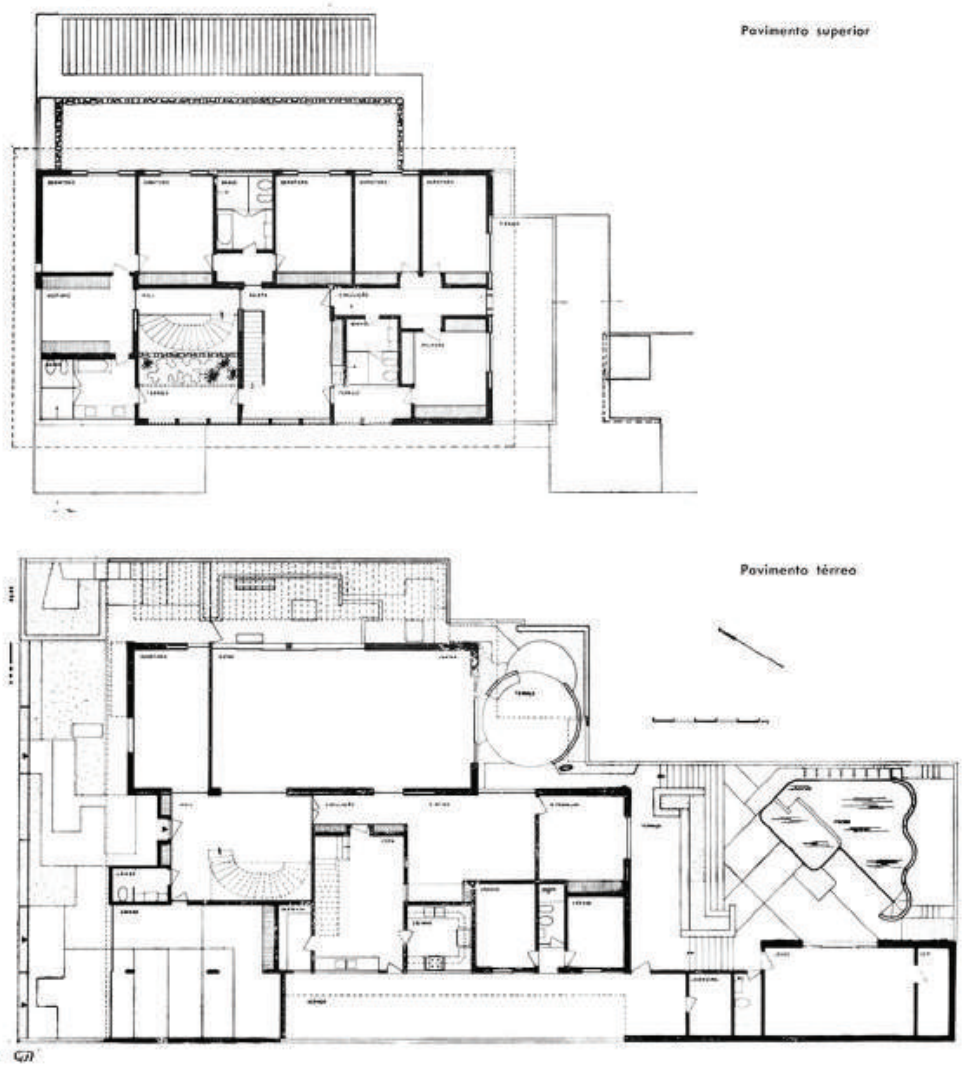

\section{RESIDÊNCIA CUSTÓDIO CORRÊA}

Cliente: Dr. José Custódio Corrêa

Data de projeto: não consta

Data da publicação: 1962

Projeto: José L. Fleury de Oliveira

Projetos complementares: não consta

Construção: não consta

Paisagismo: Roberto Coelho Cardozo

Tipologia: residencial

Endereço: São José do Rio Preto/SP

Material:

RESIDÊNCIA em São José do Rio Preto. Acrópole, São Paulo, 281, p. 154-5, abr. 1962. 


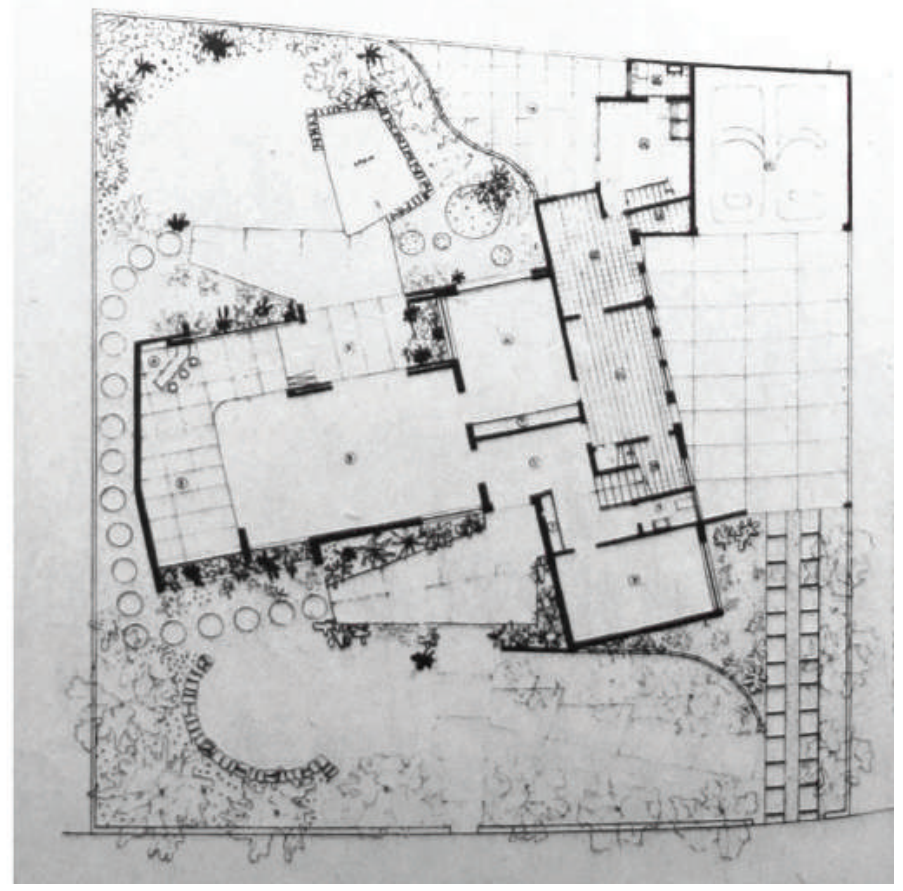

\section{RESIDÊNCIA DAVID SERSON NETO}

Cliente: David Serson Neto

Data de projeto: não consta

Data da publicação: não consta

Projeto: não consta

Projetos complementares: não consta

Construção: não consta

Paisagismo: Roberto Coelho Cardozo

Tipologia: residencial

Endereço: Rua Roberto Moreira, 165 - Jardim Leonor - São Paulo/SP

Material:

CARDOZO, R. C. Curriculum vitae. In: UNIVERSIDADE DE SÃO PAULO. Processo

52.1.14106.1.2: contrato docente. São Paulo: Departamento de projetos da Faculdade de

Arquitetura e Urbanismo. 15/12/1987. 87p.

EM terreno mais ou menos quadrangular. Casa e Jardim, São Paulo, 4, p. 10-15, out. 1953. 


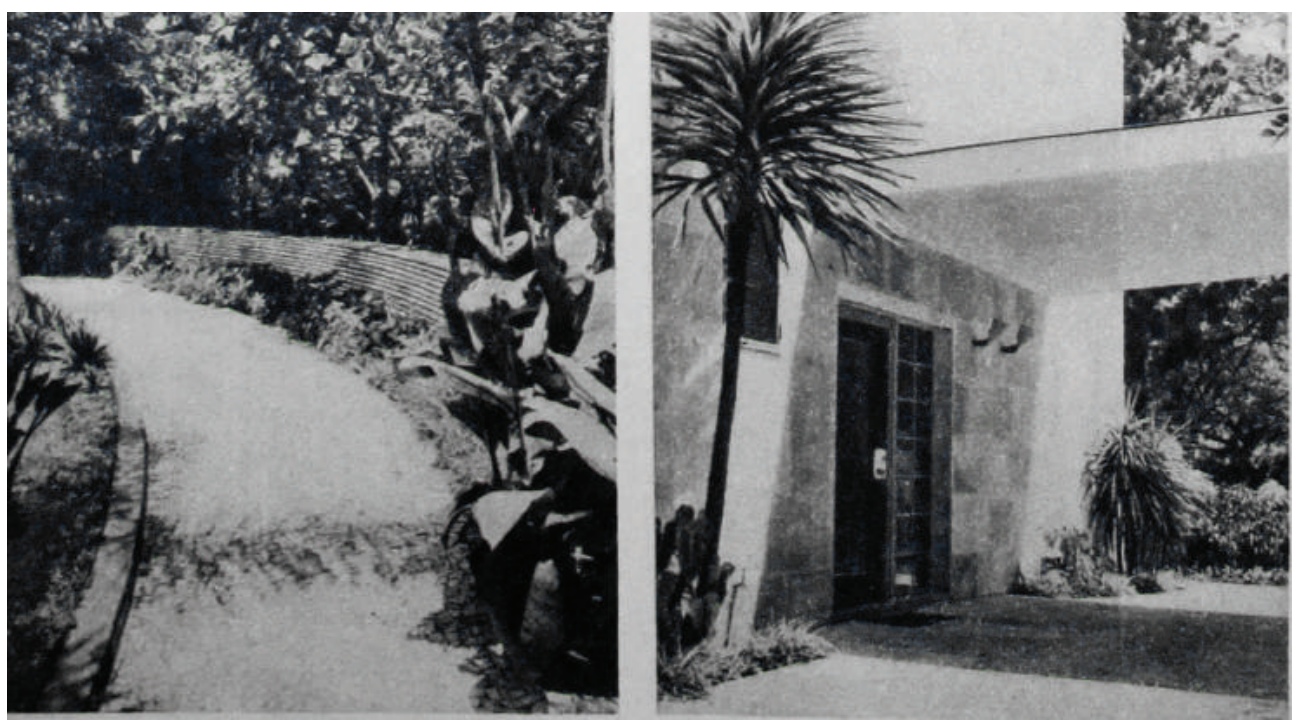

\section{RESIDÊNCIA DAWID ZEJGER}

Cliente: Dawid Zejger

Data de projeto: 1951

Data da publicação: 1954

Projeto: Marjan Ryszard Glogowski

Projetos complementares: não consta

Construção: construído por Escritório Técnico Lucjan Korngold Engenharia e

Construções.

Paisagismo: Roberto Coelho Cardozo e Suzana Coelho Cardozo.

Tipologia: residencial

Endereço: Rua San Salvador, 127 - Jardim Paulista - São Paulo/SP

Material:

CARDOZO, R. C. Curriculum vitae. In: UNIVERSIDADE DE SÃO PAULO. Processo

52.1.14106.1.2: contrato docente. São Paulo: Departamento de projetos da Faculdade de Arquitetura e Urbanismo. 15/12/1987. 87p.

CARDOZO, R. C. Living do ar livre. Acrópole, São Paulo, 192, p. 570-1, set. 1954.

CARDOZO, R. C. Pisos no jardim: terraços, passeios ou áreas privadas. Casa e Jardim, São Paulo, 15, p. 51-53, jul. 1955.

CRIVELLI, V. Graça na magnitude, encanto no detalhe. Casa e Jardim, São Paulo, 14, p. 16-22, mai/jun. 1955.

FALBEL, A. Lucjan Korngold: a trajetória de um arquiteto imigrante. Tese (Doutorado em Arquitetura e Urbanismo). FAUUSP, São Paulo, 2003. 323p.

METZENER, A. Janelas que são molduras. Casa e Jardim, São Paulo, 13, p. 35-7, mar/ abr. 1955.

SALA de jantar: luz fixa e luz móvel. Casa e Jardim, São Paulo, 32, p. 30-1, jan./fev. 1957.

Observações: Responsável técnico: Joaquim Procópio de Araújo.

Processo PMSP: 143470/50; 56110/51. 


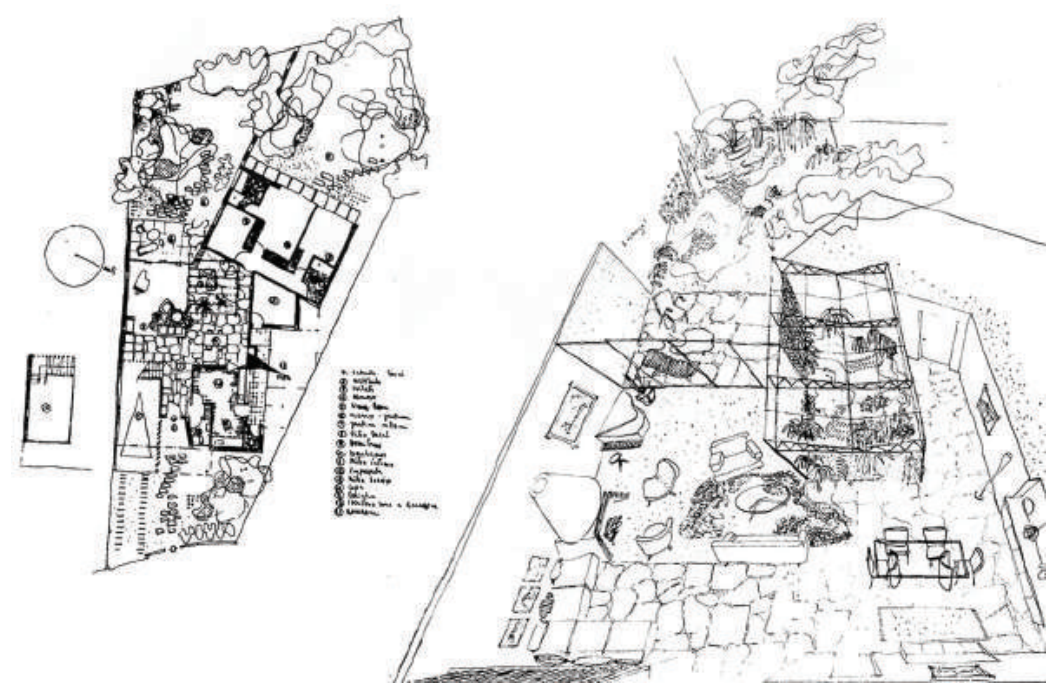

\section{RESIDÊNCIA DESIDÉRIO TOBIAS}

Cliente: Desidério Tobias

Data de projeto: não consta

Data da publicação: 1951

Projeto: Vaidergorn \& Verona Arquitetura e Construções

Projetos complementares: não consta

Construção: Vaidergorn \& Verona Arquitetura e Construções

Paisagismo: Roberto Coelho Cardozo

Tipologia: residencial

Endereço: Rua Honório Líbero, 154 - Pinheiros - São Paulo/SP

Material:

CARDOZO, R. C. Curriculum vitae. In: UNIVERSIDADE DE SÃO PAULO. Processo

52.1.14106.1.2: contrato docente. São Paulo: Departamento de projetos da Faculdade de Arquitetura e Urbanismo. 15/12/1987. 87p.

RESIDÊNCIA à Rua Honório Líbero, 154. Acrópole, n. 157, p. 10, mai. 1951. 


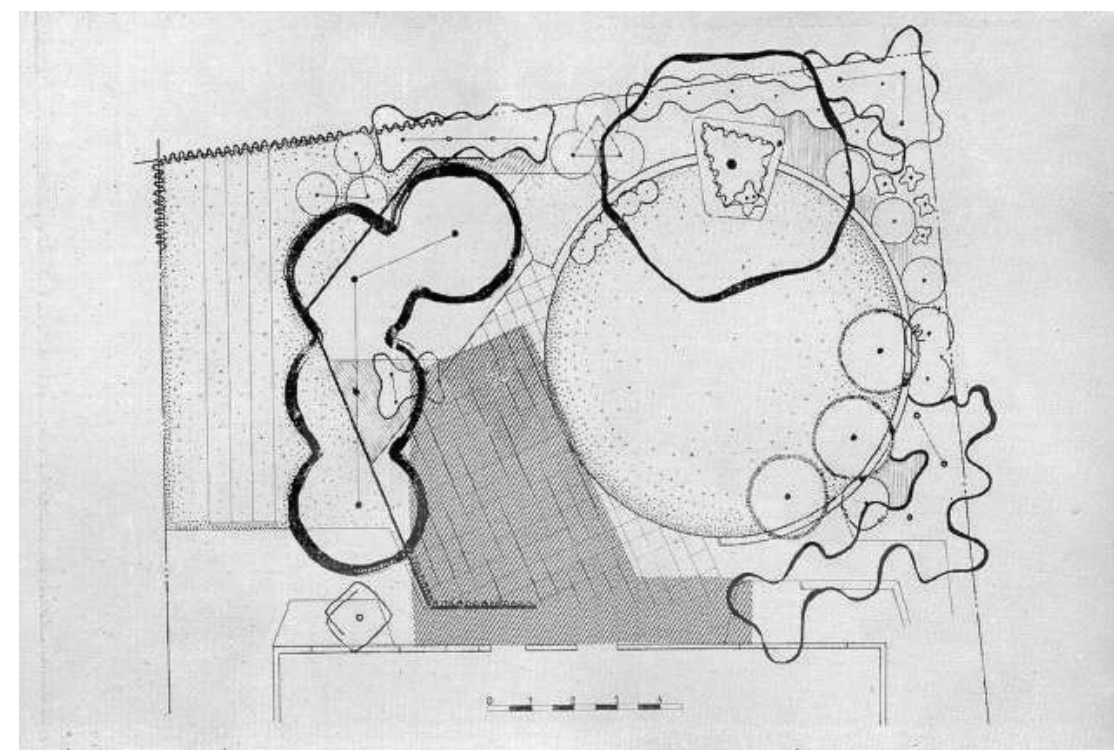

\section{RESIDÊNCIA DISCHLIA STEIVARTZ E ADOLPHO BUME GOLDENS- TEIN}

Cliente: Dischlia Steivartz e Adolpho Bume Goldenstein

Data de projeto: não consta

Data da publicação: 1955

Projeto: não consta

Projetos complementares: não consta

Construção: não consta

Paisagismo: Osborn Coelho Cardozo

Tipologia: residencial

Endereço: Rua Cândido Nascimento - Itaim Bibi - São Paulo/SP

Material:

CARDOZO, R. C. Curriculum vitae. In: UNIVERSIDADE DE SÃO PAULO. Processo

52.1.14106.1.2: contrato docente. São Paulo: Departamento de projetos da Faculdade de Arquitetura e Urbanismo. 15/12/1987. 87p.

CARDOZO, R. C. Degraus externos. Acrópole, São Paulo, 228, p. 460, out. 1957.

ABBUD, B. Um procedimento em pesquisa: A obra do arquiteto paisagista Roberto

Coelho Cardozo. Trabalho de Graduação Interdisciplinar (Graduação em Arquitetura e Urbanismo). FAUUSP, São Paulo, 1974. 100p.

CARDOZO, R. C. Biombos como barreiras. Casa e Jardim, São Paulo, 13, p. 46-49, mar/ abr. 1955.

ATIVIDADES ao ar livre. Acrópole, São Paulo, 197, p. 236-7, fev. 1955. 


\section{RESIDÊNCIA DOMINGOS PIRES}

Cliente: Domingos Pires

Data de projeto: não consta

Data da publicação: não consta

Projeto: não consta

Projetos complementares: não consta

Construção: não consta

Paisagismo: Roberto Coelho Cardozo

Tipologia: residencial

Endereço: Avenida 9 de Julho x Avenida Santo Amaro - São Paulo/SP

Material:

CARDOZO, R. C. Curriculum vitae. In: UNIVERSIDADE DE SÃO PAULO. Processo

52.1.14106.1.2: contrato docente. São Paulo: Departamento de projetos da Faculdade de Arquitetura e Urbanismo. 15/12/1987. 87p.

\section{RESIDÊNCIA EDUARDO BADRA}

Cliente: Eduardo Badra

Data de projeto: não consta

Data da publicação: não consta

Projeto: não consta

Projetos complementares: não consta

Construção: não consta

Paisagismo: Roberto Coelho Cardozo

Tipologia: residencial

Endereço: Rua das Jabuticabeiras, 405 - Cidade Jardim - São Paulo/SP

Material:

CARDOZO, R. C. Curriculum vitae. In: UNIVERSIDADE DE SÃO PAULO. Processo

52.1.14106.1.2: contrato docente. São Paulo: Departamento de projetos da Faculdade de Arquitetura e Urbanismo. 15/12/1987. 87p.

\section{RESIDÊNCIA EDUARDO CARONE}

Cliente: Eduardo Carone

Data de projeto: não consta

Data da publicação: não consta

Projeto: não consta

Projetos complementares: não consta

Construção: não consta

Paisagismo: Roberto Coelho Cardozo

Tipologia: residencial

Endereço: não consta

Material:

CARDOZO, R. C. Curriculum vitae. In: UNIVERSIDADE DE SÃO PAULO. Processo 52.1.14106.1.2: contrato docente. São Paulo: Departamento de projetos da Faculdade de Arquitetura e Urbanismo. 15/12/1987. 87p. 
Residoncia:

DONALD CAMARGO Arquiteto:

OSWALDO BRATKE

Paisagismo:

R. COELHO CARDOZO

5. OSBORN COELHO

Seixos beges da própria construçäo, com cimento. Juntas de $8 \mathrm{~cm}$ para grama.

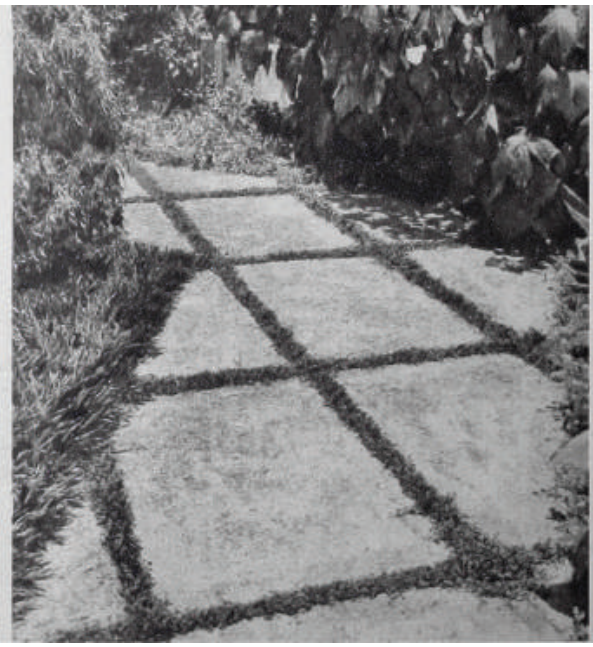

Residencia: DONALD CAMARGO Arquiteto: OSWALDO BRATKE Paisagismo: R. COELHO CARDOZO S. OSBORN COELHO

Igual ao anterior, com iuntas de modeira. Tipo de piso, cujo efeito dependo bastante da qualidade da máo-de-obra.

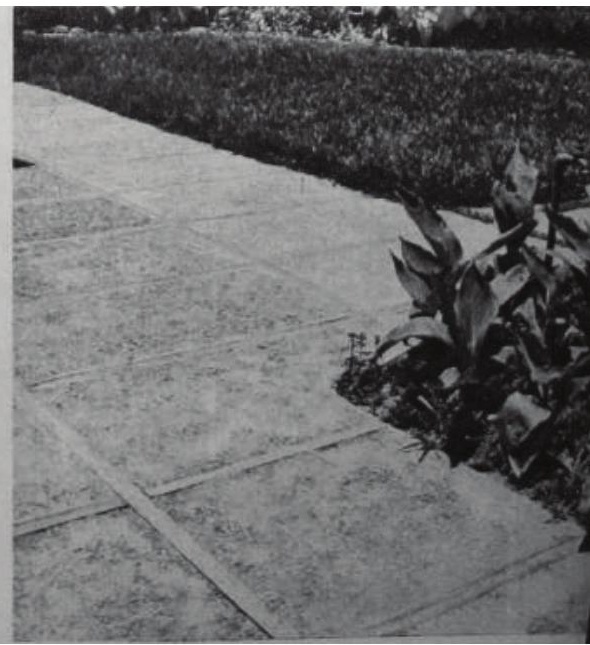

\section{RESIDÊNCIA DONALD JOSEPH ARCHER DE CAMARGO}

Cliente: Donald Joseph Archer de Camargo

Data de projeto: não consta

Data da publicação: 1955

Projeto: Oswaldo Bratke

Projetos complementares: não consta

Construção: não consta

Paisagismo: Roberto Coelho Cardozo e Susan Osborn Coelho

Tipologia: residencial

Endereço: Rua Teixeira Pinto, 146 - Jardins - São Paulo/SP

Material:

CARDOZO, R. C. Curriculum vitae. In: UNIVERSIDADE DE SÃO PAULO. Processo

52.1.14106.1.2: contrato docente. São Paulo: Departamento de projetos da Faculdade de Arquitetura e Urbanismo. 15/12/1987. 87p.

CARDOZO, R. C. Pisos no jardim: terraços, passeios ou áreas privadas. Casa e Jardim,

São Paulo, 15, p. 51-53, jul. 1955. 

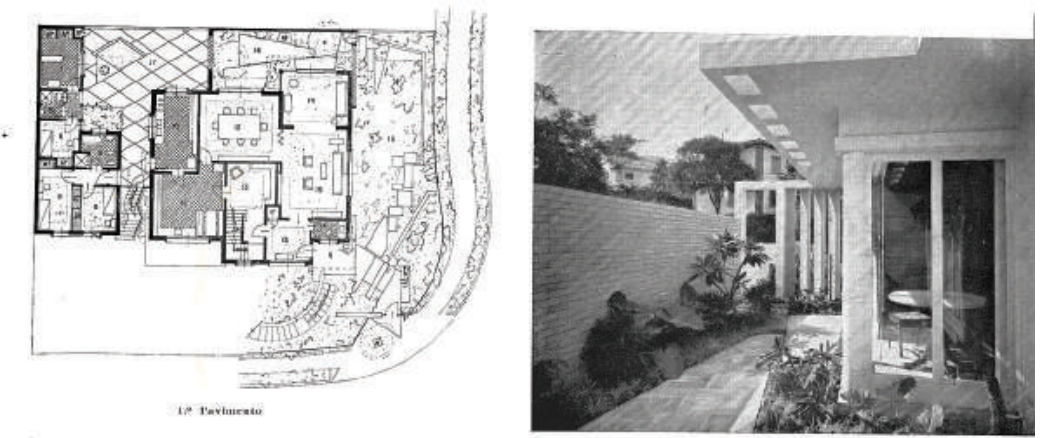

rites soctal e Jartim de tnverpo
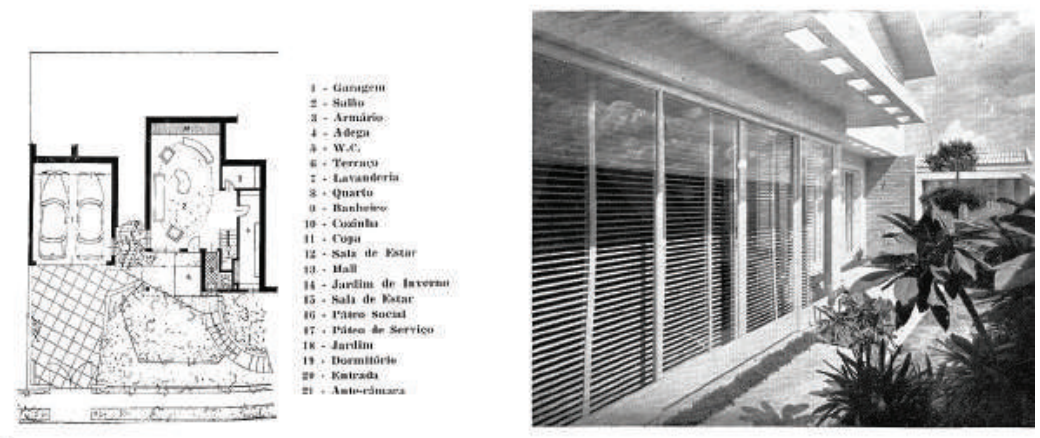

Detwille ilo wites sotiat

\section{RESIDÊNCIA EDUARDO MARCOS MONTEIRO}

Cliente: Eduardo Marcos Monteiro

Data de projeto: Rubens de Camargo Monteiro

Data da publicação: 1955

Projeto: Rubens de Camargo Monteiro

Projetos complementares: Ambiente S.A. (decoração)

Construção: Monteiro, Wigderowitz \& Monteiro Ltda.

Tipologia: residencial

Endereço: não consta

Material:

CARDOZO, R. C. Curriculum vitae. In: UNIVERSIDADE DE SÃO PAULO. Processo

52.1.14106.1.2: contrato docente. São Paulo: Departamento de projetos da Faculdade de Arquitetura e Urbanismo. 15/12/1987. 87p.

RESIDÊNCIA no Pacaembu, Acrópole, São Paulo, n.198, p. 280-3, mar. 1955. 


\section{RESIDÊNCIA EDUARDO MATARAZZO}

Cliente: Eduardo Matarazzo

Data de projeto: não consta

Data da publicação: 1961

Projeto: não consta

Projetos complementares: não consta

Construção: não consta

Paisagismo: Roberto Coelho Cardozo

Tipologia: residencial

Endereço: Guarujá/SP

Material:

CARDOZO, R. C. Curriculum vitae. In: UNIVERSIDADE DE SÃO PAULO. Processo

52.1.14106.1.2: contrato docente. São Paulo: Departamento de projetos da Faculdade de Arquitetura e Urbanismo. 15/12/1987. 87p.

FACHADAS assim não se veem todos os dias. Casa e Jardim, São Paulo, 72, p. 30-31, jan. 1961.

\section{RESIDÊNCIA EDUARDO MATARAZZO}

Cliente: Eduardo Matarazzo

Data de projeto: não consta

Data da publicação: não consta

Projeto: não consta

Projetos complementares: não consta

Construção: não consta

Paisagismo: Roberto Coelho Cardozo

Tipologia: residencial

Endereço: São Paulo/SP

Material:

CARDOZO, R. C. Curriculum vitae. In: UNIVERSIDADE DE SÃO PAULO. Processo

52.1.14106.1.2: contrato docente. São Paulo: Departamento de projetos da Faculdade de Arquitetura e Urbanismo. 15/12/1987. 87p.

\section{RESIDÊNCIA ENIA E JÚLIO GOICHBERG}

Cliente: Enia e Júlio Goichberg

Data de projeto: não consta

Data da publicação: 1955

Projeto: Victor Reif

Projetos complementares: não consta

Construção: não consta

Paisagismo: Susan Osborn Coelho e Roberto Coelho Cardozo

Tipologia: residencial

Endereço: não consta

Material:

CARDOZO, R. C. Pisos no jardim: terraços, passeios ou áreas privadas. Casa e Jardim, São Paulo, 15, p. 51-53, jul. 1955. 


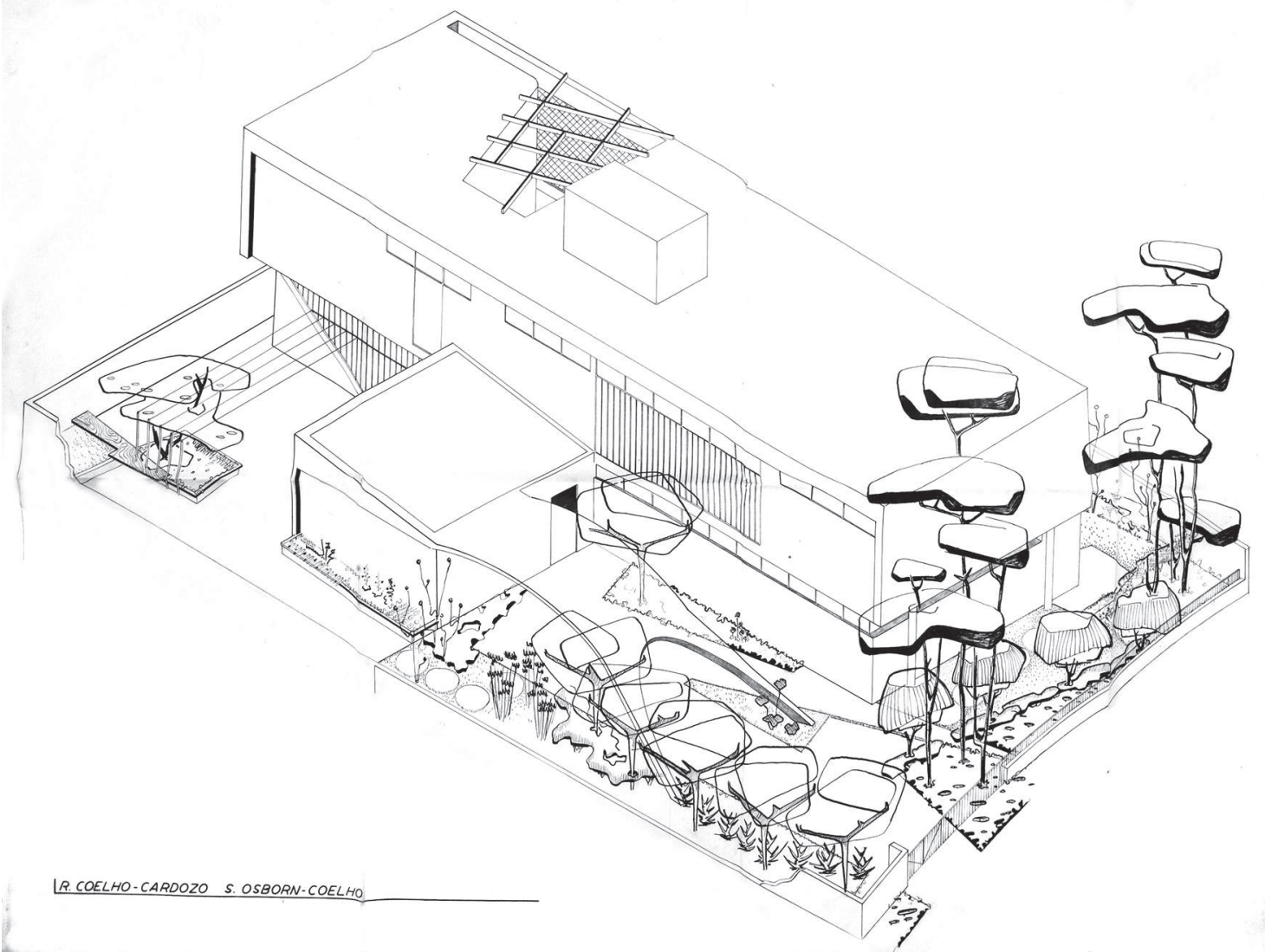

\section{RESIDÊNCIA ELPHY E ALFREDO ROSENTHAL}

Cliente: Alfredo Rosenthal

Data de projeto: 1951

Data de publicação: 1952 e 1956

Projeto: João Bapstista Vilanova Artigas

Projetos complementares: A. Carlos Vasconcelos e Luiz G. M. Vieira (cálculo estrutural)

Construção: construído

Paisagismo: Roberto Coelho Cardozo e Susan Osborn Coelho

Tipologia: residencial

Endereço: Rua Heitor de Moraes, 507 - Pacaembu - São Paulo/SP

Material:

Acervo biblioteca FAUUSP (cód. PE C179/728.3 A): 2 desenhos de perspectivas, 2 pranchas de detalhes, planta de plantação, desenho de projeto de jardim (massa de vegetação), planta de estacamento e planta ilustrativa.

Diapositivos do arquivo da Biblioteca da FAU.

BELEZA aquática nos jardins. Casa e Jardim, São Paulo, 21, p. 22-3, jan. 1956.

CARDOZO, R. C. Biombos como barreiras. Casa e Jardim, São Paulo, 13, p. 46-49, mar/ abr. 1955.

CARDOZO, R. C. Curriculum vitae. In: UNIVERSIDADE DE SÃO PAULO. Processo

52.1.14106.1.2: contrato docente. São Paulo: Departamento de projetos da Faculdade de Arquitetura e Urbanismo. 15/12/1987. 87p.

CARDOZO, R. C. Pisos no jardim: terraços, passeios ou áreas privadas. Casa e Jardim, São Paulo, 15, p. 51-53, jul. 1955.

CARDOZO, R.R.; COELHO, S.O. Um jardim. Habitat, São Paulo, 6, p. 69-71, 1952.

RESIDÊNCIA no Pacaembu. Acrópole, São Paulo, 212, p. 308-11, jun. 1956. 


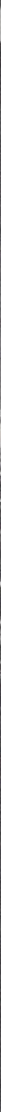

\section{RESIDÊNCIA ERNESTO BUNGE}

Cliente: Ernesto Bunge

Data de projeto: não consta

Data da publicação: 1960

Projeto: não consta

Projetos complementares: não consta

Construção: não consta

Paisagismo: Roberto Coelho Cardozo

Tipologia: residencial

Endereço: Rua Canadá, 787 - Jardim América - São Paulo/SP

Material:

CARDOZO, R. C. Curriculum vitae. In: UNIVERSIDADE DE SÃO PAULO. Processo

52.1.14106.1.2: contrato docente. São Paulo: Departamento de projetos da Faculdade de

Arquitetura e Urbanismo. 15/12/1987. 87p.

JEGOROW, W. Aspectos básicos para a formação de um jardim. Casa e Jardim, São

Paulo, 65, p. 53-55, jun. 1960.

Observações: Existem mais dois artigos de duas residências de Ernesto Bunge (Acrópole n. 197 de 1955 e Casa e Jardim n. 69 de 1960), mas pelo endereço os projetos não coincidem. Levamos em consideração o endereço que consta no Currículo Vitae de Roberto Coelho Cardozo. 


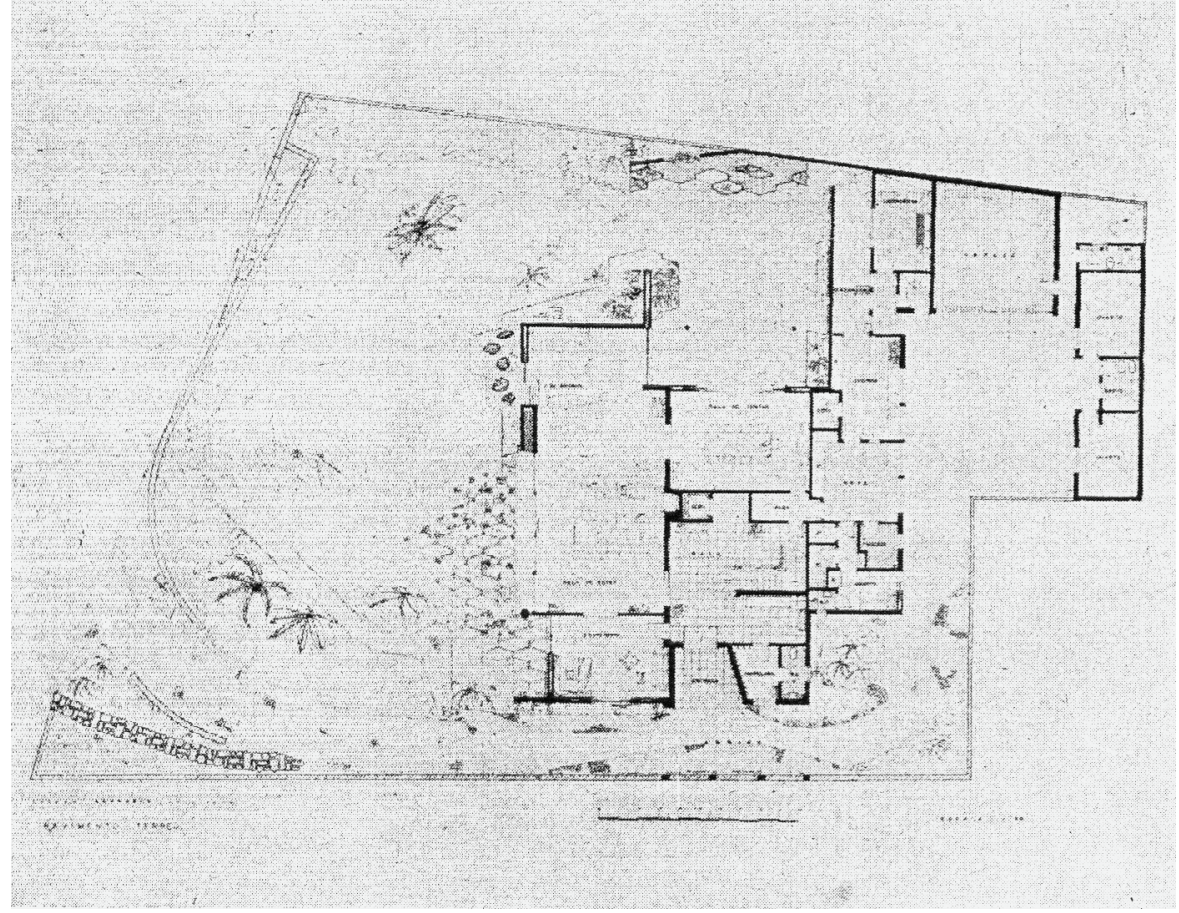

\section{RESIDÊNCIA ESTHER KLABIN E ALFREDO LANDAU}

Cliente: Esther Klabin e Alfredo Landau

Data de projeto: 1956

Data da publicação: 1960

Projeto: Lucjan Korngold

Projetos complementares: não consta

Construção: construído por Escritório Técnico Lucjan Korngold Engenharia e

Construções

Paisagismo: Roberto Coelho Cardozo

Tipologia: residencial

Endereço: Rua Bucareste, 207 - Jardim Europa - São Paulo/SP

Material:

CARDOZO, R. C. Curriculum vitae. In: UNIVERSIDADE DE SÃO PAULO. Processo

52.1.14106.1.2: contrato docente. São Paulo: Departamento de projetos da Faculdade de Arquitetura e Urbanismo. 15/12/1987. 87p.

FALBEL, A. Lucjan Korngold: a trajetória de um arquiteto imigrante. Tese (Doutorado em Arquitetura e Urbanismo). FAUUSP, São Paulo, 2003. 323p.

RESIDÊNCIA no Jardim Europa. Habitat, São Paulo, 62, p. 22-24, 1960. 


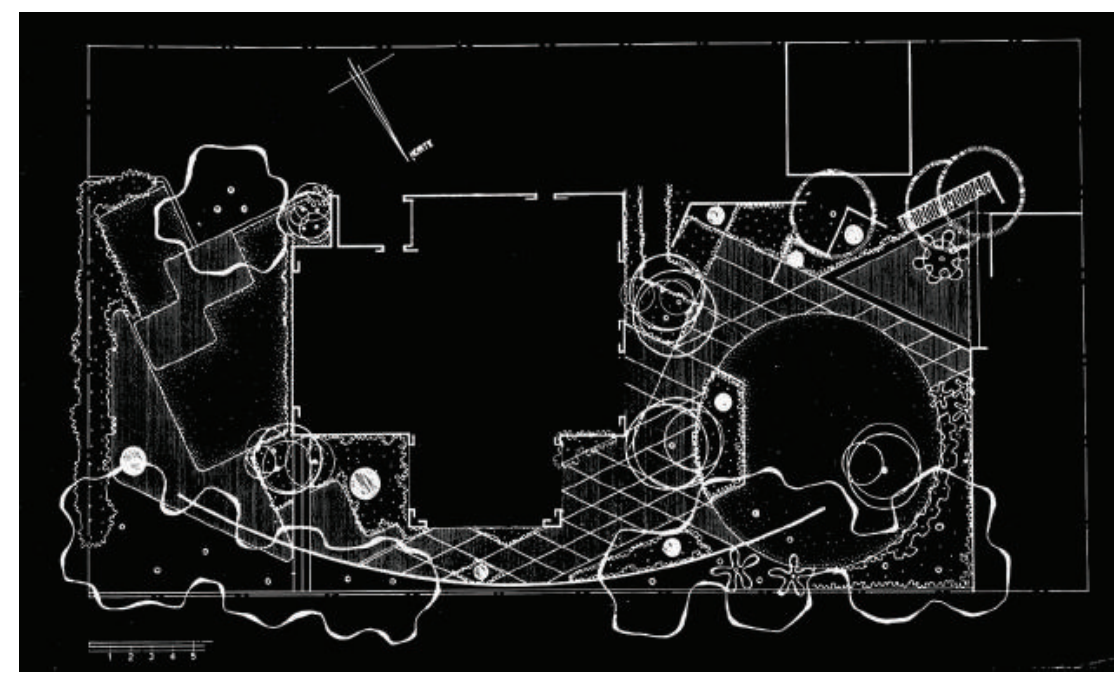

\section{RESIDÊNCIA FELÍCIA E ISAY LEIRNER}

Cliente: Felícia e Isay Leirner

Data de projeto: não consta

Data da publicação: 1966

Projeto: não consta

Projetos complementares: não consta

Construção: não consta

Paisagismo: Roberto Coelho Cardozo

Tipologia: residencial

Endereço: Rua Guadelupe, 328 - Jardim Paulista - São Paulo/SP

Material:

CARDOZO, R. C. Curriculum vitae. In: UNIVERSIDADE DE SÃO PAULO. Processo

52.1.14106.1.2: contrato docente. São Paulo: Departamento de projetos da Faculdade de Arquitetura e Urbanismo. 15/12/1987. 87p.

DA caverna aos nossos dias. Casa e Jardim, São Paulo, n. 141, p. 06-13, out. 1966. 


\section{RESIDÊNCIA FRANCISCO BERNARDO LORCH}

Cliente: Francisco Bernardo Lorch

Data de projeto: 1965

Data da publicação: não consta

Projeto: Gregório Zolko

Projetos complementares: não consta

Construção: não consta

Paisagismo: Roberto Coelho Cardozo

Tipologia: residencial

Endereço: Rua Antônio de Andrade Rebelo, 421 - Retiro Morumbi - São Paulo/SP

Material:

Acervo pessoal de Gregório Zolko.

\section{RESIDÊNCIA FRANCISCO DE PAULA MACHADO DE CAMPOS}

Cliente: Francisco de Paula Machado de Campos

Data de projeto: não consta

Data da publicação: não consta

Projeto: não consta

Projetos complementares: não consta

Construção: não consta

Paisagismo: Roberto Coelho Cardozo

Tipologia: residencial

Endereço: Rua Professor Moniz, 561 - Alto de Pinheiros - São Paulo/SP

Material:

Acervo da biblioteca da FAUUSP (Cód PE C179/728.3 FP): anteprojeto.

CARDOZO, R. C. Curriculum vitae. In: UNIVERSIDADE DE SÃO PAULO. Processo

52.1.14106.1.2: contrato docente. São Paulo: Departamento de projetos da Faculdade de Arquitetura e Urbanismo. 15/12/1987. 87p.

\section{RESIDÊNCIA FRANCISCO ROSA}

Cliente: Francisco Rosa

Data de projeto: não consta

Data da publicação: não consta

Projeto: não consta

Projetos complementares: não consta

Construção: não consta

Paisagismo: Roberto Coelho Cardozo

Tipologia: residencial

Endereço: não consta

Material:

CARDOZO, R. C. Curriculum vitae. In: UNIVERSIDADE DE SÃO PAULO. Processo

52.1.14106.1.2: contrato docente. São Paulo: Departamento de projetos da Faculdade de Arquitetura e Urbanismo. 15/12/1987. 87p. 


\section{RESIDÊNCIA FRANCISCO SCARPA}

Cliente: Francisco Scarpa

Data de projeto: não consta

Data da publicação: não consta

Projeto: não consta

Projetos complementares: não consta

Construção: não consta

Paisagismo: Roberto Coelho Cardozo

Tipologia: residencial

Endereço: Rua Canadá, 6 - Jardim América - São Paulo/SP

Material:

CARDOZO, R. C. Curriculum vitae. In: UNIVERSIDADE DE SÃO PAULO. Processo

52.1.14106.1.2: contrato docente. São Paulo: Departamento de projetos da Faculdade de Arquitetura e Urbanismo. 15/12/1987. 87p.

\section{RESIDÊNCIA FRANKLYN FAY}

Cliente: Franklyn Fay

Data de projeto: não consta

Data da publicação: não consta

Projeto: não consta

Projetos complementares: não consta

Construção: não consta

Paisagismo: Roberto Coelho Cardozo

Tipologia: residencial

Endereço: não consta

Material:

CARDOZO, R. C. Curriculum vitae. In: UNIVERSIDADE DE SÃO PAULO. Processo

52.1.14106.1.2: contrato docente. São Paulo: Departamento de projetos da Faculdade de Arquitetura e Urbanismo. 15/12/1987. 87p.

\section{RESIDÊNCIA GERALDO DENTE NEVES}

Cliente: Geraldo Dente Neves

Data de projeto: não consta

Data da publicação: não consta

Projeto: não consta

Projetos complementares: não consta

Construção: não consta

Paisagismo: Roberto Coelho Cardozo

Tipologia: residencial

Endereço: Rua Pedroso de Moraes, 1573 - Pinheiros - São Paulo/SP

Material:

CARDOZO, R. C. Curriculum vitae. In: UNIVERSIDADE DE SÃO PAULO. Processo 52.1.14106.1.2: contrato docente. São Paulo: Departamento de projetos da Faculdade de Arquitetura e Urbanismo. 15/12/1987. 87p. 


\section{RESIDÊNCIA HANNELORE FUCHS}

Cliente: não consta

Data de projeto: não consta

Data da publicação: não consta

Projeto: não consta

Projetos complementares: não consta

Construção: não consta

Paisagismo: Roberto Coelho Cardozo

Tipologia: residencial

Endereço: Rua Piracicaba, 188 - Sumaré - São Paulo/SP

Material:

CARDOZO, R. C. Curriculum vitae. In: UNIVERSIDADE DE SÃO PAULO. Processo

52.1.14106.1.2: contrato docente. São Paulo: Departamento de projetos da Faculdade de Arquitetura e Urbanismo. 15/12/1987. 87p.

\section{RESIDÊNCIA HÉLIO BICUDO}

Cliente: Hélio Bicudo

Data de projeto: não consta

Data da publicação: não consta

Projeto: não consta

Projetos complementares: não consta

Construção: não consta

Paisagismo: Roberto Coelho Cardozo

Tipologia: residencial

Endereço: Rua Araporé, 325 - Jardim Guedala - São Paulo/SP

Material:

CARDOZO, R. C. Curriculum vitae. In: UNIVERSIDADE DE SÃO PAULO. Processo

52.1.14106.1.2: contrato docente. São Paulo: Departamento de projetos da Faculdade de Arquitetura e Urbanismo. 15/12/1987. 87p. 


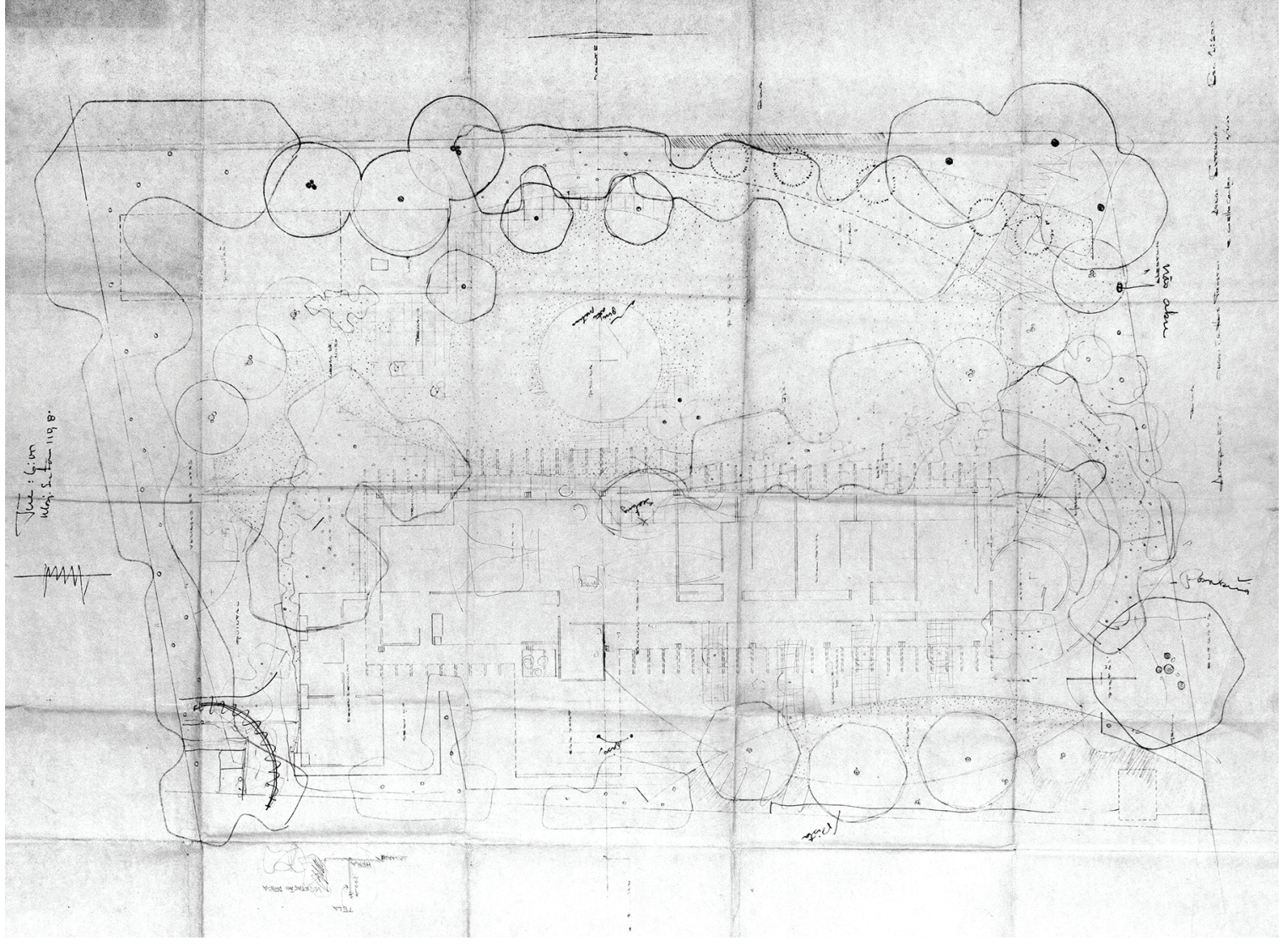

\section{RESIDÊNCIA HANNS VICTOR TROSTLI 2}

Cliente: Hanns Victor Trostli

Data de projeto: 1957

Data da publicação: não foi publicado

Projeto: João Baptista Vilanova Artigas

Projetos complementares: não consta

Construção: não consta

Paisagismo: Roberto Coelho Cardozo

Tipologia: residencial

Endereço: Cachoeirinha - São Paulo/SP

Material:

Acervo da biblioteca da FAUUSP (Cód. PE C179/712.6 HT): 1 prancha de implantação.

Acervo da biblioteca, material de Vilanova Artigas: plantas diversas da Residência Hanns

Victor Trostli 2, em Cachoeirinha.

Acervo da biblioteca da FAUUSP : diapositivos da coleção Julio Katinsky.

TAGLIARI, A.; PERRONE, R.; FLORIO, W. Os projetos residenciais não-construídos de

Vilanova Artigas em São Paulo. Pós, São Paulo, v.21, n. 35, p .98-117, jun. 2014.

TAGLIARI, A.; PERRONE, R.; FLORIO, W. Estudos dos projetos residenciais não-

construídos de Vilanova Artigas em São Paulo. Arquiteturarevista, São Paulo, v. 08, n. 01,

p. 49-61, jan/jun. 2015.

TAGLIARI, A. Os projetos residenciais não-construídos de Vilanova Artigas em São Paulo.

Tese (Doutorado em Arquitetura e Urbanismo) - FAUUSP, São Paulo, 2012. 417p.

Observações: Existem duas casas feitas por Vilanova Artigas para Hanns Trostli. A partir da tese de Ana Tagliari pudemos verificar que a residência que recebeu projeto paisagístico de Roberto Coelho Cardozo é a Residência Hanns Victor Trostli 2, em Cachoeirinha. Essa residência nunca foi construída - já a residência Hanns Trostli 1 foi construída na Rua Guará, no Sumaré. 


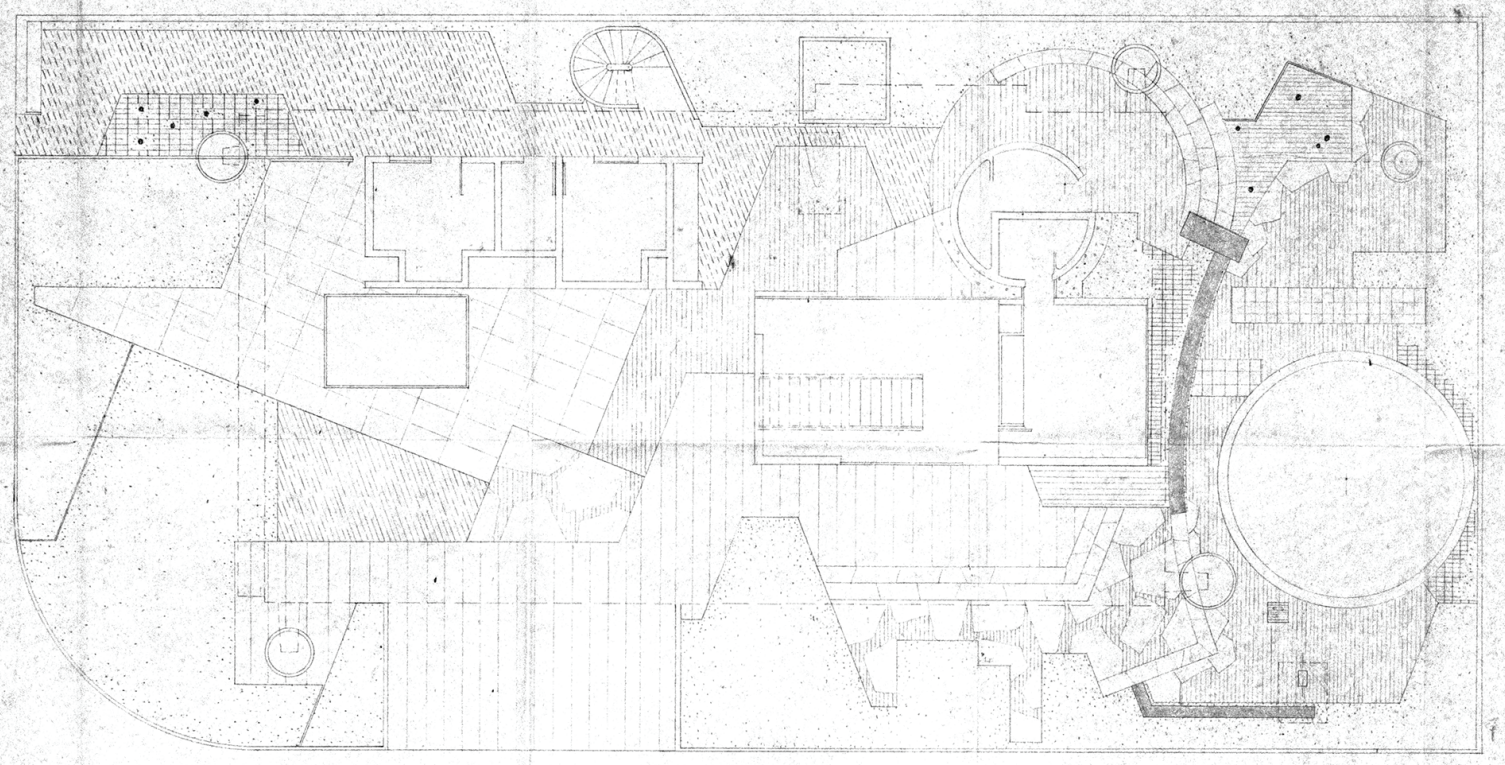

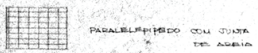
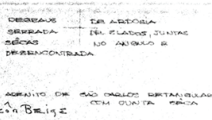

\section{RESIDÊNCIA HÉLIO CORREA}

Cliente: Hélio Correa

Data de projeto: 1968

Data da publicação: não consta

Projeto: Hélio Correa

Projetos complementares: não consta

Construção: não consta

Paisagismo: Consultoria em Paisagem Urbana - Roberto Coelho Cardozo, Antonio A.

Antunes Netto e Marcos de Souza Dias.

Tipologia: residencial

Endereço: Rua Doutor José Ferreira de Camargo, 276 - Nova Campinas - Campinas/SP

Material:

Acervo da biblioteca da FAUUSP (Cód. PE C179es/728.3 HC): anteprojeto; planta de locação áreas externas; planta de detalhes; detalhes; materiais: piso.

CARDOZO, R. C. Curriculum vitae. In: UNIVERSIDADE DE SÃO PAULO. Processo

52.1.14106.1.2: contrato docente. São Paulo: Departamento de projetos da Faculdade de Arquitetura e Urbanismo. 15/12/1987. 87p. 


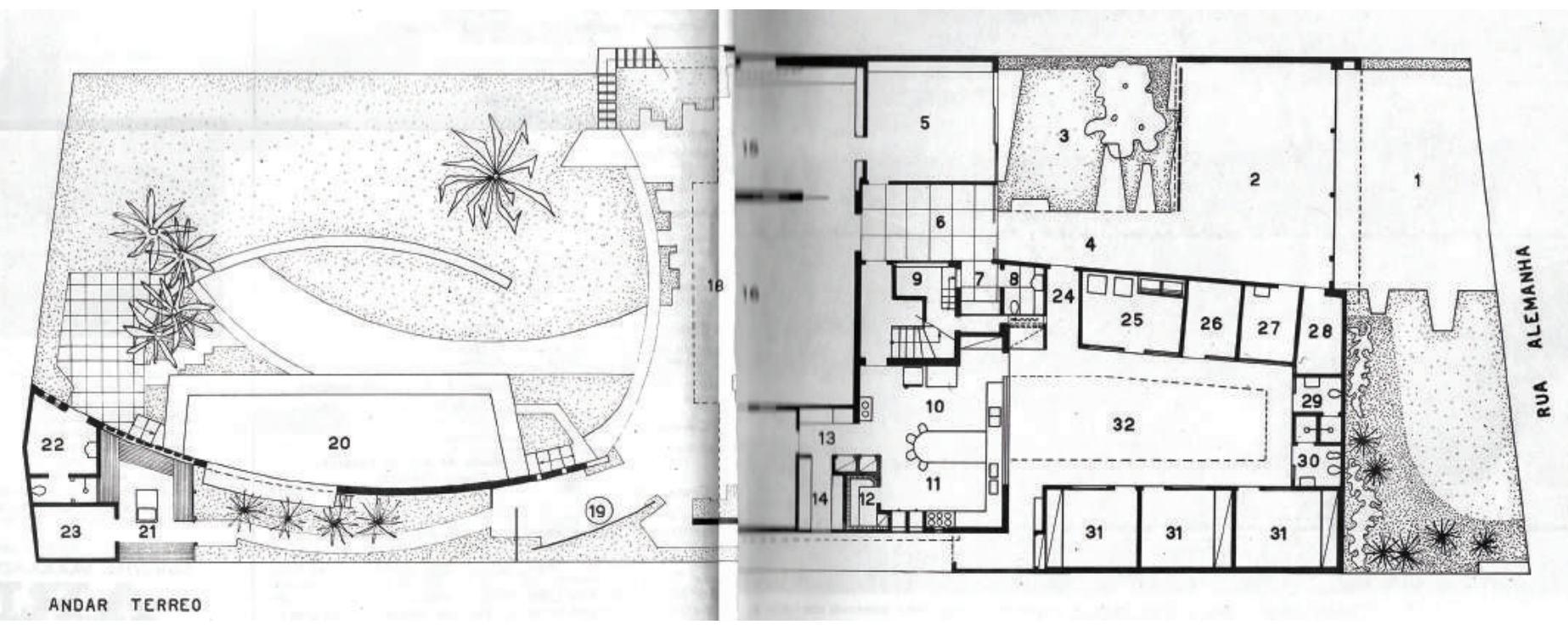

\section{RESIDÊNCIA HENRIQUE ALEXANDER}

Cliente: Henrique Alexander

Data de projeto: não consta

Data da publicação: 1957

Projeto: Henrique Alexander

Projetos complementares: não consta

Construção: Henrique Alexander

Paisagismo: Roberto Coelho Cardozo

Tipologia: residencial

Endereço: Rua Alemanha, 548 - Jardim Europa - São Paulo/SP

Material:

DORCA. A casa do arquiteto: Henrique Alexander. Casa e Jardim, São Paulo, 34, p. 10-

16, abr. 1957

CARDOZO, R. C. Curriculum vitae. In: UNIVERSIDADE DE SÃO PAULO. Processo

52.1.14106.1.2: contrato docente. São Paulo: Departamento de projetos da Faculdade de Arquitetura e Urbanismo. 15/12/1987. 87p.

TAL como foi sonhada. Casa e Jardim, São Paulo, n. 138, p. 6-12, jul. 1966. 

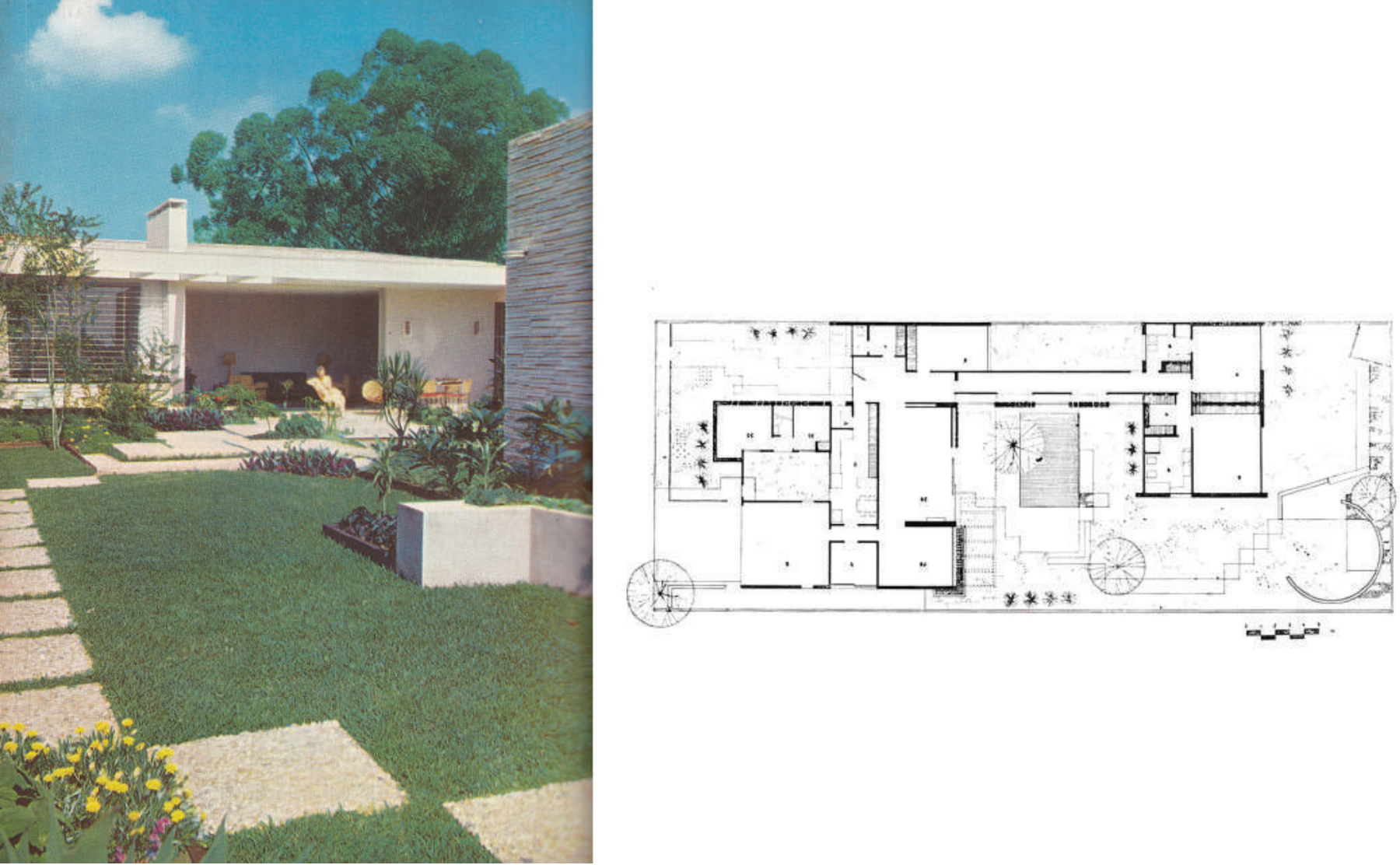

\section{RESIDÊNCIA HENRIQUE FLATAUER}

Cliente: Henrique Flatauer

Data de projeto: não consta

Data da publicação: 1959

Projeto: Jorge Zalszupin

Projetos complementares: não consta

Construção: construído por Escritório Técnico Prumo Ltda.

Paisagismo: parceria com Susan Osborn Cardozo

Tipologia: residencial

Endereço: Rua Cândido Nascimento - Itaim Bibi - São Paulo/SP

Material:

CARDOZO, R. C. Curriculum vitae. In: UNIVERSIDADE DE SÃO PAULO. Processo

52.1.14106.1.2: contrato docente. São Paulo: Departamento de projetos da Faculdade de

Arquitetura e Urbanismo. 15/12/1987. 87p.

CARNEIRO, D. G. Proprietário, arquiteto, decorador, paisagista falam sobre uma casa.

Casa e Jardim, São Paulo, 39, p. 22-33, nov./dez. 1957.

RESIDÊNCIA no Brooklin Paulista. Acrópole, São Paulo, 247, p. 252-5, mai. 1959. 


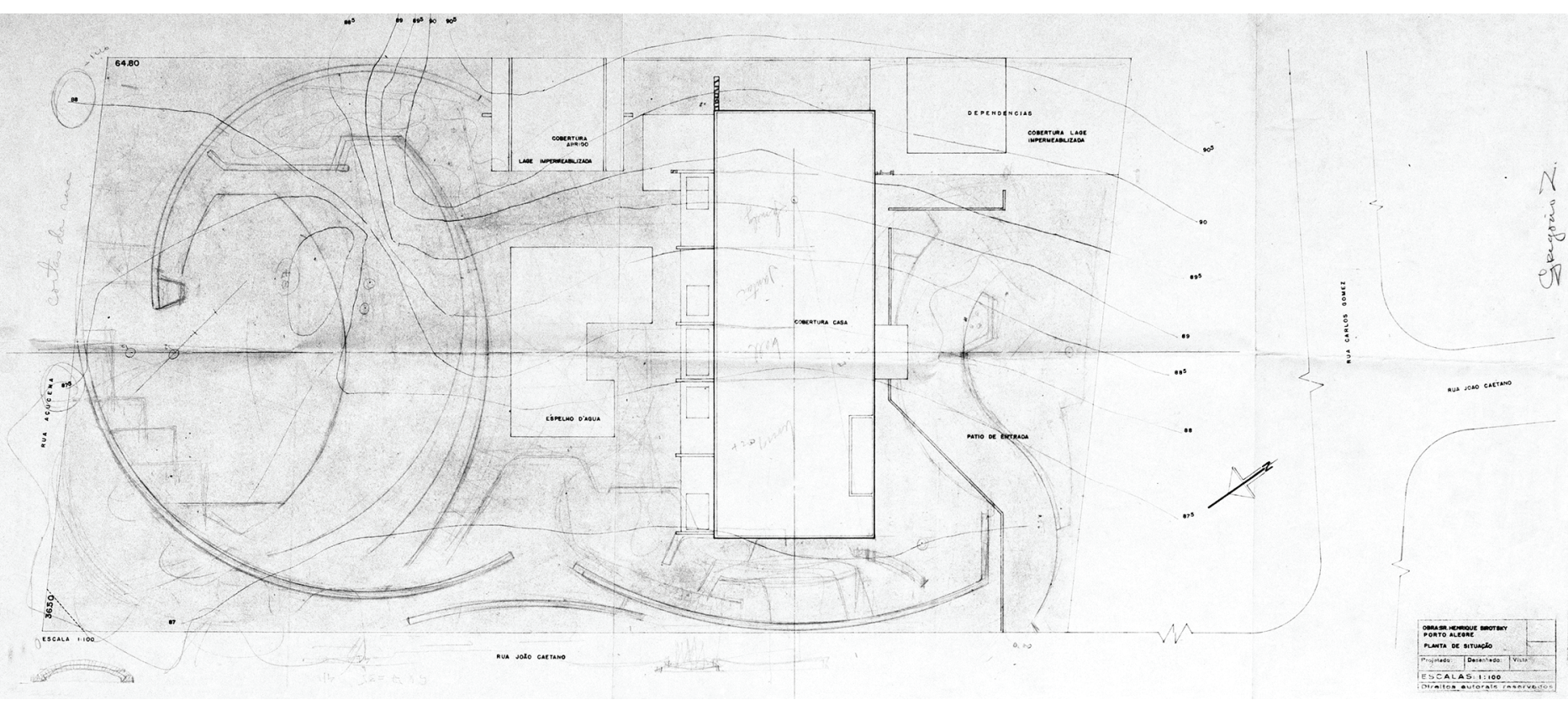

\section{RESIDÊNCIA HENRIQUE SIROTSKY}

Cliente: Henrique Sirotsky

Data de projeto: 1958

Data da publicação: não foi publicado

Projeto: Gregório Zolko

Projetos complementares: não consta

Construção: construído

Paisagismo: Roberto Coelho Cardozo

Tipologia: residencial

Endereço: Rua João Caetano, 207 - Petrópolis - Porto Alegre/RS

Material:

Acervo da biblioteca da FAUUSP (Cód PE C179/728.3 H): planta de situação.

CARDOZO, R. C. Curriculum vitae. In: UNIVERSIDADE DE SÃO PAULO. Processo

52.1.14106.1.2: contrato docente. São Paulo: Departamento de projetos da Faculdade de

Arquitetura e Urbanismo. 15/12/1987. 87p. 


\section{RESIDÊNCIA HENRIQUE ZYLBERMAN}

Cliente: Henrique Zylberman / Henryk Zylberman

Data de projeto: não consta

Data da publicação: não consta

Projeto: não consta

Projetos complementares: não consta

Construção: não consta

Paisagismo: Roberto Coelho Cardozo

Tipologia: residencial

Endereço: Rua Piauí, 900 - Higienópolis - São Paulo/SP

Material:

CARDOZO, R. C. Curriculum vitae. In: UNIVERSIDADE DE SÃO PAULO. Processo

52.1.14106.1.2: contrato docente. São Paulo: Departamento de projetos da Faculdade de

Arquitetura e Urbanismo. 15/12/1987. 87p.

\section{RESIDÊNCIA IBRAHIM SULEIMAN}

Cliente: Ibrahim Suleiman

Data de projeto: não consta

Data da publicação: não consta

Projeto: não consta

Projetos complementares: não consta

Construção: não consta

Paisagismo: Roberto Coelho Cardozo

Tipologia: residencial

Endereço: Rua Venezuela, 576 - Jardim Paulista - São Paulo/SP

Material:

CARDOZO, R. C. Curriculum vitae. In: UNIVERSIDADE DE SÃO PAULO. Processo

52.1.14106.1.2: contrato docente. São Paulo: Departamento de projetos da Faculdade de Arquitetura e Urbanismo. 15/12/1987. 87p. 


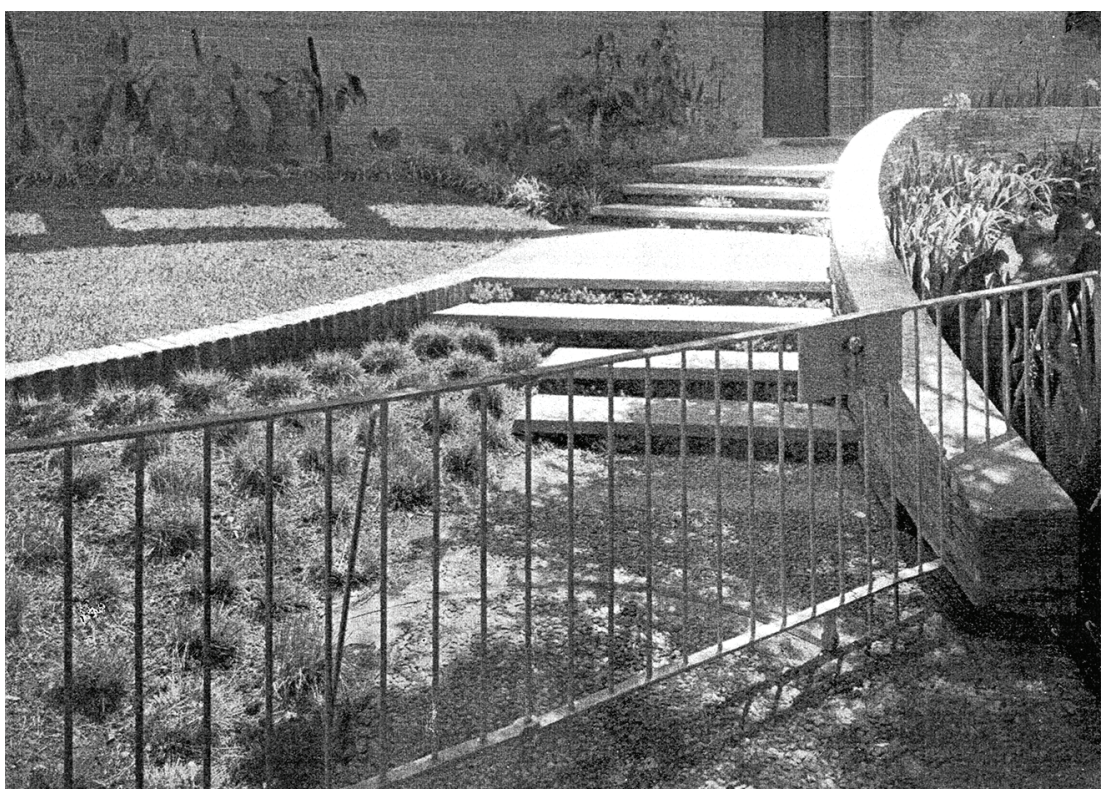

\section{RESIDÊNCIA HERBERT SCHIER}

Cliente: Herbert Schier

Data de projeto: 1952

Data da publicação: 1954

Projeto: Marjan Ryszard Glogowski

Projetos complementares: não consta

Construção: construído por Escritório Técnico Lucjan Korngold Engenharia e

Construções

Paisagismo: Osborn Coelho Cardozo

Tipologia: residencial

Endereço: Rua lquitos, 152 - Vila Madalena - São Paulo/SP

Material:

CARDOZO, R. C. Áreas de entrada. Acrópole, São Paulo, 195, p. 133-5, dez. 1954.

DEGRAUS externos. Acrópole, São Paulo, 228, p. 460, out. 1957.

FALBEL, A. Lucjan Korngold: a trajetória de um arquiteto imigrante. Tese (Doutorado em Arquitetura e Urbanismo). FAUUSP, São Paulo, 2003. 323p.

Observações: Responsável Técnico - Laércio Ramos.

Processos PMSP - 14876/51 e 88383/52. 


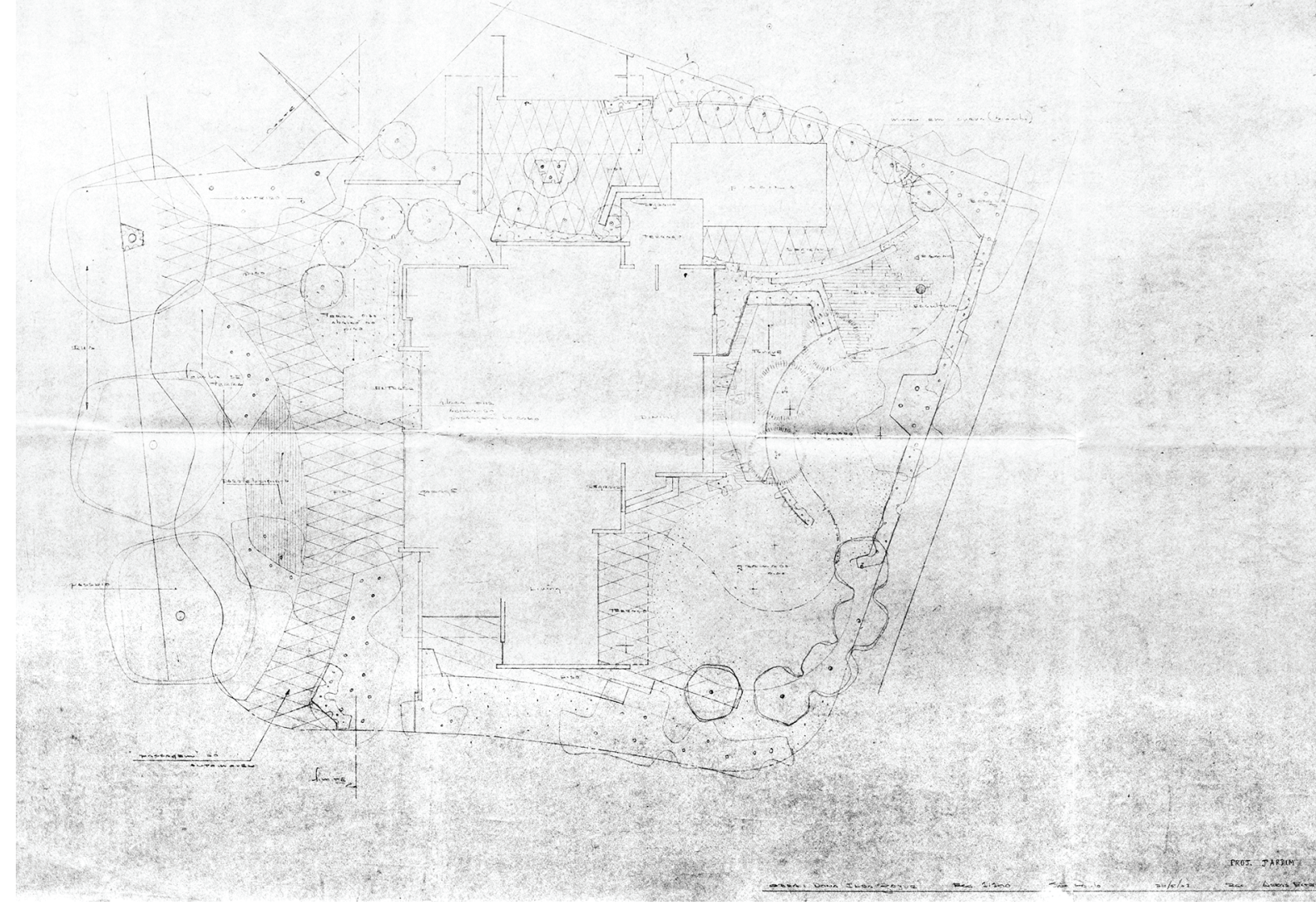

\section{RESIDÊNCIA ILDA E WALDOMIRO ZARZUR}

Cliente: Ilda e Waldomiro Zazur

Data de projeto: 1962

Data da publicação: 1966

Projeto: Rubens Carneiro Vianna e Ricardo Sievers

Projetos complementares: não consta

Construção: construído por Waldomiro Zarzur Engenharia e Construções

Paisagismo: Roberto Coelho Cardozo

Tipologia: residencial

Endereço: Rua Guaiaquil x Rua Argentina - São Paulo/SP

Material:

Acervo da biblioteca da FAUUSP (Cód. PE C179/728.3 IL): Pranchas de paisagismo - projeto jardim \#1 ao \#6, terraço e living \#7 e \#7A. Pranchas de arquitetura: cortes transversais 3-4-5, cortes longitudinais 1-2, estudo no2, planta das coberturas, do andar superior, do andar térreo, planta de nivelamento e locação de vegetação, fachadas principais, fachadas laterais da residência.

Acervo Quapá/FAUUSP.

CARDOZO, R. C. Curriculum vitae. In: UNIVERSIDADE DE SÃO PAULO. Processo 52.1.14106.1.2: contrato docente. São Paulo: Departamento de projetos da Faculdade de Arquitetura e Urbanismo. 15/12/1987. 87p.

RESIDÊNCIA no Jardim América. Acrópole, São Paulo, 328, p. 34-6, mai. 1966.

VACARINO, R. The inclusion of Modernism: Brasilidade and the Garden. In: TREIB, Marc. The Architecture of Landscape 1940-1960. Philadelphia: University of Pennsylvania Press, 2002. 208p. 


\section{RESIDÊNCIA IRWIN LOEW}

Cliente: Irwin Loew

Data de projeto: não consta

Data da publicação: não consta

Projeto: Henrique Ephim Mindlin

Projetos complementares: não consta

Construção: não consta

Paisagismo: Roberto Coelho Cardozo

Tipologia: residencial

Endereço: Rua Haddock Lobo, 1110 - Cerqueira César - São Paulo/SP

Material:

CARDOZO, R. C. Curriculum vitae. In: UNIVERSIDADE DE SÃO PAULO. Processo

52.1.14106.1.2: contrato docente. São Paulo: Departamento de projetos da Faculdade de Arquitetura e Urbanismo. 15/12/1987. 87p.

\section{RESIDÊNCIA ISRAEL ROSENBERG}

Cliente: Israel Rosenberg

Data de projeto: não consta

Data da publicação: não consta

Projeto: não consta

Projetos complementares: não consta

Construção: não consta

Paisagismo: Roberto Coelho Cardozo

Tipologia: residencial

Endereço: Rua Abegoária, 458 - Pinheiros - São Paulo/SP

Material:

CARDOZO, R. C. Curriculum vitae. In: UNIVERSIDADE DE SÃO PAULO. Processo

52.1.14106.1.2: contrato docente. São Paulo: Departamento de projetos da Faculdade de Arquitetura e Urbanismo. 15/12/1987. 87p.

\section{RESIDÊNCIA JAKOB SZPORN}

Cliente: Jakob Szporn

Data de projeto: não consta

Data da publicação: não consta

Projeto: Rino Levi

Projetos complementares: não consta

Construção: não consta

Paisagismo: Roberto Coelho Cardozo

Tipologia: residencial

Endereço: Avenida Lopes de Azevedo, 870 - Chácara Flora - São Paulo/SP

Material:

ANELLI, R.; GUERRA, A. Rino Levi: Arquitetura e Cidade. São Paulo: Romano Guerra Editora, 2001, 324p.

CARDOZO, R. C. Curriculum vitae. In: UNIVERSIDADE DE SÃO PAULO. Processo

52.1.14106.1.2: contrato docente. São Paulo: Departamento de projetos da Faculdade de Arquitetura e Urbanismo. 15/12/1987. 87p. 


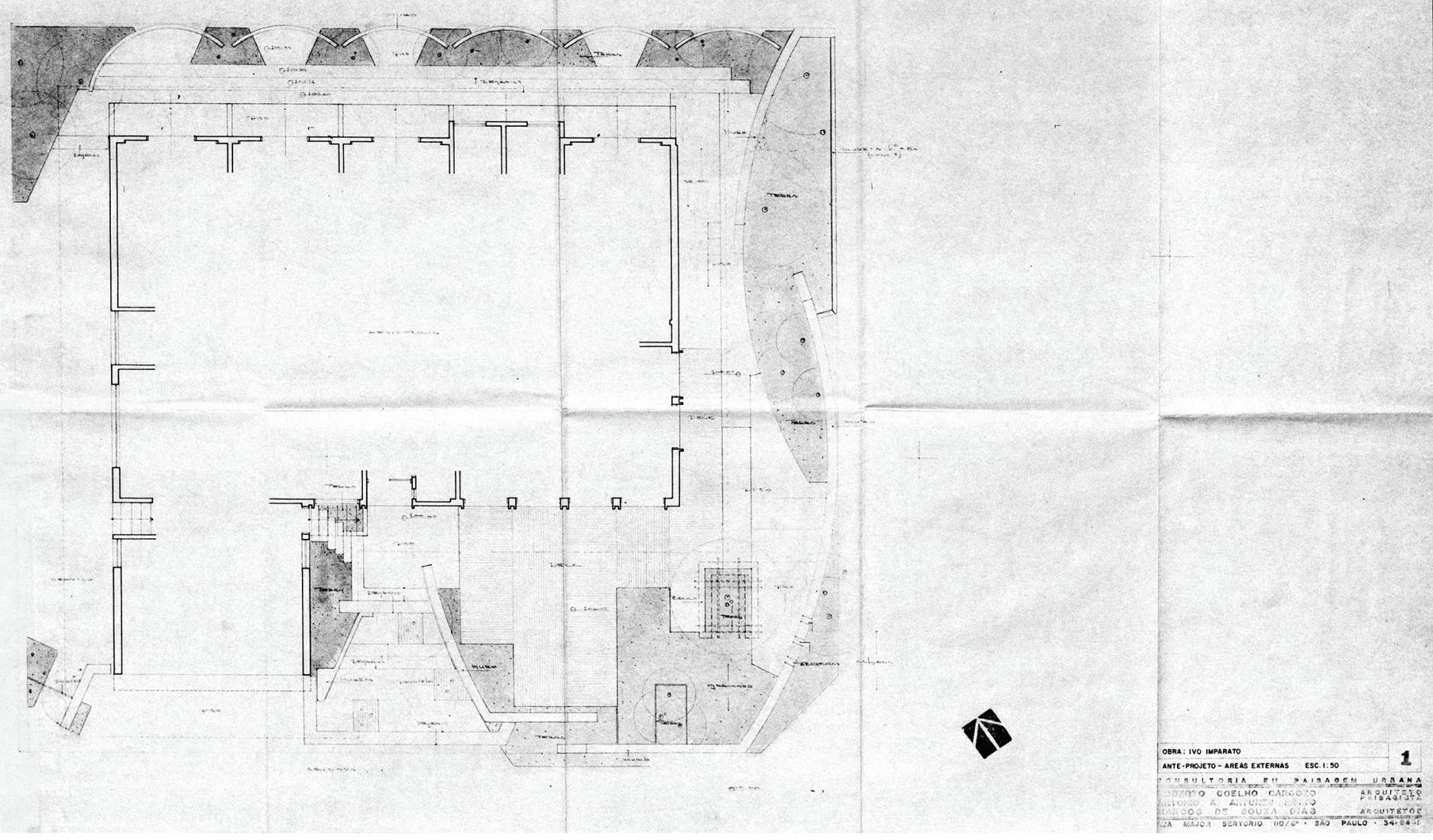

\section{RESIDÊNCIA IVO IMPARATO}

Cliente: Ivo Imparato

Data de projeto: 1969

Data da publicação: não foi publicado

Projeto: Alice e Dário Imparato

Projetos complementares: não consta

Construção: não consta

Paisagismo: Roberto Coelho Cardozo, Antonio A. Antunes Netto e Marcos de Souza Dias

Tipologia: residencial

Endereço: Rua Washington x Rua Arthur Costa Filho - Guarujá/SP

Material:

Acervo da biblioteca da FAUUSP (Cód PE C179es/728.7i): pranchas de paisagismo: anteprojeto áreas externas; detalhes de execução; planta de locação; detalhe de execução 2; projeto de plantação. Pranchas de arquitetura: projeto definitivo de fachadas, planta térreo. 


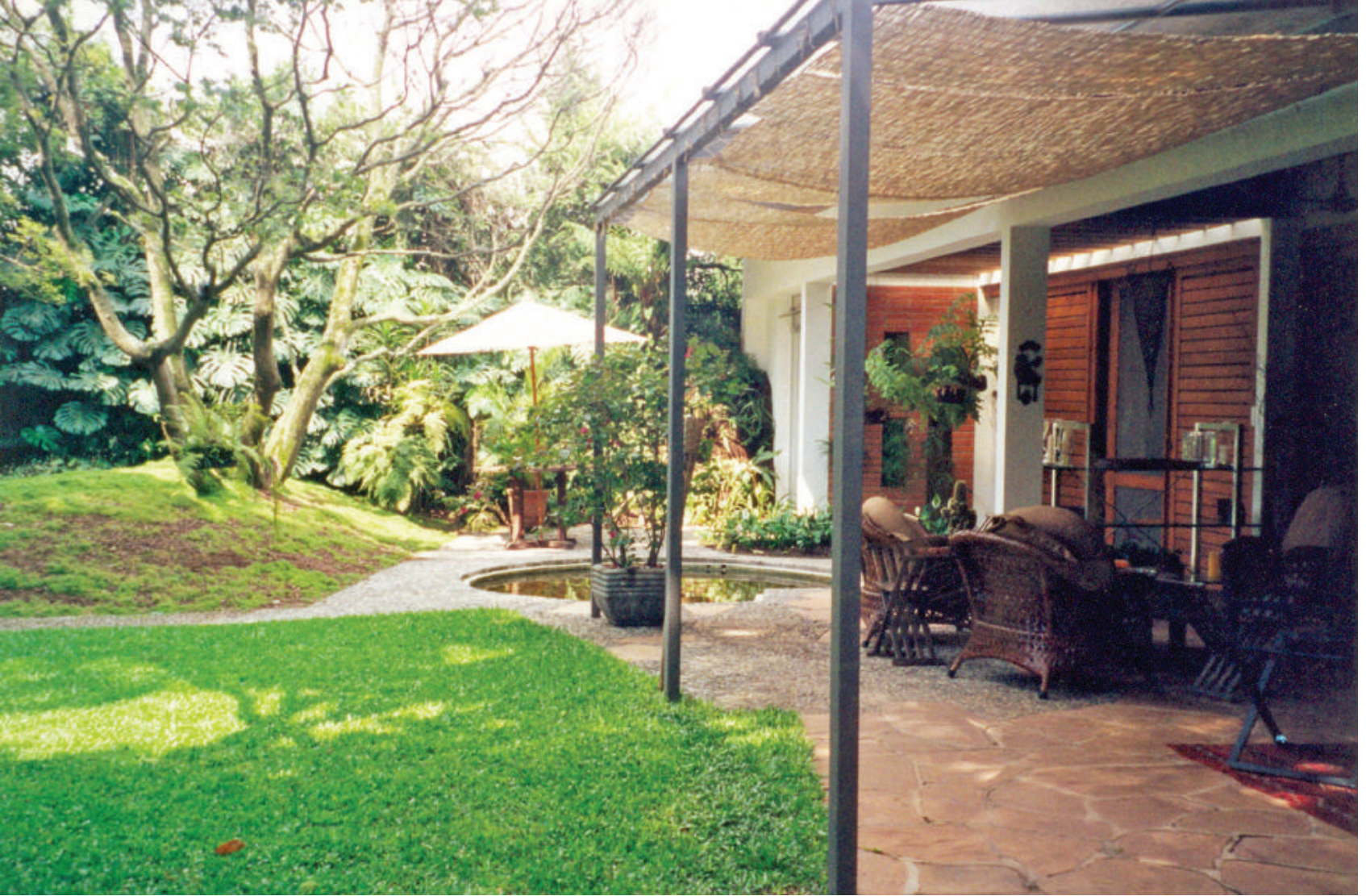

\section{RESIDÊNCIA JOAQUIM POLICIANO LEITE NETTO}

Cliente: Joaquim Policiano Leite Netto

Data de projeto: não consta

Data da publicação: não consta

Projeto: Gregório Zolko

Projetos complementares: não consta

Construção: não consta

Paisagismo: Roberto Coelho Cardozo

Tipologia: residencial

Endereço: Rua Professor Lúcio Martins Rodrigues, 310 - Morumbi - São Paulo/SP

Material:

Acervo Quapá/FAUUSP.

CARDOZO, R. C. Curriculum vitae. In: UNIVERSIDADE DE SÃO PAULO. Processo

52.1.14106.1.2: contrato docente. São Paulo: Departamento de projetos da Faculdade de Arquitetura e Urbanismo. 15/12/1987. 87p. 


\section{RESIDÊNCIA JORGE BEI MALUF}

Cliente: Jorge Bei Maluf

Data de projeto: não consta

Data da publicação: não consta

Projeto: não consta

Projetos complementares: não consta

Construção: não consta

Paisagismo: Roberto Coelho Cardozo

Tipologia: residencial

Endereço: não consta

Material:

CARDOZO, R. C. Curriculum vitae. In: UNIVERSIDADE DE SÃO PAULO. Processo

52.1.14106.1.2: contrato docente. São Paulo: Departamento de projetos da Faculdade de Arquitetura e Urbanismo. 15/12/1987. 87p.

\section{RESIDÊNCIA JORGE CURY}

Cliente: Jorge Cury

Data de projeto: não consta

Data da publicação: não consta

Projeto: não consta

Projetos complementares: não consta

Construção: não consta

Paisagismo: Roberto Coelho Cardozo

Tipologia: residencial

Endereço: Avenida República do Líbano - Moema - São Paulo/SP

Material:

CARDOZO, R. C. Curriculum vitae. In: UNIVERSIDADE DE SÃO PAULO. Processo

52.1.14106.1.2: contrato docente. São Paulo: Departamento de projetos da Faculdade de Arquitetura e Urbanismo. 15/12/1987. 87p.

\section{RESIDÊNCIA JOSÉ ALVES DE LIMA}

Cliente: José Alves de Lima

Data de projeto: não consta

Data da publicação: não consta

Projeto: não consta

Projetos complementares: não consta

Construção: não consta

Paisagismo: Roberto Coelho Cardozo

Tipologia: residencial

Endereço: não consta

Material:

CARDOZO, R. C. Curriculum vitae. In: UNIVERSIDADE DE SÃO PAULO. Processo

52.1.14106.1.2: contrato docente. São Paulo: Departamento de projetos da Faculdade de Arquitetura e Urbanismo. 15/12/1987. 87p. 


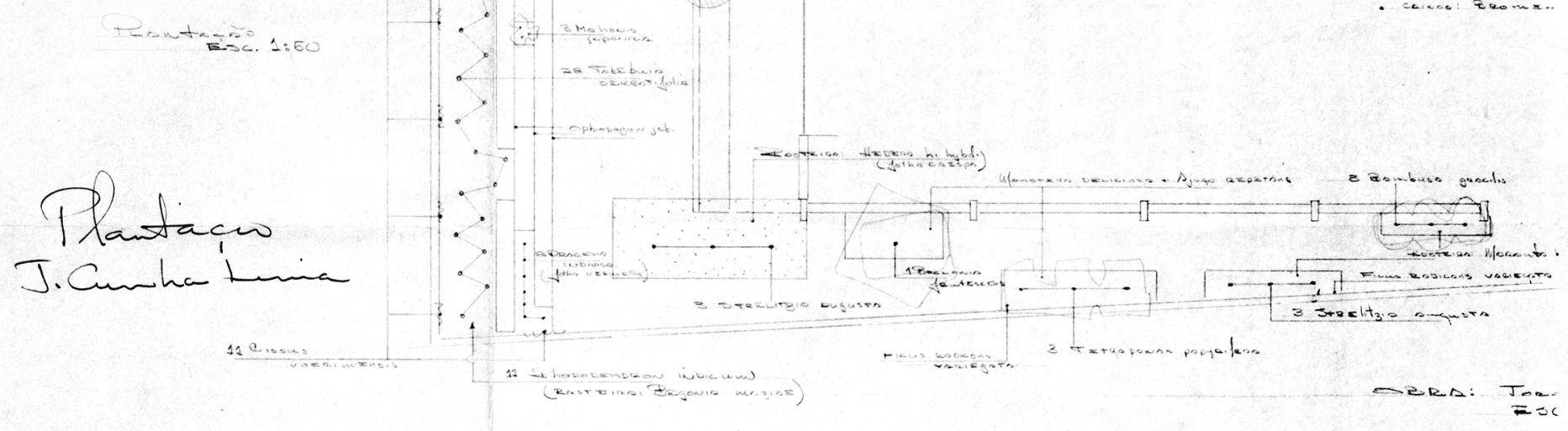

\section{RESIDÊNCIA JORGE CUNHA LIMA}

Cliente: Jorge Cunha Lima

Data de projeto: 1963

Data da publicação: não foi publicado

Projeto: Botti Rubin Arquitetos

Projetos complementares: não consta

Construção: não consta

Paisagismo: Roberto Coelho Cardozo

Tipologia: residencial

Endereço: Rua Silvio Portugal, 43 - Pacaembu - São Paulo/SP

Material:

Acervo da biblioteca da FAUUSP (Cód. PE C179/728.3 JC): Pranchas de arquitetura: cortes, pisos dos dormitórios, pisos das salas, plantas, escadas, elevações e cortes.

Pranchas de paisagismo: plantação e planta de deck.

CARDOZO, R. C. Curriculum vitae. In: UNIVERSIDADE DE SÃO PAULO. Processo

52.1.14106.1.2: contrato docente. São Paulo: Departamento de projetos da Faculdade de Arquitetura e Urbanismo. 15/12/1987. 87p. 


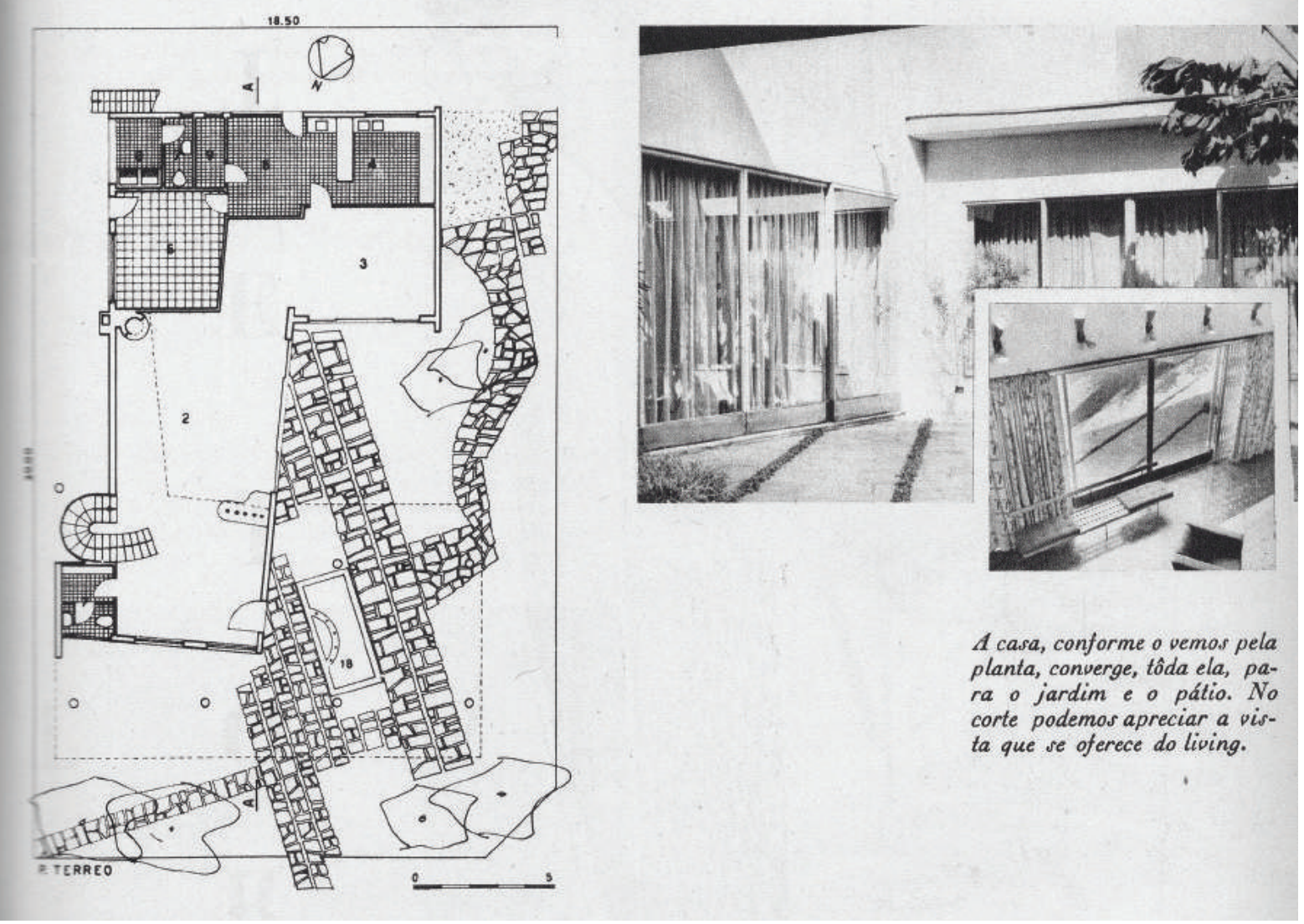

\section{RESIDÊNCIA JOSÉ MARQUES DA COSTA}

Cliente: José Marques da Costa

Data de projeto: não consta

Data da publicação: 1958

Projeto: Escritório Técnico de Engenharia Mieczyslaw Grabowski

Projetos complementares: não consta

Construção: não consta

Paisagismo: Osborn Coelho Cardozo

Tipologia: residencial

Endereço: Avenida IV Centenário, 941 - Jardim Luzitânia - São Paulo/SP

Material:

CAMPOBELO H. Modernos projetos. Casa e Jardim, São Paulo, 41, p.46-51, fev. 1958.

CARDOZO, R. C. Curriculum vitae. In: UNIVERSIDADE DE SÃO PAULO. Processo

52.1.14106.1.2: contrato docente. São Paulo: Departamento de projetos da Faculdade de Arquitetura e Urbanismo. 15/12/1987. 87p. 


\section{RESIDÊNCIA JOSÉ NOSCHESE}

Cliente: Noschese \& Souza

Data de projeto: não consta

Data da publicação: não consta

Projeto: Roberto Rossi Zuccolo

Projetos complementares: não consta

Construção: Rubens Paiva

Paisagismo: Roberto Coelho Cardozo

Tipologia: residencial

Endereço: Rua Conseguina, 53 (antiga Rua San Remigio, 14) - Cidade Jardim - São

Paulo/SP

Material:

ABASCAL, E.; et al. A Arquitetura Moderna no Brasil e a contribuição do engenheiro Roberto Rossi Zuccolo para a formação dos alunos da Faculdade de Arquitetura Mackenzie e sua atuação profissional. São Paulo: Relatório de pesquisa FAU-MACK, 2016. 116p.

CARDOZO, R. C. Curriculum vitae. In: UNIVERSIDADE DE SÃO PAULO. Processo 52.1.14106.1.2: contrato docente. São Paulo: Departamento de projetos da Faculdade de Arquitetura e Urbanismo. 15/12/1987. 87p.

\section{RESIDÊNCIA JUDITH BEKERMAN KOGAN E ISRAEL SCHACHNIK}

Cliente: Judith Bekerman Kogan e Isral Schachnik

Data de projeto: não consta

Data da publicação: não consta

Projeto: não consta

Projetos complementares: não consta

Construção: Construtora W. Zarzur

Paisagismo: Roberto Coelho Cardozo

Tipologia: residencial

Endereço: Avenida Europa, 444 - Jardim Europa - São Paulo/SP

Material:

Site da Construtora W. Zarzur.

CARDOZO, R. C. Curriculum vitae. In: UNIVERSIDADE DE SÃO PAULO. Processo

52.1.14106.1.2: contrato docente. São Paulo: Departamento de projetos da Faculdade de Arquitetura e Urbanismo. 15/12/1987. 87p.

\section{RESIDÊNCIA LAUDO NATEL}

Cliente: Laudo Natel

Data de projeto: não consta

Data da publicação: não consta

Projeto: não consta

Projetos complementares: não consta

Construção: não consta

Paisagismo: Roberto Coelho Cardozo

Tipologia: residencial

Endereço: Rua Capitão Garcindo, 115 - Pacaembu - São Paulo/SP

Material:

CARDOZO, R. C. Curriculum vitae. In: UNIVERSIDADE DE SÃO PAULO. Processo

52.1.14106.1.2: contrato docente. São Paulo: Departamento de projetos da Faculdade de Arquitetura e Urbanismo. 15/12/1987. 87p. 

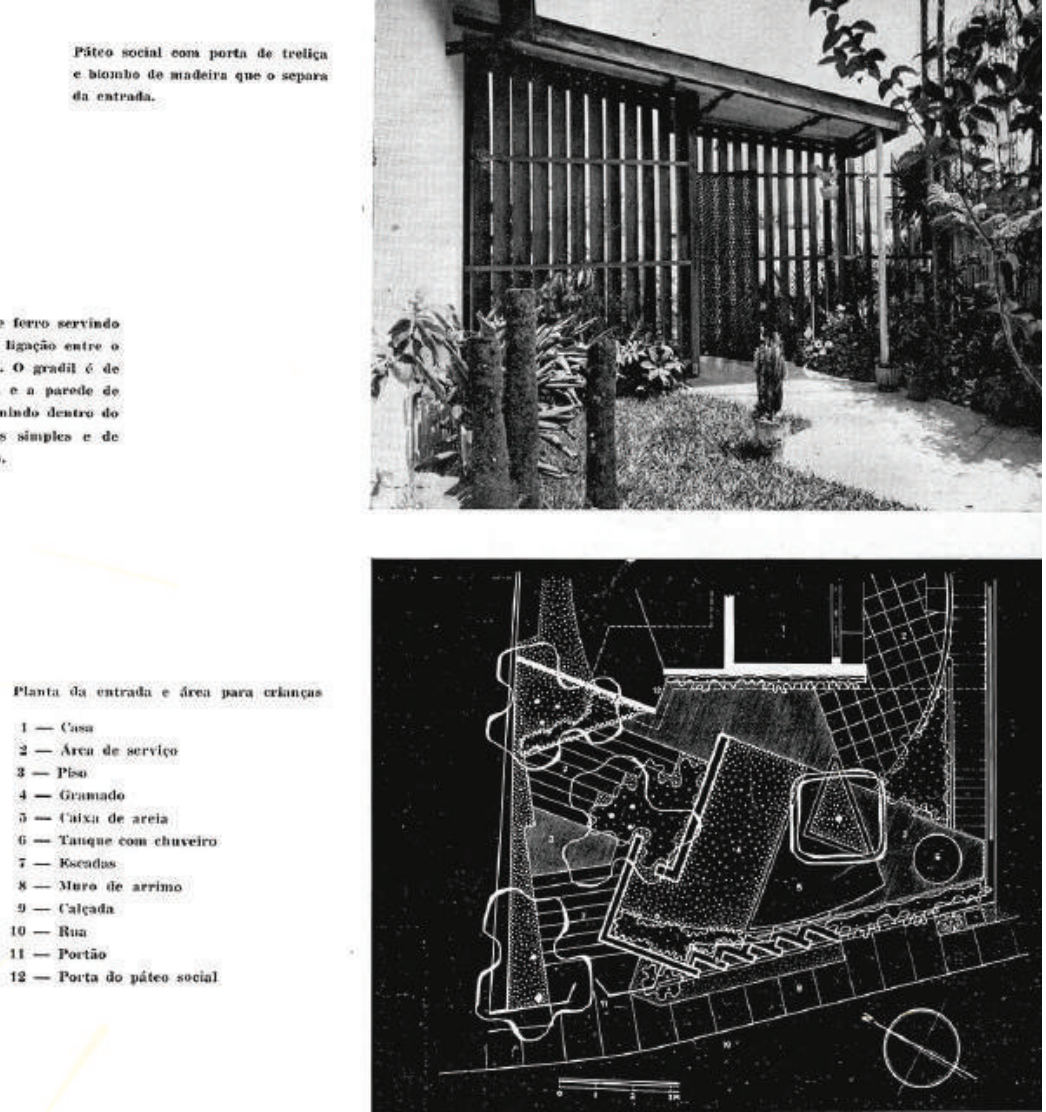

\section{RESIDÊNCIA LÉA E CHAIM JAYME GOLDENSTEIN}

Cliente: Léa e Chaim Jayme Goldenstein

Data de projeto: 1954

Data de publicação: 1956

Projeto: Abelardo de Souza

Projetos complementares: A. Carlos Vasconcelos e Luiz G. M. Vieira (cálculo estrutural)

Construção: construído

Paisagismo: Osborn Coelho Cardozo. Colaboração de Miranda Martinelli.

Tipologia: residencial

Endereço: Rua Vanderlei, 96 - Perdizes - São Paulo/SP

Material:

CARDOZO, R. C. Curriculum vitae. In: UNIVERSIDADE DE SÃO PAULO. Processo

52.1.14106.1.2: contrato docente. São Paulo: Departamento de projetos da Faculdade de Arquitetura e Urbanismo. 15/12/1987. 87p.

CONSTANTINO, R. A Obra de Abelardo de Souza, Dissertação (Mestrado em Arquitetura e Urbanismo). FAUUSP, São Paulo, 2004. p. 204-207.

RESIDÊNCIA no Pacaembu. Acrópole, São Paulo, 209, p. 172-5, mar. 1956.

UM mundo à parte. Casa e Jardim, São Paulo, 24, p. 43-5, abr. 1956. 

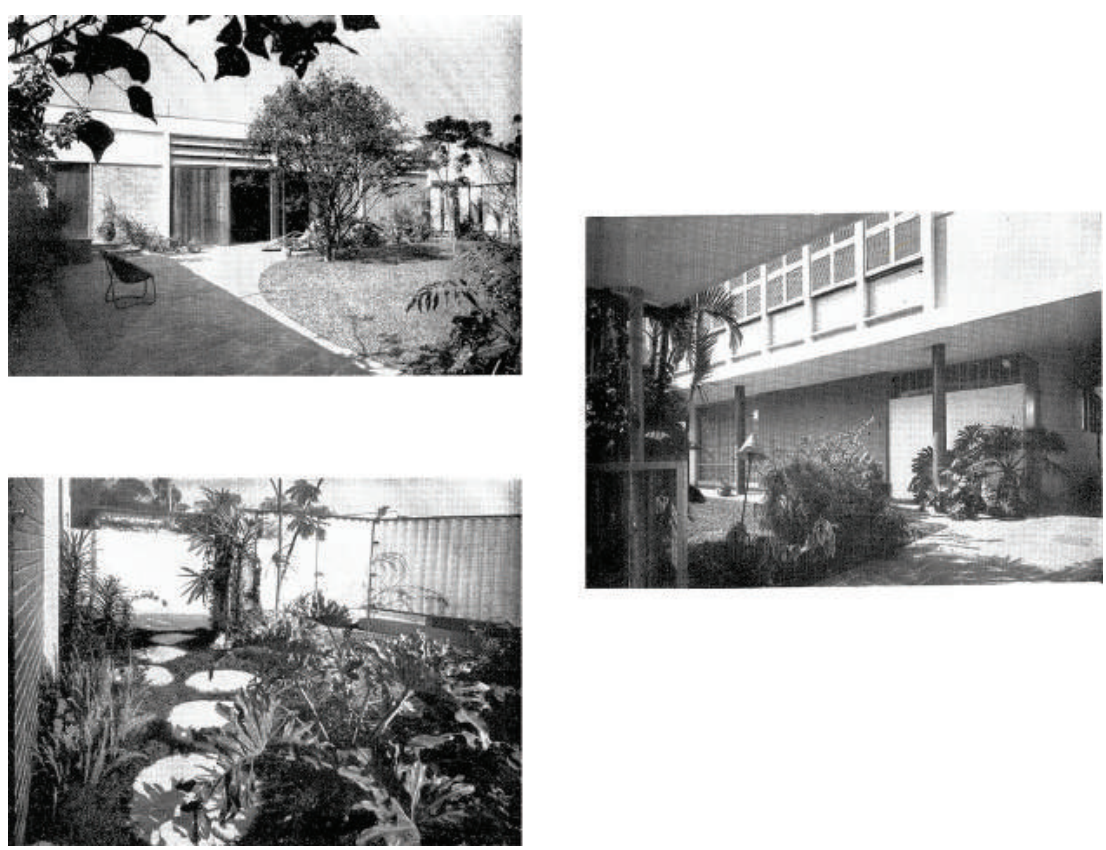

\section{RESIDÊNCIA LEONILDO S. MINDLIN}

Cliente: Leonildo Sam Mindlin

Data de projeto: 1952

Data da publicação: 1954

Projeto: Henrique Ephim Mindlin (projeto de arquitetura de 1950)

Projetos complementares: não consta

Construção: construído

Paisagismo: Roberto Coelho Cardozo e Suzana Coelho Cardozo

Tipologia: residencial

Endereço: Rua Cândido Nascimento, 91 - Jardim Paulista - São Paulo/SP

Material:

CARDOZO, R. C. Biombos como barreiras. Casa e Jardim, São Paulo, 13, p. 46-49, mar/ abr. 1955.

CARDOZO, R. C. Curriculum vitae. In: UNIVERSIDADE DE SÃO PAULO. Processo

52.1.14106.1.2: contrato docente. São Paulo: Departamento de projetos da Faculdade de Arquitetura e Urbanismo. 15/12/1987. 87p.

CARDOZO, R. C. Living do ar livre. Acrópole, São Paulo, 192, p. 570-1, set.1954.

YOSHIDA, C.B. Henrique Ephim Mindlin: o homem arquiteto. São Paulo: Instituto Roberto Simonsen, 1975. 225p. 


\section{RESIDÊNCIA LAWRENCE KING}

Cliente: Lawrence King

Data de projeto: não consta

Data da publicação: não consta

Projeto: não consta

Projetos complementares: não consta

Construção: não consta

Paisagismo: Roberto Coelho Cardozo

Tipologia: residencial

Endereço: Rua Barão de Capanema, 98 - Jardim Paulista - São Paulo/SP

Material:

CARDOZO, R. C. Curriculum vitae. In: UNIVERSIDADE DE SÃO PAULO. Processo

52.1.14106.1.2: contrato docente. São Paulo: Departamento de projetos da Faculdade de Arquitetura e Urbanismo. 15/12/1987. 87p.

\section{RESIDÊNCIA LISANDRO GARCIA}

Cliente: Lisandro Garcia

Data de projeto: não consta

Data da publicação: não consta

Projeto: não consta

Projetos complementares: não consta

Construção: não consta

Paisagismo: Roberto Coelho Cardozo

Tipologia: residencial

Endereço: Avenida George Saville Dodd - Jardim Guedala - São Paulo/SP

Material:

CARDOZO, R. C. Curriculum vitae. In: UNIVERSIDADE DE SÃO PAULO. Processo

52.1.14106.1.2: contrato docente. São Paulo: Departamento de projetos da Faculdade de Arquitetura e Urbanismo. 15/12/1987. 87p.

\section{RESIDÊNCIA LUDWIG WINKLER}

Cliente: Ludwig Winkler

Data de projeto: não consta

Data da publicação: não consta

Projeto: não consta

Projetos complementares: não consta

Construção: não consta

Paisagismo: Roberto Coelho Cardozo

Tipologia: residencial

Endereço: Avenida República do Líbano, 331 - Moema - São Paulo/SP

Material:

CARDOZO, R. C. Curriculum vitae. In: UNIVERSIDADE DE SÃO PAULO. Processo

52.1.14106.1.2: contrato docente. São Paulo: Departamento de projetos da Faculdade de Arquitetura e Urbanismo. 15/12/1987. 87p. 


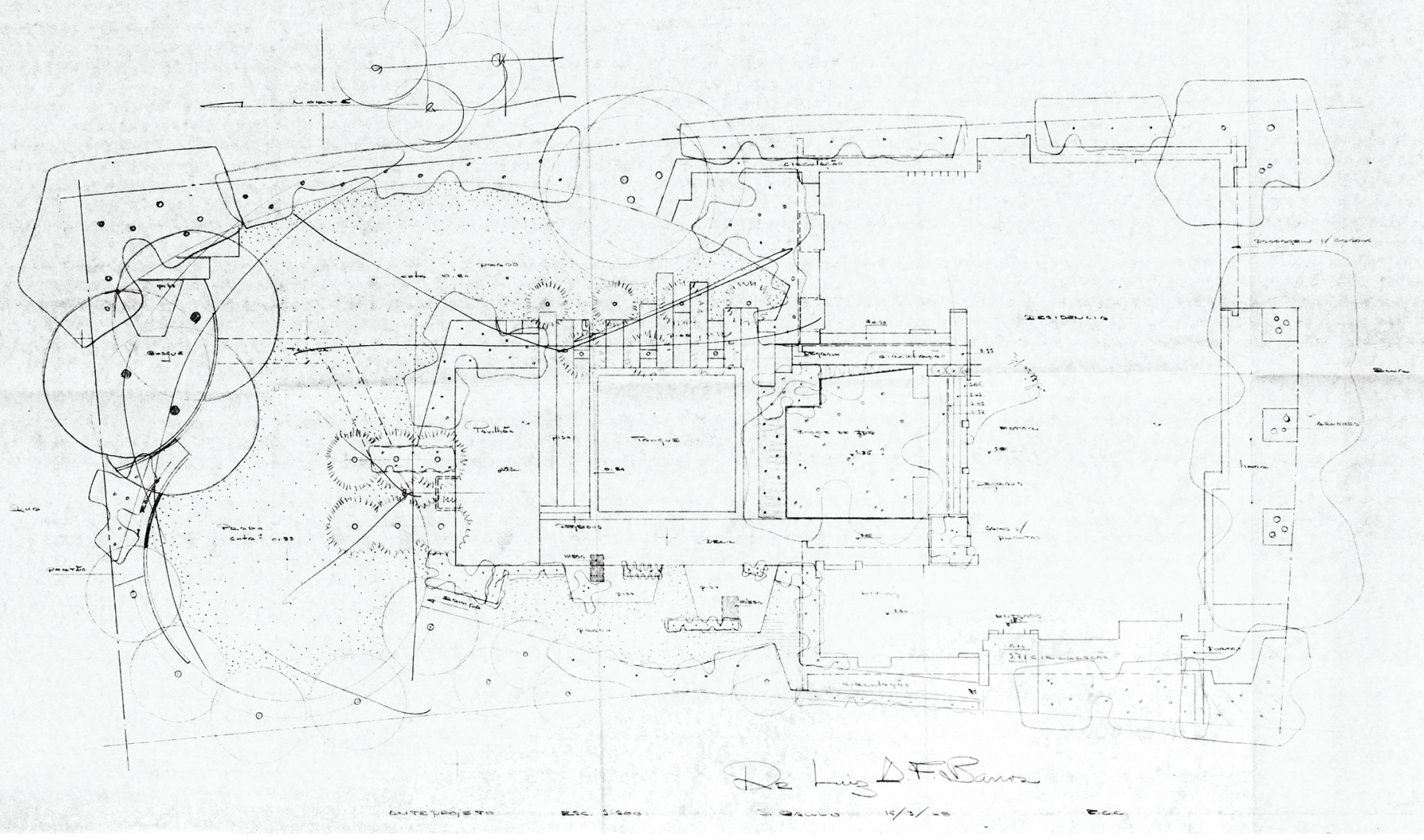

RESIDÊNCIA LUIZ D.F. BARROS

Cliente: Luiz D. F. Barros

Data de projeto: 1968

Data da publicação: não consta

Projeto: não consta

Projetos complementares: não consta

Construção: não consta

Paisagismo: Roberto Coelho Cardozo

Tipologia: residencial

Endereço: não consta

Material:

Acervo da biblioteca da FAUUSP (Cód. PE C179/712.6 LB): implantação paisagismo. 


\section{RESIDÊNCIA LUIZ SÉRGIO M. MARCONDES}

Cliente: Luiz Sérgio M. Marcondes

Data de projeto: não consta

Data da publicação: não consta

Projeto: não consta

Projetos complementares: não consta

Construção: não consta

Paisagismo: Roberto Coelho Cardozo

Tipologia: residencial

Endereço: Rua Pintassilgo - Moema - São Paulo/SP

Material:

CARDOZO, R. C. Curriculum vitae. In: UNIVERSIDADE DE SÃO PAULO. Processo

52.1.14106.1.2: contrato docente. São Paulo: Departamento de projetos da Faculdade de Arquitetura e Urbanismo. 15/12/1987. 87p.

\section{RESIDÊNCIA MARCELO RIBEIRO}

Cliente: Marcelo Ribeiro

Data de projeto: não consta

Data da publicação: não consta

Projeto: não consta

Projetos complementares: não consta

Construção: não consta

Paisagismo: Roberto Coelho Cardozo

Tipologia: residencial

Endereço: Rua Estados Unidos - Jardim América - São Paulo/SP

Material:

CARDOZO, R. C. Curriculum vitae. In: UNIVERSIDADE DE SÃO PAULO. Processo

52.1.14106.1.2: contrato docente. São Paulo: Departamento de projetos da Faculdade de Arquitetura e Urbanismo. 15/12/1987. 87p.

\section{RESIDÊNCIA MARILU E FABRÍCIO BEER}

Cliente: Marilu e Fabrício Beer

Data de projeto: não consta

Data da publicação: não consta

Projeto: não consta

Projetos complementares: não consta

Construção: não consta

Paisagismo: Roberto Coelho Cardozo

Tipologia: residencial

Endereço: Rua lquitos - Pinheiros - São Paulo/SP

Material:

Entrevista de Gregório Zolko. 


\section{RESIDÊNCIA MARTIN ROTHSTEIN}

Cliente: Martin Rothstein

Data de projeto: não consta

Data da publicação: 1954

Projeto: Victor Reif

Projetos complementares:

Construção: construído por Construtora 3 Leões

Paisagismo: Osborn Coelho Cardozo

Tipologia: residencial

Endereço: Rua Indiana - Brooklin Paulista - São Paulo/SP

Material:

RESIDÊNCIA no Brooklin Novo. Acrópole, São Paulo, 195, p. 136-9, dez. 1954.

\section{RESIDÊNCIA MAURÍCIO GRINBERG}

Cliente: Maurício Grinberg

Data de projeto: não consta

Data da publicação: não consta

Projeto: não consta

Projetos complementares: não consta

Construção: não consta

Paisagismo: Roberto Coelho Cardozo

Tipologia: residencial

Endereço: Avenida Santo Amaro - Brooklin Paulista - São Paulo/SP

Material:

CARDOZO, R. C. Curriculum vitae. In: UNIVERSIDADE DE SÃO PAULO. Processo

52.1.14106.1.2: contrato docente. São Paulo: Departamento de projetos da Faculdade de Arquitetura e Urbanismo. 15/12/1987. 87p.

\section{RESIDÊNCIA MAXIMILIANO TSCHIPTSCHIN}

Cliente: Maximiliano Tschisptichin

Data de projeto: não consta

Data da publicação: não consta

Projeto: não consta

Projetos complementares: não consta

Construção: não consta

Paisagismo: Roberto Coelho Cardozo

Tipologia: residencial

Endereço: Rua Turquia, 215 - Jardim Europa - São Paulo/SP

Material:

CARDOZO, R. C. Curriculum vitae. In: UNIVERSIDADE DE SÃO PAULO. Processo

52.1.14106.1.2: contrato docente. São Paulo: Departamento de projetos da Faculdade de Arquitetura e Urbanismo. 15/12/1987. 87p. 

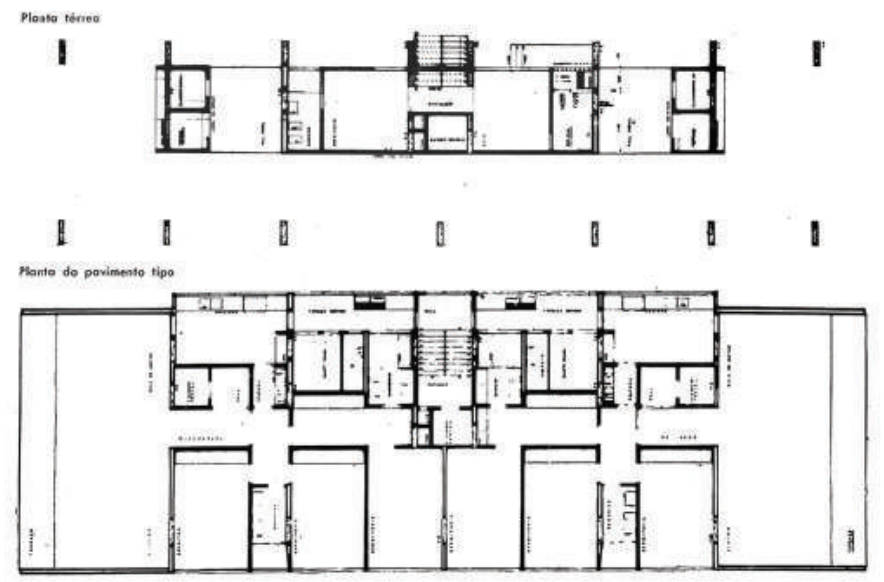

\section{RESIDÊNCIA MAURÍCIO TUCK SCHNEIDER}

Cliente: Maurício Tuck Schneider (apartamento)

Data de projeto: não consta

Data da publicação: 1964

Projeto: Maurício Tuck Schneider e Pedro Paulo de Melo Saraiva

Projetos complementares: não consta

Construção: Biro Ernesto Zeitel

Paisagismo: Roberto Coelho Cardozo

Tipologia: residencial

Endereço: Rua Albuquerque Lins, 1045 - Santa Cecília - São Paulo/SP

Material:

CARDOZO, R. C. Curriculum vitae. In: UNIVERSIDADE DE SÃO PAULO. Processo

52.1.14106.1.2: contrato docente. São Paulo: Departamento de projetos da Faculdade de Arquitetura e Urbanismo. 15/12/1987. 87p.

EDIFÍCIO de apartamentos. Acrópole, São Paulo, n. 310, p. 42-43, set. 1964. 


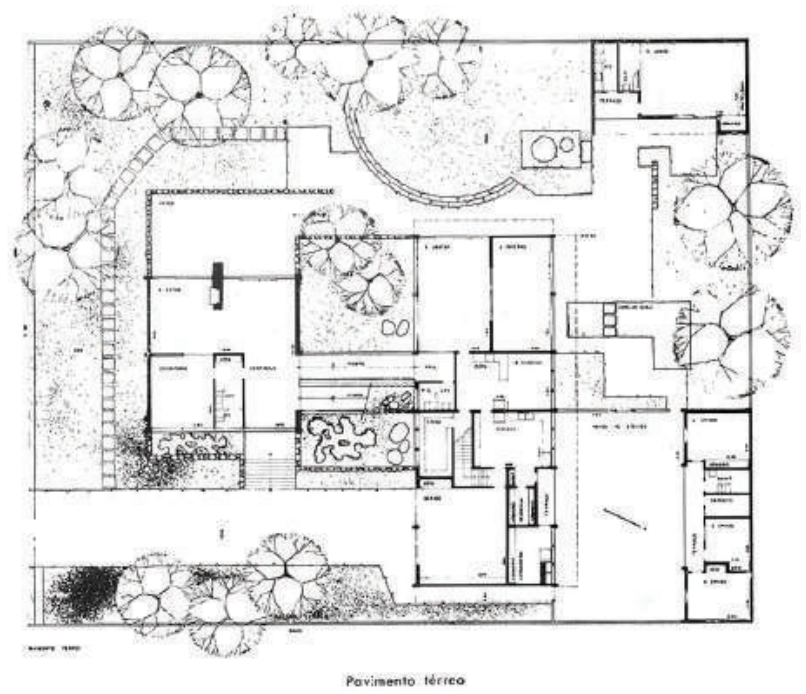

\section{RESIDÊNCIA MICHEL MATTAR}

Cliente: Michel Mattar

Data de projeto: não consta

Data da publicação: 1961

Projeto: Arnaldo Furquim Paoliello

Projetos complementares: não consta

Construção: construído por Construtora Paoliello S.A.

Paisagismo: Roberto Coelho Cardozo

Tipologia: residencial

Endereço: Rua Campo Verde, 480 - Jardim Paulistano - São Paulo/SP

Material:

CARDOZO, R. C. Curriculum vitae. In: UNIVERSIDADE DE SÃO PAULO. Processo

52.1.14106.1.2: contrato docente. São Paulo: Departamento de projetos da Faculdade de Arquitetura e Urbanismo. 15/12/1987. 87p.

RESIDÊNCIA no Jardim Paulistano. Acrópole, São Paulo, 277, p. 20-1, dez. 1961. 

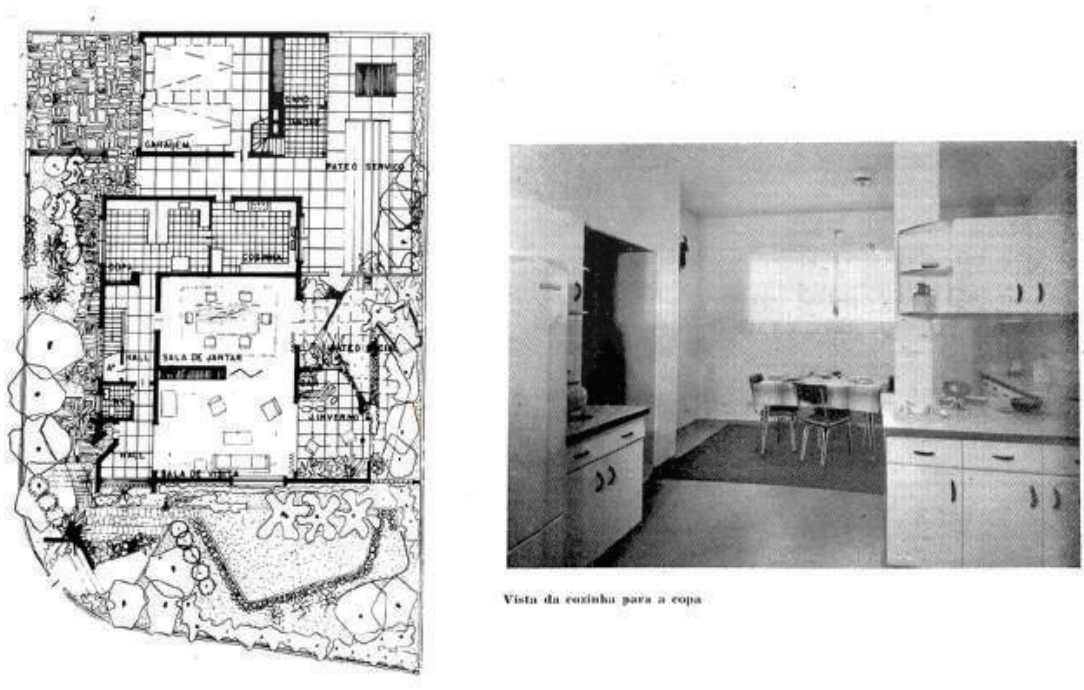

Vista du ceximbu parn a copa

Antar terro

\section{RESIDÊNCIA NÃO IDENTIFICADA - PACAEMBU}

Cliente: não consta

Data de projeto: não consta

Data da publicação: 1954

Projeto: Rubens de Camargo Monteiro

Projetos complementares

Construção: construído por Monteiro, Wigderowitz \& Monteiro Ltda.

Paisagismo: Roberto Coelho Cardozo e Susan Osborn Coelho

Tipologia: residencial

Endereço: não consta

Material:

RESIDÊNCIA no Pacaembu. Acrópole, São Paulo, 193, p. 14-8, out. 1954. 


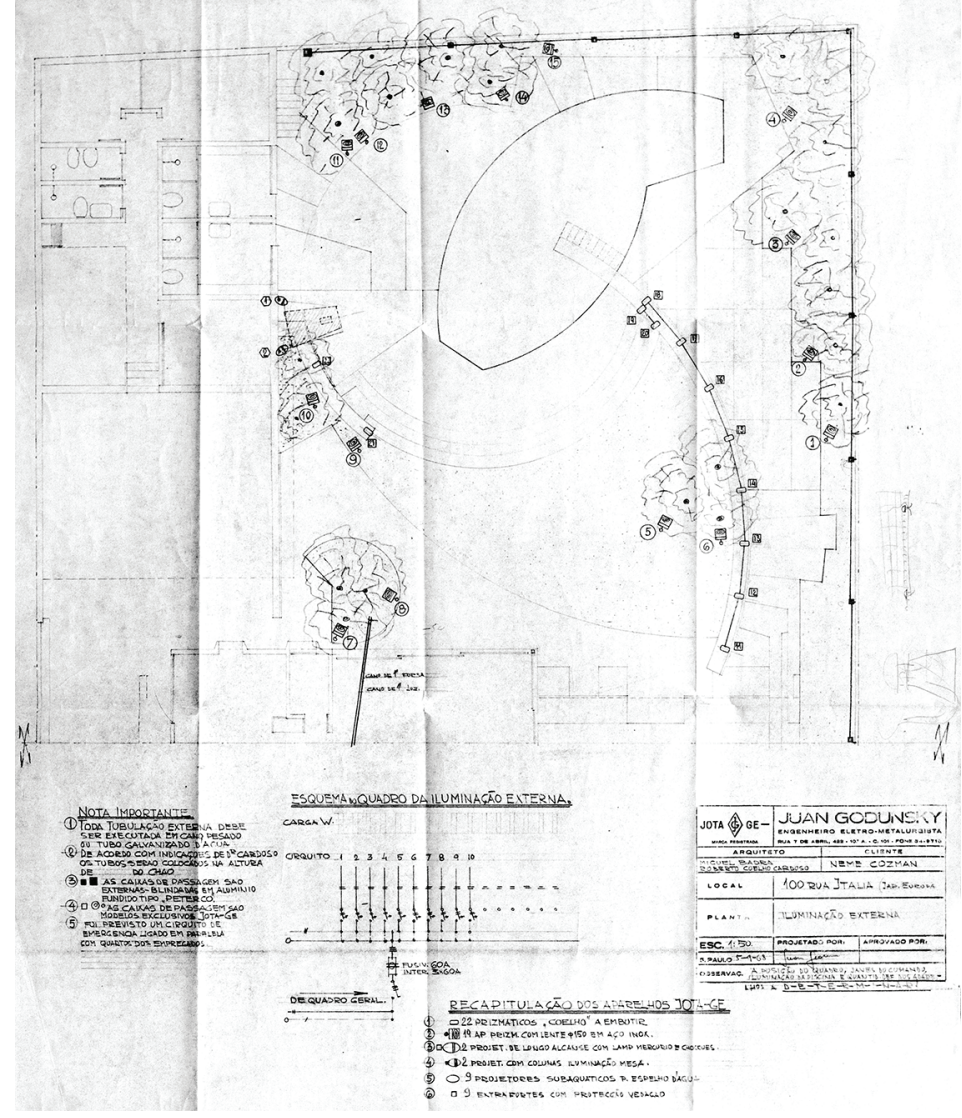

\section{RESIDÊNCIA NEME COZMAN}

Cliente: Neme Cozman

Data de projeto: 1968

Data da publicação: não consta

Projeto: Miguel Badra Jr.

Projetos complementares: Juan Godunsky Engenheiro

Construção: construído

Paisagismo: Roberto Coelho Cardozo

Tipologia: residencial

Endereço: Rua Itália, 100 - Jardim Europa - São Paulo/SP

Material:

Acervo da biblioteca da FAUUSP (Cód PE C179/728.3 N): planta de iluminação externa 1 e 2. 


\section{RESIDÊNCIA OTTO VERNER}

Cliente: Otto Verner

Data de projeto: não consta

Data da publicação: não consta

Projeto: não consta

Projetos complementares: não consta

Construção: não consta

Paisagismo: Roberto Coelho Cardozo

Tipologia: residencial

Endereço: Jardim Julieta

Material:

CARDOZO, R. C. Curriculum vitae. In: UNIVERSIDADE DE SÃO PAULO. Processo

52.1.14106.1.2: contrato docente. São Paulo: Departamento de projetos da Faculdade de Arquitetura e Urbanismo. 15/12/1987. 87p.

\section{RESIDÊNCIA PAUL SEILER}

Cliente: Paul Seiler

Data de projeto: não consta

Data da publicação: não consta

Projeto: não consta

Projetos complementares: não consta

Construção: não consta

Paisagismo: Roberto Coelho Cardozo

Tipologia: residencial

Endereço: Rua Palmeiral, 34 - Brooklyn - São Paulo/SP

Material:

CARDOZO, R. C. Curriculum vitae. In: UNIVERSIDADE DE SÃO PAULO. Processo

52.1.14106.1.2: contrato docente. São Paulo: Departamento de projetos da Faculdade de Arquitetura e Urbanismo. 15/12/1987. 87p.

\section{RESIDÊNCIA PAULO GIANNINI}

Cliente: Paulo Giannini

Data de projeto: não consta

Data da publicação: não consta

Projeto: não consta

Projetos complementares: não consta

Construção: não consta

Paisagismo: Roberto Coelho Cardozo

Tipologia: residencial

Endereço: Avenida Pacaembu, 769 - Pacaembu - São Paulo/SP

Material:

CARDOZO, R. C. Curriculum vitae. In: UNIVERSIDADE DE SÃO PAULO. Processo

52.1.14106.1.2: contrato docente. São Paulo: Departamento de projetos da Faculdade de Arquitetura e Urbanismo. 15/12/1987. 87p. 


\section{RESIDÊNCIA PAULO GIANNINI}

Cliente: Paulo Giannini

Data de projeto: não consta

Data da publicação: não consta

Projeto: não consta

Projetos complementares: não consta

Construção: não consta

Paisagismo: Roberto Coelho Cardozo

Tipologia: residencial

Endereço: Rua Barão de Iguape, 601 - Liberdade - São Paulo/SP

Material:

CARDOZO, R. C. Curriculum vitae. In: UNIVERSIDADE DE SÃO PAULO. Processo

52.1.14106.1.2: contrato docente. São Paulo: Departamento de projetos da Faculdade de Arquitetura e Urbanismo. 15/12/1987. 87p

\section{RESIDÊNCIA PAULO PASCOWITCH}

Cliente: Paulo Pascowitch

Data de projeto: não consta

Data da publicação: não consta

Projeto: não consta

Projetos complementares: não consta

Construção: não consta

Paisagismo: Roberto Coelho Cardozo

Tipologia: residencial

Endereço: não consta

Material:

CARDOZO, R. C. Curriculum vitae. In: UNIVERSIDADE DE SÃO PAULO. Processo

52.1.14106.1.2: contrato docente. São Paulo: Departamento de projetos da Faculdade de Arquitetura e Urbanismo. 15/12/1987. 87p.

\section{RESIDÊNCIA PEDRO GRAVINA}

Cliente: Pedro Gravina

Data de projeto: não consta

Data da publicação: não consta

Projeto: não consta

Projetos complementares: não consta

Construção: não consta

Paisagismo: Roberto Coelho Cardozo

Tipologia: residencial

Endereço: Avenida Pompéia, 1134 - Perdizes - São Paulo/SP

Material:

CARDOZO, R. C. Curriculum vitae. In: UNIVERSIDADE DE SÃO PAULO. Processo

52.1.14106.1.2: contrato docente. São Paulo: Departamento de projetos da Faculdade de Arquitetura e Urbanismo. 15/12/1987. 87p. 


\section{RESIDÊNCIA RAPHAEL STASI}

Cliente: Raphael Stasi

Data de projeto: não consta

Data da publicação: não consta

Projeto: não consta

Projetos complementares: não consta

Construção: não consta

Paisagismo: Roberto Coelho Cardozo

Tipologia: residencial

Endereço: Avenida Higienópolis - Higienópolis - São Paulo/SP

Material:

CARDOZO, R. C. Curriculum vitae. In: UNIVERSIDADE DE SÃO PAULO. Processo

52.1.14106.1.2: contrato docente. São Paulo: Departamento de projetos da Faculdade de Arquitetura e Urbanismo. 15/12/1987. 87p.

\section{RESIDÊNCIA RICARDO CASTRO}

Cliente: Ricardo Castro

Data de projeto: não consta

Data da publicação: não consta

Projeto: não consta

Projetos complementares: não consta

Construção: não consta

Paisagismo: Roberto Coelho Cardozo

Tipologia: residencial

Endereço: Rua Traipu, 1304 - Pacaembu - São Paulo/SP

Material:

CARDOZO, R. C. Curriculum vitae. In: UNIVERSIDADE DE SÃO PAULO. Processo

52.1.14106.1.2: contrato docente. São Paulo: Departamento de projetos da Faculdade de Arquitetura e Urbanismo. 15/12/1987. 87p.

\section{RESIDÊNCIA RIDAVIA D. BARROS}

Cliente: Ridavia D. Barros

Data de projeto: não consta

Data da publicação: não consta

Projeto: não consta

Projetos complementares: não consta

Construção: não consta

Paisagismo: Roberto Coelho Cardozo

Tipologia: residencial

Endereço: Rua Canadá, 94 - Jardim América - São Paulo/SP

Material:

CARDOZO, R. C. Curriculum vitae. In: UNIVERSIDADE DE SÃO PAULO. Processo 52.1.14106.1.2: contrato docente. São Paulo: Departamento de projetos da Faculdade de Arquitetura e Urbanismo. 15/12/1987. 87p. 


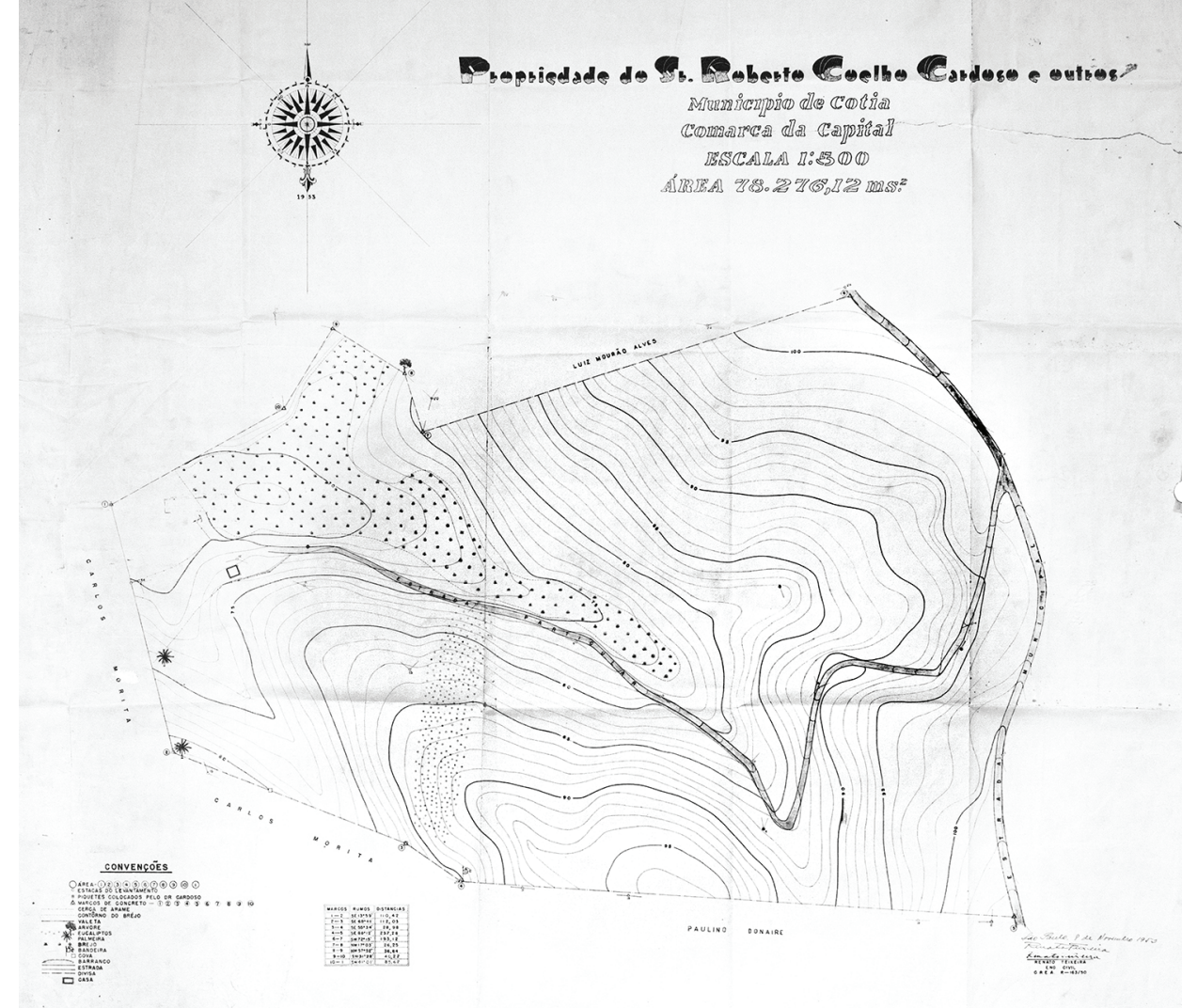

\section{RESIDÊNCIA ROBERTO COELHO CARDOZO E OUTROS - SÍTIO VARGEM GRANDE}

Cliente: Roberto Coelho Cardozo

Data de projeto: 1953

Data de publicação: não foi publicado

Projeto: Eng. Renato Teixeira

Projetos complementares: não consta

Construção: não consta

Paisagismo: não consta

Tipologia: residencial

Endereço: Estrada Municipal de Cotia - Cotia/SP

Material:

Acervo biblioteca FAUUSP (cód. PE C179/711.63 R): 1 planta do levantamento

topográfico.

Entrevista com Miranda Magnoli.

CARDOZO, R. C. Curriculum vitae. In: UNIVERSIDADE DE SÃO PAULO. Processo

52.1.14106.1.2: contrato docente. São Paulo: Departamento de projetos da Faculdade de

Arquitetura e Urbanismo. 15/12/1987. 87p. 


\section{RESIDÊNCIA ROBERTO FUCHS}

Cliente: Roberto Fuchs

Data de projeto: não consta

Data da publicação: não consta

Projeto: não consta

Projetos complementares: não consta

Construção: não consta

Paisagismo: Roberto Coelho Cardozo

Tipologia: residencial

Endereço: Rua Martim Francisco, 746 - Vila Buarque - São Paulo/SP

Material:

Entrevista com Gregório Zolko.

\section{RESIDÊNCIA ROBERTO MALUF}

Cliente: Roberto Maluf

Data de projeto: não consta

Data da publicação: não consta

Projeto: não consta

Projetos complementares: não consta

Construção: não consta

Paisagismo: Roberto Coelho Cardozo

Tipologia: residencial

Endereço: Rua dos Nenúfares - Cidade Jardim - São Paulo/SP

Material:

CARDOZO, R. C. Curriculum vitae. In: UNIVERSIDADE DE SÃO PAULO. Processo

52.1.14106.1.2: contrato docente. São Paulo: Departamento de projetos da Faculdade de Arquitetura e Urbanismo. 15/12/1987. 87p.

\section{RESIDÊNCIA RUBENS FERRAZ}

Cliente: Rubens Ferraz

Data de projeto: não consta

Data da publicação: não consta

Projeto: não consta

Projetos complementares: não consta

Construção: não consta

Paisagismo: Roberto Coelho Cardozo

Tipologia: residencial

Endereço: Rua Campo Belo

Material:

CARDOZO, R. C. Curriculum vitae. In: UNIVERSIDADE DE SÃO PAULO. Processo

52.1.14106.1.2: contrato docente. São Paulo: Departamento de projetos da Faculdade de Arquitetura e Urbanismo. 15/12/1987. 87p. 


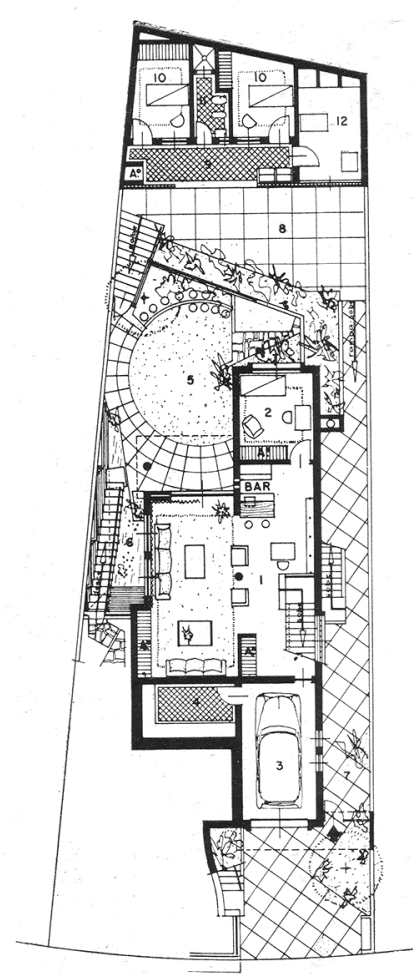

Planta do sub-sólo.

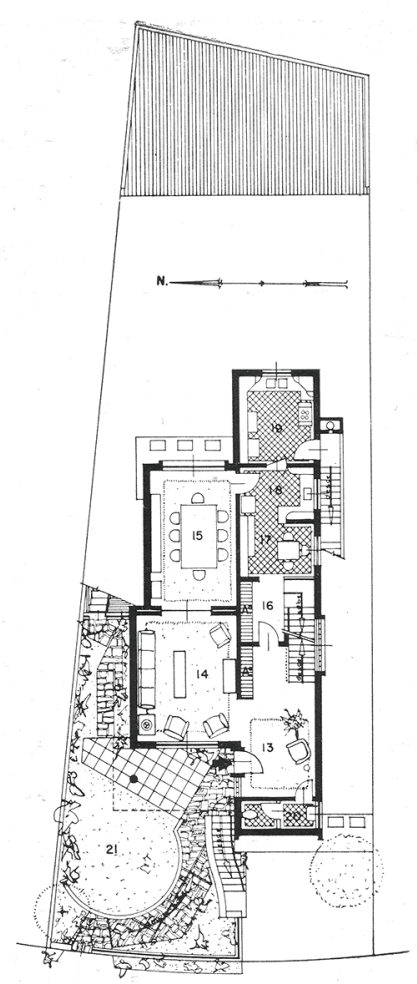

Planta do $10^{\circ}$ pavimento.
1 Salấo social.

2 Quarto costura

3 Garage.

5 Adega.

6 Tanque.

7 Entrada serviço.

9 Terraço servico.

10 Quarto.

11 Banheiro.

12 Lavanderia

13 Vestíbulo.

14 Sala visitas.

15 Sala jantar.

16 Hall

18 Sala almôco.

19 Cozinha.

20 W. C. e lavatório.

21 Jardim.

2. Hall.

23 Dormitório.

24 Toucador.

26 Banheiro.

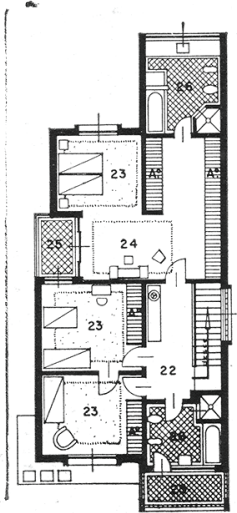

Planta do $2 .^{\circ}$ pavimento

\section{RESIDÊNCIA RUBENS DE CAMARGO MONTEIRO}

Cliente: Rubens de Camargo Monteiro

Data de projeto: não consta

Data da publicação: 1959

Projeto: Rubens de Camargo Monteiro

Projetos complementares: Ambiente (decoração interna)

Construção: Monteiro, Wigderowitz \& Monteiro Ltda.

Paisagismo: Roberto Coelho Cardozo

Tipologia: residencial

Endereço: não consta

Material:

CARDOZO, R. C. Curriculum vitae. In: UNIVERSIDADE DE SÃO PAULO. Processo

52.1.14106.1.2: contrato docente. São Paulo: Departamento de projetos da Faculdade de Arquitetura e Urbanismo. 15/12/1987. 87p.

RESIDÊNCIA de um arquiteto. Habitat, São Paulo, 22, p. 24-26, 1959. 


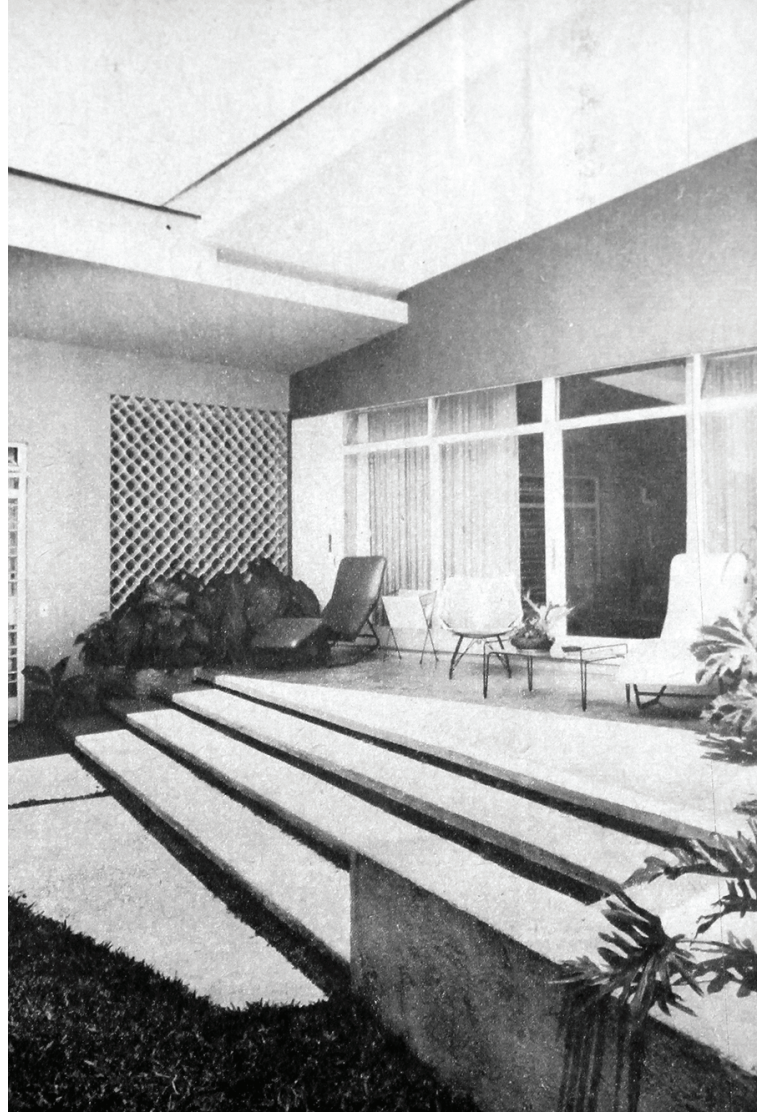

\section{RESIDÊNCIA RUTH E IGNACIO SPORN}

Cliente: Ruth e Ignacio Sporn

Data de projeto: não consta

Data da publicação: não consta

Projeto: Henrique Ephim Mindlin

Projetos complementares: não consta

Construção: não consta

Paisagismo: Roberto Coelho Cardozo

Tipologia: residencial

Endereço: Rua Lopes de Azevedo, 850 - Jardim Guedala - São Paulo/SP

Material:

CARDOZO, R. C. Curriculum vitae. In: UNIVERSIDADE DE SÃO PAULO. Processo

52.1.14106.1.2: contrato docente. São Paulo: Departamento de projetos da Faculdade de Arquitetura e Urbanismo. 15/12/1987. 87p.

FRYDMAN, L. Quando a arquitetura moderna proporciona um verdadeiro lar. Casa e Jardim, São Paulo, 02, p. 10-14, 1953.

YOSHIDA, C.B. Henrique Ephim Mindlin: o homem arquiteto. São Paulo: Instituto Roberto Simonsen, 1975. 225p. 


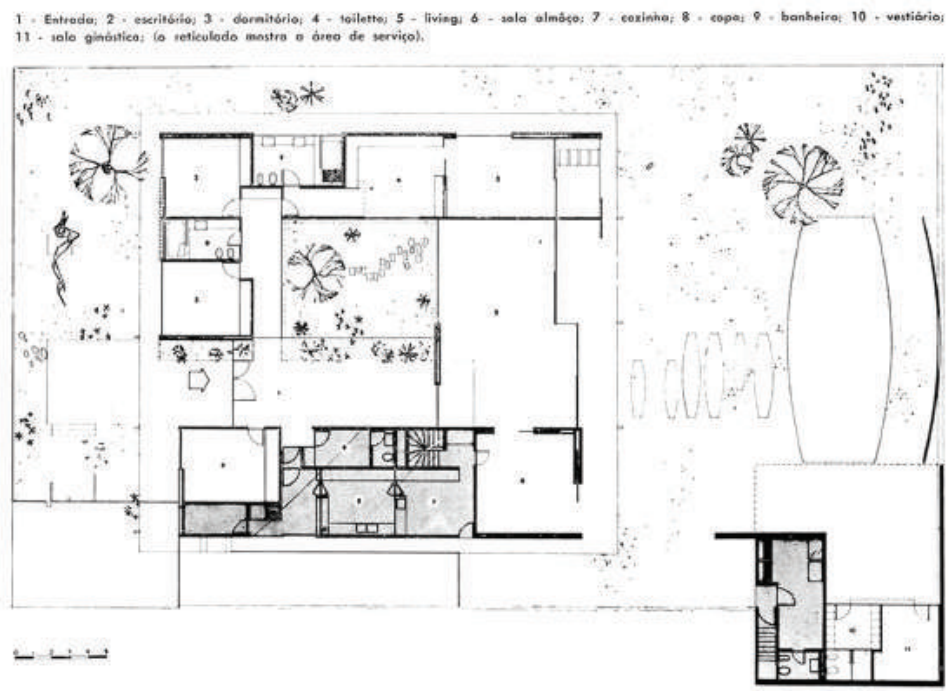

\section{RESIDÊNCIA SACHA E STEPHAN FEHER}

Cliente: Sacha Feher e Stephan Feher

Data de projeto: não consta

Data da publicação: 1963

Projeto: Jorge Zalszupin

Projetos complementares: não consta

Construção: construído por Escritório Técnico Prumo Ltda.

Paisagismo: Roberto Coelho Cardozo

Tipologia: residencial

Endereço: Rua Venezuela, 491 - Jardim América - São Paulo/SP

Material:

ABBUD, B. Um procedimento em pesquisa: A obra do arquiteto paisagista Roberto Coelho Cardozo. Trabalho de Graduação Interdisciplinar (Graduação em Arquitetura e Urbanismo). FAUUSP, São Paulo, 1974. 100p.

CARDOZO, R. C. Curriculum vitae. In: UNIVERSIDADE DE SÃO PAULO. Processo

52.1.14106.1.2: contrato docente. São Paulo: Departamento de projetos da Faculdade de Arquitetura e Urbanismo. 15/12/1987. 87p.

RESIDÊNCIA no Jardim América. Acrópole, São Paulo, 298, p. 302-4, ago. 1963. 


\section{RESIDÊNCIA SAMUEL KLABIN}

Cliente: Samuel Klabin

Data de projeto: não consta

Data da publicação: não consta

Projeto: não consta

Projetos complementares: não consta

Construção: não consta

Paisagismo: Roberto Coelho Cardozo

Tipologia: residencial

Endereço: Rua Maguari, 154 - Chácara Flora - São Paulo/SP

Material:

CARDOZO, R. C. Curriculum vitae. In: UNIVERSIDADE DE SÃO PAULO. Processo

52.1.14106.1.2: contrato docente. São Paulo: Departamento de projetos da Faculdade de Arquitetura e Urbanismo. 15/12/1987. 87p.

\section{RESIDÊNCIA SAUL CHITMAN}

Cliente: Saul Chitman

Data de projeto: não consta

Data da publicação: não consta

Projeto: não consta

Projetos complementares: não consta

Construção: não consta

Paisagismo: Roberto Coelho Cardozo

Tipologia: residencial

Endereço: Rua Argentina, 593 - Jardim América - São Paulo/SP

Material:

CARDOZO, R. C. Curriculum vitae. In: UNIVERSIDADE DE SÃO PAULO. Processo

52.1.14106.1.2: contrato docente. São Paulo: Departamento de projetos da Faculdade de Arquitetura e Urbanismo. 15/12/1987. 87p.

\section{RESIDÊNCIA SIMONE BELDA}

Cliente: Simone Belda

Data de projeto: não consta

Data da publicação: não consta

Projeto: não consta

Projetos complementares: não consta

Construção: não consta

Paisagismo: Roberto Coelho Cardozo

Tipologia: residencial

Endereço: São Paulo/SP

Material:

Entrevista de Gregório Zolko. 


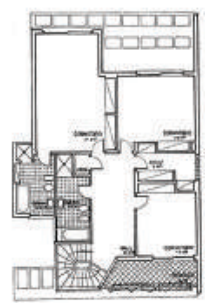

mV. scrwivos
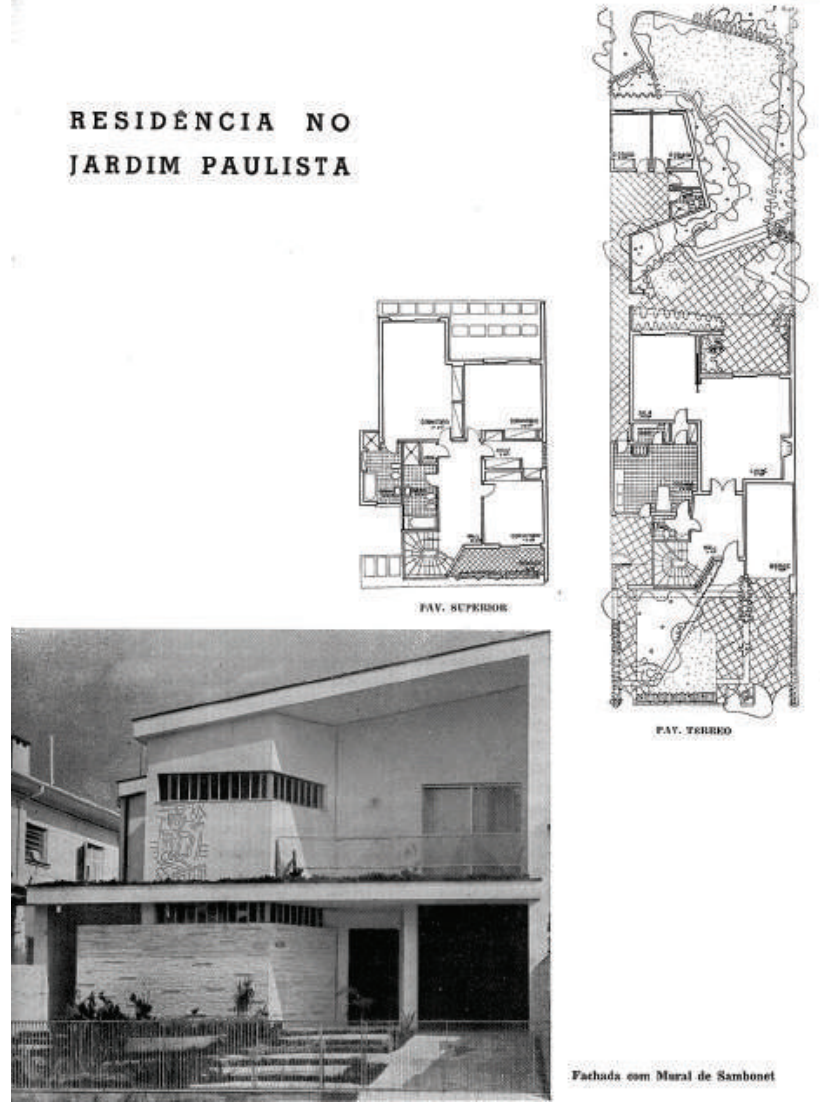

\section{RESIDÊNCIA SOFIA FLEISCHER E FILIP RIWCZES}

Cliente: Filip Riwczes e Sofia Fleischer Riwczes

Data de projeto: não consta

Data de publicação: 1953

Projeto: Marjan Ryszard Glogowski

Projetos complementares: não consta

Construção: construído pelo Escritório Técnico Lucjan Korngold Engenharia e

Construções.

Paisagismo: Roberto Coelho Cardozo e Suzana Coelho Cardozo (desenhos de Flávio

Formicola)

Tipologia: residencial

Endereço: Rua Bento de Andrade, 458 - Jardim Paulista - São Paulo/SP

Material:

CARDOZO, R. C. Curriculum vitae. In: UNIVERSIDADE DE SÃO PAULO. Processo

52.1.14106.1.2: contrato docente. São Paulo: Departamento de projetos da Faculdade de Arquitetura e Urbanismo. 15/12/1987. 87p.

FALBEL, A. Lucjan Korngold: a trajetória de um arquiteto imigrante. Tese (Doutorado em Arquitetura e Urbanismo). FAUUSP, São Paulo, 2003. 323p.

JARDINS em São Paulo. Acrópole, São Paulo, 190, p. 58-9, jul. 1954.

RESIDÊNCIA no Jardim Paulista. Acrópole, São Paulo, 183, p. 20-1, jul. 1953. 


\section{RESIDÊNCIA STEFFI E MAX PERLMAN}

Cliente: Steffi e Max Perlman

Data de projeto: não consta

Data da publicação: não consta

Projeto: não consta

Projetos complementares: não consta

Construção: não consta

Paisagismo: Roberto Coelho Cardozo

Tipologia: residencial

Endereço: Rua Polônia, 136 - Jardim Europa - São Paulo/SP

Material:

CARDOZO, R. C. Curriculum vitae. In: UNIVERSIDADE DE SÃO PAULO. Processo

52.1.14106.1.2: contrato docente. São Paulo: Departamento de projetos da Faculdade de Arquitetura e Urbanismo. 15/12/1987. 87p.

\section{RESIDÊNCIA SUHER KRASNER}

Cliente: Suher Krasner

Data de projeto: não consta

Data da publicação: não consta

Projeto: João Baptista Vilanova Artigas

Projetos complementares: não consta

Construção: não consta

Paisagismo: Roberto Coelho Cardozo

Tipologia: residencial

Endereço: Rua Heitor de Moraes, 61 - Pacaembu - São Paulo/SP

Material:

CARDOZO, R. C. Curriculum vitae. In: UNIVERSIDADE DE SÃO PAULO. Processo

52.1.14106.1.2: contrato docente. São Paulo: Departamento de projetos da Faculdade de Arquitetura e Urbanismo. 15/12/1987. 87p. 


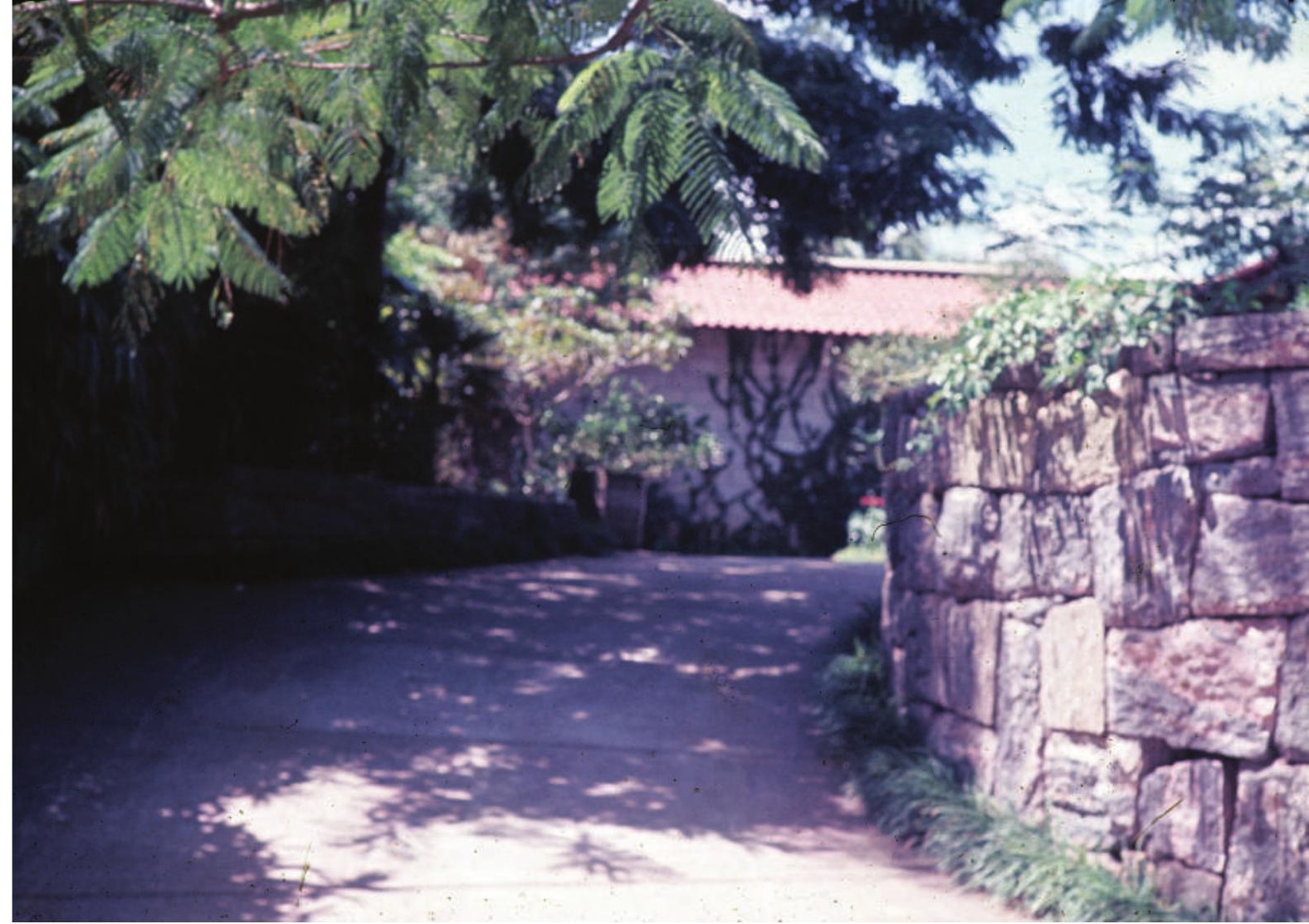

\section{RESIDÊNCIA SUSAN OSBORN E ROBERTO COELHO CARDOZO}

Cliente: Susan Osborn e Roberto Coelho Cardozo

Data de projeto: não consta

Data da publicação: não consta

Projeto: Roberto Coelho Cardozo e Rodolpho Almeida Fernandes

Projetos complementares: não consta

Construção: não consta

Paisagismo: Roberto Coelho Cardozo

Tipologia: residencial

Endereço: Avenida Lopes de Azevedo, 1336 - Morumbi - São Paulo/SP

Material:

Acervo da biblioteca da FAUUSP: diapositivos da coleção de Roberto Coelho Cardozo

Entrevista de Gregório Zolko.

Entrevista com Peri Jon Osborn Coelho. 


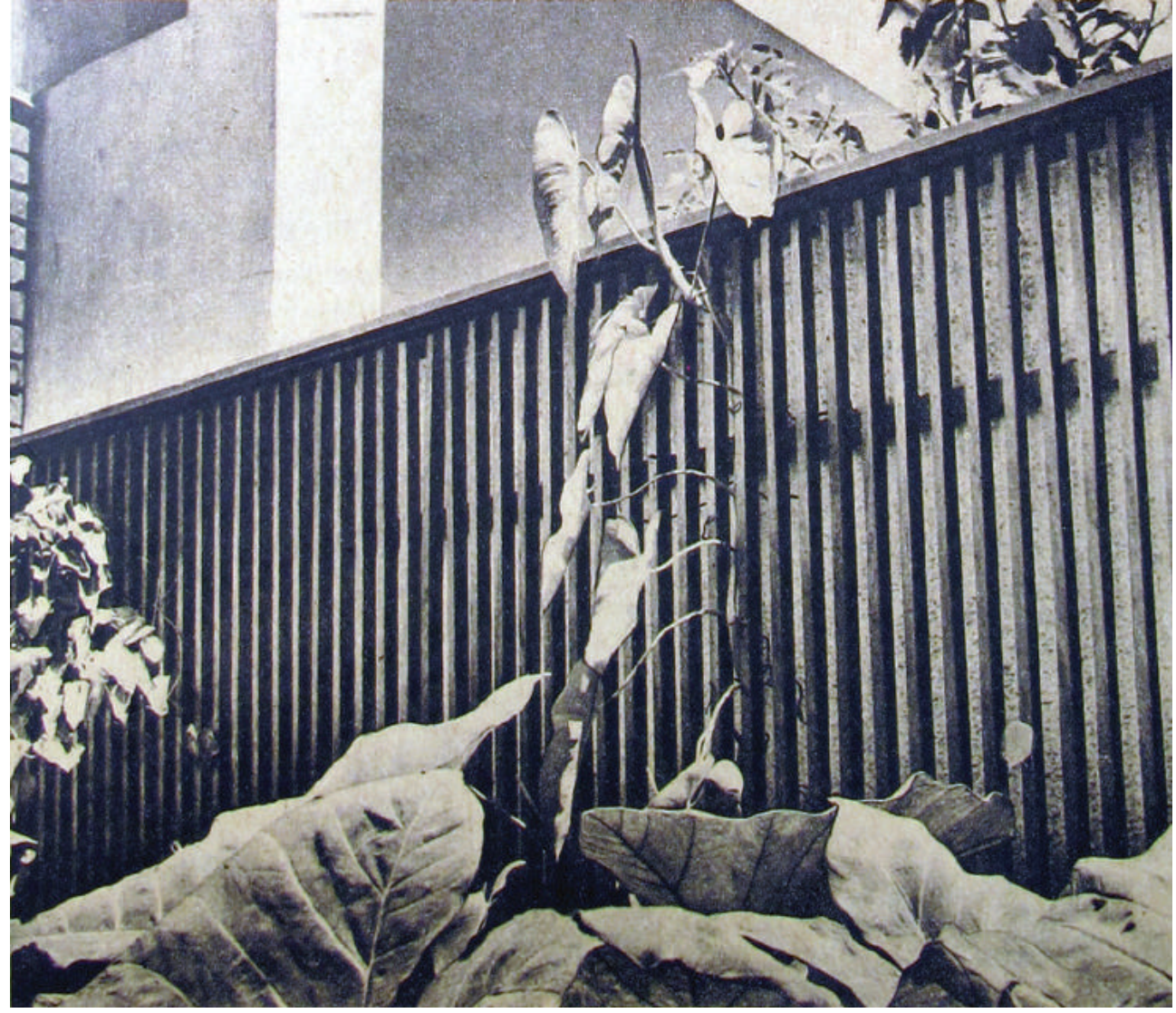

\section{RESIDÊNCIA THEODOR HESS}

Cliente: Theodor Hess

Data de projeto: não consta

Data da publicação: 1955

Projeto: não consta

Projetos complementares: não consta

Construção: não consta

Paisagismo: Roberto Coelho Cardozo

Tipologia: residencial

Endereço: Rua dos Miranhas, 109 - Vila Madalena - São Paulo/SP

Material:

CARDOZO, O. C. Pisos, suas preferências e necessidades. Casa e Jardim, São Paulo, 16, p.50-3 e p.73, ago. 1955.

CARDOZO, R. C. Biombos como barreiras. Casa e Jardim, São Paulo, 13, p. 46-49, mar/ abr. 1955.

CARDOZO, R. C. Curriculum vitae. In: UNIVERSIDADE DE SÃO PAULO. Processo

52.1.14106.1.2: contrato docente. São Paulo: Departamento de projetos da Faculdade de Arquitetura e Urbanismo. 15/12/1987. 87p.

Observação: Cardozo indica em seu currículo duas casas de Theodor Hess e nos artigos não faz diferenciação sobre as referências de imagens, somente descreve como Residência de Theodor Hess, projetada por Lucjan Korngold. Não foi possível, nessa pesquisa, descobrir sobre qual residência se refere, por isso indicamos os artigos nas duas residências. 


\section{RESIDÊNCIA THEODOR HESS}

Cliente: Theodor Hess

Data de projeto: não consta

Data da publicação: 1955

Projeto: não consta

Projetos complementares: não consta

Construção: não consta

Paisagismo: Roberto Coelho Cardozo

Tipologia: residencial

Endereço: Rua Araporé, 484 - Jardim Guedala - São Paulo/SP

Material:

CARDOZO, O. C. Pisos, suas preferências e necessidades. Casa e Jardim, São Paulo, 16, p. 50-3 e p. 73, ago. 1955.

CARDOZO, R. C. Biombos como barreiras. Casa e Jardim, São Paulo, 13, p. 46-49, mar/ abr. 1955.

CARDOZO, R. C. Curriculum vitae. In: UNIVERSIDADE DE SÃO PAULO. Processo

52.1.14106.1.2: contrato docente. São Paulo: Departamento de projetos da Faculdade de

Arquitetura e Urbanismo. 15/12/1987. 87p.

\section{RESIDÊNCIA THOMAZ FARKAS}

Cliente: Thomas Farkas

Data de projeto: não consta

Data da publicação: não consta

Projeto: não consta

Projetos complementares: não consta

Construção: não consta

Paisagismo: Roberto Coelho Cardozo

Tipologia: residencial

Endereço: Rua Itaperuna, 86 - Pacaembu - São Paulo/SP

Material:

CARDOZO, R. C. Curriculum vitae. In: UNIVERSIDADE DE SÃO PAULO. Processo

52.1.14106.1.2: contrato docente. São Paulo: Departamento de projetos da Faculdade de Arquitetura e Urbanismo. 15/12/1987. 87p.

Entrevista com Gregório Zolko.

\section{RESIDÊNCIA TUFY CURY}

Cliente: Tufy Cury

Data de projeto: não consta

Data da publicação: não consta

Projeto: não consta

Projetos complementares: não consta

Construção: não consta

Paisagismo: Roberto Coelho Cardozo

Tipologia: residencial

Endereço: Avenida São Valério - Morumbi - São Paulo/SP

Material:

CARDOZO, R. C. Curriculum vitae. In: UNIVERSIDADE DE SÃO PAULO. Processo

52.1.14106.1.2: contrato docente. São Paulo: Departamento de projetos da Faculdade de Arquitetura e Urbanismo. 15/12/1987. 87p. 


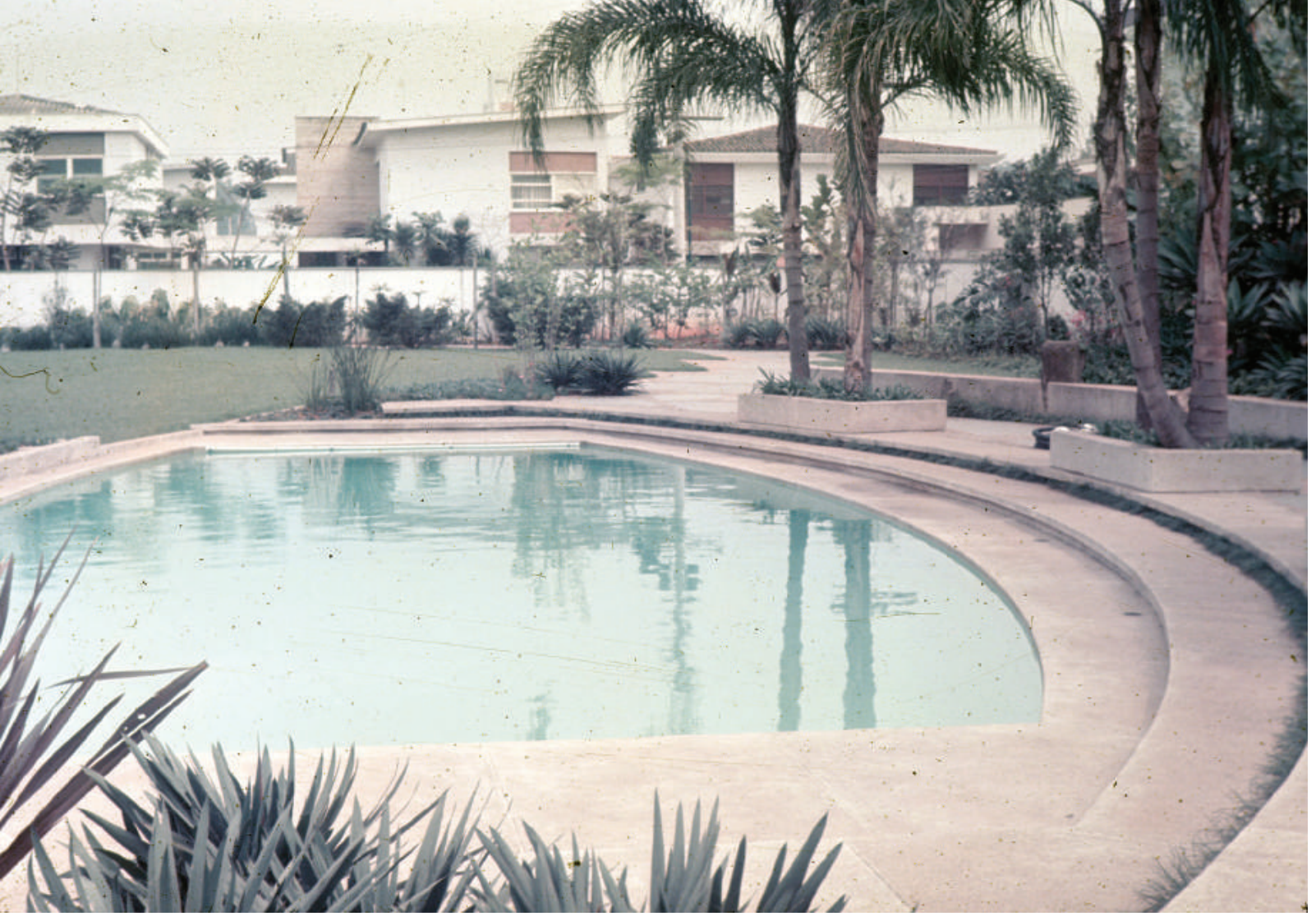

\section{RESIDÊNCIA TUFY MATTAR}

Cliente: Tufy Mattar

Data de projeto: não consta

Data da publicação: não consta

Projeto: não consta

Projetos complementares: não consta

Construção: não consta

Paisagismo: Roberto Coelho Cardozo

Tipologia: residencial

Endereço: Rua Campo Verde, 61 - Jardim Europa - São Paulo/SP

Material:

Acervo da Biblioteca da FAUUSP: diapositivos da coleção Roberto Coelho Cardozo.

CARDOZO, R. C. Curriculum vitae. In: UNIVERSIDADE DE SÃO PAULO. Processo

52.1.14106.1.2: contrato docente. São Paulo: Departamento de projetos da Faculdade de Arquitetura e Urbanismo. 15/12/1987. 87p. 


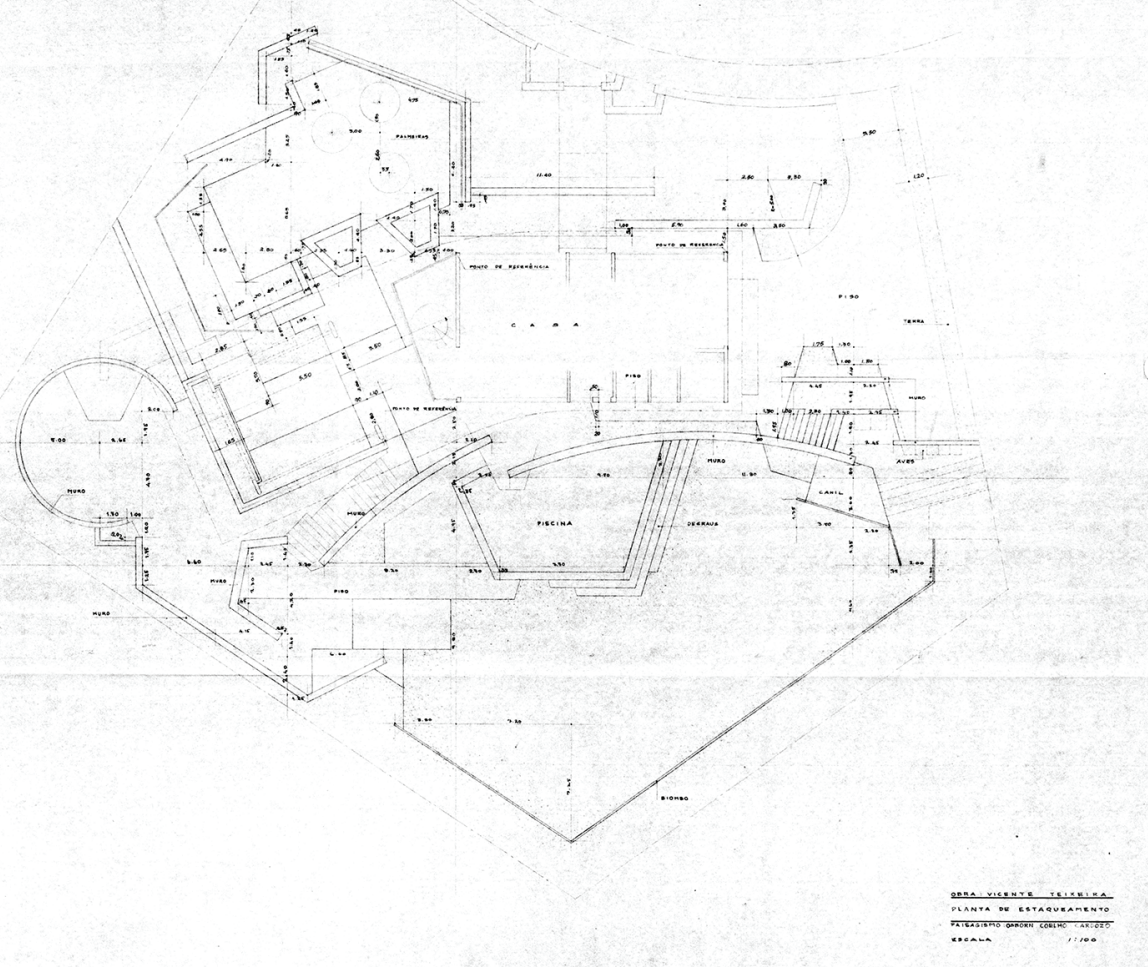

\section{RESIDÊNCIA VICENTE TEIXEIRA}

Cliente: Vicente Teixeira

Data de projeto: 1953

Data da publicação: não foi publicado

Projeto: não consta

Projetos complementares: não consta

Construção: não consta

Paisagismo: Osborn Coelho Cardozo

Tipologia: residencial

Endereço: Avenida Morumbi, 2740 - Morumbi - São Paulo/SP

Material:

Acervo da biblioteca da FAUUSP (Cód. PE C179/728.3 V): 2 plantas de estaqueamento (repetidas), 2 plantas de altimetria (repetidas), 1 prancha com cortes e fachada.

CARDOZO, R. C. Curriculum vitae. In: UNIVERSIDADE DE SÃO PAULO. Processo

52.1.14106.1.2: contrato docente. São Paulo: Departamento de projetos da Faculdade de Arquitetura e Urbanismo. 15/12/1987. 87p.

Observações: Processo da PMSP 120906/53 e alvará no. 2522/53. 


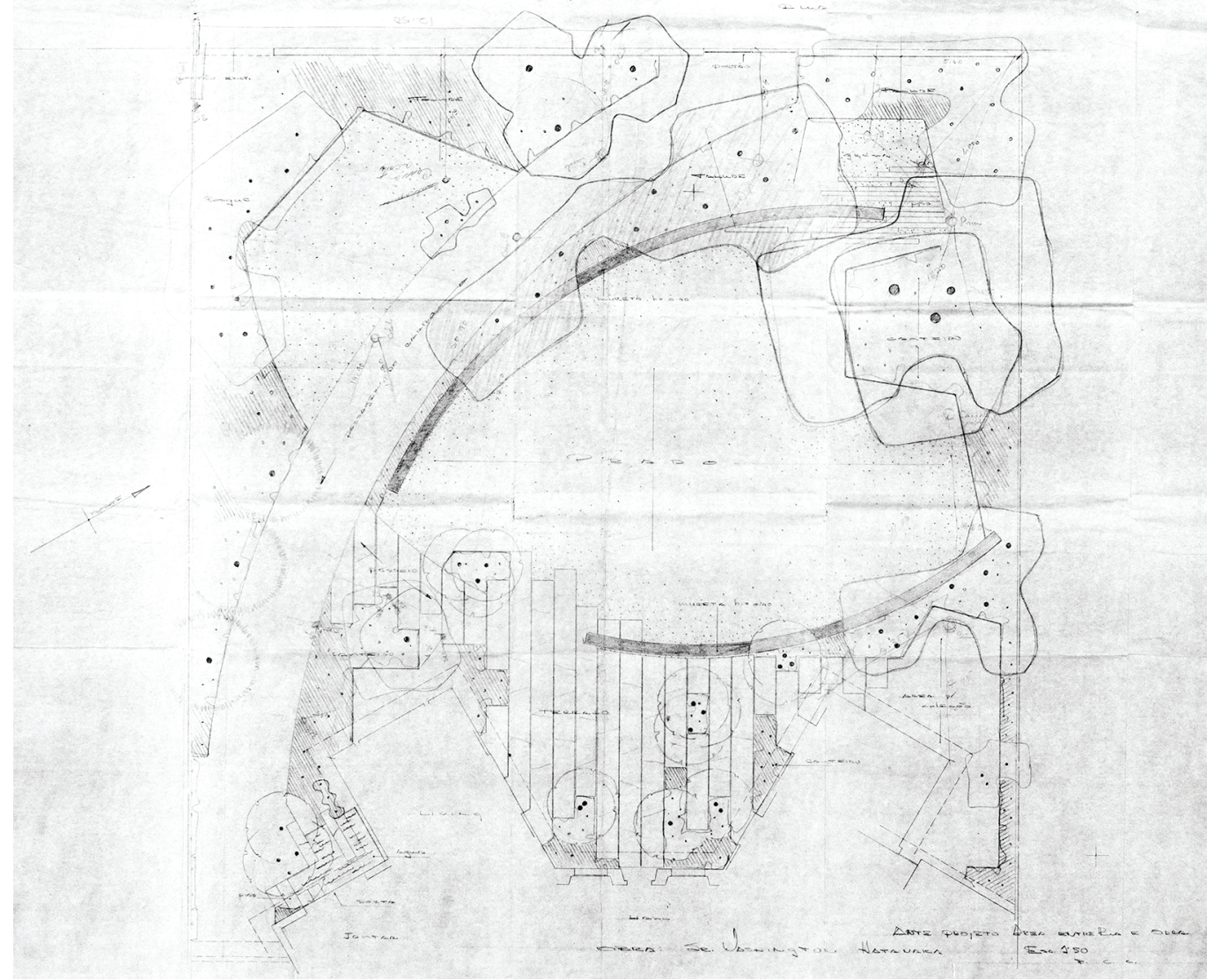

\section{RESIDÊNCIA WASHINGTON HATANAKA}

Cliente: Washington Hatanaka

Data de projeto: não consta

Data da publicação: não consta

Projeto: não consta

Projetos complementares: não consta

Construção: não consta

Paisagismo: parceria com Susan Osborn Cardozo

Tipologia: residencial

Endereço: Rua Antônio de Macedo Soares, 214 - Campo Belo - São Paulo/SP

Material:

Acervo da biblioteca da FAUUSP (Cód. PE C179/712.6 w): anteprojeto. 


\section{RESIDÊNCIA WADY MATTAR}

Cliente: Wady Mattar

Data de projeto: não consta

Data da publicação: não consta

Projeto: não consta

Projetos complementares: não consta

Construção: não consta

Paisagismo: Roberto Coelho Cardozo

Tipologia: residencial

Endereço: Rua Dona Elisa Pereira de Barros, 565 - Jardim Europa - São Paulo/SP

Material:

CARDOZO, R. C. Curriculum vitae. In: UNIVERSIDADE DE SÃO PAULO. Processo

52.1.14106.1.2: contrato docente. São Paulo: Departamento de projetos da Faculdade de

Arquitetura e Urbanismo. 15/12/1987. 87p.

\section{RESIDÊNCIA YOLANDA PENTEADO E CICCILLO MATARAZZO}

Cliente: Yolanda Penteado e Ciccillo Matarazzo

Data de projeto: não consta

Data da publicação: não consta

Projeto: não consta

Projetos complementares: não consta

Construção: não consta

Paisagismo: Roberto Coelho Cardozo

Tipologia: residencial

Endereço: não consta

Material:

CARDOZO, R. C. Curriculum vitae. In: UNIVERSIDADE DE SÃO PAULO. Processo

52.1.14106.1.2: contrato docente. São Paulo: Departamento de projetos da Faculdade de Arquitetura e Urbanismo. 15/12/1987. 87p. 


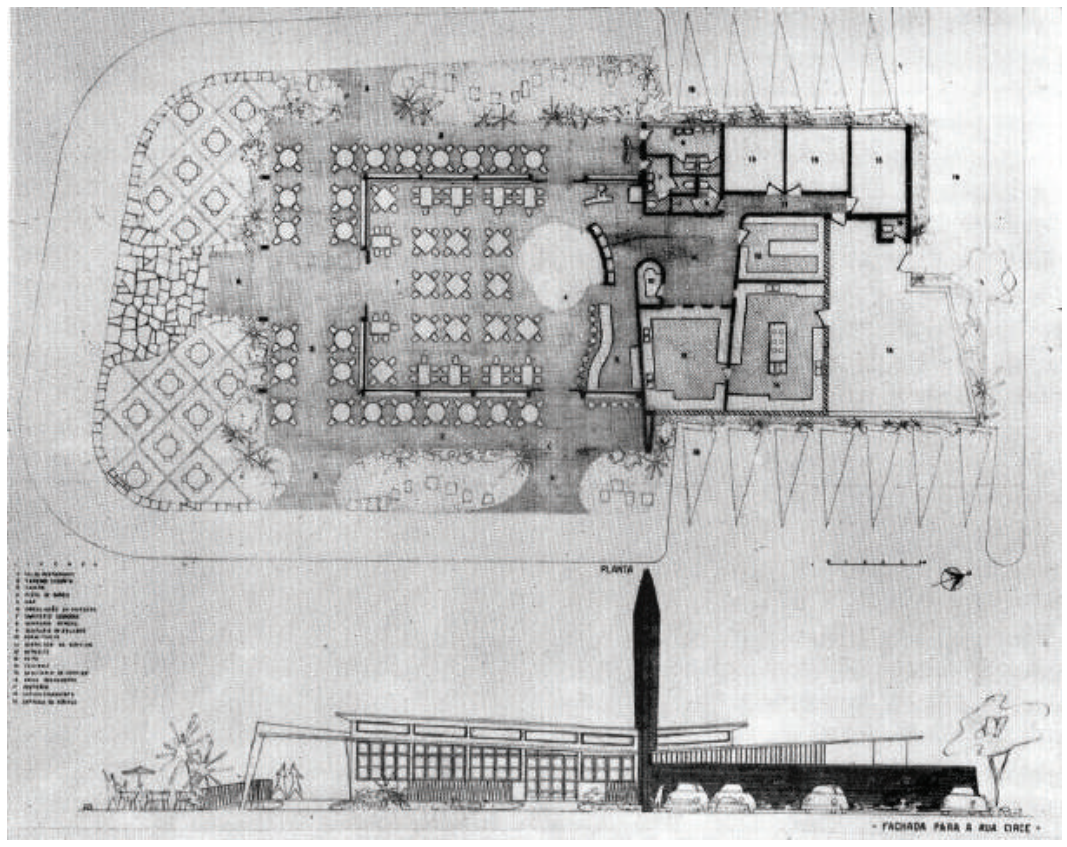

\section{RESTAURANTE LAGOSTA}

Cliente: Heitor Sanches

Data de projeto: não consta

Data da publicação: 1951

Projeto: Ibsen Pivatelli e Gilberto M. Tinoco

Projetos complementares: não consta

Construção: não consta

Paisagismo: Roberto Coelho Cardozo

Tipologia: residencial

Endereço: Rua Heitor Sanches, 49 - Canto Forte (antigo Jardim Mathilde) - Praia Grande/ SP

Material:

CARDOZO, R. C. Curriculum vitae. In: UNIVERSIDADE DE SÃO PAULO. Processo 52.1.14106.1.2: contrato docente. São Paulo: Departamento de projetos da Faculdade de Arquitetura e Urbanismo. 15/12/1987. 87p.

RESTAURANTE Lagosta. Acrópole, n. 161, p. 167-8, 1951. 


\section{RESTAURANTE EDIFÍCIO AUTOLON}

Cliente: Sociedade Auto Comercial de Londrina

Data de projeto: 1957

Data da publicação: não consta

Projeto: João Baptista Vilanova Artigas e Carlos Cascaldi (projeto de Arquitetura de 1948)

Projetos complementares: não consta

Construção: Eng. Rubens Cascaldi

Paisagismo: Roberto Coelho Cardozo

Tipologia: comercial

Endereço: Rua Minas Gerais, 194 - Londrina/PR.

Material:

CARDOZO, R. C. Curriculum vitae. In: UNIVERSIDADE DE SÃO PAULO. Processo

52.1.14106.1.2: contrato docente. São Paulo: Departamento de projetos da Faculdade de Arquitetura e Urbanismo. 15/12/1987. 87p.

\section{SHOPPING CENTER IGUATEMI}

Cliente: Grupo Iguatemi

Data de projeto: 1965

Data da publicação: não consta

Projeto: não consta

Projetos complementares: não consta

Construção: não consta

Paisagismo: Roberto Coelho Cardozo

Tipologia: residencial

Endereço: Avenida Brigadeiro Faria Lima, 2232 - Jardim Paulistano - São Paulo/SP

Material:

CARDOZO, R. C. Curriculum vitae. In: UNIVERSIDADE DE SÃO PAULO. Processo

52.1.14106.1.2: contrato docente. São Paulo: Departamento de projetos da Faculdade de Arquitetura e Urbanismo. 15/12/1987. 87p.

\section{SÍTIO PARA FRANCISCO SCARPA}

Cliente: Francisco Scarpa

Data de projeto: 1967

Data da publicação: não consta

Projeto: não consta

Projetos complementares: não consta

Construção: não consta

Paisagismo: Roberto Coelho Cardozo

Tipologia: residencial

Endereço: Rio Claro/SP

Material:

CARDOZO, R. C. Curriculum vitae. In: UNIVERSIDADE DE SÃO PAULO. Processo 52.1.14106.1.2: contrato docente. São Paulo: Departamento de projetos da Faculdade de Arquitetura e Urbanismo. 15/12/1987. 87p. 


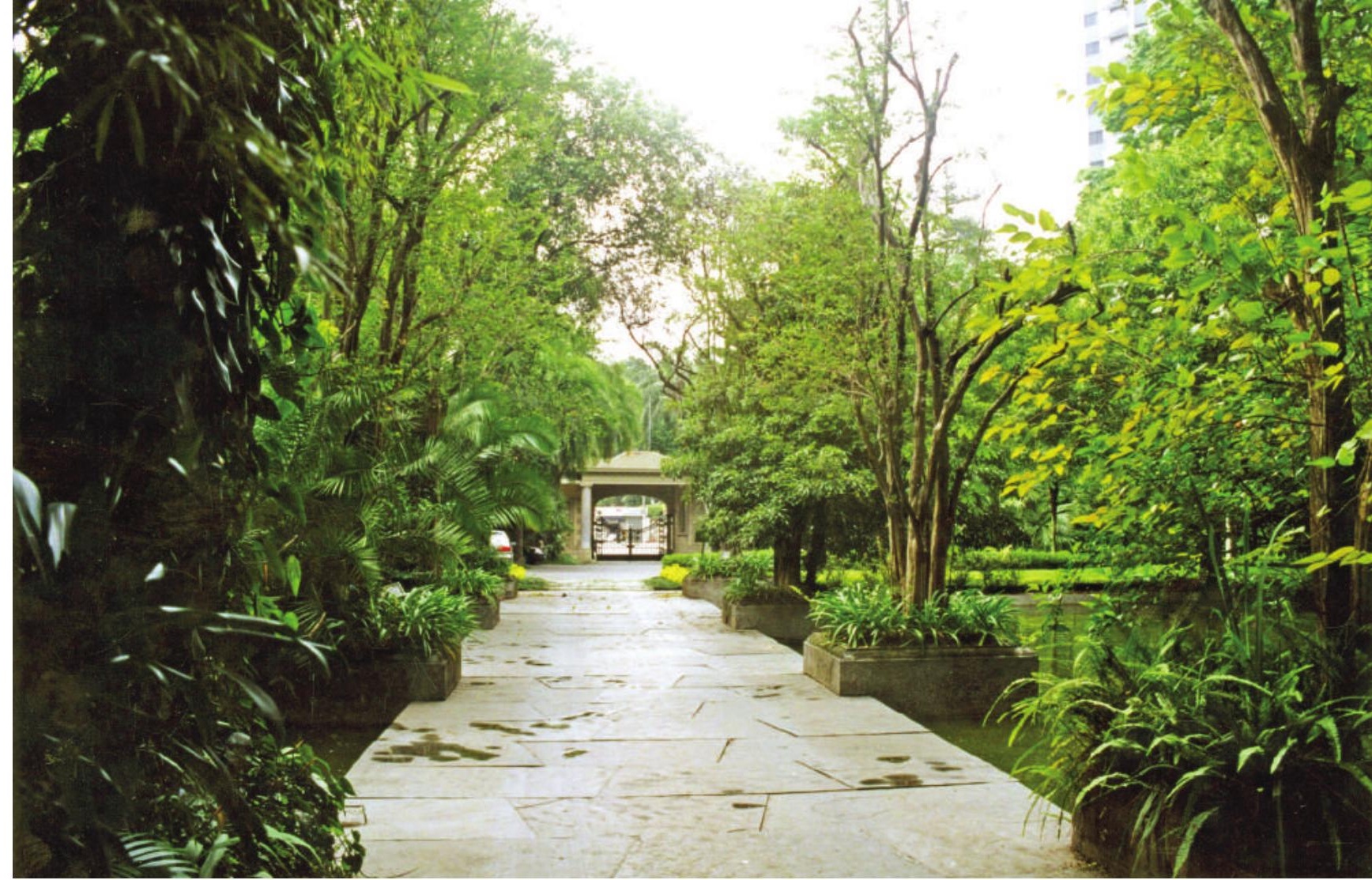

\section{SEDE SOCIAL DO SÃO PAULO CLUBE}

Cliente: não consta

Data de projeto: 1964

Data da publicação: não consta

Projeto: não consta

Projetos complementares: não consta

Construção: não consta

Paisagismo: Roberto Coelho Cardozo

Tipologia: residencial

Endereço: Avenida Higienópolis, 18 - Higienópolis - São Paulo/SP

Material:

ARAÚJO, D. B. S. G. Roberto Coelho Cardozo: vida, obra, perpetuação e resquícios de uma produção paisagística. Paisagem e Ambiente, São Paulo, n. 22, especial Enepea, p. 94-109. 2006.

ARAÚJO, D. B. S. G. A obra do paisagista Roberto Coelho Cardozo compreendida entre 1950-1970. Revista Paisagens, São Paulo, n. especial, dez./jan. 2004.

CARDOSO, O. A. Roberto Coelho Cardoso - A vanguarda da arquitetura paisagística moderna paulistana. Paisagem Ambiente. São Paulo, Ensaios IV, p. 171-186. 1992. CARDOZO, R. C. Curriculum vitae. In: UNIVERSIDADE DE SÃO PAULO. Processo 52.1.14106.1.2: contrato docente. São Paulo: Departamento de projetos da Faculdade de Arquitetura e Urbanismo. 15/12/1987. 87p. 


\section{SÍTIO PARA SALOMÃO GOLDENSTEIN}

Cliente: Salomão Goldenstein

Data de projeto: 1958

Data da publicação: não consta

Projeto: não consta

Projetos complementares: não consta

Construção: não consta

Paisagismo: Roberto Coelho Cardozo

Tipologia: residencial

Endereço: Petrópolis/RJ

Material:

CARDOZO, R. C. Curriculum vitae. In: UNIVERSIDADE DE SÃO PAULO. Processo

52.1.14106.1.2: contrato docente. São Paulo: Departamento de projetos da Faculdade de Arquitetura e Urbanismo. 15/12/1987. 87p.

\section{USINA HIDRELÉTRICA DE JURUMIRIM "ARMANDO AVELLANAL LAYDNER"}

Cliente: Companhia Elétrica de São Paulo (CESP)

Data de projeto: 1969

Data da publicação: não consta

Projeto: não consta

Projetos complementares: não consta

Construção: Construtora Sevix, entre os anos de 1956 e 1962

Paisagismo: Roberto Coelho Cardozo

Tipologia: institucional

Endereço: Rodovia SP-261 - Cerqueira César/SP

Material:

Acervo online Memória Duke.

CARDOZO, R. C. Curriculum vitae. In: UNIVERSIDADE DE SÃO PAULO. Processo

52.1.14106.1.2: contrato docente. São Paulo: Departamento de projetos da Faculdade de Arquitetura e Urbanismo. 15/12/1987. 87p. 


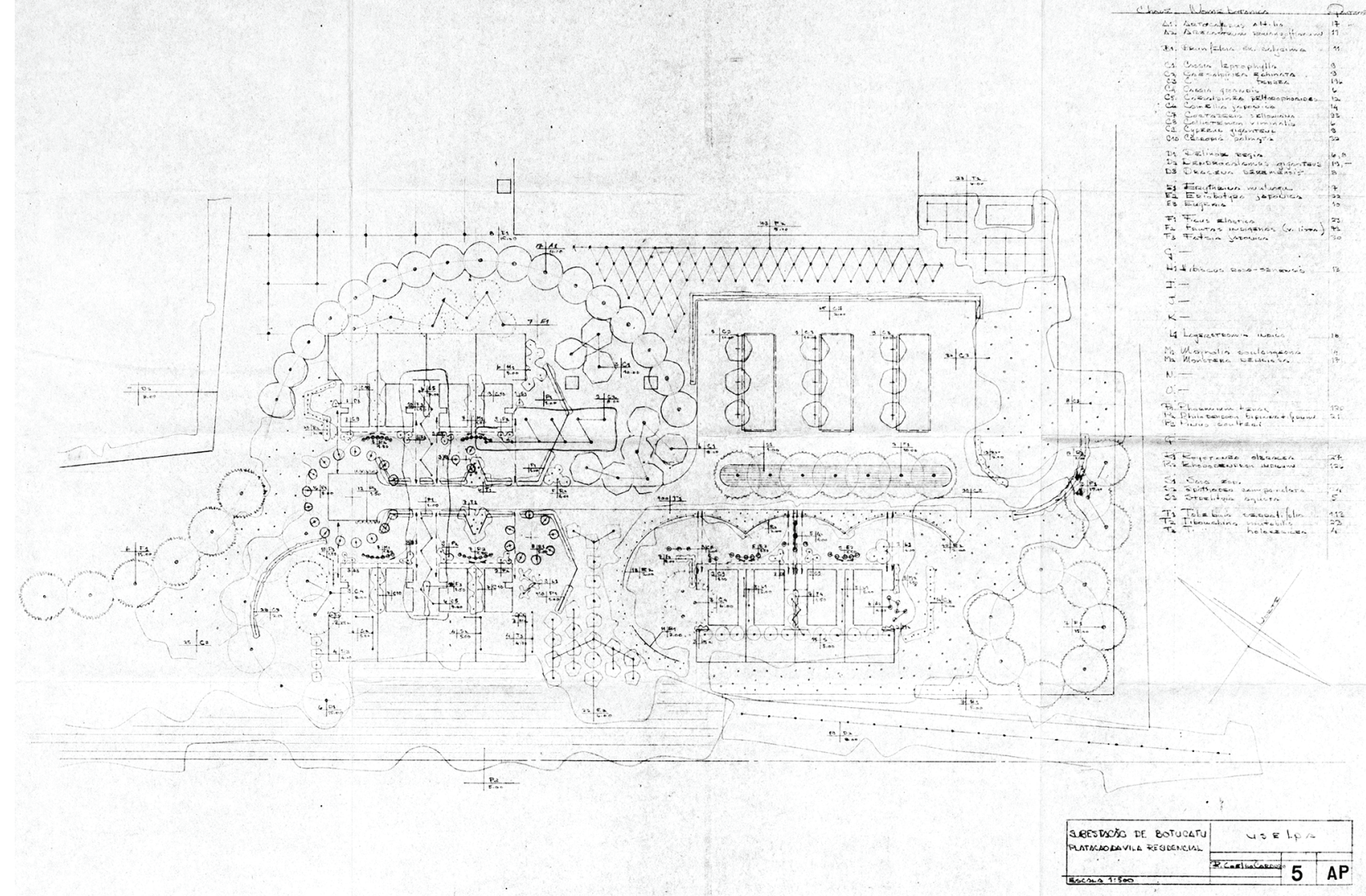

\section{SUBESTAÇÃO DE BOTUCATU}

Cliente: Usinas Elétricas do Paranapanema S. A. - USELPA

Data de projeto: 1966

Data da publicação: não foi publicado

Projeto: não consta

Projetos complementares: não consta

Construção: não consta

Paisagismo: parceria com Susan Osborn Cardozo

Tipologia: institucional

Endereço: Botucatu/SP

Material:

Acervo da biblioteca da FAUUSP (Cód. PE C179/712.6b): planta de plantação, plantação da vila residencial e localização.

CARDOZO, R. C. Curriculum vitae. In: UNIVERSIDADE DE SÃO PAULO. Processo

52.1.14106.1.2: contrato docente. São Paulo: Departamento de projetos da Faculdade de Arquitetura e Urbanismo. 15/12/1987. 87p. 


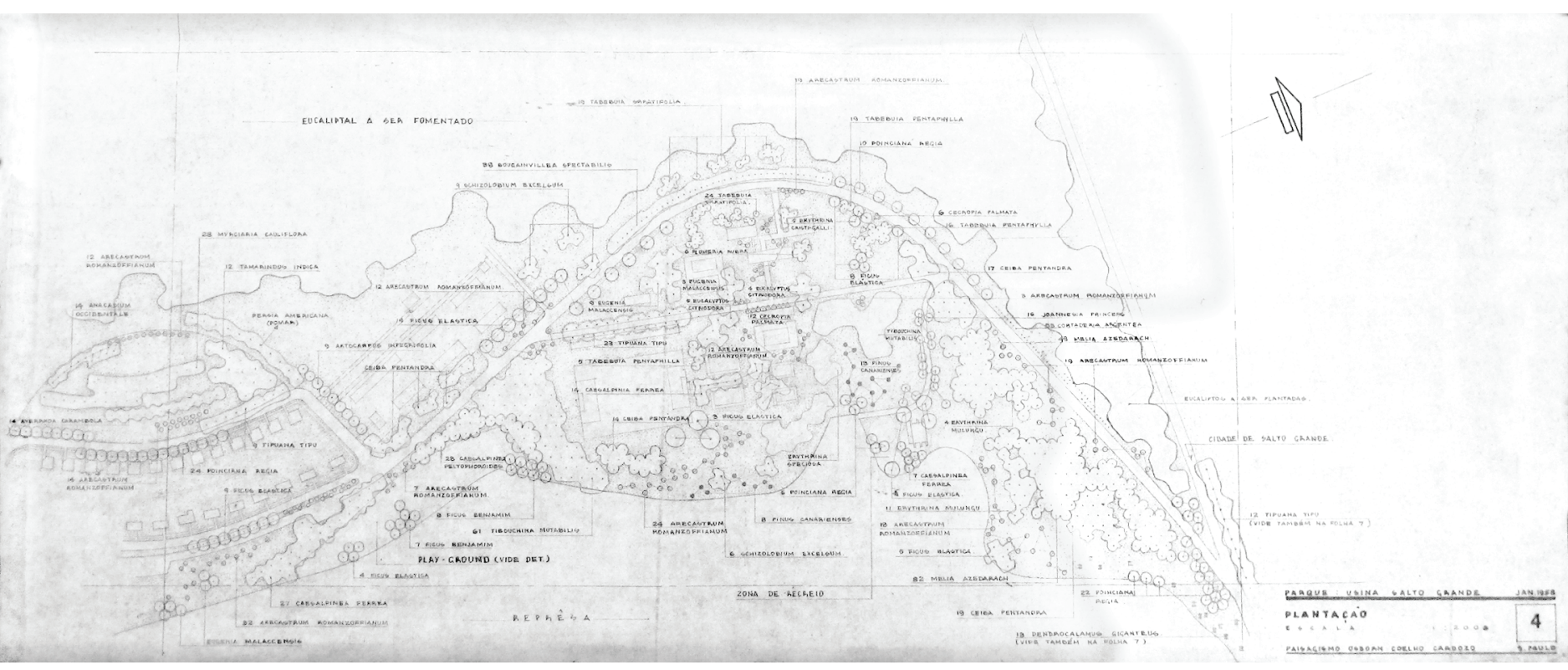

\section{USINA HIDRELÉTRICA DE SALTO GRANDE}

Cliente: Companhia Elétrica de São Paulo (CESP)

Data de projeto: 1958

Data da publicação: 1957 (projeto de arquitetura)

Projeto: Ícaro de Castro Mello e Hélio Pasta (colaboração)

Projetos complementares: não consta

Construção: iniciada em 1951 e finalizada em 1958

Paisagismo: Roberto Coelho Cardozo

Tipologia: institucional

Endereço: Avenida Abelardo de Oliveira Guimarães - Salto Grande /SP

Material:

Acervo da biblioteca da FAUUSP (Cód PE C178/712.5 PUS): não foram listados os projetos da pasta, mas os desenhos estão em ótimas condições.

Acervo online Memória Duke.

CARDOZO, R. C. Curriculum vitae. In: UNIVERSIDADE DE SÃO PAULO. Processo

52.1.14106.1.2: contrato docente. São Paulo: Departamento de projetos da Faculdade de Arquitetura e Urbanismo. 15/12/1987. 87p.

ARQUITETURA e urbanismo na Usina Salto Grande. Habitat, n. 40-41, p. 30-33, mar/abr. 1957. 


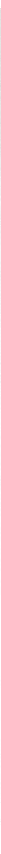

\section{VIADUTOS PARA A AVENIDA 23 DE MAIO}

Cliente: Prefeitura de Municipal de São Paulo

Data de projeto: 1968

Data da publicação: não consta

Projeto: Escritório Técnico J. C. de Figueiredo Ferraz Engenharia Civil

Projetos complementares: não consta

Construção: não consta

Paisagismo: Roberto Coelho Cardozo e Antônio A. Antunes Netto

Tipologia: institucional

Endereço: Rua Cubatão e Avenida Bernardino de Campos - Paraíso - São Paulo/SP

Material:

Acervo da biblioteca da FAUUSP (Cód. PE C179/712.6 VI): perspectiva; planta, corte e elevação; planta do sistema viário.

CARDOZO, R. C. Curriculum vitae. In: UNIVERSIDADE DE SÃO PAULO. Processo

52.1.14106.1.2: contrato docente. São Paulo: Departamento de projetos da Faculdade de Arquitetura e Urbanismo. 15/12/1987. 87p. 


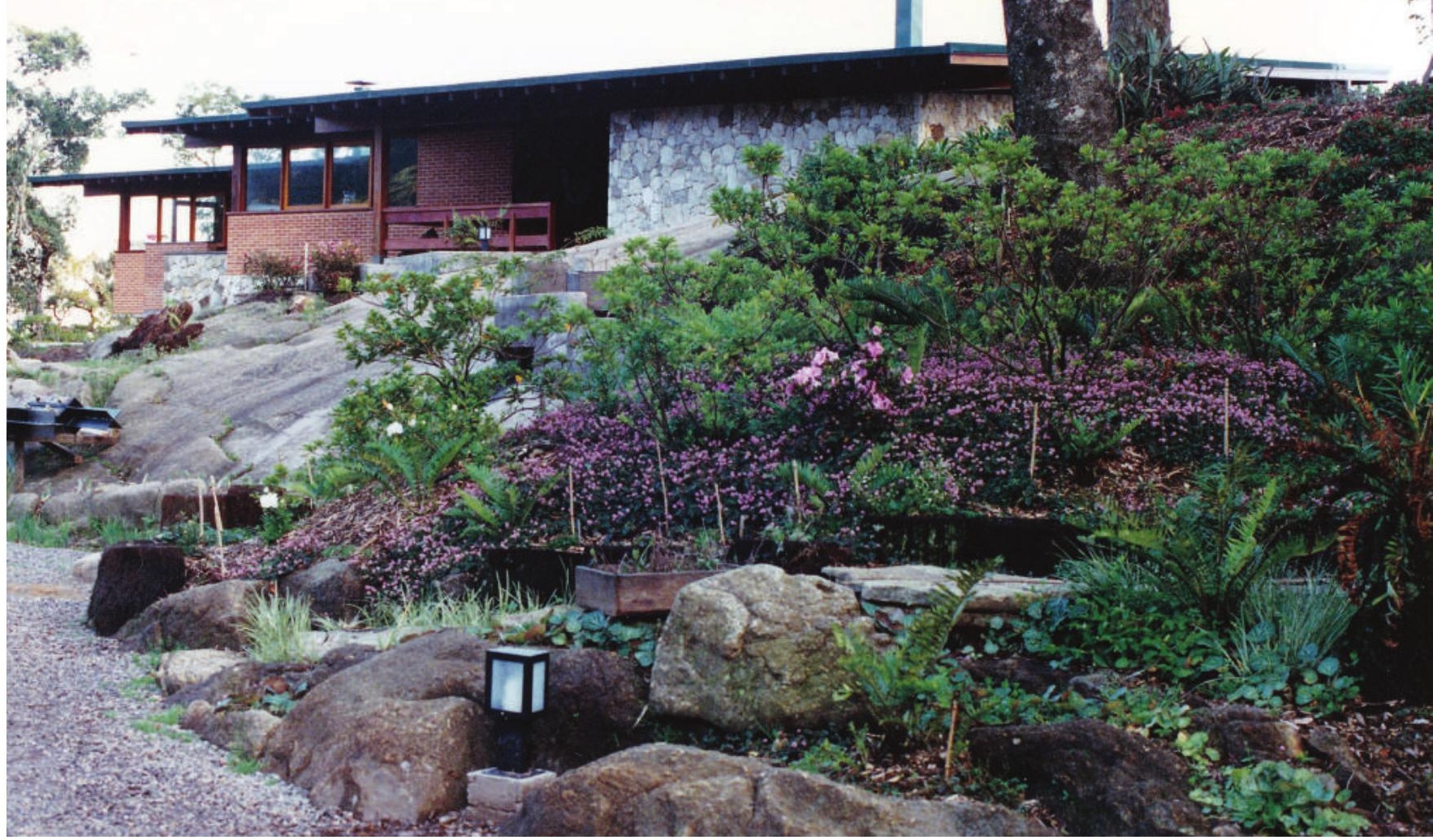

\section{CONJUNTO DE RESIDÊNCIAS EM MONTE VERDE}

Cliente: Paulo Villares

Data de projeto: 1995

Data da publicação: 2003

Projeto: Marcos Acayaba

Projetos complementares: não consta

Construção: não consta

Paisagismo: Roberto Coelho Cardozo

Tipologia: residencial

Endereço: Monte Verde/SP

Material:

Acervo de Marcos Acayaba: Pisos na área do pavilhão e piscina; Área pavilhão e piscina; Área casa de hóspedes; área da casa do caseiro e hóspedes; Área da entrada.

Imagens do acervo pessoal de Marcos Acayaba.

ACAYABA, M.A.; MIZOBE, S.; AUN, A. A casa parece brotar da pedra. Arquitetura e

Construção, São Paulo, n.especial Casas de Autor, p. 78-85, 2003.

SERAPIÃO, F. Quatro pecados louváveis. Projeto Design, São Paulo, 313, p. 84-87, mar.

2006. 

CONSIDERAÇÕES FINAIS 

Apesar de ter um caráter monográfico, este trabalho sempre teve como intuito abordar algumas questões sobre a formação do campo disciplinar do paisagismo, e mais especificamente sobre a consolidação do paisagismo moderno em São Paulo a partir da década de 1950. Ao inserir a obra de Roberto Coelho Cardozo no contexto social, econômico e cultural, foi possível compreendê-la em sua complexidade e, ao mesmo tempo, compreender os processos que permeavam sua atuação profissional e acadêmica: as relações estabelecidas entre arquitetos, engenheiros e clientes, os elos formados a partir da docência na FAUUSP, seja com os professores da instituição, seja com alunos que estagiaram em seu escritório, e o estabelecimento do paisagismo como profissão.

Mesmo com uma curta trajetória no Brasil e com alguns percalços profissionais, a atuação de Roberto Coelho Cardozo foi extremamente significativa. O paisagista se relacionou com um número grande de arquitetos modernos e, assim, acompanhou e participou da renovação arquitetônica que se dava na cidade a partir da década de 1950. Mais além, criou vínculos com as famílias da elite cultural e econômica da cidade, que, à época, eram os empreendedores e investidores do mercado imobiliário, o que lhe garantiu variados projetos, independentemente da relação que mantinha com os arquitetos. Acredita-se que sua atividade profissional foi maior do que imaginamos e possivelmente existam mais projetos além daqueles levantados nesta pesquisa.

Uma questão levantada na dissertação é a problematização entre as "duas escolas de paisagismo", paulista e carioca, que partem das figuras dos "dois Robertos". Miranda Magnoli (2015), comenta em entrevista: "Eu mesma escrevi uma coisa por muito tempo que é muito errada. Os dois Robertos. Na realidade, por acaso são Robertos, mas são completamente diferentes". De fato, percebe-se o processo de o processo de criação, as relações estabelecidas entre arquitetos e clientes, o método e abordagem no projeto são completamente diferenciados na produção de Roberto Coelho Cardozo e de Roberto Burle Marx. Ao mesmo tempo, não são construções antagônicas, mas sim construções que se desenvolvem em paralelo, apoiadas em princípios comuns de uma nova visão da paisagem, que se formulavam, se transformavam e se manifestavam a partir de modernidades específicas. Claramente 
o percurso profissional de Cardozo e de Waldemar Cordeiro se revelam análogos, visto que estavam inseridos em condições de trabalho similares (associados aos arquitetos modernos), nas mesmas situações urbanas, com uma clientela correlata (formada pela elite cultural e econômica). Porém, circunscrever essas aproximações da produção local em formatos fechados, tal como uma "escola", não nos parece interessante, uma vez que emoldurar essa pluralidade pode nos levar a perder o que há de específico em cada um, principalmente levando em consideração a historiografia do paisagismo moderno, ainda incompleta em muitos aspectos.

Em relação à contribuição de Roberto Coelho Cardozo, dentro do panorama paulista de paisagismo, chegamos à conclusão que sua contribuição mais importante foi a partir da docência na FAUUSP. Não tanto pela disciplina que ministrava, uma vez que não foi possível compreender exatamente qual foi sua repercussão dentro do ensino de paisagismo na FAUUSP, mas pela associação feita com alunos e recém-formados, empregando-os como estagiários e como arquitetos. De fato, Cardozo foi o responsável pela introdução dos preceitos projetuais californianos e transmitiu esses fundamentos a muitos desses alunos, que se tornaram arquitetos paisagistas e que formaram um quadro profissional amplo, participando de experiências inaugurais no Brasil como os Projetos de praças e parques na década de 1960, promovido pelo Departamento de Parques e Jardins ${ }^{1}$, ou a criação da Associação Brasileira de Arquitetos Paisagistas (ABAP)². Para Miranda Magnoli:

1. O Departamento de Parque e Jardins (PARQUE) foi criado em 10/01/1968 e contou com a participação de muitos paisagistas que se formaram na FAUUSP, como Rosa Kliass, Miranda Magnoli, Ary Albano, Ayako Nishikawa, Francisco Segnini Júnior, entre outros. Foi só em 14/12/1976, a partir de uma reestruturação da Secretaria de Obras e Serviços que surgiu o Departamento de Parques e Áreas Verdes (DEPAVE). A tese de Bartalini (1999) e a dissertação Steschenko (2001) discorrem sobre a criação do PARQUE e do DEPAVE e os projetos realizados por essas instituições.

2. A Associação Brasileira de Arquitetos Paisagistas (ABAP), associação que representa o Brasil na International Federation of Landscape Architects (IFLA), foi criada em 28 de maio de 1976, e tem como metas, segundo duas diretrizes estatutárias, "assistir, promover, apoiar, incentivar e desenvolver ações científicas, tecnológicas, educacionais, culturais, sociais e ambientais 
"Roberto Coelho Cardozo tinha tido um papel extremamente importante ao valorizar o desenho: a simples existência de uma disciplina com a denominação de Arquitetura Paisagística já se constituía em exigência de reflexão; até a origem americana de sua formação já despertava o interesse para enfoques totalmente desconhecidos na época; em que pesem as lacunas graves de iniciativas para a formação de quadros, sua contribuição foi fundamental, para deixar, apesar de tudo, o germe para a equipe paulista de arquitetos paisagistas" (MAGNOLI Apud MARIANO, 1992).

Definitivamente, foi a partir do trabalho técnico desses paisagistas, somado à reestruturação do ensino de paisagismo na FAUUSP³, que campo profissional da arquitetura paisagística se consolidou de fato na cidade de São Paulo.

Como é próprio de qualquer processo de pesquisa, uma série de questões surgidas durante essa empreitada acabaram por não ser desenvolvidas. Logo, lançamos aqui esses pensamentos abertos, pensando que talvez possam ser retomados em trabalhos futuros.

A partir da análise da obra de Roberto Coelho Cardozo, percebeu-se que o procedimento de participação do paisagista sempre se dava posteriormente à conclusão do projeto de arquitetura ou até mesmo após a construção dos espaços edificados. Com exceção dos grandes projetos urbanísticos, promovidos pelos órgãos públicos, o paisagista, ainda hoje, trabalha com o espaço residual dos lotes, o espaço "que sobra”. Mesmo na formação da escola norte-americana de paisagismo, onde existe uma separação clara entre os processos relacionados à arquitetura e ao paisagismo/urbanismo, um princípio sempre ressaltado por Eckbo em seus livros é o da concepção conjunta entre arquitetos e paisagistas, desde o estudo preliminar de um projeto. Fica então a questão: seria essa uma dificuldade inerente à profissão do paisagista no Brasil, sempre subjugado à arquitetura? Ou teria Cardozo contri-

que visem o desenvolvimento, a divulgação e a valorização profissional da Arquitetura Paisagística no país" (ASSOCIAÇÃO BRASILEIRA DE ARQUITETOS PAISAGISTAS, 1976).

3. Como já citado, a reestruturação do ensino da FAUUSP se deu em 1972, com a criação do grupo específico de disciplinas de paisagismo (GDPA), coordenado pela Profa. Dra. Miranda Esmeralda Martinelli Magnoli. 
buído para a fragmentação desse processo, deixando esse legado às gerações futuras?

Um outro questionamento se coloca em relação à análise de projeto e a implantação do paisagismo, o plantio. Assim como na implantação da arquitetura, onde materiais são substituídos in loco, o projeto de paisagismo também se adapta, dada a disponibilidade dos materiais e principalmente, à disponibilidade da vegetação. Com exceção de Burle Marx, que mantinha um vasto viveiro com as espécies que acreditava ser especiais, muitos paisagistas não possuíam tal recurso. Vemos essa substituição ocorrer nas obras de Cardozo, onde ipês são substituídos por paus-ferros ou primaveras são trocadas por gengibres-concha. Porém, a análise do projeto é dificultada se não houver um registro preciso do pós-plantio, visto que essa disciplina lida com matéria viva e que, muitas vezes, não deixa rastros físicos, como ocorre na arquitetura. Nesse sentido, a análise do projeto conceitual, principalmente da vegetação, é válida? Ou a concepção do projeto paisagístico se dá em conjunto, com o projeto conceitual e a atividade in loco?

Por último, valeria conferir a ressonância dos projetos de Roberto Coelho Cardozo nas produções posteriores, principalmente aquelas feitas pelo DEPAVE em seus primeiros anos de existência, quando contou com a contribuição de Rosa Kliass, Miranda Magnoli, Ayako Nishikawa, Ary Albano, entre outros que se formaram na FAUUSP até fins da década de 1960.

De modo geral, espera-se que essa pesquisa tenha esclarecido como a análise do percurso e da obra de Roberto Coelho Cardozo serviu para reconstituir a formação do campo paisagístico em São Paulo, entre as décadas de 1950 e 1970, retomando debates e avanços, expondo as diversas expressões em curso, e ampliando a historiografia do paisagismo moderno, possibilitando ampliar o panorama da disciplina, com as diferentes modernidades que ela apresenta. 
BIBLIOGRAFIA 



\section{LIVROS E MONOGRAFIAS}

ABASCAL, E.; BREIA, M.; MANZO, R.; MENDES, M.; MINOZZI, C. A Arquitetura Moderna no Brasil e a contribuição do engenheiro Roberto Rossi Zuccolo para a formação dos alunos da Faculdade de Arquitetura Mackenzie e sua atuação profissional. São Paulo: Relatório de pesquisa FAU-MACK, 2016. 116p.

ABBUD, B. Benedito Abbud: depoimento [17/julho/2015]. Entrevistadora: Gabriela Tie Nagoya Tamari. São Paulo. Entrevista concedida à pesquisadora. Um procedimento em pesquisa: A obra do arquiteto paisagista Roberto Coelho Cardozo. Trabalho de Graduação Interdisciplinar (Graduação em Arquitetura e Urbanismo). FAUUSP, São Paulo, 1974. 10op. ACAYABA, M. Marcos Acayaba: depoimento [27/outubro/2015]. Entrevistadora: Gabriela Tie Nagoya Tamari. São Paulo. Entrevista concedida à pesquisadora.

ALIATA, F. The pictorial technique of 'Ecological Painting': the gardens of Roberto Burle Marx. In: MOSSER, M; TEYSSOT, G. [org.] The Architecture of Western Gardens. Cambridge: MIT Press, 1991. P519-521.

ALMEIDA, M. F. Revista Acrópole publica residências modernas: análise da revista acrópole e sua publicação de residências unifamiliares modernas entre os anos de 1952 a 1971. Dissertação (Mestrado em Arquitetura e Urbanismo). IAUUSP, São Carlos, 2008. 472p.

ANELLI, R.; GUERRA, A. Rino Levi: Arquitetura e Cidade. São Paulo: Romano Guerra Editora, 2001, 324p.

ARANHA, M. B. de C. A obra de Rino Levi e a trajetória da arquitetura moderna no Brasil. Tese (Doutorado em Arquitetura e Urbanismo). FAUUSP, São Paulo, 2008. 344p.

ASSOCIAÇÃO BRASILEIRA DE ARQUITETOS PAISAGISTAS. Estatuto social da ABAP. São Paulo: ABAP/Nacional. 28/05/1976. 15p.

BARBOSA, M. C. A obra de Adolf Franz Heep no Brasil. Dissertação (Mestrado em Arquitetura e Urbanismo). FAUUSP, São Paulo, 2002. 188p.

BARTALINI, V. Parques públicos municipais em São Paulo: a ação da municipalidade no provimento de áreas verdes de recreação. Tese (Doutorado em Arquitetura e Urbanismo). FAUUSP, São Paulo, 1999. 302p. 
BELLUZZO, Ana Maria de Moraes [org]. Waldemar Cordeiro, uma aventura da razão. São Paulo, MAC-USP, 1986.

BENTON, T. Modern Taste: Art Deco in Paris 1910-1935. Madri: Fundación Juan March, 2015, 540p.

BIRNBAUM, C. A.; FIX, J. K. Pioneers of American landscape design II: an annotated bibliography. Washington: U.S. Department of the Interior, National Park Service, Cultural Resources, Heritage Preservation Services, Historical Landscape Initiative, 1995. 186p.

BYRNE, E.D.; LOWELL, W. B.; McDADE, C.L. [org] Landscape at Berkeley: The first 100 years. Berkeley: UCBerkeley, 2013, 266p.

CARDOZO, R. C. Curriculum vitae. In: UNIVERSIDADE DE SÃO PAULO. Processo 52.1.14106.1.2: contrato docente. São Paulo: Departamento de projetos da Faculdade de Arquitetura e Urbanismo. 15/12/1987. 87p.

CAVALCANTI, L.; EL-DAHDAH, F. Roberto Burle Marx 100 anos: a permanência do instável. Rio de Janeiro: Rocco, 2009, 247p.

CHURCH, T. D. Gardens are for the people: how to plan for outdoor living. Nova York: Reinhold, 1955. 248p.

COELHO, P. Peri Jon Osborn Coelho: depoimento [o8/novembro/2015]. Entrevistadora: Gabriela Tie Nagoya Tamari. São Paulo. Entrevista concedida à pesquisadora.

CONSTANTINO, R. A Obra de Abelardo de Souza. Dissertação (Mestrado em Arquitetura e Urbanismo). FAUUSP, São Paulo, 2004. 441p.

CONTIER, F. O edifício da faculdade de arquitetura e urbanismo na cidade universitária: projeto e construção da escola de Vilanova Artigas. Tese (Doutorado em Arquitetura e Urbanismo). IAUUSP, São Carlos, 2015. 323p.

CRONON, W. [org.]. Uncommon Ground: Rethinking the human place in nature. Nova York: W. W. Norton, 2004. 56op.

DOURADO, G.M. [org]. Visões de paisagem: um panorama do paisagismo contemporâneo no Brasil. São Paulo: ABAP, 1997. 169p.

.Modernidade verde: jardins de Burle Marx. São Paulo: Editora Senac/ Edusp. 2009. 385p.

ECKBO, G. [Carta] 13 jul. 1950a, Los Angeles [para] COELHO, Robert., s.l., 1f. 
Landscape for living. Nova York: Architectural Record w/ Duell, Sloan \& Pierce, 1950b. 262p.

. The art of home landscaping. Nova York: McGraw-Hill Book, 1956.278p. . The landscape we see. Nova York: McGraw-Hill Book, 1969. 223p. . Urban landscape design. Nova York: McGraw-Hill Book Co., 1964. 24 p.

EGGENER, K. Luis Barragán's gardens of El Pedregal. Nova York: Princeton Architectural Press, 2001. 161p.

EXPOSITION INTERNATIONALE DES ARTS DÉCORATIFS ET INDUSTRIELS MODERNES. Encyclopédie des arts décoratifs et industriels modernes au XXème siècle. Paris: Larousse, v.11, 1925. 373p.

FALBEL, A. Lucjan Korngold: a trajetória de um arquiteto imigrante. Tese (Doutorado em Arquitetura e Urbanismo). FAUUSP, São Paulo, 2003. 323p.

FARAH, I.; SCHLEE, M.B.; TARDIN, R. Arquitetura Paisagística Contemporânea no Brasil. São Paulo: Editora Senac, 2010, 232 p.

FIASCHI, L. Luciano Fiaschi: depoimento [21/julho/2015]. Entrevistadora: Gabriela Tie Nagoya Tamari. São Paulo. Entrevista concedida à pesquisadora.

FICHER, S. Os arquitetos da Poli - ensino e profissão em São Paulo. São Paulo: Edusp, 2005, 40op.

FLEMING, L. Roberto Burle Marx, um retrato. Rio de Janeiro: Index, 1996. 16op. FRAMPTON, K. In search for the Modern Landscape. In: ADAMS, W. H.; WREDE, S. [org.]. Denatured visions: landscape and culture in the twentieth century. Nova York: The Museum of Modern Art: Distributed by Harry N. Abrams, 1991. p42-61.

FRANKEL, F.; JOHNSON, J. Modern Landscape Architecture: Redefining the Garden. Nova York: Abbeville Press Publishers, 1991. 112p.

FORESTIER,J.C.N. Jardins: carnet de plans et de dessins. Paris: Émile-Paul, 1920, 240p. GUERRA, A. (org.) Textos fundamentais: sobre história da arquitetura moderna brasileira: vol. 2. São Paulo: Romano Guerra, 2010. 332p.

HARRIS, D. Writing a Modern Landscape: Thomas Church as author. In: TREIB, M. [org]. Thomas Church Landscape Architecture: Designing a modern California Landscape. São Francisco: William Stout Publishers, 2003. p176-197.

HUNT, J. D. Gardens and the Picturesque: Studies in the History of Landscape Architecture. Cambridge: MIT Press, 1994, 408p. 
IMBERT, D. Byways to Modernism: the early Landscapes of Thomas Church. In: TREIB, M. [org]. Thomas Church Landscape Architecture: Designing a modern California Landscape. William Stout Publishers, São Francisco, 2003. p18-71.

IMBERT, D.; TREIB, M. Garret Eckbo: Modern Landscapes for Living. Berkeley: University of California Press, 1997. 208p.

JANJULIO, M. A arquitetura doméstica da classe média paulistana nos anos 1950: o "bem viver" moderno. Tese (Doutorado em Arquitetura e Urbanismo). IAUUSP, São Carlos, 2014. 362p.

JEKYLL, G. Wall and water gardens. Nova York: Charles Scribner's Sons, 1901. 177p. JELLICOE, G; JELLICOE, S. The Landscape of Man - Shaping the environment from prehistory to the present day. Nova York: Thames and $\mathrm{Hu}-$ dson, 1998. 408p.

KILEY, D.; AMIDON, J. Dan Kiley: The Complete Works of America's Master Landscape Architect. Nova York: Bulfinch Press. 1999. 224 p.

KLIASS, R. G. Rosa Grena Kliass: depoimento [15/09/2009]. Entrevistador: João Clark de Abreu Sodré. São Paulo. Entrevista concedida ao pesquisador. .Rosa Kliass - Desenhando paisagens, moldando profissões. São Paulo: Editora Senac, 2006. 221p.

LEENHARDT, J. [org.]. Nos Jardins de Burle Marx. São Paulo: Perspectiva, 1994. 150 p. LIMA, C.; KAISER, A.; FRANCO, M.; LEITE, M.; PELLEGRINO, P.; MACEDO, S.; BARTALINI, V. O ensino de paisagismo no curso de graduação da FAUUSP. In: I Encontro De Ensino de Paisagismo em Escolas de Arquitetura, 1998, Rio de Janeiro. Anais...Rio de Janeiro: UFRJ, 1998. p29-34.

LIMA, Z. Beyond Roberto Burle Marx - Another genealogy of modern landscape architecture in Brazil. In: Düpelmann, S.; Beardsley, J. Women, modernity and landscape architecture. Nova York: Routlegde, 2015.

LIRA, J. Warchavichik, fraturas da vanguarda. São Paulo: Cosac Naify, 2011. 552p. MACEDO, S. S. História do paisagismo no Brasil. São Paulo: Quapá, 2002. CDROM. MACHADO, Paula M. Casa e Jardim : a revista e a divulgação do ideário moderno na década de 1950. Dissertação (Mestrado em Arquitetura e Urbanismo). UFRJ, Rio de Janeiro, 2007. 202p. 
MAGNOLI, M. Miranda Magnoli: depoimento [30/novembro/2015]. Entrevistadora: Gabriela Tie Nagoya Tamari. São Paulo. Entrevista concedida à pesquisadora.

MARIANO, Cássia. Parques metropolitanos de São Paulo: subsídios para o desenho. Dissertação (Mestrado em Arquitetura e Urbanismo). FAUUSP, São Paulo, 1992. 218p.

. Preservação e Paisagismo em São Paulo: Otavio Augusto Mendes Teixeira. São Paulo: Annablume, Fapesp, Fundação Ana Maria Luisa e Oscar Americano, 2005. 196p.

MEDEIROS, G. L. Artepaisagem a partir de Waldemar Cordeiro. Tese (Doutorado em Arquitetura e Urbanismo). FAUUSP, São Paulo, 2004. 366p.

MELLO, M. Arquitetura escolar pública paulista. Fundo Estadual de Construções Escolares - FECE: 1966-1976. Dissertação (Mestrado em Arquitetura e Urbanismo). FAUUSP, São Paulo, 2012. 419p.

MINDLIN, H. E. Arquitetura Moderna no Brasil. Rio de Janeiro: Aeroplano Editora/IPHAN, 2000, 286p.

MORALES, I. The Park Güell, Barcelona (1900-1914). In: MOSSER, M; TEYSSOT, G. [org.] The Architecture of Western Gardens. Cambridge: MIT Press, 1991. 544p.

MOSSER, M; TEYSSOT, G. [org.] The Architecture of Western Gardens. Cambridge: MIT Press, 1991. 544p.

MOTTA, F. L. Roberto Burle Marx e a nova visão da paisagem. 2a ed. São Paulo: Nobel, 1985. 255p.

NEWTON, N. T. Design on the Land. Cambridge: The Belknap Press of Harvard University Press. 1971. 714p.

OTMER, R. [org.]. Botti Rubin Arquitetos: selected and current works. Mulgrave: Images Pub. Group, 2002, 355p.

PANZINI, F. Projetar a natureza. São Paulo: Editora Senac. 2013. 72op.

PERECIN, T. Azaléias e Mandacarus: Mina Klabin Warchavchik, paisagismo e modernismo no Brasil. Dissertação (Mestrado em Arquitetura e Urbanismo). EESC, São Carlos, 2003. 271p.

RAINEY, R.; TREIB, M. Dan Kiley: Landscapes - the Poetry of Space. São Francisco: William K Stout Pub., 2009. 16op.

ROYER, C. Art Deco Gardens in France. In: MOSSER, M; TEYSSOT, G. [org.] The Architecture of Western Gardens. Cambridge: MIT Press, 1991. p460-465. 
SCARLETT, F.; TOWNLEY, M. Arts décoratifs1925: a personal recollection of the Paris exhibition. Nova York: St. Martin's Press, 1975. 104 p.

SEGAWA, H. Ao amor público: jardins no Brasil. São Paulo: Studio Nobel/FAPESP, 1996. 255p.

SIQUEIRA, R. M. A inserção da FAUUSP no campo de arquitetura e urbanismo em São Paulo: as contribuições de Anhaia Mello e Vilanova Artigas. Dissertação (Mestrado em Arquitetura e Urbanismo). FAUUSP, São Paulo, 2015. 228p.

SILVA, J. M. O arquiteto e a produção da cidade: a experiência de Jacques Pilon em perspectiva 1930-1960. Tese (Doutorado em Arquitetura e Urbanismo). FAUUSP, São Paulo, 2010. 291p.

SIMO, M. 100 Years of Landscape Architecture: Some Patterns of a Century. Washington: ASLA, 1999. 374p.

SIMO, M.; WALKER, P. Invisible gardens: the search for modernism in American landscape. Cambridge: MIT Press, 1994. 365 p.

SIQUEIRA, V. B. Burle Marx. São Paulo: Cosac \& Naify, 2001. 127p.

SNOW, M. Modern American Gardens: designed by James Rose. Nova York: Reinhold Publishing Corp., 1967. 224p.

SODRÉ, J. Arquitetura e viagens de formação pelo Brasil 1938-1962. Dissertação (Mestrado em Arquitetura e Urbanismo). FAUUSP, São Paulo, 2010. 226p.

SOMECK, N.; CAMPOS, C.M. [org.] A cidade não pode parar: planos urbanísticos de São Paulo no século XX. São Paulo: Mackpesquisa, 2008. 192 p.

STESCHENKO, W. Contribuição ao estudo e ao processo de produção da praça pública paulistana - o Departamento de Parques e Áreas Verdes de São Paulo de 1967 a 1979. Dissertação (Mestrado em Arquitetura e Urbanismo). FAUUSP, São Paulo, 2001. 236p.

SHEPEARD, P. Modern gardens. Londres: The Architectural Press, 1953, 144p.

SUANDERS, W. Daniel Urban Kiley: The Early Gardens: Landscape Views 2. Nova York: Princeton Architectural Press. 1999. 80 p.

SULLIVAN, C. Big fun: 100 years of Landscape Architecture at CAL. In: BYRNE, E.D.; LOWELL, W. B.; McDADE, C.L. [org.] Landscape at Berkeley: The first 100 years. Berkeley: CED/UCBerkeley, 2013, p16-26.

TABACOW, J. [org]. MARX, R. B. Arte e paisagem: (conferências escolhidas). 2ed. São Paulo: Studio Nobel, 2004. 223 p. 
TAGLIARI, A. Os projetos residenciais não-construídos de Vilanova Artigas em São Paulo. Tese (Doutorado em Arquitetura e Urbanismo) FAUUSP, São Paulo, 2012. 417p.

TAYLOR, L. [org.]. Urban open spaces. Nova York: Rizzoli. 1981. 128p.

TIGERMAN, B. [ed.] A Handbook of California Design, 1930-1965: Craftspeople, Designers, Manufacturers. Cambridge: The MIT Press, 2013. 32op. TOBBEY, G. A history of landscape architecture: the relations of people to environment. Nova York: American Elsevier Publishing Company, 1973. 306p.

TREIB, M. [org.]. Modern landscape architecture: a critical review. Cambrige: MIT Press, 1993. 294p. [org.]. Thomas Church, Landscape Architect: Designing a Modern California Landscape. São Francisco: William K Stout Pub, 2004. 25op. . Meaning in landscape architecture and gardens. Nova York: Routlegde, 2011. 232p.

Settings and stray paths writings on landscapes and gardens. Londres: Spon Press, 2005. 237p.

TUNNARD, C. Gardens in the modern landscape. Londres: Architectural Press New York: Scribner, 1950. 184p.

UNIVERSIDADE DE SÃO PAULO. Processo 52.1.14106.1.2: contrato docente. São Paulo: Departamento de projetos da Faculdade de Arquitetura e Urbanismo. 15/12/1987. 87p.

UNIVERSITY OF CALIFORNIA. Register, 1946-1947 with Announcements for 1947-1948 in two volumes. Berkeley: University of California Press, 1948, vol.II, 227p.

Register, 1948-1949 with Announcements for 1949-1950 in two volumes.

Berkeley: University of California Press, 1949, vol.II, 267p.

VACCARINO, R. The inclusion of Modernism: 'Brasilidade' and the garden. In: TREIB, M (org.). The Architecture of Landscape: 1940-1960. Filadélfia: Universtiy of Pennsylvania Press, 2002. P.206-231.

VIANNA, M. Da edificação ao traçado urbano: a experiência de planejamento regional integrado na CESP. Tese (Doutorado em Arquitetura e Urbanismo). IAUUSP, São Carlos, 2012. 303p.

YOSHIDA, C.B. Henrique Ephim Mindlin: o homem arquiteto. São Paulo: Instituto Roberto Simonsen, 1975. 225p. 
ZOLKO, G. Gregório Zolko: depoimento [11/novembro/2015]. Entrevistadora: Gabriela Tie Nagoya Tamari. São Paulo. Entrevista concedida à pesquisadora.

\section{ARTIGOS EM REVISTAS}

A IDADE da razão (Cosipa). Construção São Paulo, n.1992, p.8-10, abr.1986.

AB'SABER, A. N. Eckbo e o método de planejamento. Scientific American Brasil. São Paulo, n. 44, p. 98, jan. 2006.

ALLEN, P. Progress Intentionally Planned: Telesis and the Modernist agenda. The Urbanist. São Francisco, n.438, jul. 2009. Disponível em: http:// www.spur.org/publications/urbanist-article/2009-07-01/progress-intentionally-planned. Acesso em: 03 abr. 2016.

ARAÚJO, D. B. S. G. Roberto Coelho Cardozo: vida, obra, perpetuação e resquícios de uma produção paisagística. Paisagem e Ambiente, São Paulo, n. 22, especial Enepea, p. 94-109. 2006.

ARAÚJO, D. B. S. G. A obra do paisagista Roberto Coelho Cardozo compreendida entre 1950-1970. Revista Paisagens, São Paulo, n. especial, dez.jjan. 2004.

ARQUITETURA e urbanismo na Usina Salto Grande. Habitat, n.40-41, p. 3033, mar/abr. 1957.

ARQUITETURA Escolar. Acrópole, São Paulo, 197, p. 211-222, fev. 1955.

ATIVIDADES ao ar livre. Acrópole, São Paulo, 197, p. 236-7, fev. 1955.

ATRIUM. Casa \& Jardim, São Paulo, 142, p. 6-12, nov. 1966.

BAUER. L. A. F. Três escolas do Senai. Habitat, São Paulo, 12, p.16-19, set.1953.

BELEZA aquática nos jardins. Casa e Jardim, São Paulo, 21, p.22-3, jan. 1956.

CAMPINAS, Paço Municipal e Parque. Acrópole, São Paulo, 230, p. 46-9, dez. 1957.

CAMPOBELO H. Modernos projetos. Casa e Jardim, São Paulo, 41, p.46-51, fev. 1958. . A residência jardim. Casa e Jardim, São Paulo, 40, p.23-30, jan. 1958.

CARDOSO, O. A. Roberto Coelho Cardoso - A vanguarda da arquitetura paisagística moderna paulistana. Paisagem Ambiente. São Paulo, Ensaios IV, p. 171-186. 1992.

CARDOSO, R. C. Apresenta um jardim na Rua dos Açores - São Paulo. Casa e Jardim, São Paulo, 63, p.76-78, abr. 1960.

CARDOSO, R.C.; COELHO, S. O. Pisos em jardins modernos. Casa e Jardim, São Paulo, 40, p.51-53, jan. 1958. 
CARDOZO, O. C. Arquitetura e Jardinagem. Habitat, São Paulo, 06, p. 70-71, 1952.

CARDOZO, O. C. Árvores; seus componentes essenciais. Acrópole, São Paulo, 196, p. 176-7, jan. 1955a.

CARDOZO, O. C. Pisos, suas preferências e necessidades. Casa e Jardim, São Paulo, 16, p.50-3 e p.73, ago. 1955b.

CARDOZO, R. C. Acesso à residência. Acrópole, São Paulo, 193, p. 20-1, out. 1954 a. . Ardósia na arquitetura paisagista. Acrópole, São Paulo, 316: 35-7, abr. 1965.

. Áreas de entrada. Acrópole, São Paulo, 195, p. 133-5, dez.1954b.

. Artesãos do trabalho. Acrópole, São Paulo, 191, p. 512-3, ago. 1954c.

. Biombos como barreiras. Casa e Jardim, São Paulo, 13, p.46-49, mar/abr. 1955c. . Considerações sobre a escultura: esculturas de Felícia Leirner. Acrópole, São Paulo, 207, p. 101-3, jan. 1956a.

. Degraus externos. Acrópole, São Paulo, 228, p. 460, out. 1957 a.

. Living do ar livre. Acrópole, São Paulo, 192, p. 570-1, set.1954d.

. O campo do paisagismo. Acrópole, São Paulo, 198, p. 284-5, abr. 1955 d. . Paisagismo e indústria. Acrópole, São Paulo, 205, p. 9-11, nov. 1955 f. . Pisos no jardim: terraços, passeios ou áreas privadas. Casa e Jardim, São Paulo, 15, p.51-53, jul.1955g.

. Residência no Pacaembu. Acrópole, São Paulo, 212, p. 308-11, jun. 1956 b. Um “deck" de madeira. Acrópole, São Paulo, 228, p. 461, out. 1957b. . Um páteo interno. Acrópole, São Paulo, 193, p. 19, out. 1954e.

CARDOZO, R. C.; COELHO, S.O. Um jardim. Habitat, São Paulo, 6, p. 69-71, 1952. CARNEIRO, D. G. Flávio de Carvalho. Casa e Jardim, São Paulo, 40, p.32-41, jan. 1958.

CARNEIRO, D. G. Proprietário, arquiteto, decorador, paisagista falam sobre uma casa. Casa e Jardim, São Paulo, 39, p.22-33, nov/dez. 1957.

CENTRO Educacional. Acrópole, São Paulo, 368, p. 30-2, dez. 1969.

CHANG, C. [org.]. Process architecture: Lawrence Halprin. Vol.4. Tóquio: Process Architecture, 1978. 26op.

CINTRA, L. Um novo jardim de Roberto Coelho Cardoso. Casa e Jardim, São Paulo, 78, p.71-76, jul. 1961.

CONCURSO de Anteprojetos para a "Cosipa”. Acrópole, 253, p.11-3, nov. 1959. CONCURSO do Paço Municipal de Campinas. Habitat. São Paulo, 45, p.85, nov/dez. 1957. CONJUNTO Industrial da Willys Overland. Acrópole, n.265, p.24-27, nov.1960. CONJUNTO Residencial. Acrópole, São Paulo, 237, p. 441-3, jul. 1958. 
CRIVELLI, V. A passos com a época. Casa e Jardim, São Paulo, 18, p.22-28, nov. 1955. . Graça na magnitude, encanto no detalhe. Casa e Jardim, São Paulo, 14, p.16-22, mai/jun. 1955.

DEGRAUS externos. Acrópole, São Paulo, 228, p. 460, out. 1957.

DORCA. A casa do arquiteto: Henrique Alexander. Casa e Jardim, São Paulo, 34, p.10-16, abr. 1957

DUAS garagens municipais I. Acrópole, São Paulo, 378, p. 13-4, out.1970.

ECKBO, G. Site planning. Architectural Forum, n. 5, p. 263-267, mai. 1942. . Small gardens in the city: a study of their design possibilities. Pencil Points. n. 9, p. 573-586, set. 1937.

ECKBO, G.; KILEY, D. U.; ROSE, J. C. Landscape in the primeval environment. Architectural Record, Nova York, s. n., p 74-79, fev., 1940. . Landscape in the rural environment. Architectural Record, Nova York, s. n., p 68-74, ago., 1939a.

. Landscape in the urban environment. Architectural Record, Nova York, s. n., p 70-76, mai., 1939b.

EDIFÍCIO de apartamentos. Acrópole, São Paulo, 292, p.119, mar. 1963. EDIFÍCIO de apartamentos. Acrópole, São Paulo, 310, p.42-43, set.1964. EDIFÍCIO de apartamentos. Acrópole, São Paulo, 371, p. 34-5, mar. 1970. EDIFÍCIO para Escola de Administração. Acrópole, São Paulo, 275, p.287-9, out.1961. ELEMENTOS de fechamento em edifícios. Acrópole, São Paulo, 367, p.17-25, nov.1969. EM terreno mais ou menos quadrangular. Casa e Jardim, São Paulo, 4, p.10-15, out. 1953. ESCOLA Senai de construção civil. Acrópole, São Paulo, 279, p. 78-81, fev. 1962. ESCOLA Senai de construção civil. Acrópole, São Paulo, 279, p. 78-81, fev. 1962. ESCOLA Senai de construção civil. Bem Estar, São Paulo, 5/6, p.15, maio/jun. 1960. ESCOLA Têxtil “SENAI” em São Paulo. Acrópole, São Paulo, 241, p. 10-3, nov. 1958. ESCRITÓRIOS “Air France” como decoração. Habitat. São Paulo, n.48, p.36-39, maio - jun, 1958.

FÁBRICA de motores. Acrópole, 290, p.56-7, jan.1963.

FACHADAS assim não se veem todos os dias. Casa e Jardim, São Paulo, 72, p.30-31, jan. 1961.

FIASCHI, L. Depoimento: Arquiteto Luciano Fiaschi. Paisagem e Ambiente, São Paulo, n. 19, p. 9-30, 2004.

FRYDMAN, L. Quando a arquitetura moderna proporciona um verdadeiro lar. 
IDÉIAS não faltam. Casa e Jardim, São Paulo, 50, p.63-64, mar. 1959.

JARDIM de real originalidade. Casa e Jardim, São Paulo, 14, p.46-9, mai/jun. 1955 JARDINS em São Paulo. Acrópole, São Paulo, 190, p. 58-9, jul. 1954.

JEAN, Y. Um casal de arquitetos-paisagistas. Folha da Manhã, São Paulo, 10 jun., 1956, Caderno único, Vida social e doméstica, p.56.

JEGOROW, W. Aspectos básicos para a formação de um jardim. Casa e Jardim, São Paulo, 65, p.53-55, jun. 1960.

KATINSKY, J. Usina hidrelétrica de Xavantes. Módulo, n.64, p. 60-62, 1981.

MEDEIROS, F. de. A Mansão do Dr. Ermelino Matarazzo. Casa e Jardim, São Paulo, 66, p.08-22, jul. 1960.

MERAVIGLIA, O. O paisagista é importante. Casa e Jardim, São Paulo, 18, p.48-49 e 70, out. 1955.

METZENER, A. Janelas que são molduras. Casa e Jardim, São Paulo, 13, p.35-7, mar/abr. 1955. NOVA agência da Air France em São Paulo. Acrópole, São Paulo, 235, p. 354-7, abr. 1958. NOVO edifício do Paço Municipal e Parque Público Central em Campinas. Habitat. São Paulo, 43, p.40, jul/ago. 1957.

O HORIZONTAL predomina no estilo. Casa e Jardim, São Paulo, 87, p.23-36, abr. 1962. O JARDIM da residência do Dr. Ermelino Matarazzo. Casa e Jardim, São Paulo, 66, p.67-68, jul. 1960.

PANOFSKY, E. The Ideological Antecedents of the Rolls-Royce Radiator. Proceedings of the American Philosophical Society, Vol. 107, No. 4, Ago.1963, p.273-288.

PRAÇA Pública em São Carlos, SP. Acrópole, São Paulo, 345, p. 32-3, nov. 1967. PRAÇA Roosevelt, São Paulo; histórico e memorial. Engenharia Municipal, São Paulo, 43. PRAÇA Roosevelt. Acrópole, São Paulo, 380, p. 11-21, dez.1970.

REFLEXÕES sobre um jardim. Casa e Jardim, São Paulo, 30, p.63-6, nov. 1956. RESIDÊNCIA 4. Acrópole, São Paulo, 347, p.30-33, fev.1968.

RESIDÊNCIA à Rua Honório Líbero, 154. Acrópole, n.157, p.10, mai.1951.

RESIDÊNCIA de um arquiteto. Habitat, São Paulo, 22, p.24-26, 1959.

RESIDÊNCIA em São José do Rio Preto. Acrópole, São Paulo, 281, p. 154-5, abr. 1962. RESIDÊNCIA no Brooklin Novo. Acrópole, São Paulo, 195, p. 136-9, dez. 1954. RESIDÊNCIA no Brooklin Paulista. Acrópole, São Paulo, 247, p. 252-5, maio 1959. RESIDÊNCIA no Jardim América. Acrópole, São Paulo, 213, p. 339-43, jul. 1956. RESIDÊNCIA no Jardim América. Acrópole, São Paulo, 298, p. 302-4, ago. 1963. 
RESIDÊNCIA no Jardim América. Acrópole, São Paulo, 328, p. 34-6, mai. 1966. RESIDÊNCIA no Jardim Europa. Habitat, São Paulo, 23, p. 22-5, ago. 1955. RESIDÊNCIA no Jardim Europa. Habitat, São Paulo, 62, p. 22-24, 1960. RESIDÊNCIA no Jardim Guedalla, São Paulo. Acrópole, São Paulo, 324, p. 19-21, dez. 1965. RESIDÊNCIA no Jardim Paulista. Acrópole, São Paulo, 183, p. 20-1, jul.1953. RESIDÊNCIA no Jardim Paulistano. Acrópole, São Paulo, 277, p. 20-1, dez. 1961. RESIDÊNCIA no Pacaembu, Acrópole, São Paulo, n.198, p.280-3, mar.1955. RESIDÊNCIA no Pacaembu. Acrópole, São Paulo, 193, p. 14-8, out. 1954. RESIDÊNCIA no Pacaembu. Acrópole, São Paulo, 209, p. 172-5, mar. 1956. RESIDÊNCIA no Pacaembu. Acrópole, São Paulo, 212, p. 308-11, jun. 1956. RESTAURANTE Lagosta. Acrópole, n. 161, p.167-8, 1951.

ROSE, J. C. $1+1=5$. California Arts \& Architecture. n.57, p. 38-46, jun. $1940 a$. . Are You a Plant Snob. California Arts \& Architecture. Los Angeles, n. 58 , p. 30-46, abr., 1941. . Articulate Form in Landscape Design. Pencil Points, n.20, p. 98-100, fev., 1939a. . Bogeys in the Landscape. California Arts \& Architecture. n.57, p. 27-38, nov. 1940. . Creative Gardens. Nova York: Reinhold Publishing Corporation, 1958. 208p.

. Dear American Home: Developed for North Atlantic Conditions." American Home. September 1946: 76- 77.

. Freedom in the Garden. Pencil Points. n. 19, p. 640-644, out. 1938 a. . Garden Details. California Arts \& Architecture. n.58, p. 28-29, jul. 1941. . Gardens. Gardens. California Arts \& Architecture. s. n., p. 57, mai. 1940 b. . Hillside House Solves the Difficult Problem of Solar Orientation. Architectural Forum. n. 86, p.126-128, abr. 1947. . House in Pasadena, California. Architectural Forum. n.85, p. 90-93, nov. 1946.

. Integration. Pencil Points. n. 19, p 758-76o, dez. 1938 b. Landscape Models. Pencil Points. n. 20, p. 438-448, jul. 1939b. . Modular Gardens II. Progressive Architecture. s.n., p.81, out. 1947. Modular Gardens. Progressive Architecture. s.n., p.76-80, set. 1947. . My Connecticut Home and Gardens Began in Okinawa. American Home. N.36, p. 20-22, out. 1946. . Outdoor Theater. California Arts \& Architecture. s.n., p. 29, jan, 1941. Plant Forms and Space. Pencil Points. n. 20, p 226-230, abr. 1939c. 
Plants Dictate Garden Forms. Pencil Points. n. 19, p. 695-697, nov. 1938c.

. The Hanging Garden. California Arts \& Architecture. n. 57, p. 25-37, ago. $1940 \mathrm{c}$.

. This Garden Is The Garden For You. California Arts \& Architecture. n. 57, p. 26 , out. 1940 d.

. When A House Is Not A Home. California Arts \& Architecture. n. 58, p. 27 , mar. 1941.

Why Not Try Science. Pencil Points. n. 20, p. 777-779, dez. 1939d.

SAGINUR, B. Residência cinematográfica. Casa e Jardim, São Paulo, 115, p.1924, ago. 1964.

SALA de jantar: luz fixa e luz móvel. Casa e Jardim, São Paulo, 32, p.30-1, jan./ fev. 1957.

SANTOS, M. H. C. dos. Emigração e níveis de cultura: a União Portuguesa do Estado da Califórnia (1880-1980). Análise Social, vol. XIX (77-79), 1983, p. 961-986.

SENAI - Escola Têxtil Central (Brás - São Paulo). Acrópole, n. 197, p.217-218, 1955.

SHEPEARD, P. (1982). Miss Gertrude Jekyll, gardener. AA Files, (2), 67-70. Disponível em <http://www.jstor.org/stable/29543331>. Acesso em 12 dez. 2016.

SILVA, J. M. Transcrição da entrevista concedida por Miranda Maria Esmeralda Martinelli Magnoli. Paisagem e Ambiente, São Paulo, n. 21, p.1341 2006. Edição Especial Miranda Magnoli.

SPIRN, A. W. Ian MaHarg, Landscape Architecture, and Environmentalism: ideas and methods in context. In: CONAN, M. Environmentalism in Landscape Architecture. Washington: Dumbarton Oaks Research Library and Collection, 2000. Disponível em: http://www. doaks.org/resources/publications/doaks-online-publications/ environmentalism. Acesso em: 06 jun. 2016.

STEELE, F. New Pioneering in garden design. Landscape Architecture, n. 20, p. 159-177, abr. 1930.

TAGLIARI, A.; PERRONE, R.; FLORIO, W. Estudos dos projetos residenciais não-construídos de Vilanova Artigas em São Paulo. Arquiteturarevista, São Paulo, v.08, n.01, p.49-61, jan/jun.2015.

TAGLIARI, A.; PERRONE, R.; FLORIO, W. Os projetos residenciais não-construídos de Vilanova Artigas em São Paulo. Pós, São Paulo, v.21, n.35, p.98-117, jun.2014. 
TAL como foi sonhada. Casa e Jardim, São Paulo, n.138, p.6-12, jul.1966.

TUNNARD, C. Modern gardens for modern houses: reflections on current trends in landscape design. Landscape Architecture, n.32, p. 57-64, jan. 1942. UM arquiteto projeta sua residência. Casa e Jardim, São Paulo, 15, p.8-17, jul. 1955. UM dia, uma casa. Casa \& Jardim, São Paulo, 144, p. 34-9, mar. 1967.

UM jardim para velhos. Acrópole, São Paulo, 204, p. 537-9, out. 1955.

UM mundo à parte. Casa e Jardim, São Paulo, 24, p.43-5, abr. 1956.

UNIÃO ideal entre arquitetura e jardim. Casa e Jardim, São Paulo, 77, p.16-22, jun. 1961. ZANINI, I. Bienal de Jóias: 14 artistas aceitos. Folha de São Paulo, São Paulo, 13 ago., $1965,2^{\circ}$ caderno, p.o2. 


\section{LISTA DE IMAGENS}

\section{A TRAJETÓRIA DE UM PAISAGISTA MODERNO}

[1.1] Environmental Design Archives, UCBerkeley

[1.2] Fran Violich Collection, Environmental Design Archives, UCBerkeley

[1.3] UNIVERSITY PF CALIFORNIA, 1948. p.18 e UNIVERSITY OF

CALIFORNIA, 1949, p. 95

[1.4] ECKBO, 1950b, p. 139

[1.5] idem, p. 139

[1.6] idem, p. 139

[1.7] idem, p. 151

[1.8] idem, p. 151

[1.9] idem, p. 151

[1.10] Garrett Eckbo Collection. Environmental Design Archives, UCBerkeley

[1.11] Acervo de projetos da Biblioteca da FAUUSP. Referência:

P.C.179.729s

[1.12] TIGERMAN, 2013, p. 35

[1.13] https://familysearch.org/ark:/61903/1:1:V1SH-BFX

[1.14] https://familysearch.org/ark:/61903/1:1:KNG7-W48

[1.15] Arquivo de Luciano Fiaschi

[1.16] Arquivo de Peri Jon Osborn

[1.17] Acervo de projetos da Biblioteca da FAUUSP. Referência: PE

C179/728.3 A

[1.18] idem. Referência: PE C179/728.3 A

[1.19] ZANINI, 1965, p. 02

[1.20] Arquivo de Gregório Zolko

[1.21] Casa e Jardim, 13, 1955, p. 47

[1.22] Casa e Jardim, 40, 1958, p. 02

[1.23] UNIVERSIDADE DE SÃO PAULO, 1987.

[1.24] SODRÉ, 2010, p.136. 
2. INFLUXOS, RUPTURA E A NOVA FORMA DO PAISAGISMO PAULISTANO

[2.1] JELLICOE, 1998, p. 277

[2.2] idem, p. 277

[2.3] MORALES, 1991, p. 441

[2.4] https://flic.kr/p/uDTZXV

[2.5] https://flic.kr/p/eoD9By

[2.6] https://flic.kr/p/diqFQc

[2.7] https://www.flickr.com/photos/jccalvob/11787185456/

[2.8] https://flic.kr/p/6QuwbT

[2.9] BENTON, 2015, p. 325

[2.10] EXPOSITION INTERNATIONALE DES ARTS DÉCORATIFS

ET INDUSTRIELS MODERNES (1925)

[2.11] idem

[2.12] http://villacavrois.blogspot.com

[2.13] PANZINI, 2013, p. 590

[2.14] TREIB, 1993, p. 37

[2.15] PANZINI, 2013, p. 591

[2.16] ROYER, 1991, p. 461

[2.17] PANZINI, 2013, p. 593.

[2.18] http://gardenhistorygirl.blogspot.com/2010/05/man-ray-in-garden.html

[2.19] IMBERT, 2003, p. 47

[2.20] idem, p. 47

[2.21] idem, p. 47

[2.22] GREGORY, 2003, p. 77

[2.23] HARRIS, 2003, p. 186

[2.24] TREIB, 2003, p. 107

[2.25] idem, p. 106

[2.26] ECKBO; KILEY; ROSE, 1939 a. p. 68-69

[2.27] ECKBO; KILEY; ROSE, 1939b. p. 70-71

[2.28] Pencil Points, 12, 1938, capa

[2.29] Coleção Gregori Warchavchik

[2.30] idem 
[2.31] idem

[2.32] Casa e Jardim, 40, 1958, capa

[2.33] idem, p.32

[2.34] idem, p.30-31

[2.35] Casa e Jardim, 39, 1957, p.22-23

[2.36] MEDEIROS, 2004, p.156

[2.37] idem, p.221

[2.38] idem, p.229

[2.39] idem, p.257

[2.40] Acrópole, 204, 1955, p.539

[2.41] idem, p.538

[2.42] idem, p.537

[2.43] IMBERT; TREIB, 1997. P. 64

[2.44] Acrópole, 195, 1954b, p. 134

[2.45] Casa e Jardim, 78, 1961, p. 71

[2.46] Acrópole, 197, 1955. p. 237

[2.47] ABBUD, 1974, p. 66

[2.48] idem, p. 67

[2.49] Acrópole, 190, 1954, p. 459

[2.50] idem, p. 458

[2.51] idem, p. 458

[2.52] Casa e Jardim, 77, 1961, p.16

[2.53] Diapositivo do acervo da FAUUSP - Coleção Roberto Coelho

Cardozo

[2.54] idem

[2.55] idem

[2.56] idem

[2.57] idem

[2.58] idem

[2.59] idem

[2.60] idem

[2.61] idem

[2.62] idem

[2.63] idem

[2.64] idem 
[2.65] idem

[2.66] idem

[2.67] idem

[2.68] idem

[2.69] idem

[2.70] idem

[2.71] Acervo da seção de alunos da FAUUSP. Programa de 1958, p.o1

[2.72] idem, p.o2

[2.73] Diapositivo do acervo da FAUUSP - Coleção Roberto Coelho Cardozo

[2.74] idem

[2.75] idem

[2.76] idem

[2.77] idem

[2.78] idem

[2.79] idem

[2.80] Casa e Jardim, 40, 1958, p.52

[2.81] idem, p.53

[2.82] Diapositivo do acervo da FAUUSP - Coleção Roberto Coelho Cardozo

[2.83] idem

[2.84] idem

[2.85] idem

[2.86] idem

[2.87] idem

[2.88] idem

\section{PLASTICIDADE E ORGANICIDADE NA OBRA DE ROBERTO COELHO CARDOZO}

[3.1] Garrett Eckbo Collection. Environmental Design Archives, UCBerkeley

[3.2] ECKBO, 195ob. p139

[3.3] Acrópole, 328, 1966. p.35 
[3.5] idem, p.36

[3.6] Acervo de projetos da Biblioteca da FAUUSP. Referência: PE

C179/728.3 IL

[3.7] Acervo Quapá

[3.8] idem

[3.9] idem

[3.10] Acrópole, 368, 1969, p. 31

[3.11] idem, p.31

[3.12] idem, p.31

[3.13] idem, p.31

[3.14] Acervo de projetos da Biblioteca da FAUUSP. Referência: PE $\mathrm{C} 179 / 727 \mathrm{C}$

[3.15] Acrópole, 368, 1969, p. 30

[3.14] Acervo de projetos da Biblioteca da FAUUSP. Referência: PE $\mathrm{C} 179 / 727 \mathrm{C}$

[3.15] idem

[3.16] idem

[3.17] idem

[3.18] idem

[3.19] idem

[3.20] Acervo de projetos da Biblioteca da FAUUSP. Referência: PE C179/621.2 C

[3.21] Módulo, 64, 1981, p.61

[3.22] idem

[3.23] Acervo de projetos da Biblioteca da FAUUSP. Referência: PE

C179/621.2 C

[3.24] idem

[3.25] idem

[3.26] idem

[3.27] idem 


\section{ENTREVISTAS REALIZADAS PELA AUTORA}

Benedito Abbud (17/07/2015)

Luciano Fiaschi (21/07/2015)

Marcos Acayaba (27/10/2015 e 08/02/2017)

Peri Jon Osborn Coelho (08/11/2015)

Gregório Zolko (11/11/2015)

Miranda Maria Esmeralda Martinelli Magnoli (30/11/2015) 
ANEXOS 



\section{INDÍCE DE OBRAS POR ORDEM CRONOLÓGICA}

As obras foram elencadas por data de projeto e também pela data em que foram publicadas, já que não foi possível encontrar todas as datas dos projetos. Os projetos datados a partir da publicação estão marcados com um (*) para melhor serem identificadas.

Os projetos sem data especificada foram elencados a partir no curriculum vitae de Roberto Coelho Cardozo, publicada em 1968. Dessa maneira, sabemos que esses projetos foram feitos até 1968.

1950

RESIDÊNCIA VERONICA E STEFAN NEUDING

1951

RESIDÊNCIA DAWID ZEJGER

RESIDÊNCIA ELPHY E ALFREDO ROSENTHAL

1952

RESIDÊNCIA HERBERT SCHIER

RESIDÊNCIA LEONILDO S. MINDLIN

1953

RESIDÊNCIA ROBERTO COELHO CARDOZO E OUTROS - SÍTIO VARGEM GRANDE

RESIDÊNCIA SOFIA FLEISCHER E FILIP RIWCZES*

RESIDÊNCIA VICENTE TEIXEIRA

1954

EMBAIXADA DA LÍBIA

RESIDÊNCIA LÉA E CHAIM JAYME GOLDENSTEIN

RESIDÊNCIA MARTIN ROTHSTEIN*

RESIDÊNCIA NÃO IDENTIFICADA - PACAEMBU*

1955

ASSOCIAÇÃO CULTURAL RELIGIOSA BRASILEIRA ISRAELITA | COLÉGIO I.L.

CONDOMÍNIO PARQUE ACLIMAÇÃO

ESCOLA TÊXTIL CENTRAL SENAI "FRANCISCO MATARAZZO"*

HOTEL INTERLAGOS

RESIDÊNCIA ABRAHAM KASINSKI*

RESIDÊNCIA DISCHLIA STEIVARTZ E ADOLPHO BUME GOLDENSTEIN*

RESIDÊNCIA DONALD JOSEPH ARCHER DE CAMARGO* 
RESIDÊNCIA ENIA E JÚLIO GOICHBERG*

RESIDÊNCIA IBSEN PIVATELLI*

1956

RESIDÊNCIA ESTHER KLABIN E ALFREDO LANDAU

RESIDÊNCIA ZIMON LEIRNER*

1957

PAÇO MUNICIPAL DE CAMPINAS | CONCURSO

PRAÇA ROCHA POMBO - ANTIGA RODOVIÁRIA DE LONDRINA

RESIDÊNCIA HANNS VICTOR TROSTLI 2

RESIDÊNCIA HENRIQUE ALEXANDER*

RESTAURANTE EDIFÍCIO AUTOLON

RESTAURANTE LAGOSTA

1958

AGÊNCIA DA AIR FRANCE*

FÁBRICA ARMAÇÕES DE AÇO PROBEL S.A.

RESIDÊNCIA HENRIQUE SIROTSKY

SÍTIO PARA SALOMÃO GOLDENSTEIN

USINA HIDRELÉTRICA DE SALTO GRANDE

1959

ASILO DOS VELHOS - LAR GOLDA MEIR*

PARQUE MUNICIPAL DA PRAIA DE PERNAMBUCO

RESIDÊNCIA HENRIQUE FLATAUER*

RESIDÊNCIA RUBENS DE CAMARGO MONTEIRO*

1960

CLUBE ATLÉTICO PAULISTANO

ESCOLA PRIMÁRIA RURAL E PLANTAÇÃO MORRO VERMELHO

ESPORTE CLUBE SÍRIO

FÁBRICA CESTAS DE NATAL AMARAL S.A.

FÁBRICA WILLYS OVERLAND DO BRASIL S.A.

FAZENDA MORRO VELHO

FAZENDA SÃO CALIXTO

RESIDÊNCIA ERNESTO BUNGE*

RESIDÊNCIA HĖLENE E ERMELINO MATARAZZO* 
1961

RESIDÊNCIA ALBERTO CINTRA FILHO*

RESIDÊNCIA AMOS ALIPERTI*

RESIDÊNCIA MICHEL MATTAR*

1962

ESCOLA SENAI DE CONSTRUÇÃO CIVIL "FREDERICO JACOB"*

PARQUE RECREATIVO DA ESTÂNCIA DA SERRA NEGRA

RESIDÊNCIA ANIBAL ZACHARIAS*

RESIDÊNCIA CHRISTOPHER ANDREW WOOLLEY

RESIDÊNCIA CUSTÓDIO CORRÊA ${ }^{*}$

RESIDÊNCIA ILDA E WALDOMIRO ZARZUR

RESIDÊNCIA JORGE ARRUDA

1963

EDIFÍCIO RUA DOS INGLESES*

REPARTIÇÃO DE ÁGUAS E ESGOTOS - REA

RESIDÊNCIA JORGE CUNHA LIMA

RESIDÊNCIA SACHA E STEPHAN FEHER*

1964

EDIFÍCIO ANTÔNIO AUGUSTO CORRÊA GALVÃO

FÁBRICA COSIPA DE AÇO PIAÇAGUERA

HOSPITAL ISRAELITA ALBERT EINSTEIN

INSTITUTO DE GASTROENTEREOLOGIA DE SÃO PAULO

PRAÇA IGREJA MATRIZ DE COTIA - PARÓQUIA NOSSA SENHORA MONTE SERRATE

SEDE SOCIAL DO SÃO PAULO CLUBE

1965

CLUBE DE CAMPO E SEDE DE CONGRESSOS PARA A APM

FÁBRICA COFAP MAUÁ

FÁBRICA MOTORES OTTO DEUTZ

RESIDÊNCIA JAYME ALIPIO DE BARROS*

SHOPPING CENTER IGUATEMI

1966

CONDOMIINIO EDIFÍCIO SÃO MIGUEL

EDIFÍCIO PÁTIO TROPICAL

RESIDÊNCIA FELÍCIA E ISAY LEIRNER

SUBESTAÇÃO DE BOTUCATU 
1967

EDIFÍCIO DA FUNDAÇÃO GETÚLIO VARGAS

FAZENDA MARAJÓ

NEGEPAR S.A. PARTICIPAÇÕES E GERÊNCIA DE NEGÓCIOS

PARQUE JARDIM ACLIMAÇÃO

PRAÇA CORONEL SALLES | CONCURSO*

SÍTIO PARA FRANCISCO SCARPA

1968

CENTRO EDUCACIONAL DE PERUS OU FECE - FECE PERUS

ESCOLA SENAI DE OSASCO "NADIR DIAS DE FIGUEIREDO"

ESCOLA SENAI GUARULHOS "HERMENEGILDO CAMPOS ALMEIDA"

ESCOLA SENAI IPIRANGA "CONDE JOSÉ VICENTE DE AZEVEDO"

PAISAGISMO AVENIDA 23 DE MAIO

PROJETO MM

RESIDÊNCIA ASSAD ZACHARIAS

RESIDÊNCIA HÉLIO CORREA

RESIDÊNCIA LUIZ D.F. BARROS

RESIDÊNCIA NEME COZMAN

USINA HIDRELÉTRICA DE XAVANTES

VIADUTOS PARA A AVENIDA 23 DE MAIO

1969

CLUBE ATLÉTICO MONTE LÍBANO

ESCOLA SENAI SÃO CAETANO

FÁBRICA CATERPILLAR DO BRASIL S.A.

IGREJA DE ZINCO - PARÓQUIA SANTOS APÓSTOLOS

PARQUE MUNICIPAL EM LENÇOIS PAULISTA

PRAÇA ALFREDO ISSA

PRAÇA FRANKLIN ROOSEVELT

RESIDÊNCIA CLÁUDIA

RESIDÊNCIA IVO IMPARATO

USINA HIDRELÉTRICA DE JURUMIRIM "ARMANDO AVELLANAL LAYDNER"

1970

RESIDÊNCIA ANTÔNIO DE ANDRADE COSTA*

RESIDÊNCIA GREGÓRIO ZOLKO 
RESIDÊNCIA FANNY FEFFER

1995

CONJUNTO DE RESIDÊNCIAS EM MONTE VERDE

\section{SEM DATA ESPECIFICADA}

EDIFÍCIO DÓRIO PAMPHILLI

RESIDÊNCIA ALEXANDRE CHAFIC MALUF

RESIDÊNCIA ALEXANDRE MARCONDES NETO

RESIDÊNCIA ALFREDO FUCHS

RESIDÊNCIA ANTÔNIO COSTA NETO

RESIDÊNCIA ANTÔNIO ERMÍRIO DE MORAES

RESIDÊNCIA AUGUSTO PIRANI

RESIDÊNCIA AZIZ MATTAR

RESIDÊNCIA BERNARDO PASCOWITCH

RESIDÊNCIA BERTHA E BORIS BERNARDO KASINSKI

RESIDÊNCIA BIRO ERNESTO ZEITEL

RESIDÊNCIA CARLOS PASQUALLE

RESIDÊNCIA CASSIO MONTEIRO

RESIDÊNCIA CLAIRE AZADIAN

RESIDÊNCIA CONSTANZA PASCOLATO E ROBERTO HEFLEY BLOCKER

RESIDÊNCIA DAVID FEDER

RESIDÊNCIA DAVID SERSON NETO

RESIDÊNCIA DÉCIO DE MORAES

RESIDÊNCIA DESIDÉRIO TOBIAS

RESIDÊNCIA DOMINGOS PIRES

RESIDÊNCIA EDUARDO BADRA

RESIDÊNCIA EDUARDO CARONE

RESIDÊNCIA EDUARDO MARCOS MONTEIRO

RESIDÊNCIA EDUARDO MATARAZZO

RESIDÊNCIA EDUARDO MATARAZZO

RESIDÊNCIA FRANCISCO BERNARDO LORCH

RESIDÊNCIA FRANCISCO DE PAULA MACHADO DE CAMPOS

RESIDÊNCIA FRANCISCO ROSA

RESIDÊNCIA FRANCISCO SCARPA

RESIDÊNCIA FRANKLYN FAY

RESIDÊNCIA GERALDO DENTE NEVES 
RESIDÊNCIA HANNELORE FUCHS

RESIDÊNCIA HÉLIO BICUDO

RESIDÊNCIA HENRIQUE ZYLBERMAN

RESIDÊNCIA IBRAHIM SULEIMAN

RESIDÊNCIA IRWIN LOEW

RESIDÊNCIA ISRAEL ROSENBERG

RESIDÊNCIA JAKOB SZPORN

RESIDÊNCIA JOAQUIM POLICIANO LEITE NETTO

RESIDÊNCIA JORGE BEI MALUF

RESIDÊNCIA JORGE CURY

RESIDÊNCIA JOSÉ ALVES DE LIMA

RESIDÊNCIA JOSÉ MARQUES DA COSTA

RESIDÊNCIA JOSÉ NOSCHESE

RESIDÊNCIA JOSÉ VELASQUEZ VARGAS

RESIDÊNCIA JUDITH BEKERMAN KOGAN E ISRAEL SCHACHNIK

RESIDÊNCIA LAUDO NATEL

RESIDÊNCIA LAWRENCE KING

RESIDÊNCIA LISANDRO GARCIA

RESIDÊNCIA LUDWIG WINKLER

RESIDÊNCIA LUIZ SÉRGIO M. MARCONDES

RESIDÊNCIA MARCELO RIBEIRO

RESIDÊNCIA MARILU E FABRÍCIO BEER

RESIDÊNCIA MAURÍCIO GRINBERG

RESIDÊNCIA MAURÍCIO TUCK SCHNEIDER

RESIDÊNCIA MAXIMILIANO TSCHIPTSCHIN

RESIDÊNCIA OTTO VERNER

RESIDÊNCIA PAUL SEILER

RESIDÊNCIA PAULO GIANNINI

RESIDÊNCIA PAULO GIANNINI

RESIDÊNCIA PAULO PASCOWITCH

RESIDÊNCIA PEDRO GRAVINA

RESIDÊNCIA RAPHAEL STASI

RESIDÊNCIA RICARDO CASTRO

RESIDÊNCIA RIDAVIA D. BARROS

RESIDÊNCIA ROBERTO FUCHS 
RESIDÊNCIA ROBERTO MALUF

RESIDÊNCIA RUBENS FERRAZ

RESIDÊNCIA RUTH E IGNACIO SPORN

RESIDÊNCIA SAMUEL KLABIN

RESIDÊNCIA SAUL CHITMAN

RESIDÊNCIA SIMONE BELDA

RESIDÊNCIA STEFFI E MAX PERLMAN

RESIDÊNCIA SUHER KRASNER

RESIDÊNCIA SUSAN OSBORN E ROBERTO COELHO CARDOZO

RESIDÊNCIA THEODOR HESS

RESIDÊNCIA THEODOR HESS

RESIDÊNCIA THOMAZ FARKAS

RESIDÊNCIA TUFY CURY

RESIDÊNCIA TUFY MATTAR

RESIDÊNCIA WADY MATTAR

RESIDÊNCIA WALTER HABERKORN

RESIDÊNCIA WASHINGTON HATANAKA

RESIDÊNCIA YOLANDA PENTEADO E CICCILLO MATARAZZO 
